Segregation's Science:

The American Eugenics Niovement and Virginia, 1900-198ij

(In Tivo Volunes)

Volume I

Gregory Michael Dorr

Darien, Connecticut

\author{
A.B., Dartmouth College, 1990 \\ M.A., Universìy of V'irginia, 1994
}

A Dissertation presented to the Graduate Facuity of the University of Virginia in Candidacy for the Degree of

Dector of Philosophy

\title{
Department of History
}

University of Virgiaia

August, 2000

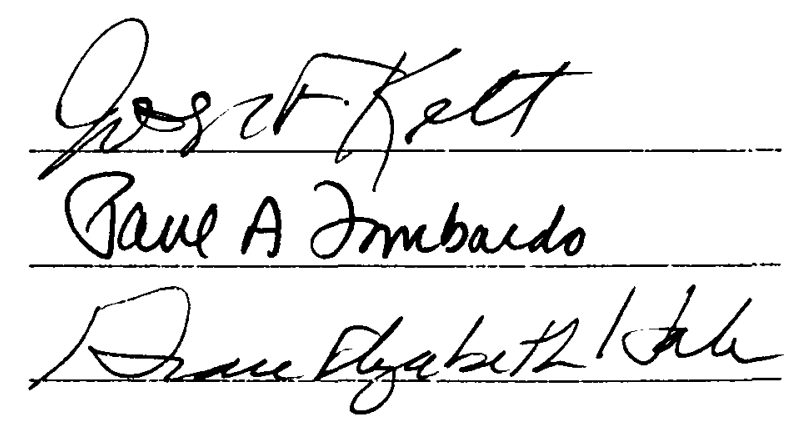


(C) Copyright by Gregory Michael Dorr All Rights Reserved

August 2000 


\begin{abstract}
Perhaps no state adopted eugenics—-the science of human hereditary improvement -as fully as Virginia. "Segregation's Science: the American Eugenics Movement and Virginia, 1900-1980" melds social, intellectual, and cultural history in analyzing Virginia's eugenics movement. Tracing the institutionalization of eugenics in Virginia's high schools, colleges, and medical schools, this dissertation illuminates how formal education inculcated ideas of racial, class, and gender superiority and inferiority. Close examination of the ideas, speeches, publications, and personal papers of Virginia educators reveals both their eugenic orthodoxy and their intimate relationships with important national-level eugenicists. Reconstructing the network among Virginia's eugenicists, eugenic institutions, and national-level eugenicists explains how and why Virginia law-makers passed and enforced eugenic marriage, segregation, and sterilization statutes. Thus, this dissertation evinces the reflexive relationship between scientific ideas and social context. It explains the rhetorical movement of white elites away from the splenetic racism of "Redemption" and toward the "scientific" and "managerial" racism of the Progressive Era. This shift allowed Virginia elites to solve the "crisis of modemity" posed by the rise of the New South. Using scientific education as the warrant for their "expert" authority, they emphasized empiricism and rationalism, portraying their eugenic society as a "modern" model for the entire nation. This modern eugenic stance permitted southem racists to bond with northern nativists and xenophobes in extolling white supremacy. Thus, adopting eugenic public policy engendered sectional rapprochement by harmonizing racism and science. The power and persistence of eugenic theory helps to explain the rise of "Massive Resistance" in Virginia - the only upper-South state to adopt such a reactionary stance-and elsewhere. While some whites and most Native and African Americans rejected eugenic ideology, some members of the black community advanced modified forms of eugenics. Denying the racial hierarchies posited by most white eugenicists, African-American eugenicists embraced the notion of a eugenically "pure" black race within Virginia. Accepting many of
\end{abstract}


the class and gender biases of their white counterparts, black eugenicists nevertheless coopted white hereditarianism, reshaping it to comport with notions of racial "uplift." 


\section{CONTENTS}

\section{Volume I:}

Acknowledgements

Introduction $\quad 1$

1. The Sacrifice of A Race 47

2. Breeding the Human Thoroughbred 123

3. Defending the Thin Red Line 206

4. Peopling Virginia 306

5. Sterilize the Misfits Promptly 370

6. Mongrel Virginians 449

Volume II:

7. The New Sparta

8. From Human Thoroughbreds to

Human Tragedy 649

9. They Saw Black All Over 708

Conclusion: I Never Knew What They'd

Done With Me $\quad 787$

$\begin{array}{ll}\text { Bïbliography } & 801\end{array}$ 


\section{Acknowledgments}

Many individuals and institutions contributed their time, energy, and spirit to the completion of this dissertation. The following account, as with all such efforts, is necessarily partial. Those unmentioned should know that they share my thanks in equal measure with those mentioned by name.

I owe a deep debt of gratitude to all the archivists who helped me ferret out the information contained in this excruciatingly-detailed account of Virginia eugenics. The staff at the University of Virginia's interlibrary loan department remained patient with my ceaseless requests for obscure articles and documents. The archivists in Special Collections at Alderman Library ferried thousands of manuscript boxes to me, always with good cheer. Archivists at Randolph-Macon College, the College of William and Mary, the Hampton Institute, Howard University, and the Library of Congress Department of Manuscripts all made my research easier and more enjoyable. Five individuals deserve special recognition: Joan Echtenkamp Klein and her assistant Joby Topper, Jodi Koste, and the American Philosophical Society's Rob Cox and Scott DeHaven. Joan and Joby, the archival staff at the University of Virginia Health Science's Center, remained constant sources of encouragement and interest. Joan, especially, worked to promote my research, arranging for me to present material as part of the History of the Health Sciences Lecture Series. Jodi Koste, archivist at the Medical College of Virginia, provided guidance in Richmond and joined Joan and Joby in supporting my work by appearing at my lectures. Rob and Scoti skillfully piloted me through the American Philosophical Society's extensive collections on eugenics, and the personal papers of many influential biologists, geneticists, and anthropologists. Both men alerted me to important information I would otherwise have missed. Their diligence and intelligence have made this a better work.

The Spencer Foundation, the American Philosophical Society, the Graduate School of Arts and Sciences, the Institute for Law, Psychiatry, and Public Policy, and the History 
Department all provided financial and intellectual backing that made this work possible. As a Spencer Fellow, I received more than money: I also joined a community of young scholars deeply invested in research relating to the history, theory, and practice of education. A heterogeneous group if ever there was one, my Spencer cohort helped me remain focused on the really important aspects of this work. The American Philosophical Society underwrote a month of research in their archives with an Andrew W. Mellon Library Resident Research Fellowship. Martin Levitt, who administered this program, has my enduring thanks. The Graduate School of Arts and Sciences awarded me a dissertation fellowship, a testimony to the open-mindedness of Dean Robert J. Huskey-a biologist who, had he been a lesser scholar and person, might well have felt threatened by this project's subject matter. The Institute of Law, Psychiatry, and Public Policy provided me with a research assistantship that helped fund my graduate career. The History Department provided me with four years of teaching, including two semesters at Instructor rank; the money and the opportunity have not been wasted.

My intellectual mentors deserve, and have, my abiding thanks and loyalty. Dr. William J. Jacobs predicted, when I was a high-school sophomore, that I would become a professional historian. He sparked an intellectual fire that has burned, with varying "brilliance," ever since. My undergraduate mentors, Margaret Darrow and Ted Mitchell, kept me on course by providing sage counsel at critical moments. I was blessed with two advisors who helped me to survive the rigors of graduate school. Paul A. Lombardo of the Law School suggested this study. Himself a scholar of eugenics, Paul taught me not only about the movement and its implications, but also about the nuts and bolts of real research. Described by one colleague as a practitioner of "fine-grained historical sleuthing," Paul's example convinced me to never take another scholar's word for what a document said, to follow hunches relentlessly and systematically, and to never say die. As much a coach as a teacher, Paul was ever-ready to read multiple drafts of the work that eventually became articles and chapters, providing the necessary prodding and praising to get me to reach my 
potential. Words alone cannot express my heart-felt thanks for his intelligence, integrity, and friendship. My other principal advisor, Joseph Kett, also led by example. His erudition and eloquence are matched only by his sharp wit; to spend time with Joe Kett is to be awed by the power of a mind honed to the keenest possible edge. Joe taught me to always "follow my nose" in research and historiographical reading. His ability to ask the penetrating question clarified my muddy thinking and prompted me to produce my best work. His example as a classroom teacher-combining intellectual rigor with the narrative ability of a born raconteur-has placed an indelible stamp on my own approach to both the practice and teaching of history. Whatever merits I have as a historian who asks "big" questions and synthesizes themes across time, I owe to Joe, who awed me my first day of graduate school and inspired me regularly thereafter. I am also indebted to Reginald Butler, Ann J. Lane, and Grace Hale for their wisdom about matters both personal and professional. Edward Ayers, Leonard Burlenstein, Charles McCurdy, Alon Confino, Nelson Lichtenstein, and Jennings Wagoner round out the cast of truly great graduate teachers.

Ultimately, as with most scholarship, it is my family that deserves the greatest and final measure of my thanks. My brothers and sisters, Kathy Welch, Chris Dorr, and Jeff Dorr and his wife Laura, have always stood by me-in front as models of intelligence, perseverance, and integrity; beside as compassionate care-givers and supporters; and behind as the loudest and most relentless cheering section I have ever known. My Motherand Father-In-Law, Mary and George Lindquist, saved me when I was at the lowest point in my life, without them this dissertation would not exist. Also, without Mary and George, I would not have met my wife, Lisa Johanna Lindquist Dorr. Perhaps the only person who could surpass her parents in graciousness and caring, Lisa's personal qualities undergird her intellectual powers. A better historian than I'll ever be, Lisa's influence on this work is peryasive and enduring. Our ability to collaborate and critique without acrimony is one of my life's chief joys. Lisa gave me THE chief joy of my life, our daughter Fiona 
Maryellen. Fiona's birth on 8 August 1999 sounded the starting gun on my mad dash to finish this dissertation and get a job. Still jobless, at least I'm done. Thank you Fiona, for everything. 
Segregation's Science:

The American Eugenics Movement and Virginia, 1900-1980

\section{Int roduction}

On January 16, 1913, the front-page headline of Charlottesville, Virginia's Daily Progress trumpeted, "Dr. H. E. Jordan on 'Eugenics."' The preceding evening Dr. Jordan, professor of histology and embryology in the University of Virginia, had addressed "a large audience on 'Eugenics-Its Data, Scope, and Promise." Doctor Jordan told his audience, comprised of university students, faculty, and members of the community, that eugenics "is the science of good birth. It deals with parents and offspring. It aims to produce a better race by better breeding. It is applied evolution in the interests of humankind." According to Dr. Jordan, increasing the common weal comprised humanity's principal interests, and the surest way to raise the general welfare was to breed better individuals. "The foundation of eugenics is heredity," Jordan intoned. "In contrast with euthenics, which aims to improve the race through improvement of the environment, eugenics is concerned with that still greater improvement possible in even a perfect environment by application of the principles of heredity." Heredity, the passing on of purportedly inborn beneficial traits, held the promise of social melioration. Humans, it seemed to Jordan, could control their own evolution-and even reach a state of near millennial perfection-by rationalizing their procreation. Since, "no environment, however ideal, can lift an individuai and his offspring beyond the upper level of inherited potentialities for development," Jordan and other eugenicists believed that society couid or.ly be perfected through attention to individual heredity. ${ }^{1}$

\footnotetext{
1 "Dr. Jordan on 'Eugenics'," The Daily Progress (Charlcttesville, VA), 16 January 1913, 1 and 6, quotations 1. The newspaper reported large sections of Jordan's paper virtually verbatim. Jordan's address subsequeritly appeared in a collection of addresses delivered under the auspices of Lucy James Wilson, a wealthy womian interested in popularizing eugenics. See Morton A. Aldrich, et. al., Eugenics: Twelve University Lectures (New York: Dodd, Mead, and Company, 1914), 107-38.
} 
Jordan informed his listeners that, "The two main aspects of eugenics are positive and negative. Positive eugenics seeks to improve the race by encouraging more abundant parenthood among the racially fitter stocks." Financial gain, social success, and light skin, hair, and eye-color all indicated, to eugenicists, the "fitness" of an individual's racial "stock." Negative eugenics, Jordan continued, "aims to prevent contamination and degeneracy [of hereditary potential] by prohibition of parenthood to the obviously and grossly unfit." Those individuals hereditarily predisposed to physical defect, criminal or immoral behavior, poverty, wanderlust, susceptibility to disease, and mental incapacity comprised the eugenic unfit. These people represented human "dead weight;" their antisocial tendencies prevented society from attaining perfection. All that was needed to solve humanity's social problems, according to Jordan and the eugenicists, was to speed up human evolution through conscious, self-directed breeding. ${ }^{2}$

If alerting white Virginians to a solution for endemic poverty, disease, and anti-social behavior was not enough to convince them of the benefits of eugenics, Jordan also "discussed the eugenic aspect of the negro question," a topic sure to pique southern interest. The problem of black/white relations in the South had been a recurring issue since chattel slavery first assumed its racial basis in the seventeenth century. ${ }^{3}$ Following the end of Reconstruction in 1877, rising rates of interracial violence, rumors of black-on-white rape, and the purported increase in "negro insanity" convinced whites that African Americans were "reverting to type"-regressing to a more primitive racial state. Fear of "race war" blanketed the southern cultural landscape. Periodic race riots alleviated the tension, as whites vented their pent-up anxiety in furious racial pogroms against neighboring blacks. ${ }^{4}$ Eugenics, according to Jordan, offered a peaceful alternative to these

\footnotetext{
2"Dr. H. E. Jordan on Eugenics," 1 and 6.

${ }^{3}$ Edmund S. Morgan, American Slavery, American Freedom: The Ordeal of Colonial Virginia (New York: W. W. Norton \& Company, 1975).

${ }^{4}$ An excellent coricise narrative of this period, the "nadir" of the African-American experience, appears in John Hope Franklin and Alfred A. Moss, Jr., From Slavery to Freedom: A History of African Americans, 7th ed., (New York: McGraw-Hill, Inc., 1994), 251-322.
} 
apocalyptic racial confrontations. "There is no biologic basis for regarding the mulatto as a degenerate type," Jordan began, assuaging white fears about "uppity" light-skinned blacks but implying the inferiority of "pure negro" African Americans. 5 "We may do well to consider that great aid in the solution of our negro problem lies in conserving the present mulatto stock and employing it as a leaven in lifting the colored race to a higher level of innate mental and moral capacity." Rather than further "polluting" themselves by engaging in interracial marriage, Jordan felt whites should seek to control black mating.

Encouraging marriages between "mulatto" and "pure" blacks would, according to Jordan, introduce sufficient white "blood" (the common cipher for genetic material) to ensure that the rising generations of blacks would be hereditarily predisposed to "know their place" in the southern raciai hierarchy. The presence of "white blood" would prevent further racial atavism, but it would not be concentrated enough to cause feelings of resentment about being "almost white."6

Jordan concluded his address with a ringing peroration that combined religious and nationalist imagery in support of eugenics. "You are your brother's keeper!" Jordan exclaimed. "Your brothers are the human race. Even patriotism should move you to want to make the American race the best and most virile of history. Wherever you go, whatever your profession in life may be, racial conservation, the eugenic ideal, needs your guiding counsel, your valiant help." Jordan's eugenics, however, was not just an altruistic social program; it was a necessary medical intervention. "Just as we are now guarding the public

\footnotetext{
5Jordan's judgment of African Americans fits neatly within the standard trope developed by eugenicists during the Progressive Era. As Donald K. Pickens put it, "If a Negro did improve his lot in society, the reason, from the eugenic point of view, was the presence of 'white blood' in the Negro." Donald K. Pickens, Eugenics and the Progressives (Naishville, TN: Vanderbilt University Press, 1968), 19.

${ }^{6}$ Jordan developed this nntion in his article "The Biological Worth and Social Status of the Mulatto," The Popular Science Monthly 82 (June 19i3): 573-82. The term "mulatto" had a precise meaning in the racial science of the day. The of fspring of a "pure" white and a "pure" black was mulatto. Many white Americans, and particularly eugenicists, believed that rising black militancy resulied from the resentment harbored by light-skinned blacks at being so close, physically, to the dominant whites but still shut out from their social and economic privileges. Famed Harvard geneticist Edward Murray East cited Jordan favorably, then went on to outline for three pages, the danger of his program. Edward M. East, Mankind at the Crossroads (New York: Charles Scribner's Sons, 1924), 142-45.
} 
health, so it is our yet more clear and sacred duty to guard the health of the race, by every humane effective means at our command," Jordan concluded. If Americans would use the science of genetics to police their heredity, and if Americans would use their knowledge of heredity to inform their mating choices, America might lead the way toward "that Utopia of which More wrote, and the Kingdom of Heaven on Earth of which Christ spoke."7 After this 1913 speech, Virginians gradually accepted Jordan's challenge to take up the eugenic creed. In 1924 the state General Assembly enacted eugenic sterilization and marriage restriction laws, while eugenics would be taught in Virginia colleges, universities, and professional schools until the 1950s. Even today, Virginia continues to deal with the legacy of its eugenic history.

Cast broadly, this dissertation centers on the social construction of knowledge, especially as that knowledge then shaped cultural practices. More narrowly, this essay explores how scielitific theories about human "nature" inform scientific and popular understandings of social behavior and societal organization. Western biological and medical sciences have consistently essentialized race and sex-and at times class distinctions as well-in ways that have often resulted in the oppression of various groups. Scientific taxonomies, being themselves hierarchical, often merge with cultural prejudices to create powerful ideologies that privilege a given race, sex, and class, consigning others to subservience. Eugenics offered scientific justification for existing, albeit faltering, racial, class, and gender hierarchies. Purporting to be an objective science, eugenics actually served a concrete social agenda by buttressing political demands for various forms of segregation: the sick from the well, black from white, male from female, and the socalled "fit" from the "unfit."

\footnotetext{
7Ibid., 6; Harvey Ernest Joldan, "Eugenics-Its Data, Scope, and Promise as Seen by the Anatomist," in Twelve University Lectures, 117.
} 
Today, the word segregation, in an American context, evokes images of the legally enforced racial apartheid blanketing the American South until at least $1965 .{ }^{8}$ One seldom thinks of the word as a scientific term, although it has a definite scientific meaning. Nor does one often consider the correspondence between the scientific term and the social environment in which it was coined. Beginning at least with Gregor Mendel, the Catholic Monk who first described the "laws" of genetic neredity, the word segregation has been used to describe the hereditary process. Mendel's belief that hereditary traits "segregated" independently and randomly in the process of sperm and egg cell formation actually built upon a long tradition of relying on the language of separation to describe the living world. ${ }^{9}$ The notion of segregation - the separation of "types"-has run throughout the biological sciences, at least since the Swedish naturalist Karl Linné, known to history as Carrolus Linnaeus, first developed his Latinate system of classification. Linnaeus divided the living world into orders, families, species, and "races." 10 From Linnaeus forward, naturalistsand their descendants the biologists and geneticists-have spent time dividing and classifying life according to ever more refined systems of analysis.

Neither fate nor the intemal workings of empirical science determined that Mendel's Law should be known as "the Law of Segregation." European scientists rediscovered Mendel's work and named his "Law of Segregation" in 1900, during the period when institutional racial apartheid was being constructed in South Africa and America. That the biologists' language mirrored the political discourse was not coincidental. Scientists had become interested in hereditary difference in the midst of a cultural and geopolitical environment that was intensely concemed with racial differences, the "white man's

\footnotetext{
${ }^{8}$ The passage of the 1965 Voting Rights Act is often characterized as the cnd of legally enforced segregation in America. The degree to which this event ended an era remains a hotly debated topic.

${ }^{9}$ This is sometimes cited as Mendel's Law. Mendel's work actually owes a debt to the scientists who rediscovered it anciarified his principles. See L. C. Dunn and Theodosius Dobzhansky, Heredity Race and Society, 5th ed., (New York: The New American Library of World Literature, Inc. 1952), 43-46.

${ }^{10}$ For a brief discussion of Linnaeus and his taxonomy, see Thomas F. Gossett, Race: The History of an Idea in America (2d ed.; New York and Oxford, 1997), 35 and 82.
} 
burden," and the meaning of racial interaction in colonial societies. Incipient geneticists described the separation of discrete genetic "racial" traits with the same word used to denote the actual physical separation of the races: segregation. At the same time, geneticists shared the modem faith in the ability of scientific inquiry and empirical knowledge to improve society. Geneticists sought to contribute to social improvement through the application of genetic laws to society, the emerging field of eugenics. Conditions intemal and extemal to the scientific practice of genetics and eugenics created the conviction that social interventions based upon genetic biology required segregating groups and individuals within society. At the time, such segregation seemed eminently objective and free of value judgments; both geneticists and eugenicists repeatedly argued that, in expressing notions of innate inequality and extending them into segregationist policy, they were simply reporting the action of iron-clad natural laws. In fact, segregation pointed the only way toward human life free from genetic "defect." As Charles Benedict Davenport, America's most famous eugenicist put it, "The law of segregation of traits, the disproof of the blending hypothesis [that traits from each parent merged in the offspring], is of the utmost imporiance since it shows now a strain may get completely rid of an undesirable irait."11 All that stood between humanity and utopia was the identification of "bad" traits, followed by careful breeding to eliminate these socially undesirable characteristics. It would take decades before the biases inherent in eugenicists' trait identifications became evident to practitioners. In some ways, the influence of value judgments and politics on empirical inquiry remain a part of today's scientific investigations.

The practice of empirical science, and the belief in its inherent vaiue-neutrality, has lead to a dangerous syllogism: science is objective, objective beliefs are moral beliefs, therefore science is, de facto, moral. This syllogism affects scientists and lay-people alike. It often elides skepticism, resulting in a significant inversion in the scientific process. Paraphrasing

${ }^{11}$ Charles Benedict Davenport, Heredity in Relation to Eugenics (New York: Henry Holt and Co., 1911), 250. 
historian Thomas Lacquer, "Seeing Is Believing" often becomes "Believing is Seeing."

Scientists tend, as Thomas S. Kuhn reminded us, to find precisely that for which they are looking. Lay observers, mystified by scientific authority, often uncritically accept the tentative findings of science as established fact. This dynamic has serious implications today; people still tum to science and technology to solve social problems. ${ }^{12}$

Risking "presentism," this dissertation explores how past action based on genetic knowledge can inform current debates regarding medical and scientific ethics. As both genomists and the media distort the implications of the Human Genome Project, we revisit familiar ethical issues in new ways. Unfortunately, just as early geneticists essentialized individual and group differences into hereditary characters, present-day genomists acknowledge the "multi-factorial" nature of genetic uraits, yet insist on the "fitness" and "unfitness" of some genotypes through the language of "genetic load" which describes the "frequency" that "debilitating" genetic traits occur in a population.

Population genetics, recombinant DNA technology, and the emerging fields of cloning and "germinal choice" all propose difíerent paths to various utopias of health and longevity. They also offer what Troy Duster has called a "back door to eugenics."13 Who decides which genetic "traits" or pathological conditions are "debilitating" and which are liberating? At what point does society agree that a certain genetic disorder, from any standpoint, dooms an individual to an inhumane, cruel fate? The issue seems clear cut with conditions like Huntington's disease or Tay-Sachs disorder. People begin to disagree, however, over other genetic conditions like Trisomy-21 (Down's syndrome), that offer the affected individual a chance at life, albeit far shorter and at an apparent cognitive reduction. Biomedical ethicists have already demonstrated that one need not go to extremes-

${ }^{12}$ Thomas Lacqueur, Making Sex: Body and Gender from ine Greeks to Freud (Cambridge, MA and London: Harvard University Press, 1990), especially 70-98. Lacqueur also makes the trenchant observation, "Biology, in other words, is restrained by cultural norms just as much as culture is based on biology." (142); and Thomas S. Kuhn, The Structure of Scientific Revolutions 3d. ed., (Chicago: University of Chicago Press, 1996).

${ }^{13}$ Troy Duster, Backdoor to Eugenics (New York and London: Routledge, 1990). 
discussions of breeding people "simply" for their sex, hair- or eye-color-to realize that value judgments are always already operating to condition our approach to genetic and reproductive technologies. The presence of value bias is particularly evident when we make our decisions based on the explicitly value-laden notion "quality of life."14 What is "quality?" How should it be decided and by whom? These questions ramify rather than resolve themselves.

Far from advocating genetic or technological Luddism, this work applauds the efforts in contemporary genetics. Nevertheless, this examination of eugenics seeks to engender increased critical debate about the implications of genetic technology. This debate should be informed by past experience and an increased understanding of how the reflexive relationship between science and social context conditioned the past and continues to influence the present. If we are to avoid engaging in segregation's science ourselves, we need to understand how our context shapes our science and the programs derived from scientific knowledge.

Virginia presents distinctive opportunities for a state-level study of the interaction between science and society. Intellectuals like Dr. Jordan accepted the eugenics creed as soon as it developed in America; they began teaching it to elite Virginians almost simultaneously. Eugenics harmonized with the reform impulse of the Progressive era that swept through Virginia's educational and political institutions, depositing accretions of eugenic ideology in its wake. Virginia's distinct race, class, and gender norms determined just how eugenics would be applied in practice. The United States Supreme Court, in the 1927 decision Buck v. Bell, upheld Virginia's 1924 eugenical sterilization law, establishing the corsstitutionality of eugenic sterilization in America. Virginia vigorously applied its statute, sterilizing more pecple than any other state, save California. In addition

\footnotetext{
${ }^{14}$ One reed only look at the upwelling among America's deaf community over issues like the cochlear implant and genetic therapy to prevent deafness to see that one group's definition of "normalcy" can, in the charged arena of "quality of life," become another group's genocide.
} 
to whites, Virginia sterilized African Americans. Virginia's Racial Integrity Act, passed in the same legislative session as the sterilization law, explicitly used eugenics to update and rationalize antimiscegenation laws banning interracial marriage. This law remained in force until the Supreme Court, in the aptly-styled 1967 case Loving v. Virginia, struck it down as unconstitutional. Virginia remained at the forefront of applied eugenics throughout the twentieth century.

This portrait of Virginia's eugenics movement gets "closer to the ground"—on both sides, protagonist and antagonist - than its predecessors in eugenics scholarship. ${ }^{15}$ The dissertation reveals how Virginians used eugenics to navigate between the extremes of New

* South "modernism" and Old South "traditionalism." Eugenics facilitated the southern embrace of positivist science and industrial economics, while maintaining traditional race, class, and gender hierarchies that dominated the cultural landscape. Voluminous source material—including correspondence, professional papers and books by Virginia eugenicists, newspaper articles, and course syllabi, lectures, and student term papers from eugenics courses-exists to document the web connecting elite Virginians to the state and national eugenics movement. This evidence also reveals the persistent power of eugenic thought throughout the twentieth century, underscoring how a shared eugenical discourse allowed otherwise ideologically disparate groups to rally behind eugenic social policy. The admixture of eugenic ideas and Virginia's social context precipitated a flexible belief system that could be used to respond to social problems in various historical contexts. Eugenics explained southern rural poverty, the apparent rise of mental illness as Virginia urbanized,

\footnotetext{
${ }^{15}$ See note 16 , below for the body of eugenic schularship. The notable exception to this statement is Nancy L. Gallagher, Breeding Better Vermonters: The Eugenics Project in the Green Mountain State (Hanover, NH: University Press of New England, 1999). The paraliels between Gallagher's study and this one are eerie, given that neither author knew of the other's work. Gallagher's book, for all its many merits, however, deals with eugenics in a relative backwater: Vermont existed even further outside the mainstream of modernizing America than did Virginia. Moreover, Vermonters embraced eugenics later and with less vigor than did Virginians. While both studies reveal how elite gron!ps self-consciously used eugenics to ease their state's transition to "modern" life, Virginians sought to make themselves the model for the rest of the nation; Vermonters sought merely to avoid being left behind.
} 
the reason the economy failed during the depression, why African Americans became more militant in pursuit of their civil rights, and why whites should resist desegregation.

Whether the facts sustained these explanations is immaterial; what is important is that eugenics provided an intellectual matrix for channeling long-standing cultural imperatives into both social policy and the defense of traditional mores.

The trajectory of Virginia's eugenics movement is intimately tied, but is not identical, to the general history of hereditarian thought. Broadly defined, hereditarians believed that the genetic legacy passed on to an individual by their ancestors (their heredity) determined their success or failure in life. Studying the discontinuities between the overarching intellectual history of hereditarianism and Virginia's experience with eugenics reveals how the dialectic between science and society shaped both the creation of knowledge and social structure. The interaction between science and society creates a "feed-back" dynamic: advances in scientific knowledge (often construed as changes internal to the scientific process) slowly permeate society and affect social structure; at the same time, changes in society (often seen as external to the scientific process) materially affect the pursuit of science, the types of questions scientists ask, and the "advances" that result. A clear view of these relationships helps to explain the timing of key events in Virginia's hereditarian and eugenic history. From its earliest appearance in Virginia, biological determinism was invoked and revoked by Virginians as much because of political context as because of any scientific merits. Comprehending the dynamics of this interaction in Virginia provides historians with insight into the nature of the scientific process, the impact of scientific ideas on society, and the ability of social culture to influence science itself.

Scientific hereditarian thought, in one form or another, has circulated in Virginia at least since Jefferson. In 1859, the year Charles Darwin published his epochal Origin of Species, Virginian James Lawrence Cabell published The Testimony of Modern Science to the Unity of Mankind, a work that affirmed the common ancestry of all humanity yet made 
allowances for the hereditary evolution of distinct racial types. ${ }^{16}$ Three related concepts have dominated the life sciences since Darwin and Cabell wrote: evolution, heredity, and genetics. Each of these ideas has awakened fierce epistemological and ontological arguments among scientists, the clergy, and lay people. Scientific consensus, religious schism, and public policy eventually emerged from these debates and conditioned social and cultural mores. The beliefs people held, the policies they supported, and the ways in which they treated one another were ali influenced by decisions about whether and how the biological basis of human life controlled individual destiny and social structure. By teasing out the strands of these three ideas from the nexus of science and society, this dissertation seeks to illuminate how scientific ideas shaped the socio-political culture of Virginia during the twentieth century.

Evolution, heredity, and genetics all begged the question of humanity's essential nature and the degree to which extemal conditions could affect that inborn essence. Intellectuals pondered the question, "Are human beings bom biologically predestined, or can our surroundings materially alter our destiny?" The so-called nature/nurture question, the debate between heredity and environment, sought to decide which "force"—an individual's inbom character or the external conditions in which they lived-determined their fate in life. Often dichotomized into two opposing camps, the hereditarians and the environmentalists, those who argued about this question actually settled along a continuum of belief stretching between the poles. ${ }^{17}$

\footnotetext{
16I use the term "scientific" here to distinguish between the empirical approach to life as opposed to the "hereditarian" thirking that characterized the political/genealogical study of royalty.

${ }^{17}$ As Thomas Lacqueur noted, "Indeed, if structuralism has taught us aniything it is that humans impose their sense of oppesition onto a world of continuous shades of difference and similarity." Lacqueur, Making Sex, 19. Historians have often described these internediate positions by invoking a crude calculus, based upon the relative power that person ascribed to nature and to nurture, to determine an individual's stance. A classic example of dichotomous thinking is Nicolas Pastore, The Nature-Nurture Controversy (New York: Kings Crown Press, 1949; reprint edition, New York and London: Garland Publishing, Inc., 1984). Pastore's benchmark study divided twenty-four scientists (six British and eighteen American) into two camps, hereditarian and environmentalist. Pastore then classified each scientist by socio-political orientation in an effort to determine whether a relationship existed between their "scientific" and "political" judgments. If a relationship existed, Pastore then hoped to deternine whether science or politics determined
} 
To estimate which viewpoint embodied scientific orthodoxy at any given time,

historians have tallied up scientists on either side of a hypothetical midpoint in an attempt to declare consensus by majority rule. This approach assumes that scientific consensus emerges solely from considerations internal to the practice of science itself - that scientific method inevitably establishes a "right" position, based on empirically observed "fact." In this model, scientific knowledge is insulated from other forms of knowing, such as politics and religion, and the cultural forces that shape these other ways of understanding the world. More recent historians of science, however, agree that scientific knowledge interacts with its cultural background to determine scientific orthodoxy. ${ }^{18}$ Which vision of life, hereditarian or environmentalist, controlled the conventional scientific and nonscientific wisdom has had as much to do with social and historical context as it did with state-of-the-art scientific theory. Ultimately, where individuals stood depended upon their profession, training, politics, and historical context.

Virginia's hereditarian thinkers reflected the gradual shifts in hereditarianism, occupying positions along that continuum. Hereditarian thought itself has evolved along a trajectory from so-called "soft" to "hard" heredity. ${ }^{19}$ Soft heredity, most often associated with Jean Baptiste de Lamarck, was essentially environmentalism by another name. Lamarck held that people could inherit traits developed by their parents—the inheritance of

the individual's stance on the nature-nurture question. Hamilton Cravens and Ronald L. Numbers performed more sophisticated analyses in their examinations of this debate. See Hamilton Cravens, The Triumph of Evolution: American Scientists and the Heredity-Environment Controversy 1900-1941, (Philadelphia: University of Pennsylvania Press, 1978); and Ronald L. Numbers, Darwinism Comes to America, (Cambridge, MA and London: Harvard University Press, 1998), Chapter 1.

${ }^{18} \mathrm{Kuhn}$, in The Structure of Scientific Revolutions, mounted the first sustained argument for the contextualization of scientific knowledge, and the effect of context on the development of science. Kuhn's book introduced the concept of "paradigm shifts" into the Ainerican lexicon, reshaping the way scholars and lay people have thought about the nature of intellectual change.

${ }^{19}$ The following summary of the development of genetic theory is, of course, a gross oversimplification. An excellent detailed history of early genetics is Hans Stubbe, History of Genetics: From Prehistoric Times to the Rediscovery of Mendcl's Laws, trans. T. R. W. Waters (Cambridge, MA and London: The MIT Press, 1972). See also, Peter J. Bowler, The Mendelian Revolution: The Emergence of Hereditarian Concepts in Modern Science (Baltimore and London: The Johns Hopkins University Press, 1989), 3; and Diane B. Paul, Controlling Human Heredity, 1865 to the Present (Allantic Highlands, NJ: The Humanities Press, 1995), Chapter 3. 
"acquired characteristics." In this schema, what parents did, where they lived, and how their environment affected them carried consequences for their children. ${ }^{20}$ The conviction that heredity was fixed and immutable, passed across generations changed only by exceedingly rare spontaneous mutations unrelated to environment, eclipsed the Lamarckian scheme during the second half of the nineteenth century. German biologist August Weismann promulgated this new, "hard" heredity after "disproving" Lamarck's theories through his famous experiment with mice. Weismann also introduced the notion of "particulate" heredity: hereditary traits were passed on in discrete elements related to the chromosomes. ${ }^{21}$ What, exactly, those particles were remained a subject of contention. The pea hybridization experiments of the Catholic monk Gregor Mendel, largely forgotten for 35 years, when simultaneously rediscovered by three scientists in 1900 , yielded the new science of heredity, genetics. ${ }^{22}$ The three dicta that came to be known as Mendel's Laws-hereditary traits are formed by non-biending gene pairs to which each parent contributes one gene, one form of a gene may be dominant over another, and genes segregate into sperm and egg cells randomly and independently making all combinations equally likely-allowed scientists to observe and then predict the transmission of hereditary characteristics in plants and animals. ${ }^{23}$ For many scientists environment, in light of the "Mendelian Revolution," receded in importance when compared with the apparent power of heredity. The advent of Mendelism, however, did not end the dialogue between the

\footnotetext{
${ }^{20}$ More a theory of evolution than strictly one of heredity, Lamarck's conception still depended on the transference of characteristics from parent to offspring, the essence of heredity. Bowler, Mendelian Revolution, 37-38. On Lamarckism and human evolution, see Peter Bowler, Theories of Human Evolution: A Century of Debaie, 1844-1944 (Baltimore and London: The Johns Hopkins University Press, 1986), 190-98.

${ }^{21}$ Among other things, Weismann cut the tails off mice through some thirty generations and demonstrated that the "acquired" characteristic of "tailess-ness" failed to be transmitted to offspring. See Numbers, Darwinism Comes to America, 35-37; and Bowler, Mendelian Revolution, 74-75, 83-88.

${ }^{22}$ The three scientists who rediscovered Mendel's work, and clarified "his" laws, were Carl Correns, Hugo DeVries, and Erich von Tschermak. Englishman William Bateson coined the term genetics in 1905. Stubbe, History of Genetics, Chapter 9.

${ }^{23}$ For a critical appraisal of Mendel's laws and how they became scientific orthodoxy, see Bowler, Mendelian K'evolution, 100-04.
} 
hereditarian and environmentalist positions. The interaction between these positions and their cultural context slowly determined the direction of overarching ideological change, and the eventual preeminence of hard heredity. First entering Virginia's institutions during the eighteenth century, hereditarianism gravitated toward the hard position by 1859 , and was firmly entrenched by 1900 . By the turn of the twentieth century, educators and propagandists had spread hereditarianism and throughout Virginia society, prompting some elite Virginians to locate the causes of social problems in the bodies and genes of "lower" and "darker" Virginians. Eugenics, the application of hereditarian knowledge to human breeding, would provide solutions to these apparently genetic social problems.

The preceding narrative of the advance of hard heredity conforms to a model that assumes that science "advances" solely as a result of changes internal to its practice. One idea superseded another in the positivist advance of knowledge; in this case the empirical demonstration of Mendelism supplanted the still "unproven" Lamarckism. The drift from soft to hard heredity appears, on first inspection, to correspond with changes in political philosophy during the same period. Soft heredity commanded attention during the Enlightenment, when the guiding philosophical preconception was one of fundamental, intrinsic human equality. The shift to hard heredity began after the failure of the revolutions of 1848 , when the intrinsic inequalities besetting humanity seemed entrenched and relatively impervious to change. Nevertheless, environmentalism died hard, lingering until the turn of the century. As Diane B. Paul commented, "Scientific theories are socially plastic; they can be and frequently are turned to contradictory purposes. Thus, we should not expect absolute correlation between scientific and social views." 24 Neither should we expect immediate changes, rather than gradual evolution. By the turn of the twentieth century hard heredity converged with apparently rising social unrest to create the specter of various "menaces" threatening society. In short order, Americans confronted the

\footnotetext{
${ }^{24}$ Paul, Controlling Human Heredity, 44-45.
} 
"menaces" of feeblemindedness, irnmigration, the so-called Negro Problem and Girl

Problem, as well as the menace of contagious diseases like tuberculosis, syphilis, and gonorrhea. Even as some scientists used Weismann and Mendel's theories to justify social inequality and the fixity of class stratification, the same theories also explained social turmoil in hard hereditarian terms. The "best" people were not reproducing fast enough, failing to propagate "favorable" traits throughout the population. The "worst" people reproduced rapidly, increasing the incidence of socially maladaptive traits, which manifested themselves in increasing rates of crime, pauperism, immorality, and unruliness that often presaged social revolution. For hard hereditarians, eugenics provided the only salvation.

Eugenics, the science of human improvement through breeding, is at least as old as Plato, but the modem iteration of the notion is commonly attributed to Sir Francis Galton. ${ }^{25}$ In 1883, Sir Francis Galton, English scientist and cousin of Charles Darwin, coined the word "eugenics," from the Greek word for "well-born." Galton wanted a "brief word" to describe, "the science of improving the stock." The proposed improvement, Galton believed, "is by no means confined to questions of judicious mating," but

${ }^{25}$ Daniel J. Kevles, In the Name of Eugenics: Genetics and the Uses of Human Heredity (New York: Alfred A. Knopf, 1985), ix and Chapter 1. The traditional standard scholarly works on the history of eugenics, in addition to Kevles's fine book, include: Richard Hofstadter, Social Darwinism in American Thought (Philadelphıa: University of Pennsylvania Press, 1944); Mark Haller, Eugenics: Hereditarian Attitudes in American Thought (New Brunswick, NJ: Rutgers University Press, 1963); Kenneth M. Ludmerer, Genetics and American Society: A Historical Appraisal (Baltimore and London: The Johns Hopkins University Press, 1972); and Alan Chase, The Legacy of Malthus: The Social Costs of the New Scientific Racism (New York: Alfred A. Knopf, 1977). A new wave of scholars has produced a series of important reinterpretations of the American eugenics movement, the most significant of which include: Gallagher, Breeding Better Vermonters; Steven Selden, Inheriting Shame: The Story of Eugenics and Racism in America (New York: Teachers College Press, 1999); Diane B. Paul, The Politics of Heredi:y: Essays on Eugenics, Biomedicine, and the Nature-Nurture Debate (Albany, NY: State University of New York Press, 1998); Paul, Controlling Human Heredity (1995); Nicole Hahn Rafter, Creating Born Criminals (Urbana and Chicago: University of Illinois Press, 1997); Marouf A. Hasian, The Rhetoric of Eugenics in Anglo-American Thought (Athens, GA: The University of Georgia Press, 1996); Martin Pemick, The Black Stork: Eugenics and the Death of "Defective" Babies in American Medicine and Motion Pictures Since 1915 (New York and London: Oxford University Press, 1996); and Edward J. Larson, Sex, Race, and Science: Eugenics in the Deep South (Baltimore and London: The Johns Hopkins University Press, 1995). 
considered also "all the influences that tend. . to give the more suitable races or strains of blood a better chance of prevailing speedily over the less suitable than they otherwise would have had." 26 An astute observer and inveterate quantifier, Galton noted that "genius" seemed to run in families. Positing a relation between the pattems he observed among the British aristocracy and his cousin's theory of evolutionary selection, Galton attempted to develop a mathematically-based system to predict and control the inheritance of physical and mental characteristics. Though his initial analysis revealed that intelligence was inheritable, he failed to establish a method for systematically "breeding" people with increased intelligence. ${ }^{27}$

Two developments rescued Galton's eugenical aspirations from the empirical ash heap. First, Karl Pearson, Galton's protégé and a more serious mathematician, refined Galton's statistical analysis. ${ }^{28}$ Now it appeared that, through careful choice of partners, parents could pass desirable traits on to their children-traits the children might then pass on to future generations. Second, the rediscovery of Mendel's theories and the nearly concurrent development of intelligence tests seemed to provide a way to both predict and measure "genius." Mendel's theory presumably clarified the identification of and breeding method for given hereditary traits. Intelligence tests, especially in the American environment, purported to measure inborn, hereditary intelligence. A shotgun wedding between

${ }^{26}$ Sir Francis Galton, Inquiries into Human Faculty and Its Development (London: J. M. Dent and Sons, Ltd., 1883; reprinted New York: E. P. Dutton and Co., 1908; reprint of 1908 reprint, New York: AMS Press, 1973), 17.

${ }^{27}$ Galton published his first book-length study relating "genius" and lineage, Hereditary Genius, in 1869. Kevles, In the Name of Eugenics, 1-18.

${ }^{28}$ Kevles, In the Name of Eugenics, 31, 34-35. Pearson established the field of "biometry" marrying quantitative analysis to studies of evolution and heredity. Pearson revolutionized statistics, inventing the theory of multiple correlation and regression, and the chi-square test. 
Mendelian genetics and intelligence tests seemed to provide scientists with all the basic information necessary to begin breeding improved human beings. ${ }^{29}$

From its British origins, eugenics spread throughout the world, developing in distinct ways depending on the scientific and cultural context in which it grew. ${ }^{30}$ The split between so-called positive and negative eugenics characterized the science in every location.

Positive eugenics revolved around encouraging procreation among the "best" stock, primarily through education about one's "social duty" to reproduce, and pro-natalist schemes like tax breaks and subsidies for "fit" families with many children. Negative eugenics, the attempt to "cut off defective germ-plasm," sought to reduce procreation among the so-called "worst" stock. Negative measures ranged from institutional segregation for the duration of one's procreative life to compulsory sterilization, birth control, and even euthanasia. ${ }^{31}$ The balance between positive and negative measures in any proposed program of applied eugenics depended in large measure on social context.

British eugenics differed in important aspects from its American counterpart. This division had as much to do with national social and political structure and cultural norms as

${ }^{29}$ Developed in France by Alfred Binét, intelligence tests were initially user to identify children at risk of falling behind their age cohort in school. Introduced to America by Henry Herbert Goddard and revised by Lewis Terman, the technology rapidly took on an aspect never intended by its French inventor-the diagnosis of children as permanently "backward" whose scholastic "retardation" actually indicated an inborn mental debility. See Steven Jay Gould, The Mismeasure of Man (New York: W. W. Norton \& Company, 1981; revised and expanded, 1996), Chapter 5; and Leila Zenderland, Measuring Minds: Henry Herbert Goddard and the Crigins of American Intelligence Testing (Cambridge and New York: Cambridge University Press, 1998).

${ }^{30}$ Richard A. Soloway, Demography and Degeneration: Eugenics and the Declining Birthrate in Twentieth-Century Britain (Chapel Hill, NC and London: University of North Carolina Press, 1990; reprint ed., 1995) presents an excellent social history of eugenics in its homeland. Kevles documents the comparative British/American history. For other international, comparative studies see, Gunnar Broberg and Nils Roll-Hansen, Eugenics and the Welfare State: Sterilization Policy in Denmark, Sweden, Norway, and Finland (East Lansing, MI: Michigan State University Press, 1996); Nancy Leys Stepan, The Hour of Eugenics: Race, Gender, and Nation in Latin America (Ithaca, NY and London: Comell University Press, 1991); Mark B. Adams, The Well-Born Science: Eugenics in Germany, France, Brazil, and Russia (New York: Oxford University Press, 1990); and Robert N. Proctor, "Eugenics among the Social Sciences: Hereditarian Thought in Germany and the United States," in JoAinne Brown and David K. VanKeuren, eds., The Estate of Social Knowledge (Baltimore, MD and London: Johns Hopkins University Press, 1991), Chapter 9.

\footnotetext{
${ }^{31}$ Kevles, In the Name of Eugenics, 85.
} 
it did with scientific methodology. ${ }^{32}$ Consonant with the entrenched class structure framing British society, British eugenicists emphasized class distinctions as markers of genetic fitness. As a result, Galtonian eugenicists concentrated on positive rather than negative eugenics, hoping to increase the birth rates among the upper class, whose status "proved" their genetic worth. Intelligence tests and Mendelian studies of inherited intelligence threatened the foundation of Galtonian eugenics, because they tended to uncover the existence of "fitness" in lower-class individuals. Karl Pearson and the Galtonians preferred their biometric studies-which relied on statistical relations rather than genetic pedigree studies_-because they tended to reinforce what they already knew, viscerally, as Englishmen. Nevertheless, British eugenics underwent an internal schism that separated the Galtonian biometricians from those scientists who followed the Mendelian school. ${ }^{33}$ Moreover, negative eugenics programs would depend on passing national laws in Britain. This represented a tall order, since in the British context extreme eugenic pronouncements effectively damned the House of Commons to genetic inferiority. 34

American eugenics, in contrast to its British progenitor, emphasized genetics, race above class, and "negative eugenics." Social mobility, not class hierarchy, underpinned the American cultural mythos. ${ }^{35}$ The rugged individual, the "self-made man," and the so-

32 Soloway, Demography and Degeneration, 36-37.

${ }^{33}$ Prominent among these eugenicists were sexologist Havelock Ellis, physician Caleb W. Saleeby, and playwright George Bernard Shaw, as well as the founders of the Eugenics Education Society. Ibid., 3137.

${ }^{34}$ Soloway tracks the British attempt for a voluntary sterilization law for "alleged defectives," a much milder law than its American analog, which still failed to pass. This had much to do with the changing political context in Britain; as socialism became a viable political impulse, negative eugenics became increasingly untenable. Ibid., especially 203-15.

35Indeed, Martin J. Burke argues in, The Conundrum of Class: Public Discourse on the Social Order in America (Chicago: University of Chicago Press, 1995), the "conundrum of class" posed by William Graham Sumner is irresolvable: a language of and about class will always be at odds with the notion that America is a "classless" society - with classless defined as the possibility of upward and downward mobility. Any attempt to categorize society into different groups will necessarily bring forward visions of 
called rags-to-riches stories of Horatio Alger stood at the center of the American cultural landscape in memory if not in reality. Mendelian genetics and intelligence testing allowed American eugenicists to explain this social mobility as a function of genetics, while simultaneously normalizing established racial hierarchies. The opportunity for class mobility existed, under the eugenic scheme, if not for oneself then for one's progeny. Moreover, by emphasizing racial differences, eugenicists bought into the long-standing American tradition of using race to resolve white class tensions. Whiteness, even more than class status, became the first marker of genetic fitness. The coincidence of "favorable" genes from otherwise "inferior" parents accounted for the careers of American "self-made" men and the existence of "superior strains" within races. Although American eugenics maintained its own class dynamic, race remained a focus for American eugenical policy. ${ }^{36}$

The American marriage of Mendelian genetics and intelligence testing "proved" what scientists long suspected: heredity produced qualitative differences between races that transcended class, culture, or environment. ${ }^{37}$ This new knowledge led to various racial taxonomies that conflated ethnicity, nationality, and race. The archetype of these

class divisions and cause tension with America's egalitarian ideal. While Burke examines the evolution and permutations of language and theories regarding class in America from 1760 through 1890, I believe his line of analysis can be extended through the early twentieth century, shedding light on ti:e way eugenicists invoked the language of class. Eugenicists understood the "conundrum of class" implicitiy, and hence relied on science to "naturalize" and neutralize class. If class differences resulted from biology, they did not exist because some groups traduced American egalitarianism to subjugate other groups.

${ }^{36} \mathrm{Kevles}$ points out this distinction, In the Name of Eugenics, 75-76. Americans emphasized race, a hierarchy most wanted maintained, while they lessened the emphasis on class as a concession to the American democratic tradition. Thomas F. Gossett also identifies this dynamic in, Race, 162-75, and Chap. 15. See Selden's discussion of "rational equalitarianism" in, Inheriting Shame, 118-21.

${ }^{37}$ The "scientific" differentiation of races ultimately rested on the analysis of IQ tests administered to African American and white inductees during World War I, and to Jewish immigrants in the early 1920s. Stephen Jay Gould develops the links between hereditary determinism, eugenics, and psychometry in The Mismeasure of Man, Chapter 5. Nicole Hahn Rafter gathered the eugenic "family studies" that purported to demonstrate these phenomena in, White Trash: The Eugenic Family Studies, 1877-1919 (Boston, 1988). Eugenically-minded scientists conflated the "Nordic ideal"—claiming the intellectual superiority cf people with northeastem-European heritage-with Mendelian genetics. Harvard-educated biologist Charies B. Davenport pushed Mendelism to its extreme by associating highly complex traits-like "nomadism" and the tendency to anger-to unit characteristics. Many other early American eugenicists followed his lead. John Higham discusses Mendelism's importance in establishing the racist dimension of American eugenics in, Strangers in the Land: Patterns of American Nativism 1860-1925 (Westport, Conn., 1963), 150-52. 
categorizations ranked the "races" in descending order from northwestern Europeans to southeastern Europeans, Jews, Native Americans, Asians, Malaysians, and finally

blacks. ${ }^{38}$ In light of racial intermixture in America, American eugenicists accepted positive eugenics, but also vigorously promoted negative eugenics: the elimination of "defective germ plasm" through sterilization, immigration restriction, institutional segregation, and bans on interracial marriage.

American eugenicists re-characterized the American "melting pot" as "race suicide. "39 Careless breeding across racial lines, and the apparent propensity of poor people to give birth to more children than wealthy people, convinced eugenicists that the "best stocks" faced extinction. The mythic "melting pot" was creating, in their view, not a strong racial alloy but a weak amalgam. Eugenicists sought to halt the damage through eugenic education that would result in the passage of appropriate legislation. Virginia eugenicists adhered to this model. While Virginia's scientific racism originated in Jefferson's Notes on the State of Virginia, twentieth-century eugenics represented cutting-edge racial science, as opposed to outmoded theories based on craniometry and rudimentary comparative anatomy. ${ }^{40}$ Virginia scientists adopted these new doctrines, taught them to their students, acted upon them in medical practice, and lobbied for the passage of eugenically informed social policy.

\footnotetext{
${ }^{38}$ This is merely a representative taxonomy that had wide currency during the first third of the twentieth century. See Robert Bennett Bean, The Races of Man: Differentiation and Dispersal (New York: The University Society, Inc., 1932), 86. Bean's ree of races is quite elaborate. Other systems ranged between the simple tri-partite division of white, yellow-red, and black to schemes with dozens of different strata. For a complete history of the idea of race and racial taxonomy, see Gossett, Race.

${ }^{39}$ Sociologist and eugenics supporter Edward Alsworth Ross coined the term "race suicide" in his address "The Causes of Race Superiority." President Theodore Roosevelt, another supporter of eugenics, popularized the phrase and alerted Americans to the "racial danger" they faced. Gail Bederman, Manliness and Civilization: A Cultural History of Gender and Race in the United States, 1880-1917 (Chicago and London: The University of Chicago Press, 1995), 200.

${ }^{40}$ The evolution of earlier forms of scientific racism into eugenics is covered in Gould, Mismeasure of Man, 51-141. See also Rafter, Creating Born Criminals, 1-34. American scientists developed agricultural and zoological laboratories to identify genetic traits-providing a "blueprint" for future breeding.
} 
Historian Daniel J. Kevles has written, "In the United States, eugenic politics and eugenic research were symbiotically linked." 41 That connection allowed eugenics to have a material impact on American law and society. Eugenicists' race- and class-based explanation of the social order whipped Americans' growing nativism and racism during the first third of the twentieth century. Eugenic appeals to racial integrity and "Nordic" superiority echoed white southem rhetoric regarding racial purity and Anglo-Saxon supremacy. Simultaneously, eugenics eased the merging of Virginians' regional identity with a new overarching identity of "pure," "100 percent Americanism." Scholars at elite northem institutions emphasized whiteness and Anglo-Saxon heritage in defining the American "race." 42 This redefinition resonated with the traditional white southem identity. Southern eugenicists applauded their northern compatriots who argued for the preservation of this distinctly "American" race. Fears of miscegenation-white intermarriage with inferior immigrant "races" or blacks—alarmed northemers and buttressed southem concerns about both African Americans and the eugenically-tainted "shiftless, ignorant, worthless class of anti-social whites of the South."43 Subsequently, American eugenicists, North and South, advanced notions of racial purity, using their theories about race mixing to shape public policy. Southern eugenicists drew analogies between racial segregation and

\footnotetext{
${ }^{41}$ Kevles, In the Name of Eugenics, 104.

${ }^{42}$ On increasing racism see, C. Vann Woodward, The Strange Career of Jim Crow, (3d. ed., New York and Oxford, 1974), Chap. 3; Higham, Strangers in the Land, 170-171; and Gossett, Race, 155-60. For a 1920s-era discussion of the "100\% American" identity, see Horace M. Kallen, Culture and Democracy in the United States (2d. ed.; New Brunswick and London, 1998), passim, especially 118-224. Harvard, Yale, Columbia, Princeton, and the American Museum of Natural History in Manhatian, served as home institutions to many prominent eugenicists. See, Eugenics Education Society, First International Eugenics Congress: Scientific Papers and Appendices (London: Eugenics Education Society, 1912).

${ }^{43}$ Eugenic Record Office Superintendent Harry Hamilton Laughlin characterized poor southem whites thus before the Circuit Court of Amherst County, Virginia during the 1924 hearings of Buck v. Bell, the case that established the constitutionality of Virginia's eugenic sterilization law. Laughlin, quoted in Paul A. Lombardo, "Three Generations, No Imbeciles: New Light on Buck v. Bell," New York Law Review, LX (April 1985): 51.
} 
northem efforts for immigration restriction, institutionalized segregation of mental patients, and restrictive marriage laws. ${ }^{44}$

Confronting the tensions between "Old South" traditions and "New South" dislocations, eugenics mediated between "Progressive" liberalism and the self-consciously "backward" Agrarian reaction. Adopting eugenics allowed southerners to undercut the northem characterization of the South as, "a section stubbornly dissenting from-and sometimes defying - the nation's progressive achievements and ideals." 45 Eugenics provided a potential solution for nettlesome social problems-dispensing with poor white trash and the "Negro Question"—while ushering in "modem" liberal-industrial society in one motion. Eugenics, a modem science, legitimized dominant social prejudices by justifying widely-held beliefs through apparently objective, scientific observations. ${ }^{46}$ The racism of eugenics reinforced the social hierarchy that elevated elite whites, extolled pacific whites as "fit," and labeled troublesome whites, poor whites, and all others as genetic defectives needing control. ${ }^{47}$

The eugenicists' appeal to scientific expertise to achieve "social efficiency" mirrored both "liberal" and "conservative" reform movements during the Progressive Era.

Progressivism is a nebulous term used to describe a diffuse movement comprised of mixed

\footnotetext{
${ }^{44}$ Without ever mentioning the role of eugenics in easing the sectional rapprochement, Dewey Grantham noted, "Pseudoscientific racial arguments in the North, for example, combined with the southern assertion of white rule over 'colored people' to create a nationalism of race and to encourage the more complete incorporation of the South into the nation." Dewey W. Grantham, The South in Modern America: A Region at Odds (New York: HarperCollins Publishers, 1994), 104.

${ }^{45}$ Grantham, South in Modern America, xvi.

${ }^{46}$ Edward A. Purcell, Jr., identified an important corollary of this dynamic. Scientists' "belief in the new objectivity opened the way for a practical role in society and possible ultimate realization of the methods of control, while at the same time suppressing any moral or social doubts about the actual consequences of their actions." Scientists simultaneously gained access to power and immunized themselves against being held accountable for the exercise of that power. Edward A. Purcell, The Crisis of Democratic Theory: Scientific Naturalism and the Problem of Value (Lexington, Ky., 1973), quotation 26, and 239-41.

${ }^{47}$ See Garland E. Allen, "The Misuse of Biological Hierarchies: The American Eugenics Movement, 1900-1940," History and Philosophy of the Life Sciences 5 (1983): 105-28.
} 
ideologies. Generally, progressivism may best be reduced to an idealistic, middle-class social impulse that emphasized the use of scientific expertise, exercised through bureaucratic institutions, to effect broad social reforms. Progressivism, like hereditarian thought, came in two forms, soft and hard. Soft progressives tended to emphasize qualitative, environmentalist reform and moral suasion, exemplified by the settlement house program of urban relief initiated by Jane Addams. Hard progressives focused more on overt social control backed by quantitative, scientific justifications for action; Frederick Winslow Taylor's famous time-motion studies establishing "efficient" work habits embodied the hard progressive tendency. Both forms attracted adherents across the political spectrum, although hard progressivism is most often associated with conservative politics and soft progressivism with liberal politics. ${ }^{48}$ Eugenics fit well within the hard progressive emphasis on quantitative, scientific study and expert control. Simultaneously, however, most eugenicists acknowledged that qualitative environmental improvements would ultimately aid the eugenic program. Politically, eugenics, like progressivism, appealed across the ideological spectrum. This broad consonance helped eugenics to win large numbers of influential adherents to the cause.

\footnotetext{
${ }^{48}$ Many historians, including the principal historian of eugenics in the Progressive Era, have commented on the ambiguous meaning of the term Progressivism. It is particularly difficult to use a single term to identify the congeries of beliefs that are often lumped under its rubric. Pickens, Eugenics and the Progressives, 18. See Arthur S. Link and Richard L. McCormick, Progressivism (Arlington Heights, IL: Harlan Division, Inc., 1983); and Robert H. Weibe, The Search for Order, 1877-1920 (New York: Hill and Wang, 1967), especially Chapters 7 and 8 . The rise of expert authority is treated in Thomas L. Haskell, ed., The Authority of Experts: Studies in History and Theory (Bloomington, Ind.: Indiana University Press, 1984) 28-80, and 180-22.5. See also the essays in, Ronald G. Walters, ed., Scientific Authority and Twentieth-Century America (Baltimore and London, 1997). The search for social "efficiency," so similar to Frederick W. Taylor's scientific management, was a familiar cencept in the technocratic culture of the 1910s and 1920s. Eugenics held appeal across the political spectrum, not just for conservatives as in this case. See Diane B. Paul, "Eugenics and the Left," in Paul, Politics of Heredity, 11-35. The "conservation" of America's "human capital" echoed the Progressive efforts of Theodore Roosevelt, Gifford Pinchot, and Margaret Sanger, all eugenics advocates. Gary Brechin, "Conserving the Ráce: Natural Aristocracies, Eugenics, and the U.S. Conservation Movement," Antipode, XXVIII (Summer, 1996): 236. Pickens, Eugenics and the Progressives, 83. See also, James W. Trent, Inventing the Feeble Mind: A History of Mental Retardation in the United States (Berkeley, 1994), 137.
} 
Progressive southemers working for the socio-economic advancement of the South echoed all of these ideas. ${ }^{49}$ Virginia, a state with an established history of control by "enlightened" elites, embraced both the Progressive and eugenics movements. Reconciling Progressive Era modernism with traditional social hierarchies, eugenics charted an ideological course between the self-consciously "backward" southern Agrarian impulse and the emerging modernist impulse embodied in science and organizational synthesis. This "middle passage" allowed Virginians to adopt ideas that many southerners derided as "northem," like economic liberalism, industrialization, and urbanization. Eugenic theories persuaded many otherwise resistant southern whites to support the invasive state interventions generally favored by Progressive reformers. Although eugenic legislation challenged traditions of local control, it sounded many of the major chords of southern society: white supremacy, patemalism, and the myth of a predatory, atavistic AfricanAmerican population. Through eugenic government action, theci neld, Americans would become racially and democratically homogenous. ${ }^{50}$

\footnotetext{
${ }^{49} \mathrm{Grantham}$ 's excellent study sheds light on the role progressive ideology played in shaping the New South. Grantham, South in Modern America, 23-116. See also William A. Link, The Paradox of Southern Progressivism, 1880-1930 (Chapel Hill, NC and London: University of North Carolina Press, 1992); Edward L. Ayers, The Promise of the New South: Life After Reconstruction (New York and London: Oxford University Press, 1994), 413-22.

${ }^{50}$ This argument differs from Edward J. Larson's study of deep-southern eugenics in, Sex, Race, and Science. Nevertheless, these conclusions would tend to support Larson's regional distinctions. Unlike the Deep South, eugenics found great support in Virginia and North Carolina, the Progressive "upper South." Elites in these states readily embraced Progressive liberalism without adopting racial liberalism. While few whites, North or South, can be characterized as committed racial liberals-those favoring immediate equalization of all civil and social rights-during the first half of the twentieth century, "southern liberalism" had a decidedly conservative cast. See Virginius Dabney, Liberalism in the South (Chapel Hill: University of North Carolina Press, 1932) for an analysis of the conservative nature of southern liberalism. In 1930, the "Vanderbilt Agrarians," in the wcrds of Paul M. Gaston, "projected their hostility to moderm industrial America into a generalized picture of the Southern past which portrayed agrarianism as the decisive factor in the region's development." Gaston, New South Creed, 10. The Agrarians, like most southerners, remained wedded to the traditional racial order. For the Agrarians' manifesto, see, Twelve Southerners, I'll Take My Stand: The South and the Agrarian Tradition (New York: Harper and Brothers, 1930).William A. Link explores these tensions throughout The Paradox of Southern Progressivism. Paul M. Gaston explains the tensions between modernity and tradition in southern mythology - in some ways the root of southern identity formation-in, The New South Creed: A Study in Southern Mythmaking (New York: Vintage Books, 1970). The most instructive interpretation of the forging of the "modern" southern identity, and its ultimate reconciliation with the modern "American" identity, both being predicated on whiteness, is Grace Elizabeth Hale, Making Whiteness: The Culture of Segregation in the South,
} 
Even as white Virginians gravitated toward a more modem model of social

organization, they feared its effect on long-standing institutions of social deference.

Urbanization and industrialization seemed to ignite class tensions that, while always simmering under the surface, had not seriously disrupted white Virginia's social cohesion since the departure of West Virginia. The emigration of poor whites and blacks to urban areas, where they were concentrated in incipient racial and class ghettos cast class and race distinctions in sharp relief. Those left in rural areas seemed mired in a bog of disease, ignorance, and quasi-fundamentalist religious conservatism. Eugenical theory permitted modern, "enlightened" Virginians to view these remnants of "poor white trash" as genetically unfit and undeserving of any consideration. Elite whites spoke about the rural poor as if they desired to live in squalor; fundamentalists were characterized as low-brow ignoramuses, just one step ahead of the feeble-minded, and probably as deserving of sterilization. These same elites portrayed rural blacks as shiftless and improvident, while urban blacks became razor-wielding sexual predators. In either case the best course was eugenic elimination. Virginia's small Native American population, seen as an unstopped conduit allowing "negroes" to pass into white society, earned the sobriquet Mongrel Virginians and became a special target for eugenic reform. ${ }^{51}$

1890-1940 (New York, 1998). Hale only obliquely considers how formal education and scientific theories shaped southern whiteness and eased the transition to modernity, preferring a cultural analysis of other phenomena, such as fiction, consumption, and spectacle lynchings. Nevertheless, the following analysis is broadly consonant with her major arguments.

${ }^{51}$ Arthur H. Estabrook and Ivan E. McDougle, Mongrel Virginians: The Win Tribe (Baltimore: The Williams ar.d Wilkins Company, 1926). J. David Smith engages similar ideas in his book The Eugenic Assault on America: Scenes in Red, White, and Black (Fairfax, VA: George Mason University Press, 1993). Smith's emphasis that Virginia eugenicists sought to control the Native American population fits well with this study; officials feared white/Native American intermarriage because they already believed Native Americans were genetically tainted by previous intermarriage with blacks. Smith, howaver, claims prejudice is a form of "mental illness" and often a "shared mania" (Smith, xiii). Such an explanation trivializes racism and exculpates racists; racism is taught, learned, and consciously passed on by those whose interest it serves. This dissertation portrays this ideological transmission from expert authorities to the rising generation of educated elites. Such theorizing and teaching was bound up with a self-conscious attempt to reconstruct an identity that was simultaneously white, southern, and modern. It also shored up the traditionai socio-economic privileges of Virginia's elite during a time when an expanding middle class appeared to threaten the status of many elites. 
The racial theories of eugenics helped Virginians bridge the cultural divides separating both the "Old South" from the "New South" and the South from the North. Virginia's experience with eugenics highlights the convergence of self-proclaimed "southem exceptionalism" with a more homogenous national norm. Virginia eugenics thus forged an ideological amalgam; a scientific, rational, patemalistic, progressive reform of Virginia's economic and social life that was inextricably linked to hardening class, gender, and racial hierarchies. Eugenics also provided Virginia elites with a new creed that fused liberal Protestant religious beliefs with positivist, rational scientism to justify observed social inequalities as the logical expression of underlying natural-and hence moral-law. The explanatory power of the eugenics creed created generations of Virginians who believed in the scientifically-verified, hereditary inequality of individuals and races. This true belief in eugenics prompted Virginians to enact its racialist theories in statutes providing for the compulsory sterilization of the so-called feebleminded, and a law forbidding marriage between whites and members of any other race. These acts, applauded by nationally and internationally prominent scientists, placed Virginia in the van of scientific, biologicallyguided, social engineering.

Eugenics appealed to white Virginians because it drew on a familiar idiom. When one reads and re-reads the eugenics sources, it becomes evident that much of eugenics' power emanated from the language and rhetorical constructions used to embody the idea of "improving the race."52 Moreover, anyone familiar with the work on race and gender in

\footnotetext{
${ }^{52}$ This is not a new observation. Martin Pernick's powerful analysis of eugenical rhetoric, along with the path-breaking linguistic analysis of Marouf A. Hasian has informed my own work. My iteration, below, of the "eugenic metaphor" is also the result of my collaboration with Paul A. Lombardo. By focusing on individual words and their relationships across contexts, I extend the analysis of eugenic discourse to reveal how it provided a matrix for understanding contemporary society, and the interaction of science and society, on a number of levels. Martin S. Pernick, The Black Stork: Eugenics and the Death of Defective Babies in American Medicine and Motion Pictures Since 1915 (New York and Oxford: Oxford University Press, 1996), and Martin S. Pernick, "Eugenics and Public Health in American History," American Journal of Public Health 87 (November 1997): 1767-72; Marouf A. Hasian, The Rhetoric of Eugenics in Anglo-American Thought (Athens, GA: The University of Georgia Press, 1996); and Paul A. Lombardo and Gregory Michael Dorr, Untitled TMs, in author's possession. See also Eva Marie Saks, "Representing Miscegenation Law," Raritan 8 (1988), 39-69.
} 
American history is compelled to acknowledge the power of language in constructing racial and gender identities and stereotypes, and the influence those identities exerted upon society. ${ }^{53}$ Language has also been central to the articulation of regionally-inflected race, class, and gender identities, a consideration of prime importance in the present study.

Eugenics stands as an obvious example of the long rhetorical development that understood humanity as the collective product of inborn essences. Eschewing environmentalism and embracing hereditarianism, eugenicists reduced the philosophical problem of human perfectionism from a moral to a physical plane. Breeding, not religion, would effect humanity's salvation. Humankind's improvement depended not on the inculcation of a fine moral sense through exposure to wholesome religious experience. Instead, eugenicists argued that human perfection-physical, intellectual, moral, and social-would result from increasing the "amount" of these traits through proper breeding. To promote their views, eugenicists developed and deployed a specific rhetorical construction that enunciated their understanding of the world; I refer to this as the "eugenic metaphor." The eugenic metaphor melded elements of political, economic, scientific, medical, and popular discourse together into a language that reduced the complexities of

\footnotetext{
${ }^{53}$ Pioneered by Michel Foucault and Jaques Derrida, discourse analysis views language and culture as constitutive of power relationships. Beyond institutional structures (or perhaps beneath them), language shapes and constrains the realm of possible actions by limiting the very terms used to think about society. This dissertation is deeply influenced by Michel Foucault, The Birth of the Clinic: An Archaeology of Medical Perception, trans. A. M. Sheridan (New York: Vintage Books, 1994). Discourse analysis has been central to gender, race, and cultural history since their inception as sub-fields. Given the body of important work in these areas, listing even a representative sample is impossible. My work has been influenced primarily by Carole Pateman's The Sexual Contrart (Stanford, CA: The Stanford University Press, 1988); Charles W. Mills, The Racial Contract (Ithaca, NY and London: Cornell University Press, 1997); Hale, Making Whiteness; David R. Roediger, The Wages of Whiteness: Race and the Making of the American Working Class (London and New York: Verso Books, 1991) and Roediger, Towards the Abolition of Whiteness: Essays on Race, Politics, and Working Class History (London and New York: Verso Books, 1994); Eric Lott, Love and Theft: Blackface Minstrelsy and the American Working Class (New York and Oxford: Oxford University Press, 1993); Robin D. G. Kelley, Race Rebels: Culture, Politics, and the Black Working Class (New York: The Free Press, 1994); and Daryl Michael Scott, Contempt and Pity: Social Policy ani the Image of the Damaged Black Psyche, $1880-1996$ (Chapel Hill, NC and London: The University of North Carolina Press, 1997). The first book that convinced me of the power of language and ideas to create a culturally inflected political response was Bernard Bailyn, Ideological Origins of the American Revolution, enlarged ed., (Cambridge, MA and London: The Belknap Press of Harvard University Press, 1992).
} 
modem human life to the relatively simple problems facing the individual farmer-

Jefferson's ideal republican, the yeoman. This new language built upon existing linguistic traditions that described the polity in organic terms, and depicted social intervention as medical therapy. Using the familiar language of breeding, genealogy, and illness/health the eugenic metaphor facilitated the redefinition of citizenship. The eugenic metaphor defined who was and who was not "fit" to be a full member of the polity, marginalizing and attempting to control all "unfit" individuals by using biological determinism to undercut their claims to equal human and civil rights.

Eighteenth-century Anglo-European concepts of society as a living organism transformed, over the course of the 19th and 20th centuries, into the eugenic metaphor. Beginning with the socio-political notion of the "body politic," European political philosophers began merging biological and political notions. ${ }^{54}$ If society was indeed analogous to a living organism, then the next logical step was to construe social problems as equivalent to physical illnesses. Social intervention by government was thus similar to the medical intervention of a physician, instituting therapy to cure a sick patient. Politics, biology, and medicine began to join in the definition of a quasi-biological understanding of social organization. This trend would accelerate throughout the 19th century, as first evolutionary and then Darwinian and Spencerian concepts of social transformation began to permeate the discursive realm of politics. 55

\footnotetext{
${ }^{54}$ For examples of the early use of organic metaphors in European political and cultural discourse, see Jonathan Gil Harris, Foreign Bodies and the Body Politic: Discourses of Social Pathology in Early Modern England (London and New York: Cambridge University Press, 1998); Antoine De Baecque, The Body Politic: Corporeal Metaphor in Revolutionary France, 1770-1800, trans. Charlotte Mandell (Starford, CA: Stanford University Press. 1993); Laura Otis, Membranes: Metaphors of Invasion in Nineteenth-Century Literature, Science, and Politics (Baltimore and London: The Johns Hopkins University Press, 1999).

${ }^{55}$ Evolutionary ideas predated Darwin, who identified not evolution, but a plausible mechanism driving evolutionary change, the phenomena of natural selection favoring random variation. Excellent books debating the impact of Darwinian and Spencerian thought on Anglo-American culture and politics include, Numbers, Darwinism Comes to America; Michael R. Rose, Darwin's Spectre: Evolutionary Biology in the Modern World (Princeton, NJ: Princeton University Press, 1998); Edward Caudill, Darwinian Myths: The Legends and Misuses of a Theory (Knoxville, TN: University of Tennessee Press, 1997); and Carl N. Degler, In Search of Human Nature: The Decline and Revival of Darwinism in American Social Thought (New York and London: Oxford University Press, 1991). Robert Bannister's important, iconoclastic, and oftentimes frustrating Social Darwinism: Science and Myth in Anglo-American Social Thought
} 
The language of incipient genetics and eugenics facilitated the eventual convergence between public policy, scientific theory, and popular culture. Using familiar images and concepts that resonated with the "common knowledge" and "conventional wisdom" among both educated and uneducated people, eugenicists gamered a broad base of support. The trajectory of language moved from genealogy to animal breeding to genetic heredity to "family studies" of genetic genealogy in near circular fashion. Early commentators on genealogy used phrases like "blood lines" and "pedigree" in tracing the "heritage" and "heredity" of individuals over time. Animal breeders began eliding the distinction between the human and non-human life by borrowing the terminology of genealogy to describe their endeavors. Good "strains" of animals "descended" from "noble sires" and evinced a good "heredity" in the sense of a strong familial "lineage" or "pedigree." Borrowing words from the barnyard, early geneticists and eugenicists' used familiar, homely terms like "stock," "breeding," "race," and "family."

Eugenicists also appropriated the established language of "blood," "kin," and genealogy to explain complex notions of genetics, hybridization, speciation, and heredity. Simultaneously, the language of agriculture and medicine converged in early genetics, as "germ," the term for a plant's seed, came to describe both bacteriological organisms and, slightly modified to "germ-plasm," the matter responsible for heredity. These words retained a familiarity, with slightly (but not insignificantly) varying meanings-depending on who invoked them, the context in which they were used, and who heard them. ${ }^{56}$ When

(Philadelphia: Temple University Press, 1979) remains an important revision clarifying how Darwinian and Spencerian ideologies operated or, more often in Bannister's view, failed to operate in shaping sociopolitical discourse and policy. Much of the debate over so-called Social Darwinism misses the point. Regardless of the intentions of either Darwin or Spencer, or of other scientists for that matter, politicians and lay people appropriated and adapted the language and concepts of both men. These individuals used Darwinian and Spencerian language to describe their vision of how society was and how it should be. These political permutations of scientific rhetoric had tremendous intended and unintended effects on social policy and cultural responses to the rapid and widespread changes facing society between 1880 and 1920.

56 Galton's works are rife with the eugenic metaphor. See, for example, Galton, Inquiries into Human Faculty, 198-200. To see this language in action in America, one need only pick up an issue of the American Breeders Magazine (later, The Journal of Heredity), or any early work on genetics or eugenics. See, for instance, William E. Castle, et. al., Heredity and Eugenics (Chicago: The University of Chicago 
cast in the eugenic metaphor, these terms made complex biological phenomena readily

accessible to lay people, while the eugenicists' social control agenda remained embedded in the language. This made it increasingly difficult for those targeted by eugenics to realize their position. Thus, for instance, uneducated, poor farmers could wander through the eugenics exhibition at their state fair, see the displays of stuffed guinea pigs explaining heredity, and make the connection between animal breeding and human procreation. These same farmers could then see the charts depicting the heredity of "defectiveness" and, based on their own experience with animal breeding, agree with the eugenicists that "culls"whether human or animal — should be eliminated. Many of these individuals would participate in the "Fitter Families Contests," which looked so familiar in format because they mirrored stock judging competitions, allowing themselves to be evaluated like animals. Yet, these same farmers, because eugenics resonated strongly with their own common sense, might never realize the full implications of their failure to win a Fitter Families Contest. Such a result might indicate that they, themselves could fall into the category of the "unfit" and be subject to eugenic culling. 57

Even as nineteenth-century biological science extended the earlier tradition of securing professional authority by developing and deploying new words-like "ontogeny" and "phylogeny" which mystified common ideas like "individual" and "family"-lay-people remained linguistically attuned and connected to the new science. ${ }^{58}$ The separation

Press, 1912); Edward Murray East and Donald F. Jones, Inbreeding and Outbreeding: Their Genetic and Sociological Signijicance (Philadelphia: J. B. Lippincott and Co., 1919).

${ }^{57}$ The American Eugenics Association and the Human Betterment Foundation sponsored traveling eugenics shows and "Fitter Families Contests" that toured state fairs. Eugenics exhibits also appeared at World's Fairs, and stood in thc halls of Congress during the debates over the 1924 Immigration Restriction Act. The most well dosumented of thcse fairs occurred ycarly at the Kansas Free Fair beginning in 1922. See "The Fitter Families Contest," Eugenical News 8 (September, 1923), 88; and Selden, Inheriting Shame, 23-37.

${ }^{58}$ The use of arcane terminology, foreign languages (particularly Latin and Greek), and advanced technology to mystify professional knowledge, rendering it inaccessible to non-specialists as a way to construct professional authority and limit access to expert knowledge, has been discussed in Burton Bledstein, The Culture of Professionalism (New York: W. W. Norton, Inc., 1976), 65-79, 90-104. Biology followed the examples of medicine and law when Swedish taxonomist Karl Linné's Latinate system of classification became the standard for all naturalists. Linné, of course, took this to an extreme, changing his own name to Carrolus Linnaeus, firmly placing himself within his system. 
between experts and lay observers remained incomplete because experts refused to use the new nomenclature to the exclusion of the older terminology. Thus, biologists often used familiar terms like "family" and "race" interchangeably with the more esoteric words "genus" and "species." Similarly, although William Bateson coined the word "genetics" in 1905 to describe the study of particulate heredity, geneticists continued to use older words derived from agriculture. 59 Thus, scientists studying genetics referred to the "germ-plasm" through the 1910s, invoking earlier bio-agricultural concepts of "germ" and "germination" familiar to most lay-people. Moreover, early geneticists appropriated "germ" at almost precisely the same time that medicine began to describe microscopic pathogens as "germs" in the 1870s and 1880s. The familiar word "germ" took on new, more precise and technical meanings when invoked by scientists. These "refurbished" words never lost their original meanings; new meanings were merely grafted onto the old words, which maintained a certain intuitive homology with the phenomena scientists wished to describe. Used by scientists, these refurbished words evoked not only their traditional meanings, but a new realm of denotation and connotation specific to the scientific study of heredity. In action, this language created a popular consensus favoring the acceptance of eugenic programs, although many in the public remained ignorant of the full implications of eugenic policy.

This linguistic transformation would have far-reaching effects, especially as eugenicists developed their ideas of applied genetics and heredity. In their attempt to transform eugenics into Galton's "secular creed"-a new religion based on biology not metaphysics-eugenicists ultimately relied on the blurred boundaries between scientific and lay discourse as they developed their "propaganda." 60 Couching complex genetic theories

\footnotetext{
${ }^{59}$ Hans Stubbe, The History of Genetics: From Prehistoric Times to the Rediscovery of Mendel's Laws (Cambridge, MA and London: The MIT Press, 1972), 272.

${ }^{60}$ The word "propaganda," in the early 20th centliry, existed free of its current negative connotations, which arose as the word was repeatedly used to describe Nazi and Soviet information control. Used by linguists like Alfred Korzybski, the father of "General Semantics," the term represented a "scientific" form of "moral suasion." Propaganda, in its original sense, resulted from using scientific knowledge of
} 
of inborn human inequality and relative "fitness" in the language of "thoroughbreds" and "culls" evoked an familiar mental images among Americans living in a predominantly rural America. 61

Using the ancient metaphor of "blood" to represent the vehicle of heredity obscured the more precise scientific mechanism of chromosomal genetics. Nevertheless, this notion of "blood" rendered genetics understandable to non-specialists. Americans, particularly those in the South, maintained a deep fascination with issues of genealogy and "kinship" expressed in terms of "bloodlines." 62 This fascination also resonated with stockyard breeding. Just as race-horses traced their "pedigrees" along a "bloodline," so too did people. To be of "good blood" meant approximately the same thing as being "eugenic" both individuals were considered "well bom." Similarly, to be of "bad blood," or to possess a mixture of "good" and "bad" blood, relegated one to a lower, sub-human level similar to what eugenicists termed "dysgenic" or "cacogenic."63 These rhetorical correspondences help to explain why America's first organized eugenics association began as a subsection of the American Breeders Association, and why the American Breeders Association Magazine morphed into the Journal of Heredity as the century progressed. Both the association and the journals juxtaposed plant, animal, and human genetics. ${ }^{64}$

Paradoxically, the eugenic metaphor had a specific effect despite arising from a language riven with potential imprecision and ambiguity. Eugenicists' rhetoric reflected the

psychology and semiotics to couch ideas in language that would ineluctably prod people to behave in predictable ways. In the 1920s and 1930s, propaganda and advertising merged; in the wake of the rise of totalitarian regimes in Russia, Germany, Italy, and Japan, propaganda took on its negative connotations.

${ }^{61}$ The majority of American citizens remained in rural areas until the 1920 census. Even then, many of the migrants swelling American cities came from rural areas in America or Europe. Familiarity with the rudiments of plant and animal breeding was thus nearly universal.

62It is unfair to limit this genealogical fascination to the South. The so-called Boston Brahmins and other pockets of New England elites were equally concerned with knowing each other's "blood" as any group in the South. Nevertheless, Edward J. Larson points out the southern tendency to fetishize kinship and "blood" in Sex, Race, and Science, 5-11.

${ }^{63}$ Cacogenic, the opposite of eugenic, means, literally, "bad kin." Like eugenics, it was coined from the Greek: "Kakos" (bad) and "Genos" (race, descent, kin, sex).

${ }^{64}$ See Mark Haller, Eugenics, 62-63; Pickens, Eugerics and the Progressives, 52-53. 
medical imagery long used to discuss social reform. By invoking the rhetoric of the eugenic metaphor, eugenicists appropriated the physician's gaze-which both perceived and constructed the world in terms of health and illness-and viewed the world through a new lens that merged biology, genetics, and medicine. The eugenicists gaze perceived the world in terms of "fitness" and "unfitness," and constructed "scientific," biological solutions to what were essentially political problems. ${ }^{65}$ Eugenicists inverted the older dynamics surrounding a "sick body politic," where politicians appropriated the language of medicine to posit policy "cures." Eugenicists diagnosed society, prescribed a policy cure justified by their understanding of biology, and then promoted it within a political arena that was willing to defer to "expert" authority. These eugenical pronouncements gained cultural force because many lay people believed they no longer reflected the whims of self-serving politicians, but rather derived from a purportedly objective, scientific study of conditions. Thus the eugenic cure would be literally permanent, whereas the traditional political nostrums lasted only as long as the ruling regime.

The language of the eugenic metaphor thus used science to render transparent the biases of both the eugenicists and their audience. Eugenicists invoked familiar terminology of the halcyon past, extolling "America's pioneer stock" when discussing the alarming phenomena of modern life like "race suicide." As a 1935 biology textbook noted, collapsing the old and the new into identity, "blood will tell, or rather to put it more scientifically, 'that the chromosomes will tell the story."'66 Students were led to believe that the old aphorisms now had scientific backing; old beliefs, in modern parlance, offered

\footnotetext{
${ }^{65}$ Michel Foucault's description of the creation and effect of the medical gaze holds for the eugenic metaphor: "A new alliance was forged between words and things, erabling one to see and to say. Sometimes, indeed, the discourse was so completely 'naive' that it seems to belong to a more archaic level of rationality, as if it involved a return to the clear, innocent gaze of some earlier, golden age." Foucault, Birth of the Clinic, xii. The formation of the medical gaze extended from that of the naturalist, because the clinician and naturalist must both be able "to see, to isolate features, to recognize those that are identical and those that are different, to regroup them, to classify them by species or families" (89).

${ }^{66}$ George William Hunter and W. G. Whitman, Science in Our World of Progress, quoted in Selden, Inheriting Shame, 74.
} 
solutions to social problems. Race suicide could be prevented (cured), eugenicist argued, by the application of positive and negative eugenic therapy: breed more fit and less unfit people. The eugenic metaphor's reliance on genealogy, breeding, and medicinal cures made both present tumult and the unknown future seem controllable-by understanding the "trend of the race" and breeding, people could work to shape their own destiny. ${ }^{67}$

Just as medical discourse normalized health and pathologized illness, eugenical discourse defined and identified genetically normal humans. It also valorized genetically exceptional individuals and demonized the genetically abnormal. This new function allowed eugenicists, like physicians, "not only to distribute advice as to healthy life, but also to dictate the standards for physical and moral relations of the individual and of the society in which he lives."68 By normalizing this hierarchical understanding of human genetic worth, eugenicists adopted more than the clinician's therapeutic gaze; they also appropriated the physician's cultural authority. Eugenicists emphasized prevention, and borrowed heavily from the lexicon the public health physician and sanitarian. Hard hereditarianism left little room for environment to change destiny. "You can't keep a good man down" became a rallying cry of eugenicists. Similarly, the only way to stop genetically "unfit" or "bad" people from pulling society down was to prevent their birth and curtail their procreation. In eugenic terms, the public health ultimately depended on directed human procreation, not mere environmental sanitation. Borrowing the language of Progressivism, eugenicists trumpeted the "social efficiency" to be achieved through such genetic selection.

As the 1900s tumed to the 1910s, and eugenics became a common subject for discussion in newspapers, periodicals, literature, movies, and academic journals, the eugenic metaphor reflected the shifting social preoccupation with "efficiency." Progressive

\footnotetext{
${ }^{67}$ Samuel J. Holmes, The Trend of the Race: A Study of the Present Tendencies in the Biological Development of Civilized Mankind (New York: Harcourt, Brace and Company, 1921).

${ }^{68}$ Foucault saw the physician's clinical gaze performing the same function, earlier in history. Foucault, Birth of the Clinic, 34.
} 
Era thinkers, whether in business, politics, science, or social reform, all emphasized the necessity of using scientific expertise to make life more pleasant by making living more efficient. In the medical field, this translated to a conviction that the best way to treat disease was to prevent morbid conditions from developing. Practically, this impulse led to the organization of schools of public health, the reorganization of the federal and state public health services, a fixation on public sanitation, and personal hygiene. Not surprisingly, mental health experts redefined their quest as "mental hygiene," and emphasized prevention as much as therapy. Eugenicists joined this efficiency and prevention vogue, linking the Taylorite-quest for rationalized, efficient business to the proactive, preventive ethos of the emerging field of public health.

Increasingly, the eugenic metaphor emphasized the economic savings that could be realized by preventing the procreation of the "unfit." Arguing from the Biblical and barnyard aphorisms that "like begets like" and that one could not "gather figs from thoms or grapes from thistles," eugenicists believed the best way to solve persistent social problems was to permanently interrupt the reproduction of problem populations. To get rid of crime, one could segregate criminals for the duration of their reproductive life. Or, one could sterilize the criminal, rendering them unable to reproduce "their kind," and saving society the expense of building prisons and maintaining inmates. The second option seemed intensely "efficient," from both an economic and an epidemiological standpoint, when compared to the first. ${ }^{69}$ Eugenicists applied this same reasoning to other institutional populations, including the mentally retarded (known then as the "feebleminded," a capacious designation embracing a constellation of "anti-social" traits), the tubercular, and the insane.

\footnotetext{
${ }^{69}$ Perhaps the most efficient form of eugenic intervention was euthanasia, which never gained a widespread following in America. Some eugenicists, however, viewed capital punishment as a modified form of euthanasia that relieved society of the burden of maintaining a criminal in prison for life. Permick, The Black Stork, 23-24.
} 
While they never exerted the permanent or hegemonic influence they sought, these elite Virginians succeeded in creating a durable ideology that influenced social policy and public opinion for at least two-thirds of this century. ${ }^{70}$ Virginia's eugenics movement provides a case study in the dynamics of eugenical organizing. Evidence demonstrates the links among education, political mobilization, and public policy, as well as the connection between local eugenicists and national eugenicists in the effort to engender eugenical consciousness. It becomes clear that educators and other eugenics supporters grafted eugenic ideology onto the dominant southern cultural norms and instilled the new ideology in their students. These individuals emerged from the formal educational process accepting eugenic ideology and, in many cases, anxious to enact eugenics in law. Virginians' experience passing and enforcing eugenic laws highlights this dynamic. Moreover, because Virginia's eugenics movement resulted in two significant United States Supreme Court decisions, Buck v. Bell (1927) and Loving v. Virginia (1967), signifying the beginning and the end of constitutionally-sanctioned hereditarian social engineering, Virginia's experience neatly encapsulates the public policy ramifications of the eugenics impulse in America.

Periodizing the ascent, apogee, and descent of the American eugenics movement is a complex task. Largely, it depends on how one defines eugenics and where one locates the impulse for change. Mark Haller's benchmark study Eugenics presented the most enduring timeline. Haller argued for a 1930 turming-point in American eugenics, after which "the

\footnotetext{
${ }^{70}$ The discussion of cugenics failure to become a hegcmonic ideology derives from the theories of Antonio Gramsci, Samuel Bowles and Herbert Gintis, and Magali Sarfatti Larson. See Gramsci, The Intellectuals and Cultural Formation [Gli Intellettuali e l'organizzazione della cultua] (Torino: Einaudi, 1966); Samuel Bowles and Herbert Gintis, Schooling in Capitalist America: Educational Reform and the Contradictions of Modern Life (New York: Basic Books, 1976); and Larson, "The Production of Expertise and the Constitution of Expert Power," in Thomas L. Haskell, ed., The Authority of Experts, 28-80. All of these scholars discuss the conservative nature of educational institutions: they socialize students to support the dominant political economy. My analysis extends this beyond the more strictly Marxist implications of these scholars. I believe eugenic education worked to buttress dominant cultural norms which themselves both constituted and supported the political economy. This cultural effect of eugenics forestalled the legal achievement of black human and civil rights by providing an ideology that prolonged de jure and de facto segregation as rational responses to racial contact and social stress.
} 
course of eugenics was rapidly downhill," accelerated by a repudiation of racism, the onset of the Great Depression, the revelations of the Nazi Holocaust, but most importantly by the internal advances of genetic science. ${ }^{71}$ Many subsequent investigators adopted Haller's general scheme, but became increasingly sensitive to the persistence of certain strands of eugenic thought. All, however, agreed that by the 1930s eugenics had split into "good" and "bad" or "reform" and "mainline" wings. What characterized these polar groups was that the good/reform group (now known as geneticists) remained founded on "objective" science, while the bad/mainline group (the eugenicists) stood mired in the pseudoscientific claims of a biased ideology based on antiquated science. ${ }^{72}$

As Diane B. Paul and Elezar Barkan have shown, the evidence simply does not sustain this trajectory and polarization. Many men lionized as reformers hewed closely to the central tenet of mainline eugenics: that "good" and "bad" genes exist and that mankind can be improved by the increase of the former and the decrease of the latter. Moreover, many geneticists credited by historians as having the foresight and integrity to recognize the flawed and racist logic of mainline eugenics, actually held to mainline positions themselves when viewed in their larger context. ${ }^{73}$ Advances internal to the science of genetics simply were not enough to undercut the eugenic impulse; they merely modified eugenics without ever abandoning the hope for genetically improved human beings. ${ }^{74}$

Contrary to Kenneth Ludmerer's assertion that, "eugenicists' misuse of genetic science became so blatant that many prominent geneticists felt obligated to step outside the

\footnotetext{
${ }^{71}$ Haller, Eugenics, 6-7. Haller actually argues a three-stage progression: 1870-1905 preparation, 1905-1930 ascent, 1930-1963 descent.

${ }^{72}$ This polarization runs throughout Degler, In Search of Human Nature; Kevles, In the Name of Eugenics; Ludmerer, Genetics and American Society. Elazar Rarkan borrows the tropes but discusses them in much more sophisticated fashion in Elazar Barkan, The Retreat of Sciertific Racism: Changing Concepts of Race in Britain and the United States Between the Worla Wars (Cambridge and New York: Cambridge University Press, 1992);

${ }^{73}$ See Diane B. Paul's excellent, close textual analysis presented in "Eugenics and the Left" in The Politics of Heredity, 11-35.

${ }^{74}$ This impulse persists today in the Human Genome Project and the asstrances genomists give the public that genetic therapies will—someday_make human beings impervious to disease.
} 
laboratory and denounce the movement publicly," America's most famous geneticists largely refrained from disputing eugenics. ${ }^{75}$ Not only does their silence imply their support for eugenic principle, the few protests they mounted actually underscored their larger support for eugenics. Geneticists like Herbert Spencer Jennings and Hermann J. Muller, credited by early historians of the eugenics movement with beginning the repudiation of eugenics, actually assumed a much more ambivalent posture. ${ }^{76}$ Jennings, lauded as the only geneticist to speak out "against" the Eugenics Record Office's Harry Hamilton Laughlin during Immigration Restriction Act's congressional hearings, only criticized Laughlin's methods, not his findings of racial difference. ${ }^{77}$ In 1928, Jennings defended Charles Davenport and his wamings against interracial miscegenation in Race Crossing in Jamaica, a work that other eugenicists criticized for faulty reasoning. ${ }^{78}$ In his 1930 book The Biological Basis of Human Nature, he relied on Davenport's study to conclude that, "To the superior race, admixture with the inferior one is adulteration; it means a lowering of quality."79 Jennings actions, in the words of Barkan, "represented the limitations of a theoretical development among the older generation," not a repudiation of eugenics. 80

\footnotetext{
75 Ludmerer, Genetics and American Society, 3. The contrary position is amply documented by the careful and comprehensive studies of Diane B. Paul and Elazar Barkan, who demonstrate that even those who "denounced" eugenics in one venue, often supported it in another, as will be discussed below.

${ }^{76}$ See Haller, Eugenics, chapter 9; and especially Ludmerer, Genetics and American Society, chapter 6 , particularly 123-29.

${ }^{77}$ Elazar Barkan concludes, "Jennings reinterpreted, but did not question, the restrictionists' data, no: did he try to discredit the biological concept of 'undesirable characteristics.'" Ultimately, "Jennings did not depart from the eugenics view on immigration restriction, nor from the correlation of social inadequacy with racial origins. He seemed to believe that racial differences carried real social and cultural consequences which could be quantified." Barkan, Retreat of Scientific Racism, 191-209, quotations in note 199 and 201.

${ }^{78}$ Barkan, Ibid., 204. Ironically, one of Davenport's critics, William E. Castle, had studied genetics under Davenport as a Harvard graduate student.

${ }^{79}$ Herbert Spencer Jennings, The Biological Basis of Human Nature (New York: W. W. Norton, 1930), 284-88; quotation 287.

80 Paul, "Eugenics and The Left," 17-20; Paul, Controlling Human Heredity, 117; Kevles, In the Name of Eugenics, 187-88; Alan Chase, The Legacy of Malthus: The Social Costs of the New Scientific Racism (New York: Alfred A. Knopf, 1977), 330. Hermann J. Muller is credited by some historians with excoriating eugenics with his speech "The Dominance of Economics Over Eugenics," which he delivered at the Third International Congress of Eugenics in 1932. Again, Ludmerer leads the charge among recent
} 
Eugenics changed in Virginia, as elsewhere, as the result of a "changing of the guard" rather than a rapid repudiation of the science underpinning eugenic contentions. This dynamic helps to explain the persistence of the most racially charged and class biased form of eugenics. It would take a younger generation, educated only partly on the old genetic and eugenic orthodoxies, working in a cultural environment of increased racial and class tolerance, to push the most severe forms of eugenics from the intellectual arena. Despite their efforts, eugenics would undergo a number of resurgences. As Virginians adopted a program of massive resistance to desegregation, eugenic notions experienced a renaissance. Not coincidentally, the political leaders organizing and directing massive resistance had been educated during the hey-day of eugenics. Similarly, efforts to defend Virginia's Racial Integrity Act would center on eugenic arguments. Later debates over proposed legislation mandating the sterilization of "welfare mothers" would also invoke eugenic rationales. Virginia's eugenic history clarifies the history of science, racism, and segregation by examining the interaction of science and society in public policy decisions.

Although eugenic ideology swayed Virginia politics and culture, buttressing class, racial, and gender hierarchies, analyzing its impact of ten begs two related questions: which came first, the science or the prejudice, and which changed first, science or society? These questions stem from the oversimplifications encouraged by triumphalist histories recounting the ineluctable advance of science. These histories contend that changes intemal to science caused rapid realignments in belief, so called scientific "revolutions." Triumphal narratives generally reccunt the appearance of a grand new theory, showing how it overwhelms earlier theories with its explanatory power, and illuminates the previously uncharted depths of natural phenomena. The debate between hereditarians and environmentalists continues today; even in periods when it appeared static, with one side

historians of genetics in making this claim. Muller's speech actually supported eugenics in principle, but argued that it could only succeed in a socialist state. Muller distrusted capitalist eugenics and repudiated fascist eugenics, but he did not disagree with eugenics in principle. 
winning the day, the intellectual terrain remained contested. In analyzing eugenics in Virginia, one runs the danger of casting the narrative of the interaction of science and society in dichotomous terms: a battle between racism and science, as if one could or has ever existed without the other. The triumphalist history of "objective" genetics overcoming "biased" eugenics is flawed beyond repair. This narrative obscures the very dynamic process of belief formation, rejection, transformation, and persistence that the dissertation hopes to elucidate. Understanding the fallacy of the triumphal narrative helps to clarify why and how eugenics could persist among academic scientists in Virginia and elsewhere.

The history of eugenics in Virginia, just like the history of science more generally, must be understood as a process, guided by the interaction of changes internal to science and external, contextual developments that are constantly in flux. Ultimately, the breakdown in the early, overtly-racist consensus of eugenics on the national level was "rooted in political, and not scientific events....the role played by events internal to science was indirect and largely unrelated to the discovery of new facts or the development of new theories." 81 The persistence of racist eugenics in Virginia ultimately resulted from the ossification of scientific beliefs that remained harmonious with the entrenched race, class, and gender biases of Virginia culture. The gradual change in external context and cultural beliefs, brought about by the political success of civil and human rights agitation, finally came into alignment with "newer" scientific conceptions held by members of a younger generation, and undermined racist eugenics' influence in Virginia.

While not formally divided into two parts, the dissertation's organization falls into two large sections. The first four chapters detail the intellectual and institutional history of eugenics in Virginia. Chapter One develops the pre-history of eugenics and hereditarianism in Virginia. It begins with Jefferson's Notes on the State of Virginia. Jefferson's musings about racial difference first broached the idea of hereditary inequality. His work set the

\footnotetext{
${ }^{81}$ Diane B. Paul, "Eugenics and the Left," in Paul, The Politics of Heredity, 27. See also Paul, Controlling Human Heredity, 114.
} 
tone for all subsequent investigators and, like most of Jefferson's ideas, it left its stamp on his cherished University of Virginia. Professor of medicine, James Lawrence Cabell, devout Christian pioneer of incipient scientific medicine, sought to reconcile Jefferson's notion of inherent racial inequality with the Biblical tenet of common creation. Cabell's 1859 Testimony of Modern Science to the Unity of Mankind resolved the conundrum between Cnristian fellowship and racial subordination. Cabell's solution revolved around a hereditarian conception of evolutionary change that anticipated Cnarles Darwin's theory of evolution by natural selection. Cabell taught his hereditarian theories to his protégé at the University of Virginia, Paul Brandon Barringer. Barringer, the first European-trained scientific physician in the South, developed his mentor's ideas of hereditary racial inequality into a scientific justification for racial segregation, disfranchisement, and the subordination of blacks to whites. Barringer, writing in 1900, set the stage for the acceptance of eugenic thought in Virginia.

The rise of eugenic ideology at the University of Virginia between 1900 and 1919 forms the focus of Chapter Two. Edwin Anderson Alderman's crusade for the progressive restructuring of Virginia's secondary and higher educational systems linked education and social engineering. Alderman believed that the public schools, especially the University of Virginia, existed to serve the state by educating experts who could bring their knowledge to bear in the rational solution of social problems. Two areas eamed Alderman's paticular attention-medicine and education. Both fields promised material improvements in Virginia's standard of living. The two men Alderman hired to help modernize the schools of medicine and education, Harvey Earnest Jordan and William Henry Heck, introduced the "first wave" of formal eugenic thinking to the University of Virginia. This chapter examines these men's ideological commitment to eugenics, establishes their ties to the most prominent eugenicists in America, and gauges the effect their teaching had in paving the way for more eugenicists. 
The hiring of the "second wave" of eugenicists at the University of Virginia between 1915 and 1930, and an analysis of these men's eugenic beliefs, forms the bulk of Chapter Three. These men found a congenial home at the university and within Virginia. Teaching in the schools of biology, psychology, sociology, education, and medicine, these men influenced generations of white Virginia elites. They imbued thousands of professionals with a hereditarian outlook and a desire to see Virginia pursue a practical program of applied eugenics. Working from within the state's capstone institution, these individuals set the tone for the teaching of eugenics elsewhere in Virginia.

Chapter Four completes the intellectual history of Virginia eugenics by documenting the teaching of eugenics in Virginia's other colleges. The widespread permeation of hereditarian thought and eugenics reveals the salience these ideas held among educated Virginians. Most notably, this chapter recounts the teaching of eugenics at Sweet Briar College for Women and the Hampton Institute. This examination of eugenics in a women's college and an historically-black institution highlights how white women and African Americans adopted eugenics and used it to advance their own agendas. Given the broad continuum of belief that composed eugenic ideology, these marginalized groups were able to adopt various aspects of eugenics and weave them into a scientifically-justified program that cut against the status quo. So, even as elite white men sought to use eugenics to buttress traditional forms of segregation, other Virginians sought to "fight fire with fire" by using eugenics to argue for different social and cultural balances.

The final four chapters of the dissertation shift focus from the intellectual history of Virginia eugenics to a consideration of its social and cultural dimensions. These chapters analyze how eugenic ideology permeated Virginia's legal structure and public health organizations until the early 1970s. Beginning with the high point of eugenic achievement in the 1920s, these chapters trace the slow transformation of eugenics over the next fifty years. 
The efforts to pass eugenic segregation and sterilization laws to control the

"feebleminded," "delinquent," and "defective delinquent" classes comprise the body of Chapter Five. The chapter evaluates the degree to which eugenics coopted medical authority to convince legislators that eugenic sterilization promised the best response to the "menace of the feebleminded." The effect of sterilization and institutional segregation on women and blacks forms a central concern, revealing how eugenics changed public perception of women, blacks, and the mentally retarded in Virginia. The capacious nature of the diagnosis "feebleminded" captured more than the mentally ill and mentally "deficient," allowing the poor, those judged "immoral," and racial minorities to be subjected to elite control. Virginia's sterilization of African Americans worked hand-inhand with the effort to prevent interracial marriage and fornication.

Virginia's eugenic Racial Integrity Act, the topic of Chapter Six, sought to protect racial purity, particularly that of the white race. This account analyzes the acceptance and resistance of eugenic racial purity ideology among both white and black Virginians. Many whites saw the act as an affront (it jeopardized the "whiteness" of the descendants of Pocahontas and John Rolfe), while many blacks, particularly followers of Marcus Garvey, supported it. The rabid efforts of some supporters to enact the law and to enforce it rigidly caused fractures among Virginia's eugenic community. This fissures prevented the formation of any centralized eugenics organization, but they did not destroy support for eugenics.

Chapter Seven traces the persistence of eugenic teaching, research, and enforcement in Virginia from the 1930s to the early 1950s. The chapter follows the rise of anti-Semitism and anti-radicalism in 1930s Virginia and relates this development to the rise and fall of fascist eugenics in Nazi Gemany. Virginia sped up its sterilization program amidst the fear that the Germans were, "beating us at our own game." 82 Virginia maintained its

\footnotetext{
${ }^{82}$ Dr. Joseph DeJarnette, Superintendent of Western State Hospital, published Nazi sterilization statistics alongside Virginia's sterilization numbers in his annual reports between 1935 and 1939 . He
} 
sterilization rate after the war, despite the revelations of the Nazi Holocaust. Virginians remained able to distinguish their eugenics from Nazi eugenics, defending it as "scientific" and therefore objective, moral, and apolitical. Simultaneously, Virginia continued to enforce the Racial Integrity Act, to the detriment of the state's Native American and black population. During this period, Virginia's most rabid eugenicists made contact with Nazi scientists. World War II, however, caused many Virginians to re-evaluate their support of Nazi-style racism. The successful civil rights mobilization by African Americans during the 1940s and 1950s provided the shift in cultural belief that would bring down the most virulently racist forms of eugenics in Virginia.

Chapter Eight forges the links between the teaching of eugenics at the University of Virginia School of Medicine and the origins of the United States Public Health Service's (USPHS) Study of Untreated Syphilis in the Negro Male-the so-called Tus'iegee syphilis experiment. Top USPHS physicians, educated in eugenics at the University of Virginia, devised and prosecuted the study. Ties between these men and their alma mater insured that a steady stream of ideologically similar men entered the USPHS. These men served on the syphilis experiment and, because of their professional training, never thought to question the scientific or moral advisability of the study. Physicians at the University of Virginia continued to do research into the "containment" of syphilis, a public health strategy devised to limit infection to certain groups of people. These incidents reveal the broad impact of Virginia's eugenic culture on the state and the nation.

Chapter Nine considers the slow demise of eugenics between 1951 and 1972. It establishes the connections between eugenics and the rise of massive resistance in Virginia, especially through the 1955 antimiscegenation case Naim v. Naim. It also examines the relationship between eugenics and laws proposed in 1962 and 1964 that sought to obtain

pressed for more vigorous use of the Virginia law. Paul A. Lombardo, "Eugenic Sterilization in Virginia: Aubrey Strode and The Case of Buck v. Bell" (Ph.D. diss., University of Virginia, 1982), 243. Philip Reilly reports that many Americans avidly followed the Nazi program. Reilly, The Surgical Solution, 108. 
the sterilization of "welfare mothers" in Virginia. A brief analysis of the failure of these legislative initiatives, and the United States Supreme Court's ruling striking down Virginia's Racial Integrity Act, reveals how the dissonance between eugenic ideology and historical context, coupled with the retirement or death of most of Virginia's staunch eugenicists, led to the failure of eugenics as a rationale for public policy. Without segregation, eugenics—segregation's science-lost a major portion of its reason for being.

The conclusion considers the ongoing repudiation of mainline eugenics in Virginia since the 1972 cessation of eugenic sterilization and the 1980 lawsuit Poe v. Lynchburg, a class action brought against the state by survivors of Virginia's euJenic sterilization program. In a political environment that has rejected most forms of legalized segregation, the science of innate human difference can no longer command broad assent. And yet, scientists and others remain committed to using genetics to establish hierarchies of difference. While scientists no longer focus on the individual as different, but rather on the trait as deviant, the implication remains that an individual with a "maladaptive" genetic trait is somehow tainted. A brief examination of the current work in medical ethics and genetics in America and at Virginia provides a backdrop against which to consider whether eugenics still survives in contemporary genetics, and whether Virginia still manifests a distinctive eugenic attitude or hews to national understandings of genetics.

Eugenics began as the science that intellectuals believed explained human difference. Even as it purported to explain "objective" difference, however, it justified social segregation in its many forms. Racial separation, the institutional confinement of the mentally ill and retarded, the intra-institutional segregation of male and female patients, the categorization of some people as "fit" and others as "unfit," the social separation of the rich from the poor, and the division of power between men and women all found support in eugenic theories. Just as it took time for eugenic ideology to supplant older rationales that had justified these forms of segregation, so too it took time for newer ideologies to 
supersede eugenics as segregation's science. Both segregation and science remain with us today. The degree to which one owes its existence to the other says as much about the power of social context as it does about the "objectivity" of the scientific method.

Ultimately, understanding the history of segregation's science offers us insights not only into the past, but into how the present interaction between science and society is shaping our conceptions of humanity. The current dynamic, despite a vamish of equalitarian rhetoric, threatens new forms of segregation rather than an acknowledgment of our essential, and vastly predominant, human similarity. Why that is probably says more about how human culture conditions science than science says about humanity's essential biological basis. 


\section{Chapter I: "The Sacrifice of a Race"}

Virginia has a long acquaintance with hereditarianism and concepts of eugenics. Major figures in Virginia's intelligentsia have expounded theories that linked ideas of biologicallydetermined inferiority and superiority to issues of public health, government, and survival of the social order. Originating with Virginia's most famed intellectual, Thomas Jefferson, these notions influenced generations of American scientists and politicians. Jefferson's musings on the differences he observed between whites and blacks amount to perhaps the first scientific observations of racial difference in Virginia and national history. Jefferson's racial views, and his thinly veiled, proto-genetic notions, shaped Virginia's political and social structure. Popularized in the Notes on the State of Virginia, these early ideas of hereditary difference opened a Pandora's box of theological, scientific, and ethical questions. Despite their ambiguous language and complicated ideological motives, Jefferson's conclusions set the foundation for all subsequent investigations. Given the cultural salience of debates over race, the topic naturally permeated the halls of Virginia higher education. There, "dispassionate" and "scientific" academicians believed they could consider these explosive biological questions in an objective manner, well-insulated from religious and political firebrands. In this cultural context, as biological science, religious liberalism, and tension over the institution of slavery converged, notions of hereditary racial inequality increasingly framed the discussion, set the terms of debate, and dominated scientists' conclusions.

Hereditarianism found a particularly congenial institutional climate in the University of Virginia, the capstone of Jefferson's monumental vision of the perfect social/educational order. ${ }^{1}$ The second professor of medicine at Virginia, James Lawrence Cabell, would

\footnotetext{
1 Virginia physician John Augustine Smith, later president of the College of William and Mary, briefly joined Jefferson in promoting racialized thought in 1808. He defended Jefferson's racial conclusions from the attack of Princeton's Samuel Stanhope Smith, with his own scientific analysis. Winthrop Jordan, White Over Black: American Attitudes Toward the Negro 1550-1812 (Chapel Hill: University of North Carolina Press, 1968), 505-06.
} 
refine Jefferson's early musings on the biological significance of race. In 1859, months before Charles Darwin unveiled his theory of evolution driven by the natural selection of random variations, Cabell arrived at similar findings with regard to human evolution. A devout Christian, Cabell argued for monogenism — the "specific unity" of all humans, descending from a common ancestral pair-and against polygenism and its belief in the "specific diversity" or separate creation of the races. Cabell built on the intellectual foundation laid by Jefferson in the Notes, where Jefferson alluded to the debate over origins but reserved final judgment. ${ }^{2}$ Bringing the most recent scientific theories to bear on the problems surrounding human origins, Cabell posited mechanistic explanations for the differentiation of the various "races." Writing on the eve of the American Civil War, Cabell's science allowed for significant hereditary variation between and among blacks and other "permanent varieties" of the human race. In effect, Cabell reconciled his racial ideas with Christian religion and qualified the meaning of Jefferson's Enlightenment universalism in one deft stroke. His work thus wove together dominant strands of social, political, and religious thought within the tapestry of scientific naturalism. Cabell created a new "hereditary creed" that he then taught to generations of students.

This institutionalized hereditarianism became overtly eugenical, in a modern sense, through the career of Paul Brandon Barringer. Cabell's personal protégé, Barringer succeeded Cabell in Virginia's chair of comparative anatomy and physiology. Barringer eventually acted as Chairman of the Faculty — a position Cabell had also held-Virginia's highest administrative post. From this influential position, Barringer announced his

\footnotetext{
2 Jefferson left open both monogenist and polygenist explanations of racial inequality when alleging black inferiority, "whether [blacks were] originally a distinct race, or made distinct by time and circumstances". Thomas Jefferson, Notes on the State of Virginia ed. William Peden (Chapel Hill: University of North Carolina Press, 1954; reprint, New York and London: W. W. Norton \& Company, 1972), 143 (hereinafter page references are to reprint edition). Jefferson's most explicit public statements on racial constitution and racial difference appeared in his Notes on the State of Virginia, written in response to queries from the secretary of the French legation in Philadelphia in 1781. Jefferson printed and privately circulated the book in 1785; it was subsequently published in 1787. See particularly Jefferson's responses to Queries VIII, IX, XIV, XVIII, XIX.
} 
scientific judgments regarding racial biology and the appropriate interracial relations warranted by that biology. Barringer's proto-eugenic racial pronouncements developed those of Cabell, solidifying the ideational shift from the splenetic racism of the Redemption Era to the scientific racism of the Progressive Era. ${ }^{3}$ Coming in the first year of the new century, Barringer's addresses on race embodied the modernist impulse motivating "New South Boosterism," the desire to lift the south out of its "backward" socio-economic station and into the mainstream of national development. Moreover, Barringer's modernism allowed him to close ranks with important national-level eugenics enthusiasts, particularly such "northern lights" as Theodore Roosevelt and Edward A. Ross. Barringer's hereditarianism and eugenics bridged the traditional theoretical and linguistic gaps that had separated northem and southem racial attitudes. His pronouncements did more than marry northem and southem racial ideology. He also biologized gender and class hierarchies in precisely the same way that northern intellectuals used science to explain the social subordination of women and immigrants. Thus Barringer's science facilitated the growing social and political rapprochement between the sections. Barringer and others used biology and medicine-the life sciences- to "naturalize" and normalize social hierarchies. Their efforts elevated and nationalized white male identities by scientifically legitimating the subordination of women, immigrants, the sick, and people of color. This biological marginalization provided justification for many forms of legal and social segregation. Building on this ideological foundation, later theorists would manage to enact ever more coercive laws that increasingly traduced individual civil and human rights.

Examining the works of Jefferson, Cabell, and Barringer highlights the continuities in the evolution of scientific racial thought in Virginia and America. Perhaps the most striking

\footnotetext{
3I term Barringer's world-view proto-eugenic because no evidence exists that, by 1900 , he had been exposed to eugenics. He may have read the one article published in America before 1900 that mertioned eugenics, George J. Preston, "Hereditary Disease and Race Culture," Popular Science Monthly 29 (September 1886): 639-42. The same issue carried a lengthy biographical sketch of Francis Galton (11721). Or, he could well have been exposed to the ideas of Francis Galton, also published in Popular Science during the 1870s and 1880s. See Haller, Eugenics, 212 notes 1 and 2.
} 
dynamic revealed is what Thomas S. Kuhn pointed to in his Structure of Scientific Revolutions. All three of these men engaged in "normal science," enmeshed in a disciplinary context that bounded their thinking. What science told them was "true" about the world, was often what they already believed to be "true" without necessity of scientific validation. Thus their "scientific" epistemology—truth as defined by science—shaped and constrained their political and social thinking about "truth," even as their political and social context conditioned their scientific process. This circular relationship became embodied in "normal science." As Kuhn wrote,

Normal science, the activity in which most scientists inevitably spend almost all their time, is predicated on the assumption that the scientific community knows what the world is like. Much of the success of the enterprise derives from the community's willingness to defend that assumption, if necessary at considerable cost. Normal science, for example, often suppresses fundamental novelties because they are necessarily subversive of its basic commitments. ${ }^{4}$

Bounded by their cultural context and prior ideological commitments to race, gender, and class hierarchies that operated alongside their scientific traditions, these men worked hard to align scientific "reality" and their expectations based on experience. Indeed, although each man encountered anomalies-for example that Benjamin Banneker, a black man, was an accomplished scientist (Jefferson); that whites and blacks could mate and produce fertile offspring (Cabell); and that not all black men regressed to the savage state of rapist (Barringer)—these men's "normal science" successfully aligned professional research and personal expectation. Their "objective" scientific observations aligned with their scientific traditions in support of social realities. This tradition would continue into the twentieth

\footnotetext{
${ }^{4}$ Thomas S. Kuhn, The Structure of Scientific Revolutions, 3d ed., (Chicago: The University of Chicago Press, 1962), 5. Kuhn analyzed the physical sciences, but argued that his theory holds for biology. Jane Maienschein, in Transforming Traditions in American Biology 1880-1915 (Baltimore and London: Johns Hopkins University Press, 1991) revises Kuhn's analysis, showing that "paradigm shifts" or "revolutions" are rare events indeed, and that "normal science" in biology often tends to "transform" rather than revolve. Peter J. Bowler, however, in his works The Non-Darwinian Revolution: Reinterpreting a Historical Myth (Baltimore: Johns Hopkins University Press, (1988) and The Mendelian Revolution: The Emergence of Hereditarian Concepts in Modern Science and Society (Baltimore and London: The Johns Hopkins University Press, 1989) reveals how new technologies, in this case genetics, really can spur "paradigm shifts." The key to Kuhn's insight is that science has not, does not, and will not ever operate in an "objective vacuum" devoid of prior assumptions and bias, and dealing only with "fact."
} 
century, even through the advent of Darwinian evolution and Mendelian genetics. The real "paradigm shift" in scientists' conceptualizations of race, when race would come to be seen as having no basis in physical, genetic reality, would remain far, far in the future.

\section{Framing the Debate Over Racial Biology: The Legacy of Thomas Jefferson}

Hereditarian thinking in Virginia, like many other traditions in the Old Dominion, traces its lineage to Thomas Jefferson, "The Sage of Monticello." The epitome of enlightenment rationalism in America, Jefferson's obeisance to the ideals of "natural law" characterized all his thinking, social, economic, political, and scientific. Jefferson was, as historian Garry Wills noted, "an eighteenth century empiricist, opposed to generalizations and concentrating on particular realities" that he could observe and evaluate. ${ }^{5}$ As the touchstone for all his observations, one would think that Enlightenment universalism would have engendered a strong consistency in Jefferson's thought. Yet the apparent contradictions between his theories and his actions-particularly regarding his stance on chattel slaveryhave confounded generations of historians, eaming Jefferson the sobriquet of "American Sphinx."6

The dissonance between Jefferson's idealistic statement that "all men are created equal" and his pronouncements on the innate inferiority of blacks has presented an enduring historical conundrum. Although the debate over the philosophical consistency of Jefferson's antislavery position is unlikely to be settled, anyone attempting to understand the history of hereditarianism and scientific racism in Virginia and America must begin with a consideration of Jefferson. Not only were Jefferson's views "more widely read, in all

${ }^{5}$ Garry Wills, Inventing America: Jefferson's Declaration of Independence (New York: Doubleday and Company, Inc., 1978 reprint edition, New York: Vintagc Books, 1979), xxii (hereinafter page references are to reprint edition).

6Joseph J. Ellis, American Sphinx: The Characler of Thomas Jefferson (New York: Alfred A. Knopf, 1997). John P. Diggins, "Slavery, Race, and Equality: Jefferson and the Pathos of the Enlightenment," American Quarterly 28 (Summer 1976): 206-28. Diggins argues that a fundamental contradiction, "the incompatibility of the doctrine of equality and the doctrine of natural rights," inhered in Enlightenment philosophy, and blinded Jefferson to "the errors in his own mode of reasoning on racial equality" (207). 
probability, than any others until the mid-nineteenth century," they were also selfconsciously embedded in the contemporary scientific tradition. ${ }^{7}$ As a result, Jefferson's judgments set the pattem for later racial scientists, despite the controversy they elicited at the time. Attempting to straighten the threads of Jefferson's tangled ideological commitments helps to explain how his scientific understanding of race influenced later thinkers, including James Lawrence Cabell and Paul Brandon Barringer.

Historian Peter Onuf, in a provocative essay relating Jefferson's political philosophy to his racial opinions, approaches the solution to the riddle posed by this American Sphinx. Attempting to rehabilitate Jefferson's "antislavery credentials," Onuf argues that "Jefferson's conception of race proceeded from his recognition of distinct national identities." 8 Thus, Jefferson's racial distinctions, propounded in his Notes on the State of Virginia, stemmed from his desire to create an autonomous, political, national identity for (white) revolutionary Americans. In essence, Onuf contends that Jefferson's natural philosophy_his "science" of race_-grew out of his political philosophy_his "science" of nationhood. First came political theory, then came science to justify the political theory.

Contending that Jefferson's political thought eventuated his racial theorizing artificially separates the two lines of thought, both of which originate in Jefferson's conception of natural law. To be sure, Jefferson is best known for championing natural rights-based political philosophy. And, the apparent sequential development of his political and racial

\footnotetext{
7Jordan, White Over Black, 429. This section draws heavily on Jordan's benchmark interpretation of Jefferson's psychological and ideological turmoil over slavery. This entire discussion is also deeply indebted to the lucid and compelling analysis presented in Peter S. Onuf, "'To Declare Them a Free and Independent People': Race, Slavery, and National Identity in Jefferson's Thought," Journal of the Early Republic 18 (Spring 1998): 1-46. While my own analysis differs slightly from Onuf's, adhering more closely, perhaps, to Jordan, I believe it remains broadly consonant with Onuf's findings. Onuf may well have taken his cue from Jordan's benchmark treatment of Jefferson in White Over Black, where Jordan hints, on page , at precisely the line of analysis Onuf follows. Alexander O. Boulton's essay, "The American Paradox: Jeffersonian Equality and Racial Science." American Quarterly 47 (September 1995): 467-92; and Thomas F. Gossett's Race: The History of an Idea in America (New York and Oxford: Oxford University Press, 1966; new edition 1997), 1-128, shaped my understanding of the relationship between natural history and race. Wills, Inventing America, 93-164.

8 Onuf, Ibid., 2, 14.
} 
thinking suggests that Jefferson's politics influenced his science, and not vice versa. Nevertheless, this neglects the common root source of Jefferson's intellectual endeavor, and obscures the reasons why Jefferson's ideas became the matrix for much subsequent racial thought in Virginia. For Jefferson, natural law was antecedent to, and therefore determined, both political philosophy and the natural world. The natural law inspiration that informed both Jefferson's scientific and political theorizing allowed him to join the two realms of thought-his science informed his political vision which, in turn, conditioned his science. Jefferson, it seems, engaged in normal science, too.

All of Jefferson's thinking extended from the precepts of Enlightenment universalism. His political philosophy and his naturalistic observations both relied on notions of natural law and economy in nature. For Jefferson, an idea was "true" and reflected reality when it comported with the dictates of natural law. Jefferson's political philosophy stressed natural law through concepts of "natural rights." His observations of the natural world recognized natural law through the ordered rationalism of Linnaen taxonomy and the Great Chain of Being. 9 Jefferson's racial judgments, as an incipient naturalist—or "natural historian" as scientists were known in the early nineteenth century —extended from his understanding of "rational" nature, as did his political theory. To divorce or rank the two realms of thought "unnaturally" compartmentalizes his thinking. As Alexander O. Boulton claimed, "The same Natural Law tradition that posited the equality of all individuals without reference to social or physical context also elevated the importance of purely physical distinctions that could be grouped together under the new conceptual categories of race." 10 Jefferson's pronouncements on race and natural rights, which seem contradictory today because of the modem (and artificial) conceptual separation of political science from the natural sciences, were not necessarily paradoxical to him. Jefferson's natural and political philosophies (his

\footnotetext{
${ }^{9}$ Diggins, "Slavery, Race, and Equality," 212; Jordan, White Over Black, 431.

${ }^{10}$ Boulton, "American Paradox," 476-77.
} 
"sciences" in an observational and deductive era before modem inductive, experimental science) were inextricably intertwined as they spiraled out from the taproot of natural law.

The racial prejudices of Jefferson's day were not, as Peter Onuf contends, "masquerading as science" any more than Jefferson's theories of government were "posing" as political philosophy. Jefferson's discussion of racial differences comported well with the theory and practice of the "science" of his time. His judgments stemmed from his observations—both direct and through "reliable sources"—of what he and others agreed were concrete phenomenon. ${ }^{11}$ He identified apparent racial differences, physical, physiological, and psychical, and he categorized them. Jefferson's opinions that blacks lacked beauty, emitted "a very strong and disagreeable odor," were "in reason muchs, 1983.hey are dull tasteless, and anomalous," excited much comment precisely because they embodied scientific observations. 12 That his critics responded with counterclaims represents the skepticism and dialectic nature of observational science, not their disqualification of Jefferson as a natural philosopher. As Garry Wills perceptively argued, Jefferson's philosophical visions all "arose precisely from the particulars of [Enlightenment] science, and can be grasped only in those terms."13 Shocked by the repugnance of Jefferson's conclusions, modern commentators often dismiss the entire endeavor as mere prejudice, especially since his methods diverged from modem scientific practice and appear at odds with his political theory. Such anachronistic repudiations of Jefferson's racial theories deflect attention from the development of science and its relationship to political and social context, redirecting historical efforts toward the psycho-

${ }^{11}$ As Garry Wills notes, this methodology fits with Jefferson's distaste for privileging metaphysical political theories and debates over real, concrete political circumstances. Wills, Inventing America, xxiii, $110,114-15$ and 118-21 (on the importance of observation). The indirect observation of phenomenon, especially the use of "reliable" eye-witness testimony, would remain an acceptable naturalistic method until scientific epistemology shifted to emphasizc the empiricism and replicability of modern experimentalism. See Keith R. Benson, "From Museum Research to Laboratory Research: The Transformation of Natural History into Academic Biology," in, Ronald Rainger, Keith R. Benson, and Jane Maienschein, eds., The American Development of Biology (Philadelphia: University of Pennsylvania Press, 1988).

${ }_{12}$ Thomas Jefferson, Notes, 138-39.

${ }^{13}$ Wills, Inventing America, 131. 
history of prejudice. To comprehend the later history of hereditarianism, one must first understand the relationship of science and political theory in Jefferson's thought.

Jefferson confronted the two central-and most explosive-questions of human morphological biology: did all humankind descend from a common ancestral pair, and could variation in human physical traits and abilities be squared with religion and Enlightenment universalism? The answers to these questions had theological, political, and scientific ramifications. Like all Enlightenment taxonomists, Jefferson mixed declarative and highly qualified language in announcing his conclusions. Many historians interpret Jefferson's apparent vacillation as a tacit admission of the flaws in his analysis. ${ }^{14}$ Jefferson's temporizing, however, may also be read as the tentative statements of an investigator not wishing to overstep his evidence. While all preliminary observations seemed to indicate African-American inferiority, and certainly evinced "natural" differences in physiognomy, further investigation would be needed to substantiate mental differences. Thus, Jefferson's statement, "The opinion, that they are inferior in the faculties of reason and imagination, must be hazarded with great diffidence. To justify a general conclusion, requires many observations, even where the subject may be submitted to the Anatomical knife, to Optical glasses, to analysis by fire, or by solvents," can be read as the paradigm of scientific caution. ${ }^{15}$ Another interpretation remains open, however. Jefferson's

\footnotetext{
${ }^{14}$ Winthrop Jordan approached this position in his discussion of Jefferson's separation of the "moral sense" from the "intellect." Jordan argued that this distinction was untenable. Accordingly, Jefferson's "science-theology rammed squarely into his larger faith [in Enlightenment universalism], and the result was intellectual wreckage." Jordan, White Over Black, 453-57, quotation 453. Alexander Boulton claims Jefferson's biological thinking suffered from "a fundamental contradiction" between ideas of stasis and dynamics. While this tension existed, Boulton overstates the case. These two ideas are not mutually exclusive, and neither Jefferson, nor many who followed him, viewed them as such. Boulton recognizes this when he notes that "Nineteenth-century science, as it turned out, developed primarily along Jeffersonian lines... a combination of order and change...." Boulton, "The American Paradox," 484. Garry Wills presents a more balanced interpretation. Wills, Inventing America, 114, 118-24. Indeed, stasis and dynamism remain very much a part of contemporary debates over the course of evolution: see Stephen Jay Gould "Bushes and Ladders in Human Evolution," and "Patterns and Punctuations in the History of Life," in, Stephen Jay Gould, Ever Since Darwin: Reflections in Nalural History (New York and London: W. W. Norton \& Company, 1977), 56-62, 113-40.

15 Jefferson, Notes, Query XIV, 143. Latter-day racial theorists, armed with intelligence tests that purportedly allowed investigators to assay intelligence as if it were a physical property, felt that they had conquered Jefferson's dilemma.
} 
circumspection in announcing his "suspicion only" that blacks were inferior to whites, and his call for further study of the problem, conformed to the skeptical style used by all natural philosophers who contemplated the origins and meaning of human variation during this era. ${ }^{16}$

Eighteenth- and nineteenth-century naturalists all recognized the sensitive nature of this subject matter and the ramifications borne by their conclusions; yet they all betrayed inconsistencies in their rhetoric and conclusions. ${ }^{17}$ Linnaeus, the father of taxonomy, showed little interest in discussing the root causes or nature of human difference, preferring to assert the unified origin of mankind; yet he went on to classify four major "varieties" of mankind. George Luis Leclerc, comte de Buffon, whose racial theories antagonized

\footnotetext{
${ }^{16}$ Although Onuf notes that Jefferson offered his observations in "the properly philosophic spirit" expected by other Enlightenment thinkers, he then contends that Jefferson's commentary on racial difference "concludes so weakly" because he recognized that "differences rooted in nature could never adequately explain or justify the deleterious effects of conquest, captivity, and exploitation...." Onuf, "Race, Slavery, and National Identity," 26. This ignores the possibility that Jefferson's equivocations were merely formal and not substantive. Jefferson believed in his conclusions, but knew they would not be considered in the scientific world of his day if he stated them absolutely. Thomas Gossett was probably nearer the mark when he argued that Jefferson "was perhaps uneasily aware that his own opinion of Negroes was not shared by most of the men of his time who were specialists in natural history." Gossett, Race, 44.

${ }^{17}$ Jordan, White Over Black, 445, 457. See also Diggins, "Slavery, Race, and Equality," 225 note 35. Winthrop Jordan advances this argument in part; he then denies that it could apply to Jefferson, preferring to argue that "a 'scientific' affirmation of Negro inferiority would have to derive at least in some measure from imperatives extraneous to science itself." What Jordan failed to acknowledge is that all science, past and present, derives its conclusions "at least in some mcasure" from contextual imperatives. Jordan assumed that some purely "objective" science exists, and that it would necessarily validate the conclusions that we find palatable today. All recent scholarship concerning the "objectivity problem" has thoroughly debunked this myth. Moreover, Jordan's criticism of Jefferson for not attempting any experiment to compare black and white educability also smacks of presentism. According to Jordan, Jefferson's lack of experimental evidence is proof that his "appeal to that highest court [science], was not the starting point for his thoughts about Negroes but a safe refuge from them." While I do not challenge the psychological aspect of Jordan's charge, I would argue that his demand that Jefferson experiment with black and white subjects ran counter to accepted epistemological traditions among natural historians. Comparative anatomy and physiology-in the modem "experimental" sense, relying on invasive dissection and vivisection-only began in earnest in the mid-nineteenth century. The experimental altering of external conditions to effect organic development began later still. Jefferson adhered to the canons of eighteenth-century natural history by observing blacks in situ, in close proximity to whites, without altering their interactions. See Wills, Inventing America, 121. Moreover, no equalitarian naturalist performed this type of experiment; those cited by Jordan-Gilbert Imlay, Benjamin Rush, Samuel Stanhope Smith, - all filtered their observations through their distinctive political and social ideologies while adhering to natural history methodology. While I agree with Jordan's equalitarian conclusions, I disagree with his analysis. The absolute equality of humankind will never be "proven" by science independent of social circumstances. Science, like all other realms of knowledge, is socially constructed and contextually contingent. Thomas S. Kuhn articulated the revisionist view of science as social construction in his classic The Structure of Scientific Revolutions; see also, Stephen Jay Gould, "On Heroes and Fools in Science," in, Ever Since Darwin, 201-06.
} 
Jefferson, also believed in the specific unity of the races, yet he felt that white was the "real natural color of man." Johann Friedrich Blumenbach, credited with co-founding anthropology (with Buffon) and called "the father of craniology" manifested his own inconsistencies. Despite arguing that "Innumerable varieties of mankind run into one another by insensible degrees" making any taxonomy arbitrary, Blumenbach went on to describe five great divisions of mankind: Caucasian, Mongolian, Ethiopian, American, and Malay. Blumenbach, who excoriated those presuming to rank the races, especially if that ranking depended on "beauty," coined the term "Caucasian," to denote the white race because he felt that the most beautiful humans originated near the southern slopes of Russia's Causcasus mountains. At the same time, Blumenbach collected books by black authors to prove that they were not innately stupid. ${ }^{18}$ All of these men felt that qualitative racial differences might exist; not enough evidence, however, existed to prove them definitively. They were as chary and as contradictory as Jefferson. All these men's conclusions, regardless of each man's proximity to or intellectual stance regarding chattel slavery, reflect the influence of a priori cultural chauvinism and a valorization of whiteness. Jefferson's reservations may have revealed his conformity to the skeptical stance of natural philosophy as much as they belied any deep-seated misgivings about the veracity of his observations.

Thus, Jefferson could espouse the political equality of all men based on natural, inalienable rights, yet make qualified but invidious distinctions among "types" of men based on the canons of natural philosophy - and still remain consistent within the framework of natural law and the epistemology of natural philosophy. Political equality did not mean biological identity. He could "acknowledg[e] the nationhood of enslaved Africans and the legitimacy of their claims to freedom and independence" without admitting

18John R. Baker, Race (New York and London: Oxford university Press, 1974), 204; Gossett, Race, 35-53; and Boulton, "American Paradox," 477-82. 
perfect biological equality. ${ }^{19}$ He preferred instead to invoke observational experience, the touchstone of the natural philosopher, and remark that, "It is not against experience to suppose, that different species of the same genus, or varieties of the same species may possess different qualifications." 20 It is because Jefferson adhered to natural law idealism in both his "sciences" that his political and natural philosophies reinforced each other, forming a circular logic that convinced and compelled subsequent generations.

In essence, Jefferson can be seen as one of the first expositors of the "nature" position in the "nature-nurture debate." And, as Thomas Gossett has pointed out about nineteenthcentury racial theorists, "Though the debate was acrimonious, the contestants do not now seem nearly as far apart as they seemed to themselves. The leading exponents of both schools of thought came more and more to believe that the Negro is innately inferior and that neither education nor environment can do much to improve him." Both positions depended, then as now, on an amalgam of political and scientific convictions. ${ }^{21}$

More than racism, nascent hereditarianism, and linguistic definition resulted from Jefferson's attempt to define a new American political identity. He actually laid the conceptual groundwork for a new "American race." The confluence of science and politics

${ }^{19}$ Onuf, "Race, Slavery, and National Identity," 12.

20Jefferson, Notes, 143.

${ }^{21}$ Gossett, Race, 54. This is equally true of Jefferson's critics, despite the fact that their equalitarian positions are congenial to moderm political sensibilities and consonant, for all the wrong reasons, with modem science. Samuel Stanhope Smith's environmentalist position, attributing racial differences in color to climatic variation, arrived at the scientifically "correct" position of basic equality by way of reasoning that is now discredited. Smith should not be viewed as prescient and Jefferson vilified as prejudiced because of this coincidence. Instead, these men should be evaluated within the framework of their science, by its standards, not our own. While Alexander Boulton identified a "fundamental contradiction" in Jefferson's attempt to wed Linnaen taxonomy (with its emphasis on stasis) to Buffon's idea of variation (which emphasized change), I fail to see the problem. Jefferson and men after him sought varieties of plants and animals, with stability within each variety. Jefferson's placement of Indians and whites within the same variety, yet evidencing differing levels of achievement, could easily be reconciled by reference to education and analogy to varied attainments among white men. It is from this dynamic that, as Boulton correctly argues, "Nineteenth-century science, as it turned out, developed primarily along Jeffersonian lines-as a synthesis of the ideas of Linnaeus and Buffon, a combination of order and change, which included new conceptions of distinctions between human beings and a positive conception of change as progression toward some ultimate, if unreachable good." Boulton, "American Paradox," 484. 
appears in Jefferson's attempt to establish the grounds for an American "national" identity based upon a new "racial" identity that would be developed by later thinkers. ${ }^{22}$

Jefferson's first battle in attempting to define the new commonwealth, as Peter Onuf noted, was taxonomic: he had to create "two peoples-British and American-in the place of one British people". In the process, Jefferson defined a third "people" when he "began to think of African slaves as a captive nation." 23 While this division stemmed from political necessity, Jefferson's naturalistic observations seemed to vindicate his distinctions. Jefferson turned to the hereditary ancestry of the colonists to substantiate his claims for independence. Just as the colonists' "Saxon ancestors," in emigrating to Britain, had acted upon their "right which nature has given to all men of departing from the country in which chance, not choice, has placed them," so too did the colonists act on this natural right when moving to America. Their autonomous action, construed as a proto-genetic ancestral birth-right, differentiated American colonists from the "people" who remained in Britain. Jefferson's emphasis on "action"-both in terms of mobility and then in the imagery of his vigorous agrarianism—did indeed "anticipate romantic and racialist constructions of national identity in the nineteenth century. "24

Later thinkers would join Jefferson's political construction of "the Saxon myth, stipulating a primal national identity" to the natural right of mobility, creating a genetic trait that characterized a "New American" race. ${ }^{25}$ The cult of "pioneer" mythology-and its

${ }^{22}$ As Peter Onuf notes, "The terms 'race,' 'nation,' and 'people' were not yet clearly distinguished before the era of the American Revolution." While "The American revolutionary cisisis precipitated a process of conceptual definition," it by no means cleared up the discursive morass surrounding race, nation, and people. Onuf, "Race, Slavery, and National Identity," 15. Rather than clarifying meaning, the revolutionary generations in America and France simply added additional meanings. These three terms, central elements in the modern discussions of both hereditarianism and identity formation, remained interchangeable well into the twentieth century. Twentieth-century cultural anthropology, emphasizing the distinction between the biological and the social, finally clarified the different scientific denotations of race, nation, and people (ethnicity). These terms remain blurred in popular parlance, however.

${ }^{23}$ Onuf, "Race, Slavery, and National Identity," 8.

${ }^{24}$ Onuf, Ibid., 20.

25 Onuf, Ibid., 9-10; Boulton, "American Paradox," 486. Just as Onuf argues that Jefferson and other revolutionary Americans "invented' a people," and "imagined one world made up of many distinct peoples, each with a just claim to [isolated] self-rule," so to did later racialist thinkers. See Ales Hrdlicka, The Old 
purportedly genetic basis-surrounding late nineteenth and early twentieth century Anglo-

Saxonism, traces its roots directly to Jefferson's glorification of Anglo-Saxon culture. ${ }^{26}$

Although the "exigencies of political and military mobilization" during the revolutionary

period "muted the traditional emphasis on race or ethnicity (derivation from a 'common

stock') in defining the new nation," the successful establishment of the nation reified these

"racial" traits. 27 While "consent supersede[d] descent" in the formation of America, racial

heredity would come to be the gatekeeper of American citizenship. Jefferson, like his

intellectual descendants, worried about the assimilation of immigrants; he feared the

purported sexual licentiousness of non-white races; and he posited education as a

socializing agent, yet restricted public access to it based on "merit"-a cipher for inborm

ability manifested through achievement. In deciding who was "fit" and "unfit" for

republican citizenship, Jefferson confronted the same taxonomic problem facing later

Americans (Baltimore: Williams \& Wilkins Company, 1925), especially 1-2. Hrdlicka, the curator of anthropology at the Smithsonian Institution and a eugenicist, believed that early settlers in America were "rather above than below the average in sturdiness and energy" and they went on to blend together so that "the first generation bom here were already thorough Americans, which term, however undefined, meant something already [biologically] different from the Old World populations to which the pioneers owed their derivation.....by the time the Revolutionary period is reached, [the population] is found to constitute already a strong new body: the American nation. How virile and successful in general, this new blend has proven to be, is a matter of history....since the war of the Revolution the Americans constitute, so far as behavior is concerned, a universally acknowledged, separate and fairly distinctly characterized unit of the white race which is no longer English, Dutch, French or Irish, but American." Note how Hrdlicka conflates nation, race, ethnicity, and family in describing the emerging American race. His project, in the book, was to evaluate the degree to which recent immigration from southeastern Europe imperilled this "new" race.

26Boulton, "American Paradox," 483-84; Gossctt, Race, 87, 126-43. Indeed, Charles Benedict Davenport would further resolve this distinction. Davenport and other eugenicists agreed with Jefferson that "inaction" or "laziness" denoted hereditary inferiority. They went further than Jefferson, however, parsing the "active" class into the "fit" and worthy "pioneers" and intrepid conquerors, and the footloose, vagrant, and improvident "wanderers." The genetic desire to wander, in the right person, expressed itself in his becoming an admiral; in the wrong person it resulted in becoming a run-away, tramp, hobo, or other "antisocial parasite." See Charles Benedict Davenport, Heredity in Relation to Eugenics (New York: Henry Holt and Company, 1911), 209-12; and Davenport in William Ernest Castle, et. al., eds., Heredity and Eugenics (Chicago: University of Chicago Press, 1912), 299. Davenport argues that "pioneer" wanderers are those who emigrate first and conquer new vistas; those who emigrate later are merely aimless wanderers without purpose. See also Davenport, "Nomadism, or the Wandering Impulse, with Special Reference to Heredity," in Davenport, The Feebly Inhibited (Washington, D.C.: The Carnegie Institution of Washington, 1915), 7-26; and Davenport, Naval Officers Their Heredity and Development (Washington: Carnegie Institution of Washington, 1919).

${ }^{27}$ Onuf, Ibid., 16. 
"biological progressives." 28 He propounded a new American "race" whose political identity rested, in par, on their hereditary attributes. In essence, Jefferson laid out the skeleton of later eugenic reforms. What he lacked, and later hereditarians had, was the quantitative empirical methodologies to buttress and "naturalize" his political conceptions.

Jefferson's fears about immigration presaged the anxieties of twentieth-century eugenicists. Jefferson's apprehension about foreigners stemmed from two sources, both of which had implicit hereditary undertones. ${ }^{29}$ First, since they would be coming from monarchies, they would "bring with them the principles of the governments they leave, imbibed in their early youth....These principles, with their language, they will transmit to their children," which would make them unassimilable in a republican polity. Worse still, they might "infuse into" the government "their spirit, warp and bias its direction, and render it a heterogeneous, incoherent, distracted mass."30 Twentieth-century eugenicists feared immigrants because they brought with them their genes, the biological substructure for their "manners and principles," that they might "infuse" into the American gene pool, rendering it "a heterogeneous, incoherent, distracted mass." Just as Jefferson felt that "A degeneracy in these [manners and spirit] is a canker which soon eats to the heart of [a republic's] laws and constitution," later eugenicists feared that introducing "inferior" genetic stock would undermine the republic by creating a population unfit for democracy. ${ }^{31}$

\footnotetext{
${ }^{28}$ Kathy Jane Cooke uses this term to describe Progressive Era thinkers for whom biological science formed the matrix molding their social reform ideals. Kathy Jane Cooke, "A Gospel of Social Evolution: Religion, Biology, and Education in the Thought of Edwin Grant Conklin" Ph.D. diss., University of Chicago, 1994, 5.

29 Onuf, too, identifies these hereditarian undertones in Jefferson's conception of Virginians as "a people." Onuf terms this implicit hereditarianism a "genealogical premise" that was "still present in a sublimated form, with all Virginian families tied together by complex and diffuse bonds of kinship-or by the prospect of future marriages - and all sharing in the great public estate." Onuf, "Race, Slavery, and National Identity," 24.

30Jefferson, Notes, Query VIII, 84-85.

${ }^{31}$ Jefferson, Notes, Query VIII, 85; Qucry XIX, 165. Indecd, eugenicist Harry Hamilton Laughlin testified to this effect during commiltec hcarings about the 1924 Johnson Immigration Restriction Act. Laughlin sought to persuade the congressmen that, "The character of our future civilization will be modified by the 'blood' or the natural hereditary qualities which the sexually fertile immigrant brings to our shores.... We should therefore make the possession of desirable natural qualities one of the conditions for the admission of sexually fertile immigrants." Laughlin, "Biological Aspects of Immigration," (April 16-17, 1920): 8, quoted in Frances Janet Hassencahl, "Harry H. Laughlin, 'Expert Eugenics Agent' for the House
} 
Worse still than white ethnic immigrants, for both Jefferson and later Virginia eugenicists, was the large number of unassimilable African Americans in the South. Twentieth-century eugenicists adopted similar solutions to these "racial" and "national" problems as those propounded by Jefferson, highlighting the striking continuity in their thinking.

Jefferson, like those who followed, posed two solutions to effect the acculturation of foreigners, one social the other biological_education and intermarriage. For Jefferson, as for the later generation, education could socialize both foreign elements and younger generations, fitting them for their republican responsibilities. Education's acculturative effect, however, depended upon the ability of those exposed to it to benefit from it. Although blacks equaled whites in memory, in Jefferson's estimation, their ability to reason was "much inferior," and their imagination (or creative genius) was "dull, tasteless, and anomalous." Despite the achievements of black exemplars like Phyllis Wheatley, Ignatius Sancho, and Benjamin Banneker, Jefferson believed that blacks could not be educated to the point of assimilation. ${ }^{32}$ Arguing that, "The improvement of the blacks in body and mind, in the first instance of their mixture with the whites, has been observed by every one, and proves that their inferiority is not the effect merely of their condition of life," Jefferson constructed whites as innately superior to blacks, providing an intellectual "leavening" that improved the (black) issue of black-white mating. ${ }^{33}$ Since even blackwhite miscegenation would fail to raise the level of the offspring to that of "pure" whites, blacks should be "brought up, at the public expence, to tillage, arts or sciences, according to their geniusses" and then expatriated to an all-black colony. Indeed, as Winthrop Jordan noted, "More than any other single person," Jefferson "framed the terms of the debate still carried on today" about racial differences in cognitive ability. Eugenicists and hereditarians

Committee on Immigration and Naturalization, 1921 to 1931" (Ph.D. diss., Case Westem Reserve University, 1970), 241.

32Jefferson denigrated Wheatley's poetry as "below the dignity of criticism," claimed that Sancho's work did "more honour to the heart than the head," and intimated that Banneker may have been aided by a white neighbor. Jefferson, Notes, Query XIV, 139-40; and Jordan, White Over Black, 445-54.

33 Jefferson, Ibid., 141. 
extended Jefferson's analysis and conclusions in a self-conscious attempt to substantiate his "suspicions." 34

Even Jefferson's famed educational plan, embodied in his 1779 "Bill for the More General Diffusion of Knowledge" and recounted in the Notes, reflects certain protohereditarian concepts regarding educational potential. Jefferson's ideal public education system, implicitly for whites only and explicitly masculine, created a hierarchy that reinforced class structure and purported hereditary "endowment" under the guise of merit. All Virginians were entitled to three years of "gratis" education in Jefferson's primary schools, "for teaching reading, writing, and arithmetic." 35 Those who wished their children to attend longer must pay for their schooling. Annually the school's "visitor" would "chuse the boy, of best genius in the school, of those whose parents are too poor to give them further education, and to send him forward to one of the grammar schools." After another winnowing process, with "twenty of the best geniuses" being "raked from the rubbish," a final cut would send half of this cohort off to become school teachers, while the other half, "chosen for the superiority of their parts and disposition," would attend William and Mary College. While Jefferson's plan absolutely democratized education as compared to contemporary standards, he built in a "meritocracy" that allowed a tiny percentage of poor children access to educational advance, ostensibly on the basis of their

\footnotetext{
${ }^{34}$ Recrudescing about once a generation, precisely these ideas of innate intellectual inferiority undergird the most recent example of hereditarian social theorizing, Richard Herrnstein and Charles Murray's The Bell Curve: Intelligence and Class Structure in American Life (New York and elsewhere: The Free Press, 1994). Hermstein and Murray are themselves lineal intellectual descendants of, in reverse order, Arthur Jensen, Lewis Terman, Carl Brigham, and Francis Galton, all of whom categorically denied the equal cognitive potential of blacks and whites. See particularly, Jensen, "How much can we boost IQ and scholastic achievement? Harvard Educational Review 39 (1969), 1-123; Lewis Terman, Genetic Studies of Genius (Stanford: Stanford Universtiy Press, 1947); Carl C. Brigham, A Study of American Intelligence (Princeton: Princeton University Press, 1923); and Francis Galton, Hereditary Genius: An Inquiry into Its Laws and Consequences (London: Macmillan, 1869). This represents only a partial list of hereditarians. A more complete discussion can be found in Stephen Jay Gould, The Mismeasure of Man (New York and London: W. W. Norton \& Company, 1981; revised and expanded edition, 1996).

35Jefferson, Notes, Query XIV, 146. See also Philip Alexander Bruce's discussion in History of the University of Virginia 1818-1919: The Lengthened Shadow of One Man (New York: The Macmillan Company, 1919), Vol 165-82.
} 
inborn abilities. ${ }^{36}$ Although Jefferson's plan implied inborn capacities, his stated purpose for educating the poor returned to a notion of equality among whites, regardless of economic class. Not denying the inborn inequality of "talents" among whites, Jefferson implied that heredity transcended class distinctions, often the most visible of the lateeighteenth and early-nineteenth centuries' social boundaries.

Of course, Jefferson's ideal educational system was for whites only-he never set out a system for educating blacks "according to their geniusses." Jefferson viewed any attempt to assimilate blacks within the American polity as an even greater threat to the integrity of the republic than assimilating immigrants. Politically and biologically, Jefferson had constructed blacks and whites as "two distinct peoples whose natural relation...was a state of war." 37 Americans faced a choice between two unpalatable solutions: expatriation of blacks and the loss of slave property, or "convulsions which will probably never end but in the extermination of one or the other race." 38 Assimilation of blacks through amalgamation-intermarriage with whites - was out of the question. Not only had Virginia law and custom barred intermarriage since 1691, natural law also seemed set against such unions. While it was known that blacks and whites could interbreed, a condition that satisfied Linnaeus and others that both races were varieties of the same species, most whites doubted that they should interbreed. Many natural philosophers felt that since "like begets like," nature had placed certain barriers between the mating of widely divergent forms. The sterility of offspring from divergent matings, as in mules which resulted from horse-donkey crosses, was though to be one outward manifestation of this barrier. Building an analogy between humans and animals, some theorists argued that "mulattos," the offspring of black-white crosses, suffered from reduced fecundity or "relative

\footnotetext{
36Jefferson, Notes, Query XIV, 146-47. Indeed, Jefferson and John Adams's long debate over the nature and existence of a "natural aristocracy" actually prefigured eugenicists and environmentalists arguments in favor of viewing the genetically "fit" as a naturally privileged group destined to lead.

${ }^{37}$ Onuf, "Race, Slavery, and National Identity," 14.

${ }^{38}$ Jefferson, Notes, Query XIV, 138.
} 
sterility."39 Other theorists suggested that the geographic separation of "races" indicatedif not special, separate and possibly unequal creation-then a divine or "natural" desire to keep the races distinct. Another barrier, according to many scientists, was what Jefferson termed "the real distinctions that which nature has made," differences in physiognomy or physiology that would cause each group to be repelled by the other. 40 Later eugenicists would develop precisely these lines of thinking, drawing them into harmony with the new discoveries in genetics, reproductive biology, and intelligence, to circumscribe black citizenship. ${ }^{41}$

According to Jefferson and the eugenicists, American whites and blacks, could not mate "without staining the blood" and increasing "this blot in our country". 42 Thinly veiling his professed repugnance toward miscegenation, Jefferson appealed to scientific interest in maintaining racial purity, writing, "Will not a lover of natural history then, one who views the gradations in all the races of animals with the eye of philosophy, excuse an effort to keep those in the department of man as distinct as nature has formed them." Ostensibly reflecting on his taxonomic effort to differentiate blacks and whites, and citing his qualified belief that blacks might represent a "variety" of the human species, Jefferson effectively presented a brief against racial mixing. Thus, while marriage between immigrants and native-born white Americans might facilitate acculturation, Jefferson

\footnotetext{
${ }^{39}$ English physician Dr. Charles White first made this argument in his 1799 work An Account of the Regular Gradation of Man. See Gossett, Race, 49-50. Later geneticists and eugenicists would take up a similar line of reasoning in the arguments about "reversion"-that crosses between widely varying stocks reverted to the more primitive type. Mark Haller, Eugenics (Brunswick, NJ: Rutgers University Press, 1963), 147-148; Diane B. Paul, Controlling Human Heredity: 1865 to the Present (New Jersey: Humanities Press, 1995), 110-14.

$40 \mathrm{Jefferson}$, of course, felt that natural repellence worked only from the top down, noting the supposed preference of "the Oran-ootan for the black women" and the similar preference of blacks men for white women. Jefferson, Notes, 138.

${ }^{41}$ See, for example, Davenport's lengthy discussion of "Relations of Barriers to Human Breeding," in Heredity and Eugenics, 289-94; and Davenport, Heredity in Relation to Eugenics, 189-203.

42Jefferson, Ibid., 141, 143; Query VIII, 87. In private correspondence, Jefferson averred that the "amalgamation" of blacks "with the other color produces a degredation to which no lover of his country, no lover of excellence can innocently consent." Jefferson to Edward Coles, August 25, 1814, quoted in Onuf, "Race, Slavery, and National Identity," 40.
} 
debarred blacks from this path to "naturalization," hiding behind his science to justify

antimiscegenation. Intermarriage with blacks was, as Onuf notes, "a dangerous, unnatural transgression"-both politically and biologically. Jefferson could, however, countenance intermarriage with Native Americans. ${ }^{43}$ Although he again temporized and called for more studies before "we condemn the Indians of this continent as wanting genius," he believed that "we shall probably find that they are formed in mind as well as in body, on the same module with the 'Homo sapiens Europæus."' Nevertheless, he also felt that very few "pure" Native Americans remained in Virginia, most having interbred with blacks. ${ }^{44}$ The best way to preserve natural differences was not merely through categorization, but through what would come to be known as "racial integrity," efforts to stop miscegenation. ${ }^{45}$ Later racial theorists would adopt this logic regarding the "varieties" of humanity and the desire to prevent racial mixing. And, in a nod to Jefferson and all "whites" who claimed descent from John Rolfe and Pocahontas, Virginia's 1924 eugenic antimiscegenation statute would recognize as white all those who had "not more than one-sixteenth the blood of the native American."46

For both Jefferson and later eugenicists, "racial purity and national identity were inextricably linked."47 Jefferson, like his intellectual descendants down to the present, saw only two outcomes: segregation or amalgamation. Indians and some immigrants could be

\footnotetext{
${ }^{43}$ This was not a new position. In an earlier generation, Virginia's own James Byrd—whose family became a political dynasty - claimed that educating Native Americans at William and Mary was not sufficient to acculturate them. Intermarriage between colonists and indigenous people offered the only way to lasting peace. Gossett, Race, 27-28.

${ }^{44}$ Jefferson, Notes, Query VI, 58-64; quotations 63 and 62. He wrote of the Mattaponies that there only remained, "three or four men only, and they have more negro than indian blood in them," although the Pamunkies remained "tolerably pure form mixture with other colors" (Query XI, 96).

45 Jefferson, Notes, Query XIV, 143. See Winthrop Jordan's penetrating discussion of Jefferson's views concerning Native Americans in relation to his derogation of blacks. Jordan, White Over Black, 47781.

${ }^{46}$ See Virginia's Racial Integrity Act, Sections 20-54 through 20-57 of the Virginia Code of 1950, discussed in Paul A. Lombardo, "Miscegenation, Eugenics, and Racism: Historical Footnotes to Loving $v$. Virginia," University of California, Davis Law Review 21 (1988): 434. Some of Jefferson's cousins proudly traced their lineage to this early interracial union.

${ }^{47}$ Onuf, "Race, Slavery, and National Identity," 40.
} 
assimilated through intermarriage. Miscegenation with blacks or "unfit" immigrants, however, threatened to destroy the republic. Segregation of widely divergent racial strains promised the only solution to the intractable tensions created by two races living in contact. With this imperative in mind, Jefferson came to champion the expatriation of American blacks to a politically and biologically autonomous state. What Peter Onuf calls a national solution that would avoid racial obliteration, was also a biological solution that was embraced by later eugenicists. ${ }^{48}$

Moreover, Jefferson went on to make the barn-to-bedroom analogy from which all later eugenic schemes extended. Jefferson invoked both Johann Friedrich Blumenbach's taxonomy and scientific breeding when he wondered aloud why, "The circumstance of superior beauty, is thought worthy attention in the propagation of our horses, dogs, and other domestic animals; why not in that of man?" Indeed, as Onuf notes, "Sex and war converged," for Jefferson and later eugenicists. Both activities could result "in the extermination of the one or the other race" through physical or biological genocide. 49 Jefferson's political philcsophy may have preceded his racial ideology, as Onuf contends. What is certain, however, is that Jefferson's theoretical efforts added moment to the impulse that shifted race from a "legal" notion derived from the mother's "political" status toward a "hereditary," biological conception. Instead of defining blackness as congruent with slavery, as a function of descent from an enslaved mother, blackness precipitated from the intermixture of genetic material: "one drop" of black "blood" caused a genetic reversion from whiteness to blackness.

\footnotetext{
${ }^{48}$ Onuf, "Race, Slavery, and National Identity," 18. In the twenticth century, Eamest Sevier Cox would become Virginia's foremost eugenic colonizationist, advancing his ideas in books and pamphlets from the 1920s to the 1960s. His most famous book, White America (Richmond, VA: The White America Society, 1921) would go through three editions and be distributed to members of congress in support of repatriation bills supported by Senators Vardaman, Bilbo, and Langer. Cox's w'orks can still be found on various white supremacist organizations Internet sites.

${ }^{49}$ Jefferson, Notes, Query XIV, 138; Cnuf, "Race, Slavery, and National Identity," 26.
} 
Since Jefferson's notions of science- his natural philosophy and his political philosophy-both extended from natural law, they remained inextricably intertwined.

While at times his emphasis may have been on the one, it went hand in hand with the other. Regardless of his intent, he set the stage for those who followed, for they collapsed any subtle distinctions intended by Jefferson. His advocacy of racial hierarchy and "scientifically managed breeding" indeed "reduced 'man' to the level of 'domestic animals,"' and did more than point "ominously toward the eugenic theories of later generations of scientific racists," as Onuf suggests. Jefferson paved the way for later eugenicists by providing a rationale that hamonized their theories with democratic political ideology. Ensuing generations of scientific racists, like Jefferson, argued that "selfpreservation was [the nation's] highest moral imperative," and that "'self-preservation' was the first law of nature." Just as Onuf contends, "In Jefferson's formulation, the very 'lives' of his countrymen, the self-preservation of Virginians as a people depended upon depriving enslaved Africans of their 'liberties,"' which included the political and procreative freedom, so too did later Virginia eugenicists seek to deprive the personal and procreative liberties of blacks, poor whites, and the "mentally defective" to prevent their destroying the lives and people of Virginia through genetic pollution.50

Jefferson also established the close connections between reason, religion, social planning, and science that characterized later eugenic thinking. As an Enlightenment philosopher, Jefferson practically collapsed reason and religion. Although he distinguished between humankind's moral/metaphysical "faculty" and the rational/intellectual faculty, Jefferson expected religion to reflect the scrutable regularity of God's natural laws. God's "book of nature" provided the best instruction manual for living a "Godly" life. Thomas Jefferson's early articulation of "science as religion" set in motion a dynamic that would

50Onuf, "Race, Slavery, and National Identity," 34; 4. Later racial thinkers filtered their beliefs through a Spencerian skein of "survival of the fittest" as the first law of nature, but that is merely "selfpreservation" by a different name. This rhetoric runs throughout the arguments deployed by Virginia eugenicists in favor of eugenic sterilization, marriage restriction, and mental institutionalization. 
characterize the later eugenics movement, which also tried to create a "secular creed" where biological imperatives took on religious significance. ${ }^{51}$

Jefferson's quest for the "virtuous" republican, the yeoman farmer, came to be construed by later biological progressives as a call for "eugenic" citizens to comprise a better society. Jefferson and the eugenicists, exposing their political, class, and biological biases, excoriated "the mobs of great cities" which "add just so much to the support of pure government, as sores do to the strength of the human body." Later eugenicists characterized "the manners and spirit of a people" as biologically-based by ascribing them to genetics. Thus they agreed with Jefferson that "A degeneracy in these is a canker which soon eats to the heart of [a nation's] laws and constitution."52 Jefferson's emphasis on the rhetoric of "commonwealth" and the metaphor of the "body politic" as afflicted by disease, mirrors ideas of public health and visions of a society beset by actual disease. The metaphor merges the biological and the political into the "natural" and organic. The best way to reform social "ills," then, is through a biologically-grounded therapy. Even in his discourse on Virginia's laws, Jefferson remarked upon the congruence of proto-biological reform and the public weal: "The laws have also descended to the preservation and improvement of the races of useful animals, such as horses, cattle, deer; to the extirpation of those which are noxious, as wolves, squirrels, crows, blackbirds; and to the guarding our citizens against infectious disorders, by obliging suspected vessels coming into the state, to perform quasantine, and by regulating the conduct of persons having such disorders within the state. 53 These same concerns would be invoked by later eugenicists to justify social policies meant to prevent the birth of "persons having such disorders" or those susceptible to them.

\footnotetext{
${ }^{51}$ See, for example, Alfred E. Wiggam's The New Decalogue of Science (Indianapolis: Bobbs-Merrill Company, 1923), which explicitly enunciates ten biological "commandments" to guide human living.

52 Jefferson, Notes, Query XIX, 165.

${ }^{53}$ Jefferson, Notes, Query XIV, 135.
} 
Changing scientific ideas did little to alter the fundamental social goals expressed by Jefferson. Instead, scientific advance sharpened the edge of the legislative scalpel, and increased the precision with which it dissected pathological agents from the body politic. This medicalization of the rhetoric surrounding government began with the homology between natural rights and natural history, both of which extended from natural law. Such rhetoric hardened to dogma throughout the nineteenth and twentieth centuries as the "advance" of science-particularly the advent of Darwin and the rise of experimental biology-allowed experts to speak with greater authority about biological processes. Herbert Spencer's conscious adaptation of Darwinism to social processes destroyed the ideational and discursive barriers between the biological and the political.

Before this melding of paradigms could occur, with both society and individuals being discussed in evolutionary terms, the nagging issue concerning the origins of humanity had to be resolved. It is perhaps not surprising that one of the most coherent expositions in favor of the specific unity of humanity emanated from the crowning jewel of Jefferson's educational structure, the University of Virginia. It is even less surprising that, in advancing the specific unity of humankind, Dr. James Lawrence Cabell would leave room to distinguish "permanent varieties" of humans that, despite their equal moral sense, might vary absolutely in their native intellect. Cabell's often overlooked treatise thus represents the next full iteration of Jefferson's racial logic. The University of Virginia's medical school thus became a seat for hereditarian and eugenic theorizing by the second half of the nineteenth century.

\section{Diversity from Unity: Reconciling Inequality and Common Creation}

The principal institutional historian of the University of Virginia, Philip Alexander Bruce, viewed the academy as "the lengthened shadow of one man," its founder, Thomas Jefferson. Writing in 1919, as America and Virginia neared the apogee of popular interest 
in heredity and eugenics, Bruce remarked, "No biography can be accepted as complete which fails to scrutinize the qualities of the parentage of its subject. The laws of heredity are equally applicable to the University of Virginia, for all its principal characteristics...derived from the moulding hand of Jefferson. ${ }^{54}$ Jefferson viewed the University of Virginia as the fruit of his intellect. Among the many great accomplishments in his life, he felt that his role as "Father of the University of Virginia" deserved to be listed, co-equally with his authorship of the Declaration of Independence and the Statute of Virginia for Religious Freedom, as his epitaph. If Jefferson was the University's father, then certainly the South - in land, custom, and myth - was the University's mother. The institution, in tum, became the alma mater for generations of Virginia, southem, and national leaders. In this way, Jefferson created an agent for the "hereditary" propagation of his intellectual "germ" across time.

Jefferson founded the university intent on providing locally-trained professionals in all the arts and sciences needed for Virginia's public weal. According to Bruce, Jefferson's love of science and "the modernity of his scientific outlook" ensured that Medicine was one of the disciplines enshrined among the original ten schools he developed to aid the "health" of the commonwealth.55 The medical school operated in conjunction with the School of Natural History, as medical students took their chemistry, botany, and comparative anatomy under the professor of natural history. The University of Virginia Medical School became associated with concepts of heredity and public health early in its history; indeed its founder was one of the first Americans to submit to vaccination for smallpox. ${ }^{56}$ Two of the medical school's giants, James Lawrence Cabell and Paul Brandon Barringer did much to convince Virginians and Virginia medical school students of the importance of public health, corsidering it one of the physician's primary responsibilities. Cabell trained

\footnotetext{
${ }^{54}$ Bruce, History of the University of Virginia, vol. $1,6$.

55 Bruce, Ibid., 27, 31; vol. II, 105-16.

${ }^{56}$ Bruce, Ibid., 35.
} 
Barringer; Barringer then directed the modernization of the school of medicine, the construction of the university hospital, and the training of two future surgeons general, an assistant surgeon general, and a number of other U. S. Public Health Service (PHS) physicians. This association between the University of Virginia and the PHS solidified throughout the twentieth century and had a direct effect on the course and character of public health provision in the South. As Chapter Five will show, the association between Virginia and the PHS would result in one of America's greatest public health debacles, the so-called Study of Untreated Syphilis in the Negro Male conducted in Macon County, Alabama between 1932 and 1972. Such would be the fruit of the seed planted by Cabell and Barringer, the first professors to cross hereditarianism and public health in protoeugenical fashion.

James Lawrence Cabell proved himself a precocious scholar. Born in Nelson County, Virginia in 1813 , he eamed the University of Virginia's most prestigious degree, the master of arts, in 1833. The next year, he earned a medical degree from the University of Maryland, and went on to post-graduate study in France. Given his widely recognized promise, Cabell gained the chair of Anatomy, Physiology, and Surgery at the University of Virginia in 1837. According to later-day Dean of the Medical School, Harvey Ernest Jordan, "Dr. Cabell was probably the most distinguished professor of this medical school" from then until the twentieth century. ${ }^{57}$ Only the second man to hold the chair of medicine in Mr. Jefferson's University, Cabell would rise to the university's highest position, serving as Chairman of the Faculty in 1846 . The nationally-recognized Cabell cast a long shadow over Virginia and southern medicine.

Cabell maintained a keen interest in the most progressive medical ideas and techniques and became an innovator in his own right. 58 After witnessing the horrible hospital

${ }^{57}$ Harvey Ernest Jordan, "A Short History of the University of Virginia Medical School," (unpublished Ms.), 4579, Special Collections, Alderman Library, Charlottesville, Virginia, 8.

${ }^{58} \mathrm{~A}$ former student wrote of Cabcll, "he bore the mint-mark of Jefferson's ideas of a medical education, 'comparative anatomy, human anatomy and the theory of medicinc, in a university atmosphere,' with its 
mortality rate as a chief surgeon in the Confederate Army, he became an early proponent of what would become known as the Listerian methods of asepsis, advocating attention to cleanliness as early as 1867.59 Moreover, after an 1870 trip to Califomia, where he visited the first state board of public health organized in America, Cabell recognized the importance of preventive medicine and sanitation in promoting public health. He founded Virginia's first State Board of Health in 1872. Unfortunately, the board was practically still-born as the General Assembly created it without an expense appropriation. It sputtered along for six or seven years, then collapsed. 60 Nevertheless, Cabell remained an exponent of govemment-sponsored public health initiatives. He was a charter member, in 1878, of the American Public Health Association, becoming its president the next year. Indeed, Cabell gained such stature in the field that he was appointed president of the first National Board of Health. Chartered in 1879 in response to yellow fever outbreaks, the board survived with Cabell as its president, until the 1883 expiration of its enabling law. ${ }^{61}$ Not surprisingly, Cabell inspired many of his students to champion public health.

Cabell held his chair at the University of Virginia until he died in 1889 , teaching hundreds of young men who entered the medical profession with varying degrees of success. None of his students, however, would match the records established by his two protégés: Walter Reed and Paul Brandon Barringer. Walter Reed's medical experiments revealed that infected mosquitoes transmitted yellow fever, thereby vanquishing one of the world's greatest public health menaces. Reed's discovery solved a great medical mystery, revolutionizing the way physicians thought about disease and sanitation. His

nine months' session, to be followed with clinical material in a city; for he believed that not until then could the student fully appreciate it." Paul Brandon Barringer, Memoir, XXXIII:324.

${ }^{59}$ English surgeon Dr. Joseph Lister (1827-1912) introduced antiseptic surgery and aeseptic (sterile) practice during the second half of the nineteenth century.

${ }^{60}$ Roy K. Flannagan, "Dr. Paul Brandon Barringer," (Address before the Alumni Association of the University of Virginia, June 7, 1941) Barringer Papers: 1: loosely filed: 5. Flannagan was himself a longtime official in the Virginia Department of Public Health. See also Paul Brandon Barringer, Memoir, XXXIII:323-25.

$61_{\text {Ibid., } 10 .}$ 
accomplishments went beyond his yellow fever findings; his use of fully-informed, volunteers as test "subjects" also set new standards for medical research. In addition, his experiments enlarged the scope of bacteriology, a fledgling science still largely confined to the laboratory. By moving beyond "bench research" with microscope and microorganisms, Reed began the earliest "practical" study of epidemiology in American history. Reed's brief career reveals the influence of Cabell's teaching through his combination of scientific, experimental inquiry and public health. Reed, like Cabell before him, used the latest technologies to solve one of the oldest pathological problems facing physicians. ${ }^{62}$

Cabell's second great protégé, Paul Brandon Barringer, did not achieve Reed's lasting fame. Yet, for a time at the turn of the century Barringer (along with Doctor Hunter McGuire, president of the American Medical Association) was one of the two most recognized southem physicians. Barringer shared his mentor's interest in public health and the practical application of "scientific" medicine to society. Ultimately, he would develop Cabell's early notions about the proper relation between religion and the sciences of evolution, heredity, and racial difference into a genetic defense of segregation. Barringer's later ideology depended, in large measure, on the notions presented in Cabell's oft overlooked 1859 book, The Testimony of Modern Science to the Unity of Mankind. ${ }^{63}$

\footnotetext{
${ }^{62}$ Bruce, History of the University of Virginia, vol. IV, 209-10. Ironically, Reed's principal biographer, William Bennett Bean, would learm eugenics at the University of Virginia, as will be discussed in Chapter 3. See William Bennett Bean, Walter Reed: A Biography (Charlottesville: University of Virginia Press, 1982).

63 James Lawrence Cabell, The Testimony of Modern Science to the Unity of Mankind; being a summary of the conclusions announced by the highest authorities in the several departments of physiology, zoology and comparative philology in favor of the specific unity and common origin of all the varieties of man (New York: Robert Carter and Brothcrs, 1859). This book is often overlooked in discussions of the development of hereditarian and racialist thought in America. Perhaps it is bccausc, on the surface, it appears to be only a synopsis of all the available scholarship. Careful reading, however, reveals that Cabell marshals contemporary discussions as evidence for his own elegant yet understated argument. Ultimately the timing of the book's release probably accounts for its subsequent invisibility. It appeared on the eve of the Civil War, and just before Darwin's epochal Origin of Species. By the time American naturalists retumed to their studies after the war, Darwin's work held the stage, shattering what Darwin called "the dogma of separate creations," and raising entirely new theological debates. Ronald L. Numbers, "Darwinism and the Dogma of Separate Creations: The Response of American Naturalists to Evolution," in, Darwinism Comes to America (Harvard University Press: Cambridge, MA and London, 1998), 24-48; 166-78.
} 
Cabell's Testimony sought to resolve the heated debate among "natural philosophers" regarding the origins of mankind that had simmered since Jefferson's time. Specifically, Cabell digested all available scholarship in an effort to decide whether all mankind descended from a common ancestor (monogenism), or if the various races each had their own distinct ancestral pair (polygenism). The answer to this question held deep ramifications for Christian theory, Enlightenment philosophy, and American social structures, particularly slavery. Polygenism denied the biblical notion of all humanity descending from Adam and Eve. This heresy facilitated the "scientific," hierarchical ranking of races, reinforcing slavery but undercutting Enlightenment natural-rights egalitarianism. Monogenism upheld Christian and Enlightenment doctrine, but it seemed to undermine chattel slavery by highlighting the immorality of holding divinely created equals in bondage. Most slaveholders, considering themselves faithful Christians, wanted nothing to do with the polygenist defense of slavery. Indeed, the Richmond Enquirer argued that southerners must reject polygenism as a support for the "peculiar institution" in favor of biblical fidelity. 64 Thus, clerics and the faithful excoriated "scientists" generally, and polygenists specifically. The task remained then, to show that monogenism could uphold both the Christian equality of the races and their secular inequality, the basis of slavery. Still as delicate a subject as when Jefferson encountered it, Cabeil would exploit shifts in philosophical and scientific ideas to create a syllogism that supported slavery: if the science of origins upheld the theology of origins, and if the science of origins upheld racial inferiority, then slavery was both theologically and scientifically justified.

The debate over origins touched a raw theological nerve. As Reverend James W. Alexander noted in his introduction to Cabell's book, "The specific unity of the races is

\footnotetext{
${ }^{64}$ The editor of the secessionist Richmond Enquirer "suspected that many readily accepted the 'infidel' doctrine of diversity" because it supporled slavery. Yet, in his mind, slave-owners could not afford the polygenic defenses of slavery if adherence to the biblc "was the price it must pay for them." Quoted in William Stanton, The Leopard's Spots: Scientific Altitudes Toward Race in America 1815-1859 (Chicago and London: University of Chicago Press, 1960), 194. Alexander Boulton notes this same dynamic, Boulton, "American Paradox," 485.
} 
concermed in the doctrine of salvation; in the fall of Adam and the Redemption of Christ. It was not a matter of indifference whether the nature which fell in Eden, was that which we inherit, and whether the humanity which Jesus bore upon the cross and carried into heaven was that of all mankind."65 Jefferson had sought to circumvent this ideological minefield by adapting Dr. Benjamin Rush's refurbished taxonomy of human cognition. Jefferson's universally held "moral faculty" established the common bond between all humans. His individually varying mental faculties-memory, reason, imagination-distinguished groups and individuals and accounted for observed human differences. Jefferson refrained from determining root causes of these differences, and avoided speculating on the specific or diverse origins of human life. ${ }^{66}$ In his assertion of humankind's specific unity, Cabell would further refine Jefferson's cognitive distinctions. Cabell's discussion, unlike Jefferson's, explicitly attempted to reconcile modern science, traditional religion, and slavery by destroying the polygenist argument while leaving open the loophole of racial inequality. He left implicit the political ramifications of his analysis.

Undertaking his project, "at the request of an honored prelate," Cabell was no overzealous Biblical literalist. Although he believed scientists should, "be very cautious how we build up scientific dogmas on the popular sense of the Scriptures," Cabell would allow "the utmost freedom of inquiry to the explorer of scientific truth, being quite satisfied that whatever conclusions he may succeed in establishing on reliable evidence, must in the end be found to harmonize with the revealed word of God...." Cabell's faith in the consonance of religion and science stemmed from his belief that harmony "must ever subsist between the two revelations which God has been pleased to give to his intelligent

\footnotetext{
${ }^{65}$ Cabell, Testimony, vi-vii.

${ }^{66}$ See Jefferson, Notes, Query XIV, 143. He notes his "suspicion" of black inferiority, but leaves open the question of cause: "whether [blacks were] originally a distinct race, or made distinct by time and circumstances...."; Jordan, White Over Black, 440-45. German physician Franz Joseph Gall would develop his own "faculty" notion of human intellect, after 1800, into the "science" of phrenology. Popularized in the United States during the mid-1800s by the Fowler brothers, phrenology in America never really influenced racial theories as much as craniometry, the measuring of skull capacity and morphology without connection to discrete intellectual capacities. Chase, Legacy of Malihus, 49, 94-7; Gossett, Race, 73.
} 
creatures, in his works and in his written word." 67 For Cabell, as for Jefferson before him, the truths revealed by science complemented the truths revealed in the Bible; nature accurately reflected God's will. Cabell, like Jefferson, was willing to segregate the metaphysical from the physical world, allowing each to operate independently, yet claim a common origin in natural law. Epistemological conflict would be avoided, according to Cabell, as long as each discipline remained focused upon its separate sphere: science dealt with the natural world, theology with the supernatural. Cabell, writing in the midnineteenth century, after experience and political wrangling had dulled the shine of natural rights rhetoric, recognized the epistemological differences that Jefferson either ignored or took for granted in his disquisitions on "natural" racial differences and natural rights.

Cabell, practicing what he preached, deployed scientific rather than religious arguments to attack the polygenist theories advanced by Harvard's Louis Agassiz-then America's pre-eminent naturalist-and the disciples of craniometrician Doctor Samuel George Morton, and ethnologists Josiah Clark Nott and George Robin Glidden. Cabell countered Agassiz's notion of "original varieties" with his own ideas about "permanent varieties." Agassiz accounted for racial differences by positing the geographically separate, multiple creation of the various races. He squared this notion with Christian and Enlightenment doctrine by averring that all races were "endowed with one common nature, intellectual and physical, derived from the Creator of all men" despite having been created separately. 68

Cabell, following Jefferson's belief in the economy of nature, envisioned a single creation with various strains arising from a common ancestor. Differences evolved and stabilized over time as a result of the interaction between environment and heredity. Cabell anticipated Charles Darwin's theory of natural selection, and like Darwin he viewed it as an

${ }^{67}$ Cabell, Ibid., ix, 13-14. For excellent discussions of antebellum evolutionary and racial theories, especially those of Agassiz, Morton, and Noll and Gliddon, see Stanton, The Leopard's Spots; and Thomas F. Gossett, Race: The History of an Idea in America reprint edition (New York and Oxford: Oxford University Press, 1997), 58-67.

${ }^{68}$ Agassiz quoted in Gossett, Race, 60. For the various views of these men with regard to race, see Stanton, The Leopard"s Spots. 
outgrowth of a Lamarckian, environmentalist view of evolution and heredity. ${ }^{69}$ Cabell argued that, "certain acquired peculiarities are often reproduced with perfect regularity so as to give rise, within the limits of a single original species, to 'varieties' marked by characters as 'permanent' as those which distinguish the species itself...." Unlike strict

Lamarckianism, which averred a constantly changing population, Cabell envisioned the creation of stable groups, displaying recurring hereditary patterns that initially were spurred by environment. Therefore, Cabell believed that mere differences between races-even if permanent-were not enough to prove their separate origins. Only historical records that could "preclude the idea of the [gradual or post-creation] appearance of variations" would destroy, for Cabell and others, the possibility of specific unity in the light of present diversity. ${ }^{70}$

Cabell accounted for the genesis of permanent varieties by advancing precise ideas regarding the interaction of environment and heredity as evolution's mechanism.

According to Cabell, environmental changes that affected an organism's physiology could result in anatomical traits that would be passed on, regardless of further environmental change. "Thus by carefully changing the food and other agents of vital stimulation," Cabell began in an environmentalist vein,

we may modify, to an extent sometimes quite considerable, the outward structural character of many plants and low animal organisms; and these newly acquired characters may then be perpetuated by hereditary transmission, under the law of assimilation between parent and offspring, even though the causes which originally determined the variation from the primitive type have ceased to operate.

\footnotetext{
${ }^{69}$ Lamarckianism, named for the Frenchman Jean Baptiste de Monet Lamarck, posited that new characteristics acquired by the parent as a result of habit, environment, or even mutilation, could be transmitted to its progeny. While Darwin himself championed natural selection of random variation as the principle method of evolution, he remained catholic enough to accept the possibility of other methods, especially Lamarckianism. The battle between absolutists of both schools-nco-Lamarckians and neoDarwinians-would rage during the 1890s. Bowler, The Mendelian Revolution, 25, 52-53, and 54-64.

${ }^{70}$ Cabell, Testimony, 20-21.
} 
Environment prompted the change, while heredity propagated it. Anticipating Darwin's identification of random variation as the cause of evolutionary natural selection, Cabell continued,

A similar effect is produced in those cases in which a given variation appears accidentally [randomly] in a single individual and is then transmitted to his offspring. This is conspicuously exemplified in human races by a strong tendency to the transmission, throughout large families, of characters whether physical or moral, which had originated as accidental peculiarities in one of the ancestors of the stock.

Without knowledge of Darwin's revolutionary Origins of Species, six years before Gregor Mendel would publish his treatise on the particulate inheritance of characteristics (and 41 years before its rediscovery), and a decade before Francis Galton would describe ancestral heredity, Cabell's incisive analysis advanced plausible mechanistic modes of human evolution that could result in individual and group differences. "Such individual peculiarities are commonly lost after a time by reason of the successive admixture of new elements," Cabell admitted, confessing his fealty to the notion of "blended" inheritance. ${ }^{71}$ Still, he held that, "when persons of both sexes all possess some striking peculiarity, and intermarry among themselves, the peculiar characters tend to become constant. In other words, a permanent variety is likely to arise."72 This second clause reveals an incipient conception of ancestral, particulate heredity. The stability of expressed characters resulted from the mating of "like" (or homozygous, in the vernacular of later geneticists) parents. Similar ideas would not be articulated, experimentally demonstrated, or recognized at large for another 40 years.

\footnotetext{
${ }^{71}$ The two major paradigms for the mechanism of heredity in the nineteenth century were "blending" and, later, "particulate" inheritance. "Blending" assumed a mixing of the parental traits, with the offspring expressing a middle position in, say, eye-color, stature, or disposition. Particulate inheritance assumed that traits depended upon the inheritance of specific "germs" that governed the trait's expression. This idea received its fullest exposition in Mendel's laws of inheritance. Bowler, The Mendelian Revolution, 21-45. See also Donald K. Pickens, Eugenics and the Progressives (Nashville: Vanderbilt University Press, 1968), 38-46; Haller, Eugenics, 59-63.

${ }^{72}$ Cabell, Ibid., 22-23, 30. Cabell also remarked that "not only are the structural characters of animals of the same original stock liable to undergo variations, accidental in their origin, yet afterwards regularly transmitted to their offspring, but...the same may be predicated of certain physiological and psychological traits" (37).
} 
As prescient and "progressive" as Cabell's analysis was, it ultimately served a conservative purpose. Cabell's system of permanent varieties comported with Scripture and recast Jefferson's ideas about the natural (biological) basis of human nature and intellect-without altering their racial conclusions. Consonant with Christian doctrine because it avoided the "needless repetition of the miracle of creation," Cabell's theory nevertheless focused on the physical, not the metaphysical. Like many naturalist after 1850 , Cabell segregated the two epistemological traditions to manage their harmonious "reconciliation."73 This allowed him to assert the universality of natural law, leaving to the clergy the task of "setting forth the harmony which must ever subsist" between God's physical and metaphysical revelations. ${ }^{74}$ According to Cabell, since all humanity stemmed from a single Divine creation, all individuals, regardless of apparent biological differences, were open to God's saving grace. This universalism echoed Jefferson's emphasis on the uniform possession of a "moral faculty." Yet, as is clear from the quotation above, Cabell felt that both physical and moral traits obeyed the laws of heredity. This position abandoned Jefferson's distinction between morality and intellect. So, Cabell created a new loophole within his theory that allowed him to leave open the question of racial superiority and inferiority.

Building on the authority of Count Arthur de Gobineau's famous racial study The Moral and Intellectual Diversity of the Races, ${ }^{75}$ Cabell asserted that the unity of humanity "is not inconsistent with the idea of permanent differences among the races," and he justified his position "by referring to the analogous case of different children of the same parents. 'If two men, the offspring of the same parents, can be the one a dunce, the other a genius, why cannot different races, though descended of the same stock, be different also

\footnotetext{
${ }^{73}$ Actually, the solutions to this epistemological problem were somewhat more varied. See Numbers, "Darwinism and the Dogma of Separate Creations," $40-43$.

${ }^{74}$ Cabell, Ibid., 146.

${ }^{75}$ The Moral and Intellectual Diversity of the Races (Philadelphia, 1856) is an abridged translation of Gobineau's Essai sur l'Inégalité des Races Humaines (4 vols.; Paris, 1853-1855). Thomas Gossett notes that this translation was arranged for by pro-slavery activists. Gosscu, Race, 352.
} 
in intellectual endowments?"'76 Although Cabell lacked a fully-articulated hereditary mechanism to explain this occurrence, he still established the basis for the hereditary inferiority of some human stocks. To harmonize his religious orthodoxy and his racial thinking, Cabell presented Gobineau's formulation that, while all humans had access to God's saving grace,

this universal capacity of receiving the light of the Gospel, must not be confounded, as is often done, with a faculty of entirely different character, that of social improvement. This latter consists in being able to conceive new wants, which, being supplied, give rise to others, and gradually produce that perfection of the social and political system which we call civilization. While the former belongs equally to all races, whatever may be their disparity in other respects, the latter is of a purely intellectual character and the prerogative of certain privileged groups, to the partial or even total exclusion of others. ${ }^{77}$

By focusing on the capacity for civilization, rather than the natural right to liberty,

Cabell subtly shifted the terms of debate that seemed, in hindsight, to confound Jefferson.

Freed from the snare-created by the tangled commitments of Enlightenment philosophy and the tensions they engendered between the "is" and the "ought"-that trapped Jefferson, Cabell thus provided for the spiritual equality of all on the metaphysical basis of faith. At the same time, he promoted a materialistic explanation for the existence and permanence of qualitative racial differences on the basis of science. ${ }^{78}$

For all that he intimated that races could manifest qualitative differences, however, Cabell expressed a diffidence and skeptical ambivalence similar to that of Jefferson and the earlier naturalists. Cabell claimed he was "not, indeed, fully prepared to admit all the conclusions" about racial inferiority made by Gobineau. He reserved his final judgment, however, because he felt that Gobineau may have "exaggerated the significance of the past as betokening the future inferiority, for all time, of certain races." Cabell did not object

${ }^{76}$ Cabell, Testimony, 243. Emphasis in original.

${ }^{77}$ Cabell, Ibid., 245.

${ }^{78}$ For an excellent discussion of Jefferson's inability to conceive of a root source of moral action, and to divorce the "is" from the "ought," see Diggins, "Slavery, Race, and Equality," 226-28. For Cabell and later thinkers, morality stemmed from the education of inborn moral dispositions, leaving all people equal potential access to heaven and moral behavior. 
because he believed Gobineau's conclusions were "intrinsically inadmissable." Cabell believed that although "a most decided inferiority in intellect, and in the capacity of social improvement is to be the permanent heirloom of certain races, a point which is not only possible but quite probable," such inferiority proved nothing about the unity or diversity of origins, his stated concern. ${ }^{79}$ His religious scruples reconciled with his science, Cabell only had one more move to make: squaring his science and religion with the institution of slavery. Though Cabell appeared to divorce his scientific conclusions from their political implications, these ramifications remained a subtext that simmered beneath his exposition, occasionally erupting to the surface.

Having demolished the heresy attendant to the "'scientific error' which asserts that the black man is an animal of different origin and species from his white master," Cabell proceeded to "protest with equal emphasis against the absurd and, in their consequences, wicked doctrines which modern fanaticism strives to erect upon the admitted truth of the unity of mankind." 80 This veiled reference to "unscientific" abolitionism, which occurred late in the book, revealed the degree to which contemporary social ideologies had shaped Cabell's scientific estimation of "the facts" throughout the book.

Cabell minced no words in laying the groundwork for differentiating the races. Referring to race theorist Johann Friedrich Blumenbach, Cabell wrote, "Blumenback [sic] long ago pointed out the great difference between the cranium of domestic swine and that of the primitive wild boar, and remarked that this difference is quite equal to that which has been observed between the skull of the Negro and the European." 81 Implicitly analogizing humans and animals, Cabell created a hierarchical relationship between race and civilization. Environment created the conditions for "domestication" and "civilization," according to Cabell. Individuals then acquired domestic or civilized behavior, which

\footnotetext{
${ }^{79}$ Cabell, Ibid., 246-47.

${ }^{80}$ Cabeli, Ibid., 249.

${ }^{81}$ Cabell, Ibid., 33.
} 
heredity fixed as "racial traits" in animals and humans. These traits were more or less permanent, depending on the length of exposure to the causal environment. Cabell thus deftly built the foundation from which his science would buttress his faith and his politics.

To secure this intellectual bulwark, Cabell had to defend his Lamarckian explanation of variation against the obvious counter-argument, that removing an organism from one environment to another should cause change:

That the [acquired] character should be so tenacious as to resist the opposite influences of other climates, through a series of generations, should not excite surprise, when it is remembered that a positive character, once stamped upon the system is not easily lost by merely withholding the conditions which originally produced it, and that the process by which it was riveted upon certain races of African negroes, extended through many centuries. ${ }^{82}$

Thus Cabell explained why blacks and whites maintained their characteristic traits even when removed from their native environments. ${ }^{83}$ Assuming that western civilization marked the apogee of development, Cabell implied that whites were permanently "civilized," since they had developed and lived under the "highest" form of civilization for the longest period of time. By extension, enslaved African Americans were only temporarily civilized. They had lived in the environment of slavery which exposed them to a level of development far "above" that of their barbaric relatives in Africa. Slavery's environment created a less permanent change, analogous to the domestication of the wild boar. By implication, enslaved African Americans would revert to their "primitive" and "barbaric" tendencies without the "salutary" influence of slavery. ${ }^{84}$ Cabell also

${ }^{82}$ Cabell, Ibid., 39.

${ }^{83}$ Cabell used the oft-cited example of the permanence of skin color to defend his position. "The fact that dark-skinned people do not lose their characteristic hue by living for many successive generations in temperate climates, is not at all inconsistent with the supposition that this hue might have been originally acquired as the effect of climatic or other external conditions. For a positive mark once acquired, is apt to be perpetuated by hereditary transmission, and is, therefore, not lost by the mere withdrawal of the influences under which it was originally formed." Cabell, Testimony, 120. A generation earlier, Samuel Stanhope Smith used the anomalous case of former-Virginia slave Henry Moss, who appeared to "tum white" to argue the exact opposite position. Sec Stanton, The Leopard's Spots, 5-12; and Gossett, Race, $40-41$.

${ }^{84}$ Referring to domesticated swine freed in the wild, he wrote, "At length, under the influences of their wild state, they have resumed the characters of the original stock; that is, their appearance [and behavior] 
acknowledged the possibility that "inferior races 'cannot come into competition with civilized man without becoming extinct before him."' Therefore, he felt, "it certainly deserves thoughtful inquiry whether the singular growth of the black population in the Southern States of our confederacy, and the marked improvement of the race in physical and moral characteristics, may not have resulted from its contact with a superior race in the only relation [bondage] that could exclude the fatal 'competition."'85 Presuming the scientifically verified inequality of the races, contact with whites under the "benign" institution of slavery may have been "intended, in the merciful and wise providence of God, as the only means of extricating [blacks] from their otherwise inevitable 'destiny,' and of bringing them under the tutelage of a superior race without danger of becoming 'extinct before' such a higher race." 86 Thus Cabell's science and religion merged with his social vision to justify slavery.

While Cabell relied on the theory of "reversion to type" to place black slaves and white masters in their proper, scientifically determined social relationships, he also denied that miscegenation might create permanent racial change. Asserting that "Occasional intermarriages have doubtless taken place [between blacks and white], and the result has been manifest in individuals," Cabell continued, "these incidental crossings of breed could hardly modify the whole nation. It is known that the impressions of one such mixture is lost in a few generations." Cabe!l, like Jefferson before him, believed that a natural aversion to intercourse between widely varying varieties of humans would prevent "intermixtures of whole nations or of considerable numbers or masses" that might otherwise "give rise to an uniform intermediate stock." 87 Lamarckian heredity operating through slavery, not miscegenation or expatriation, pointed the only way to black social

very closely resembles that of the wild boar, from which the domesticated breeds have sprung." Cabell, Ibid., 31-32.

${ }^{85}$ Cabell, Ibid., 249.
${ }^{86}$ Cabell, Ibid., 249.
${ }^{87}$ Cabell, Ibid., 105. 
improvement for Cabell. This process, of course, would take an inestimably long time. Therefore, Cabell's science effectively preserved the status quo of chattel slavery.

Southem social context regarding slavery changed dramatically between the 1787 publication of Jefferson's Notes and the 1859 release of Cabell's Testimony. Slavery was now advocated as a positive good for whites and blacks, instead of characterized as a "blot in our country." 88 It is perhaps not surprising that Cabell's science would come to justify the maintenance of the peculiar institution rather than the expatriation of the enslaved. Indeed, Cabell's science-and he was a leading authority and respected practitioner, not some backwoods crank - now used the same invidious racial distinctions Jefferson made to buttress an institution he had hoped to destroy. Jefferson opened the field to the scientific exploration of race and social structure in America. Cabell, following Jefferson's lead, introduced and supported a number of theories that used science to resolve theological concerns and attempt to quiet the political debate surrounding race and slavery. Moreover, Cabell's argument for permanent varieties resolved the problem between stasis and dynamism that Alexander Boulton claims flummoxed Jefferson. Arguing that permanent varieties manifested real distinctions but not independent creation-"not one of these characters nor any particular combination of them, has that degree of constancy which is essential to render them valid as tests of specific distinction"-Cabell affirmed both the fixity of human species and the concurrent potential for dynamic change within and among its permanent varieties. Cabell's ideas did not help forestall the Civil War, in some ways the great racial war presaged by Jefferson. Cabell's conceptions would, however, be developed by a later generation, in conjunction with the incipient science of genetics, to maintain a "scientific" justification for racial hierarchy.

\footnotetext{
${ }^{88}$ For the defense of slavery in this period, see Peter Kolchin, American Slavery 1619-1877 (New York: Hill and Wang, 1993), 181-199; and Kenneth M. Stampp, America in 1857: A Nation on the Brink (New York and Oxford: Oxford Universily Press, 1990), 110-16, 123-26.
} 
Cabell's Testimony of Modern Science to the Unity of Mankind affirmed the power of heredity because "newly acquired characteristics may then be perpetuated by hereditary transmission," and, "animals may acquire structural characters, differing in many respects from those of the parent stock, and then transmit such peculiarities to their own offspring with entire constancy, so as to give rise to a new breed." 89 Heredity ultimately trumped environment by making its influence permanent..$^{90}$ The world's races did indeed differ, yet they were all human from the same creation.

The most significant aspect of Cabell's system, however, from the standpoint of what he taught his students and their later actions, was its explanation of both morphological and physiological and psychical differences between the races. "We may remark," Cabell wrote,

that this tendency to the regular transmission to offspring of characters acquired by the progenitors of a stock...furnishes an entirely satisfactory explanation of the alleged immunity enjoyed by our negroes from attacks of yellow fever and malarious diseases. The power of resisting certain morbific influences...though acquired with difficulty...may yet, when once fully acquired, be regularly transmitted to offspring and thus become a characteristic of a race..$^{91}$

In one stroke Cabell again implicitly defined African Americans as hereditarily distinct from whites, while explicitly conferring upon them a biologically-determined, racial immunity to disease. Though Cabell promoted monogenism, he differentiated blacks and whites into biologically and medically discrete races. Therefore, what comprised the "public health" would have two very different meanings depending on race. Theoretically, environmental improvements like sanitation and pure food and water, would benefit everyone by providing a healthy atmosphere for development. If one extends Cabell's hereditary analysis, however, black "public health," indeed the very existence of the race, depended upon indefinite submission to white authority and example. Hereditary defenses against

\footnotetext{
${ }^{89}$ Cabell, Ibid., 22 and 36.

${ }^{90}$ Cabell, Ibid.., 115.

${ }^{91}$ Cabell, Ibid., 38.
} 
yellow fever and malaria would not protect blacks from racial warfare. White public health depended upon racial purity_avoiding miscegenation, which would "lower" offspring toward the black station, despite the possibly conferring disease immunity-and the continuation of slavery. Maintaining slavery was the only way to avoid the triple threat of a regressive racial warfare, a civil war, or the tainting of white "stock." While the Civil War ended slavery, Cabell would propound his ideas about racial subordination until his death in 1889. Long before he died, however, Cabell met the young man he would eventually choose to succeed him. It would be this youngster who, after ascending to the highest post at the university of Virginia, would amend Cabell's ideas in light of scientific advances and give them their widest public airing.

Dr. Cabell attended to the young Paul Brandon Barringer when the lad fell ill during his first year at the University. Cabell, "the Nestor of the Medical School" by Barringer's own estimate, became a "guiding influence" in the young man's life. 92 Barringer, like Cabell before him, would pursue the practical application of scientific medicine for the public health. He would also champion the consonance of science and religion. Additionally, Barringer would extend his mentor's hereditarian and racial analyses. Barringer believed fully in both the power of heredity and the biological differences between the races. On the surface, his convictions did not distinguish him from many other southerners of his era. Baringer's scientific training and authority, however, coupled with his prominence among southern educators as the head of the South's most prominent university, and his enduring influence upon his students-largely children of Virginia elites-put him in a position of great power. His ideas influenced generations of Virginians by modernizing their cultural prejudices and placing them on a foundation formed by the most recent science. Jefferson

\footnotetext{
92Paul Brandon Barringer, Barringer Memoir, Paul Brandon Barringer Papers 2588, Box 1, "1900-1902 Correspondence" folder, Special Collections, Alderman Library, Charlotesville. [Hereinafter referred to as Barringer Papers.]
} 
and Cabell limned the outline of racial theorizing. Barringer filled in the sketch and prepared the blueprint for Virginia's twentieth-century eugenic edifice.

\section{Racial Science Meets Public Policy}

Paul Brandon Barringer combined his deep southern roots with his training in scientific medicine to become one of the most influential Virginians at the turn of the twentieth century. Always something of a loose cannon, his independent politics, direct personality, love of a "darkey" joke, and his ideas concerning the proper solution of the so-called "Negro Problem" reverberated across the South and America. Barringer's views informed the opinions of men like Edward A. Ross and Theodore Roosevelt, as well as those of Virginia politicos, social, and business leaders. Barringer was absolutely committed to what Paul M. Gaston termed the "New South Creed"-the amorphous program designed to make the post-bellum South "rich, triumphant, and morally innocent" while conserving the "fratemal unity that the creed of the Old South had furnished."93 Old enough to remember life with slavery, yet young enough to still be at the height of his professional power at the turn of the century, Barringer successfully bridged the gaps between the Civil War, Reconstruction, "P.edemption," and the Progressive Era. Barringer alloyed a curious belief system, an amalgam of traditionalism with regard to social structure, progressivism with regard to the political economy, and a positivist, liberal Christian theism that united science and religion as the motive force behind human progress.

Barringer's Progressive convictions prompted him to use his position within the University of Virginia to advance the New South cause. As a first step, he dragged the University of Virginia's medical school into the modem age by endorsing laboratory training in bacteriology, the clinical training of students under the tutelage of established

\footnotetext{
93Paul M. Gaston, The New South Creed: A Study in Southern Mythmaking (New York: Alfred A. Knopf, 1970; reprint edition, New York: Vintage Books, 1973), 13, 22 (hcrcinafter all page references are to reprint edition).
} 
practitioners, and a lengthened course of study. ${ }^{94}$ Moreover, Barringer founded the University of Virginia's hospital, despite what one commentator remembered as the "most deeply discouraging circumstances of the ridicule and reactionary conservatism of those who would apparently keep the old school just as Jefferson built it, even if the University had to shrivel as a consequence in the competition of a modern world."95 Despite his avowed interest in Progressive causes, Barringer maintained his own strong sense of traditionalism, particularly regarding the southern social fabric. Indeed, Barringer may have been the first Virginian and southerner to use the new science of Mendelian heredity to substantiate the belief in the innate inferiority of African Americans. His scientific authority modernized the racial beliefs of earlier generations. At least in Virginia, this rationalization of prejudice attenuated the extreme racial tensions that rocked America at the tum of the century. In the end, Barringer, like so many others, presented an argument that reinforced the political disfranchisement of African Americans by criminalizing and pathologizing their very bodies. According to Barringer, blacks became unfit for citizenship because of innate pathological conditions, not because hundreds of years of servitude and subjugation rendered them unfamiliar with democratic self-determination. The interactions among his cultural background, his historical context, and his science forged his opinions on religion, race, and the public health into an ideological trammel used to bind African Americans' civil rights.

Paul Barringer was born into a family whose roots stretched back to colonial Virginia. His great-grandfather, "Pioneer Paul" Behringer emigrated from Germany in 1743, landing at Philadelphia and settling briefly in Floyd County, Virginia before moving to North Carolina and becoming "a man of consequence and a large landholder." Barringer's grandfather, General Paul Barringer, served as a brigadier general in the War of 1812 ,

\footnotetext{
${ }^{94}$ Bruce, History of the University of Virginia, vol. V, 177-81.

95 Flannagan, "Barringer," 4; Bruce, History of the University of Virginia, vol. IV, 14-16; 295-97.
} 
while his father General Rufus Barringer commanded confederate cavalry during the Civil War. After the war, Rufus Barringer served prominently in North Carolina's "Redeemer" govermment, helping to disfranchise blacks and install white supremacy as the de facto and de jure law of the land. 96

The patriotic and martial exploits of his ancestors, slaveholders all, left a deep impression on young Paul Barringer. That his elders fought again and again for "their Southland" and their way of life, imbued Barringer with a life-long passion for preserving his distinctly southem heritage and family honor. As he put it in his memoirs, "a name is simply a trust committed to our keeping for life....You are henceforth not simply a participant in the [human] race, you have become a tagged and marked participant."97 Ancestry became a clear marker of one's potential and worth; it also delineated one's social responsibilities. Barringer remembered both the Old South under slavery and the tragedy of "The Lost Cause." As a young boy he lived with his mother's sister, wife of Confederate General Thomas Jonathan "Stonewall" Jackson, and in his memoirs Barringer recounted his memories of meeting Jefferson Davis during Davis's flight after the fall of Richmond. Then, "Shortly after the visit of Mr. Davis," Barringer wrote, "a great catastrophe occurred for me, the first end result of the war, the leaving of almost all our negroes."98 Writing almost seventy years later, Barringer recounted the disbelief that characterized many southermers' accounts of emancipation. Many whites were puzzled that "their" former slaves might not have enjoyed bondage, and that slave "loyalty" was only as strong as the threat of the whip. Barringer's autobiography revealed his life-long inability to see African Americans as anything other than inferior subservients. His academic training rationalized his ideas about racial hierarchy, giving them a sophistication and a justification beyond that of antebellum nostalgia and traditionalism. Given his background,

\footnotetext{
96 Flannagan, Ibid., 3.

${ }^{97}$ Barringer, Memoir, XV:1.

${ }^{98}$ Barringer, Ibid., XII:1.
} 
it was almost foreordained that Barringer would become a "New South booster," attempting to chart the course for southern development in the twentieth century. As a Progressive physician and scientist, his sense of expert authority and the dictates of biology undergirded all his social theories.

Barringer received his early education at the knee of his Uncle, Judge Victor C. Barringer. He then prepared for college at the Kenmore School at Amherst, Virginia under "Professor" H. A . Strode, the father of Aubrey E. Strode, who would later figure prominently in establishing Virginia's eugenic sterilization statute. On a trip from Kenmore, Barringer first encountered the University of Virginia and decided to enter the general college course toward a bachelor's degree. When Barringer fell ill during his first year, James Lawrence Cabell attended him and nursed him back to health. Cabell immediately became Barringer's personal hero. He would later write, "I knew him intimately, and he shaped my life profoundly." 99 Citing his "increasing veneration for Dr. Cabell," Barringer enrolled in medical courses for his second year. Barringer blossomed under Cabell's tutelage, taking his degree in 1877; he received another medical degree from the University of the City of New York while interning at Bellevue Hospital, "the center of all things medical."100 It was in New York that Barringer was introduced to the sweeping changes overtaking American medicine.

New York truly was "the center of all things medical" in this era. Following his own intensive study in New York and Germany, William Henry Welch established America's first department of scientific, research-based pathology at New York's Bellevue Hospital in 1878. Welch led the "heroic age of American medicine," when the profession experienced colossal change at the behest of a few visionaries. Donald Fleming ascribes the "rise of modern medicine" in America to Welch's role as "the leading Influential of American science." Although he began as a "bench scientist," making pathbreaking microscopic 
investigations, Welch rapidly became the leader in the rationalization and

professionalization of American medical education. Welch, along with a few other "Influentials" rescued medicine from the generation of quackery and charlatanism the profession fell into during the Jacksonian Era. ${ }^{101}$

After six highly successful years at Bellevue, Welch answered the call to become the first member of the Johns Hopkins's medical faculty. Working from this conspicuous platform, Welch promoted and oversaw the standardization of medical education and the insitutionalization of public health training. In late 1885, after an additional year of bacteriological study in Germany, Welch and John Shaw Billings assembled the most distinguished medical faculty in North America. This group, including doctors Sir William Osler, William Halsted, and Howard Kelly, opened the Johns Hopkins Hospital in 1889. By 1893, with the addition of Franklin Mall, and eventually Mall's pupil Lewellys Franklin Barker, the Hopkins opened its medical school, the first in the nation to require that all entrants possess the bachelor's degree. ${ }^{102}$ Welch's work at the Johns Hopkins became the model for all schools aspiring to enter the top-flight of medical education. All the members of the Hopkins faculty achieved striking distinction in their respective medical specialties and in allied research. They all also shared two other interests: every one of them became involved with both the public health movement and the organized eugenics movement. Their influence extended far beyond Johns Hopkins. Among those who sought to emulate the Hopkins example was Paul Barringer and the University of Virginia's medical school.

While Barringer just missed working under William Welch at Bellevue, he remained in New York long enough to see Welch's star begin to rise and to take note of his example.

\footnotetext{
${ }^{101}$ For exhaustive treatment of Welch's career and the development of the Hopkins as America's flagship scientific medical school, see, Flexner and Flexner, William Hienry Welch and the Heroic Age of American Medicine, passim; Fleming, William H. Welch and the Rise of Modern Medicine, passim; quotation, 131. Kenneth M. Ludmerer, Learning to Heal: The Development of American Medical Education (Baltimore and London: Johns Hopkins University Press, 1985) presents an excellent survey of the rise of modern scientific medical education.

${ }^{102}$ Flexner and Flexner, William Henry Welch, 111-232; Fleming, William H. Welch, 56-118.
} 
In 1879, Barringer "considered the possibility of entering the Marine Hospital Service (which was the forerunner of the public health service)" after his stint in Manhattan. His father dissuaded him, however, offering to support him in European study. ${ }^{103}$ In March of 1881, Barringer embarked for Europe where, "for the next year and a half I went to the medical centers of London, Edinburgh, Dublin, Paris, and Vienna applying myself to the study of clinical medicine and hospital administration."104 Barringer's European experiences convinced him of the primary importance bacteriology and "scientific" medicine held for advancing therapeutic medicine. Instead of retuming to America to become a bench scientist like Welch, however, he became "an ardent exponent of Pasteur and of preventive medicine."105 Barringer appreciated Pasteur's scientific medicine not for the sake of its esoteric discoveries, but for the advances it promised in therapeutic and preventive medical intervention.

Reflecting upon his experiences abroad, Barringer revealed a primary difference between himself and Welch. Barringer felt that "the surgeons and physicians of Europe were far more learned and erudite than our own," but Americans were better practitioners because, "Any new principle which [Europeans] elucidated was at first of likely benefit 'over the ferry [in America].' The anchor of America is our practical application of the end, i.e., the welfare of the patient, to the means and not the reverse." 106 While empirical research for its own sake captivated Welch, for Barringer praxis, not theory and empiricism, remained centrai to the physician's calling. Ultimately, Barringer felt "that the practical benefit of foreign study (except for special research) was not as great as I anticipated. Also that to apply what I had learned [abroad] to medical practice as I would find it in the [South], would be, except in a general way, well nigh impossible."107

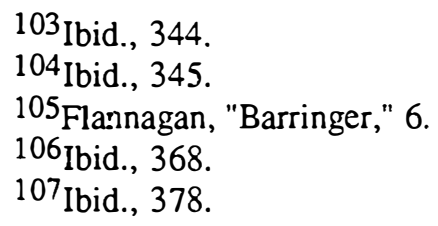


Barringer returned to America aiming to apply scientific medicine to the South. A belief that the South was sick and needed the therapeutic intervention of its best sons-its physicians—would drive the remainder of Barringer's career. Pragmatism and utilitarianism in aid of the South would shape Barringer's approach to developing Virginia's medical school. In this respect he followed in the footsteps of both his mentor and the University's founder. Plagued by an uncooperative legislature and a chronic lack of funding, Virginia crawled toward the example set by Welch at the Johns Hopkins.

Following his post-graduate study in New York and abroad, Barringer returned to the United States and addressed the Medical Society of North Carolina in 1883. Not above a bit of showmanship, Barringer gave the first-ever demonstration of the laboratory microscope, and took as his topic "Constitutional Syphilis and its Diagnosis." Speaking about syphilis challenged both his audience's sense of propriety (syphilis was still a disease seldom discussed in public) and their professional acumen. In the late 19th century, syphilis remained one of the most enigmatic diseases confronting doctors. Yet Barringerperhaps in an arrogant display of his recent European studies-asserted that all physicians had a "fair knowledge of the therapeutics and pathology of syphilis," and pronounced himself astonished by "the indifference and ignorance displayed [presumably by his audience] on this subject, the best known perhaps in all medicine."108 Barringer described syphilis in endemic and epidemic terms, referring to its "constant occurrence" and stating that, "By inheritance and contagion, (mediate and intermediate) syphilis is now becoming one of the most common of diseases." 109 Barringer scolded that, "So little attention is paid to this disease by our legislative bodies and sanitary boards," and "So little sympathy is felt for the ordinary syphilitics that. . their treatment is but little studied and their claims upon us greatly ignored," leaving the population open to infection. Such a situation raised the

\footnotetext{
${ }^{108}$ Paul Brandon Barringer, "An Essay on Constitutional Syphilis," (in two parts) North Carolina Medical Journal 12 (1883), 89-95, 137-45.

${ }^{109}$ Ibid., 90.
} 
spectre of a public health disaster because, "The prostitute and the rake, however, while forming quite a contingent, are not the only sufferers.... The unoffending as well as the offender often suffer together, for some of those who go down to the slums come from the sanctity of the marital chamber."110 Barringer's rhetoric relied upon class, moral, and racially charged imagery_prostitutes inhabited slums while unscrupulous "rakes" brought the contagion back to "the sanctity of the marital chamber"-to allow his audience to identify easily who in the population constituted public health "menaces." The most important aspect of this rhetoric is implicit, however. Very quietly, it blames certain classes for the contamination of society and its ill health. Barringer cast an implicit analogy between various classes and pathological organisms, and between sick individuals and a sick society. Were it not for certain contaminated individuals and pathological organisms, society would be disease free. Just as Jefferson decried "mobs" as "sores" and "cankers" on the social organism, Barringer stigmatized very definite race, gender, and class groups. An apparently neutral metaphor when taken out of context, in a southem environment Barringer's analogy stigmatized readily identifiable groups.

Given the widespread beliefs regarding white female chastity and black female license-especially within the southern context-Barringer projected an image of the lowest-class white women and most black women selling their bodies on "the wrong side of the tracks."111 In contrast, however, stood the philanderer. Implicitly a white male, outwardly of the better sort but inwardly morally degraded and diseased, this lascivious "rake" brought the pox back into hearth and home. For Barringer there was but one remedy: eradication through enactments by "legislative bodies" enforced by "sanitary

${ }^{110}$ Ibid., 89. Similar fears and tales of contagion making its way in to the "sanctity of the marital chamber" appeared 54 years later in Surgeon General Thomas Parran's classic, Shadow on the Land: Syphilis (New York: Reynal and Hitchcock, 1937), 13-14.

${ }^{111}$ See Alan M. Brandt, No Magic Bullet: A Social History of Venereal Disease in the United States Since 1880 (New York and Oxford: Oxford University Press, 1985), 31-37, Barbara Meil Hobson, Uneasy Virtue: The Politics of Prostitution and the American Reform Tradition (New York: Basic Books, Inc., 1987), 145-46, 189; and Ruth Rosen, The Lost Sisterhood: Prostitution in America, 1900-1918 (Baltimore and London: Johns Hopkins University Press, 1982), Chapters 3 and 4. 
boards." Since the only solution for this plague praying on the morals, health, and productivity of the South involved anti-Jeffersonian government intervention, boosters and Progressives like Barringer believed that these policies should be determined by "disinterested" (objective), expert, elite authorities. Citing 45,000 annual syphilis cases in New York, Barringer sounded the tocsin, averring, "there are towns even with us in the South where the percentage is little lower." Given this endemic presence, "A disease like syphilis, laying aside its heredity, must increase in proportion to its basis of contagion, and spreading from a class in which its propagation is, with the majority, a business, who can see the end, unless it be checked by some appropriate legislation."112 The obvious bias in Barringer's remarks, his singling out prostitutes and those he considered of "loose" morals, belies the influence of class and gender prejudices. His invocation of "heredity"which he construed as both the congenital transmission of the disease from parent to child, as well as the constitutional (genetic) susceptibility to the disease-was meant to impress his audience as "medical men." By "laying aside" the hereditary aspect of the disease, he appealed to their fears of "accidental" contagion; they, themselves, might acquire the disease either through "dalliances" or their household "help."

The state should intervene in the name of public health, Barringer argued, cracking down on prostitutes—the "basis of contagion." Implicitly, Barringer let "respectable" white men off the hook for their sexual peccadilloes, despite the social cost of philandering, apparently preferring to control men and women of low class and dark skin. Barringer counseled that lying was "one symptom that runs through the evolution of the whole disease," therefore physicians should "not take any serious present walk and conversation as a standard by which to judge [their male patients'] younger days." Outward appearance provided no indication of inward aberrance or infection. Understanding that physicians might rely on the myth of "mediate contagion"- that a man caught syphilis from a toilet 
seat, for instance-Barringer advised doctors to remember that while such stories "might protect an offending man from embarrassment for his dalliances," it could allow him to "bring this disease into the 'high places' and leaves no man above suspicion."113 The "high places" Barringer alluded to undoubtedly represented white marriages generally, and the temple of white female bodies particularly. Thus, physicians should recognize the sexual nature of the disease and treat it aggressively if they hoped to stop its spread. Should physicians fail to take action, Barringer predicted a dire fate for all whites: "This yearly increasing addition of infected blood cannot fail to have its influence upon the stamina of the race or fail to affect, however remotely, all the constitutional ills of its subjects." As a racial poison, syphilis threatened the very existence of white society and civilization. As Charles Davenport would remark in 1911, "Venereal diseases are disgenic [sic] agents of the first magnitude and of growing importance." Only scientifically trained physicians, with an allegiance to protecting the public health (and implicitly the white race), could halt the scourge. Barringer eventually met his own challenge by training numerous men "public-spirited" physicians who enlisted in the PHS. After four years as attending physician at Davidson College, where he established a pre-medical training program, Barringer answered his mentor's call to Virginia. ${ }^{114}$

Upon his retirement in 1888, James Lawrence Cabell nominated Barringer as his successor in the chair of physiology. 115 While Cabell produced Paul Barringer and a number of other men who entered the PHS, Barringer produced Surgeons General Rupert Blue and Hugh Cumming, Assistant Surgeon General and Director of the Division of

113 Ibid., 143-44.

${ }^{114}$ Ibid., 90. Davenport, Heredity in Relation to Eugenics, 2. Syphilis invariably made early eugenicists lists of "racial poisons," environmental and genctic pathogens that increased the incidence of mental illness and purportedly harmed the "gcrm plasm" and increased the likelihood of "defective" offspring. Paul, Controlling Human Heredity, 19. Hallcr, Eugenics, 69 and 121. Barringer's career is detailed in Flannagan, "Barringer," 3-4.

${ }_{115}$ Barringer, Memoir, 304. 
Venereal Disease Taliaferro Clark, and many other members of the PHS corps. ${ }^{116}$ Hugh Cumming remembered Barringer as a favorite among the students, and regarded him as having "one of the most brilliant intellects I have known." 117 Barringer rose to immense stature at the university, becoming Chairman of the Faculty - a position analogous to president—and holding that position through annual election, from 1897 to 1903.118 Renewing old ties between the University and organized public health, Virginia's Governor McKinny appointed Barringer president of a revived state board of health during the cholera outbreak of 1893.119 Always the Progressive, Barringer tirelessly lobbied state and university officials for the construction of a hospital. Building a university-affiliated hospital, after the manner of Johns Hopkins, would provide medical students with direct access to clinical experience. After an abortive start, where the foundation hole filled with water and became known derisively as "Paul's Frog Pond," the hospital opened in 1901. Moreover, Barringer advised Edwin Anderson Alderman, who succeeded him as Chairman of the Faculty by becoming Virginia's first president, on matters of hiring and modernizing

${ }^{116}$ Blue, Clark, and Cumming took physiology and surgery under Barringer: Blue and Clark in 188990, and Cumming in 1891-92. When Bluc and Clark took Barringer's course, it emphasized histology and pathology, as well as "modern aseptic surgical procedure." By the time Cumming took the course, it included work in "hygiene" which included, "contamination of water, food, air and soil. . . the natural history of the contagious and infectious diseases, their modes of propagation and methods of prevention. Instruction is also given in the proper location and construction of habitations, hospitals, barracks, etc., stress being laid upon the modern methods of heating, ventilating and draining." Cumming also took materia medica under Barringer in 1893. See, University of Virginia, Catalogue and Announcements, (Richmond: Everett Waddey, 1889-1890) viii-ix, 28. Also, for the year 1890-91, ix, 59, 63, 65; and 1891-1892, 44; and 1892-1893, ix, 59; 1893-1894, 69.

${ }^{117}$ Cumming Memoir, 6: 773. One of Barringer's eulogists, a former student and Virginia public health official, Roy K. Flannagan wrote that, "He had the facility of making his words live before the eyes, exhibiting the talent of a bom teacher. . . His genius as a teacher impressed me most and stands out in my mind ahead of any other aspect of his truly distinguished career, beyond even that of his great administrative ability." Roy K. Flannagan, "Dr. Paul Brandon Barringer." (Address before the Alumni Association of the University of Virginia, June 7, 1941) Barringer Papers: 1: loosely filed: 4.

118 Barninger rose to mythic stature for spearheading the efforts to rebuild the Rotunda-the architectural focal point of Jefferson's academic village, and the touchstone of the university community's spirit and sense of mission-after a devastating fire in 1895. See Bruce, History of the University of Virginia, vol. IV, 195; vol. V, 270.

${ }^{119}$ Barringer drafted a hasty but comprehensive memo on the public health aspects of cholera prevention, "Cholera and its Prevention: a Circular by the State Board of Health" (Richmond, 1893). This memo represented cutting edge medical technology and it fueled Barringer's interest in public health. 
the medical school. ${ }^{120}$ This influence affected the tenor of the teaching at Virginia's medical school for generations, as will be discussed in Chapter Two.

Just as a concern with public health runs through the history of the University of Virginia, so too does a strain of hereditarian and eugenic thought. While Cabell and Barringer taught their students a respect for public health, they taught with greater intensity about the power of heredity over humanity's destiny and health. After Cabell and Barringer died or retired, a new cast of characters, hired in part on Barringer's recommendation, took their place and surrounded themselves with like-minded physicians and scientists. From the tum of the century onward, the University of Virginia and its medical school became infused with a hereditarian ideology that investigated, and presumed to prove, the biological differences separating the "races" of mankind. Paul Barringer began this trend in public, with his explicitly hereditarian pronouncements on race in three published addresses that appeared between February 1900 and March 1901.121 Over the ensuing years, Barringer would buttress these public ideas in his private poetry and writing, as he developed his own conception of the organic relationship among religion, science, race, and social policy.

Barringer first formally enunciated his beliefs about the hereditary inferiority of African Americans in an address before the Tri-State Medical Association of Virginia and the Carolinas. Delivered on 20 February 1900, "The American Negro, His Past and Future" announced "the rapid increase of the negro and his relatively greater increase in crime." Barringer began by stating that, "Sociological problems are in most cases biological problems," and the-efore any attempt to solve racial tensions must recognize the biological underpinnings of race that preconditioned race relations. Barringer, following the well-trod

${ }^{120}$ Bruce, History of the University of Virginia, vol. IV, 295-97; vol. V, 178. Barringer, The Natural Bent (Chapel Hill, N.C.: University of North Carolina Press, 1949).

${ }^{121}$ The public addresses and their date of delivery are, "The American Negro, His Past and Future" (20 February 1900); "The Sacrifice of a Race" (10 May 1900); and, "Negro Education in the South" (28 December 1900). The last address was published in Educational Review in March 1901. All reside in the Barringer Papers: 10: 1896-1925 Printed material re: Race Rclations. 
path of Cabell, invoked the biological ideas of recapitulation and reversion to explain what he, and many other whites of the era, considered to be an alarming increase in black "criminality."

To set his address on the appropriate scientific foundation, Barringer first quoted German-biologist Ernst Haeckel's "short, crisp biological axiom" that describes recapitulation theory, the poetic statement that "'the ontogeny is the repetition of the phylogeny."' This doctrine holds that each individual organism reflects, in its development from conception to maturity, all the evolutionary stages that its ancestry passed through to assume its presentform. Or, as Barringer succinctly put it, Haeckel held that, "'the life history is the repetition of the race history. ... In other words, it is a terse expression of the force we call 'heredity' in life." Heredity dictated the life course of "an individual from the fertilized ovum to the grave, and declares that throughout all this period the child shall tread the path his fathers trod; and this tendency to repeat is not only structural," Barringer averred, "but physiological and psychic as well."122 This rigid hereditary determinism held dire consequences for blacks, according to Barringer, for it biologically predetermined the absolute limit of their social advance. Annealing Cabell's reversion theory with the more modern embryological, evolutionary concept of "recapitulation," Barringer denied the further possibility of environment to "improve" or "civilize" African Americans. Relying on "recapitulation theory," Barringer held that African Americans followed an ineluctable "generic tendency" to "savagery."123 American blacks reenacted the limited evolutionary potential of their race, evidenced by the "backward" and "barbaric" cultures of Africa, in their individual development in the United States. Amending Cabell's Lamarckianism and his musings on "reversion to type," Barringer argued that only the controlled environmen:

122Paul Brandon Barringer, "The American Negro, His Past and Future," 1. For a further explication of this "axiom" and its place in the epistemology of scientific racism, see Gould, Mismeasure of Man, 142143.

${ }^{123}$ English scientist William Bateson would coin the word "genetic" in 190.5. Barringer's use of the word "generic" is roughly equivalent, referring to one's family by its scientific term "genera," the root of genetics. Barringer, Ibid., 13 and 18. 
of slavery had restrained atavistic black passions. With emancipation came reversion to "savage" status, creating a new biack generation that could not possibly survive in contact with white society. Barringer's drift away from Lamarckianism reveals the confluence of his social ideas and the most modem biological theories.

"I will show," Barringer asserted, "that the ages of degradation under which he ["the Southern negro"] was formed and the fifty centuries of historically recorded savagery with which he came to us can not be permanently influenced by one or two centuries of enforced correction if the correcting force [slavery] be withdrawn." 124 Recapitulation and reversion thus accounted, in Barringer's mind, for the apparent surge in black criminality that terrified whites in the two decades surrounding the turn of the centlury-a criminal tendency "substantiated" by the increasing "need" of whites to resort to lynching and race riots in the post-bellum period. ${ }^{125}$ Invoking the spectre of the "born criminal," Barringer continued, "The young negro of the South, except where descended from parents of exceptional character and worth, is reverting through hereditary forces to savagery....It is the nature that makes the criminal and imperils a civilization, not the language, the skin or the clothes." 126 Barringer admitted the possibility of some small percentage of blacks genetically endowed with "exceptional character." This population however, was too small to "save" the black race. Without white intervention, Barringer condemned free African Americans to a life of barbarism where, "tubercuiosis and syphilis vie for each other to be 'first in at the finish' which is the potter's field." African Americans, in Barringer's view, simply could not outsurip their genetically determined "racial history." Worse still, this whole degraded existence would be lived, "even down to the last, at the white man's

${ }^{124}$ Barringer, Ibid., 5, 15, and 21.

${ }^{125} \mathrm{C}$. Vann Woodward presertted the benchmark discussion of white apprehension during this era rising racial violence and hardening racism in The Strange Career of Jim Crow (New York: Oxford University Press, 1955; 3d. revised edition, New York: Oxford University Press, 1974), 67-109 (hereinafter page references are to third revised edition).

${ }^{126}$ Barringer, Ibid., 15. For a discussion of the "science" that substantiated the notion of "born criminality" in this era, and its links to !ater eugenics, see Nicole Hatin Rafter, Creating Born Criminals (Urbana and Chicago: University of Illinois Press, 1997), especially Chapters 4, 6, and 7. 
expense. During his whole life he [the "young Southern negro"] has not produced for the State a thousand dollars, and he has cost it four-fold that sum."127 Not only was the black race doomed, it posed an economic burden that threatened to drag down white civilization.

Barringer reinforced his "scientific" judgment about black genetic limitation by invoking the "scientific" expertise and social bogeys shared by his medical audience. "And yet all you, as medical men," Barringer began, "know of that sadness of heart with which you. . . look upon the relatively precocious intelligence of negro childhood, for we know that with the advent of puberty and sexual development there will be an almost total arrest of subsequent mental growth," followed by reversion to barbarism. ${ }^{128}$ If any of his audience lacked this experience, Barringer revealed the power of heredity in another example. Surely, he felt, the physicians in his audience had, "watched the development of physical beauty or high mental attributes in the members of some [white] families doomed by hereditary tendencies to premature death." 129 If heredity predestined white life, he seemed to say, then think of how it controlled inferior blacks. Then, to clinch his argument, Barringer deployed stereotypical imagery from minstrelsy. "A young savage by instinct," Barringer felt that young black men idolized, "the swaggering bully of his own color," the so-called "bad man" or "bad nigger" of black vernacular. Armed with, "a cheap pistol, a pair of 'knucks' and a razor" this "rake," so similar to the dandified but dangerous Zip Coon of the minstrel stage, was ready for a rampage of crime and rapine. Such genetically programmed activity, Barringer pronounced, would lead to his swift death at the hands of the courts or vigilantes. Only white intervention could "save" the black race from itself. 130

${ }^{127}$ Barringer, "The American Negro," 19.

${ }^{128}$ Barringer, Ibid., 17.

${ }^{129}$ Barringer, Ibid., 17.

130For descriptions of the "bad" black from minstrelsy, see Eric Loll, Love and Therft: Blackface Minstrelsy and the American Working Class (New York and Oxford: Oxford University Press, 1993), 2529, and Chapter 5; Joel Williamson, The Crucible of Race: Black-White Relations in the American South Since Emancipation (New' York and Oxford: Oxford University Press, 1984), 206-310; and George M. Frederickson, The Black Image in the White Mind: The Debate on Afro-American Character and Destiny, 
Barringer proposed a tri-partite solution: political disfranchisement, removing responsibility for African-American education from black to white teachers, and training blacks to be "law abiding laborers and artisans." Disfranchisement would, according to Barringer, "deprive the ignorant negro of the political liberty, which he now uses for license." It would also "bring again the old relations in feeling that existed between the races at the close of the war," because young whites were beginning to hate young blacks, viewing them as a "political menace" and without the paternalistic "love" of their fathers' generation. Placing black education in white hands would ensure that the type of education offered to blacks would comport with their ontogenetic capacities. To educate blacks like whites, Barringer claimed, would fail "so long as [educators] attempt to estimate the needs of the negro race by the experience of the white. The phylogenies of the two races are so divergent that the results of experience with one are not safely applicable to the problems of the other." Blacks should not be trained to be "ladies" and "gentlemen," because "These ambitions are absolutely unattainable...and result in a soured and vindictive generation." So Barringer fell back on attempting to inculcate class and race deference and subservience, making, "the next generation of negroes in the South honest, law-abiding laborers and artisans, with an ambition for the respect of the better class of their own people and of the whites."131 Anything less would result in racial apocalypse for, "even the lower [white] classes of the South are of pure Saxon blood," who, if forced to recapitulate their own Saxon phylogeny, "will put an end to the negro problem, because it will be the end of the negro," presumably through extermination in a genetically programmed pogrom. ${ }^{132}$

1817-1914 (New York: Harper \& Row, 1971), 275-82. In an undated, untitled address among Barringer's papers, he alerted "a great conference, devoted solely to the improvement of the southem women of the farm" to the dangers of black rapists. The "absolute death-like silence of every member of this conference on the one prime factor of this suuthem problem [poor southern farm women]" filled Barringer with "astonishment." The "prime factor," of course, was "fear of negro assault." Barringer Papers, Box 7 , "1911-1912, n.d. Race Relations" folder.

${ }^{131}$ Ibid., 19-21.

132Ibid., 22. Barringer's use of the atavistic white "barbarian" raises one of the fascinating contradictions of this era. Barringer, like the novelists Jack London, Owen Wister, and the German 
Barringer's title, "The American Negro: His Past and Future," was misleading.

Posing as a champion of the "hereditary" salvation of the black race through a pseudo-

Lamarckian environmental intervention, Barringer's primary concem always lay with the white South. The real problem, according to Barringer, was "to save the white man of the South from barbarism by reclaiming the savage to whom he is inseparably tied." Natural antinomies between whites and blacks would eventually cause whites to regress to a more savage state to defend themselves against rapacious blacks. Solving the "Negro problem," Barringer held, echoing Jefferson's earlier concerns, "rises above a question of altruism and becomes a question of self-preservation." 133 White civilization faced a racial apocalypse. Either white retribution for alleged incidents of black-on-white rape would spark "race war," or black-white miscegenation-resulting from rape or white intermarriage with blacks "passing" for whites, would pollute the white gene pool. Barringer decried black criminality not because crime is inherently evil, but because of the effect it had on whites-particularly white women, whom he took to be the preferred targets of lascivious black men. Barringer, like many white males intent on maintaining both black and white female subservience, conjured images of the "black beast rapist."134 The idiom took on a different meaning when used by Barringer; from him these spectral images of "savage" black men embodied ineluctable scientific "fact."

philosopher Fredrich Nietzsche, valorized this Teutonic savage in contradistinction to the "black beast rapist." The grounds of the distinction scems to be the role of will. "White savages" used their willpower to restrain their instinctual savagery, whereas inferior blacks lacked this "germinal trait" that allowed whites to create civilization by repressing their natures. Blacks, even more animalistic than whites, were truly governed by their passions. See Gray Brechin, "Conserving the Race: Natural Aristocracies, Eugenics, and the U.S. Conservation Movement," Anlipode 28 (1996), 234 and 242 note 21.

133 Ibid., 14.

${ }^{134}$ The literature on the rape myth is extensive. Three of the most important works tracing the development of this phenomena are: Martha Hodes, White Women, Black Men: Illicit Sex in the Nineteenth Century South (New Haven: Yale University Press, 1997); Diane Miller Sommerville, "The Rape Myth in the Old South Reconsidered," Journal of Southern History 61 (August 1995), 481-518; and Jacqueline Dowd Hall, Revolt Against Chivalry: Jessie Daniel Ames and the W'omen's Campaign Against Lynching (New York: Columbia University Press, 1974), Chapter 5; and Hall, "'The Mind That Burns in Each Body': Women, Rape, and Racial Violence," in Ann Snitow, Christine Stansell, and Sharon Thompson, eds., Powers of Desire: The Politics of Sexuality (New York: Monthly Review Press, 1983), $328-49$. 
Unless these racial tensions were defused, upper-class whites would emigrate from the South. This would increase the proportion of lower-class whites who, in contact with the blacks, would be degraded and either revert to their savage Saxon state, leading to race war, or worse still, interbreed with black women. Either result would rend asunder the socia' and racial fabric so dear to Barringer. In its defense he rallied a scientific analysis that attempted to turn back the clock on southem race relations. Barringer thus constructed himself as the "scientific Redeemer." His appeal to the Tri-State Medical Association to deal with broad problems, including "race suicide," resonated with larger social and scientific concerns about the future of American civilization. ${ }^{135}$ This approach, in tum, made the "Negro problem" implicitly and explicitly a public health problem facing the entire country. Nothing less than the survival of the "American race"-biologically and politically-was at stake. Barringer's alarmist tone insured that his ideas would reach a wide audience.

"The American Negro" was so well received that, overnight, Barringer became the most visible, learned, and "scientific" southern expositor on the "Negro problem." The Central Presbyterian ran a laudatory synopsis, commending Barringer's "scientific acumen." Letters poured in from professionals and laymen, North and South, many of which Barringer retained. Holland Thompson, Professor of Political Science at Columbia called Barringer's address the "best statement of the difficult Southem question that I have ever seen." Rector of the University of Virginia Armistead C. Gordon effused, "No intelligent Southemer can arise from its perusal without the conviction that what you have said is so luminous, so convincing, so historically, scientifically, and socially exact as to exclude all negation. I wish every politician, philanthropist and negrophile from Massachusetts Bay to San Francisco could read it." Frank P. Brent, Virginia's secretary of education wrote, "Any man who now contends that the Negroes are making substantial

\footnotetext{
${ }^{135}$ For the currency of "race suicide" as a source of anxiety at the turn of the century, and its links to the eugenics movement, see Haller, Eugenics, 79-82; Paul, Controlling Human Heredity, 100-06.
} 
progress in moral, mental, or material development simply shuts his eyes to the actual state of things." Another supporter wrote, "You have met the issue like a philosopher and as only a southem Anglo-Saxon could You laid your foundation deep and well, on Lord Palmerston's reply to the Scotch Kirk and your biological axiom and structure is expert." Echoing Barringer's racial rhetoric, he re-emphasized the probability of racial cataclysm, "The Anglo Saxon, and the Southerner is the most perfect Anglo Saxon, was never known to move out, as a race, in front of any other race except to drive off and destroy the other race." 136

The only response that equivocated, and that just barely, came from the president of Westem Reserve University. Asking Barringer if he had not perhaps "work[ed] your main thesis a little too hard," he wondered "Do you give a proper value to the element of environment and also do you give a proper value to the worth of individual will?" Despite these cavils, he asked Barringer for extra copies and offered to suggest "names of people in the north who would be more than glad to receive it." Indeed, Paulus A. Irving, Secretary of the State Board of Health of Virginia, informed Barringer that he was attempting to raise money to secure the publication of the address. Barringer's words reverberated across the state and nation, establishing him as a recognized authority on the "race question," and serving to unite northemers and southemers who viewed the "problem" in the same light. ${ }^{137}$ Barringer's other major addresses hammered the same themes, increasing his dependence on genetic and proto-eugenic ideologies.

136"The Negro in the South," The Central Presbyterian, April 11, 1900, 2. This article also announced the Montgomery race conference discussed below. In the same issue, the Reverend Thomas D. Hoyt of Bryn Mawr, Pennsylvania opines in "A Vindication of the South" that racial prejudice stands "as armed sentries at the gates, to guard the sanctity of the home, the purity of blood, the just pride of the superior race." Barringer saved 27 letters, all from professionals and men of eminence, regarding "The American Negro." See Holland Thompson to Paul Brandon Barringer, March 8, 1900; Armistead C. Gordon to PBB, March 27, 1900; Frank P. Brent to PBB, April 12, 1900, Barringer Papers Box 1, "19001902 Correspondence" folder.

${ }^{137}$ Charles F. Thwing, President of Western Reserve University to PBB, April 6, 1900; and Paulus A. Irving to PBB, April 28, 1900, Barringer Papers Box 1, "1900-1902 Correspondence" folder. 
Noted southem Progressive Edgar Gardner Murphy gave Barringer his next

opportunity at wide publicity. Murphy invited Barringer to address "A Southern Society

for the Consideration of Race Problems in Relation to the Welfare of the South." Though

the conference promised Barringer a "bully pulpit" for his ideas, Murphy had to assure him

that, "No negro is upon the program, or a member of the Society, and those who may be

present will be assigned separate seats in the gallery of the auditorium." 138 Barringer

announced that he would speak on "The Sacrifice of a Race." Booker T. Washington,

Principal of the Tuskegee Institute, perhaps alerted to Barringer's forthcoming speech by

Murphy himself, sought to convince the powerful Virginian to visit Tuskegee before going

on to the conference. Possibly one of Washington's diplomatic efforts to defuse a potential

adversary by convincing him that Tuskegee was no real threat, the invitation fell on deaf

ears. Pleading that his was "a necessarily hurried trip to Montgomery," Barringer declined

the invitation. Yet he took a moment to preface his address for Washington. ${ }^{139}$

${ }^{138}$ Edgar Gardner Murphy to PBB, April 13, 1900, Barringer Papers, Box 1, "1900-1902

Correspondence" folder. Barringer's name was suggested by his friend, Neal L. Anderson, who was a founding sponsor of the conference. Murphy invited Barringer to address the gathering after he read "The American Negro" and pronounced it, "as able a discussion of the subject from that standpoint as I have ever seen." Murphy, a noted southem racial "liberal" and "humanitarian," asked Barringer to concentrate on his "constructive contribution to the problem, the necessity for the white man and for the peace of the South of the industrial education of the Negro race." Murphy seconded Barringer's call for limited black education, noting that "the true remedy (in relation to the welfare of the white man) is not the abandonment of education, but a more general change in the form of education. Slavery was in the most vital sense an educative institution." Murphy argued a position that appealed to Barringer. "To leave the Negro, however, without any education, without the industrial form whirh slavery piovided, and without the academic form provided by the public schools, it seems to me, is to invite disaster-disasier not only to the Negro, but to the whole social fabric of the South." The real threat with "non-education" according to Murphy was that such a stance "would result in the reproduction along educational lines of the conditions of the reconstruction period. The South would be the subject of a Northern army of educational invasion, for the plain reason that, whether we like it or not, the country at large has made up its mind that the Negro shall be educated." So, it was "of vital necessity" that black education "should be conducted under Southem auspices, and that his [the black man's] equipment should bear a sympathetic relation to the actual environment of his life." Edgar Gardner Murphy to Paul Brandon Barringer, April 16, 1900, Barringer Papers, Ib:d. For additional information on the conference, see the trochure, "A Southern Conference for the Discussion of Race Problems in Relation to the Welfare of the South," Barringer Papers, Box 10, "1896-1910, n.d. Printed Material re: Race Relations" folder. See also, Woodward, Origins, 353.

${ }^{139}$ PBB to Booker T. Washington, May 5, 1900, Barringer Papers, Box 1, "1900-1902 Correspondence" folder. 
"You are doubtless aware that, as regards your people," Barringer began patemally, "I am a pessimist, but this does not prevent my profound admiration for those of you who are standing bravely against the current." Noting that he wished that "all of your people could understand that in dealing with racial matters I speak of the race and not of individuals," Barringer made clear his biological and scientific standing-his conclusions were based not on personal antipathy toward any individual black but, in his eyes, based on his understanding of black biology. He made his biological conclusions explicit in his very next line, which delivered a left-handed compliment to Washington. "The very generic [Barringer's term, a precursor to and synonym for "genetic"] tendencies which you have to combat makes the assumption of the position of worth and prominence among men the more to be appreciated." The "you" in the sentence remained sufficiently vague; it might refer to the entire black race, or to Washington himself. Barringer, who prided himself on clever wordsmithing, no doubt intended the construction as a jac at Washington, who had to fight the "generic" tendencies among his fellow blacks and within himself to "assume," not eam or merit, his leadership position. Removing his kid gloves, Barringer closed, "I am of the South, for the South, and primarily for the white people of the South-my own people-but," he continued, straining to acknowledge white resporsibility but wash his own hands clean, "as a native of that section of which your people form so essential a part, I can take interest and pride in all that they do to rise above the condition in which their brother man, regardless of motive, has placed them."140 Barringer's address, with clever rhetoric paralleling this letter, would amplify these same "scientific" judgments.

"The Sacrifice of a Race" again argued that any attempt to solve America's race problem without attention to the "racial history" of African Americans would fail. "Amendments to the Constitution count as naught when pitted against the inexorable laws of nature," Barringer wrote. ${ }^{141}$ African Americans had "already gone back to original

$140 \mathrm{PBB}$ to Booker T. Washington, Ibid.

${ }^{141}$ Paul Brandon Barringer, "The Sacrifice of a Race," 14. 
racial tendencies." Any "intelligent, upright, honest negro[s]" that one might encounter were "as a rule" bom slaves. Barringer asserted that African Americans needed to be "taught to work," because "The present system of industrial education gives too little industry and too much education." The only other solution to the "Negro problem" would be "euthanasia" unless the "soul and the hand" of black America were educated "more than the mind."142 Writing just five years after Booker T. Washington's "Atlanta Compromise" speech, Barringer sought to use science to permanently circumscribe black socio-economic opportunity. Although Washington envisioned blacks temporarily as "hewers of wood and drawers of water," Barringer concluded that blacks were hereditarily unfit to ever rise above this menial station.

Barringer elaborated his hereditary analysis of the African-American socio-economy. He argued that blacks under slavery were "allowed to multiply, but this under a careful selective process of breeding that outstripped nature itself." Enslaved African Americans, according to Bariinger, benefited from eugenical breeding that "was the first and only application of intelligent hygiene to a special race" which established "the vigor and prepotency" of a race otherwise destined for indolence and eventual extinction. ${ }^{143}$ Prior to emancipation, according to Barringer, "the negro, as a race, was not subjected to natural law" in America. Enslaved blacks did not live under the merciless natural law of "survival of the fittest" in competition with whites. Instead, Barringer maintained, the survival of the naturally "unfit" blacks was "absolutely artificial"; the benevolence of white slave owners saved blacks from death, improving their meager racial stock at the same time. ${ }^{144}$ With emancipation, blacks reembarked on their path to extinction in America. While this result would be "good" from the standpoint of disarming racial tensions, Barringer claimed to be

142 Barringer, Ibid., $3-4$.

${ }^{143}$ Barringer, Ibid., 7. Indeed, Barringer made the stockyard to bedroom analogy explicit, "The laws of breeding obtained through centuries of experience with the lower animals had here found a wider and higher field" (6).

${ }^{144}$ Ibid., 16. 
appalled by the "horror" of whites idly standing by while blacks suffered their cruel, fate, their reversion to barbarity hastened by their genetic susceptibility to various diseases and criminality.

By linking medical pathologies and criminality to heredity, Barringer characterized all blacks as inherently diseased, immoral, and "unfit." The high incidence of tuberculosis, syphilis and typhoid fever among African Americans indicated nothing to Barringer about their environment. Instead, the occurrence of these diseases proved to be the "the three great influencing diseases" attending the demise of "a markedly criminal race."145 Until that race died out, then, they posed a massive public health threat; the "public," of course, implicitly construed as white. Marshaling reams of statistics, Barringer substantiated his case that blacks were becoming more criminal and more unhealthy. Moreover, the apparently new form of black criminality, the rape of white women, was really nothing new at all. Rape and savagery were the natural instincts of the black race, according to Barringer. "Did our prognathic, dolichocephalic cannibal come to us with brutal instincts moulded by centuries of crime on every lineament of his visage and yet clothed in the beatitude of sexual purity?" Barringer asked, brandishing the terminology of craniometry. "No! When I see the leopard change his spots then will I believe it. It is a reversion pure and simple and these figures simply point again to the superb moral influence of slavery."146 Thus the "Negro problem" was more than a political problem, it was a social disease and a threat to the public health. Barringer's pronouncements cast his racial views in sharp relief, embedding them within the framework of his concern for public health, broadly construed.

145 Ibid., 26. Barringer conceded that blacks were less susceptible to malaria and yellow fever, but he saw this as a mark of inferiority, not superiority. Their primitive constitutions could withstand these diseases, while the genetically rarefied white constitution could not. Similarly, while both races were susceptible to syphilis, tuberculosis, and typhoid, its prevalence in the black race proved that they were the source of white infection. Hence, like malarial swamps, the source should be eradicated.

146 Ibid., 20-22. 
Instead of posing as the savior of the black "race," Barringer used his authority as "a Southerner and a physician...familiar with the physicians of the South" to sound the death knell for African Americans. Invoking Spericerian "survival of the fittest," he claimed that few who used the concept "ever stop to think of the complemental axiom, 'the death of the unfit."' Making an analogy between his sons' domestic rabbits and African Americans, Barringer commented that "Subjected to natural law they would go like snow before the sun, and so, in due time, will the negro go."' Black hereditary susceptibility to disease was increasing mortality and tending toward extinction, according to Barringer. Unable to reintroduce slavery, the artificial conditions most likely to "save" the black race, Barringer claimed that nothing could stop "this grand but ghastly tragedy-The Sacrifice of the Race." Reversing his earlier position, Barringer argued that even industrial education could not save the race. "The wealth of the Indies could not give this entire race technical training....Industrial training should be reserved for a more industrious people. In my opinion nothing is more certain than that the negro will go as the Tasmanian and the Carib have gone, but until then he is our problem." Extinction might be delayed as the "future of the negro surely prompts compassion, charity and mercy - these he will get in full measure," Barringer wrote. Whites would limit their efforts, however, because, "the white man of the South should not and will not re-enslave himself for the benefit of the black."147 Again, Barringer retumed to the sine qua non of his analysis: white southern society, although jeopardized, must not be allowed to fall.

Barringer returned to his theme of "Negro Education in the South" in his final popular declaration on race relations before the Southern Educational Association at Richmond, Virginia on December 28, 1900. He opened this third address by noting that,

Those of us of the South who have elected to abide by the South must, for that reason if no other, take a proper and natural interest in any specific class of its people which numbers nearly forty per cent. [sic] of its population....If this forty per cent., [sic] the negro race, improve, the South to that extent will improve; if it go backward, it will

${ }^{147}$ Ibid., $25-29$. 
either carry the South with it or, failing in this, it will demand as the price of progress an expenditure of energy on the part of the whites which no people can endure.

Placing "All general questions of humanitarian interest aside," Barringer asked, "Shall we prepare [African Americans] to be a political antagonist? Shall we make of him an economic antagonist, or can we prevent him from becoming either and yet have the South as a whole improve?" Again, Barringer openly lobbied for the repression of African Americans to second-class citizenry.

Asserting that politics and economics underpinned the rising racial antagonism, Barringer called the 14th and 15th Amendments to the Constitution "failures." $148 \mathrm{He}$ opened "Negro Education in the South" by pining for the days of slavery. "[T]here are hundreds here who remember the old slave days, the manifest affection of the negro for and his pride in the old master, the mistress, the young master, and all." Racial antagonism, he concluded, began after the Civil War, after the "first racial flight of freedom" when freedpeople "like birds, startled but not afrighted, they circled but to return [to their old masters]."149 The 14th and 15th Amendments, which Barringer termed a "sectional" and a "national" crime, respectively, served in his rnind to create a break on national prosperity by hamstringing the South and raising the horror of political equality for people of color in America's "new" territories - the island nations captured during the Spanish-American War.

Political friction loosed economic competition that white men could not win; according to Barringer (following the eminent sociologist Edward A. Ross), other races could "underlive" white laborers. The "primitive" heredity of blacks, Malaysians, Chinese, and Polynesians allowed them to subsist on far less than the average white. Although the best "specimens" of black genotypes inevitably migrated to areas where they might succeed economically, the northem migration of "best-trained workers of their race in the South"

\footnotetext{
148 Barringer, "Negro Education," 236.

${ }^{149}$ Barringer, Ibid., 234.
} 
caused the economic friction that sparked northem race riots, according to Barringer.

While "It is all very well to ignore racial hatred in New York and Chicago, with a

policeman at every comer....In the South policemen do not patrol the fields, and race hatred must be kept down if only for the sake of the black. Read any account of a Southern race riot and see who usually furnishes the funerals. Almost always the black."150 The only solution, according to Barringer, was to restrict black education. "What the negro needs as a race is moral training, some 'thou shalt not,' something to form character. When we have given him a morality which will save him from degeneracy, and the hand training which will make him an even respectable servant or laborer, then, and not till then, may we think of the technique of higher industries." Thus Barringer's New South Progressivism, like that of many other boosters, was, in the words of historian C. Vann Woodward, "for whites only." Moreover, Barringer's ideology, unlike that of Jefferson, and to an even greater degree than that of Cabell, completely compartmentalized the "moral" and the "natural," that which could be taught and that which was inherent. Barringer followed Cabell in believing that morality would have to be instilled in the black race, because it was congenitally missing.

Years later, Barringer's memorialists would remember him as one of the few southerners who advocated more educational opportunity for blacks, not less. ${ }^{151}$ The striking distinction is that Barringer asked for more of an extremely limited type of education. "The public-school training of this people [African Americans should be primarily a Sunday school training, given by those to whom morals mean more than words [i.e. white southerners]." Believing that "The negro race is essentially a race of peasant farmers and laborers, and their education should first be directed to improving them as such," Barringer argued that "Every negro doctor, negro lawyer, negro teacher, or other

\footnotetext{
${ }^{150}$ Barringer, Ibid., 236-39.

${ }^{151}$ Barringer's daughter Anna wrote in this vein in the final pages of Barringer's autobiography, which she edited and published for him, posthumously. Barringer, The Natural Bent, 262.
} 
'leader' in excess of the immediate needs of his own people is an anti-social product, a social menace." Educating blacks with "ambition and capacity" in the face of "caste prejudice and racial instinct" was, for Barringer, "to commit a crime against nature." Since "Nature made the white man and the black, it made the natural and unalterable prejudice between the two races," biology, not society, ultimately dictated racial aversion. Social context could exacerbate or attenuate these tensions, it could not eradicate them. America's foremost educational authority, Professor Nicholas Murray Butler of Columbia University, pronounced Barringer's address "the most statesmanlike contribution since the [Civil] War."152

Revealing not only Barringer's beliefs, these three addresses form an ideological triptych joining hereditarian notions of race, educability, and public health. The addresses encapsulate widely-held, Progressive-Era views regarding the "management" of the "race problem." They also reveal the statist approach to problem solving favored by both white supremacists and public health officials. After a generation of decrying the exercise of federal power over southem social conditions, Barringer and other Redeemers were more than anxious to use the same type of govemmental intervention-provided it was under the "local," state-level control of educated, elite whites. Barringer's rhetoric appealed to deep racial fears and hatreds, and prompted the agreement of many Southerners. One of Barringer's southem supporters wrote, "When the old darkey [African Americans raised under slavery] passes away the young ones will be so worthless that I am afraid much hemp and lead will be required to keep them in bounds." 153

What Barringer achieved with his addresses, then, was an early enunciation of the ideas that were coming to dominate discussions of Southern educational reform. The emerging consensus effected the marriage of northem and southern progressives, a union predicated on the educational, social, and political disfranchisement of blacks. As historian Michael

152 Nicholas Murray Butler to PBB, , Barringer Papers, Box 1, "1900-1902 Correspondence" folder.

153 J. C. Morrison to PBB, December 29, 1900, Ibid. 
Dennis argues, "northern philanthropists and southern educators found common ideological ground on the principles of universal education, white supremacy, and industrial education for blacks." Northemers, however, willingly made several concessions to southern progressives. Southern advance would be a "white-only" affair, where whites would "supervise the appropriate education for disadvantaged AfricanAmericans," southem whites would be free from northern interference in "managing" the race problem, and northem philanthropists accepted increasingly national and "scientific" ideas about the inferiority of blacks. The extremism of Barringer's rhetoric, and his belief in the unavoidable regression of African Americans, separated him from the rising vanguard of Southern educational Progressives. While his career would taper off, these new reformers would carry on a modified version of his program. These ascendant reformers "superimposed the ideology of southern progressivism on the framework of the New South Creed." Tempering Barringer's New South racial rhetoric with the "dispassionate" language of emerging genetic and eugenic science, Barringer's intellectual descendants achieved the same subordination of blacks, the poor, and "loose" women, without constantly resorting to inflammatory catastrophism. Still, these later reformers were, "compelled to sell their vision of education and its place in a society to a South skeptical of reform, suspicious of those who fraternized with northern do-gooders, intolerant of the region's critics, and hostile to anyone who extended a helping hand to blacks, even in the name of social control."154

Barringer made one other address in 1900, and it brought him face-to-face with Booker T. Washington. Perhaps swelled by his other successes, Barringer would reach new rhetorical heights and, ultimately, lose his position of influence by securing for himself a

${ }^{154}$ My next chapter develops this transition in tone among southern Progressives. Michael Dennis, "Educating the 'Advancing' South: Statc Universitics and Progressivism in the New South, 1887-1915," Ph.D. diss., Queen's University, Kingston, Canada (1996), 1-20, quotations 16, 29, and 63. See also James D. Anderson, The Education of Blacks in the South, 1860-1935 (Chapel Hill: University of North Carolina Press, 1988), 84, 96-97, and especially 99. Anderson, on page 96, briefly mentions Barringer's third address. 
reputation as an extrememist. Nevertheless, his vehement denunciation of "savage" races stood firmly on a carefully-laid foundation of biological, medical, and ethnological scientific "bricks."

Invited by the Merchants Club of Chicago to address their meeting devoted to "The Race Question in America," Barringer, former President Harrison, Chinese Minister Wu, and Washington all presented their opinions on racial tensions in America. Delivering "Race Problems in America," Barringer squared off against all "barbaric" races—-the red, yellow, and black —and lauded the white race as the epitome of "strenuous" masculinity. The Native American warrior's "inherent characteristics," made him, "a savage but every inch a man." In fighting the Anglo Saxons, Native Americans "forced upon them a necessary appreciation of manhood" that, in time, "grew into a national trait". The fight for survival against the "savage" Indians caused the Anglo Saxon to become an "absorbing nation" that blended "Celt and Teuton, Frank and Latiri" who could be amalgamated because they "were Aryans all." So, Native Americans, destined to die out in front of the conquering Aryans, nevertheless provided the conditions that "moulded the Aryan."155

The black race, however, "another savage, an imported pagan" was to have an influence "as pronounced as that of the other, but in a different way." Ascribing purposive agency to Indians fighting in self-defense and blacks that were dragged to America by slavers, Barringer wrote, "Where the indian [sic] had united the negro came to divide; what the red man had built up [Anglo Saxon civilization in America] the black man was to destroy." Blacks would create "distortions and perversions" of American society; the "negro slave was to create in America sectional hatreds" and "deluge the land with the blood of kinsmen". Throughout this rampage, blacks would remain unassimilable, despite

155 Paul Brandon Barringer, "Race Problems in America," Barringer Papers, Box 7, "1911-1912, n.d. Race Problems in America" folder, 1-2. Although this address is undated, it is written on University of Virginia "Chairman's Office" stationary. Given its tone and content, it must be the address delivered in Chicago. Newspaper accounts corroborate this conclusion. For the popularity of A.nglo Saxonism and Aryanism in 1900, see Gossett, Race, Chapter XIII. 
the fact that northern whites advocated miscegenation. Barringer ascribed this lack of assimilation to "instinctive prejudice," within "Saxons" that was "nature's slowly matured and only method of preserving the purity of race". 156

This "natural" repuganance was logical, according to Barringer, because blacks posed a biological threat. Arguing that a "physical peculiarity" called "tropical lung" allowed blacks to prosper and propogate in the South but not in the North, Barringer traced subsequent political developments to this biological source. Fearing the political ascendancy of a southern population bolstered by slave procreation, New England "began a propaganda" to destroy slavery. What New England missed, Barringer held, was that the South's rapid growth "was abnormal, that it was not homogeneous, that it was a pseudo-hypertrophy which contained in itself its end." Beneath Barringer's rhetoric is Jefferson's notion of slavery as a "canker," only now modernized to the language of cancer pathology. The War and Reconstruction ended in "the folly and the untold injury to the negro of [the North's] attempting to prolong the animosities of the war through him" by enfranchising blacks.

"To take a simple race of peasants, absolutely unfitted by heredity or training for governmental functions," Barringer argued, extending his biological notion of politics, "was simply to mock them" and "to damn them to destruction." Racial antagonism extended from unratural political relations in the South. ${ }^{157}$

Turning to the West, Barringer announced the appearance of "another barbarian-this time the yellow man, the Chinaman." Creating his racial taxonomy, Barringer stated that Asians were "Ethnologically higher than either the negro or the indian of more intelligence, thrifty, industrious and capable". Yet, despite these positive attributes, Barringer supported Asian exclusion as "the single evidence of a sound governmental policy" in an

${ }^{156}$ Barringer, "Race Problems," Barringer Papers, 3-5 Barringer quoted "Miscegenation," an 1864 New York pamphlet, as proof of the norhem-white desire to interbreed with blacks. David Roediger proved that this pamphlet was the creation of northern Democrals in an effort to sabotage Lincoln's re-election campaign. Roediger, "Irish American Workers and White Racial Formation in the Antebellum United States," in Roediger, Wages of Whiteness, 155-56.

${ }^{157}$ Barringer, "Race Problems," Barringer Papers, 5-8. 
otherwise blighted era. Asians, as "unabsorbable" as blacks, must be excluded to make way for the "potent" Anglo Saxons. "The final law of nature," Barringer pronounced, invoking Herbert Spencer, "is the survival of the fit and the death of the unfit. This is applicable not only to the lower forms of life, but to the highest, and among humankind it is crystallized in the law that inferior races in the presence of a higher [race] invariably die." Only amalgamation or economic necessity — the need for cheap labor — could stop this racial Armageddon. ${ }^{158}$

Thus, Barringer retumed to his theme of racial "sacrifice," writing, "The South prefers the negro [laborer], and if he is content to remain a useful but non-aggressive factor in her evolution while his own evolution lifts him to a higher plane, he may yet live; but if political antagonism continues or a more intense competition begins and natural law has full sway, he is doomed." While southerners sought to remove political antagonism through disfranchisement and economic antagonism through limiting black access to industrial jobs, black "reversionary tendencies to savagery" were leading to "rapidly growing fear of his criminality."159 So, again, the atavistic "black-beast-rapist" would bring on "racial death." As "reverting" African Americans retraced their evolutionary path, Barringer believed they would become "a burden to the state and a menace to the social order. They are just as blood-thirsty, lustful and savage as their great-grandfathers who fought for human flesh...the only difference being that the American savage can read and his prototype could not." So much for the civilizing effects of education which, in Barringer's mind, brought on the "death agony" by "trying to force nature." After "thirty years of sacrifice" the result was "some eight or ten cultured and educated men, a hundred thousand more probably well fitted for citizenship and a race of over seven million eternally blasted" by the false hopes inculcated through "northern" education. Barringer, with no small sense of irony,

${ }^{158}$ Barringer, Ibid., 8-9.

${ }^{159}$ Barringer, Ibid., $10-11$. 
consigned blacks "to the soil," either in labor or death, as the solution to racial and sectional tensions. ${ }^{160}$

Hemon Butler, the organizer who invited Barringer, later wrote of this address that, "it was probably the most important debate since the historical one between Douglas and Lincoln that has taken place in this country in the last fifty years." Describing the crowd, he continued,

We sat in our seats, spellbound, until quarter before twelve, and the guests were stirred deeply by the presentation given. Dr. Barringer had very much the hardest side of the proposition. His treatment was scientific and skilled...like a marble statue in its perfection and beauty. I could have but wished that Mr. Washington was absent so that Dr. Barringer would have been freed from any possible restraint, which he seemed to think necessary, owing to the presence of the representative of the race discussed.

A charitable account, Hermon glosses over the fact that Barringer's excoriation of Northemers drew hostile fire from the press. Washington, always trying to turn an enemy to a friend, wrote Barringer, "the more I consider what you said [in Chicago] the more I am sure that on the vital points connected with the elevation of our race there is not so much difference between us as I feared there was." Washington applauded Barringer's call for a national conference "where the whole matter can be studied not from a sentimental standpoint but where the cold hard facts can be carefully weighed" which would "accomplish much good..." Never convening such a conference, and fading from the national stage, Barringer manifested an indirect effect through the writings of G. Stanley Hall, who would teach a generation of early psychologists and sociologists about the racial inferiority of blacks. In 1905 Hall asked Barringer for copies of any "pamphlets which you have published...on the racial question. I have become, within recent years, very deeply interested in the matter from a purely psychological and anthropological point of view, and have been diligently collecting material."16i

${ }^{160}$ Barringer, Ibid., 13, 15.

${ }^{161}$ Hermon Butler to Mr. John Hannah, April 20, 1901, Box 1, "1901-1909 Correspondence" folder, 5858-j Papers of Paul Barringer, Special Collections, Alderman Library, Charlottesville; G. Stanley Hall to PBB, June 9, 1905, Barringer Papers, Box 1, "1903-1908 Correspondence" folder. 
Barringer extended his influence in subtle, but even more far-reaching way's. He taught these views to his students while on the faculty at the University of Virginia, and then for years afterwards. Leaving the University in 1907, Barringer held the presidency of Virginia Polytechnic Institute, where he continued to teach and lecture. Following an early retirement in 1914, Barringer moved back to Charlottesville, and resumed his relationship with the university. He often drew a rocking chair up under a favorite oak tree, "constantly in touch with a group of young students, medical and otherwise, who daily stopped by for a chat about their problems or some angle of development in thought or experiment that Dr. Barringer might suggest"-including race and health. ${ }^{162}$ In his spare time he wrote poetry, filled with racist and eugenical imagery; he also sought to develop a "natural history of religion" that married religion and science; and he lobbied for Virginia's eugenic laws and the national Immigration Restriction Act. ${ }^{163}$ One of Barringer's last "official" acts involving the University of Virginia, in 1907, was to tap his successor as Professor of Anatomy—recapitulating his own history. He recommended young Harvey Emest Jordan, educated at Lehigh University, Columbia, and Princeton. Jordan would eventually become Dean of the University of Virginia Medical School. Throughout his tenure on the faculty, he advocated and taught eugeriics and approved the appointment of eugenicists to the medical school faculty. By 1930, no fewer than seven members of the faculty engaged in medical training were outspoken eugenicists.

That the university taught eugenics through its college and medical school divisions is not surprising. As historian Diane B. Paul reminded scholars, "Most pioneers in the field

${ }^{162}$ Anna Barringer, Barringer's daughter, included this reminiscence at the end of Barringer's memoir, "Autobiography of a Post-Bellum Boy," which she edited and had published as The Natural Bent after his death.

163 Barringer's poem "Germ or Sperm" bemoans the fact that humans do not practice good breeding for: "Of lust unloosed and fools in stud / imbeciles were born." If, however, peopic would just obey "natural law" the result "Of type with type, breed with breed / Of germ and sperm the best" would produce "matings wise of brains and size" providing "strains that captured every prize." In 1924, at the height of American eugenics and eugenically motivated immigration restriction, Barringer wrote, "Teach 'Em Birth Control." a poem advocating birth control to "stop the heathen / from crowding Christian [sic] lands / And underliving lighter folks / And making fool demands." Barringer Papers: 7: 1925, n.d. Poetry. 
of human genetics were active eugenicists. And they were not ashamed to say so.

Eugenics was not yet a term of opprobrium among scientists and would not be until the 1960s." 164 Eugenics was cutting edge science, especially in the first thirty years of the twentieth-century. The men who came after Paul Barringer, beginning with Harvey Emest Jordan, all encountered eugenical ideas in their own training, and developed them in their professional endeavors. That they found a congenial horne at the University of Virginia resulted, at least in part, from the "lengthened shadow of one man," Thomas Jefferson.

The incipient sciences of racial biology and racial anthropology, propounded by Jefferson and developed by Cabell, held immediate relevance for the social, political, and religious concerns preoccupying Virginians from the late eighteenth- through the nineteenth century. The "problem of the color line" that W. E. B. DuBois identified as "the problem of the Twentieth Century," was obviously of great concern to earlier generations. ${ }^{1}$ That each generation brought its most advanced technology-however flawed we may view it from our standpoint - to bear in attempting to resolve intractable racial prejudices, only stands to reason. That each generation's historical and social context informed their science, only itself to be modified by scientific ideas in an endless ideological "feed-back" loop is now a commonplace of historical interpretation of the "objectivity problem." The salient issue is not the "objectivity" or "empirical veracity" of these early scientific beliefs. What is important, however, is that people invested authority in theories backed by scientific warrants. In so doing, they established a syllogism that related science and moral behavior: objective beliefs are moral, science is objective, therefore science is moral. The natural extension of this logic is that any public policy based on scientific principles is, de facto, the most moral course to pursue. Such would be the logic of the intellectual heirs to the tradition established in Virginia by Jefferson and Cabell.

${ }_{164}$ Paul, Controlling Human Heredity, 124.

165 W. E. B. DuBois, The Souls of Black Folk, (A.C. McClurg \& Company, 1903; reprint edition, New York: Penguin Books, 1989), 1 (page reference to reprint edition). 
Paul Brandon Barringer ably shouldered the responsibility of bearing his mentor's nineteenth-century theories into the twentieth century. Barringer and his students presaged the transition of the Redeemed South from a separate and spumed, conquered region back into being an integrated part of America. This generation bridged the gap between resentment of northern modernism and acceptance of Progressive "New South Boosterism." Barringer continued these activities, developing them in lock-step with new scientific advances, until his death in 1941. In this way they built the culture of segregation in Virginia on a foundation equal parts Old South Racism and New South Progressivism that yielded a new, modem, Progressive hyper-racialist theory of social organization. Moreover, through their attempts at reconciling religion and science, New South Boosters like Barringer inoculated the state, at an early date, against the Fundamentalist fever that resulted in Tennessee's anti-evolutionist Scopes Trial. ${ }^{166}$ Thus, their faith in progressive, scientific social engineering and the symbiotic relationship among religion, science, and culture all helped to undercut any "populist" revolt against their ideas. Virginia's elitecontrolled political culture relied on the "democratic" rhetoric of eugenically informed white supremacy to rally support for public policy that curtailed the individual liberties of blacks, poor whites, and mental patients. Virginia's ideological seed-bed provided ample sustenance to the nascent eugenics movement, which would grow and flower in Virginia and the nation.

${ }^{166}$ While the history of the Scopes trial is more complex than the popular expression of Fundamentalist revolt, the trial became an iconic representation of just this sort of "backward," antiintellectualism. The best narrative history of Scopes is, undoubtedly, Edward J. Larson's, Summer of the Gods: The Scopes Trial and America's Continuing Debate Over Science and Religion (New York: Basic Books, 1997). 


\section{Chapter II: "Breeding the Human Thoroughbred"}

Edwin Anderson Alderman succeeded Paul Brandon Barringer at the helm of Virginia's flagship educational institution in the autumn of 1904. Awash in the maelstrom of New South change, with its single-minded emphasis on "efficiency," Virginia's Board of Visitors decided to alter the university's traditional structure of governance. Barringer, nurturing political aspirations and aware of the visitors' desire to modemize the university's administration, removed himself as Chairman of the Faculty in 1903. In a move symbolic of the changing southern tides, the Visitors jettisoned the traditional, but increasingly archaic position of "Chairman of the Faculty" in favor of the modern, efficient executive office of university president. Henceforth, the university's administration would reflect the corporate hierarchies and organizational synthesis developing in the commercial sector.

Virginia's Board of Visitors chose Alderman, one of the South's most nationally-prominent progressive educators, to steer the university between the twin shoals of traditional reaction and "modernist" radicalism. ${ }^{1}$

The shift from Barringer to Alderman signaled more than an educational institution undergoing "organizational synthesis" along the corporate pattern. The change in leadership paralleled the final separation of the "better sort" of southern leaders from the gut-level, Redemption-Era racism that marked even Barringer's theorizing. Now, the scientific racism of the Progressive Era, with its cooler, rational tone and national outlcok,

\footnotetext{
${ }^{1}$ Laurence R. Veysey discusses this institutional focus on business-like efficiency in, The Emerzence of the American University (Chicago and London: University of Chicago Press, 1965), 258-59, 302-17, and 346-56. Philip Alexander Bruce, The History of the University of Virginia 1819-1919: The Lengthened Shadow of One Man (New York: The Macmillan Company, 1920), Vol. V, 1-66. Bruce wrote, "The fundamental reason for the change was to be found in that new spirit of the South which refused to be satisfied with less than the highest degree of efficiency that was attainable, whether the organization to be piloted was scholastic or industrial in its character" (3). The ensuing discussion draws heavily on Michael Dennis's excellent dissertation, and his article, a slightly altered version of the dissertation's Chapter 8, Michael Dennis, "Reforming the 'Academical Village': Edwin A. Alderman and the University of Virginia, 1904-1915," Virginia Magazine of History and Biography 105 (Winter 1997): 53-86.
} 
would hold ideological sway over elite discussions of the "race problem." 2 This transition aided the final resolution of tensions between "Old South" traditionalism and "New South" progressivism. Southemers no longer faced a Hobson's choice between "modem" political and economic liberalism—with its corporate ethic and racial toleration-and selfconsciously "backward," anti-modem Agrarianism—with its failure to accept the economic realities of a national economy. Instead, progressive southemers confronted what historian William Link has identified as the "paradox" of southem progressivism. They reconciled southem tradition and modem innovation by promoting centralized, bureaucratic social reform programs as the way to "democratize" southem life. Such programs increased local community and individual access to the benefits of modem living, public health, public education, and "social uplift." By promoting rational, scientific management as the watchwords of social organization in both sections, Progressives offered an "enlightened" elitism as the new matrix for democratic governance. The common-weal became a surrogate for individual success, as a rising tide lifts all boats. Ultimately, progressivism sheltered reformers in both sections from tempestuous social change; this, in tum, facilitated the rapprochement of the North and South. Reformers in both sections "spoke the same language" and shared the same concems about their position in society. ${ }^{3}$

Alongside political disfranchisement, industrialization, and educational reform, the science of eugenics offered a "modem" solution to the South's "oldest" problem. Hereditarian and eugenic understandings of "race" assisted southerners' quest to reclaim control of social boundaries and to subvert northem self-righteousness regarding the

\footnotetext{
${ }^{2}$ George M. Frederickson noted this transition in, Frederickson, The Black Image in the White Mind: The Debate on Afro-American Character and Destiny, 1817-1914 (New York: Harper and Rowe, 1971)

${ }^{3}$ William A. Link, The Paradox of Southern Progressivism 1880-1930 (Chapel Hill and London: University of North Carolina Press, 1992), xii, 3-30. See also the excellent discussion in the first three chapters of Michael Dennis, "Educating the 'Advancing' South: State Universities and Progressivism in the New South, 1887-1915), Ph.D. diss., Queens University Kingston, Ontario, Canada (1996), 1-97. The foregoing analysis, of course, extends from the pathbreaking interpretations of Progressivism: Robert $\mathrm{H}$. Wiebe, The Search for Order 1877-1920 (New York: Hill and Wang, 1967); and Richard Hofstadter, The Age of Reform: From Bryan to F.DR. (New York: Vintage Books, 1955).
} 
"Negro problem." Incipient genetics apparently clarified the natural, universal, and

biological basis for racial differences. Genetics, by its extension to social policy through eugenics, thus offered a way to resolve the tensions arising from racial distinctions.

Southem eugenicists could announce that the South approached the "problems" posed by blacks and "poor white trash" in the same scientific, rational-and hence objective, moral, and acceptable-fashion as the North confronted the "immigrants problem." This new ideology combined the "best" of both worlds, collapsing the dichotomies facing southem Progressives. Eugenic thinking correlated modemity and racism, white advancement and social stability, uplift and subordination, Progressivism and Agrarianism. Eugenic theories promised to elide southem "distinctiveness" without losing the South. Science thus erased outdated political rationalizations for hierarchy, re-inscribing transformed class, gender, and racial boundaries on the basis of "objective fact" and "expert" authority. ${ }^{4}$

These new ideas attenuated tensions arising from the attempt to create a monolithic white identity (whiteness) and the concurrent eruption of white class consciousness. Eugenics combined "newfangled" science with the pastoral lessons of the breeding pen, familiar to the southem gentry and yeomen alike. The new ideology allowed whites to feei superior to blacks and justified upper-class whites in their exploitation of lower-class whites, presumed to be eugenically inferior. At the same time, eugenics promised to foreclose protest from the "unfit." Laboring under the treble burdens of socio-economic oppression, educational deprivation, and scientific stigmatization, the people marginalized by eugenics would have a difficult time contesting the experts.

\footnotetext{
${ }^{4}$ Dennis notes that in the South, "Progressives were little troubled by intellectual contradictions, as they linked southern rehabilitation to practical, service-oriented education." Dennis, Ibid., 21. While this is largely true, hereditarianism provided another solvent for whatever traditional obstructions obstrucied southem social theorizing. J. David Smith engages similar ideas in his book The Eugenic Assault on America: Scenes in Red, White, and Black (Fairfax, Va., 1993), 1-12. Smith overstates his case for dramatic purposes, as he compares Virginia and Nazi eugenics and ascribes a genocidal aim to all Virginia eugenicists. There were, indeed, Virginians intent on genocide, but they, as will be shown, were in the minority and were not the individuals discussed by Smith. My conclusions differ from Edward J. Larson's study of deep-southern eugenics in, Sex, Race, and Science: Eugenics in the Deep South (Baltimore and London, 1995).
} 
Theoretical eugenic public policies offered refined controls for "adjusting" class and racial tensions through various notions of segregation. Adopting eugenics allowed Virginians to participate in the same spectacles of segregation as their fellow regionalists, but with less overt violence. Eugenics offered the incarceration/institutionalization, sterilization, and eventual elimination of the problematic classes, without the negative publicity attendant to lynching. Eugenics substituted "humane" social therapy for reactionary extralegal violence. It defused modernity by making it central to the culture of segregation.

This chapter examines how the administrative goals of Edwin Alderman and the men he hired to modernize the university, when placed within the larger context of the southern progressive movement, set the conditions for the successful germination of eugenic ideas at the University of Virginia. The structural reform of the University of Virginia placed a new emphasis on scientific experts and research into human nature and the root causes of social problems. The university was to work for social reform by training the experts who would man government bureaucracies. These bureaucratic institutions would capitalize on advances in technology to improve southern life. Medicine, education, and biology, three areas deeply infused with eugenic ideology, also happened to have captivated the progressive mind. Advances in each field brought them a new visibility as agents of social improvement. Squared with administrative efficiency, these three disciplines would form the four cornerstones of Alderman's progressive foundation at Virginia. The men he hired, Harvey Emest Jordan, William Harry Heck, and Ivey Foreman Lewis, would infuse each of these departments with eugenic ideology. While this chapter develops their initial activities, and the gradual permeation of eugenic ideas into other Virginia institutions, the lasting influence of these men at Virginia and in the state, will occupy subsequent chapters.

Southern Progressivism, Education, and the Rise of Expert Authority 
Popularizing eugenics through modemizing southem universities capitalized on the tendency of institutions to inculcate conservative social traditions. ${ }^{5}$ As historian Michael Dennis noted, echoing themes developed by other historians of Progressivism, "modernizing southem universities offered an institutional vehicle and intellectual guidance for the efforts of a new middle class to impose order on a society in flux." Progressive educators in the South, after the tum of the century, built on the ideas expressed by men like Paul Brandon Barringer; but they tempered his rhetoric, subtly amending his solutions to social problems. These new leaders "spoke the language of practical education and social service, subordinating liberal culture to the demands for trained experts and professionalization." For Virginia's educated white males, the eclipse of the liberal arts tradition in favor of professionalization changed their approach to the "white man's burden" from noblesse oblige to bureaucratic patemalism. University-trained, authoritarian experts would deftly steer society, with such accuracy as to make the control imperceptible, toward utopia. The importance of education could not be overstated. As famous southem educator Samuel Mitchell said, "Education represents a structural process in society...the South has found in the school the latent potency that will create industries, uplift the

\footnotetext{
5Italian Marxist Antonio Gramsci opened the debate on the conservative nature of educational institutions in The Intellectuals. See generally Magali Sarfatti Larson, "The Production of Expertise and the Constitution of Expert Power," in Thomas L. Haskell, ed., The Authority of Experts: Studies in History and Theory (Bloomington: Indiana University Press, 1984), 28-80, by Perhaps the classic Marxist interpretation of this conservative function of American education is Samuel Bowles and Herbert Gintis, Schooling in Capitalist Ameerica: Educational Reform and the Contradictions of Economic Life (New York: Basic Books, 1976). The insights of Gramsci, Bowles, and Gintis are subverted by their insistence on a hegemonic regime that is simply not supported by the facts. No elite group has ever managed to create complete social control. William A. Link underscores the difficulty of establishing social, cultural, or political hegemony throughout, The Paradox of Southern Progressivism, as does Dewey Grantham in Southern Progressivism: The Reconciliation of Progress and Tradition (Knoxville: The University of Tennessee Press, 1983). Both studies reveal the generally conservative cast of southern progressive reform; neither asserts that elites wielded complete social control. The most instructive interpretation of the forging of the "modem" southern identity, and its ultimate reconciliation with the modern "American" identity, both being predicated on whiteness, is Grace Elizabeth Hale, Making Whiteness: The Culture of Segregation in the South, 1890-1940 (New York, 1998). Paul M. Gaston, The New South Creed: A Study in Southern Mythmaking (New York, 1970), explains the tensions between modemity and tradition in southern mythology - in some ways the root of southern identity formation.
} 
masses, adjust racial differences, and regain political prestige. ${ }^{6}$ When applied to women, poor whites, and blacks, this pedagogical and social ideal emphasized coordinate and segregated education that fit each group for a subordinate slot in the social order. Blacks would be educated for manual labor, poor whites for industry, and women as nurturers (teachers, wives), caregivers (mothers, nurses), and helpmeets (secretaries, ancillary industry). ${ }^{7}$ "In a region unsettled by economic change, racial unrest, political realignment, and cultural dislocation, modemizing southem universities portrayed themselves as the voices of rational and controlled social development," conservative reform not radical revolution. ${ }^{8}$

Southern educational progressives focused on contained, disciplinary reform through "adjustments" that would calibrate the social balance. They did not envision any wholesale social or racial restructuring. As Michael Dennis wrote, "Social stability, racial stratification, and regional cohesiveness - tenets central to the southern brand of the progressive movement-meshed with the educators' plans for racial harmony, southern freedom from northern interference, and industrial growth. The school and the university

\footnotetext{
${ }^{6}$ Mitchell quoted in Dennis, "Educating the 'Advancing' South," 30. Such technocratic utopianism had been on the upsurge since the publication of Edward Bellamy's novel Looking Backward in 1887. The release of H. G. Wells's fabulously popular A Modern Utopia in 1905, in which Wells described the "samurai" class of benign, technocratic social engineers running England, boosted the Progressive cause. See Mark R. Hillegas's introduction to H. G. Wells, A Modern Utopia (New York and London: Chapman and Hall, 1905; reprint edition, Lincoln, Neb. and London: University of Nebraska Press, 1967), v-xxiv, and Chapter 9 ("The Samurai").

7Dennis, "Educating the 'Advancing' South," Chapter 3. James D. Anderson, The Education of Blacks in the South, 1860-1935 (Chapel Hill and London: The University of North Carolina Press, 1988), 110 147; Eric Anderson and Alfred Moss, Dangerous Donations: Northern Philanthropy and Southern Black Education, 1902-1930 (Columbia, MO and London: University of Missouri Press, 1999); 39-62; and Joseph Kett, "Women and the Progressive Impulse in Southern Education," in Walter J. Fraser, jr., R. Frank Saunders, jr., and Ron L. Wakelyn, The Web of Southern Social Relations: Women, Family, \& Education (Athens, GA: The University of Georgia Press, 1985), 166-80. Resistance to co-education at the University of Virginia was massive whenever the issue arose; the university was the last major state university to admit women, and did so only under the threat of litigation, by federal court injunction, in 1970. See Philip Alexander Bruce, History of the University of Virginia: The Lengthened Shadow of One Man 5 vols. (New York: The Macmillan Company, 1919-1922), vol. 4, 63-68; vol. 5, 86-103; University of Virginia, "Report of the Committee of the Faculty on the Admission of Women to the Academical Schools" (1894) Rare Virginia Pamphlets 240; and Mrs. Mary Newton Stanard, "The Petition for a Woman's College at the University of Virginia" (1913), Broadside 1913.S736, Special Collections, Alderman Library, Charlottesville.

${ }^{8}$ Dennis, Ibid., ii.
} 
were not repositories for rarefied knowledge but agents of social cohesion." 9 Southem universities, like American universities generaliy in this period, remained ballast for the status quo, not crucibles of revolutionary innovation. Impelling this conservativeprogressive thrust, Edward Anderson Alderman became one of the major reformers in Virginia.

\section{Alderman's Progressive restructuring of Virginia reflected C. Vann Woodward's} description of him and his contemporaries as highly principled men whose vision "included no basic alteration of social, racial, and economic arrangements." 10 Alderman, a native North Carolinian who had spearheaded that state's efforts to modernize public education, came to Virginia from the presidencies of Tulane University and his alma mater, the University of North Carolina. A seasoned crusader, Alderman was well prepared to propel Virginia's educational flagship against the currents of traditionalism and penury that swamped the institution. Even as Alderman and the Board of Visitors committed Virginia to becoming a "modem" research institution, they self-consciously attempted to maintain the university's "southem" character and its place in the van of "southem" higher education. They agreed that the university should increase its already powerful ability to shape social conventions. Using the University of Wisconsin as the "model" state school, Alderman thoroughly reorganized the University, placing increased emphasis on the instruction of professionals and experts. ${ }^{11}$ He enlarged every professional school, updated offerings in the natural and social sciences, and created vigorously promoted university extension. The authorities produced by these departments would then apply their

\footnotetext{
${ }^{9}$ Dennis, "Educating the 'Advancing' South," 4.

${ }^{10}$ Woodward, Origins of the New South, 397; Dennis, "Educating the 'Advancing' South," 21-23. A letter, askirig Alderman if anyone at the university advocated racial amalgamation, prompted immediate response from Acting-President Newcomb (Alderman had died a few months earlier), "you need have no fear. ... No institution could be further from teaching that sort of doctrine than the University of Virginia." Dr. Lillian Crockett Lowder to Edwin Alderman, June 9, 1932; and, John Lloyd Newcomb to Dr. Lillian Crockett Lowder, June 10, 1932, "L" Folder, Box 13, President's Papers, .491, subseries I.

${ }^{11}$ Alderman followed the trend among American college presidents, started by Daniel Coit Gilman at Johns Hopkins, Dennis, "Reforming the 'Academical Village,"' 58-59.
} 
knowledge to solving the social and economic problems confronting Virginia and the

South. Alderman's belief in the social service ethic that, "If a state comes to the conclusion that its public health must be conserved, or its roads improved, or its economic resources developed, ... it has a perfect right to turn to the university for help and direction," guided his every move as president. ${ }^{12}$

Alderman articulated a specific relationship between school and society, a symbiosis in which each existed to the mutual benefit of the other. Alderman articulated this notion explicitly, "The social centre of gravity of the South to-day is neither the courthouse nor the hustings, but the schoolhouse and the university, and its prevailing mood is social sympathy."13 As Andrew Jackson Montague sermonized at Alderman's inauguration on April 15, 1905, in terms Alderman surely applauded,

This school lives of the State, but it also lives for the State; and while we must be careful of what we get from the people, we must be more eager about that which we give back to the people. We must demand that this agency of the people, as it grows in new power and strength, shall also grow in service to the people of the land. We must place hand in maternal touch with the common schools of our land, thereby energizing all the forces that make for popular enlightenment. These primary schools should know that in the halls of this University are lights of guidance for them, and in her chairs are fathers and friends of all forms of education. We must ask her to set herself anew to the democratization of education in order that an equality of opportunity shall come to every child who would know and serve his day and generation. ${ }^{14}$

Alderman himself would write, "At this stage of our [southern] culture, when millions are to be impressed with the importance of knowledge, the Southem scholar must forego his office of prophet and seer and become ruler and reformer. Southern universities and colleges must do the work of social regenerative forces, reaching out directly into the life of the people, making known how much better light is than darkness."15 Favoring this

\footnotetext{
${ }^{12}$ Alderman quoted in Dennis, "Educating the 'Advancing' South," 319 (status), 321-28, 351-67, and 376-81 (quotation 326). Dennis, "Reforming the 'Academical Village,"' 68-71 (quotation 57).

${ }^{13}$ Alderman quoted in Dennis, "Educating the 'Advancing' South," 38.

${ }^{14}$ Richard Quantz, "Founding of the University of Virginia School of Education," Occasional Paper Series in the Social Foundations of Education 3 (April 1979) Curry Memorial School of Education, Charlottesville, 3.

${ }^{15}$ Edwin Anderson Alderman, "The University and the State in the South," Rare Virginia Pamphlets 23 (n.d.), 53-56.
} 
positivist educational ethos that moved academics from the periphery to the center of social power, faculty members flocked to Alderman's banner and joined the fight to "advance" the South. Professor Charles Kent remarked after Alderman's first year that the president should lead students, coordinate the faculty, and be dedicated to "the democratization of the University without the loss of its birthright of aristocratic origin and history, the identification of the University with other educational movements,...and possibly the attraction of comely beneficences." A bit tongue-in-cheek, perhaps, Kent's remarks nevertheless revealed the faculty's appreciation of Alderman's program and the obstacles in his way, as well as their fealty to the social traditions of the South. ${ }^{16}$

While the "democratization" of education might sound radical, the emphasis on efficiency translated into a desire to fit every individual perfectly for the socio-economic niche they would fill. The net effect of this program was conservative. Southern Progressive educators enunciated social indoctrination as a pedagogical goal. "Hence solidarity is a motive force in democratic education," Samuel Mitchell, a Virginia educator who rose to prominence as president of the University of South Carolina, opined in 1908. "The splendid efforts which the Southern States are now making to train all the children within their borders throb with national energy. The public school is the exponent of Americanism. Agencies to the same end are the colleges of which a prime function is to give right orientation to their students." 17 Mitchell's rhetoric, redolent with mechanical imagery ("motive force", an engine's "throb") and the precise control of student thought (the "right orientation") underlined the Progressive fixation with technocracy, control, and corporatism.

Alderman shared in these ideals, even to the point of repudiating traditional southern individualism, the bedrock of the Agrarian political tradition since Jefferson. "It has been

\footnotetext{
${ }^{16}$ Kent quoted in Corks and Curls (Charlottesville: Michie Publishing Company, 1905), 4.

${ }^{17}$ Mitchell quoted in Dennis, Ibid., 47. Mitchell's piece, "The Nationalization of Southern Sentiment" appeared in the South Atlantic Quarterly 7 (April 1908).
} 
settled," Alderman wrote in describing "The Achievement of a Generation" in the postbellum South, "That the South is hereafter to place its chief emphasis upon community effort, rather than upon individualism." No longer suffering from parochial insularity, southemers could turn to the reform of their "communities and their aspirations and their developing genius for concerted action." 18

Alderman's ideas flourished, despite this redirection of southern sentiment toward the corporate nature of society. As one commentator noted, "Using the institution to promote public elementary and secondary education, Alderman and his associates were able to tie the University to the public school system without destroying its conservative image."19 Virginia's distinct political structure helps to explain Alderman's success. Virginia, with its long history of elite political domination, never underwent the Populist tumult that swept states like North and South Carolina in the late-nineteenth and early-twentieth centuries. Instead, as Michael Dennis points out, "The state was dominated by a tightly organized oligarchy," that "leamed from its bouts with [the pseudo-Populist] Readjusters to maintain control by accommodating political insurgency." Thus, when confronted with educational reform, "the Virginia oligarchy combined political hegemony with concessions to the progressive movement." 20 Political elites largely fell into line behind Alderman's plan; while he constantly battled the legislature for appropriations, they remained supportive of his vision because of its promise of economic advance and increased social stability.

Alongside his campaign for public school reform and the professional education of teachers to increase the common weal, Alderman relentlessly lobbied the state for funds to improve Virginia's medical school and the university hospital. By 1917, he was able to boast that the university had spent over $\$ 600,000$ dollars "in multiplying its scientific laboratories and their equipment ten-fold, increasing its instructorial staff, and, above all,

\footnotetext{
${ }^{18}$ Edwin Anderson Aldennan, "The Achievement of a Generation," South Allantic Quarterly 5 (January-October 1906), 241.

${ }^{19}$ Quantz, "Founding of the University of Virginia School of Education," 7.

${ }^{20}$ Dennis, "Educating the 'Advancing' South," 328.
} 
developing the advantages of its own hospital to the point where fifteen hundred cases of disease pass through it yearly, and where, in surgery, its service for the students enrolled equals the best in America."21 This boast represented the culmination of a decade long effort. The medical school and the hospital stood, in Alderman's eyes and those of many others, in the best position to make a rapid, positive impact on the quality of southem life. As Alderman said in 1910, on the eve of the spending spree,

I believe the State will make a wise use of the funds to give us the power to make this Institution what it should be in the advancement of public health in the State. There is no more practical servant of the State than the doctor, and it is fast becoming to be recognized that his greatest function in our civilization is not only to cure and restore to economic efficiency those who are sick, but to keep the community at large in a normal condition of health. 22

Alderman envisioned the hospital as more than an educational factory churning out physicians. It was, like the university itself, "an interventionist social agency guaranteeing community health and providing at the same time a 'great clinical laboratory."'23 Physicians, dressed in their "pure" white lab coats, and armed with the latest technology of modem science, became the iconic representation of progressivism in the South.

Physicians presented a more powerful image than that of the esoteric scientist: theirs was an applied science that could drainatically improve the quality of life in a brief period. For a region that sensed it was in need of therapy—wracked with hookworm, pellagra, tuberculosis, and syphilis-phy'sicians offered hope.

The public, too, eventually recognized that an important relationship existed between institutions of higher education, science, and society. As the Charlottesville Daily Progress reported, "Nothing is more evident than the fact that modem life...finds its basis in science....The scholar versed in the great achievements of the past and possessing exact and extensive knowledge of modern science, can interpret modern life as no one else is able

${ }^{21}$ Dennis, "Educating the 'Advancing' South," 349-51; Dennis, "Reforming the 'Academical Village,"' 74-78; Bruce, History of the University of Virginia, vol. 5, 177-92, quotation 187.

${ }^{22}$ Alderman quoted in Dennis, "Educating the 'Advancing' South," 349.

${ }^{23}$ Dennis, Ibid., 350. 
to do...." The Daily Progress expressed the emerging popular faith in the ability of university-trained "experts" to improve society. Alderman felt similarly: "The ultimate mission of the state university in America is to supply training" to experts who would then study, "the actual conditions of life in the state which the university exists to aid and strengthen." 24 Alderman's ideal perfectly fit the Progressive Era ethos of scientific positivism.

Alderman applied the same rationale to the social problems facing the South, particularly the "Negro Problem." Like most "liberal" southern progressives, Alderman's view of public education marginalized blacks. While southem progressives "created a professional caste," as Michael Dennis has noted, they also envisioned "an army of disfranchised but exploitable black laborers for the South's agricultural-industrial complex." 25 Disarming the explosive issues surrounding black education, Alderman believed that southemers should cultivate "a scientific habit of investigation as to the facts of his [African-Americans'] progress, coupled with an intelligent interest in his development." 26 The "progressive" social policies of segregation and disfranchisement would separate the volatile racial ingredients, allowing southern elites to perform a "scientific" analysis of the problem. Dispassionate "objectivity" temporized Alderman's rhetoric for advance and the prospect of real improvement by emphasizing that black "progress" and "development" would come only after lengthy study. Indeed, the seed-

\footnotetext{
${ }^{24}$ Both quotations in, "The University of Virginia," Charlottesville Daily Progress, December 29, 1916, p. 18. Biology Professor Ivey F. Lewis would echo Alderman, commenting that the biology department contributed to, "the teaching profession of the Southern States. We hope to encourage the spirit of research and sound scholarship in the teachers of our colleges and secondary schools." Ivey F. Lewis, "The Last Ten Years in Biology at the University of Virginia." See paper and undated clipping, labeled "Chattanooga News," in "Articles on University" Folder, Box 3, President's Papers, .491, subseries I.

${ }^{25}$ Dennis, "Educating the 'Advancing' South," 64. See Anderson, The Education of Blacks in the South, especially Chapter 3; and

${ }^{26}$ Alderman, "The Growing South," World's Work 16 (1908), 10377-78.
} 
money for Virginia's sociology department came from the Phelps-Stokes Fund, a northem philanthropy dedicated to "Negro uplift."27

Alderman, head of a cash-poor school, gratefully accepted the Phelps-Stokes money for the study of southern blacks in 1911. True progressives themselves, the Phelps-Stokes trustees felt "that the right way to go about" the improvement of southern blacks, "was to get first all the best information available on the subject, and then to analyze and classify it in a scientific way." The best means to this end was "to provide means tc enable Southem youth of broad sympathies to make scientific examination of that people." 28 After scrambling to maintain this fund, which had sat dormant from 1911 to 1914 , Alderman wrote that, "the right adjustment of relations between the white man and the colored man in American life, still remains perhaps our most complex and momentous public question." Although he felt that southerners had acted with "a great deal of instinctive wisdom," it was time that, "patient, wise, scientific, just men should labor at the problem and seek to place it where it belongs among the great economic and sociological questions of the time."

Alderman called for scientific study of an intractable problem, not amelioration. His use of bloodiess phrases like "the right adjustment" of race relations reveals his faith in expert control. Alderman felt that, rather than hoping for a solution, Americans "should be grateful for the fact that the negro has somehow gotten off the southemer's nerves and out of the northerner's imagination." 29 Alderman's studied deliberation regarding the "race

\footnotetext{
${ }^{27}$ Established in 1911 by Mrs. Caroline Phelps Stokes, a prominent New England philanthropist, the Phelps-Stokes Fund provided $\$ 12,500$ to the University's of Virginia and Georgia for "lectures by representative Southemers on the negro and his problems." The charter also stipulated an annual fellowship award of \$500, from the income of the fund, for scholarship relating to the study of southem African Americans. Anson Phelps Stokes to Edwin Anderson Aidcrman, May 11, 1914; and APS to Chancellor Barrow of the University of Georgia, carbon copy, February 8, 1915, in President's Papers, RG 2/1/2.472, subseries I, box 20, "Phelps-Stokes Fund" folder. [Hereinafter cited as, box number, folder title, President's Papers, three-digit suffix, subseries number.]

${ }^{28}$ Quoted in Bruce, History of the University of Virginia, vol. 5, 168.

${ }^{29}$ Edwin Alderman, "Untitled Address to Commission (December 20, 1915)," Box 8, folder 103, President's Papers, .472, subseries III, Special Collections, Alderman Library. See Gregory Michael Dorr, "Assuring America's Place in the Sun: Ivey Foreman Lewis and the Teaching of Eugenics at the University of Virginia, 1915-1953," Journal of Southern History 66 (May 2000): 271.
} 
question" placed him squarely in the ranks of the "accommodationist racists" who, while striving to maintain a biracial, segregated society, also argued that black advance and racial cooperation would benefit the white South, too.

In spite of his "liberal" attitude toward black improvement, Alderman was no racial equalitarian. He agreed with his good friend (and racial "liberal") Edwin Mims, that "segregation in school, church and society is in the interest of racial integrity and racial progress."30 Writing in 1906, Alderman advocated universal public schooling, provided that the children of the white and black races shall be taught in separate schools." In 1908 he again argued for the "absolute social separateness" of the races if both were to advance. $^{31}$ Definitely an ardent segregationist, Alderman may have adhered to eugenics, as will be discussed in the next chapter. Alderman's racial views, however, if not extending from any particular science, betrayed the aggregate effect of "reform Darwinism" on the intelligentsia of the South. Darwinian evolutionary theory, Spencerian rhetoric about the "survival of the fittest," and the misapplication of these ideas to society ran rampant in the first decades of this century. Any erudite intellectual, and Alderman was certainly that, could not fail to be influenced by these ubiquitous ideas. They would condition the changes he made at Virginia, from the men he hired to the programs he improved. That eugenics and hereditarianism became guiding scientific principles within Virginia's progressive curriculum, especially in medicine, education, and biology, should come as no surprise.

\section{Medical Eugenics: True Belief, Biological Inequality, and Public Health}

Identifying medicine and the public health infrastructure as one of the surest agencies for promoting southern progress, Alderman inherited an institution crying ou: for continued

${ }^{30}$ George M. Frederickson termed racial moderates like Alderman "racial accommodationists." Frederickson, The Black Image in the White Mind, 283-297. Edwin Mims, "President Theodore Roosevelt," South Atlantic Quarterly, 4 (January 1905), 59-60.

${ }^{31}$ Alderman, "Achievement of a Generation," 239; and Alderman, "The Growing South," 10378. 
modemization. The advent of Mendelian genetics in 1900 coincided with Paul Barringer's crowning achievement, the construction of the university hospital. The promise of eugenics captivated many of the best and brightest physicians and biologists of the day. The medical faculty Alderman hired, beginning most notably with Harvey Emest Jordan, looked to genetic and eugenic technologies for solutions to medical and, ultimately, social problems. Eugenics offered new ways to understand both endemic southem public health problems like syphilis, pellagra, and tuberculosis, and the biological background "causing" southem racial problems.

Harvey Ernest Jordan, born in 1878 to a Pennsylvania farmer's family, would become one of the most respected medical educators in the New South. On his way to becoming Dean of the University of Virginia Medical School, Jordan achieved an impressive record as a researcher in histology, embryology, genetics, and eugenics. His personal bibliography lists 177 journal articles. He also authored three books, War's Aftermath: A Preliminary Study of the Eugenics of War (1914), A Textbook of Histology, which became the standard work in its field and went through seven editions between its first publication in 1916 and 1940, and A Textbook of Embryology (1926). ${ }^{32}$ Jordan was trained by, and maintained personal associations with two of American embryology's giants, Edmund Beecher Wilson and Edwin Grant Conklin. 33

Jordan also established close personal friendships with many nationally-prominent eugenicists, among them Charles Benedict Davenport, Harry Hamilton Laughlin, Conklin,

32Harvey Emest Jordan, Pubilications of Harvey Ernest Jordan, 3 vols., (collected and bound, 1940), Wilhelm Moll Rare Book and Medical Library, Universitv of Virginia Medical School, Charlottesville; David Starr Jordan and Harvey Emest Jordan, War's Aftermath: A Preliminary Stiudy of the Eugenics of War (Boston and New York: Houghton Mifflin Company, 1914); Harvey Emest Jordan, A Textbook of Histology, 3d. ed., (New York and London: D. Appleton and Company, 1920); and Harvey Emest Jordan and James E. Kindred, Embryology (New York and London: D. Appleton , 1925). The preface to the second edition of Histology (1917) indicates that the book was originally co-authored in 1916 with Jeremiah Ferguson.

${ }^{33}$ Wilson became Jordan's doctoral advisor. Jordan met Conklin through Wilson, as will be discussed below. For these individuals' significance in shaping American biology in the early twentieth century, see Jane Maienschein, Transforming Traditions in American Biology, 1880-1915 (Baltimore and London: Johns Hopkins University Press, 1991). 
Robert Cook, Clarence C. Little, David Starr Jordan, and Paul Popenoe. Through these associates, Jordan joined the organized eugenics movement. He did his share as researcher, author, and lecturer to advance and popularize the eugenics creed in Virginia and around the nation. Virginia's eugenics movement developed, in large part, through the efforts of Harvey Ernest Jordan and his ties to national organizations like the American Eugenics Society, the Eugenics Research Association, the Eugenics Record Office, the American Genetics Association, and the American Association of Physical Anthropologists. Jordan alerted national-level eugenicists to research possibilities in Virginia. He also organized like-minded Virginia scientists and lay people in support of eugenics education and social policy. In many ways, it is Jordan's career that links the proto-genetic, hereditarian racial beliefs of Paul Barringer to the race thinking of Edwin Alderman and other Progressive Era Virginia intellectuals. His tenure as professor and then dean of Virginia's premier medical school ensured that generations of Virginia physicians, nurses, and state health-care institution administrators learned and acted upon the tenets of the eugenics credo. Jordan's humble Pennsylvania origins belied his ultimate influence in linking bench scientists, practicing physicians, and eugenicists in efforts to achieve a social order devoid of the "unfit"—whether of mind, body, race or, as we shall see, political persuasion.

Little remains to document Harvey Ernest Jordan's early years. Jordan wrote that he was born in Coopersburg, Pennsylvania, "home of T.S. Cooper, the breeder of fine Jersey com," and three famous race horses. Jordan explained that, "As a mere lad, I was impressed with the importance of heredity, while playing about the barns with [Cooper's] sons."34 Jordan graduated from Keystone State Normal School in Kutztown, Pennsylvania in 1897 and entered Lehigh University. At Lehigh, Jordan took his

\footnotetext{
${ }^{34}$ Harvey Emest Jordan to Charles Benedict Davenport, October 8, 1912, "Jordan, H.E." Folder, Charles Benedict Davenport Papers, American Philosophical Society Library, Philadelphia. [Hereinafter referred to as Davenport Papers.]
} 
bachelor's (1903) and master's (1904) degrees, the latter in bacteriology and organic chemistry. He then proceeded to teach as assistant in histology at the Comell University Medical School from 1904 to 1906. During the academic year 1905-1906, Jordan simultaneously taught at Cornell's medical school and studied cytology as a "special student" at Columbia under renowned cellular biologist Edmund Beecher Wilson. The following year, Jordan attended Princeton, where he finished his training as a cellular anatomist - completing, in June of 1907, a dissertation on chromosome formation in Asterias Forbesill that he had started under Wilson. ${ }^{35}$

These early years of study brought Jordan into close contact with scientists studying medicine, cellular biology, evolution, and incipient genetics and eugenics. As Jordan's own professional preparation reveals, all these fields existed in flux, with overlapping methodological boundaries and areas of investigation. Disciplinary specialization during the first third of this century came later in an investigator's career, after a broad technical training. Columbia and Princeton were both leading institutions with distinguished faculties that emphasized "bench research" in microbiology. As a result, students like Jordan had access to the leading cadre of biological investigators. Through those leading lights, young scientists gamered research appointments at prominent "field stations." Attaining bench assignments at Massachusetts's Woods Hole Marine Biological Laboratory (MBL), and the Camegie Institution's Station for Experimenta! Evolution (SEE) and the

\footnotetext{
35Jordan to Davenport, December 3, 1906, Ibid. See also Jordan's Curriculum Vita and the text read when he received the "Raven Award" for outstanding services to the University of Virginia, bound in the Collected Papers, vol. 1. Jordan's scant "personal" papers contain no revaaling manuscript material, consisting mostly of the sketches he made during microscopic investigations and the illustrations that accompanied his scientific publications. A file also exists containing annotated clippings, mostly from 1940s and 1950s popular periodicals, conceming the "Communist Threat." Harvey Emest Jordan Collection, Special Collections, Alderman Library, University of Virginia, Charlottesville. Like many of the individuals discussed in this dissertation, Jordan viewed himself as an ardent patriot and vigilant anticommunist. The ties between his anti-radicalism and hereditarianism will be discussed later. The Carnegie Institution of Washington published a distilled version of Jordan's dissertation, probably at the behest of, among others, Charles Benedict Davenport. Harvey Ernest Jordan, "Relation of the nucleolus to the chromosomes in the primary oocyte of Asterias forbesil," Publication Number 102 (Washington, D.C.: Carnegie Institution of Washington, 1908), 37-72. For a sketch of Jordan's mentor Edmund Beecher Wilson that documents his role in shaping modern cell biology and genetics, see Maienschein, Transforming Traditions, Chapter 6.
} 
Brooklyn Institute of Arts and Science's Biological Laboratory (BIBL), both in Cold Spring Harbor, Long Island, depended as much on who a young investigator knew as on his (or rarely, her) promise as a scientist. All three of these institutions provided research opportunities to the scientific core of American biology. Summers spent at these laboratories established close personal and professional friendships among the relatively rarefied biological community. ${ }^{36}$ Moreover, this group also formed the nucleus of the emerging American eugenics movement. Indeed, the latter two laboratories were directed by the founder of American eugenics, Charles Benedict Davenport., while the moderate eugenicist, Edwin Grant Conklin, directed the former. ${ }^{37}$

Harvey Jordan availed himself of these educational opportunities, and there can be no doubt that his first exposure to eugenical ideas came during this period. Indeed, he spent three summers at Woods Hole with Conklin: in 1905 and 1906 as a student and in 1908 as an instructor in embryology. One of the most prominent cellular biologists in America, Conklin was also an early advocate of eugenics. Conklin would surely have seen a reflection of himself in Jordan. Both men were committed Protestant Christians, and faith infused and informed their careers as biologists, scientists, and educators. As Kathy Jane Cooke has noted, both men were "biological progressives" who saw in eugenics a method for "biologically informed social reform." In their early writings on eugenics, both men acknowledged the co-equal importance of heredity and environment in shaping the individual. Jordan's initially temperate views may well have reflected Conklin's influence. Yet, while Conklin ultimately would eschew the most strident of "mainline" hereditarian

\footnotetext{
36Philip J. Pauly, "Summer Resort and Scientific Discipline: Woods Hole and the Structure of American Biology," in The American Development of Biology, Ronald Rainger, Keith R. Benson, and Jane Maienschein, eds. (New Brunswick, NJ: Rutgers University Press, 1988), 121-150; and Lee Richard Hiltzik, "The Brooklyn Institute of Arts and Sciences' Biological Laboratory, 1890-1924: A History," Ph.D. diss. State University of New York, Stony Brook (1993), 106. Hiltzik notes that for many scientists who attended these stations, "payment was in the form of learning new methodologies and establishing new professional contacts."

${ }^{37}$ For a complete history of the Brooklyn Institute's biological laboratory, see Hiltzik, "Brooklyn Institute."
} 
eugenics, Jordan would eventually come to embrace those theories, in large part as a result of his association with Charles Benedict Davenport. ${ }^{38}$

In December of 1906, the twenty-nine-year-old Jordan, probably at the behest of his mentor Edward B. Wilson, approached Davenport for an appointment as a summer instructor at Cold Spring Harbor. 39 After interviewing Jordan at the 1906 American Association for the Advancement of Science meeting, conveniently located at Columbia, Davenport offered Jordan "the position as assistant in embryology," with "the free use of the laboratory and its equipment and a [sic] honorarium of \$25." Jordan's duties would not be unfamiliar, for he would assist one of his former instructors, who had charge of the embryology laboratory. Jordan accepted the offer, spending the summer before his arrival at the University of Virginia studying embryology during work-hours, and soaking up genetic and eugenic ideas from Davenport and others during his free time. Indeed, after giving a course on variation in 1899, Davenport began using "the Biological Laboratory as a springboard for his own scientific agenda in the field of eugenics." 10 The intimate relationship created by small classes, familiar instructors, and a shared "campus" at Cold Spring Harbor elided the titular divisions between the various biological stations. This close interaction created both a productive learning environment and a professional network among investigators. ${ }^{41}$ Thus, Jordan left Cold Spring Harbor for his new position as

\footnotetext{
${ }^{38}$ The definitive intellectual biography of Conklin is Kathy Jane Cooke, "A Gospel of Social Evolution: Religion, Biology, and Education in the Thought of Edwin Grant Conklin" (Ph.D. diss., University of Chicago, 1994). Cooke notes strong similarities between Jordan and Conklin in their early approach to eugenics, but she never establishes the connection between the men. Nor does she note Jordan's later divergence from Conklin's views. Cooke, Ibid., 4-6 (biological progressives); 148-150 (Jordan's views similar to Conklin's).

${ }^{39}$ Jordan to Davenport, December 3, 1906, Davenport Papers. Wilson almost assuredly introduced Jordan and Davenport; Wilson served as a member of the non-resident staff of Davenport's SEE. Hiltzik, "Brooklyn Institute," 225; Oscar Riddle, "Biographical Memoir of Charles Bent-dict Davenport 1866-1944," National Academy of Sciences Biographical Memoirs, vol. 25, (Washington, D.C.: National Academy of Sciences, 1948), 83. Davenport may have helped Jordan secure publication oí his dissertation, see note 35.

${ }^{40}$ Hiltzik, "Brooklyn Institute," 156 note 284.

${ }^{41}$ Davenport to Jordan, December 6, 1906; and Davenport to Jordan, February 13, 1907, Dave.ıport Papers. Pauly, "Summer Resort and Scientific Discipline," ; and Hiluzik, "Brooklyn Institute," 144-147, 156 note 284, 225, 229, 245-251, 266, 270-271. Indeed, after the formation of the ERO in 1910, the BIBL, SEE, and ERO operated so closely together that Davenport noted that eugenics, botany, and zoology constituted the three "leading subjects" taught at the BIBL. Hiltzik, "Brooklyn Institute," 270-271.
} 
professor of anatomy at the University of Virginia well acquainted with, and well regarded by, some of the most important figures in American biology, eugenics, and medical education.

His professional training completed, Jordan accepted the call to the medical school of the University of Virginia, and began teaching in the fall of 1907. Almost nothing remains in the University of Virginia's records indicating the circumstances of Harvey Jordan's hiring. As mentioned above, Virginia's Board of Visitors accepted the resignation of Paul Brandon Barringer as Chairman of the Faculty in 1903, electing Edwin Anderson Alderman as the first president of the university. Barringer remained on the faculty of the medical school, however, lecturing in anatomy and ophthalmology and helping to organize and administer the new hospital until the end of 1907.42 Barringer, like James Lawrence Cabell before him, probably anointed his successor in the Chair of Anatomy by recommending and approving of Harvey Ernest Jordan's appointment. If Barringer and Jordan met at this time, it is likely that they would have found common ground in their opinions about preventive medicine and hereditary determinism. Barringer would have appreciated Jordan's rigorous scientific training and his desire to apply his knowledge directly to patient care and preventive medicine. How Jordan would have responded to Barringer's racial views in 1907 is unknown. Beginning after 1910, however, Jordan's racial and scientific opinions would begin to approach those of Barringer and the university's larger community, through a happy marriage in eugenics.

Jordan's burgeoning interest in eugenics at Virginia spills forth from a particularly revealing letter that he wrote to Charles Davenport. After a two-year lapse in Davenport's correspondence files following Jordan's assistantship in 1907, Jordan's next missive-in March 1910-reveals the source of his eugenics enthusiasm. "I have just received, and

\footnotetext{
${ }^{42}$ Barringer maintained a lifelong interest in and influence over the affairs of the university, its medical school, and the hospital. In 1907 he accepted the presidency of the Virginia Polytechnic Institute, a position he held until 1914.
} 
read with interest," Jordan wrote Davenport, "your little book on 'Eugenics.'" Jordan gushed, "It contains just such facts as I have been searching for in preparation of a thirty minute address on 'Heredity as a factor in the improvement of social conditions' before a meeting of the State Society of Charities and Corrections...."43 Jordan next announced his motivation, writing, "I have become interested in the questions of race improvement through my cytological studies, reflections on heredity and my reading of such books as those of Saleeby, Haldane, and Rantoul - and especially by noting the distressing racial conditions in our colored population in the South." The British and French eugenicists cited by Jordan tended to explain class differences in biological ierms, a pattem familiar to European eugenics. Jordan had already started to shift the analysis of "race" from issues of class to those of class and skin color, reflecting one of the major ideological divergences between European and American eugenics. ${ }^{44}$ Not only was Jordan interested in applying eugenics to the American "Negro problem," he also stated that, "I made a talk on Eugenics, advocating sterilization in extreme cases of hereditary defects, at a meeting of our Civic Club some time ago which aroused much discussion and some hostile comment." In the very year the Eugenics Record Office was being founded, Harvey Jordan already possessed well formulated ideas about eugenical policies, and was engaged in spreading the "eugenics creed" to the wider community. Before even Charies Davenport was ready to

\footnotetext{
43 Jordan to Davenport, March 21, i910, Davenport Papers. While this is the first preserved letter between the two men in Davenport's files, they no doubt remained in contact at various professional meetings, as is reflected in their later correspondence. Davenport's "little book" of just 35 pages, Eugenics (New York: Henry Holt and Company, 1910), became the nucleus of the first American eugenics textbook, Heredity in Relation to Eugenics. See Charles B. Davenport, Heredity in Reiation to Eugenics (New York: Henry Holt and Company, 1911). Jordan's address would later be published by the American Breeder's Association. Harvey Emest Jordan, "Heredity as a Factor in the Improvement of Social Conditions," American Breeders Association Magazine 2, no. 4 (1911), 246-51.

44 Although American eugenics maintained its own class dynamic, race remained a focus for American eugenical policy. Daniel Kevles points out this distinction, In the Name of Eugenics: Genetics and the Uses of Human Heredity (New York: Alfred A. Knopf, 1985), 75-76. I contend that British eugenicists' class bias reflected the stable class structure of British society. Americans emphasized race, a hierarchy most wanted maintained, while they lessened the emphasis on class as a concession to the Arnerican democratic tradition. Thomas F. Gossett also identifies this dynamic in, Race: The History of an Idea in America (2d ed.; New York and Oxford, 1997), 162-75, and Chap. 15. See also Steven Selden's discussion of "rational equalitarianism" in, Inheriting Shame: The Story of Eugenics and Racism in America (New York and London: Teachers College Press, 1999), 118-21.
} 
advocate eugenic sterilization, Jordan already had formulated a public policy program.

Finally, Jordan confessed his interest in eugenic research, writing, "I am particularly interested in Part II of your book which outlines 'A Plan for Further Work' and gives the personnel of the several sub-committees [of the ABA] appointed for the purpose of investigating the hereditary influence of insanity, imbecility, pauperism, etc." Thus, Jordan stood in the van of eugenics researchers, theorists, and popularizers. ${ }^{45}$

Jordan's letter to Davenport continued with the plea of a newly converted believer: "I have been wondering if I could be of service in this great work-due to my favorable situation close to Staunton [Virginia] with its alms house and insane asylum, Petersburg with its state hospital for the insane, and Richmond with its various hospitals-perhaps in gathering statistics at close range at these several places. I should be very glad for an opportunity to help, if my efforts could be of real assistance."46 Davenport's response to this letter does not survive, but the ensuing 25 years of correspondence depicts the close relationship forged between these two men.

In May, Jordan related his plans for a pilgrimage to the Mecca of eugenics, the Galton Laboratory of National Eugenics at the University of London. Jordan asked Davenport for a "letter of introduction to some one you may know sufficiently well in the Eugenics Laboratory in London." Knowing full well that Davenport was acquainted with Sir Francis Galton, Jordan was angling for a chance to meet the founder of modern eugenics. In

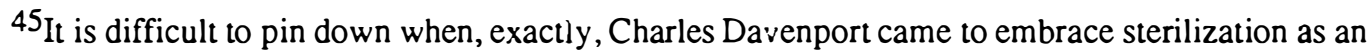
efficacious eugenic policy. Certainly it was not until after 1914 and the release of the Eugenics Record Office's Bulletin 10A, "Report of the Committee to Study and to Report on the Best Practical Means of Cutting Off the Defective Germ-Plasm in the American Population: The Scope of the Committee's Work" and Bulletin 10B, "The Legal, Legislative and Administrative Aspects of Stcrilization." Written by the committee's secretary, Davenport's assistant Harry H. Laughlin, report 10B concluded by claiming that $15,000,000$ sterilizations would be required to cut off the worst 1/10th of the "germ-plasm" in America. Harry Hamilton Laughlin, "The Legal, Legislative and Administrative Aspects of Sterilization," Eugenics Record Office Bulletin 1OB (Cold Spring Harbor, Long Island: Eugenics Record Office, 19!4), 145. Construed in the press as an active program, the report raised an uproar. Davenport wrote the editor of the New York American, "...the Eugenics Record Office has never launched a campaign [for sterilization] and, indeed is opposed to campaigns for sterilization...." Charles B. Davenport to Editor, New York American, September 4, 1915, "American (NY), Editor" folder, Davenport Papers.

${ }^{46}$ Jordan to Davenport, March 21, 1910, Davenport Papers.
} 
exchange, he offered Davenport additional research matter for a study on skin pigmentation in "negro-white crosses"-the offspring of black-white interracial unions. "Material for the study of skin pigmentation is coming in very slowly from autopsies," Jordan wrote, continuing, "But I have just spoken to our surgeon about the matter and he promises to procure specimens for me from all abdominal operations he may have during the summer. I am almost certain, therefore, to have a nice lot of material for this work in the fall." 47 Davenport rose to the bait, predictably from a man with deep interests in the social and scientific issues surrounding skin color. He wrote letters of introduction to both Karl Pearson and Francis Galton. In the letter to Galton, he noted that Jordan 'was, "interested in the study of human heredity and eugenics. He comes from the Black Belt of America and has been making some interesting quantitative determinations on inheritance of skin color in members of families of negro white crosses which he is permitting me to publish."48 Thus armed, Jordan headed off to England, birthplace of eugenics.

Davenport did not allow Jordan to wander into the wilderness unaware of the methodological schisms dividing British and American eugenicists. Davenport appended a lengthy letter that noted the tensions between the English "Biometric" school of statistical eugenics and the American Mendelian school of hereditary eugenics. "Karl Pearson has lately declared war on me as a representative of modern studies in heredity," Davenport wrote, "He has branded me with the term Mendelian and used other opprobrious phrases so I would advise you not to use the letter of introduction lest you receive scant courtesy." Noting that he felt Pearson was "overworked," and had "gained an exaggerated opinion of his own importance," Davenport wamed Jordan not to mention his planned visit to Galton. "Professor Pearson would try to dissuade you, telling you that Galton is too feeble to see anybody. Do not pay any attention to what Pearson says as he seems to be very desirous

\footnotetext{
47 Jordan to Davenport, May 27, 1910, Davenport Papers.

${ }^{48}$ Charles Benedict Davenport to Sir Francis Galton, May 28, 1910, Davenport Papers; see also Charles Benedict Davenport to Karl Pearson, May 28, 1910, Ibid.
} 
of dissuading people from visiting Galton who, aside from being somewhat deaf, was at last accounts in fair health." Davenport's final lines of advice seem, with the benefit of hindsight, to imply the coming alliance between American and German racial scientists, foreshadowing the parallels between American and Nazi persecution of minorities. "If you are in Berlin," Davenport counseled, "it might be a good plan to see Ploetz, Archiv für Gesellschafts Biologie, who is interested in eugenics; also Plata at Jena." Unknowingly, Davenport put Jordan in touch not only with the two founders of the modem eugenics movement-Pearson and Galton—but also with two men who would become integral components of the Nazi eugenics regime during World War II. In addition, Davenport and Jordan's correspondence reveals a cavalier attitude toward the gathering of "material" for their own experiments in human biology. Davenport concluded, "I am very glad to leam that you have a prospect of getting mulatto skin material for work next winter."49 He never questioned the propriety of surgeons merely taking samples from anesthetized patient. This apparent disregard for the fact that the "material" came from human beings would becorne a hallmark of some American and Nazi eugenicists and eugenically-trained medical practitioners throughout the coming century. 50

Davenport and Jordan's initial contact grew into intimate cooperation that continued for the next four years. Jordan regularly sent pedigree charts to Davenport for filing in the fledgling Eugenics Record Office (ERO), building its archives. Jordan's association with the university hospital, and his chairmanship of the Eugenics Section of the American Association for the Study and Prevention of Infant Mortality (AAS\&PIM), gave him access to plentiful medical statistics. ${ }^{51}$ Thus he, "invited members [of the AAS\&PIM] to send to

\footnotetext{
${ }^{49}$ Davenport to Jordan, May 28, 1910, Davenport Papers.

50 In part, their behavior both conformed to, and contradicted, contemporary understandings of medical ethics. This issue will be discussed, in detail, in Chapter 5.

${ }^{51}$ For a discussion of the AAS\&PIM and eugenics, see Richard A. Meckel, Save the Babies: American Public Health Reform and the Prevention of Infant Mortality, 1850-1929 (Baltimore and London: Johns Hopkins University Press, 1990), 109-123, especially 116-19. Meckel never discusses Jordan's role as chairman of the section on eugenics. Prominent Johns Hopkins-physician Llewellys Franklin Barker presided over the AAS\&PIM. Barker himself advocated eugenics, although in a moderate, skeptical form.
} 
the Chairman [himself] complete family histories of cases indicating the hereditary transmission of pathological conditions or defects as they seem to bear on infant mortality." He also sent Davenport pedigrees he collected on a fatal kidney defect, carcinoma, neurofibroma, melancholia, twinning, lefthandedness, tuberculosis, and "disastrous first cousin marriages." 52 This earned him Davenport's esteem and trust. As a result, the men exchanged research papers to be read at various scholarly meetings. Davenport aiso referred requests for eugenics lectures to Jordan. Together, the men collaborated on research projects, discussed their views on "race" as an eugenical category, and developed their ideas about practical eugenics.

Examining Jordan and Davenport's actions along each of these lines- professional and lay popularization of eugenics through papers and lectures, research and scholarly production, and racial views-reveals the subtle shifts in Jordan's eugenic thought, presaging his involvement in more repressive eugenical campaigns during the 1920s. During the period of Jordan's greatest "eugenical output," from 1909 through 1915, his views shifted to a more "mainline" position. He increasingly thought, wrote, and spoke of eugenics in a quasi-religious and racially-biased vein, and he portrayed its findings as well established facts, rather than as tentative conclusions.

Their friendship blossoming, Jordan and Davenport turned to each other for contributions to scholarly meetings. Davenport contributed a paper to the 1911 AAS\&PIM conference, while Jordan answered Davenport's call for a paper for the First International

He wrote, "True eugenics is, at present, in less danger from its avowed enemies than from those who masquerade as its friends.... Surely much harm may easily result from eugenic zeal without sufficient eugenic knowledge!" Yet, he felt that the organization of the ERO opened "a new period in eugenic study and in education along eugenic lines in the United States." Llcwellys Franklin Barker, "Foreword," in Morton A. Aldrich, et. al., Eugenics: Twelve University Lectures Mrs. Huntington (Lucy James) Wilson, ed. (New York: Dodd, Mead and Company, 1914), xi.

${ }^{52}$ First quotation in Davenport to Jordan, November 21, 1911 (kidney defect), Davenport Papers. "Disastrous first cousin marriages" probably meant the occurrence of mental or physical malformations in progeny. Davenport to Jordan, December 17, 1912. See also Davenport to Jordan, November 22, 1911 (carcinoma, neurofibroma); Jordan to Davenport, October 11, 1912 (melancholia, tuberculosis, left handedness); and Jordan to Davenport, January 6, 1913, (twinning and lefthandedness); Jordan to Davenport, March 4, 1913 and March 8, 1913 (lefthandedness), Ibid. 
Congress of Eugenics in the summer of 1912.53 Davenport allowed Harry H. Laughlin, Superintendent of the ERO, to answer Jordan's call for a paper for the 1912 AAS\&PIM conference with a statistical study of "the incidence of infant mortality in defective families" tabulated from ERO records. ${ }^{54}$ By 1913, Davenport, always in high demand for papers and addresses, attempted to dodge the AAS\&PIM engagement. Writing that, "I have thought and thought and can not find that I have anything that would be appropriate to say," Davenport noted an ideological difference between eugenics and the reduction of infant mortality, implicitly indicating a personal divergence from Jordan. "My own thoughts run in another groove from the euthenical ideas and plans of the association. My work impresses upon me the beneficent results of most infantile mortality." Thus, he sent an abstract guaranteed to alarm the secretary of the conference. It emphasized "extensive" infant mortality as a eugenic factor, stating that infant death, "maintains a high physical if not mental status of the race. The elimination of the beneficent action of selection would probably cause the deterioration of the average of the race [by allowing the unfit to survive] and the same effect within limits will follow among the more cultured strains also."55 Despite this apparent difference, Jordan and Davenport's eugenic views converged more than they diverged. While both men noted the integral relationship of heredity and

\footnotetext{
${ }^{53}$ Davenport's paper "The Eugenical Limitations to the Prevention of Infant Mortality," is listed in his professional bibliography. See Riddle, "Charles Benedict Davenport," 99. Jordan to Davenport, May 22, 1911; Davenport to Jordan, August 16, 1911; and Jordan to Davenport, November 21, 1911, Davenport Papers. For discussion of Jordan's paper for the eugenics congress, see Jordan to Davenport, November 14 , 1911 and February 3, 1912; Davenport to Jordan, February 5, 1912, Ibid. See Harvey Ernest Jordan, "The Place of Eugenics in the Medical Curriculum," Problems in Eugenics: Papers Communicated to the First International Eugenics Congress (London: Eugenics Education Society, 1912), 396-99.

54Jordan to Davenport, May 20, 1912; and Davenport to Jordan, May 25, 1912, Ibid. Davenport acquiesced in this request, despite noting that, "the office force which already has well defined duties which it can hardly keep up with has to make the required tabulations one can readily see that there might be a serious interference with the work but I think that the tabulations can be made under Mr. Laughlin's direction without interfering with the other work...." Davenport to Jordan, May 25, 1912, Ibid.

${ }^{55}$ Davenport to Jordan, August 18,1913; and attached "Abstract," Ibid. Apparenuy, Davenport relented because his name had al ready been placed on the program as the result of an administrative misunderstanding. Jordan to Davenport, August 16,1913, Ibid. Davenport often asked Jordan to deliver papers at the ABA meetings. Davenport to Jordan, December 19, 1912, Ibid. Davenpor would have to back up his words with his actions three ycars later, when his own son "little Charlie" died after an acute attack of polio. See "Personals," Eugenical News 1 (September 1916), 65 for Charlie Davenport's obituary.
} 
environment, they privileged heredity as the limiting factor on human potential, since it occurred before environment.

In his own public writing, Jordan repeatedly cast himself as the "objective" scientist, and then went on to assert a point he explicitly denied earlier. Jordan often began by affirming the co-equality of nature and nurture in shaping the individual. Such an apparently balanced view served two purposes. It appealed to the rational and skeptical scientists in the audience, and it reinforced Jordan's own sense of being an "objective" investigator-basing his judgment on a dispassionate analysis and not preconception. Rather than advocating both environmental and eugenic interventions equally, however, he always stressed negative eugenics and "prohibiting parenthood to the unfit." As he saw the situation, echoing his mentor Davenport, environmental intervention "largely defeats its own ends by counteracting the working of the principle of selection," allowing the unfit to survive. In a manner reminiscent of Jefferson's equivocation, Jordan's pronouncements can be seen as adhering to epistemological convention, not as evidence of a confused mind trying to reconcile mutually exclusive principles. Indeed, Jordan remained engaged in "normal science"; he was not about to cause a revolutionary shift in the biological or social sciences. ${ }^{56}$ Typically progressive, Jordan looked for the most "efficient" solution to social problems. Since environmental intervention had already proved to be slow and costly, biological policies seemed to offer a quick, permanent and efficient program for social uplift. Eugenics thus offered other scientists facile solutions to nagging anomalies between their research findings and the world they "knew" around them.

Davenport and Jordan went beyond spreading the eugenics creed to other investigators, however. Both sought to introduce eugenics to wider realms of educated, progressive Americans. Jordan addressed the Civic Club of Charlottesville on numerous occasions, the

\footnotetext{
56Jordan's rhetoric was allowing him to do what Thomas Kuhn called "normal science"; "knowing" what the world is like already, through his daily observations and acculturation, Jordan-like most scientists-brought his research findings into line with that prior knowledge. Thomas Kuhn, The Structure of Scientific Revolutions, 3d ed., (Chicago and London: University of Chicago Press, 1962), 5, 24-34.
} 
State Society of Charities and Corrections, as well as the Child Welfare Conference held in Richmond in 1911.57 Davenport, recognizing Jordan as a motivated and articulate spokesman for eugenics, referred speaking engagements to him. As a result of Davenport's intervention, Jordan delivered eugenics lectures at the 1912 Intemational Congress of Hygiene and Demography, before the Rensellaer County, Pennsylvania Medical Society, before college audiences at Trinity College and Dickinson College, and to "lay" groups in Boston and New York. ${ }^{58}$ Davenport even arranged for Jordan to deliver a series of collegiate lectures under the auspices of Lucy James Wilson, a wealthy eugenics enthusiast. ${ }^{59}$ An ardent proselytizer, Jordan assured Davenport, "I shall be glad to give as many of these lectures for expenses, or a little better in certain cases, as my time will permit." 60 Jordan, retuming Davenport's kindness-and reflecting his own early training experiences-arranged for University of Virginia students to study at the ERO and SEE during the summers. ${ }^{61}$ Moreover, with the initiation of the Phelps-Stokes fellowship, noted above, Jordan attempted to funnel even more graduate students to Cold Spring Harbor. The 1913-1914 recipient, Jordan wrote, "expects to take your work in eugenics at the Record Office before quitting the work of the fellowship. I shall try to arrange hereafter that the applicant for the fellowship, besides the present qualifications, must have had training in biology and economics, and be willing to take the summer course in eugenics with you." Jordan saw immediate benefits for the entire South from such an arrangement.

57Jordan to Davenport, March 21, 1910; February 3, 1912 (Civics Club; Charities and Corrections); and Jordan to Davenport, May 22, 1911 (Child Welfare Conference). Ibid.

${ }^{58}$ Davenport sent Jordan lantern slides to illustrate his lectures. Davenport to Jordan, September 5 , 1912; Jordan to Davenport, November 27, 1912; Jordan to Davenport, December 17, 1912, Ibid. Alderman library still has the slides, in their original case.

${ }^{59}$ Davenport to Jordan, October 7, 1912. The lecture that Jordan eventually wrote and delivered at a number of colleges, including the University of Virginia, "Eugenics: Its Data, Scope and Promise as Seen by the Anatomist," was published in Aldrich, Eugenics: Twelve University Lectures, 107-38. See Jordan to Davenport, December 17, 1912, Ibid., for a discussion of ihis appointment.

60 Jordan to Davenport, July 16, 1913, Ibid.

${ }^{61}$ The first two students from Virginia to attend summer school at Cold Spring Harbor arrived in the summer of 1911. See Jordan to Davenport, May 22, 1911; and Davenport to Jordan, August 16, 1911; for 1912 see, Jordan to Davenport, May 20, 1912; and Davenport to Jordan, May 25, 1912, Ibid. 
"This would be a means of recruiting to the eugenics work in the South some of the best men we have. I believe that effective work as concerns the betterment of negro conditions and the relations between negros and whites must be through a biologic approach; and the various investigations necessary are far preferably done by southerm men."62 The South provided fertile soil for eugenic investigation. Trained by men like Jordan and Davenport, its physicians would be prepared to conduct those investigations and institute necessary therapeutic interventions.

Jordan readily convinced Davenport of Virginia's fitness as a locus for eugenical research. In this early era of eugenics, dominated by pedigree studies of "eugenic" and "cacogenic" families, Virginia provided ample investigative "material."63 Virginia still cherished its reputation as cradle of outstanding southem and national leaders. Virginia had produced seven United States presidents, many of the "firebrands of the Revolution," and numerous leaders of the Confederate States of America. The descendants of the fabled "First Families of Virginia"—-the Lees, Randolphs, Jeffersons, and Lewises for examplewith their long and well maintained genealogies, seemed to offer the perfect "material" for studying the inheritance of admirable social qualities like intelligence, leadership, and beauty. As Davenport enthused to Jordan, "what a great study could be made of the traits of the Lees and others of the first families of Virginia!"64 Such studies, it was hoped,

62Jordan to Davenport, July 16, 1913, Ibid.

${ }^{63}$ Nicole Hahn Rafter has collected the most significant of these studies of "unfit" or "cacogenic" families in her book, White Trash: The Eugenic Family Studies 1877-1919 (Boston: Northeastem University Press, 1988). Investigators titled their studies with evocative pseudonyms like "The Jukes" (Dugdale, 1877), "The Kallikaks" (Kite 1912; Goddard 1916), "The Dack Family" (Finlayson, 1916), and the "Dwellers in the Vale of Siddem" (Rogers and Merrill, 1919). These appellations' dissonance exoticized the subjects and increased their status as other. Both Gertrude and Charles Davenport authored studies with similarly evocative names: "The Zeros" (G. Davenport, 1907), and "The Nams" and "The Hill Folk" (C. Davenport, 1912). The ERO's principal researcher, Arthur H. Estabrook also updated Richard Dugdales famous 1879 study The Jukes to The Jukes in 1915, Carnegie Institution of Washington Publ. No. 240 (Washington, D.C.: Carnegie Institution of Washington, 1916).

${ }^{64}$ Davenport to Jordan, April 10, 1911, Davenport Papers. See Davenport's brief musings about Virginia in Castle, et. al., Heredity and Eugenics, 295-96, 303-05; and in Davenport, Heredity in Relation to Eugenics, 206-07, 228-30. 
would provide keys to the eugenic breeding of humankind, answering half of the eugenic equation. Virginia contained material for the other half of the eugenic problem, too.

Virginia's hinterlands promised other investigations that held intense interest for Davenport and other eugenicists. The isolated Chesapeake peninsula and the mountains and hollows of the Blue Ridge and Western Virginia harbored the "dysgenic" branch of Virginia's family tree, poor whites. 65 Studying family pedigrees in these areas might, eugenicists supposed, explain the hereditary nature of deleterious social traits-pauperism, physical and mental "defect", incest and inbreeding, low intelligence, and diseases like pellagra and tuberculosis which seemed to "run in families."66 As Davenport wrote Jordan, "There is some evidence that the peninsular conditions along the Chesapeake and the isolation of its islands have lead to consanguineous marriages and it would be a fine thing to have these investigated."67 Later, Davenport became interested in a bit of eugenical research conducted by the Charlottesville Civics Club on "defectives of the Ragged Mountains."68 Jordan reported that, "The work relative to the effects of inbreeding of defectives was suggested by myself." However, he continued, the work "was not done as thoroughly nor as extensively as I had wished; but I have not been able to help personally in the investigation." He assured Davenport that, "There is here a very promising field, and some day we may be able to arrange to have the work done on a more extensive and scientific scale."69 Eugenicists like Davenport and Jordan hoped that

\footnotetext{
${ }^{65}$ As Gray Brechin ascerbically commented, "The conventional White Anglo-Saxon Protestant (WASP) acronym is, of course, redundant. Wealth even more than color, indicates worth, particularly as it becomes hereditary, and those ASPs lacking this gene frequently fell into the category of 'white trash." As such, they were just as eligible for sterilization as any of the lower races, since poverty was taken as a symptom of hereditary weakness...." Gray Brechin, "Conserving the Race: Natural Aristocracies, Eugenics, and the U.S. Conservation Movement," Antipode 28 (1996), 241 note 14.

${ }^{66}$ Most early geneticists and eugenicists assumed the hereditary basis of all these conditions. Davenport, in particular, argued that pellagra was a constitutional, not an environmental condition, even after Dr. Joseph Goldberger proved its dietary basis in 1915. See Allan Chase, The Legacy of Malthus: The Social Costs of the New Scientific Racism (New York: Alfred A. Knopf, 1977), 201-25.

${ }^{67}$ Davenport to Jordan, April 10, 1911, Davenport Papers.

${ }^{68}$ Davenport to Jordan, February 1, 1912, Ibid.

${ }^{69}$ Jordan to Davenport, February 3, 1912, Ibid.
} 
comparative studies among the "best" and "worst" stock would reveal the hereditary nature of social inequality and, hence, the biological basis of social hierarchy. Such analyses would conveniently explain class differences as natural biological outcomes for different white "races" or strains. Experts could then devise social policies that would reduce tensions between the rich and poor, and simultaneously increase the birthrate among the socially adapted and reduce it among the "unfit." Sanitizing "white trash," this possibility did little to resolve the pressing Southem concem about miscegenation and racial separation.

The presence of blacks, whites, and Native Americans provided excellent conditions for studying miscegenation's effect on "racial quality"; whether or not racial intermarriage was advantageous or deleterious to "the race." Such studies could clarify the biologically determined differences between races, indicating appropriate "rational" and "progressive" social policies. Before deciding policy issues, however, the eugenicists had to settle questions of taxonomy: who was and was not black, white, or Native American. Instances of "crossing" (light-complected blacks posing as whites) and racial intermarriage could provide "material" for the genetic study of color inheritance. Eugenicists hoped to define quantitative measures that would permit the inscription of scientifically determined boundaries around segments of the population. Rather than the traditional racial markers based on appearance and "blood genealogy," designations like "one drop" or some proportion ("one-quarter") of interracial blood, eugenicists hoped to discover the exact boundaries between the "permanent varieties" of humanity. Once taxonomic questions were settled, eugenicists could turn their attention to questions of "quality": What salubrious inheritable traits correlated with racial markers? Did "hybridizing" races through miscegenation preduce "vigor" or "decay"? Ostensibly rejecting most of the notions of earlier generations, eugenicists purported to test these issues objectively. In the final estimate, as we shall see, eugenic family studies were foiled by both the strength of cultural 
tradition and the subjectivity of their analytic categories-rather than prompting a Kuhnian paradigm shift, eugenics remained well within the normal scientific tradition, thereby reinforcing the social and scientific status quo.

Jordan proposed just such a family study of miscegenation as early as 1911 . "Perhaps you will be interested in a piece of work I am just taking up," he wrote Davenport. "About two years ago I heard of a 'lost tribe of Indians' over in Amherst County about 30 miles from here. The tribe got lost:" Jordan explained, "through intermarriage with negroes. I have thought there ought to be fine material here for a study in human heredity." Clearly, the topic caught Davenport's attention. He underlined the passage in Jordan's letter, and in his reply Davenport urged, "I trust you will take up the study of the lost tribe of Indians or put a student on it." While Jordan indicated that he had, "completed plans which will make the work possible...as soon as my university work stops," and assured Davenport that he had, "made permanent mental notes of your several suggestions regarding [eugenic] scholarship from my laboratory," the study was not to be. Facing the strains of an underfunded and understaffed university, Jordan apologized, "things move slowly in the South. In time I hope all this, and more, may be accomplished. For the present I must spend the best part of my time teaching, and do what work I can as opportunity permits."70 In the end, Jordan tumed the "lost tribe" project over to the same Civics Club that had investigated "defectives" in the Ragged Mountains. That group never followed through. Charles Davenport, however, never forgot the "lost tribe" of Amherst Virginia, and neither did other Virginia eugenicists interested in "racial integrity." In 1923-1924 Davenport dispatched ERO fieldworker Arthur Estabrook to investigate the tribe. The resulting eugenic "family study," Mongrel Virginians_and its place in Virginia eugenic public policy—will be discussed in the next chapter.

\footnotetext{
${ }^{70}$ All Jordan quotations from Jordan to Davenport, May 22, 1911, Ibid; Davenport quotation from Davenport to Jordan, August 16, 1911, Ibid.
} 
In spite of the various challenges confronting them, Jordan and Davenport were able to cooperate on and complete a number of racial studies. Jordan and Davenport's first successful collaborative investigations, concerning the inheritance of skin color in humans, served a reflexive purpose. Davenport drew Jordan into eugenics' internecine Mendelian/Galtonian battle on the side of hereditarianism, while Jordan infused Davenport with an interest in researching the "race problem."71 Proving the significance of their collaboration, Davenport's first papers on skin pigment, when coupled with Jordan's ensuing papers, firmly established the Mendelian basis of pigment heredity. Co-authored with his wife Gertrude Crotty Davenport, "Heredity of Skin Pigmentation in Man" began a series of publications that established Davenport as the authority on the hereditary determination of skin color. ${ }^{72}$ Davenport acknowledged his indebtedness, citing "Professor H.E. Jordan, of the University of Virginia, who fumished all of the quantitative data" on black and mulatto skin. ${ }^{73}$ Jordan's own microscopic histological examination of skin color tested, "the theory of discrete unit characters in color inheritance (discontinuity theory; segregation theory)," and ably supported Davenport's findings. ${ }^{74}$ Jordan thus

\footnotetext{
${ }^{71}$ Indeed, Jordan became a firm Mendelian. In 1914, when the British eugenicists attacked Davenport's Mendelian family studies as methodologically unsound and promoting unwarranted conclusions, Davenport broke with his personal policy of not answering critics and came forth with a lengthy defense. Jordan wrote Davenport that he was, "delighted!" with Davenport's response. "Heron's 'criticism' gave me no concem," Jordan wrote, "except in so far as I saw that the widespread publicity kindled much suspicion regarding eugenics among the laity. It will take considerable time to counteract the effect of Heron's despicable work; but it will of course be done." Jordan to Davenport, March 25, 1914; Davenport to Jordan, March 31, 1914, Ibid. See also Charles B. Davenport and A. J. Rosanoff, "Reply to the Criticism of Recent American Work by Dr. Heron of the Galton Laboratory," Bulletin 11 (Cold Spring Harbor, Long Island: Eugenics Record Office, 1914).

${ }^{72}$ Gertrude Crotty Davenport and Charles B. Davenport, "Heredity of Skin Pigmentation in Man," The American Naturalist 44 (November, 1910): 641-72. Davenport, his wife, and their associate Morris Steggarda (an ERO field worker) published the most authoritative studies on the inheritance of skin color between 1909 and 1928. Charles B. Davenport, Heredity of Skin Color in Negro-White Crosses, (Washington, D.C.: Camegie Institution of Washington, 1913); and Charles B. Davenport and Morris Steggerda, "Race Crossing in Jamaica," Scientific Monthly 27 (September, 1928): 225-38. After receiving Davenport's Camegie report on skin color, Jordan remarked, "This is a splendid investigation; the data here assembled should satisfy even Pearson that skin color follows in inheritance Mendelian laws." Jordan to Davenport, June 26, 1914, Davenport Papers.

${ }^{73}$ Davenport, "Skin Pigmentation," 664.

${ }^{74}$ Harvey Ernest Jordan, "A Comparative Microscopic Study of the Melanin Content of Pigmented Skins with Special Reference to the Question of Color Inheritance Among Mulattos," The American
} 
became a committed Mendelian eugenicist. He believed that the inheritance of unit characteristics determined physical and psychical differences between whites, blacks, and mulattos. These studies re-paved the way for the development of a taxonomy of races, with its attendant qualitative hierarchy. Thus, inequalities in society could be explained as the natural result of biology, and not simply the sequelae of cultural prejudice. Social policy regarding the "race question," eugenicists believed, could now be made in conformity with natural law. At long last, changes in technology and slight transformations in methodology aligned normal science, expectation, and "what the world was like," resolving the outmoded debates that confronted earlier thinkers like Jefferson and Cabell.

Even with this apparent scientific epiphany, Davenport and Jordan's correspondence and publications reflect the continuing tensions over the significance of race as a scientific, social, and most of all eugenic analytic category. The early findings did not answer all the questions raised by the American dilemma. Both men agreed that visible racial differences betokened the existence of biological differences. What the nature and import of those differences was for society remained a matter of indecision for both men, at least at first. Analyzing their correspondence and professional writings illustrates the influence of "normal science" on their conclusions. Jordan and Davenport's thinking, at precisely the moment when the paradigm shift brought on by the Mendelian revolution was itself undergoing further transformations, underscores how preconceptions ultimately conditioned their scientific "objectivity," predetermining their conclusions in favor of "normal science" rather than resolving the remaining anomalies presented by new genetic discoveries. Both men believed they were engaged in value-neutral investigation; at the very least they went through the motions of "objective" investigation. Yet their prior Color," Science 36 (new series):918 (August 2, 1912), 151-52. 
knowledge of the "innate" inferiority of blacks conditioned their investigations, their interpretation of findings, and their approach to "improving" society through eugenics.

Jordan might well lay claim to being "racial liberal" in this era of virulent racial prejudice and violence. In sending students to Davenport's summer school, Jordan recommended "another of my good students, a splendid young Chinaman, Chon Mung Yu." He asked, somewhat sheepishly, "You do not object to them, do you?" While Jordan's language and phrasing - "Chinaman" and "object to them"-might offend modern sentiments, at the time they showed more than a modicum of respect, both for young $\mathrm{Yu}$ and for the racial climate. Davenport's response seemed less open, more clinical than liberal. "We are certainly grateful to you," Davenport began, "for suggesting to three of your young [white] men to come...to Cold Spring Harbor." He promised that, "We shall do the best we can to make the summer highly profitable for them," meaning the white students. "Ye shall also be interested," Davenport continued in a slightly different tone, "to receive the young Chinaman of whom you write."75 Davenport's language implies a degree of skepticism. He could take Jordan's word for the qualities of the whites; he reserved judgment on the "Chinaman" pending his own scientific observation. Indeed, Davenport wrote of "receiving" the student more as a piece of "material" to be investigated, than as a guest. While Davenport assured Jordan of his efforts on behalf of the white students, he provided no such guaranty for the Chinese student's experience.

Davenport, in contrast to Jordan, seemed willing to interact with other races only on a professional level-either in furtherance of his own research, or in unambiguously professional settings like conferences. The differences in the men's racial tolerance is evinced by another exchange between the men, which highlights Davenport's discomfort with personal and social interracial interaction. Jordan inquired, in July of 1913, "Would you be willing to admit a mulatto to the course next summer? I want the son of Dr. Quarles

\footnotetext{
75 Jordan quotations from Jordan to Davenport, May 20, 1912; Davenport quotations from Davenport to Jordan, May 25, 1912, Davenport Fapers.
} 
[African American] of Charlottesville, one of Dr. Gerould's students in biology at Dartmouth, to take up eugenics work in the interest of his race."76 Jordan supplied Davenport with a number of endorsements in this brief letter. The boy was a mulatto, hence he "contained" white blood, which ostensibly made him superior. He was the son of a physician and he attended Dartmouth, both further certifications of his good hereditary endowment. Finally, the student had studied eugenics under Professor John H. Gerould, an inveterate eugenicist well known to Davenport. ${ }^{77}$ Quarles would seem an unobjectionable candidate, perfect for proselytizing eugenics within the black community. Nevertheless, Davenport replied with a letter that vacillated between liberal acceptance and old-fashioned prejudice. "I havn't [sic] a faintest trace of feeling against admitting a mulatto to the course because he is a mulatto," Davenport magnanimously began. "If you can vouch for it that he has a reasonable amount of sex control," he qualified, "it would seem as tho there ought to be no difficulty admitting him." In order to provide some empirical basis for this last implication, Davenport stated that the last "colored" man admitted, "a professor from a colored college," was of "a scandalously erotic nature. The example he set to the young people here was frightful." Finally, as if this show had not been enough to dissuade Jordan from his suggestion, Davenport raised the bogey of southern sensitivities. He wrote, "We have a great many Southerners here and we usually have several Southerners in our eugenics class." Worse, the eugenics classes often had to take field trips and stay overnight, sharing rooms in hotels. Telling Jordan that, "Our people are thrown in to much intimate contact," he averred that Jordan could, "picture better than I how' these white people of Southem bringing up [sic] will react to having a mulatto so intimately associated with the party." Davenport closed with the rhetorical question,

\footnotetext{
${ }^{76}$ Jordan to Davenport, July 16, 1913, Ibid.

${ }^{77}$ Gerould was one of the most prominent eugenicists North of Boston, certainly in New Hampshire. He maintained a lengthy correspondence with Davenport about matters eugenic. See "Gerould, John H." Folder, Davenport Papers.
} 
"Would the success of the larger interests be jeopardized by the presence of one mulatto."78

Davenport's plans for eugenic education and uplift, as in many American schools and public accommodations of the era, was either "for whites only" or "blacks to the rear." As Daryl Michael Scott has noted, "Although white Progressives were willing to grant that the mulatto suffered, they were not willing to bend racial categories to bring relief. To do so would have been to introduce persons of African descentt into white society and to risk amalgamation with an allegedly inferior race." Apparently Jordan understood Davenport, for no more was said of Mr. Quarles, and there is nothing to indicate that he attended the summer session. ${ }^{79}$

The influence of "normal science" only partially explains Davenport and Jordan's views regarding race. Very different personal factors also influenced Davenport and Jordan's attitudes. Normal science required that both men maintain a front of studied diffidence regarding the relative "civic value" of the mulatto population during this period. Unlike Edwin Grant Conklin, whose three-year experience as a teacher of Freedmen in Mississippi convinced him of the educability of all African Americans, Davenport and Jordan both

${ }^{78}$ Davenport to Jordan, August 7, 1913, Ibid. Davenport, brought up in a rigid, Puritanical family, probably had exceptionally Victorian notions of propriety. Coupled with the common knowledge of black "salaciousness" and his own ambivalence toward blacks, it is difficult to accept his testimony. See Riddle, "Charles Benedict Davenport," 75; E. Carleton MacDowell, "Charles Benedict Davenport, 1866-1944: A Study of Conflicting Influences," Bios 17 (March 1946): 3-50; and Davenport's correspondence with his father in the Davenport Papers.

${ }^{79}$ Daryl Michael Scott, Contempt and Pity: Social Policy and the Image of the Damaged Black Psyche 1880-1996 (Chapel Hill, NC: University of North Carolina Press, 1997), 15. Jordan appears to have stopped sending students after 1914. In May 1914 he told Davenport that entrance requirements to the medical school had been tightened so that "it is probably impossible for a candidate to qualify on the basis of simply a summer's course in biology." Additionally, "the department of Zoology makes a strenuous effort to secure all available students for its summer course." Jordan felt that, "I could of course not work counter to their efforts." Finally, Jordan confessed that the Phelps-Stokes scholar for 1914 would have to break their plans and miss the eugenics course at Cold Spring Harbor. Despite being "one of the most promising young men [Jordan] had ever known," he, "broke down in health about a month ago-probably a case of tuberculosis-and was forced to drop his work." Davenport replied in kind, "I am sorry to know that we shall not have some of your good students at Cold Spring Harbor this summer. We should have liked very much to have had [the Phelps-Stokes fellow] and as you know we have a very great interest in the negroes here from the biological point of view. Perhaps another year the Phelps-Stokes fellow may come here." Davenport to Jordan, May 20, 1914, Ibid. With Ivey Foreman Lewis's arrival in 1915, as will be discussed, Virginia undergraduates could take eugenics in the biology department. 
believed in the inferent intellectual inferiority of "pure blooded" blacks. ${ }^{80}$ Despite this conviction, however, neither man considered racial interbreeding-miscegenation-a selfevidently dangerous phenomenon. As Davenport put it in Heredity and Eugenics, the way to reduce the incidence of "defect" would be to, "Let abnormals marry normals without trace of the defect, and let their normal offspring marry in turn into strong strains; thus the defect may never appear again," provided all offspring avoided consanguineous marriage. ${ }^{81}$ While Davenport held this view in relation to feeblemindedness, he remained much more chary regarding procreation between whites and African Americans.

In "The Biological Status and Social Worth of the Mulatto," Jordan wrote that, "I admit the general inferiority of black-white offspring. Defective half-breeds are too prevalent and obtruding to permit denying the apparently predetermined result of such crosses. But I emphatically deny that the result is inherent in the simple fact of cross-breeding." This opinion presented a radical challenge to the accepted wisdom of the time. Jordan defended his position ty invoking the idea of "hybrid vigor" so familiar to breeders of com and cattle. "Indeed, it frequently happens that an unusually fortunate combination of the best racial characteristics of both races appears in an offspring of such a cross, resulting in an extraordinarily endowed human being." Yet, for all his equanimity, Jordan's language betrayed his bias. A favorable outcome occurred only as the result of "an unusually fortunate combination"; in other words, crossing was most often deleterious. "The reason for the frequently inferior product of such crosses," Jordan continued, invoking the timehonored notion of biological barriers, "is that the better elements of both races...feel an instinctive repugnance to intermarriage. Under these usual circumstances a white man who

\footnotetext{
${ }^{80}$ Cooke, "Gospel of Social Evolution," 28-35. Conklin, whose Methodist background led him to abhor racial prejudice, felt that his experience teaching African Americans "influenced my views of human nature ano its development, of the influences of heredity, environment and education on the development of the bodies, minus and morals of young persons." Conklin quoted in Cooke, Ibid., 33. Conklin embraced the eugenic ideal, but never carried it to the extremes of men like Davenport and Madison Grant, despite his association with them.

${ }^{81}$ Davenport, Heredity and Eugenics, 286. Davenport presents a fuller discussion of how to effect eugenic improvement in Heredity in Relation 10 Eugenics, 255-59.
} 
stoops to mating with a cclored woman, or a colored woman who will accept a white man, are already of quite inferior type." 82 Race itself imbued the desire for like to mate with like.

Notwithstanding the "mulatto's" poor ancestry, Jordan maintained that, "the mulatto, measured by present-day standards of Caucasian civilization, from economic and civic standpoints, is an advance upon a pure negro." 83 For Jordan, as for many scientists and lay people, the alchemy of blood/genetics worked a zero sum game. White "blood" raised the quality of black "blood" as black blood simultaneously lowered the quality of white blood, until they reached a static point in the offspring intermediate between the two. As Jordan wrote, "the development of the higher psychical activities [in the mulatto as compared to the "negro"] corresponds in degree quite uniformly with the amount of 'white' blood as judged by color of the skin." 84 Since the mulatto represented "an advance on the negro," then mulattos constituted "a real national advantage in our efforts to adjust the negro 'problem."'85 Through eugenic crossings of mulattos and "pure" blacks, Jordan hoped to effect the "upiift"-moral, mental, and physical—of the "naturally handicapped" black race. "The mulatto is the leaven with which to lift the negro race. He serves as our best lever for negro elevation." Rather than advocating black-white intermarriage and procreation, which risked disharmonious crossing, Jordan argued for black-mulatto

\footnotetext{
${ }^{82}$ Harvey Emest Jordan, "The Biological Status and Social Worth of the Mulatto," The Popular Science Monthly 82 (June, 1913), 576. The famous Berkeley biologist-eugenicist Samuei J. Holmes held similar convictions. Kevles, In the Name of Eugenics, 75.

83 Ibid., 576.

${ }^{84}$ ibid., 577. An analogy for this version of race crossing comes from the isostatic principles of simple thermodynamics. Adding an ice-cube to a warm liquid lowers the temperature of the liquid, but it also raises the temperature of the ice cube until equilibrium is reached. The final temperature depends on the initial size of the cube or the heat of the liquid; but in either case both ingredients are qualitatively changed. In eugenic terms the initial quality of the each "germinal" ingredient mediates the other until isostasy is reached. Eugenicists did not assume all whites to be superior to all blacks, just the vast majority. Thus, men like Davenport and Jordan would have had no problem accepting the idea that a "fit" black marrying an "unfit" white would lower the quality of the black and raise that of the white. Yet, since they felt that anyone marrying across race lines was "abnormal" in some sense, the product of such a union necessarily started out behind the eugenic eight ball.

85 Ibid., 578.
} 
matings. "The mulatto does not feel the instinctive mental nausea to negro mating," Jordan averred. "He might even be made to feel a sacred mission in this respect. Since "the negro aspires to be mulatto, and the mulatto to be white," then Jordan believed the, "Possibility of marriage with mulatto[s] would be a very real incentive to serious efforts for development of the negro." 86 The mulatto, according to Jordan, was "as loyal to his country, his friends and his conscience, according to his lights, as a 'white' man," so he could be counted on as a reliable citizen and enfranchised. Giving the mulatto access to the vote would resolve the "negro problem"- the "canker of our present political condition" and the "moral sore of a stultified conscience" — created by the dissonance between Constitutional guarantees and southern disfranchisement. Jordan's eugenics, as applied to the southern black population, could effect not only a gradual lightening of complexion, but also a concomitant raising of intellect and "civic value." Eugenics thus solved the ancient Jeffersonian fear of a black "nation" within a white "nation." 87

At this time, Davenport remained equally undecided about the value of the mulatto, although he, too, agreed about the inferiority of "pure" blacks. As Davenport wrote to Madison Grant, one of the most virulent racists of the period, "We [Davenport] think of a negro as a pure blooded black. We do not think of a [cross between] a negro and a white as a negro at all. I have far greater difficulty in thinking of the white, straight haired, emotionally controlled offspring of two such hybrids, capable of doing satisfactory college work as a negro." 88 Indeed, Davenport's letter discouraging the enrollment of Mr. Quarles

${ }^{86}$ Ibid., $580-81$.

${ }^{87}$ See my discussion of Peter Onuf's essay, "'To Declare Them a Free and Independent People': Race, Slavery, and National Identity in Jefferson's Thought," Journal of the Early Republic 18 (Spring 1998) and Jefferson in Chapter 1, 47-70.

88Davenport to Madison Grant, July 1, 1914, "Grant, Madison \#1" Folder, Davenport Papers. Grant could not countenance Davenport's belief, expressed in Heredity in Relation to Eugenics, that whites descended from blacks. Davenport felt that "the ancestors of all of us had a black skin" because white skin "is highly abnormal and, no doubt, of relatively recent acquisition." Grant acknowledged the "abnormality of the white skin," but doubted "very much whether we ever had any direct negro blood in our ancestry. It seems to me that anthropology points to the negro being a side line, and widely separated from the line of our ancestors, and his intensely black skin as a specialization." Grant worried that, "The inferior races are struggling so hard to assert their equality with the dominant races, that I think it a pity to give them any 
in the eugenics fieldworker's course began with a brief disquisition stating his interest in "the study of the negro problem," and his desire to cooperate with Jordan in training Phelps-Stokes Fellowship recipients to study race relations. "Of course," he wrote, "my interests in the negro problem are like yours from the eugenical standpoint and I shall be glad to cooperate you." Davenport had a more specific goal in mind, however. "I think it would be a fine thing if we could demonstrate the heredity of such matters as serve to differentiate the two races: such as the alleged difference to resistance to cancer; to tuberculosis; to caries [cavities] of the teeth; to immunity from fevers; to educability; to sex control." If such investigations proved the hereditary basis of these matters-which, not coincidentally, all had a long history in the academic and vermacular traditions surrounding racial differences--"Then there might be something definite to say about the consequences of miscegenation."89 Davenport clearly indicated his belief in the inferiority of blacks, but remained ambivalent about the place of the "mulatto" in the racial hierarchy. For Davenport, quantitative studies that would allow qualitative judgments would clarify the racial taxonomy. His search for scientific certitude, however, barely masked his desire to reinforce the status quo.

Davenport and Jordan felt that qualitative racial difference could only be established by empirical measurements of intelligence, a characteristic more descriptive of social "worth" than skin color. Both men, following Francis Galton, advocated the use of intelligence tests to investigate and substantiate differences between the races. ${ }^{90}$ In 1912 , six years

statements, which by misquotation could be twisted to their advantage." Davenport had already noted, with sanctimonious detachment, "I suppose the political consequences of the statement of a truth are the last things in the mind of a scientific writer." Davenport quotations, Ibid. Grant quotations from Madison Grant to Charles Benedict Davenport, July 6, 1914, Ibid. Gencticist Herbert Spencer Jennings, zoologist William E. Castle, and biologist Edwin Grant Conklin all disputcd the idea of hybrid inferiority. Kevles, In the Name of Eugenics, 319 note 38; Kathy Jane Cooke, "Gospel of Social Evolution," 138. Harvard geneticist Edward M. East, however, had deep reservations. East, Mankind at the Crossroads (New York and London: Charles Scribner's Sons), 141-45; and East, Inbreeding and Outbreeding: Their Genetic and Sociological Significance (Philadelphia and London: J. B. Lippincott Company, 1919), 252-65.

${ }^{89}$ Davenport to Jordan, August 7, 1913, Ibid.

${ }^{90}$ Galton's initial eugenic study, Hereditary Genius, explained socio-economic success, and hence individual "fitness," as a function of the inheritance of "genius," a concept that had at its root, a notion of 
before U.S. Army psychologists used the new intelligence tests to study large groups of men, Davenport and Jordan mused about such an application. Jordan proposed testing black, white, and mulatto school children in Charlottesville, asking Davenport, "Don't you think this is a very significant piece of work?" Davenport agreed, calling the work, "of supreme importance." Yet, he added, "I think it is important to get the pedigree of the mulatto, whether the first or second generation of hybrids." 91 This additional data would be crucial in order to prove that intelligence segregated in a Mendelian fashion, and did not represent a Galtonian "blending" of parental traits. Only a precise determination of ancestry would help fortify the racial taxonomy. A year later, Jordan argued forcibly that mental tests offered the only way to prove racial difference "on a scientific basis" and provide a plan for education based on mental ability. Such a plan promised economic savings for the state, by winnowing school enrollments by "ability," thereby assuring that expensive resources would be expended only on the worthy. Jordan's program would also increase social harmony by allowing each race to maximize its potential. Not coincidentally, it echoed Jeffersonian notions of annually "raking scholars from the rubbish."92

Thus, Jordan and Davenport's racial ideas meshed well because both men believed they approached the "race problem" from a dispassionate, scientific perspective. Jordan sought to measure the intellectual capacity of "pure" African Americans and "mulattos" to facilitate the political enfranchisement of at least some black Americans. Jordan's eugenic plan, advocating intermarriage between "pure" blacks and mulattos, sought to raise the genetic

\footnotetext{
innate, "natural ability." Later generations would recast "natural ability" as "inborn intelligence," particularly in America in the work of psychologist/psychometrician Henry Herbert Goddard. Francis Galton, itereditary Genius (London: Macmillan and Company, 1869). See Daniel J. Kevles, In the Name cf Eugenics: Genetics and the Uses of Human Heredity (New York: Alfred A. Knopf, 1985), 3-5; 76-79. This movement would reach its apogee in 1923, when Princeton psychologist Carl C. Brigham published his study of the intelligence tests administered to army inductees in World War I, A Study of American Intelligence (Princeton: Princeton University Press, 1923), which purported to document racial differences in intelligence.

91 Jordan to Davenport, November 27, 1912; Davenport to Jordan, November 30, 1912, Davenport Papers.

92Jordan, "Biological Status and Social Worth of the Mulatto," 579.
} 
endowment of the black population, making them at least fit citizens if not socially coequal with whites. He saw this as a way to ameliorate the racial tensions rending the South specifically and America generally, while bolstering social segregation by creating clearly white and "mulatto" populations. Davenport, equally convinced of the inferiority of pure "negroes" purportedly reserved judgment on "mulattos." His desire to measure intelligence, however, stemmed from an interest in maintaining absolute segregation. In 1929, with his publication of "Race Crossing in Jamaica," which examined "the relative capacity of negroes, mulattoes, and whites to carry on a white man's civilization," he openly concluded that the hybrid group were inferior to both pure strains. The exhibited a higher proportion of "muddled and wuzzle-headed" individuals. Thus, both men were interested in the maintenance of racial integrity, especially white racial "purity." Over time both men would gravitate toward more extreme positions.

Jordan's views on racial matters would outstrip even those of Davenport, as he joined white supremacist groups. His eugenical views ranged beyond Kathy Jane Cooke's idea of "biological progressivism." Ironically, Jordan seemed to accept eugenics as proven, and move away from direct eugenical research, at the very moment that it began to encounter its stiffest resistance among erstwhile adherents and investigators. Instead of merely seeking to use biologically informed notions of heredity and environment to inform social policy, Jordan adhered to what Mark Haller termed the "eugenics orthodoxy."93 Jordan hoped that biological knowledge would dictate the modes of government-directed social reform. Social health should be gauged by biomedical standards and adopt eugenic "therapies."

When one analyzes Jordan's formal eugenics addresses, it becomes clear that he shared the hall-mark attitudes of the most conservative, "mainline" eugenicists. ${ }^{94}$ Although

\footnotetext{
93 Mark Haller, Eugenics: Hereditarian Attitudes in American Thought (New Brunswick, NJ: Rutgers University Press, 1963), 76-82.

${ }^{94}$ Daniel Kevles differentiated between "mainline" and "reform" eugenicists in, In the Name of Eugenics: Genetics and the Uses of Human Heredity (New York: Alfred A. Knopf, 1985), 88; and 173-75.
} 
Jordan paid lip service to the co-equal importance of heredity and environment in shaping the individual, he ultimately accepted heredity as more important. While Jordan advocated positive and negative eugenics, he emphasized the practical application of negative eugenics. Like other strident eugenicists, Jordan believed America faced "race suicide"the swamping of the eugenic, "fit" American stock by the "cacogenic," genetically "unfit" because of the failure of the best people to reproduce. His millennial tone found its match in his elevation of eugenics as a quasi-religious creed. Jordan called for the eugenic education of professionals, especially physicians, and the integration of eugenics into medical therapeutics. Such eugenically informed medical intervention would improve the quality of the American race. Jordan cast his eugenics to underscore its applicability to southern conditions; in his consideration of the eugenic state of the American South one sees the hardening of his racial and eugenic convictions. Ultimately, Jordan is recognizable as a reflection of Davenport, who Mark Haller characterized as "a strange mixture of scientist and advertiser."95 Although Jordan performed creditable scientific research that had eugenical applications, his pronouncements about eugenics far outstripped any evidentiary warrant provided by his studies.

Jordan's earliest eugenic scholarship stemmed directly from his involvement with his mentors Edmund Beecher Wilson and Edwin Grant Conklin. As Jane Maienschein has noted, these older men transformed traditional American biology, tuming its focus inward toward heredity and determining the underlying causes of the easily observed development of external morphology. 96 No longer satisfied with the biologist's traditional roles of description and categorization, these investigators sought to understand the mechanisms controlling organic development and operation. Harvey Jordan, trained by these pioneers,

While this dichotomization is an oversimplification, it effectively stresses the multifarious political permutations of eugenics.

95 Haller, Eugenics, 75.

96 Maienschein, Transforming Traditions, 4-5; Kevles, In the Name of Eugenics, 44. 
followed in their path. Yet, his interest in applying biological knowledge to social reform through eugenics influenced his selection of research topics and his conclusions.

Jordan's early publications evinced the influence of Wilson's interest in the heredity of sex determination. ${ }^{97}$ One of the most intriguing problems of early-twentieth-century biology, the precise nature of sex-determination remained shrouded in mystery until the 1950s. Still, Jordan's sex scholarship revealed his keen scientific intuition, his strong commitment to Mendelian inheritance, and his awareness of the eugenic import of understanding and controlling sex determination. Writing in June of 1909, Jordan noted that those investigating "the enigmas of sex" were inspired "as much by a pure scientific motive of love of truth as by the practical bearing of the completer knowledge respecting sex-determination on the matter of the control and regulation of sex." The ability to control sex-determination offered the ability to control breeding in both animals and humans.

Noting that investigators had, since 1900 "become very generally agreed that sex is inherited," and that the inheritance "May be regarded as the result of a Mendelian segregation," Jordan championed Mendelism. 98 In a caustic review of E. Rumley Dawson's book, which advanced the unlikely hypothesis that male children resulted from ova produced in the mother's right ovary while female children resulted from ova produced in the left ovary, Jordan derided the author for ignoring the work of Edmund Wilson and other important Mendelian biologists: William Bateson, Charles Davenport, and William

${ }^{97}$ Harvey Ernest Jordan, "Accessory Chromosome in Aplopus Meyeri," Anatomische Anzige 32 (1907): 284-95; Jordan, "Facts Conceming the Determination and Inheritance of Sex," Popular Science 69 (June 1909): 540-50; Jordan, "Causation of Sex by E. Rumley Dawson," American Naturalist 43 (December 1909): 756-ó2; Jordan, "Recent Literature Touching the Question of Sex-Determination," American Naturalist 44 (1910): 245-52; Jordan, "Cytologic Study of the Egg of Cumingia, with special reference to the history of the chromosomes and the centrosome," Archiv für Zellforschung 4 (1910): 24352; Jordan, "Asterias Forbesil"; and Jordan, "Causation of Sex." Jordan would retum to examine abnormal sex formation later in his career. See, Jordan, "Description of a Case of False Hermaphroditism," Anatomical Record 15 (1918): 27-35; and Jordan, "The Histology of a Testis from a Case of Human Hermaphroditism, with a Consideration of the Significance of Hermaphroditism in Relation to the Question of Sex Differentiation," American Journal of Anatomy 31 (September 1922): 27-52.

98 Jordan, "Determination and Inheritance of Sex," 541-44 (quotation 541). Jordan's mentor, E. B. Wilson and Nettie M. Stevens were the first to posit the Mendelian segregation of sex, in 1905. Their conclusion was not confirmed absolutely for decades, although the discovery is attributed to them retroactively. Kevles, In the Name of Eugenics, 44. 
E. Castle. Jordan announced that, "the essence of sex resides probably as much in the male gametes as in the female, and its final elucidation seems indicated along the lines of a cytological (chromosomal?) interpretation of Mendelian phenomena." Without knowing it, Jordan foreshadowed the precise method that would be used to determine the causation of sex, although he erroneously ascribed causality equally to male and female gametes. ${ }^{99}$

In his next published review of recent investigations, however, Jordan acceded to new experimental evidence that seemed to show that sex-determination was causally related to cellular metabolism. ${ }^{100}$ This vacillation underscores Jordan's flexibility and skepticism as a scientist in the matter of sex determination. He did not allow his allegiance to Mendelism or eugenics to prefigure his conclusions, instead remaining open to alternative explanations. Although understanding sex inheritance offered eugenic retums, Jordan remained chary about formulating eugenic policy until scientists understood the exact mode of sex determination. Remaining circumspect about sex-determination, Jordan investigated other aspects of heredity that were both more concretely observed and of potentially immediate benefit to society. All of these studies sought to defend Mendelian heredity against its detractors, and then extend its application into public health. His studies of skin color, discussed above, offered potential solutions to "the Negro problem," and supported the applicability of Mendelism to humans.

\footnotetext{
${ }^{99}$ Jordan, "Causation of Sex," 762. Jordan offered the same erroneous hypothesis about sex segregation in his earlier piece, "Determination and Inheritance of Sex," where he backed Carl Correns's hypothetical model of modified Mendelism that would eventually be confirmed as the mode governing human sex determination. Jordan, "Determination and Inheritance of Sex," 543, 544, 549-50. Correns's hypothesis was confirmed, by cytological analysis of the chromosomes, in 1956. While both male and female gametes contribute to sex determination, the male gamete is ultimately "responsible" for the final result. Only males carry both the X- (female) and Y- (male) chromosomes, which separate during the meiotic production of gametes. Since females gametes carry only the $\mathrm{X}$-chromosome, it is the addition of sex chromosome from the paternal gamete that determines the female $(\mathrm{XX})$ or male $(\mathrm{XY})$ sex chromosome combination.

100Jordan, "Recent Literature," 252. Jordan would maintain this mixed hereditarian/environmentalist position in his later scholarship on hermaphroditism. He argued that although a hereditary determiner for sex, including the "monster" of both sexes, existed, its expression relied on environmental (metabolic) considerations that had their own hereditary origin. Jordan, "Hermaphroditism," 52.
} 
Jordan also studied the heredity of left-handedness as a way to bolster Mendelism, and perhaps as a way to predict antisocial behavior. 101 Ultimately, Jordan believed, "Facts regarding the conduct of the variation of left-handedness in heredity may reveal valuable information for the science of eugenics." 102 In his first study on "sinistry," Jordan noted the work of the famous Italian craniometrician and criminologist Cesare Lombroso and his associate L. Lattes, who viewed left-handedness as one of the hereditary "stigmata" or physical markers of delinquency. ${ }^{103}$ Lattes added a racial twist, concluding that lefthandedness occurred more frequently among blacks than whites. This result begged the inference that blacks, therefore, were more often criminals. A congenial conclusion, particularly in the American South, this explanation of black criminality could replace the discredited notion of reversion. Jordan accepted that, "there is no escaping the conclusion that left-handedness is at least twice as frequent among colored as among white families." Yet, he noted that an environmental difference may account for the greater frequency among blacks: "The less active repressive efforts counteracting the factor of imitation may probably be responsible for the high percentage among colored children." White children, reared in a culture that actively sought to discourage lefthandedness at home and in schools, might repress their genetic predisposition. Black children, allowed to develop without such interference, expressed their "hereditary" disposition. Nevertheless, Jordan believed his evidence was "conclusive" in proving that "left-handedness is hereditary," although he balked at claiming it followed strict Mendelian principles or successfully predicted criminal tendencies. Yet, he concluded hopefully, bringing the eugenic connection to the foreground,

${ }^{101}$ Harvey Emest Jordan, "The Inheritance of Left-Handedness," American Breeders Magazine 2 (1911): 19-29, 113-124; Jordan, "Studies in Human Heredity," Bulletin of the Philosophical Society, University of Virginia 1 (July 1912): 293-317; and Jordan, "Hereditary Lefthandedness, with a Note on Twinning," Journal of Genetics 4 (1914-1915): 67-81.

102 Jordan, "Inheritance of Left-Handedness," 123.

${ }^{103}$ For a discussion of Lombroso's links to American criminology and eugenics see Nicole Hahn Rafter, Creating Born Criminals (Urbana and Chicago: University of Illinois Press, 1997), Chapter 6. 
Superficially considered, it seems a far cry from the inheritance of coat-color [which followed Mendelian rules] to that of such a subtle characteristic as left-handedness. The gap here is perhaps only as wide as between this characteristic and such apparently still more subtle characteristics as virtue, justice, temperance, integrity, thrift, sagacity, etc.- characteristics of prime significance for the future trend of human history - and if the former gap can be bridged by hereditary formulae, as seems possible, why not the latter? Once the principles which govern the transmission of these highly desirable human qualities are known, their 'fixation' in continually increasing numbers of individuals seems a comparatively easy problem.

With faith and further research, the exact rules of inheritance might be discerned, including the discovery of the etiology of criminality, paving the way for an efficient eugenic program. 104

Jordan's eugenic goals became the framework for his next study of left-handedness, which also included pedigree-chart analyses of various pathological conditions. Analyzing the correlation between left-handedness and the incidence of disease might provide insights into the hereditary basis of disease susceptibility. Left handedness would become the visible marker (stigma) of an otherwise invisible genetic predisposition. "No one of these [left-handedness or medical conditions] would perhaps have much import. However, the consistent evidence of the mass seems significant from the standpoint of human inheritance and its eugenic bearing," he remarked. "If pathological conditions are determined even in part by hereditary constitutional bases, then methods looking to permanent racial cure, i.e., complete eradication, must reckon more intelligently and widely with the hereditary aspect of disease." 105 Clearly, Jordan envisioned a new therapeutic intervention in disease management: preventing morbidity and mortality by "breeding out" inherited susceptibility. Where Jefferson, Cabell, and Barringer could only note and speculate upon the meaning of differential susceptibility, with the aid of the new genetic technology Jordan sought to put these patterns to eugenic use.

104 Jordan, "Inheritance of Left-Handedness," 121, 122-23. Jordan extended his observation on black left-handedness while at the Carnegie Institution Biological Station in Montcgo Bay, Jamaica in 1912. There he found a slightly higher incidence of lcft-handedncss ( 5.5 percent versus 4 percent) among black Jamaican school children as compared to southern black school children. Jordan, "Studies in Human Heredity," 304.

105Jordan, "Studies in Human Heredity," 293. 
Jordan abandoned his earlier circumspection about the relationship of left-handedness and Mendelism. While in his first paper he concluded, "The writer does not however delude himself - nor does he wish to leave the impression of attempting to mislead his readers in this matter-that left-handedness even appears (on the basis of the limited data presented) to follow Mendelian principles of inheritance," in his next paper he wrote that his earlier paper "showed that left-handedness is hereditary, probably following Mendelian principles of segregation and dominance." $106 \mathrm{He}$ also jettisoned his environmental explanations of handedness, arguing, "Left-handed nurses [governesses] are frequently held responsible for the left-handedness of their charges....Possibly in some cases of acquired left-handedness this occurs. But usually if careful search is made left-handedness or ambidexterity appears somewhere in the pedigree."107 Jordan extended his hereditarianism even further in his consideration of tuberculosis, which began alongside left-handedness in "Studies in Human Inheritance." This rigid hereditarianism formed a recurrent theme in developing his conception of the relationship between eugenics and medicine.

Susceptibility to tuberculosis, according to Jordan, obeyed "a definite hereditary aspect." His analysis again failed to reveal a Mendelian pattern, yet for him it substantiated a hereditary rather than an environmental etiology and, "that is the all important matter by reason of its eugenic bearing." Jordan advocated an astringent eugenic therapy, restricting marriage among the tuberculous, because he believed "the inheritance of a constitutional predisposition or susceptibility or lack of resistance to infection" governed affliction.

Despite having just confessed that his evidence did not reveal a Mendelian pattern, he then

\footnotetext{
106Jordan, "Inheritance of Left-Handedness," 123; and Jordan, "Studies in Human Heredity," 294. Jordan concluded, in "Studies in Human Heredity," that left-handedness acts as a Mendelian recessive (p. 308). In his final article on left-handedness, "Hereditary Left-Handedness, with a Note on Twinning," Jordan concluded that the data on left-handedness "are overwhelmingly in accord with Mendelian theory," despite the fact that in his next sentence he temporized, "Certain real exceptions appear [to this conclusion]." He felt the exceptions proved the rule and could be accounted for by various accepted modifications of Mendelian theory. Jordan, "Hereditary Left-Handedness," 79.

107 Jordan, Ibid., 297.
} 
asserted exactly that claim, arguing that "matings where both parents are tubercular would seem to be ill advised," because it doomed the progeny to susceptibility. Marriages between tuberculars and "normals" would produce heterozygotes-asymptomatic carriers of the predisposition, who "would again be in danger of producing a tubercular among every four offspring," according to Mendelian ratios. So, Jordan felt that, "The eugenic bearing is obvious; and restrictive measures clearly indicated in the interests of a final control of the 'white plague."'108 On the basis of five cases, and despite the sure knowledge of the tubercle bacillus's virulence, Jordan decided that susceptibility to infection was decidedly hereditary — without ever considering obvious environmental causes of "predisposition."

Jordan followed the path blazed by his mentor Davenport, who in 1911 wrote in the Popular Science Monthly, "It is an incomplete statement to say that the tubercle bacillus is the cause of tuberculosis....Experience proves it, for...not all that harbor the tubercle bacillus die of consumption-else we should all die of that disease...."109 What accounted for susceptibility, according to Davenport and Jordan, was not environmental conditions, but genetic "stock." Rather than changing the environment (which would require expensive sanitation and hygiene reforms), and instead of eliminating the germ (which Davenport called a "supra-herculean task" because of its ubiquity), Davenport recommended-marriage restriction. ${ }^{110}$ This correspondence between Davenport and Jordan's solutions to the "white plague" is not just coincidental; it represents Harvey Jordan's increasing alignment with the mainline eugenics program.

108 Jordan, "Studies in Heredity," 310.

${ }^{109}$ Charles B. Davenport, "Eugenics and Euthenics," Popular Science Monthly, (1911), 19. Davenport claimed that it was not the living and working conditions that caused high rates of tuberculosis in female domestics; rather it was the fact that most "servants are largely Irish (who as a nation lack resistance to tuberculosis)...."

${ }^{110}$ Davenport noted, "It is, then, highly undesirable that two persons with weak resistance should marry, lest their children all carry this weakness." Davenport, Heredity in Relation to Eugenics, 165. 
Jordan addressed "The Need for Genetic Studies of Pulmonary Tuberculosis," hewing closely to the hereditarian analysis of tuberculosis etiology. He called on America's physicians for such investigations in a 1912 article in the Journal of the American Medical Association. ${ }^{111}$ Jordan again used pedigree analyses, this time bolstered by evidence from British eugenicist Karl Pearscn's work, to argue for the "significance of the hereditary aspect of this disease." He first conceded that, "The evidence is as yet too meager and of too uncertain indication to warrant very extensive or drastic action along the lines suggested."112 Jordan argued that increasing the number of studies would dispel doubts about the genetic component of tuberculosis morbidity, allowing for the implementation of eugenic programs.

Jordan then shifted tone from investigator to proselytizer. Calling on professional authority and patriotism, Jordan sought to rally physicians to the eugenic banner. "Because of the universal deference paid the physician and the consequent great influence he wields, the best interests of the nation require that he take the initiative in genetic studies of human pathologic conditions and in a eugenic propaganda with respect to their eradication."

Should these motives not provide sufficient inducement, Jordan tumed to the economics of tuberculosis. Noting that "In 1911 approximately $\$ 15,000,000$ was expended in antituberculosis efforts," Jordan argued that, "the people who pay have a right to demand that

${ }^{111}$ Harvey Emest Jordan, "The Need for Genetic Studies of Pulmonary Tuberculosis," Journal of the American Medical Association 59 (1912): 1518-1519 [page references refer to the offprint of this paper in Jordan's collected papers, which is paginated differently]. This was not the first time the JAMA reported Jordan's eugenical idcas. They reported his addresses before the ASS\&PIM in 1911. See "Hereditary Tuberculosis and Infant Mortality," JAMA 52 (November 25, 1911): 1786; and "Recommendations on Eugenics," JAMA 52 (December 2, 1911): 1864. Eugenics was not a new subject in the JAMA; it appears by name in titles five times between 1908 and the appearance of Jordan's work.

${ }_{112}$ Jordan, "Genetic Studies," 1 and 3. See also Jordan, "Hereditary Tuberculosis and Infant Mortality," Transactions of the American Association for the Study and Prevention of Infant Mortality 2 (1912): 144-45. Jordan made the same argument in this address from the 1911 meeting of the AAS\&PIM. was countered by Dr. Sachs of Chicago who "attach[ed] very little importance to hereditary tuberculosis," believing that, "most of these cases are the result of infection, from tubcrcular persons or tubercular surroundings." Sachs noted that Chicago annually spent between "one and one and one-half million dollars to fight tuberculosis," precisely the type of expenditures Jordan saw as wasteful because they allowed those predisposed to tuberculosis to survive and transmit their predisposition to the next generation. See Jordan, "Infant Mortality in Relation to the Hereditary' Effects of Tuberculosis," Transactions of the American Association for the Study and Prevention of Infant Mortality 3 (1913): 154-55. 
in the expenditure of these vast sums something permanent be accomplished." Denigrating the effect of sanitary reforms, he claimed that "the annual loss from sickness and death due to tuberculosis is estimated to be from $\$ 200,000,000$ to $\$ 300,000,000 "$ despite environmental improvements. The situation cried out for more than palliation, steps should be taken toward "the ultimate eradication of disease." The best way to do that, given tuberculosis's apparently genetic nature, would be to "breed out" carriers of genetic susceptibility. Only eugenic therapy of the gene pool, not individual bio-medical intervention, promised a "final solution" to the tuberculosis crisis. Jordan admitted that, "Certainly the present generation of tuberculous patients should be cared for as generously and as comfortably as is possible." "But society should have a care," he wamed, "lest by its possibly short-sighted charity it lay up unbearable burdens for posterity." Interventions like adequate sanitation, public hygiene, and other environmental adjustments seemed, to Jordan, misguided, "sentimental" charity that conserved the unfit as well as the fit, raising the specter of "race suicide" through a superabundance of "degenerate" genes. ${ }^{113}$

Ultimately, he concluded, "The eradication of tuberculosis seems at base a problem of establishing a resistant race." In Jordan's view, the state should take control of the tuberculosis crusade, wrenching control from voluntary and eleemosynary groups. "State control would naturally be followed by legal restrictions against the intermarriage of the tuberculous." In a nod to his environmentalist audience, Jordan closed, "As long as the environment remains in many quarters unfavorable and dangerous to the public health, efforts should primarily be directed toward improvement. But while this is in process of accomplishment, it would seem well-advised, in view of tuberculous family histories, at least to give waming of the racial danger of the intermarriage of the tuberculous." Such counseling would dissuade potential tuberculars from marrying which would, according to Jordan, "unquestionably aid both in the numerical decrease of non-resistant constitutions

113 Jordan, "Genetic Studies," 4. 
and the lessening of sources of infection."114 Eugenics offered more than a solution to the "white plague." Jordan felt it could stop another of America's "racial diseases," venereal infection.

In "The Eugenical Aspect of Venereal Disease," delivered before the AAS\&PIM in 1912, Jordan noted that, "The most insistent reason for the eradication of the venereal diseases, namely, the eugenic, does not seem to have received adequate popular emphasis." Jordan identified venereal infections as "extremely pemicious anti-eugenic factors," that like tuberculosis could weaken the hereditary constitution of the American "race." Again, Jordan called on physicians to enter the lists against this scourge, not on the level of individual therapy, but because he viewed the problem as "supremely significant from the standpoint of the future race." Since the common weal subsumed individual right, Jordan wrote, "No interest can be paramount to that of the race. There can be no loftier motive than that to aid in the production and universal establishment of the highest type of physical, moral and intellectual man within the limits of human protoplasm." Given this communitarian outlook, he felt that in the battle to conquer syphilis, "all questions of practicality and constitutionality must give way to right. Nothing can be more practical than the elimination of economic and racial inefficiency." Jordan's pragmatic search for efficiency clearly marked him as a Progressive reformer. His program remained punitive, arguing for "the legal registration, isolation or detention and prohibition from marriage of certain contagious gonorrhoeal [sic] and syphilitic patients." 115

The targets of Jordan's eugenic prohibitions carried other eugenic stigmata, beyond the symptoms of disease. Jordan located the "racial poison" witnin a particular race, class, and gender cohort. The venereal-eugenic threat, according to Jordan, existed "especially among the 'household help' class." Clearly reflecting on his own regional experience,

${ }^{114}$ Jordan, Ibid., 6.

${ }^{115}$ Harvey Emest Jordan, "The Eugenical Aspect of Venereal Disease," Transactions of the American Association for the Study and Prevention of Infant Mortality 3 (1912-1913): 156. 
Jordan noted that, "Among the colored population, from whom this kind of 'help' is very largely drawn, this condition is unusually prevalent." Infected black domestics, almost entirely female, posed a grave "racial threat" not because they might carry infection into their own homes, but because, "Through carelessness on the part of such 'help' in the performance of household work, in the capacity of nurse or cook or housemaid, infections might readily occur with dire consequences to the members of the employing household." Since white southemers comprised the vast majority of employers, Jordan cast the threat of disease in a specifically racial framework. "The serious menace of affected 'help,"' he added ominously, "must thus be apparent."116 The echoes of Paul Barringer's syphilis address ring out of Jordan's piece. After thirty years, the only significant difference between the addresses is the overt invocation of eugenics.

In this era before antibiotics, eugenics offered the only possible therapy for Jordan. Only compulsory registration of those infected, marriage restriction, and segregation would prevent future infant death from "native debility, an inaptitude for life, a lack of what might be termed 'biologic capital."'117 Only the passage and enforcement of eugenic legislation could solve what Jordan viewed as "perhaps as much an economic and social as a moral problem."118 Typically progressive, Jordan's efforts sought to reform society not merely through therapeutic intervention, but instead by encouraging economic and sociai efficiency through the labeling, segregation, and eradication of a population cohort defined as diseased.

The foregoing close analysis of Harvey Jordan's eugenical response to the "color line," left-handedness, tuberculosis, and venereal disease paints a portrait of a eugenics "true believer." Jordan's five major eugenics essays all reiterate the same points covered in his 1910 address, "Heredity as a Factor in the Improvement of Social Conditions," delivered

116 Jordan, Ibid., 157.

117 Jordan, Ibid., 158.

118 Jordan, Ibid., 162. 
before the Virginia State Conference of Charities and Corrections. ${ }^{119}$ Jordan repeatedly portrayed eugenics as a quasi-religious, patriotic, and altruistic solution to endemic problems threatening America's survival; he argued for stringent negative and positive eugenic measures; he noted the economic efficiency of eugenic reform; he linked eugenics and medicine; and he promoted eugenic education. These themes all correspond to the mainline sentiments put forth by Charles Davenport in Heredity in Relation to Eugenics. Jordan adhered to all the convictions that eventually typified the conservative wing of the eugenics movement, despite his own self-characterization as a "moderate" eugenicist.

Like most main-line eugenicists, Jordan believed America faced a rising tide of "degeneracy" and confronted the "menace" of an increasingly large "feebleminded" population. With "criminality, pauperism, degeneracy, idiocy, insanity, and various forms of maladjustment apparently on the increase," Jordan felt that it was "incumbent upon the patriotic, and the strong and intelligent, and especially those in positions of trust, influence, and responsibility to use every means, to search every resource, to make any sacrifice, and to go to any reasonable extent to ameliorate, and if possible to eradicate, this human woe...."120 Embracing the Progressive Era ethos emphasizing the authority of experts, Jordan argued that only "disinterested" elites_experts trained in the medical and social sciences--could save the nation from dysgenic declension. The authoritative guidance of benign experts would point the way toward a eugenic utopia.

Jordan used the quasi-religious rhetoric of main-line eugenics. He couched the eugenic struggle in the terms of a holy crusade, piting purity against contamination, virtue against vice, sickness against vitality. "Purity, strength, and wisdom, allied with initiative,

${ }^{119}$ This address was also published in the American Breeder's Magazine. Harvey Emest Jordan, "Heredity as a Factor in the Improvement of Social Conditions," American Breeders Magazine 2 (1911): 246-54. In addition to this piece, Jordan's four most comprehensive published eugenics essays are: "Eugenics: the Rearing of the Human Thoroughbred" (1912); "The Eugenic Bearings of the Efforts for Infant Conservation" (1912): "Surgical Sex Sterilization: Its Value as a Eugenic Measure" (1913); and "Eugenics: Its Data, Scope and Promise, as Seen by the Anatomist" (1913).

120Jordan, "Improvement of Social Conditions," 247. 
insistence, persistence, courage and patience, must grapple with the social monsters-vice, crime and disease, the enemies of race improvement." Invoking St. Paul's dictum that, "'to the pure all things are pure," Jordan argued that "We want religion to appeal to strength and to health - and we want it to help in the effort to restore racial health....Religion to appeal more universally must become suffused with modem biological teaching."121 Jordan, following Charles Davenport, and Francis Galton before him, sought to collapse science and religion into a new secular creed, eugenics. To do otherwise would be to court disaster, as misguided "humanitarianism" would traduce the natural law of "survival of the fittest," allowing the unfit to propagate.

Drawing a pragmatic line, Jordan argued against religion as mere moralizing metaphysics and charity as irrational sentimentalism. Instead, he posited a new religion, one that evolved from the marriage of biological science and traditional religion, promising improvement in this world. "An intelligent understanding of the laws of heredity and reproduction would do more toward minimizing vice than much impersonal religious teaching," according to Jordan. "I do not want to rob the human heart of the commendable virtues of pity, sympathy, and charity," he wrote, mollifying the "sentimental" humanitarians in his audience. But charity, he wrote in 1913, "has counteracted the beneficent influence of natural selection. Promiscuous and unguided by scientific wisdom it works for a condition of reversed selection. It favors the unfit at the expense of the fit." Instead of traditional charity Jordan championed a "rational charity" that, "would neutralise the dysgenic effect of misguided emotional charity." 122 Defusing the "threat" of charity required that people develop "the courage to recognize our duty and forbid parenthood to the proved, and universally admitted, unfit." Jordan's focus on "responsible" and "rational" charity paralleled the trend in "scientific philanthropy" pioneered by John D. Rockefeller and Andrew Camegie.

121 Jordan, Ibid., 250.

122Jordan, "Eugenics: It's Data, Scope and Promise," 118. 
Jordan, invoking images from his childhood in rural Pennsylvania, relentlessly reaffirmed the practical possibility of the organic improvement of human beings. "There is no issue so vital to this nation today as the rearing of the human thoroughbred," he often wrote. This phrase appears in almost every one of his eugenics tracts, titling one, "Eugenics: The Rearing of the Human Thoroughbred."123 For him the analogy between animal husbandry and human procreation merged into identity through eugenics and Mendelian heredity. ${ }^{124}$ His views only strengthened over time. Speaking before a large audience at the University of Virginia's YMCA in 1913, Jordan stated that eugenics, "aims to produce a better race by better breeding. It does not aspire to create; it seeks merely to prevent subtraction and contamination, and by appropriate combination of the best hereditary traits now in existence or in future to arise to produce a race of thoroughbreds, considered physically, mentally and morally."125 Even as he invoked "positive" eugenics through salutary mating, Jordan also emphasized "negarive" eugenics—the eradication of negative genetic traits through marriage restriction, segregation of the unfit, and sterilization.

"The time is ripe for at least negative eugenics-i.e., the prohibiting of parenthood to the unfit," Jordan wrote in 1910. At that time, he remained somewhat skeptical about the use of compulsory sterilization, warning, "I am not yet persuaded that recourse to surgical procedure is the best alternative, except in most extreme cases of hereditary degeneracy; but I do advocate-and there can be no objection to this measure - that the inmates of our institutions for deficients be detained, no matter what temporary improvement they may show, until after the procreative period." The deficient must be segregated to protect the fit and the unborn. Jordan minced no words in identifying the unfit, "Criminals, paupers, degenerates, the incurably sick and their kind are a serious burden-in cases even a

${ }^{123}$ Harvey Ernest Jordan, "Eugenics: The Rearing of the Human Thoroughbred," Cleveland Medical Journal 11 (1912): 875.

${ }^{124} \mathrm{He}$ makes this move explicitly; see "Improvement of Social Conditions," 249.

125Jordan, "Eugenics: Its Data, Scope and Promise," 108. 
menace-to society. Society has a right, even an obligation, to protect itself."126 Following eugenicists like Davenport and H. H. Goddard, Jordan was willing to criminalize "deficiency" and allow the state's police power to trammel individual rights in the name of eugenic protections. Jordan termed eugenic marriage, segregation, and sterilization laws, "peculiarly public and racial health measures" that "should form part of the health code, to be administered under the State Police Powers."127 Eugenics and public health were, for Jordan and almost all eugenicists, precisely identical.

By 1913, however, Jordan outstripped even Davenport's negative eugenics, firmly supporting the use of eugenic sterilization to protect public health. In "Surgical SexSterilization: Its Value as a Eugenic Measure," the lead article in the prestigious American Journal of Clinical Medicine, Jordan staunchly defended eugenic sterilization "for the protection of society against distressing economic and moral burdens and racial decay...." While he felt that segregating "unfit" individuais during their procreative period "is almost incomparably the preferable" negative eugenic method, he realized that sterilization offered a viable option. Since not everyone, and especially not the degenerate class, was selfless enough to respond to "eugenics propaganda...that will potently appeal to the altruistic instincts," Jordan felt that, "some extemal repressive methods must be instituted against those unwilling or incapable of response to intemal appeals. "128 Sterilization was forced altruism, sacrificing the individual's right to procreate for the well-being of society.

Jordan debunked the notion that eugenic sterilization offered any therapeutic effect for the individual, although he noted that castration in "certain extreme cases" like "sexual perverts and rapists" might have both a eugenic and a therapeutic effect. ${ }^{129}$ Jordan's interest, as he made clear, was not in therapy for the individual, but eugenic prophylaxis

126 Jordan, Ibid., 252.

127Jordan, "Eugenics: Its Data, Scope and Promise," 137.

${ }^{128}$ Harvey Ernest Jordan, "Surgical Sex-Sterilization: Its Value as a Eugenic Measure," The American Journal of Clinical Medicine 20 (1913), 983.

${ }^{129}$ Jordan, Ibid., 985. 
for society, which he construed as "the race." Envisioning an epileptic population that "doubles every thirty years," and deeming it "altogether likely that the number afflicted with feeblemindedness or with syphilis...doubles in an equally short period of time," Jordan claimed that, "Something radical, then, must be done; and it must be done quickly....sterilization seems to be our only hope."130 Without eugenical sterilization, "the Anglo-Saxon race surely is doomed to the fate of the Greeks and Romans." Mounting this defense would depend on education. Americans, and as Jordan's previous quotation makes clear he addressed himself to white Americans, must be taught about the "racial threat" and the eugenic response. White Americans must overcome their antiquated objections to sterilization and their "traditional feticism [sic] of 'personal liberty' and 'equal rights," and learn to defend "the race."131

Professionals in medicine, biology, social sciences, and allied fields like psychology should all be taught to think in eugenic terms, according to Jordan. "Courses in heredity and applied eugenics in our medical schools and training schools for social service are urgently demanded," he wrote. Only eugenic education could prepare physicians to fulfill their civic role. Progressive "physicians will be more efficient public servants if they approach their work with a eugenic outlook on life" which would allow them to discem rapidly what maladies deserved scarce resources and curative therapies, and which deserved eugenic interventions. To make eugenic interventions available, "The future physician must also take a more active part in helping to shape legislation in the interests of race welfare," Jordan announced to the First International Congress of Eugenics. ${ }^{132}$ As he noted two years later, "The solution of our great social problems from this [the eugenic] standpoint, you see, is primarily in the hands of the scientist, notably the physician and

${ }^{130}$ Jordan, Ibid., 985.

131 Jordan, "Eugenical Aspect of Venereal Disease," 160.

132 Harvey Ernest Jordan, "The Place of Eugenics in the Medical Curriculum," Problems in Eugenics vol I, (London: Eugenics Education Society, 1912), 397, 399. Jordan's paper was read at the conference by American eugenicist Dr. Vemon Kellogg, brother of John Harvey Kellogg of cereal fame. Problems in Eugenics vol II, (London: Eugenics Education Society, 1912), 66. 
trained biologist."133 Transforming scientists to biological technocrats, Jordan espoused his own version of the "gospel of social evolution," replacing natural selection with eugenics.

More significant than his reliance on expert authority, however, was his implicit connection between public health, the law, and eugenics. Jordan called for the creation of a national public health service, as a eugenic measure, two years before Congress reorganized the Marine Hospital Service into the United States Public Health Service (USPHS). Jordan argued that a reformed national public health service must be founded on eugenic principles because, "What sanitary science and hygiene seek to accomplish by attention to external conditions alone largely defeats its own ends by counteracting the working of the principle of selection....Rigidly applied eugenics would accomplish the end in several gene-ations. The resulting healthy, happy race would require, and, indeed, could compel a more purified environment." 134 Once again, eugenics and public health became the same thing. Invoking economic and social efficiency as the best motives for the provision of public health, Jordan wrote, "it is more desirable to be able to prevent the production of social inferiors than to raise such elements to physical, mental, and moral par," because, "Social therapy is economically much more expensive than social prophylaxis." The progressive impulse was rationalizing medicine, according to Jordan, making it "less a curative and more a preventive science. From an art of curing illness, it is becoming a science of health." 135 And, as Jordan argued the next year, "just as we are now guarding the public health, so it is our yet more clear and sacred duty to guard the health of the race, by every humane effective means at our command."136 Thus, even in preventive medicine, the traditional bailiwick of the public health service, heredity trumped

133Jordan, "Eugenics: The Rearing of the Human Thoroughbred," Cleveland Medical Journal 11 (1912), 885.

134Jordan, "Improvement of Social Conditions," 253.

135 Jordan, "Eugenics in the Medical Curriculum," 396.

136Jordan, "Eugenics: Its Data, Scope and Promise," 138. 
environment, and progressive rationalism trumped traditional humanitarianism. Jordan understood that, "The sciences of bacteriology and genetics, or the physiology of heredity, had to be bom before certain steps could be taken in the control of human evolution." Now that those sciences had arrived, the time to apply eugenics was nigh. Applied eugenics required the aegis of legislation so, when addressing a large audience of Virginia undergraduates Jordan attempted "especially to solicit the interest and aid of the coming legal profession." Applied eugenics depended upon competent lawyers drafting and helping to enforce eugenic statutes. ${ }^{137}$ Practical eugenics would advance in lock step with the eugenic education of those professionals most intimately involved in the life sciences and public policy.

The public, particularly women, should be eugenically informed, too. Once public opinion embraced eugenics, Jordan believed nothing could stop humankind from achieving utopia. "The public schools also can do a spiendid work here in dissipating harmful ignorance and foolish sentimentality by giving well-planned courses in botany and zoölogy."13S Once students understood the iron dictates of biological law, eugenics would become a self-evident necessity. Jordan appealed to women, deploying both feminist and sexist rationales. Pouncing on the feminist demand for a single moral standard for men and women, Jordan linked it to the eugenics creed, arguing for a new moral standard.

Supposing himself a new eugenic "minister," Jordan "would give every boy an opportunity to pledge himself to a life of continence until marriage, and every girl to the enforcement of the single standard of morals - not on any mystical or sentimental ground primarily, but for the very practical reason of personal gain in happiness and efficiency and of racial welfare." 139

137Jordan, Ibid., 136.

138 Jordan, "Improvement of Social Conditions," 250. See also Jordan, "Eugenics," 885; and Jordan, "Surgical Sex-Sterilization, 983.

139Jordan, "Eugenics: Its Data, Scope and Promisc, 135. 
Extending his pragmatism to the political realm, Jordan saw suffragism as a force that "contains great possibilities for powerfully abetting the eugenic propaganda," both to achieve and to enforce eugenic laws. Essentializing women to their biological capacity for motherhood, Jordan argued, "Woman will legislate to properly protect herself as the 'mother' of the race against wanton infection. She instinctively feels more keenly the importance of conserving the greatest national asset - human life-and will bring about proper action for the preservation of the best elements of the race." 140 For the same reasons, women would encourage eugenic laws to stop the spread of venereal infection, and they would "originate and help enforce laws providing for surgical sterilization as a eugenic measure."141 Women, politically co-equal with men, occupied an essential position in the battle for Eugenics, offering the ultimate form of social control and disease prevention, appeared to offer the most efficient, practical path to the millennium.

Jordan's vision mixed idealism and pragmatism. The notion that practical eugenics leads to utopia rings out of his work. "The ultimate ideal sought is a perfect society constituted of perfect individuals." 142 His faith was so strong that in 1912 he announced, "It is not too much to say, I believe, that the idea of eugenics, based upon the science of genetics, will work the greatest social revolution the world has yet known." 143 Jordan based this millennial vision on the altruism and "chivalry" that eugenics drew forth from its adherents. In extolling the eugenic creed before a large audience at the University of Virginia's YMCA in 1913, Jordan claimed, "This new emphasis on the claims of the future and the race is awakening a world-wide more intelligent interest in eugenics and its foundations, and promises to convert society into that Utopia of which More wrote, and that Kingdom of Heaven on Earth of which Christ spoke."144 Jordan's millennialism

140Jordan, "Eugenical Aspects of Vencreal Disease," 162-63 (quotation 163).

14 IJordan, "Surgical Sex-Sterilization," 987.

142 Jordan, "Eugenics in the Medical Curriculum," 396.

143 Jordan, "Eugenics," 876.

${ }^{144}$ Jordan, Ibid., 878. Jordan describes the "chivalrous spirit" of the German Gesellschaft für Rassenhygiene founded by Dr. Alfred Ploetz. Ploetz became involved in Nazi eugenics. See Stefan Kuhl, 
knew few bounds. Like many of the most strident eugenicists, he found in eugenics a monistic theory that reconciled science and religion, rationalism and mysticism, physics and metaphysics into a single ideology directed toward achieving the perfect society.

Yet Jordan considered himself a moderate eugenicist. Although he acknowledged that in setting forth his evidence in favor of a eugenic program, "I may perhaps at points seem to err on the side of radicalism," he still felt that his conclusions and policy proposals were "conservative."145 Indeed, in answering Charles Davenport's criticism that efforts to lower infant mortality were dysgenic, Jordan labeled his erstwhile mentor and compatriot a "radical eugenist," constructing himself as a moderate. ${ }^{146}$ Jordan self-identification as moderate stemmed from his conviction that, despite Davenport's statement "that the indiscriminate efforts for infant conservation are anti-eugenic, and despite the cold reasonableness of the arguments presented," he felt, "We must save all the babies we canbut recognize at the same time that we thus save some unfit stock-and then plan for some compensatory action, as suggested in the paper by Mr. [eugenicist Roswell] Johnson." 147 Thus, Jordan rhetorically posed as a moderate by championing infant "conservation." $\mathrm{He}$ ended, however, at the "radical" position, advocating increased negative eugenics to counter any dysgenic effect of reduced infant mortality. Jordan's understanding of infant conservation's goal-"Our ideal is the production of the human thoroughbred, i.e., the highest type of physical, mental and moral manhood and womanhood"—cemented his position as a mainline eugenicist. The goal was not merely the salvation of infant life. "To save the babies is only half the work; we must have as our ultimate aim the salvage of the

The Nazi Connection: Eugenics, American Racism, and German National Socialism (New York and Oxford: Oxford University Press, 1994), 94.

i45Jordan, "Eugenics: Its Data, Scope and Promise," 107.

146Jordan, "The Euzenic Bearings of the Efforts for Infant Conservation," Transactions of the American Association for the Study and Prevention of Infant Mortality 2(1912), 117 and 118 . In "Eugenics: Its Data, Scope and Promise," Jordan constructed himself and his audience as "conscientious, high-minded, rational and conservative [meaning cautious] eugenist" (page 136).

147 Jordan, "Eugenic Bearings," 118. 
race." 148 Racial salvation would come through protection and improvement of the "germ plasm," and not environmental interventions or "sentimental" infant conservation.

Jordan's rhetorical stance regarding the "nature/nurture" question also appeared, at first glance, to place him with more moderate eugenicists who recognized the power of environment as well as heredity. "Heredity and environment go hand in hand," began Jordan's signature formulation of the balance between nature and nurture, "As absolute essentials they are relatively equally important....Attention to either heredity or environment alone under present economic and political conditions will be largely abortive of telling results." 149 Yet, while he noted the significance of environment, he always ended by reinforcing the salience of heredity because, "heredity comes first; environment, however necessary, can onily follow." Quoting Karl Pearson, Jordan relegated environment to secondary importance, "'No environment or educational grindstone is of service unless the tool to be ground is of genuine steel —of tough race and tempered stock." 150 Ultimately, Jordan joined the mainstream of "radical" hereditarians in believing that "It is a popular fiction that 'men are born free and equal."' Nothing really is further from the truth....As Davenport puts it, 'Men are born bound by their protoplasmic make-up and unequal in their powers and possibilities."151

Jordan's discussion of both negative and positive eugenic programs mimicked the ambivalent terms that he used in his discussion of heredity and environment. As in that case, he eventually gave way to a hard line that emphasized negative eugenics and controlled mate selection. Since hereditary inequalities were established and foreordained, Jordan felt justified in advocating "conservative" negative and positive eugenics. He

148 Jordan, Ibid., 120.

${ }^{149}$ Jordan, Ibid., 121-22. See also Jordan, "Social Improvement," 251; Jordan, "Eugenics," 881-82; and Jordan, "Eugenics: Its Data, Scope and Promise," 109 and 115.

${ }^{150}$ Jordan, "Eugenics," 882. Jordan also quoted Pearson approvingly as rating "the influence of the environment at less than one-tenth that of hcredity." Jordan, "Eugenics: Its Data, Scope and Promise," 110.

151 Jordan, Ibid., 116. 
appealed first to his audience's sense of "altruism" and "responsibility" in persuading them to "harbour and cherish the eugenic ideal."152 Jordan then argued for enlisting "the church, and charitable and scientific institutions, and the medical profession generally, to help shape public sentiment in favor of good-sized families among the racially best, and to change the standards for a 'good match' from simply externals and largely material things to stock and intrinsic worth of hereditary equipment in characters of the highest survival value."153 By coopting "sentimental" and "humanitarian" institutions, eugenics could rationalize belief and life. Jordan's efforts at eugenic moral suasion sought individual conversion to the eugenics creed.

Despite this apparent emphasis on voluntarism, however, Jordan always retumed to the need for compulsory measures, embedded in the law, to ensure eugenic behavior. "Surely, in his view, "society has a right, even an obligation, to protect itself against [dysgenic] harm." The sucial organism must be inoculated against infection by "contaminated" individuals through eugenic policy. Anticipating the rationale that Justice Oliver Wendell Holmes, Jr. would rely on in declaring the constitutionality of compulsory eugenic sterilization, Jordan argued, "Exactly as society has a right to protect itself by most rigid safeguards-little recognizing individual and personal comforts and wishes-against smallpox, cholera, and so on, so it would seem to have an equal right to protect itself by adequate methods against idiocy, syphilis, and pauperism." Going even farther, Jordan asserted that, "Man does not have an inalienable right to personal or reproductive freedom, if such freedom is a menace to society." 154 In the final analysis, Jordan clearly protested too much; his conclusions belied his early rhetoric inveighing against "radical eugenists"-

${ }^{152}$ Jordan, Ibid., 136.

153Jordan, "Eugenic Bearings," 122.

154 Jordan, "Surgical Sex-Sterilization," 986. Holmes's decision in the Virginia sterilization case, Buck v. Bell (274 U.S. 200), which relied in part on the preventive analogy between sterilization and inoculation against smallpox, will be discussed in Chapter 5. 
whether discussing heredity and environment, positive and negative eugenics, or suasion and compulsion-revealing him as a member of their ideological camp.

Jordan stopped publishing on eugenics in 1914, but he rever gave up his eugenic convictions. Jordan's apparent retreat should not be viewed as an abandonment of eugenic ideology. A more likely explanation stems from the interaction of four concurrent developments: the ossification of Jordan's beliefs, an increasing workload within the medical school, the dispersal of eugenics ideology throughout Virginia's curriculum, and the advent of a national "eugenics boom" spearheaded by other popularizers. First, Jordan's increasingly rigid adherence to mainline eugenic ideas reveals changes in his approach to science and how he viewed the relationship between science and social policy. As Jordan became more and more committed to a Mendelian interpretation of heredity, he became more convinced of the efficacy of eugenic intervention as social reform. Science no longer informed social policy, it dictated it. Despite the fact that-beginning in 1915 with the iteration of the Hardy-Weinberg theorem and Franz Boas's studies of immigrant families—ugenics faced increasing scientific challenges, Jordan and many others, truebelievers and skeptics alike, stood behind eugenic principles. ${ }^{155}$ Jordan would remain active in national- and state-level eugenics until he retired. Considering the hereditarian basis of eugenics well established, perhaps Jordan felt it was time for others to take charge of implementing the policies he had identified for them. He was simply too busy both to prove the veracity of eugenics and spread its message singlehanded.

The increase in his workload provided the second development that diminished Jordan's high-profile eugenic activity. Jordan himself became increasingly overburdened with teaching and administrative tasks; as early as 1911 he was handing off eugenics

${ }^{155}$ The Hardy-Weinberg theorem proved that the elimination of a genetic trait from the population would take a nearly infinitely long time, even under ideal circumstances. Diane B. Paul, The Politics of Heredity: Essays on Eugenics, Biomedicine, and the Nature-Nurture Debate (Albany, NY: State University of New York Press, 1998), 117-18. Boas used anthropometric methods to measure immigrants and disproved craniometric notions of racial difference. Chase, The Legacy of Malthus, 183-84. 
investigations to other groups. ${ }^{156}$ Always under-funded and understaffed, faculty in the medical schooi and hospital, as well as the university more generally bore heavy teaching and administrative loads. In addition to his teaching duties, Jordan acted as the principle admissions officer for the medical school, reading and judging all the applications. And, like academics elsewhere, Jordan sat on his share of medical school and university committees. Also funds and support for "pure" research seemed woefully lacking to many instructors. ${ }^{157}$ As a result, he began to confine his research to self-contained studies on readily available material. His bibliography reveals that many of his later studies were not the result of lengthy experimentation, but rather brief studies based on easy observations of interesting "material" that happened into the hospital. This "method" helps to explain the wide variety of histological, embryological, and anatomical topics about which Jordan published. ${ }^{158}$ Unlike many other investigators who confined themselves to one area of investigation and then probed it in depth with complex experiments, Jordan capitalized on whatever "material" fate and the university hospital presented. Studies in human heredity, depending at the time on the labor-intensive compilation of extensive family pedigrees, simply took too long and required too much investment of scarce resources. Jordan lacked the wherewithal to direct such studies himself, particularly when other interesting research came readily to hand. So, again, he left the research to the capable hands of the full-time investigators from the ERO.

The third reason for Jordan's receding from the eugenics limelight stemmed from the creation of a "critical mass" of like-minded men on the Virginia faculty. By the end of the

156 Jordan to Davenport, May 22, 1911 , Davenport Papers.

${ }^{157}$ Dr. William Bennett Bean, son of University of Virginia anatomist and eugenicist Robert Bennett Bean who joined the faculty in 1916, remembered that, "I remember Father's, I won't say bitterness, but his repeated reiteration of the fact that research was not supported in the Medical School. I don't believe that research was supported much, in those days, under the best of circumstances. Father was at least one of the people who was doing it and this was [cugenical] anthropological rescarch which many people didn't understand because obviously it wasn't going to cure cancer...." William Bennett Bean, Interview with Michael Plunkett, 24 May 1972, interview 4, transcript, University of Virginia Oral History Collection, Special Collections, Alderman Library, Charlotesville.

${ }^{158}$ See the bibliography in his Collected Papers. 
decade, and increasing into the 1920s, Virginia expanded the range and scope of eugenical teaching within its medical and undergraduate divisions. Jordan no longer had to carry the load alone. And Virginia, while still the institutional epicenter of eugenics, would be joined in the field by most of the other institutions in the state. Jordan could become one of the advanced eugenic contingent, rather than single-handedly blazing the eugenics trail.

Finally, after 1914, popular support for eugenics mushroomed. With greater public awareness, advanced by more prolific and stylistically-accessible authors, the need for Jordan's public role decreased. With men like former-President Theodore Roosevelt, Madison Grant, and Alfred E. Wiggam working to popularize eugenics ideas, Jordan gave over his role as an active propagandist. He remained ready to answer the call of the movement, however. And, he continued to teach eugenics incidentally through his courses in the medical school. By 1912, however, he was no longer alone in teaching eugenics at Virginia. That year, William Henry "Harry" Heck would begin teaching eugenics through the university's school of education.

\section{Cognitive Differences: Hereditarianism, Eugenics, and Educational Policy}

In his quest to modernize the University of Virginia, President Alderman dedicated himself to advancing every area of instruction, not just maintaining the medical school's preeminence. Education, long viewed as the ultimate panacea for social problems, occupied a special place in the plans of New South boosters like President Alderman. In his inaugural address, Alderman adverted to the unified, hierarchical educational system modeled in Jefferson's 1799 Bill for the More General Diffusion of Knowledge. "The largest social task of this University, co-operating with all educational forces," Alderman averred, "is to strive for the accomplishment of these [Jefferson's] unrealized ideals.... The University that solves the problem [of unifying all the educational levels] holds the future." The first step toward this bright future "would be the establishment here of a school of 
education of such power that its teachers could approach this and other problems of educational statesmanship with insight and authority. This school should comprise not only the philosopher, but the sociologist, the organizer, and the sympathetic publicist."159 Alderman thus outlined the desideratum of progressive educational reform. Expert educational authorities would lead society forward in an effort to teach people to understand society and fit them for their role in it. Boosters hoped that just as better-trained, southernborn physicians educated at a southem institution would guarantee the improvement of southern public health, so too training expert southem teachers and administrators would fortify the South's socio-economic health, by producing a better-educated citizenry. Both efforts would find a ready link through eugenics. Public health and educational reform both sought to prevent social problems: disease and antisocial behavior, respectively. ${ }^{160}$ Eugenics embraced precisely the same preventative ethos, yet it linked its "therapy" to the identification of "fit" and "unfit" genetic stock. Eugenicists viewed the public health and education systems as institutional infrastructures through which they could implement eugenical public policy. Public health physicians and educators could themselves operate more efficiently, wasting fewer scarce resources, if they understood the genetic basis of morbidity and cognitive deficiency. By keeping eugenics in mind, educators and doctors could simultaneously direct their therapeutic efforts at both the worthiest individuals and society. Such a combination of efforts, eugenicists believed, promised the rapid improvement of social health and harmony. In the South, a region excoriated since before the Civil War for being backward, unclean, and anti-modem, such prerogatives paved the pathway to the bright "New South" proclaimed by Progressive boosters.

Famed for rationalizing and modemizing southern higher education, particularly as president of the University of North Carolina and Tulane University, Alderman continued

${ }^{159}$ Alderman quoted in Quantz, "Founding of the University of Virginia School of Education," 5.

${ }^{160}$ Historian George B. Tindall noted that "The growth of schools...paralleled a significant, if lesser, growth of public health services," but he neglected to note the overlap and cooperation between public school and public health efforts. Tindall, Emergence of the New Soulh, 276. 
this mission at Virginia by founding its Curry Memorial School of Education. Alderman hoped to promote the "scientific" training of Virginia's teachers and educational administrators. Logically, for Alderman, the university should become the locus of professional training for those who would "teach teachers." In this way, the university would materially contribute to "the life of the state," the pre-eminent goal of state institutions in Alderman's mind. Following the model set out by Columbia University's Teachers College, Alderman reorganized Virginia's efforts at teacher training. With a $\$ 100,000$ grant from the General Education Board (GEB), the giant educational philanthropy started by oil tycoon John D. Rockefeller, Alderman founded the Curry Memorial School of Education, named after Alderman's friend, the famed southern educator J.L.M. Curry. In so doing, he explicitly sought to create an institutional basis for social therapy-intervention in Virginia's social problems by experts trained in scientific notions of education and hygiene. ${ }^{161}$

Honoring the Progressive Era's impulse toward efficiency, scientific measurement, and rationalized professional training, Alderman and educators nationwide engaged in a search for the "one best system" of modern education. ${ }^{162}$ Applying the theoretical and empirical findings of the emerging science of psychology, "Progressive Education" came to have two fairly distinct theoretical schools. The so-called "soft progressive" camp, headed by philosopher/educator John De'wey and psychologist John Broadus Watson, emphasized the effect of experience and environment in shaping the individual scholar. Developing

${ }^{161}$ Teachers College became, and remains today, the pre-eminent institution for the "scientific" training of teachers and school administrators. Geraldine Jonçich Clifford details Columbia's acquisition of Teachers College and its rapid rise to educational prominence in, Edward L. Thorndike: The Sane Positivist 2d. ed., (Middletown, CT: Wesleyan University Press, 1984), 179-190. On the founding of the Curry School, see Quantz, "Founding of the University of Virginia's School of Education"; Bruce, History of the University of Virginia, 198-211; Dennis, Reforming the 'Academical Village," 68-71; and Dennis, "Educating the 'Advancing South,"' 352-56.

162David B. Tyack, The One Best System: A History of American Urban Education (Cambridge, MA and London: Harvard University Press, 1974). While Tyack focuses on urban education, he also discusses the problems facing southern rural and urban educational reform. See also Woodward, Origins of the New South, 398-406; Tindall, Emergence of the New South, 256-76. 
from John Locke's early notion of a child's mind as a tabula rasa-a blank slateenvironmentalists viewed individual cognitive potential as limited only by external circumstance: the quality of one's educational experiences. The other wing, promoted by Henry Herbert Goddard, Lewis Terinan, and Edward L. Thomdike, identified the immanent potential of each individual as the determiner of educational outcomes. In their view, individual potential was finite and fixed by inborn characteristics; environment could aid in the utmost expression of potential, but the inborm potential for leaming could not be exceeded by either additional training or the most favorable environment. The new technologies of quantitative psychology—intelligence and "aptitude" testing—undergirded these "hard" progressive educational theories, promoting hereditarianism with scientific evidence purporting to document qualitative differences among individuals' intelligence.

The quantitative analysis of intelligence, pioneered in France by Alfred Binet, became in America the justification for the "labeling" of school children as "feeble-minded," "normal," and "gifted," and provided a new pedagogical and administrative paradigm. These "scientifically determined" labels then translated into the "tracking" of school children into rigid vocational and academic curricula, designed to "fit" their potential and aptitudes to a future career. Decked out in the trappings of cutting-edge scienceexperimental investigations using empirical tests that rendered quantitative resultsdeterministic educational theory attracted many progressive educators seeking a clearly defined program for modem "efficiency" in education.

When Alderman looked to increase the quality of the University of Virginia's offerings in education, he sought instructors with two main characteristics. Candidates should display the same missionary zeal toward education as Alderman, and they had to be trained in the "hard science" tradition of the new psychometricians. The man Alderman tapped to revamp the University of Virginia's school of education was just such an educational scientist. Interested in improving southem public health through healthful education, 
William Henry "Harry" Heck had both the most advanced "scientific" training, and direct ties to the largest philanthropic organization promoting southern public education.

Harry Heck perfectly fit Alderman's desire for a "conservative Progressive." A "tarheel" like Alderman, Heck was born in 1879 in Raleigh, North Carolina. Thoroughly steeped in southem Methodist culture, Heck attended Wake Forest College, where he earned both his bachelor's and master's degrees in English, in 1897 and 1899. During one year of his master's studies, Heck taught public school in Raleigh, sparking his interest in education. Heck proceeded to Columbia University with the intention of obtaining a doctorate in English literature. In his second year, however, he encountered educational theory at the two-year-old Mecca of scientific education, Teachers College Columbia University. Swayed by the "masterful" lectures of Nicholas Murray Butler, Heck wrote home that, "this subject of education, or the development of the individual (it should not be narrowed to school work), is absorbingly interesting to me, and I could read on it for weeks without getting tired." 163 Attracted by Butler, Heck found his formative influence under Edward L. Thomdike, then famous for his studies in animal intelligence.

Recognized as a brilliant student, and being a native southerner, the GEB hired Heck as a field agent, surveying the status of public education in the southem states. ${ }^{164}$ While serving on the GEB, Heck met the most famous and influential American progressive educators, especially those from the South. It is during this time that Heck most likely made the personal acquaintance of Edwin Aiderman. When the GEB appropriated the funds for a school of education at Virginia in 1905, Heck - given his initial graduate training, his experience with the GEB, and his southern heritage-became a natural first choice for the deanship. Between 1905 and his untimely death during the influenza pandemic of 1919, Heck would become, behind Alderman the most visible educational

${ }^{163}$ Heck quoted in Ivey F. Lewis, "William Henry Heck 1879-1919," Alumni Bulletin (October 1919), 363-64.

${ }^{164}$ Lewis, Ibid., 365, 366. 
reformer in Virginia. He would also begin the first formal course in eugenics at the University of Virginia. Heck's hereditarian and eugenical beliefs revealed Thorndike's impress on his thinking, and influenced his educational reforms throughout his career.

Heck spent the first six years of his tenure at Virginia teaching during the regular and summer sessions, and traveling throughout the state spreading his gospel of progressive education. Heck believed that, "Through society are we educated for society," therefore schools existed to "socialize" students, familiarizing them with social norms and providing them with the skills necessary to enter society and contribute to its progress. ${ }^{165}$ Schools, especially southern schools, performed a quasi-religious "mission" vital to society's success. The year before he arrived at Virginia, Heck outlined this role, writing that, "teachers in the South are called to a mission broader than schoolbooks and class exercises, a mission of social leadership in a section full of great, yet partially developed resources. More than any other part of our nation, the South is looking to its schools for leadership in all phases of its growing life." 166 Heck enjoined Virginia educators to accept the mission according to his educational gospel.

Heck's gospel had three major commandments, each directly inspired by Thorndike's work. For students to learn, Heck and Thorndike held, they must study in clean, hygienic schools; they must be taught specific subjects related to their probable life experiences; and their training must be adapted to their innate biological potential as determined by mental tests. In the second edition of his Educational Psychology, Thorndike complained that, "the American public school system rests on a total disregard of hereditary mental differences between the classes and the masses." The curricular specialization he and Heck argued for would take into account students' inborn potential because, "The one thing that

165William Henry Heck, Mental Discipline and Educational Values 2d. ed. (New York: John Lane and Company, 1911), 174. This book originally appeared in 1909. The argument in the second edition remained, "for the most part as it was in the first edition" (Preface to Second Edition).

${ }^{166}$ William Henry Heck, "Citizenship in Southem Education," Alumni Bulletin (October 1919), 382. This piece originally appeared in the School Review 12 (1904), 810-19. 
educational theorists of to-day seem to place as the foremost duty of the schools-the development of powers and capacities-is the one thing that the schools or any other educational forces can do least." 167 In short, teachers did not mold young minds so much as identify the appropriate social slot into which they fit, "preparing boys and girls for environmental [social] usefulness...."168 To that end, schools should abandon the classical "formal" curriculum that was the same for all students regardless of their future aspirations or possibilities. Instead, schools should increase "social efficiency" by teaching the students social sciences that prepared them for life. ${ }^{169}$ The school curriculum should reflect the environment into which young scholars would graduate. Only then would scholastic training be relevant and effective.

Heck developed this thesis in his 1909 monograph Mental Discipline and Educational Values, where he hinted at the role of heredity in the educational process. "We are more or less a bundle of specific abilities and of specific inabilities, doomed to our efficiencies and our inefficiencies by the activities which have made out of our native tendencies whatever we are to-day." 170 Education could aid or retard students in maximizing the potential of their "native tendencies," but little more. Heck, sounding a bit like John Dewey, argued that his program of "specialization" was more democratic than the traditional formal curriculum. Heck again followed in the footsteps of Thorndike, however, concluding that improvement in thinking was "due not to the subject, but to the original capacity of the individual." Rather than creating equality of opportunity by presenting each student with

${ }^{167}$ Edward Lee Thorndike, Educalional Psychology 2d. ed. (New York: Teachers College Columbia University, 1910), 2, 141.

${ }^{168}$ Heck, Mental Discipline, 198.

${ }^{169}$ Heck, "Citizenship in Southern Education," 384-385. Heck invoked the concept of "social efficiency" repeatedly throughout his writing.

${ }^{170} \mathrm{Heck}$, Mental Discipline, 120. A second edition of this book appeared in 1911; both editions reveal Thorndike's influence cn Heck's thinking. Thorndike performed the pathbreaking research in this area in 1901, while Heck was a graduate student at Columbia. Edward Lee Thorndike and R. S. Woodworth, "The Influence of Improvement in One Mental Function upon the Efficiency of Other Functions," Psychological Review 8 (May, July, November 1901): 247-61, 384-95, 553-64; and Thorndike, "The Opportunity of the High Schools," Bookman 24 (October 1906): 180-84. 
an identical curriculum, Heck and Thomdike viewed specialization as egalitarian because it offered each student the equal opportunity to maximize his innate potential. Thus, they amended Jefferson's idea of the best way to diffuse knowledge by making public schooling capacious enough to teach more than academic subjects. The egalitarianism of education would not be judged by each scholar's achievement beyond school, but rather how well fitted they were for the niche they occupied in the post-graduate social order. In the end, Heck's program, like Jefferson's before him, was little more than a hereditarian justification of what, in practice, would amount to a class-biased reinforcement of the social status quo. ${ }^{171}$ Heck's hereditarian tendencies received a strong boost in 1910, when he purchased Charles B. Davenport's small book Eugenics, and again when he retumed to Columbia University for a year in 1911.172 Heck would finish his doctoral coursework, begin his dissertation, and develop his eugenic convictions under the direction of his erstwhile mentor, Edward L. Thorndike.

${ }^{171}$ For a discussion of the conservative implications of this idea, as espoused by Thomdike, see Merle Curti, The Social Ideas of American Educators 8th ed. (Totowa, NJ: Littlefield, Adams \& Co, 1974), 46870. Heck argued that each subject studied in school should be eval uated according to its "intrinsic value" as determined by its "environmental importarice" and the "environmental usefulness of the specific ability developed" by the subject. In other words, subjects taught should be relevant to the child's likely career, as judged by the local environment. Hence, rural and urban schools should emphasize subjects and skills appropriate to their respective settings. Invoking a Spencerian image of curricuiar survival of the fittest, Heck claimed that "a rigid and relentless selection" should be used to determine which subjects were most relevant to the environment. Acknowledging that, "Of course, our standard is a utilitarian one. It would be wasteful and wrong to have any other," Heck attempts to diffuse the class bias by stating that, "this standard is by no means that of a narrow, materialistic utilitarianism; it simply stands for the test of usefulness to the whole person in relation to the whole environment, emphasizing especially those ethical, intellectual, and aesthetic ideals that minister to the best uses of the human spirit." Heck imbued his system with flexibility, arguing that "domestic, industrial, and commercial elements would be free to assert their value and rights in elementary education. Progressive changes in the environment would cause progressive changes in the curriculum, by the elimination of old elements, the introduction of new elements, or a redistribution of emphasis upon elernents," without ever considering the power differentials between the domestic, industrial, and commercial elements of society. Heck, Ibid., 163, 165, 156, 185.

${ }^{172}$ The University of Virginia's sole copy of Davenport's Eugenics was bequeathed to the library by Heck. Heck wrote his name, and the year he acquired the book (1910), on the inside front cover. All the first editions of Thorndike's work in the University of Virginia library also came from Heck's personal library. Many of the library's other eugenical works, like David Starr Jordan and Harvey Earnest Jordan's 1914 eugenical work War's Aftermath, bear the book-plate of Heck's personal library, which was bequeathed to the university by his widow. 
By 1910, Thomdike had spent almost a decade directly measuring and describing human cognition through statistical analyses of performance and mental testing. Thomdike joined the testing vogue that swept the American psychological community in the early decades of the century. As Mark Haller noted, Thorndike "was the most important figure in tuming American psychologists to a study of intelligence."173 "Like all progressives," Thorndike's principal biographer has noted, "Thomdike combines moral idealism and optimism with a faith in statistics and efficient organization." Indeed, his faith in quantified, experimental measurement as the basis of all "fact" and "truth" led him to the statement, "If any' virtue is worth seeking, we shall seek it more eagerly the more we know and measure it.... Of science and measurement in education as elsewhere, we may safely accept the direct and practical benefits with no risk to idealism." Thomdike's belief in the analytic power and objective veracity of statistical analysis and mental testing stemmed from his admiration of Francis Galton and Karl Pearson, the fathers of eugenics. As a result, Thomdike himself became an ardent hereditarian for the remainder of his career. ${ }^{174}$

Thorndike's hereditarianism naturally led him into the eugenics movement. He and his meritor, Columbia Psychologist James McKeen Cattell, maintained a close collaboration with Charles Davenport and organized eugenics. In 1909 Davenport selected Thomdike and Harvard psychologist Robert Yerkes, to chair the committee on the inheritance of

${ }^{173}$ Haller, Eugenics, 164. Psychologists Henry Herbert Goddard and Lewis Terman joined Thomdike as the great triumvirate of early mental testers. Haller also discusses Terman and Goddard (165-66, and 106-07). Leila Zenderland has produced the most comprehensive and snphisticated analysis of Goddard and mental testing, as well as his eugenic beliefs. See Leila Zenderland, Measuring Minds: Henry Herbert Goddurd and the Origins of American Intelligence Testing (New York and London: Oxford University Press, 1998), especially 120-42. Stephen Jay Gould discusses the checkered history of IQ testing in his Mismeasure of Man.

174Thorndike quoted in Clifford, Edward L. Thorndike, 283. Thomdike made this statement in 1921, which reflects his commitment to the salience of "objective measurement. On Thorndike and Galton, see Ibid., 290-91; Chapter 9 discusses his hereditarianism and relation to eugenics. Merle Curti's sketch of Thomdike is particularly revealing of his hereditarianism. Curti, Social Ideas of American Educators, Chapter 14. Curti notes that Thomdike's stance on specialization in education "might mean that the conservation of the past and the adjustment of the individual to existing environment would gain the upper hand at the expense of social insights and the desire and ability to participate in social reconstruction." See also Nicholas Pastore's treatment of Thomdike in, The Nature-Nurture Controversy (New York: King's Crown Press Columbia University, 1949), 65-76. 
mental traits for the eugenics section of the American Breeder's Association. Thomdike also joined the Eugenics Committee of the United States, which became the American Eugenics Society. He sat on the Advisory Council of the AES between 1923 and 1935, and chaired its committees on psychometry and formal education. Like Harvey Emest Jordan, Thomdike delivered a eugenics lecture sponsored by Mrs. Lucy Wilson in 1913. Thomdike was a charter member of Davenport's elite eugenics group, the Galton Society, founded in 1918. This group restricted its membership to fewer than 25 men and tapped the most high powered scientists, lawyers, physicians, and writers for membership. Eugenics informed all of Thomdike's writing, and he championed it as late as 1940. Ultimately, however, Thomdike's hereditarianism diverged from the simple Mendelianism of Davenport and other extreme eugenicists. Thomdike thought that, "The germinal determination of intellect, morality, sanity, energy or skill" followed a more complex pattern than simple unit inheritance. While he "dare[d] to believe that the time wili come when a human being idiotic by germinal defect will be extinct," he had "no hope that such a change can be made with the ease with which we can change short peas to tall...."175 Thorndike also equivocated when confronting the question of racial differences.

Thomdike adhered to the eugenics creed that improving the human race resulted only from "fostering its good elements and encouraging their fertility and by debarring the worse elements from reproduction or eliminating them outright." 176 And, while Thomdike

${ }^{175}$ Haller, Eugenics, 64; Donald Pickens, Eugenics and the Progressives (Nashville, TN: Vanderbilt University Press, 1968), 138-44. The history of the AES, and Thorndike's involvement in it, is covered in Earry Mehler, "A History of the American Eugenics Movement," Ph.D. diss. University of Illinois at Urbana-Champaign (1988). Thorndike's Wilson lecture is in Aldrich, Eugenics, 319-42. It was also published in The Popular Science Monthly 81 (August 1913): 125-38. For Thorndike and the Galton Society, see Haller, Eugenics, 73; and Chase, Legacy of Malthus, 165-66. Other Galton Society charter members included Madison Grant, Henry F. Osborn, Robert Yerkes, Frederick Adams Woods, and John C. Merriam of the Carnegie Institute of Washington. Thorndike invoked eugenics repeatedly in his book, Human Nature and the Social Order (New York: The MacMillan Cumpany, 1940), 442, 453-59, 878, and 938. While he eschewed Davenport's simplistic Mendelianism, hi still felt that, "Improvement of the human genes, though much slower than some enthusiasts for eugenics have represented it, is the surest means of fostering the good life; it operates at the source by producing better people" (453). See also his earlier statements in Thomdike, "Intellect and Character," 339.

${ }^{176}$ Thorndike quoted in Pickens, Eugenics and the Progressives, 141. 
believed differences existed within the entire "race," he also believed that qualitative differences existed between humanity's sub-groups or "races." Acknowledging that "race directly and indirectly produces differences so great that government, business, industry, marriage, friendship. and almost every other feature of human instinctive and civilized life have to take account of a man's race," Thomdike argued that interracial differences were small when compared to intraracial difference. ${ }^{177}$ Thus, race alone failed to be sufficient grounds for the eugenic sorting of humanity, according to Thorndike. He argued that, in any attempt to improve educational outcomes, "selection by race of original natures to be educated is nowhere nearly as effective as selection of the superior individuals regardless of race." 178 Heck's published work and his subsequent career bears the strong impress of his second encounter with Thorndike.

Harry Heck returned to Columbia in 1911-1912 to work under Thomdike. Heck's advisor exerted a controlling influence over both the subject matter and the methodologies he would pursue. Thomdike was "at the peak of his influence"; indeed, he would be named president of the American Psychological Association in 1912.179 The sole surviving letter between Heck and Alderman speaks volumes about the connections between himself and Thomdike, and their notions about eugenics, public health, and education.

Writing to President Alderman in October of 1911 , Heck noted that he was studying "Mental and Social Measurements" under Thorndike, as well as taking another unspecified course with the master. Heck told Alderman that he was also studying "the hygienic aspects of education." Working under the Bureau of Child Hygiene of the City Department 34.

${ }^{177}$ Thorndike, Individuality (Boston, New York, and Chicago: Houghton Mifflin Company, 1911),

${ }^{178}$ Thorndike, Educational Psychology, 68. Thorndike probably came by his relative racial toleration as a result of his upbringing; he was the son of a Methodist minister who preached against Slavery, and he was educated at the Methodist Weslyan College. Clifford, Edward L. Thorndike, 27. Thorndike would shift toward a more racist stance as a result of his experience with the mental testing of blacks and whites during and after World War I.

${ }^{179}$ Clifford, Thorndike, 335. 
of Health, Heck observed the medical inspection and treament of New York City School children. Beginning on the Lower East Side, Heck noted that he would "accompany different school nurses to the clinics and homes to see the children treated," and he envisioned leaming about the "State systems of school inspection in Massachusetts, Pennsylvania, and New York."180 His interest in school hygiene reflected Thomdike's own early studies of the effect of environment on performance. Moreover, Thorndike clearly dictated Heck's dissertation topic, "Studies of Mental Fatigue," and the statistical methodologies he used to generate his data. ${ }^{181}$ Heck's conclusions about the effect of fatigue on school performance parroted those of Thorndike. "The decrease in quality of work by pupils as the day advances, considered to be more or less general in schools, is mainly due," Heck wrote, "(a) to the improper ventilation, lighting, heating, seating, etc., (b) to physical defects in the children, and (c) to loss of interest by pupil and teacher in the monotonous school routines." Heck concluded that the problem of fatigue could be solved by, "sound bodies, a hygienic school, proper classification [of students], a vital and varied curriculum, and live teachers...."182 Heck's conclusions, like Thorndike's, mixed environmental and hereditary palliatives. Heck returned to Virginia in 1912 with new ideas about the role of biology in education and society.

Heck brought more than Thorndike's positivist, hereditarian approach back to the University of Virginia when he returned in 1912. The year he obtained his leave of

${ }^{180}$ William Henry Heck to Edwin Anderson Alderman, October 9, 1911, copy of letter in Armistead M. Gordon Papers, 38-145, Box 3, folder "1911 September-December," Special Collections, Alderman Library, Charlottesville. Heck had written both Gordon, President of the university's Board of Visitors, and Alderman to thank them for the year's leave of absence that was allowing his continued study. Heck's doctoral thesis was to be "a study of the effect of time of day and of fatigue upon the school work of children."

${ }^{181}$ Heck acknowledged Thomdike's influence explicitly, writing "I am greatly indebted to Dr. Edward L. Thomdike, Teachers' College, Columbia University, for many suggestions regarding this work. The summaries of experiments on Fatigue in his Educational Psychology, vol. iii...render unnecessary any bibliographical discussion in this monograph." William Henry Heck, Studies of Mental Fatigue (Lynchburg, VA: J. P. Bell Company, Incorporated, 1914), 4. Thorndike cited Heck and noted that Heck used his methods in Educational Psychology, vol. iii, 94-96, and 393.

${ }^{182}$ Heck, Ibid., 38. 
absence to attend Columbia, he offered a new course, "Education $\mathrm{Cl}$ : Principles of

Education." The University Record described the course as, "A summary of present educational theory and practice.... Theories of organic evolution are outlined and discussed in their influence on theories of education. Texts supplemented by parallel reading." Upon retuming from Columbia in 1912, he offered this course again. For the 1913-1914 school year, however, Heck retitled the course to "Education C1: Evolution, Heredity, and Education." The description broke the course down into its three-term divisions: "First term, stages and factors of organic evolution; second term, heredity and eugenics; third term, biological aspects of education." 183 One student recalled that the course "was unique in subject matter," and that, "The purpose at every stage was to discuss man philosophically." After the "systematic development of the doctrine of organic evolution," the course continued with "a detailed consideration of the principles of heredity and eugenics," culminating with "the discussion of certain biological and sociological questions, with special reference to education." 184 For the first time in the history of the University of Virginia, eugenics explicitly entered the curriculum, shaping students' philosophical debate over human nature and education's effectiveness in molding humankind. The Eugenical News reported Heck's teaching of eugenics in its 1916 survey of college and university courses in genetics and eugenics. ${ }^{185}$

"As a teacher," one faculty member remembered, "Professor Heck was a pioneer." His course in the biological and eugenic foundations of education "was duplicated in no other university in the United States." Heck was known for presenting both sides of an argument and challenging his students "to constructive and critical thinking for

183University of Virginia, University Record (Charlottesville, VA: Michie Company, 1911), vol. 5, Catalogue 1911-1912. [Hereinafter referred to as Catalogue (year), page number.] Alderman Library maintains complete sets of the University Record from the late-19th century to the present. In 1916-1917, Heck changed the course title to "Biological Foundations of Education." He reported this course, and the summer school's "Heredity and Education" to Charles Davenport in 1916. See University of Virginia Questionnaire, "Eugenics and Genetics in Colleges, \#1" folder, Davenport Papers.

${ }^{184}$ Stanley C. Moulton quoted in Lewis, "William Henry Heck," 372.

${ }^{185}$ See "College Courses in Genetics and Eugenics," Eugenical News 1 (April 1916), 27. 
themselves." As a result, his classes did not attract masses of students; however, "those who came in contact with his teaching were always profoundly impressed by it." His students remembered him as "a striking figure in the class-room," "brilliant" with a "fearless devotion to the truth." Heck's "great love of truth" led to his "burning desire to see things as they are regardless of consequences...." Lacking the obscuring lens of sentimentalism, Heck "unflinchingly faced facts and the most valid conclusions that could be drawn from them. Neither tradition, nor personal comfort, nor fear of popular disapproval seemed to stand in his way in his pursuit of truth and the presentation of the truth as he saw it. He had the true instincts of a scientist." This description of Heck's dogged pursuit of "scientific truth" not only reflects the influence of his mentor's philosophy, but it also echoes the realist rhetoric that other eugenicists used about themselves. Constantly claiming to be objective, neutral observers of society, eugenicists claimed that "facts" and "truth" motivated their "unsentimental" policy nostrums-whether extolling careful mate selection or compulsory sterilization. ${ }^{186}$ Heck, however, balanced his hereditarianism with attention to the salience of environmental factors.

Heck pioneered in both eugenic and euthenic interventions. For all that he emphasized the biological basis of education, he also argued for the improvement of school hygiene. He was "universally recognized in the State as 'the leading exponent to the people of Virginia of the most modern principles of the hygiene of school life and the sanitation of school buildings,"' noted a colleague. Heck's experience in graduate school and as a surveyor for the GEB convinced him of the need for better hygiene in southern schools. "He believed in his mission so strongly, that he felt it to be his mission to carry the doctrine

\footnotetext{
${ }^{186}$ Professor of secondary education Charles G. Maphis wrote of Heck, "No professor in the University left a profounder impression on his students." Maphis quoted in Lewis, "William Harry Heck," 381. Both Merle Curti and Geraldine Jonçich Clifford noted Thomdike's dedication to "scientific truth," although Curti sees it as a cipher for Thomdike's "own unconscious participation in the prejudices of our own time" while Clifford views Thomdike as an unsentimental realist. Curti, Social Ideas, 498; and Clifford, Thorndike, $375-76$
} 
of better conditions for school children to as many teachers as possible."187 To spread his gospel, Heck taught an extra course for teachers during each summer session, in addition to his lecturing around the state. Thus, he continually propagandized on behalf of improving the environment to ensure that each child could maximize her or his hereditary potential through schooling. Heck thus mirrored Harvey Emest Jordan's rating of environment and heredity as co-equal essentials, with heredity ultimately deciding the limits of individual potential. Heck's emphasis on the role of schools in providing both a sanitary physical environment and student training in personal hygiene married public education and public health, providing medical therapeutics simultaneously with the "social therapeutics" of education. In an eminently efficient manner, children could be taught all the cognitive skills required of good citizens, as well as the necessary hygienic skills to insure that they would remain healthy "human capital" and not become sickly public charges.

Ironically, Heck would himself fall victim to the largest epidemic in United States history, the great influenza pandemic of 1919. The vigorous young Heck, like millions of others world-wide, died on January 4, 1919 at age 39 . His teaching outlived him in the state through the careers of numerous Virginia teachers and school administrators. Within the University, his course Education B1 would be reconstructed. The year after Heck's death, hereditarian psychologist George Ferguson would begin to offer "Education B6: Mental Tests" and "Education C1: Advanced Education Psychology" which focused on individual and group differences. During the summer terms, Ferguson would offer courses in "Individual and Group Differences" and "Mental Deficiency," cornerstone concepts of eugenics. Ferguson's course emphasized, "The value and amount of differences among individuals and groups due to such factors as race, sex, heredity, environment, maturity. Methods of adjusting school organization to individual

${ }^{187}$ Charles G. Maphis quoted in Lewis, "William Harry Heck," 381. 
capacities." 188 Ferguson would continue to teach eugenic notions through his education and psychology courses, focusing particularly on the relative intelligence of whites and blacks, as will be discussed in the next chapter. As a self-contained subject, evolution and eugenics would be taken up by Heck's memorialist, Professor of Biology Ivey Foreman Lewis in his course "Biology B5: Evolution and Heredity" which would eventually become "Biology $\mathrm{Cl}$ : Evolution, Heredity, and Eugenics." Lewis, one of the most outspoken eugenicists in Virginia's history, was chairman of the Miller Schocl of Biology, and President Alderman's close advisor and confidant.

The attractive new explanations offered by eugenicists first captured the elite institutions and then effectively created generations of students who were literally taught to think about the world along eugenic lines that buttressed the status quo (Gramscian hegemony). Virginians came to accept the southern culture of segregation as the natural ordering of the world along lines delineated by biological law. As eugenics simultaneously won over professionals and students as a way of instantiating their social position (as members of the elite), eugenics rose to its highpoint in Virginia. In order to trace this development, we must consider first how eugenics developed in the educational structure; then we can tum to the eugenical influence in and impact upon Virginia's professional, political, and social structures. The next two chapters develop these issues, explaining the momentum that the eugenics movement gained -- a momentum that would carry over long-past the time that other institutions abandoned eugenical reasoning.

188University Record 1919-1920, 113-114; and University Record 1920-1921, 26. Ferguson began his summer courses in 1921. 


\section{Chapter III: "Defending the Thin Red Line": Academics and Eugenics}

"The dawn of peace and the new year find the principles of eugenics more strongly than ever entrenched upon the field of science and ready to play their role in national reconstruction," Harry Hamilton Laughlin announced in the January 1919 issue of the Eugenical News. According to Laughlin, organized eugenics needed to pursue four major goals to assume its proper place guiding post-war social development. Immigration policy, the efficient retrofitting of soldiers to appropriate peace-time jobs that capitalized on their special training, improving the management of the "socially inadequate" classes, and increasing the availability of eugenic education were the tasks Laughlin set before his audience. Toward this final goal, "In constructive or aristogenic eugenics," Laughlin crowed, "one after another our colleges are offering instruction in genetics and eugenics."1 The University of Virginia was among those institutions steadily increasing the amount of eugenic instruction available to college and professional students.

Increasing the number of professionals training the next generation of elites in eugenic thought provided the surest path to "appropriate" eugenic popularization. For eugenics to become truly effective, it had to reach a specific segment of the population. College and professional students became the target of eugenics proselytizers. These individuals' educational status certified their genetic worthiness. The likelihood that they would assume positions in the social, political, and economic elite justified the expenditure of effort in educating them. If eugenics supporters were to achieve their programmatic goals of immigration restriction, sterilization, marriage restriction, and race, gender, and class segregation - all of which depended upon legislative enactments - they would need to gain converts among influential Americans. It would be these individuals who would defend America's genetic heritage, "that 'thin red line' tipped with genius which is ever growing

\footnotetext{
${ }^{1}$ Harry Hamilton Laughlin, ed., "1919," Eugenical News 4 (January 1919): 4-5.
} 
thinner, and which is all that ever stands between any nation and its doom." 2 The urgent necessity of this mission was not lost on Virginia eugenicists.

This chapter explores the increasing entrenchment of hereditarian and eugenic thought in Virginia's educational institutions between 1915 and 1930. The proliferating number of instructors teaching eugenics in Virginia increased the ties between Virginia academics and nationally and internationally renowned eugenicists. Cooperating within Virginia, these individuals established a web of affiliation. The mesh of this net became finer and finer with each additional believer, increasing the number of converts captured by eugenics' attractive ideology. The institutionalization of eugenics in Virginia reflects both the national trend and Virginia's particular conditions. Between 1914 and 1928 the number of colleges teaching eugenics skyrocketed from 44 to 376 , with an estimated enrollment of almost 20,000 students. $^{3}$ Virginia colleges and universities mirrored this growth, with more instructors devoting more course time to eugenics throughout this period. Moreover, the permeation of eugenics into teacher training and teacher continuing education, hereditarian theories seeped into the high school curriculum. The infusion of eugenics into Virginia's educational structure highlights how eugenical theory, as taught in schools, ensured the influence of hereditarian social policy for generations to come. Eugenics spread throughout the curriculum, entering through the established portals of education and medicine, and gaining access through courses in biology, psychology, sociology, law, and even English literature.

The growth of Virginia's eugenics intelligentsia did not occur in a vacuum. Just as Mark Haller identified the period from 1905 to 1930 as the hey-day of the national eugenics

\footnotetext{
${ }^{2}$ Albert E. Wiggam, The Nern Decalogue of Science (Indianapolis, IN: The Bobb-Merrill Company, 1922), 174-75. The "thin red line," expropriated from British military imagery, here recalled the red "bloodlines" of families that had contributed America's leaders.

${ }^{3}$ Selden, "Educational Policy and Biological Science: Genetics, Eugenics, and the College Textbook, c. 1908-1931," Teachers College Record 87 (Fall 1985): 42; Hamilton Cravens, The Triumph of Evolution: American Scientists and the Heredity-Environment Controversy. 1900-1941 (Philadelphia: University of Pennsylvania Press, 1978), 53.
} 
movement, so too Virginia, operating perhaps a step behind the national leadership, experienced a rising tide of eugenic activity between 1915 and World War II. As the last chapter explained, Virginia's initial eugenic impulse emerged directly from the southem progressive impulse and concomitant scientific developments. This chapter begins by revealing how academic eugenics developed against the background of World War I and the post-war backlash against modernism and science. This environment created the social and intellectual context in which eugenics became a viable response to tensions straining Virginia and America's social fabric. Resolving the focus from social context to individual scholars, the chapter then examines the careers of the "second wave" of University of Virginia eugenicists. Additions to the medical, biological, psychological and sociological faculties increased the breadth of Virginia's eugenic offerings. Indeed, so many instructors began teaching eugenics that Mr. Jefferson's "Academical Village" fairly transformed into the "Eugenical Village."

Finally, Virginia eugenicists were not confined to the University of Virginia's faculty. Throughout this period, instructors at other state colleges and professional schools began to declare their adherence to the eugenics creed. By 1927 there were enough eugenicists scattered around the state that the American Eugenics Society could establish a state committee on eugenic education. The chapter concludes by describing the efforts of these other Virginia eugenicists, developing the ties that bound them to their colleagues at the University of Virginia and on the national stage. This network of association created the mesh that facilitated and reinforced the mobilization for the social policy initiatives discussed in the rext chapter.

\section{The Rising Tide of Eugenics}

The University of Virginia would undergo a renaissance between 1915 and the Great Depression. Riding the surging wartime economy with the rest of the nation, Virginia 
experienced increased enrollment, expansion of facilities, and additions to the faculty.

After the war, despite the downtum in the southem economy, Virginia's enrollment continued to rise and the university obtained increased funding from the usually parsimonious legislature. ${ }^{4}$ These indicators of the triumph of progressivism existed, however, under the lingering shadow of World War One. For many intellectuals, the war represented the imminent downfall of western civilization. "Efficiency," "science," and "management," the watch-words of the Progressive Era, seemed to transform war from a noble enterprise among "honorable" gentlemen into an unfeeling mill that chumed out mass-produced death and destruction.

Eugenicists had wamed of the impending doom both before and during the war. On the eve of the Great War, Virginia's professor of histology and embryology, Harvey Emest Jordan, co-authored War's Aftermath: A Preliminary Study of the Eugenics of War with Stanford University's chancellor David Starr Jordan, a famed ichthyologist, pacifist, and avid eugenicist. Comparing the effect of the Civil War on the American South and the war between Macedonia and Turkey on the Balkan states, this book "proved" the dysgenic effect of warfare. Belligerent nations enlisted the most fit men as leaders and warriors, leaving the physically and mentally "defective" at home. The result, as David Starr Jordan wrote, was that, "The sons of those whom war could not use replace those who gave their lives for the country. When a man of distinction gives up his life for any cause he sacrifices more than himself. He closes the door of the long future of those who might have been." 5 The consequences of sacrificing the "flower of manhood" during the Civil

\footnotetext{
${ }^{4}$ Philip Alexander Bruce, The History of the University of Virginia 1819-1919: The Lengthened Shadow of One Man (New York: The Macmillan Company, 1920), Vol. V. This new prosperity is also evident throughout the President's Papers from this period. The administration still struggled to hold Virginia to a higher standard, but, as compared to years gone by, it was apparent they were succeeding.

5 David Starr Jordan and Harvey Emest Jordan, War's Aftermath: A Preliminary Study of the Eugenics of War (Boston and New York: Houghton Mifflin Company, 1914), xviii-xix. David Starr Jordan was one of the founding members and the first chairnan of the American Breeder's Association's Committee on Eugenics, alongside Charles Davenport. Mark Haller, Eugenics: Hereditarian Attitudes in American Thought (New Brunswick, NJ: Rutgers University Press, 1963), 62-63. See also Donald Pickens' sketch
} 
War were evident everywhere one looked in the backward and benighted south. The

present war in Europe promised a eugenic threat to America, too. People displaced by the ravages of war, the dregs of society deemed unfit to fight and die, would try to flee the destruction, emigrating to America. Eugenics became the leading-edge of a rising wave of nativism that crested in 1924 with the enactment of Representative Albert Johnson's Immigration Restriction Act. 6

Both academic journals and more popular high- and middle-brow books trumpeted the eugenic threat facing America. The Journal of Heredity, successor to the American Breeder's Magazine as American eugenicists' journal of record, ran numerous articles concerning the eugenic implications of the war and the wave of immigration that would "inevitably" follow. ${ }^{7}$ In June 1916, ten months before the United States entered the war, the fledgling Eugenical News began to run stories concerning the eugenic implications of

of D. S. Jordan in, Eugenics and the Progressives (Nashville, TN: Vanderbilt University Press, 1968), 5964.

${ }^{6}$ Although the bill bears Johnson's name, it was really the product of a collaboration between American eugenicists and nativists. Although a discussion of this bill and its origins is a staple of eugenics and immigration scholarship, the best treatment remains unpublished. Frances Janet Hassencahl, "Harry H. Laughlin, 'Expert Eugenics Agent' for the House Committee on Immigration and Naturalization, 1921-1931" (Ph.D. dissertation, Case Western Reserve University, 1970). For a detailed discussion of the rise of racist nativism in the 1920s culminating in immigration restriction, see Thomas Gossett, Race: The History of an Idea in America, 2d ed., (New York and Oxford, Oxford University Press, 1997), chapter 15. John Higham tends to minimize the role of eugenicists, preferring to focus on the battles between nativists (who were, to a man, members of eugenic organizations, if only for instrumental reasons) and organized business. See John Higham, Strangers in the Land: Patterns of American Nativism, 1860-1925, 3d ed., (New Brunswick, NJ: Rutgers University Press, 1992), 149-53, especially 152-53. For standard discussions by historians of eugenics, see, Diane B. Paul, Controlling Human Heredity 1865 to the Present (New Jersey: Humanities Press, 1995), chapter 6; Daniel J. Kevles, In the Name of Eugenics: Genetics and the Uses of Human Heredity (New York: Alfred A. Knopf, 1988), 96-97; and Haller, Eugenics, chapter 10; and Kenneth M. Ludmerer, Genetics and American Society: A Historical Appraisal (Baltimore and London: The Johns Hopkins University Press, 1972), 95-113.

${ }^{7}$ See, "War and Biology," The Journal of Heredity 6 (February 1915): 51-53; "War's Aftermath," (review of Jordan and Jordan's book) JOH 6 (September 1915): 404-07; "The Effect of War," (review of book by D. S. Jordan) JOH 7 (March 1916): 118; "War Hurts Scientific Breeding Abroad," JOH 7 (April 1916): 168; "War, Immigration, Eugenics," (report of the Committee on Immigration) JOH 7 (June 1916): 243-48; "Emigration After the War," JOH 7 (October 1916): 477; "Immigration after the War" JOH 8 (April 1917): 147; "Some Eugenic Aspects of Military Registration," JOH 8 (July 1917): 298; "Eugenics and Military Exemptions," JOH 8 (August 1917): 360; "America's Fighting Stocks," JOH 8 (October 1917): 435-41; "Kaiserism and Heredity," and "Effect of War on Crime, Marriage and Insanity," JOH 9 (December 1918): 348-54 and 365-67; "The Fighting Ability of Different Races," JOH 10 (January 1919): 29-32; "War and Genetic Values," JOH 10 (May 1919): 223-26. 
the war. ${ }^{8}$ Madison Grant released his best-selling book The Passing of the Great Race in October of 1916. Grant's book, a paean to the racial supremacy of the "Nordics" from northeastem Europe, wamed that racial intermingling inevitably led to the destruction of civilization because contact between races always resulted in either warfare or miscegenation. This theme resonated in all sections of America. Southemers worried about their contact with blacks, northerners becarne apprehensive over the increased number of white-ethnic immigrants in their midst, while the West continued to worry about their contact with Asian, Mexican, and to a lesser extent Native American populations.

Moreover, Grant announced a new theme that would become a hot topic of discussion in scientific circles during the early post-war years. In conformity with Charles Davenport and other strident eugenicists, Grant argued that heredity determined both physical and psychological characteristics. Extending this analysis, he contended that heredity "has a most important bearing on the theory of democracy and still more upon that of socialism, and those engaged in social uplift and in revolutionary movements are consequently usually very intolerant of the limitations imposed by heredity." Since democratic governments rested upon equalitarian "dogmas" that assumed "environment and not heredity is the controlling factor in human development," Grant felt that most Americans had lost sight of the power of heredity in dictating the terms of the social contract. "The laws of nature operate with the same relentless and unchanging force in human affairs as in the phenomena of inanimate nature, and the basis of the government of man is now and always has been, and always will be, force and not sentiment, a truth demonstrated anew by the

\footnotetext{
${ }^{8}$ The Eugenical News began in January 1916 as a monthly newsletter published by Charles Davenport's ERO, edited by Harry Hamilton Laughlin. It would become the "Official Organ" of the American Eugenics Society, the Eugenics Research Society, and the Galton Society; it also allied itself with the British Eugenics Review. "The Dysgenic Force of War," Eugenical News 6 (June 1916): 43, reported an article from the Eugenics Review. The November 1917 issue ran "Mental Strain of War," "The War and the Race," "Regeneration From War," Eugenical News 2 (November 1917).
} 
present world conflagration."9 Power, according to Grant, naturally' and appropriately devolved to those most genetically equipped to exercise it; democracy was a chimera.

This "crisis of democratic theory," as historian Edward A. Purcell, Jr. has termed it, flourished throughout the 1920s and 1930s. ${ }^{10}$ As Purcell notes, scholars and "pseudoscholars" produced rafts of publications debating the viabiiity of democracy in America. Many of these works relied on biology and race to explain defects in American democracy. Not coincidentally, these individuals—scholars and pseudoscholars alikeoverlapped organizationally as well as ideologically. Coming to the debate from different academic disciplines, all of these individuals held membership in eugenic organizations.

No scientific discipline did more to highlight the perceived problems with democracy than did psychology. Mental testing experiments by America's most prominent academic psychologists-Robert M. Yerkes, Edward L. Thorndike, Henry H. Goddard, William McDougall, and Carl C. Brigham—fueled the crisis. Yerkes directed the now infamous mass-administration of intelligence tests to some 1.75 million army inductees during the war. ${ }^{11}$ Yerkes's analysis of the results sparked a firestorm among American

\footnotetext{
${ }^{9}$ Madison Grant, The Passing of the Great Race: Or, The Racial Basis of European Hisiory (New York: Charles Scribner's Sons, 1916), xv-xvi. The questioning of democracy outstripped the eugenics movement. Walter Lippman, who was a critic of eugenics, nevertheless shared in the general concern over the fate of democracy in America. His books Public Opinion and The Phantom Public slowly undermined faith in the democratic process and held forth the hope of government by enlightened elites-a vision of government wholly embraced by eugenicists. The relationship between heredity and democracy elicited its own firestorm within the pages of the Journal of Heredity, a debate contributed to by Madison Grant and Edward Grant Conklin, following the publication of Alleyne Ircland's "Democracy and the Accepted Facts of Heredity." See Alleyne Ireland, "Democracy and the Established Facts of Heredity," Journal of Heredity 9 (December 1918): 339-43; Walter Sonneberg, "Biology and Politics," Journal of Heredity 10 (March 1919): 139-41; Edwin Grant Conklin, "Heredity and Democracy"; Madison Grant, "Discussion of the Article on Democracy and Heredity"; Prescott F. Hall, "Aristocracy and Politics"; and Frederick Adams Woods, "The Racial Limitation of Bolshevism," Journal of Heredity 10 (April 1919): 161-68, 188-91. On Lippmann, see Edward A. Purcell, Jr., The Crisis of Democratic Theory: Scientific Naturalism \& the Problem of Value (Lexington, KY: The University Press of Kentucky, 1973), 104-07; and Ronald Steel, Walter Lippman and the American Century (New York: Vintage Books, 1980), chapters 14, 17, and 18.

${ }^{10}$ See note 9 , above. Purcell explores how the application of scientific naturalism to society-by social scientists, political scientists, and legal scholars undermined the traditional Enlightenment justifications for American democracy. Destabilizing democratic theory precipitated an ideological crisis that was not resolved until after WWII, when a backlash against naturalism and totalitarianism reestablished democratic theory as an a priori norm for "good" government.

${ }^{11}$ The results and ramifications of the Army Alpha and Beta intelligence tests are staples in the history of psychology, immigration, and eugenics. Particularly useful discussions are presented in Steven Jay
} 
psychometricians. ${ }^{12}$ Predictably, given the context of the times, Yerkes's conclusions reaffirmed the hereditarian basis of intelligence. Perhaps equally predictable was the conclusion that whites were far superior to blacks in intelligence. What alarmed investigators and the public, however, was the finding that the average mental age of inductees rose just above the clinical definition of a "moron" at 13.08 years. This led Harvard psychologist William McDougall to ask, in the title of his 1921 book, Is America Safe for Democracy? McDougall, like many others, doubted that such a mentally dense population could handle the electoral responsibilities of citizenship. ${ }^{13}$

Carl C. Brigham's A Study of American Intelligence, released in 1923, exacerbated the fears about democracy's viability. Brigham, one of Yerkes's lieutenants during the army testing, married the quantitative conclusions from the army tests to the racial theories of Madison Grant. ${ }^{14}$ Brigham's entire argument devolved to a few simple, unnerving statements. "According to all evidence available, American intelligence is declining, and will proceed with an accelerating rate as the racial admixture becomes more and more extensive. The decline of American intelligence will be more rapid than that of the intelligence of European national groups, owing to the presence here of the negro." The only way to stop American declension, then, was through eugenic protection of the superior gene pool: immigration restriction and "the prevention of the continued propagation of defective strains in the present population" by limiting procreation and

Gould, The Mismeasure of Man (New York: W. W. Norton and Company, 1981; revised and expanded edition, New York: W. W. Norton and Company, 1996), 222-63 (page references are to revised and expanded edition]; and Alan Chase, The Legacy of Malthus: The Social Costs of the New Scientific Racism (New York: Alfred A. Knopf, 1977), chapter 10.

${ }^{12}$ National Academy of Sciences, Memoirs of the National Academy of Sciences (Washington, D.C.: National Academy of Sciences, 1921), vol. 15, Psychological Examining in the United States Army, Robert M. Yerkes, ed. Yerkes lengthy and technical tome, almost 900 pages in length, did not reach a wide popular audience. His protégé Carl C. Brigham's work, discussed below, distilled the results and amplified their racial implications in 210 pages easily accessible to the non-specialist.

13William McDougall, Is America Safe for Democracy? (New York: Charles Scribner's Sons, 1921).

${ }^{14}$ Carl C. Brigham, A Study of American Intelligence (Princeton: Princeton University Press, 1923). The best account of the genesis of Brigham's study, and his ultimate repudiation of its conclusions, is in Chase, Legacy of Malthus, 264-73, 321-22. 
miscegenation through sterilization, marriage restriction, and segregation of the unfit from the fit and between the races. ${ }^{15}$ Free of the technical jargon of Yerkes's ponderous tome, Brigham's work gained a wide popular audience and influenced the writings of the "pseudoscholars."

Theodore Lothrop Stoddard would today be considered an "independent scholar." Stoddard held a Harvard doctorate in history and a Harvard law degree, but not a university position. He made his living as a popular author and itinerant lecturer. Stoddard's bestselling books, The Rising Tide of Color Against White World-Supremacy, Revolt Against Civilization: The Menace of the Under-Man, and Re-Forging America spread the racial and eugenic ideas of men like Grant, Yerkes, and McDougall like wildfire. ${ }^{16}$ An avowed white supremacist, Stoddard rallied nervous Americans to his banner, becoming popular enough to be parodied in F. Scott Fitzgerald's The Great Gatsby. 17 Stoddard fanned the flames of intolerance-nativism, racism, and anti-radicalism—and spawned a host of alarmist imitators, including Alfred E. Wiggam. Wiggam equated religion and eugenics in his $A$ New Decalogue of Science, and lectured to thousands of audiences throughout his career. $^{18}$

Virginia even had it own version of Stoddard and Wiggam, Earnest Sevier Cox. A real-estate agent by profession, and self-trained ethnologist and black repatriationist by

$15_{\text {Brigham, American Intelligence, } 2 \mathrm{i} 0 .}$

${ }^{16}$ Lothrop Stoddard, The Rising Tide of Color Against White World-Supremacy (New York: Charles Scribner's Sons, 1920); Revolt Against Civilization: The Menace of the Under-Man (New York: Charles Scribner's Sons, 1922); Re-Forging America: The Story of Our Nationhood (New York: Charles Scribner's Sons, 1927).

${ }^{17}$ F. Scott Fitzgerald, The Great Gatsby, New Edition, (New York: Simon and Schuster, 1995), 1718. Fitzgerald's work itself is an extended rumination on the nature/nurture debate that betrays the currency of eugenic thought in 1920s America. A recent dissertation explores these issues, particularly with regard to Emest Hemingway, Hilda Doolittle, and F. Scott Fitzgerald. See Betsy Lee Nies, "Eugenic Fantasies: Racial Ideology in the Literature and Popular Culture of the 1920s," (unpublished Ph.D. diss., University of Florida, 1998).

${ }^{18}$ Alfred E. Wiggam, A New Decalogue of Science (New York: Bobbs-Merrill Company, 1922) married Protestant Christianity and eugenics, proclaiming, "had Jesus been among us, he would have been president of the First Eugenics Congress" (Wiggam, 110). In 1917 alone, at the beginning of his career as a eugenics popularizer, Wiggam addressed 86 groups on the Chautauqua circuit. Eugenical News 3 (January 1918): 5. 
avocation, his book White America went through four editions between 1923 and 1937. He dedicated his life and his income to announcing the eugenic dangers of black/white intermingling in speeches, pamphlets and books. ${ }^{19}$ Like Wiggam, he felt that popular education was the key to salvation. Other men agreed, but felt that education should be focused on those most likely to benefit from it - the eugenically-fit upper classes pursuing higher education. These individuals would most likely rise to positions of power and authority; movement leaders sought to tap their genetic and political potential. Many eugenicists believed that the best way to reach these rising leaders, ensuring the perpetuation of eugenics, the attainment of eugenic public policy, and the defense of civilization, was to make sure eugenics found a prominent place in the college curriculum.

\section{Mr. Jefferson's Eugenical Village}

Throughout the late-1910s and 1920s, Edwin Alderman found himself swept along by the surge of scientific racism. In 1909 he hosted Stanford University's Chancellor David Starr Jordan as he toured the South. It is likely that it was this visit that prompted Jordan to conduct the study that resulted in War's Aftermath. Discussions between David Starr Jordan and Harvey Eamest Jordan regarding the eugenic condition of the South may well have alerted Alderman to the significance of eugenics to southern social policy. ${ }^{20}$ Alderman's desire for social uplift led him to join a number of groups freighted with eugenics supporters. As the leading progressive in the South, Alderman was constantly asked to serve on the boards of various reform organizations. In 1915, Clifford Beers, the

\footnotetext{
${ }^{19}$ Eamest Sevier Cox, White America (Richmond, VA: White America Society, 1923). The story of Cox's career, his books, and his ties to the Virginia eugenics movement will be related in chapters 4 and 5 .

${ }^{20}$ Charles Davenport may have introduced the two Jordans at an earlier date. Alderman frankly anticipated Jordan's visit, writing, "It will be most delightful and agreeable to me if you can stop off at Charlottesville on Thursday....I shall be most delighted to have you see the institution, and for our people to know you. Alderman to David Starr Jordan, January 3, 1909, President's Papers, RG 2/1/2.472, subseries II, Box 6, "J" folder. [Hereinafter cited as, folder title, Box number, President's Papers, three-digit suffix, subseries number.]
} 
famed mental health reformer, approached Alderman to join the board of the National

Committee for Mental Hygiene. Alderman joined such eugenics supporters as Lewellys F.

Barker, G. Alder Blumer, Walter Fernald, Irving Fisher, David Starr Jordan, Gifford

Pinchot, and William Henry Welch, in supporting Beers project. ${ }^{21}$ Records indicate that

by 1930 , just before his death, Alderman had ties to The Aristogenic Association. This

group of elite Americans believed that, "[white] Race survival and advance depend much

on leadership ... The study and understanding of the biological characteristics of leaders is

therefore of importance." Founders of The Aristogenic Association included Lewellys

Franklin Barker, David Starr Jordan, Albert E. Wiggam, and the ubiquitous Charles B.

Davenport and Madison Grant. 22

Familiar with eugenics through his associations, the press, "high-" and "mid-brow"

journals like The Literary Digest and The American Mercury, and works of non-fiction and

fiction,

Alderman moved closer to the main-line eugenics creed. ${ }^{23}$ It appears that he, like many

${ }^{21}$ Clifford Beers to EAA, February 8, 1915, "B" folder, Box 1, President's Papers, .472, subseries IV. Barker was one of Welch's chief lieutenants at the Johns Hopkins School of Medicine, and advocated a moderate eugenics. See his "Foreword," in Morton A. Aldrich, et. al., Eugenics: Twelve University Lectures Mrs. Huntington (Lucy James) Wilson, ed. (New York: Dodd, Mead and Company, 1914), xi. William Welch was a principle advisor during the founding of the Eugenics Record Office. See the ERO Board of Directors Minutes, 1910-1917, Charles Benedict Davenport Papers, American Philosophical Society Library, Philadelpnia. For Blumer's eugenics see Ian Dowbiggin, Keeping America Sane: Psychiatry and Eugenics in the United States and Canada, 1880-1940 (Ithaca, NY and London: Comell University Press, 1997); Nicole Hahn Rafter, Creating Born Criminals (Urbana and Chicago: University of Illinois Press, 1997), 156-59, 198-99. Pinchot's eugenic career and David Starr Jordan's eugenic teaching are detailed in Gray Brechin, "Conserving the Race: Natural Aristocracies, Eugenics, and the U.S. Conservation Movement," Antipode 28 (1996), 236, 241 note 13. Ali except Blumer served on the advisory board of the American Eugenics Society. See Barry Alan Mehler, "A History of the American Eugenics Society, 1921-1940," (Ph.D. diss., University of Illinois at Urbana-Champaign, 1988), 307-10.

${ }^{22}$ Correspondence remains in "A (2)" folder, Box 1, President's Papers, .491, subseries I. The Eugenical News defined "aristogenics" as occurring when "Superior endowment occurs by the segregation of factors in the crossing of aristogenic strains." Eugenical News 3 (September 1918): 71.

${ }^{23}$ Eugenics made its way into World's Work, one of the progressive journals in which Alderman published, as well as the mass-circulated Good Housekeeping, where President Coolidge argued that "Biological laws tell us that certain divergent people will not mix or blend," and then when on to espouse the eugenic arguments for immigration restriction. See M. P. Daggett, "Women: Building a better race," World's Work (December 1912); and Calvin Coolidge, "Whose counry is this?" Good Housekeeping 72 (February 1921): 14. In letter of recommendation, Alderman often invoked the language of eugenics. Of a 
other well-read Americans, consumed the works of Madison Grant and Lothrop Stoddard.

Stoddard sent Alderman a complimentary advance copy of his book Re-Forging America:

The Story of Our Nationhood, in April of 1927. Stoddard characterized his book as a survey of "the problems of national reconstruction which confront us." $24 \mathrm{He}$ argued that the Civil War, immigration, and the "negro problem" all conspired to "destroy our [American] ideals, our culture, our very nationhood itself". Rather than the pessimism of Grant's Passing of the Great Race, Stoddard's book fairly oozed optimism. Thanks to Grant and others, Americans "awoke to the peril and are to-day engaged in the inspiring task of fulfilling the early promise of American life." Stoddard envisioned the creation of a "like-minded" American resolve dedicated to preserving the values of the Founders through immigration restriction and racial segregation. To solve the "negro problem," Stoddard advocated "Bi-Racialism - a parallel evolution of white and negro race lives, biologically distinct, yet bound together by mutual interests and co-operating amicably for common ends," a sort of biologically-framed Atlanta Compromise. Throughout his discussion Stoddard hammered the same term favored by Alderman in discussing race relations"constructive adjustment." 25

Stoddard sent his book to Alderman because, "As a leader of Southem thought you will, I believe, be interested in my interpretation of our national problems and the South's vital part therein." Alderman thanked Stoddard for "thinking of me so kindly," and then gushed that, "I have read, I think, practically all of your books except the one entitled

young woman Alderman wrote, "He [her father] belongs to the best blood there is in the South and this young woman, both on her father's and mother's side comes of the best stock in this region of America." Edwin Anderson Alderman to Miss Mina Hall, 1928, "W" folder, Box 3, President's Papers, .472, subseries VIII.

${ }^{24}$ Lothrop Stoddard to EAA, April 23, 1927, "1925-1927 Miscellaneous" folder, Box 21, President's Papers, .472, VII.

${ }^{25}$ Lothrop Stoddard, Reforging America: The Story of Our Nationhood (New York: Charles Scribner's Sons, 1927), vii, 310-311, and chapter 12. 
'Scientific Humanism', and I have found them full of stimulation, suggestion, and thoughtful interpretation of the national movement and the national spirit."26 Alderman did not come to Stoddard's work unprepared, however. His faculty and outside associations doubtless introduced him to these ideas and instructed him in their veracity and utility. ${ }^{27}$

Alderman hired the first professor in a succession that would become the "second wave" of eugenics teachers at Virginia, in 1915. These individuals complemented the work of Harvey Emest Jordan and William Henry Heck. They began to weave the associational network that would control eugenics state-wide. Upon Heck's death in 1919, these new advocates directed the work in eugenics toward a more mainline position. While Heck himself had been an avowed hereditarian, all remaining sources indicate that he presented the "facts" of eugenics as an open question. Heck somehow managed to hew to the hereditarian creed without seeming dogmatic to his students. The other men and women comprising the second wave felt no such compunction to skepticism. They presented hereditarianism as the preeminent force guiding human life. Eugenics, therefore, became the only viable human intervention into social conditions. Directed evolution was, for these folks, social reform. "Social engineering" offered the only sure path to progress. The interaction between Jordan and this new faculty cohort homogenized and concentrated eugenic teaching at Virginia, increasing persuasive strength.

The addition of five men and one woman, in particular, was enough to shift the university's center of gravity toward the hereditarian camp. Ivey Foreman Lewis (biology), Robert Bennett Bean (anatomy), George Oscar Ferguson (psychology), Lawrence Thomas Royster (pediatrics), Adelaide A. Mayo (riursing), and Orland E. White

26Lothrop Stoddard to EAA, April 23, 1927; and EAA to Lothrop Stoddard, April 25, 1927, "19251927 Miscellaneous" folder, Box 21, President's Papers, .472, VII.

${ }^{27}$ Physical anthropologist, anatomist, and eugenicist Robert Benett Bean, who will be discussed below, gave Alderman personally inscribed off-prints of all his articles. These reside in various volumes of Rare Virginia Pamphlets, Special Collections, Alderman Library, Charlottesville. 
(genetics) all had close ties to the organized eugenics movement. The first four were true believers; Mayo followed suit, although scant records make it difficult to gauge her commitment. ${ }^{28}$ Orland White appears to have been the lone moderate, but he did not begin to articulate this tempered notion of eugenics until later in his career. All of these individuals, plus Jordan, advanced to positions of prestige within the university community. They then helped sway the opinions of other faculty members in law, literature, and sociology. They also had a pronounced effect upon their students. ${ }^{29} \mathrm{~A}$ chronological presentation of the careers and beliefs of these individuals between 1915 and 1930 illustrates the steady accretion of eugenical thinking at the university. Examining the interactions among this "second wave" at Virginia, and between them and eugenicists elsewhere in the state and nation, reveals the close linkages connecting the Virginia and national eugenics movements.

\section{Biology, Eugenics, and Progressive Education: The Career of Ivey Lewis}

Ivey Foreman Lewis would be responsible for revamping the biology program at the University of Virginia, although his influence ir the state began earlier and grew beyond Charlottesville. Lewis taught biology in Virginia colleges for 44 years. He first worked at Randolph Macon College for six years between 1905 and 1912. In 1915, after year-long appointments at the Universities of Wisconsin and Missouri, he joined the faculty of the University of Virginia. Lewis, another North Carolina "tar-heel" like Alderman, actually had family ties to the University of Virginia: his father had attended medical school at the university before settling in North Carolina. Steeped in southern culture, Lewis-like Alderman-remained wedded to the ideal of preserving the distinctly southern heritage of

\footnotetext{
${ }^{28}$ Mayo's general support for eugenics is revealed in a single letter in the files of the American Eugenics Society. She also supported the recommendation that nursing students take the university's eugenics course. Given the broad currency of eugenics among medical professionals, it is quite likely Mayo's support stemmed from philosophical agreement with the eugenic program.

${ }^{29}$ Student acceptance of eugenics forms a central feature of chapter 5.
} 
the University of Virginia. Beginning as chairman of the biology department, Lewis would rise to the highest levels of the university administration. Constantly consulted by President Alderman, and Alderman's successors John Lloyd Newcomb and Colgate Darden, Lewis became Assistant Dean, Dean of Men, and ultimately Dean of the College. Merging his eugenic ideology and his liberal Protestantism, Lewis-like Jefferson, Cabell, Barringer, and Jordan—sought to reconcile science and religion, physics and metaphysics in his approach to teaching, university administration, and life. Natural law and biological law became inseparable; they were also the guideposts to moral behavior and proper social organization for Lewis. His ideology ultimately made Lewis one of the university's most beloved and most reviled figures during his 38-year career.

Bom in 1882 and reared in Ralejgh, North Carolina, Ivey Lewis's genealogy reveals strong southem roots, of which he was immensely proud. One of five children of an established doctor, Lewis grew up as the South systematically disfranchised African Americans. ${ }^{30}$ Although Jim Crow's grip did not absolutely preclude cross-racial interaction, it sought to "manage" and "administer" such contacts, and thereby taught children about racial hierarchy. ${ }^{31}$ More significantiy, Lewis matured as inter-class tensions rocked the southem white population. Battles over voting rights increased the strain among southern whites, fracturing the racial solidarity often presupposed by white supremacists of an earlier era. At the same time, however, systematic racism became a national phenomenon. America's 1898 victory in the Spanish American War merged

\footnotetext{
${ }^{30}$ Lewis's mother Comelia Viola Battle was the granddaughter of University of North Carolina president Kemp Plummer Battle. The Lewis and Battle families have distinguished histories, being among the most prominent "founding" families of Virginia and North Carolina. Lewis's correspondence reveals his genealogical pride. See Boxes 1-5, IFLC, passim; and Edwin Alderman to Ivey Lewis, January 13, 1928, "L" Folder, Box 2, President's Papers, .472, subseries VIII.

${ }^{31}$ Edward L. Ayers, Promise of the New South: Life After Reconstruction (New York and Oxford, 1992), 132.
} 
nationalism with nativism and racism. ${ }^{32}$ These social currents shaped Lewis's personal development before he entered college.

Lewis enrolled at the University of North Carolina, receiving his A.B. and M.S. degrees in Biology in 1902 and 1903 respectively. Captivated by biological research, Lewis proceeded to Johns Hopkins where he studied under the legendary zoologist William Keith Brooks and animal physiologist William Henry Howell. ${ }^{33}$ Lewis completed his Ph.D. in biology, with a concentration in botany, in 1908. Lewis's star rose rapidly. After studying at the University of Bonn, Germany, he taught at Randolph Macon for four years, moving to the University of Wisconsin in 1913. Churning out publications, Lewis occupied the prestigious Smithsonian Table at the Stazione Zoologica in Naples, Italy, and then was elected a Fellow of the American Association for the Advancement of Science (AAAS) in $1914 .{ }^{34}$ Recognized as an excellent teacher and investigator, Lewis taught botany at the Marine Biological Laboratory, Woods Hole, from 1910 to 1917 . In 1918, Lewis directed the Woods Hole botany program, a position he would hold until he helped open the University of Virginia's own biological station in 1927. At Woods Hole Lewis, like Harvey Jordan before him, met all the giants of biology - both botany and zoologyand eugenics, including Jordan's mentors Edward Wilson and Edwin Grant Conklin.

\footnotetext{
${ }^{32}$ Higham, Stangers in the Land, 170-71; C. Vann Woodward, Origins of the New South 1877-1913 (Baton Rouge and London, 1951), 321-26, and 355-56; and, Woodward, The Strange Career of Jim Crow, 31-109.

${ }^{33}$ Lewis to Edwin Anderson Alderman, "Biology" folder, Box 5, President's Papers, .472, subseries III. Brooks trained most of the scientists who emerged as the "giants" of biology in the twentieth century. Lewis thus joined a family that included Edmund Beecher Wilson (Jordan's mentor), Edwin Grant Conklin, and Thomas Hunt Morgan. Jane Maienshein, Transforming Traditions in American Biology, 1880-1915 (Baltimore and London: Johns Hopkins University Press, 1991), especially 43-47.

${ }^{34}$ Ivey Lewis to Edwin Alderman, January 5, 1914, "Biology 1908-1914" Folder, Box 5, President's Papers, . 472 subseries I. Announcement of his AAAS fellowship induction in letter, Ivey Lewis to Dean J. M. Page, January 12, 1914, Ibid. Lewis's scientific stature increased throughout his career. In 1929 he was appointed to the National Research Council, chairing its division of biology and agriculture from 1933 to 1936. He became president of the American Society of Naturalists in 1939, of the American Biological Society in 1942, and of the Botanical Society of America in 1949. In 1950-1951 he was president of the biology section of the AAAS. All of these positions brought him into personal contact with major figures in the American eugenics movement.
} 
Lewis also taught at the Long Island Biological Laboratory, where he undoubtedly became acquainted with Charles B. Davenport and the eugenics movement. ${ }^{35}$ Lewis's training and his growing reputation as an "influential" in the world of biology, fit him perfectly for the role of progressive modemizer that Alderman would ask him to play.

In early 1914, Lewis approached President Alderman regarding an opening in Virginia's biology department. During correspondence about the position, Lewis provided Alderman with advice that allowed the president both to modernize the biology department and to retain its endowment, the Miller Fund. ${ }^{36}$ On the basis of this interaction, Alderman developed abiding respect for Lewis. "I am more and more convinced of his splendid fitness for our work," Alderman wrote Dean James M. Page. ${ }^{37}$ Page's own research into Lewis's background corroborated the president's opinion. Samuel C. Hatcher, Vice President of Randolph Macon College wrote Page, "While with us, he [Lewis] made his department so interesting that our students were enthusiastic for classes under him. He is also a valuable asset to any faculty in that while he is alert and progressive. . he does not project himself in an unpleasant way." 38 Already, Lewis displayed the tact and diplomatic skill that would characterize both his professional career and his promotion of eugenics. Alderman valued savvy and good judgment, traits infinitely important in wrangling with politicians and other bureaucrats involved with the university.

Lewis's southem heritage also made him an attractive candidate. "Lewis is a very fine man and being one of our own people [North Carolinian/southemer], I think you would

\footnotetext{
35Ivey Foreman Lewis to James M. Page, January 12, 1914, "Biology" folder, Box 5, President's Papers, .472 , subseries III. Thus, Lewis's training and eugenical experiences matched those of Jordan in some important ways. See my discussion of Jordan and Davenport in chapter 2.

${ }^{36}$ The deed for the trust funding the school of biology stipulated that the money further experimental agriculture. Some trustees questioned using the fund to support academic biology. Lewis provided a rationale that finessed the distinction by claiming that academic biology provided all the fundamental knowledge for experimental agriculture. See collected letters in, "Biology 1908-1914" Folder, President's Papers, .472, subseries I.

${ }^{37}$ Edwin Alderman to Dean J. M. Page, January 29, 1915, Ibid.

${ }^{38}$ Samuel C. Hatcher to Dean J. M. Page, February 7, 1914, Ibid.
} 
like him better than anybody whom you could get who is not one of us," averred Robert E. Blackwell, President of Randolph Macon College. Blackwell added, "he is a man of strong religious character, and was a leader in the Episcopal Church while here. I should like very much to have him back in the state." Alderman agreed, writing of Lewis in neoeugenic terms, "He is a gentleman by birth and breeding, and a cultivated gentleman." 39

Alderman succeeded in securing Lewis as Miller Professor of Biology beginning in September $1915 .{ }^{40}$ Alderman offered Lewis a hefty starting salary, the department chairmanship, complete control over the curriculum, and exemption from summer school duties to allow Lewis to focus on research. ${ }^{41}$ "I would not want you to come unless there would be opportunity for you to do research work," Alderman wrote, because, "There is nothing I welcome more than the thought of someone doing real research work."42 On February 20, Lewis assured Alderman he would accept the position.

With this "Progressive modernization" of its biology department, the University of Virginia entered the race toward national preeminence. Alderman desperately desired to ratchet the University of Virginia up into the top notch for American universities, but he was not willing to compromise the university's southem heritage. With the hiring of Ivey Lewis, Alderman gained an important ally in his quest. Moreover, both men sought to increase the university's role in producing knowledge that would aid government in developing social policy. Alderman and Lewis, however, swayed between deep

\footnotetext{
${ }^{39}$ Blackwell's description of Lewis's "breeding" and "cultivation," so reminiscent of the language of the eugenic metaphor, reveals how well eugenic ideas fit with older cultural notions of propriety. So impressed by Lewis, Alderman asked him his opinion of other candidates for the job. See Ivey Lewis to Dean J. M. Page, May 25, 1914; and Ivey Lewis to Dean J. M. Page, June 22, 1914, Ibid. Quotations from Robert E. Blackwell to Dean J. M. Page, January 14, 1914; and Edwin Alderman to R. T. W. Duke, Secretary of the Miller Board, January 14, 1914, Ibid.

${ }^{40}$ Ivey Lewis to Edwin Alderman, February 20, 1915, "Biology" Folder, Box 2, President's Papers, .472 , subseries III.

${ }^{41}$ Edwin Alderman to Ivey Lewis, February 6, 1915, Ibid.

${ }^{42}$ Ivey Lewis to Edwin Alderman, February 9, 1915; and Edwin Alderman to Ivey Lewis, February 12, 1915, Ibid.
} 
commitment to social change through applied expertise and promoting programs merely for their popular appeal. Not surprisingly, Lewis clearly viewed biologists and those trained in the biological sciences-physicians, physical anthropologists, psychologists, and some sociologists-as the experts most qualified to control social development. Regardless of ultimate profession, Lewis sought to ensure that all educated Virginians exercised their function as citizens informed by a solid understanding of the biological laws determining social organization.

To enlarge the sphere of action for Virginia's biology department, Lewis joined Alderman's crusade for university extension. As its name implies, university extension sought to bring the knowledge of university experts out of the "ivory tower" and into the fields and homes of "common" Virginians. As Alderman put it, the job of the university was to "get close to the life of the people and to serve that life practically," especially by offering correspondence courses, facilitating "debate and public discussion," and conducting research in areas of "community and State importance." 43 Lewis himself lectured on the extension circuit, presenting on "The Food of Plants and the Potash Question," "The Biological Factor in History," and "Darwinism Today." The first topic clearly answered the Alderman's demand for the spreading of utilitarian knowledge, while the second topic allowed Lewis to disseminate his hereditarian and eugenic ideas to interested audiences. Lewis's lecture on Darwinism, beginning in 1920, may well have come in response to early anti-Darwinian rumblings among fundamentalists that began the year before. The extension bureau also offered "Package Libraries"-pre-assembled

\footnotetext{
${ }^{43}$ Alderman quoted in Michael Dennis, "Reforming the 'Academical Village': Edwin A. Alderman and the University of Virginia, 1904-1915," Virginia Magazine of History and Biography 105 (Winter 1997), 66, 81-82.
} 
groups of readings for loan-on a number of topics, including immigration, "the negro," feeble-mindedness, race, and heredity. ${ }^{44}$

Lewis did more than lecture on the extension circuit, however. Lewis taught Virginia's secondary biology teachers during the university's highly successful summer session. 45 Lewis shared these duties with professor William Allison Kepner of the biology department. The men taught "Education B-10, Principles of Teaching High School Biology" from 1922 until 1928, when duties at the university's Mountain Lake Biological Station called Lewis away for the entire summer. While at Mountain Lake, however, Lewis worked with graduate students and other scholars, spreading his eugenics in much the same way Charles Benedict Davenport did during the summer sessions at the Long Island Biological Laboratory and the ERO summer school. ${ }^{46}$

Lewis maintained this focus on outreach. In "The Last Ten Years in Biology at the University of Virginia," Lewis wrote that, "The primary aim of the Miller School of Biology in recent years has been to establish fruitful programs of research and to relate this to education in the south by wide contacts with teachers from southem colleges and schools." He added that, "The important application of these activities, aside from their intrinsic value in furthering the discovery of new truth, is to the teaching profession in the southem states. We hope to encourage the spirit of research and sound scholarship in the teachers of our colleges and secondary schools." Lewis explicitly identified the University of Virginia as the capstone of Virginia's educational system, the font of all necessary

\footnotetext{
${ }^{44}$ The list of available extension lectures and topics appeared in the University of Virginia Record new series, (1916-1921). After 1921 the University ceased publishing the lectlire slate, requiring those interested to apply to the Extension Bureau for information. Lewis offered the first lecture from 1916 onward, the second lecture from 1917 onward. The "Package Libraries" appear in "University Extension" folder, Box 7, President's Papers, .472, subseries VII.

45 Dennis describes the scope and success of the summer session in "Reforming the 'Academical Village,"' 78-79.

${ }^{46}$ University of Virginia, Record (1922-23), 164. See the discussion of Davenport and summer training in Chapter 2.
} 
training to effect social southern social uplift. Lewis even offered an index for the

effectiveness of the Miller School of Biology's work. Success was "shown by the fact that in the last eight years [1924-1932] graduates have come to the Miller School of Biology from fifty-two colleges, representing twenty states and one foreign country. Most of these graduates receive higher degrees and return to their teaching posts. Some go into medicine, and others continue a research career with the government or elsewhere." The significant result from the perspective of southem uplift, however, was that, "Most of the teachers locate in the south, and it is in the training of these college professors and teachers in secondary schools that the Miller School of Biology is making its chief effort." 47 These well-trained experts could then materially contribute to the effort to uplift and reform the South.

Lewis clearly adhered to what Kathy Jane Cooke has called "a gospel of social evolution." Lewis believed that society followed the same biological and evolutionary "laws" that governed the growth, development, and change of individual organisms. ${ }^{48}$ The "social organism" evolved like any other, therefore people should look to biological laws to help shape and determine statute law, custom, and governance. Knotty social problems could best be solved, in Lewis's view, by understanding the degree to which biological laws determined their existence. He agreed with the sentiments expressed by Charles B. Davenport that, "the progress of the human race will be solid and secure in so

\footnotetext{
${ }^{47}$ Ivey Foreman Lewis, "The Last Ten Years in Biology at the University of Virginia," in "Articles on University" folder, Box 3, President's Papers, .491, I.

${ }^{48}$ Kathy Jane Cooke, "A Gospel of Social Evolution: Religion, Biology, and Education in the Thought of Edwin Grant Conklin," (Ph.D. diss., University of Chicago, 1994). These beliefs will be examined in detail, as they developed throughout Lewis's career, in succeeding chapters. The notion of a scientific law as an unchanging rule guiding natural phenomenon, however, should be familiar to most people. Scientists must maintain a basic skepticism that holds that even "laws" are merely well established theories still open to revision. Lewis, and many scientists like him, lacked this skepticism: laws became immutable absolutes for him.
} 
far as it accords with biological law."49 Religious tensions, race relations, class and gender friction could all be resolved by understanding the biological substructure that determined the existence and virulence of these phenomena. As we shall see, Lewis and Alderman's responses to two issues-the Scopes controversy and the value of sociological studies of "the race problem"-reveal their commitment to applying biological principles to social policy.

Lewis and Alderman defended science against fundamentalist religion's attack on evolution in the Scopes Trial. Alderman's correspondence reveals his campaign to protect the University from any creationist challenge. 50 Approached by a Virginian who wanted to know his position, Lewis affirmed the biology department's acceptance of Darwinian evolution as early as 1922. For Lewis, science existed as a natural extension of God's goodwill toward humanity: science and religion were complementary, not antagonistic, modes of thought. ${ }^{51}$ God allowed humans to discover natural laws in order to improve their condition on earth. Hereditary determinism, a natural law created by God and discovered by science, could be controlled by man through science: eugenics. A society of eugenically "fitter" individuals would operate intelligently and efficiently, easing the strain of survival. An efficient society left time and resources for cultivating morality through religion and education, making society more humane. A eugenically improved population would be better equipped to receive moral instruction, for there would be no "moral

\footnotetext{
${ }^{49}$ Davenport wrote this in a 1915 report, quoted in Hiltzik, "Brooklyn Institute," 251.

${ }^{50}$ Extensive correspondence documenting Alderman's position exists in "Evolution" Folder, Box 7, President's Papers, .472 subseries VII.

${ }^{51}$ Ivey Lewis to V. B. Harris, esquire, November 2, 1922, "1922 Letters" Folder, Box 1, IFLC. Lewis lectured to various churches on "Evolution and Religion" and "Science and Religion" both before and after the Scopes Trial. See, W. H. Ruffin to Ivey Lewis, February 2, 1927, "1927 Letters" Folder, Box 1, IFLC; and Ivey Lewis to Tom H. Garth, Westminster Presbyterian Church, October 1, 1947, "1947 Letters" Folder, Ibid. See also generally, Boxes 1-37, Dean's Papers 5119, Special Collections, Alderman Library, Charlottesville, passim. [Hereinafter referred to as Dean's Papers.]
} 
delinquents." 52 Humanity could then refine the "higher things in life," such as "courage, honor, a descent [sic] reserve, gentleness, magnanimity, pride in ideals." 53 This theme of moral improvement following eugenic advance informed all of Lewis's writing. Lewis's eugenics harmonized with a Protestant ethic of introspection, upright living, and service to one's community. ${ }^{54}$ The address celebrating his twenty-five years of service to the university effectively estimated Lewis's eugenic approach: "with scientific knowledge of the laws of life you have brought to your duties as Dean of the University a broad and strong capacity to deal with the human problems present in the lives of your students." 55 Although Lewis believed that university students represented the fittest segment of the population, he still applied biological/eugenic rationales in administering his office as Dean.

While Lewis appreciated religion's "environmental" ability to improve society's morals, he still remained deeply skeptical of sociology's environmental interventions. Lewis and Alderman's positions regarding the "race problem" reflect their conservatism. Their Progressive "objectivity" did not entirely transcend their regionalism. In December 1915, Alderman wrote that, "the right adjustment of relations between the white man and the colored man in American life, still remains perhaps our most complex and momentous

52 "Moral delinquent" was a term developed to describe the feeble-minded during the Buck v. Bell case. Lombardo, "Three Generations, No Imbeciles," 49.

${ }^{53}$ Lewis, "Address to New Students (September 3, 1940)," in "Speeches" Folder, Box 5 IFLC. See also, Ivey F. Lewis, "Ancient Wisdom and Modern Knowledge (May 5, 1935)," Ibid.

${ }^{54}$ Lewis echoed eugenics popularizer Alfred E. Wiggam, whose New Decalogue of Science, (Indianapolis, The Bobbs-Merrill Company, 1922), merged protestant Christianity and eugenics. Wiggam proclaimed, "had Jesus been among us, he would have been president of the First Eugenics Congress" (110). Lewis's role as a founder and then Chairman of the university's YMCA reveals his commitment to "hands on" attempts to help people realize their genetic potential. See, "1929 Letters" Folder, Box 1,. Lewis, who became a Senior Warden of his church in 1931, also occupied seats on the board of St. Anne's School and the diocesan school board. His views about the relation of natural law to man influenced his Christian commitment to help through education. See, Ivey F. Lewis, "Untitled Essay (undated)"; and Ivey Lewis to Bishop W. R. Mason, March 24, 1949, loosely filed, Box 24, Dean's Papers; and Ivey F. Lewis, "Address before the American Association of University Women, Wytheville, VA (April 5, 1946)," in "Dean Lewis" Folder, Box 11, President's Papers .581; hereinafter referred to as AAUW.

55 "Address Commemorating Dean Lewis's 25th Anniversary," in "Articles and Addresses not by Ivey F. Lewis" Folder, Box 2, IFLC. 
public question." Although he felt that southemers had acted with "a great deal of instinctive wisdom," it was time that, "patient, wise, scientific, just men should labor at the problem and seek to place it where it belongs among the great economic and sociological questions of the time." The question, in Alderman's opinion, must be removed from the crucible of rash public debate to the coldly "objective" arena of scientific inquiry. Alderman called for scientific study of an intractable problem, not amelioration. His use of bloodless phrases like "the right adjustment" of race relations reveals his faith in expert control. Rather than hoping for a solution, people "should be grateful for the fact that the negro has somehow gotten off the southerner's nerves and out of the northerner's imagination." 56 Although Alderman championed university reform, his studied deliberation regarding the "race question" conserved the social status quo. Similarly, Lewis's hereditarianism left him hostile toward environmental solutions to the "race problem," whether involving blacks or immigrants.

A staunch hereditarian, Lewis believed in the controlling power of genes over individual destiny. Acceding to this "natural law," Lewis backed both eugenic immigration restriction and interracial marriage restriction laws. Only social engineering based upon a genetic, biological foundation would improve life in America. As he told Virginia students in a 1924 speech reported by the New York Times, "The one clear message that biological investigation has brought as its gift to the thought of the twentieth century is that the idea of environment molding something out of nothing is sheer nonsense." Lewis continued, "This disproved theory of the creative environment has been put forth in siren tones until the idea of the great American melting pot, into which one can put the refuse of three

\footnotetext{
${ }^{56}$ Edwin Alderman, "Untitled Address to Commission (December 20, 1915)," Box 8, President's Papers, .472, subseries III. Many commentators have noted southerners' desire to have "the South's problems solved by southemers." See particularly, John Egerton, Speak Now Against the Day: The Generation Before the Civil Rights Movement in the South (New York, 1994) 33-47, and 301-16.
} 
continents and draw out good, sound American citizens, has reached wide acceptance. It is simply and perilously false." The American environment, notwithstanding all its advantages, could do nothing to improve the progeny from poor genetic stock. "What goes into the hereditary mill is what comes out of it," Lewis continued. Conceding that, "Education and opportunity can do great things," Lewis set absolute limits on their effect: "They can bring out the best in a man, but what is in him to be brought out is a matter of heredity." 57

Lewis, like Alderman before him, enjoined academics to examine pressing social problems along scientific lines. Biological law, Lewis felt, must replace emotion in determining social policy. "Sentimental" attachment to humanitarian interventions, epitomized for Lewis by Robert Park's school of environmental sociology, could only end in dysgenic catastrophe. 58 "We [Americans] have undertaken the direction of human evolution," through environmental intervention Lewis said, "At present we are bungling the job." Unless eugenicists displaced sociologists, America's "fit" genetic stock would become hopelessly polluted. "The qualities of mind and body, good or bad, do not fuse and melt in the mixed breed. They may be shuffled and recombined, but they all come out in the wash unchanged." Thus, interbreeding promised the perpetuation of deleterious hereditary traits, not their gradual elimination. Lewis staunchly maintained that heredity

57Lewis's speech, "What Biology Says to the Man of Today," was reported as, "Biologist Supports Curb on Immigrants," New York Times, April 6, 1924, p. E5. Unless otherwise noted, all quotations in the ensuing discussion are from this article. This piece appeared the same day the Times ran a story about the House of Representatives' consideration of the Immigration Restriction Act. "Immigration Bill Taken Up in House," New York Times, April 6, 1924, p. 10. The Times' coverage of Lewis was reprinted in the Virginia Teacher, the leading professional magazine for Virginia educators. See, "Environment Cannot Mold Something out of Nothing, Says Biologist," Virginia Teacher, V (June, 1924), 163-64.

${ }^{58} \mathrm{Park}$ was one of the leading proponents of a "scientific" environmental sociology. On Park, and his views on race, see Daryl Michael Scott, Contempt and Pity: Social Policy and the Image of the Damaged B lack Psyche 1880-1996 (Chapel Hill, NC: University of North Carolina Press, 1997), 22-25; 61-62; and Dorothy Ross, The Origins of American Social Science (New York: Cambridge University Press, 1991), 346-89. 
and racial purity, not environmental intervention, controlled human evolution and, by extension, social structure.

"The only foundation for an enduring culture," Lewis argued, presenting his brief for racial purity, "is a sound stock of fairly homogeneous races." Echoing the words of Madison Grant, Lewis averred that, "Great races may be formed by the fusion of nearly related stocks." His insistence on the "similarity" of "original" stocks like the Teutonic Germans and Anglo-Saxon English allowed him to construct notions of fitness that relied upon racial "purity." Purity began by ranking the races and their subdivisions. Creating a new "racial contract" as a substitute for the "social contract" traditionally believed to be undergirding American democracy, Lewis wrote certain racial and ethnic categories out of citizenship.59 Maintaining a front of scientific "objectivity," Lewis acknowledged that, white Americans themselves descended from Britons, who "were the result of the interbreeding of many races or subraces." So, he claims, "It is of doubtful service to consider it [the American race] as superior to other races. Nevertheless, "whatever its virtues and defects, it is our race, and it has built what we have of civilization," therefore the "American race," implicitly white, Anglo-Saxon, and Protestant, deserved eugenic defense to prevent "immediate deterioration and ultimate destruction."

Using rhetoric reminiscent of Jefferson, Lewis noted that immigration of dissimilar people and "prolonged contact with a race which may be considered unassimilable [i.e. African Americans] presented the "two sources of danger" to the "American race." Recent immigration, according to Lewis and many of the eugenicists of the 1920s, had brought

\footnotetext{
${ }^{59}$ Philosopher Charles Mills, building on the feminist analysis in Carol Pateman's The Sexual Contract, convincingly argues that all western social contract theory has implicitly been grounded upon an underlying racial contract. The racial contract privileges the race in power with access to power.

Simultaneously, it forbids access to power for races deemed subhuman. The result is a society ultimately founded, in part, on racial subordination. In many ways, the efforts of Lewis and other eugenicists sought to reveal and sustain the terms of the racial contract by justifying them on the grounds of scientific natural law. Charles Mills, The Racial Contract (Ithaca, NY: Cornell University Press, 1997).
} 
"people who are relatively deficient in intelligence, character, and willingness to enter into American traditions and life." Therefore, Lewis told his audience at Jefferson's academy, "It is the duty of every good citizen to support restrictive immigration legislation."

Lewis's racial views remained rooted within the Jeffersonian tradition, as well. Adopting Lord Bryce's opinion that blacks constituted the "'one unsolvable American problem,"' Lewis related the conventional wisdom that "there are only two solutions: one is miscegenation and the other segregation of the members of the negro race now in this country." Eschewing repatriation as totally impracticable, Lewis supported the progressive solution of racial apartheid as the best way to "manage" race relations. Noting that Virginia's black population had dropped from 35 to 29 percent of the total population in the last two decades, and resting on the shibboleth of southern "negro loyalty," Lewis praised the recently passed eugenic Racial Integrity Act (RIA).60 The RIA banned intermarriage between whites and anyone with any trace of black "blood." Despite his protests to the contrary, Lewis concluded his speech with a sentiment that has served as a touchstone for white supremacists from his era to our own. "The cause of racial integrity is of immediate and vital importance," because, "The purity of the white race in America we regard as a basal necessity for the maintenance of the heritage which we have received." Any dilution of white "blood," the colloquial term for genetic heritage, with that of African Americans or other races, including "inferior strains" of the white race, would lead to the declension of American civilization. Environmental interventions in social policy, as advocated by the Park and Lester Frank Ward wing of sociology, might temporarily lessen the symptoms of racial tension. In the long term, however, Lewis and most other main-line eugenicists chapter.

${ }^{60}$ The passage of this act, and Lewis's role in supporting and enforcing it, will be discussed in the next 
believed that environmental policies would actually undermine civilization by promoting the survival of the "unfit," miscegenation, and the despoliation of America's genetic legacy.

Correspondence between Alderman and Lewis concerning the qualifications for a professor of sociology, reveals the influence Lewis's hereditarianism had upon university policy. In 1923, the university organized a School of Rural Social Economics headed by economics professor Wilson Gee. By 1926, Alderman was ready to create a department of sociology, independent of the department of economics which had previously offered sociology courses. Confronted with a choice between two candidates, Frank Bane from the State Department of Public Welfare, and Floyd N. House recently graduated from the University of Chicago, Lewis championed House against Gee's choice of Bane.

"I know Mr. Bane well and like him very much," Lewis opined. "I would not recommend his election as professor of sociology for the reason that he has never received the rigorous training in fundamentals which one has a right to expect in a university professor." Without the doctoral degree to certify his expert authority, Lewis viewed Bane as just a dabbler. "The Social Sciences suffer in public estimation from dilettante-ism, and I think it would be a mistake to put in as full professor of sociology any man who has not been thoroughly trained in the best thought of his times in theory, principle and practice of his subject. The appointment of Mr. Bane would, in my opinion be derisively received where solid work is being done in sociology." ${ }^{61}$ Gee wanted Bane because he felt it would

\footnotetext{
${ }^{61}$ Alderman accepted Lewis's arguments over those of Professor Wilson Gee, the department chair. Ivey Lewis to Edwin Alderman, May 18, 1926; and Wilson Gee to Edwin Alderman, May 26, 1926, "Institute for Research in the Social Sciences" Folder, Box 12a, President's Papers, .472, subseries VII. Alderman followed Lewis's recommendation regarding faculty appointments in every instance found; in each case, the result conserved Virginia's "southern" identity. Aldeman dismissed a candidate he favored for Dean of Women as a result of Lewis's appraisal: "She is a very attractive woman of great ability. I think she would find a good deal of adjusting of her point of view necessary, and if I were charged with any responsibility in this matter, I would look first for a Southern woman." Ivey Lewis to John Lloyd Newcomb, July 18, 1927, "L-Le" Folder, Box 7, President's Papers, .472, subseries IX; and, Edwin Alderman to Florence Lowther, Ph.D., July 18, 1927, "Women at the University" Folder, Box 29, President's Papers, .472, subseries VII.
} 
be easier to "secure a man who can give the more formal courses in sociology" than it would be to find someone who could connect theory and practice in the "largest service to the State."62 Alderman would side with Lewis and other members of the search committee, however, hiring House as full professor. He would appoint Bane an associate professor of "applied sociology" as a sop to Gee. In the end, Lewis's gambit would backfire in part. While Gee and Bane operated out of a biological/hereditarian standpoint that matched Lewis's ideology, House had been trained in environmentalist and racially liberal sociology by Robert Park. Lewis argued the skeptic's position: unsure of sociology's value, he wanted a professor with a solid empirical —and for Lewis that meant biological-background. Ultimately, Lewis backed the candidacy of a man who would teach ideas about race diametrically opposed to his own. ${ }^{63}$

Still, despite this conflict, Lewis consulted on the proposed curriculum for the incipient sociology department and its Institute for Research in the Social Sciences. Lewis's input, and the beliefs of Wilson Gee, would ensure that a hereditarian, eugenic bent influenced the sociology department in the near run. Lewis backed the hereditarian projects forwarded by Wilson Gee, especially Gee's proposals to study the intelligence of Virginia's blacks and rural whites. Hereditarian and racialist courses packed the advanced offerings of the proposed curriculum, including an offering "Races and Nationalities." Courses in other schools that would be recommended to graduate students in sociology included mental testing and, of course, Lewis's eugenics course, Biology $\mathrm{Cl}{ }^{64}$ Thus, despite House's training under Park, it would be years before his influence-even as full VII.

62Wilson Gee to EAA, May 26, 1926, "IRSS" folder 1, Box 12a, President's Papers, .472, subseries

${ }^{63}$ For discussions of Park, see sources cited in note 56, above. Just as Lewis looked to science to legitimate his racial views, Scott argues racial liberals, especially Floyd N. House, did the same in their attempt to subvert the culture of segregation. Scott, Contempt and Pity, 59, and 220 note 7.

${ }^{64}$ See the "IRSS" folders, Box 12a, President's Papers, .472, subseries VII, especially the memo dated January 16,1926 , folder 1 . 
professor of sociology — would undermine the decidedly hereditarian and eugenic nature of instruction at Virginia.

Rather than condoning sociology's environmentalist public policy, Lewis himself answered the hereditarian call of the American Eugenics Society, joining its Virginia State Education Committee. This group of four men, headed by Harvey Jordan, sought to educate Virginians about the hereditary basis of social structure. ${ }^{65}$ Comparing Lewis's actions in the 1920s with the opinion he expressed in March of 1948 vividly demonstrates the consistency of his beliefs. Responding to a eugenics-based query regarding race relations, Lewis stated,

There is a lot of sap-headed thinking about it [race as it relates to heredity], mostly based on the silly notion that all men are brothers and therefore alike in their potentialities. Actually, there is no biological principle better established than that of inequality of races, and yet sociologists, especially the Jewish ones, are loud and effective in their denial of any racial differences, even saying there is no such thing as race. They deride and laugh to scorn such books as Madison Grant's "Passing of the Great Race." 66

Lewis revered authors like Grant, Lothrop Stoddard, and Virginia's own Earnest Sevier Cox. These men represented America's primary eugenical propagandists, sounding the racial alarm in provocative books entitled: The Rising Tide of Color Against White World-Supremacy, Revolt Against Civilization, White America, and Teutonic Unity. ${ }^{67}$

${ }^{65}$ Lewis's name first appears on the rolls of the American Eugenics Society in 1925. The Eugenical News called for the creation of education committees in May 1926. Lewis accepted his nomination to the committee writing, "I shall be glad to serve as a member of the Virginia Committee of the Eugenics Society." Ivey Foreman Lewis to Leon Whitney, February 18, 1927, "Lewis, I. F." folder, American Eugenics Society Papers, Library of the American Philosophical Society, Philadelphia. The list of chapters created appeared in the October 1927 issue of the Eugenical News. Eugenics Research Association, The Eugenical News: Current Record of Race Hygiene, XI (May 1926), 72; and, Eugenical News XII (October 1927), 138-139.

${ }^{66}$ Ivey Lewis to John D. Martin, Jr., Esquire, March 6, 1948, "M" Folder, Box 7, Dean's Papers. Lewis was a virulent anti-Semite. He tracked and controlled the number of Jewish students admitted to the university. Though he extolled Jewish efforts to defend their own racial purity, he felt that Jews as a "race" remained inferior to "Nordic" whites. Ivey Lewis to John Lloyd Newcomb, January 31, 1939, "Dean Lewis" Folder, Box 5, President's Papers, .491, subseries III. His statements in favor of Jewish racial purity appear in, "Biologist Supports Curb on Immigrants," New York Times, p. E5.

${ }^{67}$ Mark Haller termed Stoddard and Grant propagandists. Haller, Eugenics, 147. Cox's books White America (Richmond, Va., 1923, 1925, 1937) and Teutonic Unity: A Basis for Peace (Richmond, Va., 
These works became texts for Ivey Lewis's course and his personal ideological guides.

Lewis displayed little tolerance for individuals or methodologies that denied what he

considered self-evident scientific fact. Both his teaching and his ruminations about

educational policy manifest this intolerance.

Lewis became an influential figure in Virginia education, rising to Dean of the College

of Arts ard Sciences at Virginia, and traveling throughout the state speaking to educators.

Two main ideas characterize all of Lewis's writing on education. First, education should

"make good and useful citizens." Second, the inherent, hereditary inequality of students

limited educators' ability to achieve the first goal. Regarding education's constraints,

Lewis wrote:

It seems to me that the greatest discovery of the twentieth century is the establishment of the laws of heredity as they relate to human beings. . . Not even the most round eyed believer in the doctrine of equality, even in the nineteenth century when the doctrine ran wild, could imagine that such things as skin color or eye color can be produced by training, but it is still a comparatively new idea that the laws of heredity hold also for mental traits and that human destiny is predetermined to a much greater extent than has been supposed by hereditary factors. The very best education can do is to cultivate and intensify the natural capacities. ${ }^{68}$

Lewis felt that students came equipped with an inborn potential, a capacity that education could not enlarge or exceed. ${ }^{69}$ Lewis advocated education for its socializing aspect-it integrated individuals into society at the level determined by their heredity. In light of these beliefs, Lewis concluded that,

1951) mimic Grant's The Passing of the Great Race (New York, 1916) and Stoddard's Rising Tide of Color Against White World-Supremacy (New York, 1920), and Revolt Against Civilization: The Menace of the Under-Man (New York, 1922) in style and tone.

${ }^{68}$ Ivey F. Lewis, "AAUW," 1; and "Address before the Roanoke Teachers Association (December 11, 1937)," in "Speeches" Folder, Box 5, IFLC, 7-8. See also, Ivey Lewis to John Dale Russell, Director Division of Higher Education, U. S. Office of Education, January 14, 1948, "R" Folder, Box 8, Dean's Papers.

${ }^{69}$ Lewis scomed the Lamarckian theory that posited the inheritance of acquired traits and the increase of innate potential through training and environmental influence. See also, Ivey Forman Lewis, "Biological Principles and National Policy: Address of Retiring Chairman of Section G [Lewis] American Association for the Advancement of Science (December, 1951)," in "Speeches" Folder, Box 5, IFLC, 6. 
We must reword the bold statement to read that all men are created equal only in the sense that all have a right to equality of opportunity and equality before the law. Actually all men are created unequal in their hereditary equipment and potentialities, in their natures. Given identical training, the same food, the same home environment, the fact remains that people look different, act differently, and are different. ${ }^{70}$

Thus, it seemed essential to Lewis that education target a student's innate potential, as gauged by intelligence tests. Without such conscious direction of students, "Compulsory education laws force the offering of such a curriculum that all can, if not profit by it, at least endure it. This means that the level of achievement must be graded down to the lowest common denominator." Decades before anyone used the term, Lewis described the "dumbing down" of education and vigorously advocated "tracking"—placing students into rigid vocational, general, and college-preparatory programs based on psychometric measurements that purported to indicate inborn ability, affinity, and intelligence. ${ }^{71}$ Applied racially, these tracks limited blacks to manual education. In his retirement address before the American Association for the Advancement of Science, "Biological Principles and National Policy," Lewis invoked Jefferson's ideal of a pyramidal educational system that left higher education for the elite and a few "scholars raked from the rubbish." Jefferson, in Lewis's view, "accepted the fact that many could not or would not take an education beyond the $3 \mathrm{Rs}$, and proposed that. . higher education be reserved for the aristoi who could profit by it. Strange doctrine for the apostle of democracy!" While he believed in the scientific reform of education and society, he posited changes that failed to challenge, and indeed actively reinforced, existing inequality.

${ }^{70}$ Ivey F. Lewis, "Resource Use in the South (n.d.)," and "The High School Program in Relation to Success in College Work (February 8, 1946)," in "Articles and Abstracts" Folder, Box 2, IFLC, 18. In "Resource Use in the South," Lewis bemoans the "human erosion" experienced by the South as its best scholars leave for other sections.

${ }^{71}$ Ibid., quotation 19; and use of IQ tests 3. Lewis also sat on the boards of the Miller School for Manual Labor and the Blue Ridge Industrial School, in addition to his involvement with parochial schooling. Lewis often used IQ tests as diagnostics in his capacity as Dean of Students. See, for example, Charles H. Kauffman, Director of Personnel and Placement Office to Ivey Lewis, February 1, 1950, "F" Folder, Box 15, Dean's Papers; and Kauffman to Ivey Lewis, May 31, 1948, "K" Folder, Box 6, Dean's Papers. 
The three strands of educational Progressivism, religious liberalism, and social

conservatism wound together in eugenics, creating an ideological tether that anchored Ivey

Lewis to contemporary social trends within Virginia and its state university. The

conditions present in Virginia pre-disposed the state to an early acceptance of eugenics.

Virginia's experience differs from that which Edward J. Larson depicts for the "Deep

South" in Sex, Race, and Science: Eugenics in the Deep South. The factors that Larson

argues retarded eugenic development in the Deep South-religious fundamentalism, lack of

higher education and scientific research in the biologic sciences, and lack of literacy-

applied less to Virginia. ${ }^{72}$ Virginia's religious culture tended, as evidenced by the limited

reaction to the Scopes Trial, toward a more moderate strain; deeply religious, the state was

not rife with the organized fundamentalism evident further South. The University of

Virginia, which historically stood atop the South's educational structure, modernized far

earlier than institutions in the Deep South, which could claim only Tulane as a research

university. ${ }^{73}$ As a result of its status, the University of Virginia became an epicenter of

eugenical thought, closely linked with the national movement, the Virginia anti-

miscegenation movement, and tied to the state mental health professionals who promoted

eugenic sterilization. ${ }^{74}$ And, coupling the lack of a strong populist impulse in Virginia's

${ }^{72}$ Larson, Sex, Race, and Science, Chap. 1. Moreover, Virginia and North Carolina embraced eugenic sterilization with vigor. Virginia and North Carolina rank second and third, respectively, after Califormia, for the total number of people sterilized under eugenical statutes. Virginia and North Carolina sterilized the most people in the country between 1950 and 1972. Phillip R. Reilly, The Surgical Solution: A History of Involuntary Sterilization in the United States (Baltimore and London, 1991), 94. For the most accurate compilation of statistics on eugenic sterilizations, see Jonas Robitscher, Eugenic Sterilization (Springfield, Mass., 1973).

${ }^{73}$ Larson, Sex, Race, and Science, 40. Again, the presence of well-developed research universities in Virgiria and North Carolina helps to explain why these states eagerly accepted eugenics.

${ }^{74}$ John Lloyd Newcomb and Lewis corresponded with Harry H. Laughlin, Colonel Eamest Sevier Cox, Dr. Walter A. Plecker (Registrar of Virginia's Bureau of Vital Statistics), and Colonel Wickliffe P. Draper, a prominent eugenicist. These men sought to make Virginia a leading state in eugenics. See, H. H. Laughlin to JLN, February 18, 1936, "D" Folder, Box 9, President's Papers, .491, subseries II. Laughlin wrote, "I called on you last October about the desirability and possibility of work in eugenics by University of Virginia. ... [Draper] is in position to give substantial financial support of work which he believes would definitely revive American racial ideals and would advance them substantially." Newcomb replied affirmatively. See, John Lloyd Newcomb to H. H. Laughlin, February 18, 1936; and John Lloyd Newcomb to Wickliffe P. Draper, February 21, 1936, Ibid. Professor Paul A. Lombardo provided me with 
political culture with the large number of university graduates in the state assembly, elites schooled in eugenics had a distinct advantage in affecting social policy. ${ }^{75}$ Thus, Virginia and its university provided fertile intellectual soil for the growth and propagation of eugenical seed planted by Lewis's teaching.

Lewis took over the teaching of eugenics to undergraduates after the untimely death of William Henry Heck in 1919. Heck and Lewis undoubtedly knew each other well, because Lewis listed Heck as a character reference while applying for the biology job in 1914. ${ }^{76}$ They both believed deeply in the power of heredity and the promise of eugenics. This intellectual affinity probably was enough to draw them together; the fact that they worked in adjacent buildings and shared similar concerns about public education ensured their cooperation. Lewis's eugenics course, Biology C1: Evolution and Heredity, continued the major themes of Heck's course, but gave them even deeper biological underpinnings. Lewis used Biology $\mathrm{Cl}$ as a forge to link evolution, heredity, and eugenics together in students' minds, teaching them a scientific method for social improvement. The catalog described the course as, "Evolution, the theory and its history; the principles of

ccpies of letters not appearing in university files, particularly, Wickliffe P. Draper to H. H. Laughlin, March 1, 1936, which describes Lewis's reaction: "Lewis especially seemed interested in my ideas and suggested that I meet with Messrs. Cox and Powell. ..." Originals reside in the H. H. Laughlin Papers, Pickler Library, Northeast Missouri State University, Kirksville (copies remain in author's possession). See also, Gregory Michael Dorr, "Assuring America's Place in the Sun: Ivey Foreman Lewis and the Teaching of Eugenics at the University of Virginia, 1915-1953," Journal of Southern History 56 (May 2000): 276, note 61 ; Lombardo, "Miscegenation, Eugenics, and Racism," 432-35; and, Lisa Lindquist Dorr, "Arm in Arm: Gender and the Racial Integrity Act of 1924," Journal of Women's History XI (Spring 1999): $143-66$.

${ }^{75}$ For an account of Virginia's political culture during this period, see Ronald L. Heinemann, Harry Bird of Virginia (Charlottesville, Va., 1996). Many Virginia graduates populated the state General Assembly during this period. One such assemblyman, Lemuel Smith of Charlottesville, voted for both Virginia's eugenic sterilization bill and the Racial Integrity Act. Thirty years later, as a justice of Virginia's Supreme Court of Appeals, Smith voted to uphold the annulment of a "miscegeneous" marriage between a Chinese sailor and a white woman. See, Gregory Michael Dorr, "Principled Expedience: Eugenics, the Supreme Court, and Naim v. Naim, American Journal of Legal History, XLII (June 1999): 1-41.

Eugenicists teaching at the other state universities exposed many other assemblymen to eugenical theories.

76Ivey Foreman Lewis to James M. Page, January 12, 1914, "Biology" folder, Box 5, President's Papers, .472, subseries III. 
heredity and their application to human problems." ${ }^{77}$ Biology $\mathrm{Cl}$ had a distinct sociological flavor, albeit a deterministic and not environmental sociology. ${ }^{78}$ The content of the course is apparent from the few surviving lectures, two of Lewis's own notebooks - including his topical bibliography - as well as two student notebooks, some final exams, and 27 student term papers. ${ }^{79}$

Lewis emphasized reading, and which books and articles he considered important is evident from his topical bibliography and his notations in students' papers. The most frequently required "texts" for the course appear to have been Darwin's Origin of Species and Paul Popenoe and Roswell Johnson's 1918 "classic," Applied Eugenics, although by 1947 Lewis had also been using Horatio H. Newman's Evolution, Genetics and Eugenics. ${ }^{80}$ Surveying the books Lewis listed under the topics "Birth Control", "Birth Rates", "Color Problem", "Eugenics", "Immigration Laws", "Mentally Deficient Classes", "Negro", and "Population Problem" reveals a preponderance of eugenical opinion. The few works that are not overtly eugenic tend to be neutral. The only book that might be considered anti-eugenic was W. E. B. DuBois's Souls of Black Folk, which appeared

${ }^{77}$ University of Virginia Record-Catalogue, 1919 (Charlottesville, Va., 1919), 108.

${ }^{78}$ Lewis used Paul Popenoe and Roswell Johnson's text Applied Eugenics (New York, 1918). Lewis agreed with Popenoe and Johnson that, "The science of eugenics consists of a foundation of biology and a supersiructure of sociology" (Popenoe and Johnson, v).

${ }^{79}$ Student Notebook: Jim Putnam, "BIO C1: Evolution, Genetics, Eugenics Notes from Lectures by Ivey Lewis," undated student notebook, Box 43, Dean's Papers. The course title changed to "Biology 102: Heredity and Eugenics" in 1947, a moniker it maintained until 1952. The course became "Biology 101: Evolution" by 1953, but the final exam shows that Lewis still taught heredity and eugenics. See, "Final Exams," Box 42, Dean's Papers. The "Topical Bibliography" and lecture notes are in "Miscellaneous" Folder, Box 1, Dean's Papers. Other lecture notes in "Examinations and Lectures" Folder, Box 3, IFLC.

${ }^{80}$ On the flyleaf of Alderman Library's copy of the 1922 edition of Applied Eugenics, neatly written in Lewis's hand is "Miller School of Biology 1923." In the preface to the 1933 edition, the authors assert that, "This revision of Applied Eugenics after fifteen years has not necessitated any significant change in the social philosophy, the science, or the technology of eugenics as presented in the first edition, 1918."

Apparently Orland E. White, genetics professor and eugenicist, agreed, for he inscribed the flyleaf of his copy: "honest, clear judgment, lack of emotional exaggcration, fair, calm." See, Popenoe and Johnson, Applied Eugenics (New York, 1933), Science and Engineering Library, University of Virginia, Charlottesville. Concerning the Newman text, see, Ivey Lewis to Miss Betty K. Rudman, University of Chicago Press, December 29, 1947, "R" Folder, Box 8, Dean's Papers. 
under the "Negro" heading—along with both Earnest Sevier Cox's and Madison Grant's volumes. In the bibliographies of the students' papers (and on some of the book lists in the 1953 final exams) Lewis placed a check mark next to certain books and articles. In every case, the checked entry was a eugenic or race-biased text. These works established race as both a biological category and "an explicit and eloquent expression of elitist attitudes." This deeply conservative, racist and elitist attitude, tempered by a patronizing sense of noblesse oblige, colored Lewis's writings on education, and his classroom lectures. ${ }^{81}$

Little remains revealing the contents of Lewis's lectures, yet what exists is telling. The degmatic character of Lewis's eugenical teaching rings out of his surviving lecture:

The two forces that mold the individual are heredity and environment. Both are essential but it has long been a question which is the more important....In the 18th century the view was generally held that heredity played little part. ... This thought was reflected by Jefferson when he said, "All men are created equal." . . In the 20th century an abundance of experimental evidence proves that the large part ascribed to environment was mostly imaginary and that the capacity and natural bent of an individual are due to heredity. ${ }^{82}$

Lewis, referring to the American eugenicists' favorite whipping boy, Thomas Jefferson, set up the humanistic, egalitarian reasoning of the enlightenment for a fall..$^{83}$ Most American eugenicists agreed that Jefferson's statement was utopian, and applied only in regard to man's equality before the law. In gauging the relative importance of heredity (nature) and environment (nurture) in forming the human being, main-line eugenicists such as Lewis all emphasized nature. He stated later in the lecture,

81 "Topical Bibliography," in "Miscellaneous" Folder, Box 1, Dean's Papers. For examples of Lewis's approval, see, NZF, "Race Mixture (June 1935)"; and WCG, "A Plan of Eugenics (undated)," Term Papers 3567 , Box 2; hereinafter cited as TP, Box number, page number. Of the 27 term papers, only eight actually have grades indicated upon them. Quotation from, Haller, Eugenics, 150.

${ }^{82}$ Ivy F. Lewis, "Untitled Lecture (Handwritten Ms)," in "Examinations and Lectures" Folder, Box 3 , IFLC, 1. The back of this document also has outlines for other lectures on it.

${ }^{83}$ Eugenicists repeatedly flayed Jefferson's statement that "all men are created equal" and the egalitarian, democratic ideal it expressed. See, Popenoe and Johnson, Applied Eugenics, 75. 
Mentally, morally and physically the hand of heredity lies heavily on us all. We know now that, while education can bring out the best in the child, it cannot create ability or aptitude. In training young people therefore, parents must discover and develop those traits which a child inherits or naturally possesses and not attempt to force the growth of qualities which are not naturally present. ${ }^{84}$

Echoing this lecture, in an undated quiz Lewis asked students, "1. Name factors now existing tending to a. improve, b. injure the race. 2. Discuss the question: are mental capacity and moral qualities inherited to the same extent as physical characteristics? 3 . What reason have we to believe that conclusion?" Given Lewis's relentless hereditarian emphasis, it seems unlikely that he presented any countervailing, environmental arguments. ${ }^{85}$

Lewis regarded as "sentimentalists" anyone who viewed racial inequalities as the result of prejudice rather than biology. In a 1924 letter written to Eamest Sevier Cox upon the publication of White America, he lamented the "drag of the negro on our civilization," and criticized, "the large class of the falsely sentimental ... who see in him [the African American] one who by his cheap and willing service helps to relieve the daily burden of living." Lewis further condemned the "conspiracy of silence" that surrounded racial amalgamation, calling it, "the greatest damage." Thanking Cox for "bringing home the truth to the minds of white people," he promised to bring the book to the attention of his students. ${ }^{86}$ Lewis not only brought Cox's book to his students' attention, he had Cox address his class in $1924 .{ }^{87}$ As a result of Cox's and Lewis's teaching, students expressed

\footnotetext{
${ }^{84}$ Le:wis, untitled lecture, "Examinations and Lectures" folder, Box 3, IFLC, 11. Believing lefthandedness to be hereditary (undoubtedly building on the work of his good friend Harvey Emest Jordan), Lewis cited stammcring, psychoses of a severe nature, and inferiority complex as possible results of parental attempts to "force" a hereditarily left-handed child to use its right hand.

${ }^{85}$ Undated Quiz, Box 1, 5119 Dean's Papers. Countervailing arguments, propounded by the anthropologist Franz Boas (a Jew who the anti-Semitic Lewis dismissed as sentimental), as well as other British and American scientists and lay people, existed almost from the beginning of the eugenics movement. See, Kevles, In the Name of Eugenics, 113-163; and Selden, Inheriting Shame, Chap. 6.

${ }^{86}$ Ivey Lewis to Eamest Sevier Cox, February 26, 1924, "1924 Letters" Folder, Box 1, IFLC. This letter actually appears as a blurb in the fly-leaves of the book, along with other testimonials from Madison Grant. Lothrop Stoddard, and John Powell.

${ }^{87}$ Ivey Lewis to Eamest Sevier Cox, April 25, 1924, Eamest Sevier Cox Papers, Rare Book, Manuscript, and Special Collections Library, Duke University. Lewis invited Cox to address the class on,
} 
detailed opinions on race and amalgamation in their term papers. The papers reflect the conservative, elitist beliefs embodied in Lewis's writing on education and his teaching of eugenics.

Notwithstanding Lewis's avowed belief in eugenics, he may have preached better than he practiced. Lewis fathered three children, a son and two daughters over whom he exercised a strong, albeit affectionate guidance. His progeny represented a eugenic risk, however, because of taints in his own "germ plasm." Manic depression, a form of mental illness eugenicists sought to eradicaie, affected his sister Nell. Nell Battle Lewis held her own prominent place in Southem history. For years she was the outspoken editor of the Paleigh News and Observer. Through the pages of this newspaper she advocated her own brand of "southem liberalism" that sought the democratic uplift white women and poor whites, while controlling blacks and the "feebleminded" without resorting to lynching or inhumane institutional conditions. ${ }^{88}$ Correspondence between Lewis and his siblings exposes their family's "dirty little secret," and speaks tellingly of Lewis's own personal attitude.

Ivey Lewis, as the senior brother and scientist in the family, exerted near total control over the disposition of his sister's care. She often came to stay with him during periods of depression. During a particularly bad bout in 1932, she stayed at Lewis's house as the

"the historical significance of the new Virginia law," the eugenic Racial Integrity Act for which Cox had lobbied. Lewis introduced Cox to the other faculty eugenicists. Cox's papers preserve the correspondence between Cox and Lewis over a 35-year period, also revealing Cox's close friendship with Madison Grant and Lothrop Stoddard, and his ties to the Eugenics Record Office. Smith's Eugenic Assault on America does not identify the connections between Lewis and this movement, largely because Smith confined his research to the John Powell Papers at Virginia, and did not consult either the Lewis or Cox Papers.

${ }^{88}$ Darden Asbury Pyron, "Nell Battle Lewis (1839-1956) and 'The New Southern Womanhood," in Perspectives nn the American South: An Annual Review of Society, Politics, and Culture, vol. e, ed. James C. Cobb and Charles R. Wilson (New York: Bordon and Breach Science Publishers, 1985), 63-85. Indeed, in her run for the North Carolina legislature in 1928, she reflected the racial and eugenical views of her brother. Opening a speech with two "darkey" jokes, she went on to state that, "I believe, further, in adequate provision for the State's dependents, the insane, the feeble-minded, the delinquent, the orphan, the crippled, the neglected.....And I believe not only in an intelligent program of alleviation, but also one of prevention as even more important." The mode of prevention, of course, followed eugenic dicta and relied on sterilization and segregation. A copy of this speech resides in the "Articles and Abstracts by IFL" folder, Box 2, Ivey Foreman Lewis Collection, RG 6/2/5119a, Special Collections, Alderman Library, Charlottesville; hereinafter cited as IFLC. 
family debated whether or not to commit her to a sanitarium. Lewis's sister Anne expressed the feelings of all the Lewises, as well as the conventional wisdom regarding depression, when she wrote, "Nell simply will not believe that her ultimate recovery can only rest upon her own efforts and upon the exercise of her will power." 89 Her brother Dick concurred, admitting that, "I can see nothing else but further treatment for her in an institution, and I think the sooner the better before she spends all her money" on quack remedies. 90 When Ivey Lewis revealed these plans to Nell, a scene ensued. Nell "seemed quite upset to learn that we were considering Broad Oaks. She says she is never going into another sanitarium, and for us not to make further inquiries." Writing that same day to his younger brother Kemp, Lewis reported, "Nell is somewhat improved, and I am encouraged over her progress....Her periods of depression do not last as long as they did, nor are they so violent, so I am hoping she is on the upgrade. "91 Nell's symptoms, as portrayed by Lewis, indicated a serious mental condition. Yet, in confessing to his sister that he felt the trip to a Baltimore "a waste of time and money," Lewis revealed his own opinion of the origins and nature of Nell's illness: "[S]he still hugs the delusion that her troubles are due to something else than her mental attitude."92 For the Lewises, there was nothing organically or hereditarily wrong with their sister; instead, her poor attitude and lack of fortitude degenerated to depression.

\footnotetext{
${ }^{89}$ Anne (Lewis) Perry to Ivey Foreman Lewis April 24, 1932, "1932 Letters" folder, Box 1, IFLC. Anne wrote, "I wanted her to think the suggestion [for institutional treatment] came from you because she trusts your judgement [sic] absolutely."

$9^{0}$ Dick Lewis to Ivey Foreman Lewis, April 27, 1932, Ibid.

${ }^{91}$ Ivey Foreman Lewis to Kemp Plummer Lewis, April 29, 1932, Ibid. A letter to Dick Lewis revealed that Nell also suffered from pain in her mouth, which Ivey Lewis seemed to think psychosomatic rathei than pathologic. Nell herself favored non-traditional healing approaches, including Christian Science, Anne (Lewis) Perry to Ivey Foreman Lewis, April 24, 1932, Ibid. Nell remained "eccentric," arguing for the power of spiritualism, clairvoyance, and the possibility of contact with the deceased to improve the lives of the living. See Nell Battle Lewis to Ivey Foreman Lewis, February 24, 1945, "1945 Letters" folder, Ibid.

92 Ivey Foreman Lewis to Anne (Lewis) Perry, April 29, 1932, "1932 Letters" folder, Ibid.
} 
In light of his sister's long battle with mental illness and his own avowed espousal of eugenics, Lewis's fatherhood seems, at first glance, a glaring inconsistency. ${ }^{93}$ One can only speculate how Lewis resolved this issue for himself. He may have felt that since Nell was the only sibling to be so afflicted, that the chances of him passing on this "genetic" defect were so small as to make the risk negligible. This would provide a convenient rationalization for his becoming a father. Alternatively, since the extant record is unclear about the first episode of Nell's depression, her condition may only have developed later in life, after Lewis had begun his family. In that case, the die was cast and all he could do would be to counsel his own children not to raise families. This scenario is a distinct possibility that gains added support from a number of circumstances. Lewis's eldest daughter, Penny, was born with a genetic defect that left her completely hairless and without fingernails. As Virginia's historian Raymond A. Bice recalled, "She did pretty well hiding the hairlessness, but the fingernails were tough to hide." With this obvious genetic failing in his immediate family, Lewis would have been hard put to justify continued procreation among his children. The University of Virginia cemetery bears mute witness to the fact that neither of the daughters married and Ivey junior had no children: all three children lived long lives and all are interred next to their parents with no indication of marriage or progeny. ${ }^{94}$ A final option exists. Lewis may simply have held a hypocritical stance, applying eugenics to others but not to himself. This final option seems unpersuasive, given Lewis's clear and consistent belief of all things eugenical throughout his career. Ivey Foreman Lewis was assuredly among the staunchest eugenical "true believers" in Virginia. He was not alone among the faculty of the university.

\footnotetext{
${ }^{93}$ After all, Charles Davenport had concluded that manic depression was a form of inherited mental defect in 1917. Lewis was quite familiar with this work. See Davenport, "Inheritance of Temperament with Special Reference to Twins and Suicide," in Davenport, The Feebly Inhibited (Washington, D.C.: The Carnegie Institution of Washington, 1915), 71-124, especially 73-74, 122.

${ }^{94}$ Conversation with Raymond A. Bice, 1 December 1999 and 25 January 1999, tapes in author's possession. Bice had been a professor in the psychology department and had taught Penny during her graduate studies.
} 


\section{Medical Eugenics: Physical Anthropology and Pediatrics}

In 1916, the year after Ivey Foreman Lewis joined the faculty and assumed responsibility for undergraduate pre-medical training, the medical school hired a prominent American eugenicist. William Bennett Bean came to the university to assume the chair of anatomy, vacated by Jordan as faculty expansion allowed him to return to his specialties of histology and embryology. Bean is a familiar figure in the history of scientific racism and eugenics in America. From the start of his career, he made it his life's work to substantiate qualitative differences between the races through comparative anatomy. He began his work studying crania. Then, while teaching at the University of Manila, Bean analyzed the physique of Philippine Islanders. Upon his return to America, he returned to the comparative study of white/black anatomy, investigating the "stature" of so-called "Old Americans"-people descended from the original settlers at Jamestown and Massachusetts Bay. Proud of his own "racial heritage," and determined to make others appreciate theirs or their lack of it, Bean's students applied a moniker that still reveals much about the man: Baron Bean. 95 As one of the leaders of America's physical anthropologists, he was wellacquainted with Charles Benedict Davenport and eugenics. American Eugenics Society documents list him as an "active" member during the 1920s. ${ }^{96}$ Although times changed and science moved on, Bean never abandoned his quest to prove the existence and significance of racial differences in physiognomy.

\footnotetext{
95 Bean himself favored this appellation, and signed some of his letters to his good friend Ivey Lewis "Baron." During a 1972 interview, Bean's son William Bennett Bean, himself a prominent internist, remembered, "The combination of awe and respect for Father [among the students] are perhaps indicated by the fact that his nickname was 'The Baron'....I think that he was one of a number of, you might say characters, people in the academical village who were unusual and didn't have any notion of conforming for conformity's sake." William Bennett Bean, Interview by Michael Plunkett, 24 May 1972, interview 4, transcript, University of Virginia Oral History Collection, Special Collections, Alderman Library, Charlottesville.

96"AES Membership Campaign, Miscellany" folder, n.d., American Eugenics Society Papers, American Philosophical Society Library, Philadelphia. [Hereinafter cited as AES Papers.]
} 
Bom in 1874, Bean grew up in Boutetourt County, Virginia before beginning a peripatetic career that would take him around the country and across the globe. Bean was the third child of eight in a family that proudly traced its ancestry to the colonial era in Virginia and Maryland. His father served in the Army of Northern Virginia as an artillery lieutenant during the Civil War. Bean grew up, his son later recalled, "under the most trying circumstances of economic distress in the backwash of the Reconstruction period," and was schooled by a disciplinarian aunt. The Bible became "a strong factor in his life" and Bean remained a devout Christian throughout his life.

That Bean became a doctor is a testament to his tenacious personality. From thirteen to twenty two, Bean worked myriad jobs_-farming and selling farm machinery, clerking, managing the dining room at a summer resort, teaching, mining, guarding convict laborers, and writing for a county newspaper — that "gave him a wide background of useful knowledge" and began to form his ideas about the nature of humanity. Bean entered the Virginia Polytechnic Institute in 1896 at age 22, graduating in 1900. Bean's sister then provided the financial backing for him to enter the Johns Hopkins Medical School, the most rigorous medical training then available in America. ${ }^{97}$

Entering Hopkins during "the Heroic Age in American medicine," Bean studied in the shadow of America's inedical giants, men immortalized by John Singer Sargent as "The Four Doctors," William Henry Welch, William Osler, Howard A. Kelly and William S. Halsted. Bean concentrated in anatomy under Franklin Mall, the leading human anatomist in America. After graduation in 1904, Bean stayed on as instructor in Mall's anatomy lab for the next year. Next, Bean became assistant professor of anatomy at the University of

\footnotetext{
${ }^{97}$ Hopkins was the first medical school to require that every entering student hold the bachelor's degree. The four year course in medicine, which began with two years work in the allied sciences of chemistry, biology, and anatomy before exposing the student to clinical work in the final two years, revolutionized American medical training. See Abraham Flexner and Simon Flexner, William Henry Welch and the Heroic Age of American Medicine (New York: The Viking Press, 1941; reprint with Foreword, Baltimore and London: Johns Hopkins University Press, 1993), 211-33 (page references to reprint edition); and Donald Fleming, William Henry Welch and the Rise of Modern Medicine (Boston: Little, Brown and Company, 1954), chapter 8,118 .
} 
Michigan from 1905 to 1907 , before he answered the call to direct the anatomical laboratory at the Philippines Medical School in Manila. Returning to the United States in 1910, he spent the next six years at Tulane University as associate professor and then professor of anatomy. Finally, in 1916, he retumed to his Virginia roots by coming back to Mr. Jefferson's university. 98

An anatomist by training, Bean's real academic passion lay in the field of physical anthropology. During medical school he began the studies of racial differences, and the social significance of those differences, that would become the hallmarks of his career. His son recalled that, "He began his career as an anatomist and anthropologist during his student days," and he sought to carry "the study of man outward to the macrocosm of type and race rather than inward to microanatomy and the biophysics of the cell." 99 He spent his postgraduate year with Mall "pursuing studies of the subclavian artery and peculiarities of the Negro brain," and then in the summer of 1906 he studied under Léonce Manouvrier at the Ecolé d'Anthropologie de Paris. Manouvrier, one of Paul Broca's students, pioneered modern comparative human anatomy and its system of measurement, anthropometry. Bean would bring these methods back to the United States and, in concert with Charles Davenport, Ales Hrdlicka, and Franz Boas help set the standards for the field. Despite having studied under Mall and Manouvrier, two confirmed skeptics who mistrusted determinist explanations of human nature, Bean rapidly gravitated to the hereditarian camp with Davenport and Hrdlicka.

The year he studied in France, Bean published his first paper documenting structural differences between white and black brains. Building on a long tradition of scholarship that began with Johann Friedrich Blumenbach, reached its apogee with Paul Broca, and in America was represented most famously by Josiah Nott and George Gliddon, Bean's

\footnotetext{
98 Marquis Who's Who, Inc., Who Was Who in America, 1943-1950, 7th ed., vol. II, (Chicago: Marquis Who's Who, Inc., 1975), 51; William Bennett Bean, "Robert Bennett Bean, 1874-1944," Science 101 (April 6, 1945), 346-48, quotation 346.

99 Bean, Ibid., 2
} 
conclusions regarding racial differences revealed less about the brains of his subjects than they did about his own personal prejudices. 100

In "Some Racial Peculiarities of the Negro Brain," Bean compared numerous measurements of brain structure, particularly of bodies within the corpus callosum of black and white brains. The corpus callosum is the tissue-bridge that connects the left and right hemispheres of the brain. It has a number of substructures, the major two of which are the genu toward the front, and splenium toward the rear. Bean conformed to the neurological conventions of the day, which held that the rear of the brain controlled "the powers of conception in the concrete," while the front of the brain controlled "the powers of thought in the abstract."101 Extrapolating from these basic assumptions, Bean reasoned that races with higher intelligence would require a larger genu to handle the increased activity in the frontal lobes. Conversely, races with lower intellect but stronger "animal" instincts would develop larger spleniums

Bean measured the genu and splenium in 152 brains, and plotted them on a graph. A striking pattern emerged: virtually all the white brains displayed larger genus and clustered in a group, while virtually all the black brains exhibited larger spleniums and clustered together in their own group. While there was slight overlap between the groups, they segregated almost perfectly by race [see figure 1]. The logical conclusion, according to Bean, was that brain structure evinced the superiority of white intelligence. Moreover, blacks were even less intelligent than the size of their genus might indicate, because the neuro-transmitters for smell resided in the genu along with those for intelligence. Working from the conventional wisdom that blacks had a better sense of smell than whites, Bean

${ }^{100}$ Excellent summaries of the work of all these men, including Bean, appears in Stephen Jay Gould, The Mismeasure of Man (New York and London: W. W. Norton \& Company, 1981; revised and expanded, New York and London: W. W. Norton \& Company, 1996), chapters 2-4. My interpretations agree entirely with Gould's; my analysis, however, places Bean within the context of the national and Virginia eugenics movement, where Gould uses his work as an illustrative example of prejudice influencing science. Allan Chase also recounts this part of Bean's career in The Legacy of Malthus, 179-80. 379.

${ }^{101}$ Bean, "Some Racial Peculiarities of the Negro Brain," The American Journal of Anatomy 5 (1906): 
concluded that the size of black genus resulted from their olfactory, not their cognitive powers. If, despite the enlargement due to olfaction, black genus were smaller than white genus then blacks must be mentally dull, indeed.

Bean concluded that the structure of black brains revealed striking differences in cognitive ability between blacks and whites. He presented telling psychological portraits of the races. "The Caucasian-more particularly the Anglo-Saxon...is dominant and domineering, and possessed primarily with determination, will power, self-control, selfgovernment, and all the attributes of the subjective self, with a high development of the ethical and aesthetic faculties." Of African Americans, Bean averred:

The Negro is primarily affectionate, immensely emotional, then sensual and under stimulation passionate. There is love of ostentation, and capacity for melodious articulation; there is undeveloped artistic power and taste-Negroes make good artisans, handicraftsmen - and there is instability of character incident to lack of selfcontrol, especially in connection with the sexual relation; and there is lack of orientation, or recognition of position and condition of self and environment, evidenced by a peculiar bumptiousness, so called, that is particularly noticeable. ${ }^{102}$

Bean left little to the imagination in deciding the relative position of blacks and whites in the order of humanity.

Comparing Bean's conclusions with Jefferson's, made almost one hundred twenty years earlier, reveals a striking continuity of ideology. Jefferson believed that blacks were inferior in "reason," gifted musically, trainable to "the handicraft arts," and sexually "they are more ardent after their female: but love seems with them to be more an eager desire than a tender delicate mixture of sentiment and sensation." 103 Bean's ideas matched Jefferson's, with the single exception of "artistic" ability. Jefferson dismissed black artists, whereas Bean felt this talent lay undeveloped. Jefferson judged blacks unable to produce "high" art equal to that from the western classical tradition. Bean, writing after over 60 years of blackface minstrelsy had popularized notions of black musical and

102 Bean., Ibid.

${ }^{103}$ Thomas Jefferson, Notes on the State of Virginia ed. William Peden (Chapel Hill: University of North Carolina Press, 1954; reprint, New York and London: W. W. Norton \& Company, 1972), 70-71, $138-42$ (hereinafter page references are to reprint edition). 
narrative creativity, operated from a more capacious definition of "art" and with a surer sense of what "blacks" were really capable of creating. 104 Writing in 1906, the year of the Atlanta race riot, which was sparked by false reports of a black man raping a white woman, it is not surprising that Bean would find the superimposed images of the "black beast rapist" and Jim Crow the minstrel physically inscribed in the black brain.

Bean's conclusions extended beyond contemporary racial ideology, explaining gender differences as well. Breaking down his sample by sex, he found that males had relatively larger genus than females, and that this distinction held within races. So, the rank order of intelligence, as indicated by the size of the genu as revealed by Bean's measurements would be white men, white women, black men, black women in descending order. Clearly, according to Bean, nature had written the laws of social hierarchy within the structures of the human brain. Moreover, because these differences were structural, training could not hope to alter them. Bean's conclusions provided ammunition for those who sought to limit the social, political, and educational opportunities of African Americans and women.

Bean published a "popular" version of his paper, accessible to laymen, in the September 1906 issue of the progressive journal Century Magazine. He argued that, "the fundamental physical and mental differences of the white and black races should be considered in any rational adjustment of the relations between them," concluding that racial differences in brain size made blacks and whites "fundamentally opposite extremes in evolution."105 Later in 1906, Bean published "The Training of the Negro" where he wrote that, "The negro is lacking in apperception, faulty in reasoning, and deficient in judgment." Thus, "The object to be attained in training the true negro is to cultivate his natural endowments and to fit him for positions that he can fill. The training should be in manual

\footnotetext{
${ }^{104}$ The most comprehensive analysis of minstrelsy and the psycho-social functions it performed in 19 th century white society, is Eric Lott, Love and Theft: Blackface Minstrelsy and the American Working Class (New York and Oxford: Oxford University Press, 1993).

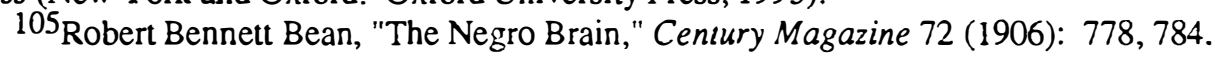


labor of various kinds, useful in the industrial development of the South, and in intellectual pursuits for the production of men of affairs among their own people," under "white male teachers of the highest moral caliber". 106 Bean essentially pulled a page from Paul Barringer's earlier ideas about black education and capacity. He also anticipated Harvey Eamest Jordan's article "Eugenics in Relation to Venereal Disease" when he wrote, "The negroes in the South prepare our food, and in this way tuberculosis, or worse contagious discases [syphilis], may be transmitted....As washerwomen, they contaminate our clothes. They are foci of infection in any community. For our own preservation and purity," whites had to control black moral and intellectual education. 107 "History, investigations, experiments, and existing conditions indicate that the [mental and moral] traits [among African Americans] are hereditary and stable, and that the negro is not capable of mental development in the same way that the Caucasian is," Bean remarked, sealing the intellectual fate of blacks in the minds of many white Americans.

These articles convinced the editors of American Medicine that Bean had "rightly" proved that "no amount of training will cause that [the black] brain to grow into the AngloSaxon form." Bean had proved, the editorial continued, "the anatomical basis for the complete failure of negro schools to impart the higher studies - the [black] brain cannot comprehend them any more than a horse can understand the rule of three." Invoking the shibboleth of the "Crime of Reconstruction," the editors commented, had politicians known "these anatomical facts when we placed a vote in possession of this brain which cannot comprehend its use," America would have avoided the lingering sectional animosities. Registering their support for black disfranchisement, the editors claimed that Bean's study may help "remove a menace to our prosperity —a large electorate without brains." Lashing

${ }_{106}$ Robert Bennett Bean, " The Training of the Negro," Century Magazine 72 (1906): 950-51.

${ }^{107}$ Obviously, Bean's sentiment anticipates that expressed by Harvey Ernest Jordan in "Eugenics in Relation to Venereal Disease." For the currency of these beliefs about black women beyond Virginia, see Tera Hunter, "Domination and Resistance: The Politics of Wage Household Labor in New South Atlanta," in Darlene Clark Hine, Wilma King, and Linda Reed, eds., "We Specialize in the Wholly Impossible": A Reader in Black Women's History (Brooklyn, NY: Carlson Publishing Company, 1995), 347-49. 
pervasive racist sentiment, Bean's first major study gained widespread publicity and launched his career. ${ }^{108}$

For reasons that remain unclear, in 1909 Bean's mentor at Hopkins, Franklin Mall, attempted to verify his student's conclusions by an independent analysis of 106 white and black brains. He included in his sample 18 brains in which Bean claimed to have found distinct anatomical variations. Mall, however, made a crucial change in methodology from that employed by Bean. Mall understood that while the scientific method, in the abstract, is objective, it becomes liable to the biases of the individual scientist employing it. "In order to exclude my own personal equation [biases], which is an item of considerable importance in a study like this," Mall wrote in his rebuttal article in the American Journal of Anatomy, "all of the tracings as well as the measurements of all the areas were made without my knowing the race or sex of any of the individuals from which the brains were taken. The brains were identified from the laboratory records just before the results were tabulated."109

Mall either knew his student or knew himself very well, probably both; he definitely knew his science. His results completely destroyed those of Bean. When he plotted the relative sizes of genus and spleniums, his graph showed absolutely no meaningful correlations between brain structure and race or sex. While "there are great individual variations" among the brains, "they seem to be of like extent in both the white and the negro brains." Totally discrediting Bean's study, Mall noted, "I have now had considerable experience in the dissection of the negro and have yet to observe that variations are more common in the negro than in the white." 110 This categorical

${ }^{108}$ American Medicine quoted in Chase, Legacy of Malihus, 179.

${ }^{109}$ Franklin Mall, "On Several Anatomical Characteristics of the Human Brain Said to Vary According to Age and Sex, with Special Reference to the Frontal Lobes," American Journal of Anatomy 9 (1909): 132, quotations 9. Mall also used slightly more accurate measuring devices, but that alone was not enough to account for the drastic difference in his findings.

110 Mall, Ibid., 9 and 21. Implicitly Mall charged Bean and all earlier investigators with measuring their own bias along with brain size. 
renunciation of Bean's work came too late. Published after the worst of America's turn-ofthe-century race riots had occurred, after disfranchisement had stripped most blacks of the vote, and in a culture more concerned with the advent of aircraft and automobiles, Mall's study drew little attention outside professional circles. Bean had won the day for scientific racism, just as Carl Brigham's conclusions would convince generations of Americans that intelligence tests had "proved" blacks inferior, despite Brigham's subsequent recantation. ${ }^{111}$

- Bean's entire career can be seen as an extension of this first academic foray. For the next three years he studied the anatomy of the Philippine Islanders in an attempt to document their racial distinction from whites. The book that resulted from these studies is an extended essay on the heredity of racial inequality, as proved by comparative anatomy. As Bean put it, he had discovered "a method of segregating types" that "affords a ready means of comparing different groups of men." 112 Bean was so convinced that he had discovered in the Philippines an instance of human breeding that matched Mendelian ratios, that he was willing to dispute Charles Davenport, America's foremost Mendelian. Davenport held that Mendel's laws held only insofar as they related to individual characteristics-i.e. height, eye color, susceptibility to disease, and so forth. Bean, however, believed that it could apply to entire types, aggregations of individual characters also understood as species.

Bean believed he had found "separable or unit characters which persist as a charactercomplex in the form of types as well as break up in the formation of new charactercomplexes." Thus, Bean described a primitive form of what later geneticists would term

${ }^{111}$ On Brigham's recantation, see Gould, Mismeasure of Man, 262-263; and Chase, Legacy of Malthus, 321-22.

112Robert Bennett Bean, The Racial Anatomy of the Philippine Islanders (Philadelphia and London: J. B. Lippincott Company, 1910), 7. The subtitle announced that Bean was "introducing new methods of anthropology and showing their application to the Filipinos with a classification of the human ears and a scheme for the heredity of anatomical characters in man." 
"linkage": two traits that tend to be inherited together. 113 "I base my belief," he wrote Davenport, "on the fact that I have found two systematic species of men in the Philippines who have much the same proportion as the types of tomatoes produced by Price and Drinkard, and the biotypes of com observed by Shull." Bean offered to send Davenport off-prints of his papers proving this point. He went on to emphasize that his taxonomy of Filipinos divided "them into systematic species, elementary species and varieties. The definitions I assign to systematic species, elementary species, and variety enable me to classify the types in this manner rationally." Bean based his system on the work of England's foremost Mendelian, William Bateson. This incredible oversimplification of genetics and its dogmatic application to human beings became characteristic of Bean's scholarly work. ${ }^{114}$

Bean, like Harvey Eamest Jordan, collaborated with Davenport and became involved with the national eugenics movement during this period. Bean's letter indicates that Davenport had queried him regarding studies Bean had made of Virginia blacks. Bean wrote to Davenport that, "judging from the records of a few negro families that I collected in Virginia during the year 1906, both light and dark colored children appear as offspring from half tint parents, although I cannot exclude outside parentage as a cause of some of the very dark or very fair children." Bean noted that, "Similar expressions of heredity have been noted by me in the Philippines, and investigations are being pursued not only as to skin color, but also as to hair form, head form, physiognomy, stature, etc. Observations of the hair form corroborate your work, although an occasional family has dominant

${ }^{113}$ The analogy between the phenomenon Bean described and the modem notion of genetic linkage is, admittedly, imperfect. Still, it reveals how Bean's science reflected both physical processes that did indeed exist, yet warped them into supporting his a priori notions of racial taxonomy. For a concise discussion of linkage sse Daniel J. Kevles, "Out of Eugenics: The Historical Politics of the Human Genome," in Daniel J. Kevles and Leroy Hood, eds., The Code of Codes: Scientific and Social Issues in the Human Genome Project (Cambridge, MA: Harvard University Press, 1992), 12-13, 380.

${ }^{114}$ All preceding quotations from William Bennett Bean to Charles B. Davenport, September 24, 1909, Charles B. Davenport Papers, American Philosophical Society Library, Philadelphia. Bean published in numerous anatomical, anthropological, and medical journals. Many examples of his work are scattered throughout the Rare Virginia Pamphlets collection, Special Collections, Alderman Library, Charlottesville. 
straight hair."115 These studies reveal both men's interest in heredity and its physiological effect on developing body form. Whether or not Harvey Eamest Jordan knew Robert Bean personally, at this time, is unclear. It is fairly certain, however, that after 1907 the two became familiar with each other's work, if only through Davenport.

Hired as professor of anatomy at Virginia in 1916, Bear bolstered the ranks of eugenicists on the faculty and within the medical school. Not surprisingly, he became fast friends with Harvey Jordan, William Harry Heck, and Ivey Lewis. As Bean's son William recalled, "Professor Lewis was a very good friend of Father's; the Lewises and our family were very close together."116 Lewis and Bean together founded Virginia's chapter of the scientific honor society Sigma Xi in 1923. They brought many of the university's professors of science into the fold, turning especially to Harvey Eamest Jordan and other eugenics enthusiasts. The society invited prominent eugenicists to address them at their 1924, 1927, and 1928 annual dirıners. Thus, these men were responsible for exposing most of the university's scientific faculty and many of its best students of science to eugenics. ${ }^{117}$ Bean offered medical students courses in physical anthropology, in addition to his anatomy courses which were themselves strongly influenced by physical anthropology. In all these venues, Bean continued to insist that measurable biological differences existed between the races. Bean's anthropometric investigations always buttressed the extant racial hierarchy.

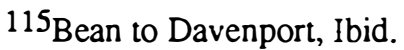

116In fact, the Beans and Lewises were neighbors living on the "Lawn" in Jefferson's Academical Village. William Bennett Bean, Interview with Michael Plunkett, transcript, 6 and 15.

${ }^{117}$ The founding of Virginia's chapter of Sigma Xi is covered in, Henry Baldwin Ward, ed., Sigma Xi Half-Century Record and History, 1886-1936 (Burlington. VT: Free Press Interstate Printing Corp., 1936), 773-75. Bean's post-graduate mentor, the physical anthropologist and eugenicist Ales Hrdlicka spoke on "Early Man in Europe and his Development" in 1924; prominent eugenicist Ellsworth Huntington delivered "Why Races Differ" in 1927. Paleontologist John C. Merriam's 1928 address "The Value of Evolution to the Individual," rounds out the group. For brief resumes detailing each of these men's deep association with organized eugenics, see Barry Alan Mehler, "A History of the American Eugenics Society, 1921-1940" (Ph.D. diss., University of Illinois at Urbana-Champaign, 1988), 372-73, $375-76$, and 400-01. 
When America entered World War I, Bean joined the wave of scientists who offered their services in an effort to make the army more efficient. While Yerkes, Thorndike, Brigham and the psychologists began measuring men's minds, Davenport, Hrdlicka, Bean and America's physical anthropologists measured men's bodies. Ostensibly, their mission was to take measurements that would allow the army to design better fitting, more functional uniforms. These scientists used the data they collected to other ends as well. Davenport and his collaborator A. G. Love published their findings as Army Anthropology in 1921. He then used this work as the basis of his books, Body-Build and Its Inheritance and How We Came by Our Bodies. ${ }^{118}$ All of these works emphasized how heredity determined physique, and physique provided a reliable index of racial difference.

Davenport wrote, "That there are marked racial differences in build is notorious. The slender Scotchman [sic] is in striking contrast with the South Italian, Greek, or Russian Jew....The racial differences in body-build are so great that, when feasible, race should be taken into account in studies of body build."119 Ignoring that human morphology blends in a seamless normal distribution, with members of every race exhibiting physiques across the spectrum of stature, Davenport's claims literally "embodied" racial difference. Other physical anthropologists agreed and, indeed, still agree. ${ }^{120}$

${ }^{118}$ Charles Benedict Davenport and A. G. Love, Army Anthropology, vol XV in Medical Department, U. S. Army in World War, Statistics, part I, (Washington, D.C.: U. S. Government Printing Office, 1921); Davenport, Body-Build and Its Inheritance (Washington, D.C.: Carnegie Institution of Washington, 1923); and Davenport, How We Came by Our Bodies (New York: Henry Holt and Company, 1936). The last book was owned by Orland $E$. White, professor of genetics at the University of Virginia.

11 Savenport, Body-Build and Its Inheritance, 7.

120 Physical anthropology is a rarefied field, yet its practitioners today still hold to versions of the ideas advanced by Davenport. In the era before DNA analysis, the science of forensic anthropology, often engaged in identifying remains of war dead or decomposed victims of crime, relied on racial generalizations to make identifications. For modem views of physical anthropology, see Noel T. Boaz and Linda D. Wolfe, eds., Biological Anthropoiogy the State of the Science (Bend, Ore.: International Institute for Evolutionary Research, 1995). For historical appraisals of physical anthropology, see George W. Stocking, Jr., ed., Bones, Bodies, Behavior: Essays on Biological Anthropology (Madison, Wisc.: University of Wisconsin Press, 1988); and Frank Spencer, ed., A History of American Physical Anthropology, 1930-1980 (New York: Academic Press, 1982). 
During this period, Bean and Davenport's interests coincided to such an extent that they corresponded regularly. ${ }^{121}$ Bean himself measured both black and white inductees at Virginia's Camp Lee. He used his findings in many of his subsequent studies. True to established form, Bean claimed that this anthropometric data "proved" black inferiority. Even his innocuously titled paper, "The Sitting Height," advanced invidious racial distinctions. Bean acknowledged the complexity of anthropometry, writing, "The sitting height depends on age, stature, sex, race and type as well as evolution, environment and individual development, and in any consideration of this measured part of the body all of the factors should be known." Bean still felt confident enough to conclude not only that, "The sitting height index is shown to vary with race, type, stature, and sex," but also that, "Racial differences that remove the Negro further from the remainder of mankind than any other group of people have been demonstrated." 122 Under no circumstances could blacks measure up to white performance by Bean's anthropometric yardstick.

Bean assuredly taught his students these ideas-he announced this in correspondence and student work accorded with Bean's ideas. In 1919, Bean released a series of papers in conjunction with his student, Wilmer Baker, that examined the relative differences in the weights of black and white spleens, livers, and hearts. ${ }^{123}$ Basing his conclusions on measurements made from cadaver organs, as he did in his 1906 study of black and white brains, Bean again emphasized the inferiority of blacks. The paper on spleen weight ends with an interpretive leap. First they establish that the differences in the weight of normal spleens substantiates a biological marker of racial difference. Then, comparing diseased spleens, Bean and Baker concluded that,

${ }^{121}$ See the "Bean, R. B." folder in the Davenport Papers. Also, Bean outlined his measurements of men at Camp Lee in a letter to Davenport filed in the "Book Review" folder, Davenport Papers.

${ }_{122}$ Rubert Bennett Bean, "The Sitting Height," quotations 372 and 377.

${ }^{123}$ Robert Bennett Bean and Wilmer Baker, "Some Racial Characteristics of the Spleen Weight in Man," AmJ.Phys.Anthro 2 (1919): 1-9; Bean and Baker, "Some Racial Characteristics of the Liver Weight in Man," American Journal of Physical Anthropology 2 (1919): 167-74; and Bean and Baker, "Some Racial Characteristics of the Heart and Kidney Weight in Man," American Journal of Physical Anthropology 2 (1919): 274-281. 
the racial difference is even greater, in spite of the fact that more tall, young, well nourished negroes and more small, old, thin whites constitute the records; and this difference is especially noticeable between the males. This would seem to indicate that the whites are more viable than the negroes, and the large size of the spleen in the whites may play a part in this greater viability, especially when we consider that the spleen reacts to infections, and plays an important part in the resistance of the body to disease. ${ }^{124}$

Thus, African Americans not only differed anatomically from whites, this difference accounted for their increased morbidity and mortality. Anatomy predestined whites, in Bean and Baker's estimation, for survival. The duo's comparison of liver weights made substantially the same conclusions, documenting larger livers among whites and underscoring that, "The racial difference is considerable in spite of the fact that more tall, young, well nourished negroes and more small, old, thin whites constitute the records." 125

Bean knew better than to compare the size and weight of black and white brains, so he turned to the other vital organ of equivalent physiological significance: the heart. Other investigators had debunked 19th century measurements of differences in cranial capacity.

Even Bean himself, in his 1906 paper on differences in black-white brain anatomy, had to bury in a footnote his admission that the brains he examined exhibited no significant difference in size or weight. ${ }^{126} \mathrm{He}$ ran into the same difficulty when examining heart size. Blacks and whites showed no appreciable difference in heart weight. Despite this, Bean and Baker fell back on their earlier measurements, writing,

When the weights of the heart and kidneys are compared with the weights of the spleen and liver a marked difference is manifested due to race: the liver and spleen of the white are larger than those of the negro. This is the first time that attention has been called to these differences, and we believe that they are fundamental and may have an important bearing in relation to medicine and evolution. The negro is probably being bred out and is certainly dying at a more rapid rate than the white in America, due to

${ }^{124}$ Bean and Wilmer, "Spleen Weight," 9.

125 Bean and Wilmer, "Liver Weight," 170.

${ }^{126}$ Stephen Jay Gould discusses the nineteenth-century efforts at measuring cranial capacity in, Mismeasure of Man, chapter 3; he discusses Bean's effort to dismiss equivalent brain weight on page 111. Moreover, by 1919 scientists looked to intelligence tests, more than morphological anatomy, to prove differing cognitive capacities and capabilities between races. 
climate, bad living conditions and neglect, but the physical makeup of the race in

America may have more to do with this than we can at present determine. ${ }^{127}$

Apparently hoping his audience would miss the fact that he never presents any comparison of heart and kidney weights to liver and spleen weights, Bean pressed his conclusion that blacks represented an evolutionary dead end, an unfit variety doomed by natural selection to extinction. Bean's belief in the "important bearing" of such racial differences "in relation to medicine" informed his conception of appropriate medical care.

To treat patients efficiently and effectively, Bean advocated teaching physical anthropology in medical school. As early as 1916, while writing about variations within the white race, Bean argued that, "Human types that represent different degrees of susceptibility to disease may be segregated" and given different medical therapies. ${ }^{128}$ Physicians who could identify different racial types would reach speedier diagnoses, and then decide on the most effective treatment option. As an example, Bean distilled his own work, stating that,

It is possible by the ear form alone to determine differences of 10 feet in the length of the small intestine, of 500 grams in the weight of the liver, of differences in the size of the brain, cerebellum, heart, kidneys and spleen, of the position and shape of the viscera; thus anthropology becomes the handmaid of anatomy in the medical curriculum, an essential adjunct in teaching medicine.

Since "Different human types represent different forms of intellect and different immunities and susceptibilities to disease," Bean argued that, "psychology and pathology become associated with anatomy and anthropology" and "the necessity for the teaching of both race and type differences to medical students becomes more and more imperative." Noting that, "This has been done for the past ten years by the writer at Tulane or Virginia," Bean argued that elsewhere, "The physical and psychical sides of man in relation to diagnosis, prognosis and treatment have been too much neglected in the medical curriculum, due in

${ }^{127}$ Bean and Wilmer, "Heart and Kidney Weight," 274.

${ }^{128}$ Robert Bennett Bean, "Disease and Death Rate in Human Types," New Orleans Medical and Surgical Journal 69 (September 1916), 16 (page number corresponds to the pagination of the off-print from this article, located in Rare Virginia Pamphlets, vol. 186, Special Collections, Alderman Library, Charlottesville). 
part to the enormous exacerbation of interest in germ diseases following the brilliant studies of Pasteur as to the role of bacteria in the production of disease."129 Bean, like Davenport, Jordan and Barringer before them, believed in "racial medicine," that there existed separate, race-specific therapeutic approaches to disease. Racial medicine represented a significant divergence from the bio-medical notion that germs are the most democratic of all life forms, because it held that each race reacted differently to the same pathogen. Thus, in circular fashion, differences in morbidity revealed the existence of racial types, racial types determined differences in morbidity. 130

As an anatomist and physical anthropologist, racial taxonomy defined Robert Bean's career, particularly during the 1920s. ${ }^{131}$ Almost exactly a month before his article on "Anthropology in the Medical Curriculum" appeared in Science, Bean had attended the Second International Congress of Eugenics, held at the American Museum of Natural History in Manhattan. There Bean delivered "Notes on the Body Form of Man." At the congress, Bean elucidated the differences in stature that characterized the "Asiatic, American, African and European" people who represented "the fundamental [human] stocks which carry evolution." All other peoples, according to Bean's taxonomy, "apparently represent modifications through mixture, blend, mosaic and isolation who have

${ }^{129}$ Robert Bennett Bean, "Anthropology in the Medical Curriculum," Science 56 (October 21, 1921), 371-373.

${ }^{130}$ Bean augmented his courses in anatomy during the 1920 s with a summer session course in "Development and Evolution in Man" that highlighted racial differentiation. University of Virginia, "Summer Quarter," Record (Charlottesville, VA: The Michie Company, 1923-1925). Between 1931 and 1941, Bean offered physical anthropology as an elective course for graduate students and third and fourth year medical students. See University of Virginia, "Deparunent of Medicine Announcements," Record (1930-1941). For a discussion of racial medicine, see James H. Jones, Bad Blood: The Tuskegee Syphilis Experiment (New York: The Free Press, 1981; revised and expanded edition, New York: The Free Press, 1993), chapter 2; and John S. Haller, jr., "The Physician Versus the Negro: Medical and Anthropological Concepts of Race in the Late Nineteenth Century," Bulletin of the History of Medicine 44 (1970): 154-67.

${ }_{131}$ Bean churned out articles about racial taxonomy, including, "Two European Types," The American Journal of Anatomy 31 (March 1923): 359-71; "The Three Anatomic Types of Africa," The American Journal of Anatomy 33 (March 1924): 105-18; "Types of Man in the Yellow-Brown Race," The American Journal of Anatomy 35 (March 1925): 63-80; "Human Types," The Quarterly Review of Biology 1 (1926): 360-92; "Types of the Three Great Races of Man," The American Journal of Anatomy 37 (1926): 237-71. Eventually, Bean would combine all his work into his 1932 book, The Races of Man: Differentiation and Dispersal of Man (New York: The University Society, 1932). 
undergone great changes from the fundamental stocks; and are mere remnants, the survivals under adverse conditions in different environments." Bean did more than merely catalog the varieties of humankind, however. Throughout the paper, Bean subordinated the position of Africans and those of African descent to the white groups he studied. Remarking on the "sitting height index," Bean wrote, "The index of Africa is higher than that of the true [pure] negro, because the records are of Africans with a large admixture of European blood." The same held true for the American blacks he measured, whom he classified as, "hybrid Afro-Americans with a preponderance of white blood." In every instance, he used "black blood" as the causal factor contributing to a particular group's lack of physical stature. He extended this "shortcoming" through his evaluation of black anatomy, which undercut black claims to equal humanity. 132

Bean implied black kinship with "lower" animals. He relied not only on the measurements he presented, but also his observations of black spines "for many years" during cadaver dissections. Bean explained the "sinuosities of the vertebral column in the negro" and "The great muscular development of the trunk in the negro" as "due to the attempt on the part of the negro to maintain the erect posture."133 The "natural" posture of blacks, Bean implied, was some modified form of quadrupedia; blacks walked upright as a force of will not a result of nature. Bean completely ignored the role of environment in conditioning both the "natural" curvature of black spines and the muscularity of African Americans' torsos. Grueling agricultural labor and heavy lifting seems a more likely cause of the overdevelopment of black musculature and the extra-curvature of black spines. This is all the more compelling an explanation when one recalls where Bean obtained his cadavers. Virginia law allowed medical schools to claim the bodies of executed criminals,

${ }^{132} \mathrm{He}$ also claimed that "The negro influence is seen in the Pacific where the Australian [sitting height] index is the lowest in the world." Robert Bennett Bean, "Notes on the Body-Form of Man," in Davenport, et. al., eds., Eugenics in Race and State, vol. II of Scientific Papers of the Second International Congress of Eugenics (Baltimore: Williams \& Wilkins Company, 1923), quotations 8, 13; see also 9 and 12.

${ }^{133}$ Bean, "Body-Form of Man," 15-16. 
the unclaimed remains of individuals who died while incarcerated, and the bodies of the indigent-all individuals likely to have worked as common laborers.

The physical anomalies in black bodies that Bean attributed to race are easily ascribed to the effect of environment. Black bodies comprised a disproportionate amount of the "material" dissected in the University of Virginia's anatomical laboratory, just as they composed the majority of the state's agricultural and unskilled labor, the criminal "class," and the indigent-categories that often overlapped in the history of any given cadaver. Nevertheless, Bean alerted his students to all the supposed "racial differences," reinforcing notions of biological divisions between the races. ${ }^{134}$ From this beginning, Bean embarked on his effort to define the "true" American racial stock.

Bean collaborated with physical anthropologist and eugenicist Ales Hrdlicka in his efforts to discern the nature of America's "pioneer" racial stock. Hrdlicka, who had also been trained as a physician and had studied under Manouvrier in France, was at this time curator of anthropology at the Smithsonian Institution. He founded and edited the American Journal of Physical Anthropology, and in 1930 he and Bean founded the American Association of Physical Anthropologists at the University of Virginia. Hrdlicka had a long history of involvement with the American eugenics community. He had served as part of the American consultative committee to the First International Congress of Eugenics in 1912. He was a member of the American Eugenics Society's board of Advisors from 1923 to 1935, and he maintained active membership in the Eugenics Research Association by publishing frequently on eugenical matters in the Eugenical News and the Journal of Heredity.

Bean helped Hrdlicka gather information for his 1925 book, Old Americans. Hrdlicka's book purported to trace the development of a distinctly American race that

${ }^{134}$ This presents a significant irony in the dynamics of Virginia's medical training. White medical students learned anatomy by dissecting black bodies, while their instructors underscored notions of black difference. One wonders how competent the students felt while examining white patients, if their ideas of gross anatomy stemmed largely from experiences with black bodies. 
descended from the original "Nordic" settlers of the colonial era. Not coincidentally, the profile embossed on the cover of the book is that of Thomas Jefferson. Jefferson embodied the ideal "type" of the "American race" that Hrdlicka and Bean sought to trace and to defend eugenically. Bean's contribution to the work stemmed from his work on "Old Virginians," all of which had been suggested to Bean by Hrdlicka in 1917. Bean published four papers on "Old Virginians," whom he believed to be the most genetically gifted segment of Virginia's population, individuals that had descended from the earliest settlers. Bean, of course, having traced his own roots back to the pioneering colonial stock, considered himself an "Old Virginian." In 1938, he published his book The Pecpling of Virginia, which established the eugenic pedigree for Virginians in the same way Madison Grant had extolled Nordics in The Passing of thie Great Race and The Conquest of a Continent. ${ }^{135}$

Bean would gain assistance in his research from two new members of the university faculty: George Oscar Ferguson and Lawrence Thomas Royster. Ferguson took courses under Heck before going to Columbia to train in psychometrics under Thorndike. He then returned to Virginia and ascended to the chair in education upon Heck's death in 1919. Royster, a University of Virginia-trained pediatrician and social reformer, would return to his alma mater in 1923 to head the department of pediatrics. A progressive of the Jane Addams, Hull-House stripe, Royster nevertheless held eugenic commitments that were reflested in his research and teaching. He was an early collaborator with Heck in the eugenic evaluation of Virginia school children. Royster and Bean would collaborate on a number of anthropological/eugenical studies during their tenure at the University of Virginia Medical School.

\section{George Oscar Ferguson and the Mental Status of the American Negro}

${ }^{135}$ This will be discussed, in detail, in chapter 5 . 
After the death of William Henry Heck in 1919, the school of education fell under the control of George Oscar Ferguson. Ferguson, a disciple of Heck and Edward L.

Thomdike, became the leading authority in America on the purported qualitative intellectual differences between blacks and whites. Even before his arrival at Virginia, Ferguson used the newest intelligence tests to establish the hereditary inferiority of the African-American intellect. Convinced of psychometrics' predictive power, Ferguson promoted the use of intelligence tests to guide students and workers into intellect-appropriate slots in society.

Born in Leesburg, Virginia, and educated at the College of William and Mary, Ferguson maintained a life-long commitment to improving the social life of the state. His entire career hinged on public education and the application of scientific methods to the administration, grading, and teaching in the common schools. Although in 1919 Heck held a secure position at Colgate University, one of his friends wrote, "he feels too isolated [there] and would prefer an institution that was more in contact with the public life of the state."136 Indeed, as Ferguson would later write Edwin Alderman, after reading Alderman's "The Function and Needs of Schools of Education in Universities and Colleges," "I felt that the University was aiming at just such work of social service through scientific education as that outlined in your paper," and he desperately wanted to be a part of the effort.

"My experience in educational work began in 1905-1906 when I was principal of a small school in Albemarle County," Ferguson reminisced. That same year, the year Alderman and Heck opened Virginia's new "scientific" department of education, Ferguson "enrolled in Professor Heck's course at the University." Thus, before he had even graduated from William and Mary, which he would do with high honors in 1907, Ferguson was simultaneously engaged in public education and taking Heck's course in evolution, eugenics, and education. Beginning in 1907, Ferguson joined William and

136John W. Ritchie to Charles G. Maphis, February 16, 1919, "1919 Education" Folder, Box 3, President's Papers, .472, III. 
Mary's faculty, first as adjunct professor of philosophy and education, then as professor of philosophy and psychology. While at William and Mary, Ferguson also completed his doctorate in psychology, doing summer work with James McKeen Cattell and Edward L. Thomdike at Columbia. If his work with Heck had not been enough to convince him of the eugenic prospects of education and mental testing, surely his work with Thomdike pushed him in that direction. Ferguson's choice of topic for his doctoral thesis reveals his desire to use scientific knowledge of intelligence to solve the most intractable problems facing his beloved Virginia, the "race question."137

Ferguson's magnum opus, "The Psychology of the Negro," appeared as the thirtysixth installment of Columbia University's series, Archives for Psychology, in April of 1916, and drew immediate attention from the eugenics community. ${ }^{138}$ This lengthy monograph, written in the even, dispassionate tones of the "objective" scientist, set the pattem for all subsequent American studies in comparative racial intelligence. Ferguson felt that intelligence testing could accurately diagnose the "fitness" of Virginia's "human capital." Blacks seemed to present the most difficult problem of social assimilation, and the most questionable asset to the state's welfare. Therefore, Ferguson investigated the qualitative differences between black and white intelligence to identify possible interventions that would help educators "fit" African Americans to appropriate and productive social roles. The scientific allocation of the state's limited educational resources, based on the inbom educability of blacks and whites, would increase social

\footnotetext{
${ }^{137}$ George Oscar Ferguson to Charles G. Maphis, February 18, 1919, Ibid. That Ferguson learned eugenics under Heck is attested to in John W. Ritchie to Charles G. Maphis, February 16, 1919, Ibid. Ritchie wrote, "because [Ferguson] had taken courses with Professor Heck at your University he knew evolution and its educational and social implications."

${ }^{138}$ George Oscar Ferguson, "The Psychology of the Negro," Archives of Psychology 36 (April 1916). This was Ferguson's doctoral dissertation from Teacher's College, Columbia University. Ferguson acknowledged his advisors J. McKeen Cattell and E. L. Thorndike, prominent eugenicists, in the Author's Note. The Eugenical News announced the release of Ferguson's work, calling it "an extremely important paper," and summarizing his major conclusions. "Negro Efficiency," Eugenical News 1 (November 1916), 79. In 1921, Ferguson released a synopsis of "The Psychology of the Negro" that included references to the Army intelligence tests. George Oscar Ferguson, "The Mental Status of the American Negro," The Scientific Monthly 12 (June 1921), 533-543.
} 
efficiency. Tuning education to the innate capacities of blacks and whites would increase social harmony by quietly fitting individuals into their niche in the social machine.

Ferguson's monograph began with a review of all previously published work on "negro intelligence," both psychological and anthropological. He covered the nonexperimental, observational, and experimental work of the early mental testers, as well as the "neurological" work of Robert Bennett Bean, Franklin Mall, and Ales Hrdlicka. Establishing himself as a "true" scientific investigator, Ferguson began by complaining that, "for the most part the literature consists of articles which have grown out of limited and untrustworthy observation, and of articles which have attacked the problem from the standpoint of preconceived theories and have reached conclusions a priori from the premises thus held." Despite these shortcomings, Ferguson found among the literature several studies of note. Francis Galton's 1892 edition of Hereditary Genius won special praise, perhaps because Ferguson's study would clcsely confirm Galton's initial estimates. ${ }^{139}$ At the same time, Ferguson claimed, "there is no valid evidence to show significant brain differences from the point of view of race, sex or genius." Ferguson thereby undercut the anatomical analysis of intelligence, setting the stage for his psychometric approach to the problem. Ferguson also approvingly summarized Harvey Earnest Jordan's "The Biological Status and Social Worth of the Mulatto."140

Ferguson compared black and white school children's results on four tests that, psychologists believed, measured general innate intelligence. ${ }^{141} \mathrm{He}$ refined the methods

${ }^{139}$ Ferguson, "Psychology," 1, 8.

140 Ibid., 88-89.

${ }^{141}$ The four tests were mixed relations (Eye-see Ear— , where the subject should answer "hear"), completion (adding the word that makes the best meaning in a sentence. "The poor baby as if it were ___ sick."), a "maze test" where the subject tried to rapidly draw a line between two parallel lines weaving up and down without touching those line (the score was an index of contacts versus total distance), and a cancellation test, which consisted of lines of letters where the subject must cross out (cancel) as many of the letter "a" as possible. Ferguson gave examples of the tests in an appendix. Ferguson, "Psychology," 136-138. 
used by other early experimenters in applying mental tests to black and white children. ${ }^{142}$ Ferguson believed he improved upon previous work through his more careful attempt to compare groups of children with similar social and scholastic backgrounds. Holding backgrounds constant would eliminate environment as a cause of difference, resulting in a more accurate comparison of inborn intelligence. Moreover, Ferguson claimed to create the first study that accurately established the intraracial difference between "mulattos" and "pure negros." The results obtained allowed Ferguson to establish a racial hierarchy of intelligence that placed whites on top, mulattos in the middle, and blacks on bottom. Within the mulatto group, Ferguson valorized "white blood," purporting to find that individual intelligence varied directly with the "amount" of white blood. ${ }^{143}$

Although Ferguson eschewed a priori conclusions about African-American intelligence, his methodology set him up to operate on a number of prior assumptions. After summarizing all the work on intelligence, he noted that "by far the greater number of writers who have dealt with the problem of the relative mental ability of the white and the negro take the view that the negro is inferior."144 Since this conclusion was "particularly true of those investigators who have used quantitative methods," it is unsurprising that Ferguson's results substantiated these prior claims

Ferguson extended this same basic assumption when he analyzed the relative quality of the black and white school populations he tested. According to Ferguson, black students who persisted in school represented the very best of the black population, to a much greater degree than did white students. "Among the causes of the elimination [of black children] from school," Ferguson wrote, "are such matters as poor health, poverty, mental or moral deficiency, lack of ambition or energy." While every one of these factors could be attributed to environment, Ferguson preferred a hereditarian interpretation, writing, "It

\footnotetext{
${ }^{142}$ Ferguson cited the work of A. C. Strong, "Three Hundred Fifty White and Colored Children Measured by the Binet-Simon Measuring Scale of Intelligence," Pediatric Seminar 20 (1913), 485-515.

${ }^{143}$ Ferguson, Ibid., 93, 111, 130.

${ }^{144}$ Ferguson, Ibid., 25.
} 
would seem that these forces, in the long run, must select for survival in the school system those who by reason of their own capacity, as represented in themselves and in the inheritable traits which prompt and enable their parents to send them to school, are best fitted to make progress in academic work." Black students entered high school because of their "ability and determination," whereas white students attended high school "by reason of social pressure, custom, or the tradition of his race." 145 Imbalances in school attendance rates represented heredity for blacks, environment for whites. Ferguson entirely ignored the obvious qualitative differences between black and white segregated schools, and the effect this might have upon attendance and performance. Instead, he treated black and white schools as perfectly equivalent educational environments. ${ }^{146}$

Finally, Ferguson used a highly subjective measure of "racial purity" in assigning African American students to intraracial groups. He relied on "color of skin, hair texture and general facial and cranial conformation, the main emphasis being placed on color." Charles B. Davenport and other eugenic-minded physical anthropologists would certainly object to such subjective determinations, particularly given the Mendelian mode of color inheritance. The only truly accurate way, in their eyes, to rank blacks would be by performing pedigree analyses of their ancestry. Ferguson sidestepped this difficulty, arguing that, "in the main, children conform closely to the characteristics of their parents in all respects, and such variations as occur will off set each other in any considerable number of persons, and leave the group type predominant." Invoking suspiciously circular logic, Ferguson argued that since, "Certainly the [intelligence] results here obtained indicate that the correlation between skin color and racial purity is high," therefore, "There was

145 Ferguson, Ibid., 29, 30.

${ }^{146}$ See his discussion of the schools on pp. 32-33. He chose elementary schools in Richmond not at random, but "because in the opinion of the school authorities their pupils were fairly typical of the average white and colored populations of the city." He ignored the possible contamination that prejudice among the administrators may have introduced, accepting their word for the similarity in conditions. In Fredericksburg, he compared a private black high school to a public white high school, ignoring the many poteritial differences involved. 
apparently nothing except native racial ability that could bring about the results found herein for the different classes of negroes." 147

Ferguson used this circular logic and his prior assumptions to increase the gulf between black and white students. Since black high school students represented what Ferguson termed the "'chosen few' of their race," their achievements represented an artificially high mark; when averaged with all blacks, the figure would be lower. Thus, Ferguson concluded, "it appears to be certain that racial mental differences discovered by means of tests upon school children are in reality smaller than the actual differences between the races." Ferguson went on to explain that "the colored pupils were farther advanced academically than were the white pupils in each of the four years," because the black students tested had completed both the first and second half of each grade's work, while white pupils were tested at mid-year. Ferguson felt that this difference gave black students an "unfair" advantage over the whites — despite the fact that the tests are supposed to gauge intelligence not education. ${ }^{148}$ Rather than evaluating intelligence, the study actually clarifies Ferguson's deep desire to establish an unbridgeable gap between blacks and whites.

"The tests employed in this investigation," Ferguson wrote, "were selected primarily with a view to ascertaining racial differences in the higher rather than the lower intellectual capacities." By adopting this approach, Ferguson remained within the tradition begun by Jefferson. that blacks and whites were similar in "lower" traits, and differed in the so-called higher faculties which included the powers of abstract reasoning. "These latter traits," Ferguson claimed, in consonance with Jefferson and those who came afterward, "divide

${ }^{147}$ Ibid., $91,110$.

${ }^{148}$ Ferguson, Ibid., 31-32, 35, note 104. Ferguson extended this effort at black subordination even into his statistical analysis. In a particularly tortured and flawed example, Ferguson claimed that, since on some tests no blacks reached or exceeded white levels of achievement, "the percentage was put down as zero. But such percentages are really less than zero. And when they are counted as zero, as they are, in obtaining the average for all ages or grades, it is obvious that this procedure tends to make the average percentage too high. That is, it tends to make the racial difference appear to be less than it really is." (p. 49) 
mankind into the able and the mediocre, the brilliant and the dull, and they determine the progress of civilization more directly than do the simple and fundamental powers which man has in common with the lower animals."

Given these basic assumptions and methods. Ferguson's conclusion that blacks were, indeed, mentally inferior to whites comes as no great surprise. He found that, "the average performance of the colored population of this country in such intellectual work as that represented by the tests of higher capacity, appears to be only about three-fourths as efficient as the performance of whites of the same amount of training. It is probable, indeed, that this estimate is too high rather than too low," because of the more astringent "selection" that culled black student ranks. Black students did as well as they did, according to Ferguson; because of the influx of white blood in the African-American population. Again drawing on a prior notion as old as Jefferson and sustained by Galton, Ferguson claimed, "If one were to test the capacity of the unselected masses of negroes, with their much smaller percentage of white blood, and make a comparison with unselected masses of whites, the results would almost certainly reveal greater racial differences than those found herein." 149 The factor accounting for black educational success, white blood, also explained the intraracial differences in black success between "mulattoes" and "pure" blacks. His telling summary emphasized this separation, "it does not seem possible to raise the scholastic attainment of the negro to an equality with that of the white. It is probable that no expenditure of time or of money would accomplish this end, since education cannot create mental power, but can only develop that which is innate." Only two options remained, since most African Americans lacked higher mental capacities: one was to train the mass of blacks in the manual arts; the other, borrowing a thesis from Jordan's article, was to increase interbreeding between "pure" blacks and mulattoes. ${ }^{150}$

${ }^{149}$ Ferguson, "Psychology of the Negro," 123.

${ }^{150}$ Ibid., 125-126, 130. Ferguson held with Galton that, "eminence is independent of circumstance; that innate power can be neither crushed nor created by adverse or favorable influences." (128) 
In comparing the "sub-classes of negroes," Ferguson set out a number of propositions that would become standard tropes among later investigators. First, he noted that the census indicated a greater percentage of mulattoes in the North than in the South. Although he acknowledged the difficulty in accounting for this imbalance, he felt that a difference in intelligence between "pure" and "mulatto" blacks might be a "reasonable" cause. Such a difference resulted in mulattoes being "more attracted than are pure negroes by the reputed advantages held out to colored people in the North, and by the reputed opportunities of city life. If so, it would seem that mulattoes have greater capacity for perceiving opportunity and greater ambition to take advantage of it."151 Seven years later, in attempting to account for the differences in intelligence between black recruits from the North and South, Carl Brigham drew directly on Ferguson's work, citing the same factors identified by Ferguson, particularly his notion of "differential" emigration:

The superior intelligence measurements of the northem negro are due to three factors: first the greater amount of educational opportunity, which does affect, to some extent, scores on our present intelligence tests; second the greater admixture of white blood; and third, the operation of economic and social forces, such as higher wages, better living conditions, identical schooling privileges, and a less complete social ostracism tending to draw the more intelligent negro to the north. It is impossible to dissect out of this complex of forces the relative weight of each factor. ${ }^{152}$

Hailed by both Yerkes and Thorndike, Brigham's work clearly drew directly from Ferguson, who collaborated with the other three men in the Army Alpha and Beta mental testing campaign.

When the United States went to War, Ferguson found himself called to service in the Army's psychological section. Ferguson became the Chief Examiner at Virginia's Camp Lee, in charge of ten men measuring the minds of over 150,000 inductees from Virginia, West Virginia, and Pennsylvania. Given his dactoral research, this represented the logical assignment of Ferguson and his talents. The experience quickened Ferguson's resolve to

\footnotetext{
${ }^{151_{\text {Ibid., }} 85-86 .}$

${ }^{152}$ Carl C. Brigham, A Study of American Intelligence (Princeton: Princeton University Press, 1923), 192.
} 
use his science for the betterment of the state. He wrote his mentor William Henry Heck, "My experience at Camp Lee has impressed me daily with the magnitude of the educational and psychological problems and opportunities for service in Virginia and the South." Not only did his measurements of white reveal startling gaps in both intelligence and education, but his work with black inductees confirmed the worst fears he expressed in his dissertation. "As yet I have not been able to learn anything of the performance of the negroes in actual warfare," he informed Heck, "but we have examined thousands of drafted negroes here, and I have been able to check and amplify my former conclusions." He felt that, "In the main, the negroes here have been real negroes, not the kind found in city schools," individuals Ferguson considered more likely to be mulattos. ${ }^{153}$

Ferguson's military experience convinced him that intelligence tests promised the perfect technocratic solution to human resources allocation. Presciently, he wrote to Heck, "I think there will be a much wider use of intelligence tests in schools and colleges as a result of their use in the army." Indeed, in the wake of A Study of American Intelligence, school administrators jumped on the testing bandwagon. The tracking of students by IQ score became standard procedure across the country and in many colleges. Ferguson also realized the commercial implications of intelligence testing, pioneered by university investigators. In language redolent with the imagery of university extension, Ferguson wrote, "It seems to me that an important service would be rendered by a state institution if such testing could be placed at the disposal of firms in the industrial centers as a part of the institution's extension work; in this time of industrial reorganization, such service should be especially useful."154 intelligence testing could pave the way for truly scientific management, where every laborer and employee might be set at only those tasks for which he or she was cognitively suited.

${ }^{153}$ George Oscar Ferguson to William Henry Heck, November 27, 1918, "1919 Education" Folder, Box 3, President's Papers, .472, III.

${ }^{154}$ Ferguson, Ibid. 
Edwin Alderman immediately recognized the practical benefits of such research.

Although he could not hire Ferguson in 1918, he assured him "I want you to know, however, that I am very much interested in you." When Heck died the following year, and funds became available for hiring two new professors of education, Ferguson's appointment was a near certainty. ${ }^{155}$ In the interim, Ferguson proselytized on behalf of the intelligence test at every opportunity. His associate John W. Ritchie wrote, "He sees wonderful things that can be done in the public schools, industry, and the re-arrangement of some of our social programs with mental tests and he wants to be at that." Converted, Ritchie wrote, "In my judgment this movement [mental testing/eugenics] will effect greater social changes than anything that has come into the world in centuries, and Ferguson will doubtless have a share in it somewhere." He continued, revealing the impact of Ferguson's conclusions, "The whole negro race practically has proved feeble-minded by white standards, and Ferguson has a special interest in that question."156 Ferguson seemed, to Ritchie, the perfect man for the University of Virginia to hire to fill Heck's position. Ritchie went so far as to write to Ivey Foreman Lewis in Ferguson's behalf, noting, "I should like to see Ferguson kept in Virginia. He is really scientific in his attitude of mind," and that would make him of great use in social reform.

Heck's death devastated Ferguson, but provided for his election to Virginia's faculty. Ferguson wrote, "The death of Professor Heck is a source of great regret to me. Shortly before he died he wrote me that it was his wish that I should come to the University. His teaching left a lasting impression upon me, and I regarded him always as a friend."157 When he finally received his appointment to the faculty, Ferguson brought with him the hereditarian influence of Heck and their common mentor, Edward L. Thorndike. Captivated by Alderman's notion of university outreach, in accepting his appointment, an

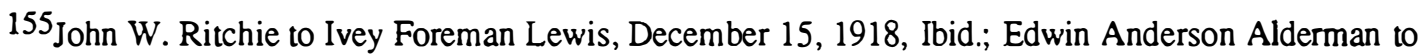
George Oscar Ferguson, December 8, 1918, Ibid.

156John W. Ritchie to Charles G. Maphis, February 16, 1919, Ibid.

${ }^{157}$ George Oscar Ferguson to Charles G. Maphis, February 18, 1919, Ibid. 
ecstatic Ferguson wrote, "I should rather be connected with the University than with any other institution. And it is a great pleasure to me to know that such energy as I have may be devoted to educational service in Virginia." His service would teach generations of students and Virginia educators that blacks were inherently inferior to whites in intellect, and therefore should, in the main, be provided with manual rather than "literary" education. ${ }^{158}$ In hindsight his final comment to Alderman speaks volumes, "My shortcomings while at the University will be due to lack of knowledge and skill but not to lack of desire."159 Lacking the skill to see the biases inherent in his own "knowledge," Ferguson capitalized on his desire to transmit hereditarian and eugenic notions about white fitness and black unfitness to his students and Virginia educators. Ferguson taught about mental testing and championed psychometrics and the use of intelligence testing to "track" students to "appropriate" educational courses for the remainder of his career. He used these principles to guide his decision making once he became Dean of Admissions for the university. Ferguson continued Harry Heck's efforts with the public schools. He found congenial allies at Virginia, men like Jordan, Lewis, and Bean who shared Heck's vision of eugenics, education, and social improvement for Virginia. Ferguson's work would be confirmed by the psychological and anthropological investigations of Virginia's first Professor of Pediatrics, Doctor Lawrence Thomas Royster. Royster was another associate of Heck and the Virginia eugenicists, and a card-carrying member of the American Eugenics Society.

\section{Pediatrics and Prevention}

${ }^{158}$ Raymond Bice, Historian of the University of Virginia and emeritus professor of psychology, recalled that Ferguson was "extremely prejudiced" against blacks and Jews. He deemed both groups inferior to whites and, in his capacity as Dean of Admissions, exercised his prejudice by grudgingly admitting a bare minimum number of Jewish students. Bice Interviews, 1999.

${ }^{159}$ George Oscar Ferguson to Edwin Anderson Alderman, May 5, 1919, Ibid. 
Bom in Norfolk, Virginia in 1874, Lawrence Thomas Royster rose to the heights of Virginia social philanthropy. Initially embracing the "settlement work" ethos of Jane Addams and other social meliorists, Royster evolved toward a more hereditarian view of social paihology. By the time he beçame professor of pediatrics in the University of Virginia Medical School and head of the department of pediatrics in the University Hospital, Royster had all but abandoned his environmentalist notions of social reform. Instead, he substituted a mainline eugenical belief in racial difference and white superiority. These beliefs confirmed his scientific beliefs, and his own personal sense of self.

Like many of those who supported eugenics, Royster was intensely proud of his own "racial" heritage. Correspondence with various genealogical societies dominates his papers, particularly in the twilight of his career. He applied for and received membership in Burke's Landed Gentry, The Sovereign Colonial Society Americans of Royal Descent, the Society of the Cincinnati, and the Jamestowne Society. He was a proud member of the Order of the First Families of Virginia, which placed him firmly within Robert Bennett Bean's category of "Old Virginians," making him a living example of the "American race." 160

Royster spent his youth as a son of privilege. He attended Norfolk Academy from age 10 until he graduated from high school. He then proceeded to the University of Virginia in 1892. Royster studied under Paul Brandon Barringer in the medical school, receiving a healthy dose of hereditarianism and taking his degree in 1897. Royster worked as a clinical assistant at the university dispensary under Barringer. ${ }^{161}$ Like Barringer before him, Royster then proceeded to New York (and also Boston and Baltimore) for post-graduate work at the major centers of American education. Royster's choice of pediatrics as a specialty underscores his status as a progressive, forward-looking physician. Pediatrics

${ }^{160}$ Lawrence Thomas Royster Papers, 7781a, 3 boxes, Special Collections, Alderman Library, Charlottesville. [Hereinafter cited as Royster Papers I.]

${ }^{161}$ University Dispensary letterhead in Box 2: Notebooks LTR, Royster Papers. 
had only recently come into its own as a discipline. ${ }^{162}$ Royster pioneered pediatrics in the South, were the specialty remained under-represented. As one reviewer wrote, in commenting on Royster's book Diseases of Infants and Children, "Dr. Royster, well known for years as one of the most able pediatricians of the South, not to say the country, has of late years created a pediatric department at the University of Virginia that is a credit to the traditions of that fine old institution of learning." 163 His activities would result in his becoming chaiman of the pediatrics sections of both the American Medical Association and the Southern Medical Association, a Fellow of the American Academy of Pediatrics, and an elected Fellow of the American Academy for the Advancement of Science. ${ }^{164}$

After his post-graduate training, Royster retusned to private practice in Norfolk in 1900, where he entered into the public life of the city. Royster became a member of many governmental and civic institutions dedicated to child welfare. Clearly affected by Barringer's emphasis on public health, Royster became a member of the State Board of Health. He was also an 11-year member of the Norfolk school board, where his efforts to promote the medical examination of southern school children undoubtedly brought him into contact with William Henry Heck. ${ }^{165} \mathrm{He}$ joined the Children's Code Commission of Virginia, founded and presided over the Norfolk Society for the Prevention of Cruelty to Children, and led the crusade for a "home for wayward girls." His interest in female morality resulted in his presidency of the Norfolk Association of Philanthropics' Bonney

162 By 1880 major cities had established dedicated infant dispensaries and hospitals. The American Medical Association organized a section on pediatrics in 1880, and the American Pediatric Society began in 1887. Richard A. Meckel, Save the Babies: American Public Health Reform and the Prevention of Infant Mortality, 1850-1929 (Baltimore and London: Johns Hopkins University Press, 1990), 45-46.

163 Frank Howard Richardson, "Review," Medical Review of Reviews, n.d., "William Wood and Co. ca. 1925" folder, Box 1, Lawrence Thomas Royster Papers, 1893-1947, 4198a, Special Collections, Alderman Library, Charlottesville. [Hereinafter cited as Royster Papers II.]

${ }_{164}$ Marquis Who's Who, Inc., Who Was Who in America, vol. V, 1969-1973, (Chicago: Marquis Who's Who, Inc., 1975), 624. Certificate of Election, American Association for the Advancement of Science, December 27, 1932, Box 1, Royster Papers II.

${ }_{165}$ Royster demanded a five-point examination for hearing, sight, healthy tonsils, sound teeth, and weight as an indication of nutrition. He also wanted to add a test for tuberculosis and mandatory inoculation. See untitled essay, Box 1, Royster Papers. 
[Bon Air] Home for Girls, and his founding and becoming chief of staff of the King's Daughters Clinic. ${ }^{166}$

Royster's invocation of "race suicide" first appeared in a review of his paper, "The Medical Profession's Duty to the Children of America." The Medical Counselor quoted Royster as writing, "Above all, the mother must be told how to inform the child who is about to change from youth to young but mature physical adult life about matters pertaining to sex, on a correct understanding of which and on the proper care along these lines depends the protection of the race." 167 Like most physicians and social reformers during the first decade of the twentieth century, Royster feared social declension. A progressive, he sought to prevent the adulteration of the American race through appropriate education in the biological facts of life, rather than by invoking repressive moral standards alone.

Royster also favored direct efforts at social control, however. He justified these interventions on eugenic grounds. Writing in the Richmond Guardian in 1907, Royster advocated the establishment of a home for "wayward" girls. "There are in Virginia," he began, "at least 300 wayward girls. Hundreds of others, inhabiting the slums of our cities, are growing up to lead vicious lives." The notion of "vicious" women-morally loose, venereally diseased, and feebly-minded-dominated the discussions of early progressive reformers. 168

Royster substantiated his fears by referring to the descendants of "a single neglected girl" in New York. He probably relied on Richard Dugdale's famous family study, The Jukes, which became the model for all subsequent eugenical family studies. Playing on Virginians' fears of increased economic distress, Royster wrote that in 75 years the

166 Marquis Who's Who, Who Was Who, vol. 5, 624; Box 3: Clippings, Royster Papers.

${ }^{167}$ Clipping, The Medical Counselor, n.d. circa 1908, Box 3, Royster Papers II.

${ }_{168}$ Mary E. Odem, Delinquent Daughters: Protecting and Policing Adolescent Female Sexuality in the United States, 1885-1920 (Chapel Hill, NC: University of North Carolina Press, 1995), chapter 4, especially 96-97; Ruth M. Alexander, The "Girl Problem": Female Sexual Delinquency in New York, 1900-1930 (Ithaca, NY and London: Cornell University Press, 1995), chapter 2; and Regina G. Kunzel, Fallen Women, Problem Girls: Unmarried Mothers and the Professionalization of Social Work, 18901945 (New Haven, CT and London: Yale University Press, chapter 2, especially 53-55. 
descendants of this one woman comprised "1,200 criminals and paupers, that have cost the State of New York $\$ 1,225,000.00$. Measure, if you can, the damage done to Virginia in the next generation from the host of girls now drifting to destruction." Despite the hereditarian overtones, Royster, like Dugdale before him, believed in the efficacy of environmental iniervention and so supported the institutionalization of wayward girls. "No one has heretofore especially tried to save them," Royster wrote of these unfortunates, "but now the Virginia Home and Industrial School for Girls begs to call the attention of our people to this matter, and beseeches them to arise and save these little ones that are being driven to destruction." 169 Segregating the wayward from the "normal" would allow them to be rehabilitated, to conform to social norms, and iead a "productive" rather than a "vicious" life upon their discharge.

The gender bias of Royster's social reforms is inescapable and not particularly surprising for this era. Of greater interest, however, is his notion of eugenic segregation of the wayward. Some could be rehabilitated. Incorrigibles, however, needed to be dealt with more severely to protect society. Some girls might be "beyond the parental influence, and in these cases the law must come to the rescue." Legal commitment of wayward girls "must be divested of the customary red tape of institutions in general," Royster opined. Girls committed by courts "must be accepted at once, without formal application and a session of a Board of Trustees or committee. Such an investigation may be conducted after she is an inmate, if necessary." Only expeditious action to restrain and segregate "vicious girls" could properly protect society. ${ }^{170}$

The prevention of infant and child mortality also ranked high on Royster's list of reforms. He joined the pure food and milk campaign as a way to lower the high death rates from food poisoning and typhus. Here, too, he revealed how his hereditarianism was tempered by the realities of daily living. Proper nutrition might have a "euthenic" effect that ${ }^{169}$ Clipping, The Guardian (Richmond), August 12, 1907, Box 3, Royster Papers II. ${ }^{170}$ Ibid. 
would improve humanity. "Perhaps through a knowledge of the chemistry of food, its digestion and metabolism, that is the building of the body, we may say that the human race is maintained and possibly improved," Royster wrote in an address to pediatricians. Beyond feeding, however, heredity must be acknowledged as controlling. "To be sure we are born with a definite biological pattern and that cannot be altered," Royster averred, continuing, "unfortunately in dealing with human beings we cannot force mating in accordance with a knowledge of their desirable attributes as we can with animals." Given the limit that "love match" mating put on positive eugenics, Royster felt that, "we must direct our efforts toward the making of the best possible adult out of the material presented to us at birth and I think we should regard the feeding of children as a public health measure."171 Royster self-consciously connected public health and eugenics as the same thing: both agencies aimed at "making the best possible adult out of the material presented to us," although eugenics sought to ensure that the "human ore" was of the purest variety.

Royster continued this hereditarian theme in evaluating the responsibility of physicians toward poor whites. Appraising the effect of Virginia's medical school on the state's welfare, he complained that, "The influence of the University of Virginia Medical Department is felt wherever medicine is known, and yet within the radius of the old Rotunda, there reside a group of people who have not touched the hem of her garment, for her light has not penetrated the darkness of the mountain cabin." Many mountain whites, Royster believed, suffered more from bad environment than heredity, "Could we but trace the true genealogy of many of these [mountain] children, most of whom are of the finest Anglo-Saxon blood, back to the source, we would find that more than one is as true an heir to a temporal throne as was the babe of Bethlehem to the throne of Almighty God."172 With this conclusion, Royster updated Jefferson's effort to "rake scholars from the rubbish." The eugenic promise of some mountain whites' was submerged beneath their

${ }^{171}$ Royster, untitled lecture to pediatricians, n.d., Box 1, Royster Papers II.

${ }_{172}$ Royster, untitled address, circa 1923, Ibid. 
stultifying environment. Isolated in "hills and hollers" their genetic genius went unnoticed for lack of an environment suitable for its expression. Moreover, they risked permanently destroying that genetic potential through inbreeding, miscegenation, and other forms of genetically ill-advised procreation.

By 1930, Royster's millennial tone reached its apogee. In his oft delivered address, "Religio Medici Recentis," Royster likened physicians to priests, medicine to religion, health to grace, and disease to sin. Royster, in common with many scientists, but particularly with eugenicists and the men discussed heretofore, collapsed science and religion into a single entity in the service of mankind. "Medicine is an outgrowth of religion....Religion is a way of living; medicine is the application of scientific knowledge through the practice of an art. The practice of medicine is not a religion in itself, but there is a religion in the practice of medicine." Physicians thus occupied a special place in the physical and metaphysical lives of humanity. "The life of the physician combines the offices of Priest and King, as no other calling does," Royster asserted. As priest the physician gave "solace" and "consolation to the straying one, point[ing] out the error without censure and aids in reformation." As King, the doctor's "word is final, he is an absolute monarch." The physician's "sacred" responsibility was to evangelize the "religion of health," convincing patients that,

Health of mind and body are both necessary if each of us is to carry on in the usual activities of life. We owe it to society to do our part to the best of our ability, and to do this our bodies must be sound. We are equally obligated not to be a menace to those around us, and to fulfill this obligation we must be free from communicable disease.

This portion of Royster's gospel of health emphasized the individual's immediate social responsibility which "are duties which are apparent to all who will think about the subject for a moment". He then outlined the individual's eugenic responsibility as:

by far our greatest responsibility is to posterity. It is incumbent on us to produce and endeavor to perpetuate soundness of body and mind in those who are to bear the burdens of the future; those on whom will rest the responsibilities of government, education, business and parenthood, when we have ceased to labor. This is our duty to mankind, and duty to mankind constitutes in large measure a religion. 
Royster thus invoked the same notion of eugenics as a secular creed as that propounded by every eugenics supporter since Francis Galton. Health consummated the marriage of science and religion for Royster, because "a belief in science and the utilization of scientific knowledge becomes a religious duty rather than an evidence of infidelity." 173

To spread his version of the gospel of social evolution, Royster collaborated with both William Henry Heck and Robert Bennett Bean. In an address to the University of Virginia's graduating medical class, Royster linked pediatrics, school inspection, eugenics, and social reform in ways that clearly reflected his involvement with Heck. He encouraged graduates to "give closest attention to the welfare of children of your community....for in this way as in no other can you become useful citizens in your respective communities." Pediatrics, according to Royster "is in truth the greatest preventive medicine in the world." By attending to pediatrics, physicians could apply the laws of heredity and hygiene to school children and prevent the creation of social misfits. "Do we ever stop to consider what kind of race of human beings we are permitting to be reared?" Royster asked rhetorically. If physicians paid more attention to preventing congenital and "hereditary" transmission of tuberculosis, blindness, venereal disease, and feeblemindedness, society would be greatly improved. Although he advocated the segregation of "feeble-minded" children in small classes, preventing them from retarding the progress of others while permitting them the best opportunity for achievement, he preferred the entire elimination of feeble-mindedness through eugenics. Unfortunately, however, "even the knowledge of heredity and pre-natal environment at our command is not utilized. By simply applying the small amount we have in these directions," Royster contended, "all feeblemindedness can be wiped out in one or at most two generations. Think what a difference this would be since from feeblemindedness results the bulk of dependency and criminality." 174 Royster's advocacy of school hygiene, medical inspections of school children, and his

${ }^{173}$ Lawrence Thomas Royster, "Religio Medici Recentis," Box 1, Royster Papers II.

${ }^{174}$ Royster, untitled address to graduating medical class, Box 1, Royster Papers II. 
involvement in the playground movement all brought him into sympathetic contact with Heck.

Royster's most explicitly eugenical work, "The School Child in its relation to Eugenics," appeared in the Transactions of the Fourth International Congress of School Hygiene, the report of a meeting held at Buffalo, New York in August of 1913. This address emphasized all the tenets of mainline eugenics—hereditarianism, marriage restriction, legislation for the segregation and sterilization of the feebleminded, and the importance of education in spreading the eugenics creed. Like Jordan, Royster posed as a "conservative" eugenicist himself. He began with the usual reconciliations-between religion and science, and heredity and environment-that characterized most "balanced" eugenic writing. Arguing that "the proper study of mankind is certainly man ," Royster contended that knowledge of man would come from "a close scanning or critical scrutiny of God himself through an investigation of His laws, i.e., the laws of Nature." Thus science, the study of natural law, was in fact religion-it provided a greater understanding of divine purpose and governance. "Conservative" students of eugenics like himself, according to Royster, were idealsitic not fatalistic; heredity was not predestiny. Conservative eugenicists recognized "the vast importance of heredity yet give due consideration to the part played by environment in the development of cells and their determiners."175 Given the common misconception that eugenics was merely genetic Calvinism, eugenicists needed to help in the "awakening of thinking men and women" to the idealism of the eugenics creed.

Eugenicists were idealists, Royster argued, because they hoped to substitute rational procreation, with its "altruistic" aim of improving the future, for the irrational and selfish sex drive. Although, "The public will recoil at the idea of mating on a purely intellectual or rational basis, because sentiment is a strong and useful characteristic of the human mind,"

${ }^{175}$ Lawrence Thomas Royster; "The School Child in its Relation to Eugenics," Transactions of the Fourth International Congress on School Hygiene 4 (1914), 26. 
Royster felt that eugenicists could achieve an impact through marriage restriction. "The marriage license should certainly, even at once, be accompanied by a certificate of health embracing freedom from active venereal disease or tuberculosis and freedom from inherited taint of feeblemindedness." 176 Restricting marriage to the healthy would help ensure that the progeny of any marriage would meet at least a minimum standard of "fitness."

From these basic interventions to rationalize procreation, Royster argued that "The improvement of the human stock can be accomplished through two great measures, legislation and education." Legislation should seek to "prevent marriage among the manifestly unfit, both physical and mental." Royster defined the physically unfit as those with active venereal disease and "the tuberculous, alcoholic, openly immoral (probably mental defectives) and the feebleminded." Royster's conflation of the "immoral" and "feebleminded" into the category "mental defectives" shows the congruence between his beliefs and the conventional wisdom among mental health and vice reformers of the day. "The feeble minded call for our most careful supervision for very many reasons," Royster claimed. He invoked the "menace of the feebleminded" by asserting that, "they are exceedingly prolific; illegitimacy is very common among them, and from their ranks are recruited a large per cent. of the habitually immoral." Royster and many other progressive reformers believed that the feebleminded, as a monolithic class, represented the locus of almost all social immorality and sexual perversion.

Legislation for segregation and sterilization offered the best legal solutions for the menace of the feebleminded. Royster argued that "In regard to the feeble minded the law should certainly require segregation at least, in the home if preferred by those who are able to supply the proper care for those afflicted, but preferably in proper institutions; the latter should be compulsory where home training is impossible." Royster's demands for segregation came three years before Virginia passed a law providing for the commission of

${ }^{176}$ Royster, Ibid., 27. 
the feebleminded to state institutions. Although he favored universal commitment, his remarks built an obvious class bias into his program: those with the resources to care for their afflicted family members could do so at home. The underclass, however, forfeited their right to self-determination. Poor folk would be consigned to state institutions both for their own good and for the good of society. Regarding sterilization, Royster admitted that it "will prevent reproduction," but noted that it "will not prevent immorality and the consequent spread of venereal disease." Ultimately, he hoped that a "combination of these methods [segregation and sterilization] will prevail."177

Royster's entire eugenic program, however, devolved to school children. Since "Legislation is so dependent on the education of the people as to the importance of health and virility in a nation that, in reality, through education alone may be seen the ultimate solution of the problem."178 Since eugenic improvement would take more than a generation to bear fruit, Royster felt that, "Our best opportunity lies manifestly in the school room, here we can implant the principle of eugenics when the mind is pliant and receptive, during the formative years of life, and so implant these principles that they will become just as inherent as honesty, patriotism, veneration and other desirable characteristics." He invoked the customarily masculinist imagery of the eugenics movement, appealing to the desire to create "that patriotism which means better citizenship, health conditions and all that makes for virile manhood...." To bring eugenics home to the school child, "Biology should be regarded as a fundamental just as the three R's are, for only through biology can be taught the laws of nature by which the race is propagated, the conception of cells and cell plasma and that they are of two kinds-the good and the bad...." Royster cloaked his moralizing in the "progressive" advocacy of sex education. He felt that biology courses offered the best way to teach the "sex relationship in a delicate manner and entirely within the bounds of propriety," thereby avoiding the abrupt education

${ }^{177}$ Royster, Ibid., 27.

178Royster, Ibid., 27. 
"from sources which are rarely wholesome but rather vulgar and suggestive." Only through education, Royster concluded, could children "be impressed with the moral wrong done in bringing unfit offspring into the world." Eugenics was not only a scientific necessity, it was a moral imperative.

Royster restated Galton's hope that eugenics would become a "new religion." The immorality of unfit births "should be taught as a fundamental principle and in such a way as to be incorporated into the whole make up of the individual." Public schools would thus create eugenic automatons, whose first principle would be fit procreation. "The public school system should be the pioneer in such a movement," Royster concluded, "and thus serve the cause of eugenics as it can be served in no other way."179 Eugenic programs thus relied on eugenic education, a sentiment echoed by all major eugenicists of the period, who saw in the public school system the ultimate institution for inculcating the eugenic creed.

Royster returned to the topic of controlling the unfit two years later. He presented his views on the "Custodial Care of the Feebleminded" before the annual meeting of the Medical Society of Virginia, in December of 1915. The speech was deemed significant enough to warrant abstracting in the Journal of the American Medical Association Royster argued that individual "responsibility" depended upon a person's "mental age" not their chronological age. Feebleminded individuals, therefore, could not be responsible for themselves and required institutionalized care. With the advent of mental testing, however, feeblemindedness could be diagnosed early, and "treatment" applied. Since the feebleminded had "a lowered resistance to immoral influences" they often contracted venereal disease, spreading it among those who had sexual congress with them. Royster claimed that "A large percentage of prostitutes are not over 12 years of age," so early detection was crucial—school children must be tested. Moreover, since "Defectives always

${ }^{179}$ Royster, Ibid., 27, "virile manhood" and last quotations, 28. 
breed true," producing more of their own kind, society needed to diagnose defectiveness early to allow prompt segregation and avoid increasing the number of feebleminded. "There are three lines on which to work" to reduce the number of defectives, Royster maintained. The first method should be "prevention of propagation" whether through sterilization or institutional segregation. The second method would be "state control to care for the defectives," another way of saying institutionalization. The final method to cut off "defective germ plasm" would be the relief of indigent parents. 180

Doctor Royster managed to reconcile the social meliorist and social control viewpoints in his own ideology. Beginning as an environmental reformer who campaigned for health inspections of school children and reformatories to "save" wayward women, he came to champion eugenics and the eugenic creed. While social meliorism promised palliatives for current problems, eugenics promoted a "final solution." Using the medical metaphors so popular among eugenicists, physicians, and politicians, while social interventions provided a therapeutic response that alleviated the symptoms of social ills, eugenics would prevent those social ills entirely. For Progressive Era physicians like Royster, eugenics offered the holy grail of efficiency, humanity, and permanence in reforming society. Royster remained active in the organized eugenics movement throughout his career. The Eugenical News listed him as an active, dues paying member of the Eugenics Research Association in 1926. Royster and Bean collaborated in anthropological and medical eugenic surveys of Virginia school children. Both men would present papers before the Third International Congress of Eugenics in 1932. ${ }^{181}$ Eugenics remained alive and well in the minds of university medical professors through the 1930s.

180"Custodial Care of the Feebleminded," Journal of the American Medical Association, 65 (December 18, 1915), 2192.

${ }^{181}$ Eugenical News 11 (Jan 1926), 18. Royster also became a member of the American Association of Physical Anthropologists. He also wrote a glowing review of Bean's book, The Races of Man, that is preserved in his papers. See, "Untitled Review," Box 1, Royster Papers II. The papers before the Third International Congress of Eugenics will be discussed in chapter 6. 
Staying the Course: The Virginia Eugenics Education Committee

While Bean and Royster continued to teach about heredity and eugenics throughout the 1920s, so too did Harvey Earnest Jordan. Jordan rarely published work relating to genetics and eugenics after 1914, perhaps in large part because Virginia's faculty had so many men who were performing the very investigations he had suggested to Charles Davenport. Nevertheless, during the 1920s Jordan remained active as a lecturer and organizer beyond his classroom teaching. ${ }^{182}$ During 1923 he became a member of the white supremacist Anglo Saxon Clubs of America, and worked with other eugenicists to promote Virginia's eugenic marriage restriction law, the Racial Integrity Act. That same year he joined the Advisory Council of the American Eugenics Society (AES), a position he would hold until 1935. When the AES called on him to become chairman of a state eugenics committee, he responded with alacrity.

President Roswell H. Johnson of the AES wrote to Jordan about becoming the state chairman in 1927. Johnson, who co-authored with Paul Popenoe the most popular college eugenics text Applied Eugenics, remained a towering figure in the national eugenics movement. He wrote to Jordan that, "At a recent meeting of the Board of Directors of the American Eugenics Society, I was authorized to appoint State Chairmen for each state in the United States and provinces in Canada." The chairmen were to organize a state committee "to do [eugenics] propaganda and legislative work in the state although not thereby precluding direct activity from the main office in cooperation." With luck, the state committee would become "the nucleus for a state eugenics society at some later time when deemed desirable."183 The AES thus hoped to colonize each state with a cell of their organization, a leadership cadre that would begin eugenic organizing. Ironically' Johnson,

182Jordan was listed as a member in good standing of the Eugenics Research Association in 1926. Eugenical News 11 (January 1926), 18. The American Eugenics Society, "A List of Eugenics Lecturers," pamphlet, (1927), "Print Orders" folder, AES Papers, listed Jordan as available to deliver "Eugenics: Its Data, Scope, and Promise" for $\$ 50$ and expenses.

${ }^{183}$ Roswell H. Johnson to Jordan, January 15, 1927, "Jordan, H. E." folder, AES Papers. 
who as much as any other mainline eugenicist of the time viewed political radicalism as a dysgenic hereditary trait, was promoting a decentralized, insurgent structure that anticipated mobilizing strategies used by populist insurgents around the world.

Jordan's letter of reply indicates the strength of his eugenical commitment, even as it identifies others who felt similarly. Jordan thanked Johnson for the "compliment of appointing me chairman," and then suggested the names of three individuals to comprise the state committee. Topping Jordan's list was his good friend Ivey Foreman Lewis. The next man Jordan nominated, the Reverend Beverly D. Tucker, was a University of Virginia alumnus and one of the most prominent Anglican clerics in the South, if not the nation. Finally, Jordan nominated Dr. J. Shelton Horsley of Richmond's St. Elizabeth Hospital. Horsley, too, was a Virginia alumnus, a surgeon trained by Paul Barringer during Barringer's first four years on the faculty. His sons, J. Shelton, Jr., Guy Winston, and T. Braxton would all attend Virginia, all take courses in eugenics under Lewis, Jordan, and Bean, and all become physicians. Jordan suggested that, "it might be well, I think, in each case to inform them of the other members of the committee and to state further that three or four additional members are to be appointed in a conference of this original group." Appreciating the demands on the time of these prominent men, Jordan nevertheless sought ways to insure their cooperation. His advice also suggests that each knew well the views of the others. Thus, the eugenics network in Virginia preceded this national-level organizing thrust. ${ }^{184}$ Delighted by Jordan's willingness, someone at the AES scrawled "Hooray!" across the top of his letter.

Jordan's nominations met with somewhat mixed success. Lewis, already a member of the AES, readily accepted the nomination. Tucker declined the nomination, stating, "I am

${ }^{184}$ Harvey Earnest Jordan to Roswell H. Johnson, January 26, 1927, Ibid. The Horsley boys will be discussed in great detail in chapter 5. J. Shelton, Jr. and Guy Winston's membership as physician alumni is indicated in McLane Tilton, ed., Directory of the Living Alumni of the University of Virginia, 1931 (Charlottesville, VA: The Michie Company, 1931), 77. T. Braxton Horsley's term paper for Ivey Foreman Lewis resides in Alderman Library. 
already a member of so many committees and find that my membership is of necessity merely nominal, and, therefore, I do not think that at this time I ought to extend the number, inasmuch as I can not render helpful service thereby." No doubt a frank estimation of the demands on his time, Tucker's demurrer does not indicate either support for or rejection of eugenics. The fact that Jordan nominated him, however, suggests that he thought Tucker was sympathetic to the goals of the movement. Horsely, who had joined the AES in 1925 at the "sustaining member" level, initially expressed hesitance, but then acquiesced. "Your letter of February 3rd has just come," he wrote Leon F. Whitney, Field Secretary of the AES, "I did not understand that my friend, Dr. H. E. Jordan of the University of Virginia, was chairman of the Virginia Section of the American Eugenics society. I feel that if he is much interested in this it must be a good cause, and I will be glad to accept the appointment as indicated on the Virginia Committee." Clearly the AES's enthusiasm over Jordan' cooperation was well founded, for his name landed the most prominent surgeon in Richmond for their cause. To complete the committee, Jordan nominated Professor Donald W. Davis of the College of William and Mary. Davis leaped at the chance, writing, "I shall be glad to serve....I am much interested in this work and shall be very glad to do all I can to forward it." Davis, a professor of zoology, completed the Virginia Eugenics Committee. 185

Finally, beyond his work for the education committee, Jordan also helped the AES in its ill-fated 1930 membership drive. Jordan nominated C. M. McFall and H. E. Hayden of Virginia's biology department, Floyd N. House and F. W. Hoffer from sociology, James E. Kindred from histology, Robert Bennett Bean (who was already a member), Adelaide A. Mayo from nursing, and W. R. Smithey from education. This gives some idea of the many people sympathetic to the eugenics movement who Jordan felt were not members. He also nominated C. E. Miller from the Medical College of Virginia, the state's only other

${ }^{185}$ Davis was also listed as an active member of the Eugenics Research Association in 1926, see note 172 above. 
medical school. The onset of the Depression in October of 1929 made 1930 a particularly inauspicious year for a membership drive. Few people had money to spare to pay dues. Adelaide Mayo replied, "Although I am in sympathy with the Eugenics movement, I have no desire to become a member of the society at the present time," as she thanked the AES for its information and pamphlet. ${ }^{186}$

\section{Orland Emile White: Reluctant Eugenicist?}

Even as Harvey Eamest Jordan was finalizing the roster of the Virginia State Eugenics Committee, Ivey Foreman Lewis was hiring the final major figure in the second wave of eugenicists at the university of Virginia. Lewis realized that Virginia's biology department required a trained geneticist if it was to remain competitive with biology programs at other top-flight institutions. Lewis regarded himself as perfectly capable of teaching the rudimentary genetics necessary in introductory biology and his eugenics course. He envisioned, however, upgrading the graduate program so that it produced students trained in this newest of biological sciences. A chance bequest of some farmland by an alumnus of the university provided Lewis with the opportunity to expand the biology departments capacities. Lewis pushed hard to organize Virginia's second biological experiment station, The Blandy Experimental Farm. He had in mind something similar to a successor to Harvard University's fabled Bussey Institution, where Harvard eugenicists Walter E. Castle and Edward M. East-who themselves had been taught by Charles B. Davenporttaught the second generation of American geneticists their trade.

As director of this new experimental station, Lewis would succeed in securing one of America's best known plant geneticists. Orland Emile White rose from obscurity to the heights of academic genetics. A student of Edward M. East at Harvard's Bussey

186Jordan's nominations are in "AES Membership Campaign, 1930 A-Z by State \#2" folder; while Adelaide A. Mayo to Fletcher, October 18, 1930, is in "1930 (M-S by Surname)" folder, American Eugenics Society Papers, American Philosophical Society Library, Philadelphia. 
Institution, White never attained East's prominence. Nevertheless, among all the scientists at Virginia, each of whom attained high levels of national distinction, White may have achieved the most. Not only did he himself contribute some 90 publications to the literature, but he guided the studies of numerous graduate students who went on to fame as geneticists in the 1940s and 1950s. Out of a tiny backwater farm, housed in renovated slave quarters, White carved an institution that advanced American agricultural genetics like no other. Overshadowed by developments in animal genetics from the labs of Herman Muller and Thomas Hunt Morgan, the Blandy Experimental Farm's contributions have been lost in the mists of memory. The links between White, the organized eugenics movement, and the Blandy Farm have been overlooked along with the institution's more laudable achievements. Nevertheless, they represent a significant chapter in Virginia's eugenic history.

Orland Emile White, like so many of America's first generation of geneticists, grew up in the wilds of the American heartland. White, born in Sibley, Iowa in 1885, he was reared in the Black Hills region of South Dakota. Nature and organic life captivated White from an early age. He called Thoreau's Walden his "youthful Bible," and his hero was the great American naturalist John Burroughs. A story about a young boy who collected bugs and plants and was scorned by his schoolmates until they realized how much he knew about the natural world touched young White deeply. The story's hero kept a picture of John Burroughs in a place of honor; this inspired White to write the famous mar.

Burroughs's response, became one of White's most cherished possessions. "My Dear Young Friend," Burroughs began, addressing the then-seventeen-year-old White, "

I cannot answer all of your questions now. Some of them are very hard to answer. Your mother was right, if you 'just keep plugging away' earnestly enough you will succeed. Keep your eyes \& ears open, read the best books, practice writing whenever you have something you want to say. But don't try to publish till you are older. I was 23 when I began to publish my things. An editor will not reject your piece because of 
any grammatical errors, if it has the real stuff in it. Get the life of Huxley \& read that if you can, or the life of any other great naturalist. ${ }^{187}$

White took the great man's advice to heart, kept on with his observations of nature, and worked his way through South Dakota State College (SDSC). While there, his father wrote him, "The brighter you make that tool of all tools- the mind, the farther it will carry you and the easier. You cannot have it too bright and keen."188 White heeded his father's advice, eaming a bachelor of science degree in 1909 with high marks.

Edgar William Olive, White's teacher at South Dakota, first introduced the young man to eugenics. Olive had been trained by Edward M. East at Harvard's Bussey Institution, where he, undoubtedly, first encountered eugenics himself. ${ }^{189}$ Olive put his protégé White in touch with East and William E. Castle at Harvard. Castle wrote to White, "Dr. East and I will together have charge of the work in genetics. You could be under one or both of us, as you preferred, or as the material you were working with suggested," surely an attractive offer to White. A lack of funds forced White to postpone graduate studies at Harvard, so he worked as a research assistant with the SDSC through 1909-1910. Castle and East, impressed by White's persistence, arranged for him to come to Cambridge in the summer of 1910. White would return to SDSC for 1910-1911, and earn a master's degree in

187John Burroughs to Orland Emile White, December 4, 1902, "Correspondence: John Burroughs" folder, Box 1, Orland E. White Papers, RG 21/66.831, Special Collections, Alderman Library, Charlottesville. [Hereinafter cited as White Papers.] Whites Papers exist in three separate accession numbers, the first, already listed, then a second group RG $21 / 66.811$ and a third group 21/66.832. The last two groups will be referred to, hereinafter, as White Papers II, and White Papers III, respectively.

${ }_{188}$ Father to Orland E. White, August 3, 1909, "Correspondence, Family of O. E. White" folder, Box II, White Papers III. Lctters between White and his parents shows both of them, particularly his father, to be quite erudite. This letter also reveals the harsh quality of their prairie life, where a storm could wipe out an entire crop in three minutes. White clearly inherited his father's dry sense of humor; he liked to say he "grew to manhood on a Sioux reservation."

${ }^{189}$ Indeed, a copy of Olive's "Family Records" form, from the "Camegie Institute of Washington, Station for Experimental Evolution, and American Breeders' Association: Committee on Eugenics" is in Orland E. White, Ms. 7095, Special Collections, Alderman Library, University of Virginia. This form represents Davenport's early efforts to gather data for pedigree analysis. Dates on the document indicate that it was filled out in November of 1909 and updated through 1912. The Eugenics Committee listed on the form includes David Starr Jordan, Alexander Graham Bell, Ales Hrdlicka, Roswell Johnson, William E. Castle, Vemon Kellogg, Frederick Adams Woods and Davenport among others. 
botany. By that time, however, he had so impressed East and Castle that they arranged scholarships for him to come to Cambridge for two years. ${ }^{190}$

White entered "The Bussey"—as it was known to intimates-in the fall of 1911 as East's first graduate student, and earned a master of science degree in genetics the following spring. A year later, in the spring of 1913, he earned his Doctor of Science degree. While at Bussey, White also took courses under Robert M. Yerkes in genetic psychology, which well fit the eugenic temper of the times. ${ }^{191}$ White's own investigations centered around two plants, tobacco (nicotianna) following the suggestion of East, and, like Gregor Mendel, peas (pisum). In his two years at Harvard, White would meet many of the nation's foremost geneticists and eugenicists. His own student cohort included many men who would achieve great distinction in the field, including Albert Blakeslee, Robert Cook, and Clarence C. "Pete" Little. He also came to know well Charles $\mathrm{H}$. Danforth of the Washington University Medical School, another prominent eugenicist. ${ }^{192}$ Upon graduation in 1913, White took a job as assistant curator of plant breeding at the Brooklyn Botanic Garden in New York. In 1916 he was promoted to curator of plant breeding. In 1924 his job title became curator of plant breeding and economic plants. "Economic plants" refers to White's increasing interest in the genetics of marketable plants like the castor bean and corn. White sent his doctoral thesis off to Germany, to the famous geneticist and eugenicist Erwin Baur, who published it in the Zeitschrift für

${ }^{190}$ Castle to White, August 3, 1909; White to Castle, n.d., circa November 1909, "Correspondence, General, of O. E. White (1909-1910)" folder, Box 2, White Papers III. East to White, "Correspondence, General, of O. E. White (1911-1919)" folder, Ibid. See also, "Dr. Orland E. White" and "Academic and Professional positions held," in "Correspondence, Miscellaneous" folder, Box 9, White Papers.

${ }^{191}$ White claimed he was East's first graduate student in Orland E. White to Cardenas, October 27, 1953, "Correspondence, Ca-Com" folder, Box 3, Ibid. His classes with Yerkes are mentioned in Edgar W. Olive to White, November 26, 1911, "Correspondence, General, of O. E. White (1911-1919)" folder, Box 2, White Papers III.

192Little would go on to be president of the University of Maine and the University of Michigan, and then head the Roscoe B. Jackson Cancer Research Laboratory in Bar Harbor, Maine. Cook would go on to serve for many years as the editor of the Journal of Heredity, as well as serving as one of the chief organizers of the American Genetics Association. All of these men-Castle, East, Little, and Cookmaintained close ties to the American eugenics movement. See Mehler, "History of the American Eugenics Society," 321-22, 324-25, 335-36, 393-94. See also Orland E. White to Charles H. Danforth, January 15, 1912, "Correspondence, General, of O. E. White (1911-1919)" folder, Box 2, White Papers III. 
Gesellschaftsbiologie. During this period, and especially while World War I raged, White also held simultaneous positions with the United States Department of Agriculture. He sat on the editorial board of the American Journal of Botany in 1920-1921. In 1921 White joined the year-long Mulford Expedition to explore the Amazon River Basin. So, between 1913 and 1927, White's job kept him in close touch with his mentors and the genetics community; the position also allowed him to continue his own scientific research in plant genetics.

Having finally succeeded in becoming a professional scientist, White re-established contact with an old acquaintance. "Fourteen or fifteen years ago, you were kind enough to answer a very boyish letter from one who was ambitious to be a naturalist," White began his second letter to his boyhood idol, John Burroughs. "You wrote him a very nice and encouraging letter at a time when he needed it most, and though he has never written to thank you until now, he has certainly appreciated that encouragement many, many times." White told Burroughs how he had followed the great man's advice, become a scientist, and that he was forwarding copies of his published articles.

White did not have to wait long for Burroughs's gratified response. "It gives me very deep pleasure to know that any word of mine has born such fruit in the life of a young man as your letter discloses," the aged John Burroughs wrote White. "A good many boys and young men have written tome first and last asking advice and I usually try to give it, but in no other case before have I appeared to hit the mark as with you." Confessing that he did not remember just what he wrote to White, Burroughs then commented on some of White's offprints in a fashion that echoed the earlier missive. "[White's work] is full of solid substance. I see I must become your pupil to read it all. You have the art of making science attractive." Burroughs invited White to visit him at his legendary Hudson River retreat "Slabsides." So began a remarkable friendship that would last until Burroughs died in 1919. White would visit Burroughs many times and become a trusted critic and editor of 
Burroughs last works. So the May-December friendship capped White's personal success story. 193

White's position at the Brooklyn Botanic Garden and Burroughs's friendship brought him into contact with many of New York City's wealthiest and most influential people. White maintained contact with the scientific community, particularly Charles Benedict Davenport and the Eugenics Record Office. Always a free-thinker, however, White also became involved with Margaret Sanger and the birth control movement-a move Davenport would surely have disapproved. ${ }^{194}$ Indeed, White's papers contain an original copy of Sanger's famous 1914 pamphlet, "Family Limitations." When the Birth Control Review began publishing, White contributed many reviews of books dealing with heredity and eugenics. Perhaps as a lingering tribute to his strong-willed mother, White maintained staunch feminist views throughout his career. After his arrival at the University of Virginia, he eagerly took on female graduate students, many of whom took their doctorates and achieved solid academic careers. ${ }^{195}$

${ }^{193}$ The touching letters between White and Burroughs reside in "Correspondence: John Burroughs" folder, Box 1, White Papers. White wrote Burroughs, "The idea of writing you [in 1902] came first from a story I read in a Sunday school paper-a story in which you were mentioned and that described my own desires, ambitions, eccentricities and feelings so accurately that it was hard for me to believe that I had never been the living subject for the fanciful character." A copy of the story, "A Lover of the Fields," Young People's Weekly 15 (May 12, 1901) remains in the file.

${ }^{194}$ Charles Davenport's papers make it clear that he did not consider birth control a viable eugenic measure. "I have persistently kept out of the Birth Control movement as I am not convinced that, despite their high motives, the movement will not do more harm than good.... While, at the present moment, I feel the Birth Control movement probably acts dysgenically by keeping down the families of the intellectuals, still it might conceivably act eugenically in the future, if applied to defectives or families of low mentality." Charles B. Davenport to Rev. John J. Burke, January 21, 1926, Davenport Papers. Although Burke was a Catholic priest, Davenport's statements represented his true beliefs, not just an attempt to win an ally. Davenport consistently distanced himself from Sanger and the Birth Control Review. He worked hard to keep the eugenics organizations he was involved with-ERO, AES, Galton Society-distinguished from the birth control movement.

${ }^{195}$ Davenport-White correspondence resides in "Correspondence D (1914-1952)" folder, Box 3, White Papers. Margaret Sanger's "Family Limitations" is in "Miscellaneous Scientific Papers, Lists, Diagrams" folder, Box 4, White Papers III. Copies of many of his book reviews are in "Book Reviews folder, Box 9, White Papers. Correspondence with his many loyal graduate students is scattered throughout all three collections. The University of Virginia began admitting women to its graduate programs in the 1920s and White admitted women as students in genetics from the inception of his program in 1927. 
The reviews White wrote for The Birth Control Review paint a clear picture of his own views of eugenics. By the 1920s White hewed to the same line expressed by Margaret Sanger, who wrote, "The [British] eugenists wanted to shift the birth-control emphasis from less children for the poor to more children for the rich. We went back of that and sought to stop the multiplication of the unfit. This appeared the most important and greatest step toward race betterment."196 Eugenics, for White, revolved around "better parenthood" as he made clear in a laudatory review of Major Leonard Darwin's Eugenic Reform. He agreed with all of Darwin's main themes, particularly that prohibition of parenthood among the "definitely deficient" would reduce the number of "feebleminded" people born. White also concurred in Darwin's opinion that, "Conception control, on account of its wide possibilities, is likely to be the most powerful agency which exists for racial improvement or racial deterioration as the case may be."197 Darwin addressed "so many questions from so many angles, that I hardly see how any person interested in human affairs could avoid reading this book." Reviewing a book by Julian Huxley, White expressed his opinion that unless "civilized societies...invent and enforce adequate measures for regulating human production, for controlling the quantity of the population, and at least preventing the deterioration of quality of racial stock, they are doomed to decay and so be submerged in some new barbarian flood."198 The use of such millennial imagery was uncharacteristic of White, who usually adhered more closely to the eventempered eugenics of his mentor Edward M. East.

White leamed advanced eugenics from Charles Benedict Davenport and East, who published on the subject from the 1910s through the 1930s. In 1919, White worked

${ }^{196}$ Sanger quoted from her Autobiography, in Donald K. Pickens, Eugenics and the Progressives (Nashville, TN: Vanderbilt University Press, 1968), 30. Sanger's eugenics come forth in her other books, Pivot of Civilization and Women and the New Race.

${ }^{197}$ Orland E. White, "Review of Eugenic Reform by Leonard Darwin," February 6, 1928, in "Book Reviews 1927-1928" Folder, Box 9, White Papers. [Hereinafter referred to as Book Reviews.] Although written in 1928, many of White's reviews did not appear in The Birth Control Review until 1930-1931.

${ }^{198}$ Orland E. White, "Review of Know Thyself by Julian Huxley," n.d., Book Reviews. 
alongside Davenport in the Society for Experimental Biology and Medicine. This group dedicated itself to the application of Mendelian genetics and racial anthropology through medical therapeutics. 199 During the twenties East launched a sustained effort to "popularize" genetic knowledge and "responsible" views of eugenics in books like Inbreeding and Outbreeding, Mankind at the Crossroads, and Heredity and Human Affairs. $^{200}$ In all of his books, East considered it too early to enforce a stringent "eugenic system of conduct" because "the acquisition and diffusion of knowledge are needed more than widespread dogma and ill-advised legislation at the present day."201 East was reacting against the version of eugenics popularized by Madison Grant and Lothrop Stoddard, to whom he referred obliquely as "newspaper men and professors of journalism" and "certain retired lawyers and bartenders." He characterized these enthusiasts as jack-asses abusing genetic knowledge which "is a treasure...not to be abandoned to the tribe with long, silky ears."202 In the end, despite his obvious qualification as one of America's foremost geneticists, East's eugenic beliefs differed more in degree than in kind, from those of Grant and Stoddard.

East's thorough belief in Thomas Malthus's thesis, that uncontrolled procreation would cause population to outstrip food supply, led him to become an ardent proponent of birth control. Unlike Charles Davenport, East defended birth control as one of the eugenicists'

\footnotetext{
${ }^{199}$ White's Papers contain the remnants of his correspondence with Davenport. These letters reveal the scope of both men's interest in genetics and eugenics, particularly Davenport's interest in plant genetics as reflective of animal genetics. See especially Orland E. White to Charles Benedict Davenport, May 14, 1919, re: Society for Experimental Biology meeting; White to Davenport January 22, 1920; and Davenport to White, January 26, 1920, "Correspondence D 1914-1952" Folder, Box 3, White Papers. This correspondence continued sporadically after White joined the Virginia faculty, although by then it almost entirely concemed plant genetics and plant specimens.

200 East contributed essays on plant heredity to Heredity and Eugenics (Chicago: University of Chicago Press, 1912). In Inbreeding and Outbreeding: Their Genetic and Sociological Significance (Philadelphia and London: J. B. Lippincott Company, 1919), East included two chapters on eugenics. East's Mankind at the Crossroads (New York: Charles Scribner's Sons, 1924) and Heredity and Human Affairs (New York: Charles Scribner's Sons, 1927) represent his fully-articulated eugenic views and his attack on men like Madison Grant and Lothrop Stoddard.

${ }^{201}$ East, Inbreeding and Outbreeding, 15, 227-228.

${ }^{202}$ East, Heredity and Human Affairs, vi. Grant was a lawyer, Stoddard often wrote for newspapers and sometimes taught journalism.
} 
most effective tools and sat on the National Council of the American Birth Control League. "Eugenics is sorely needed," East averred, "social progress without it is unthinkable; but the eugenics which merely prevents the procreation of those who are so defective as to be confined in institutions and which asks the most intelligent of the remainder to make up the difference is nonsense."203 East believed that "decreas[ing] the numbers of the unfit in the future, either by a thoroughgoing scheme of segregation or by sterilization," was important but, "The really useful eugenics is properly directed birth-control, and the only practical directive agent is education."204 The entire lower class, which East termed "the stolid portion of humanity," must be taught to lower its birth rate, too. Else, East feared population pressures from within "white couritries" would result in their decay through a Malthusian reaction. Rather than Stoddard's "rising tide of color" he saw a rising tide of mediocrity and mouths to feed.

Nevertheless, East was no racial equalitarian. Miscegenation was ill advised because, "the negro race as a whole is possessed of undesirable transmissible qualities both physical and mental, which seem to justify not only a line but a wide gulf to be fixed permanently between it and the white race." Medically, East felt that, "There is a real inferiority in resistance to certain diseases" among blacks. ${ }^{205}$ Intellectually, East adopted all the arguments offered by the Army testers, and he approvingly discussed George O. Ferguson's study of black intelligence. ${ }^{206}$ He concurred with Ferguson in the opinion that "mixed blood" African Americans tended to be socially disruptive because, as East put it, "white germ-plasm in the negro complex spurns its hopeless situation when in contact with the dominant race."207 East recast the "negro problem," therefore, as a "the problem of the mulatto and his descendants. The only surge in the "tide of color" that worried East was

${ }^{203}$ East, Mankind at the Crossroads, 316.

${ }^{204}$ East, Ibid., 295, 299.

${ }^{205}$ East, Ibid., 133. East felt similarly about breeding between native born whites and southeastern Europeans (309); he supported immigration restriction.

${ }^{206}$ East, Ibid., 135-136.

${ }^{207}$ East, Ibid., 120. 
the ripple in the American South: "Looking to the north, the east, the west, the horizon is unclouded. Only in the south appears a little cloud no larger than a man's hand. It may be a passing mist, but it bears watching....the southland outpost is the post of danger. This is the direction in which to double the guard."208

White's own publications regarding eugenics neatly parallel the opinions expressed by East. In reviewing East's book Inbreeding and Outbreeding in the New Republic, White echoed hereditarian mainliners, writing,

Greatness...is governed by many factors....But granting the importance of these environmental factors, which all students of heredity do, inherent capacity, inherited potentialities are the foundation stones on which these other factors are but superstructures.....You can only with difficulty keep a 'good' man down, but alas for those poorly equipped with a 'fit' equipment of hereditary characters-for these, the social worker and the charity organization are often the perennial prop.

With regard to miscegenation, White wrote, "Racial mixing of yellow and white, of black and white is in general to be deplored, from the standpoint of the 'whites."'209 In reviewing East's most alarmist eugenical tract, Mankind at the Crossroads, White again approved his mentor's views on the dysgenics of miscegenation. Applauding East for debunking "the bogey of Stoddard's 'yellow peril'," White then supports East's warning "to watch the 'little cloud no larger than a man's hand' on the southern horizon," the threat of "mulattoes" passing into the white population through intermarriage. ${ }^{210}$ More personal correspondence revealed White's "racial" views regarding blacks and white ethnics from southeastem Europe. Writing his wife, who was in Europe for almost White's entire first year at Virginia, White often referred to blacks as "darkies," a common epithet at the time.

${ }^{208}$ East, Ibid., 145. East hoped that "The black race will follow the American Indian into a gradual decline, except that part of it which is amalgamated with the white and yellow." (235)

${ }^{209}$ Orland Emile White, "Inbreeding and Outbreeding," The New Republic (November 10, 1920): 279-280. White also collected articles from the New York Tribune like "Sees Extinction of the AngloSaxon Race in America," and "Mental Expert Blames Society for Defectives," in "Newspaper Clippings of O. E. White" folder, Box 6, White Papers III.

${ }^{210}$ Orland Emile White, "Mankind at the Crossroads: A Review by Orland E. White," Birth Control Review 8 (February 1924): 55-56, quotation 55. White gushed, "I think of it as one of the outstanding books of the last few years, along with 'The Outline of History' and 'Mind in the Making'....So reader, read it." (56) 
About meeting the Italian ambassador at a tea, White remarked, "we really did meet him in a cordial and non perfunctorial [sic] manner. Of course, he was but slightly Italian (as we think of them) in appearance-probably mostly Nordic_-Visigoth, Ustrogoth, Vandal or some other strand of the 'fair skins."'211 White was no stranger to mainline eugenic notions of race.

Eugenical sterilization also seemed a sound policy to White. The Birth Control Review ran a special issue dedicated to sterilization in March 1928, the year after the Supreme Court upheld the constitutionality of eugenic sterilization. By this time, Margaret Sanger's own views on eugenics had hardened to such a point that the subtitle of the Review was "Fewer but Fitter Children." White contributed to a "symposium" on sterilization, citing his own "contacts" and Harry Hamilton Laughlin's work as his sources. "I am convinced that sterilization legislation is the only effective method of dealing with certain elements in our population by way of keeping them down numerically." The use of sterilization as a punitive, rather than a eugenic, measure should be deplored, White held, continuing "For feeble-minded and insane, whether at large or in institutions liable to turn them out into the population again, I believe in compulsory sterilization." Sterilization was also warranted, as a eugenic measure for "chronic criminals" [emphasis in the original]. White closed with an call to action, "But no such laws should be put on the statute books of any state unless they are ready to use them. It is deadening to pass such laws and let them lie unused, as some states seem to have done." Written just a month after he joined the University of Virginia faculty, White's "contacts" doubtless included his department chairman, Ivey Foreman Lewis, and his new friend Harvey Earnest Jordan. ${ }^{212}$

211 Orland Emile White to Loto White, February 29, 1928 ("darky" humor); April 27, 1928, (Of the Blandy Experimental Farm, "this old 'quarters' once housed ten darky slave families"); June 28, 1928 (About finding a cook for the Blandy Farm, "Yes, we caught the cook...Her father lived here in the old slave days and her name is Ursula and she is a class conscious darky." Also the farm gate was made "by old darky slaves."); and December 11, 1927 (quoted above), "Correspondence, general, of O. E. White (1927-1928)" folder, Box 2, White Papers III.

212Orland Emile White, "Sterilization: A Symposium," Birth Control Review 12 (March 1928): 8990. White became fast friends with Jordan and his family, writing his wife, "Have just come from a friend's 
Finally, writing in Eugenics in 1929, White also supported counseling members of families exhibiting dementia praecox (adolescent insanity) not to reproduce. The editors posed the theoretical problem, "Should individuals, themselves sound, but having fifty per cent of their brothers or sisters afflicted with dementia praecox, be encouraged to reproduce?" White began by defining dementia praecox as a Mendelian recessive, based on the work of Charles Davenport, Abraham Meyerson, and Ernst Rudin. Given its recessive nature, White felt that "I would be exceedingly loathe to encourage sound brothers or sisters in such families to have children. Still further to strengthen the statement, were I a normal brother or sister in such a family, I would not be willing, in the light of our present genetic knowledge of the subject, to take the risk of having children." A statistical analysis of the likely ratios of afflicted to healthy offspring revealed that, although many matings would produce normal children, many others would likely produce "tainted" individuals. Therefore, White would counsel "against taking the great risk." 213 White thus adhered to the central tenets of mainline eugenicists.

White supported the American eugenics movement through his teaching and by contributing money to the Second and Third International Congresses of Eugenics, in 1921 and 1932. ${ }^{214}$ It is highly likely, given his personal beliefs, the state of the science, and the institutional culture at Virginia, that he introduced eugenics, at least incidentally in his genetics and medical genetics courses. The remaining syllabus for his extension division course, "Heredity, Variation and Environment in Plants and Animals Including Man" proves that he dealt with eugenics, for among the assigned texts are Popenoe and

house-Dr. Jordan's. My first visit and they are very charming people full of jokes and good humor." Orland E. White to Loto White, November 27, 1927, "Correspondence, general, of O. E. White (19271928)" folder, Box 2, White Papers III. This letter is dated a week after his letter included in the Review's symposium.

213Orland E. White, "Is Dementia Praecox Inheritable? Should a Victim's Relatives Marry?" Eugenics 2 (October 1929): 23.

${ }^{214}$ See Harry Hamilton Laughlin to Orland Emile White, Aril 24, 1931, re: Third International Congress of Eugenics, "Correspondence I-J" Folder, Box 5, White Papers. 
Johnson's Applied Eugenics, East's Heredity and Human Affairs, and Herbert Spencer Jennings's The Biological Basis of Human Nature. ${ }^{215}$

Notwithstanding these commitments to eugenics, White thought of himself, first and foremost, as a geneticist. Indeed, in agreeing to write for Eugenics, White's draft response reveals some tantalizing clues about the depth of his eugenic commitment. First, he delayed almost three weeks in answering the request for a contribution. Then, he wrote, "I will be glad to contribute from the standpoint of a geneticist and not a eugenics specialist, which I am not." Reluctantly, he added, "I say I will be glad to send you a contribution within the next three months provided undue complexities do not arise in the meantime in my world." White might have been adverting to the fact that this correspondence was occurring in May and June, in the midst of the growing season at the Blandy Experimental Farm. As busy as that time of year kept White and all the graduate students in genetics, he may not have wanted to take on an additional burden. Or, he may have been reluctant to contribute because he did not feel himself a eugenics authority. His draft ends with a broken sentence that leaves one wondering. "You see, I am cautious in promising, because...." Although White may have been sliding into an explanation on the basis of his reservations about eugenics, given all his previous work on eugenics and with eugenicists, this seems unlikely. As one of the upper-echelon members of America's relatively tiny genetics and eugenics elite, White most likely had few qualms about weighing in on the question of dementia praecox, which could be tackled with relatively simple equations.

This fragmentary correspondence, placed in the context of White's career and the history of genetics and eugenics, underscores historian Diane B. Paul's contention that by the 1920s, "a consensus among geneticists concerning the role of heredity in the determination of intellectual, psychological, and moral traits" existed that was "so complete that virtually no one-including Marxist and other Left geneticists—is to be found outside

215 Orland Emile White, "Heredity, Variation and Environment in Plants and Animals Including Man," in "Writings of O. E. White" folder, Box 8, White Papers III. 
it."216 Regardless of whether or not White believed himself to be a geneticist or a eugenicist, the common ground between the two disciplines was so well established that his writing on the eugenical implications of heredity posed no intellectual obstacle or political obstacle. Just as support for birth control and eugenics created no insuperable difficulty for East, so too White managed to reconcile these ideas.

Orland White, like all the other people depicted in this chapter, accepted the promise of eugenics as a viable possibility. This opinion held sway throughout scientific America, with only a few lone voices crying out against eugenics. What this tells modem historians is that eugenics truly was the "lingua franca" of science in America. This contention is buttressed when one examines the roll of eugenics supporters and their professional pedigrees. Each of the academics mentioned in this chapter, with the exception of nurse Adelaide A. Mayo, was an elected fellow of America's premier scientific body, the American Association for the Advancement of Science. Moreover, many of these men held positions on the National Academy of Science, and all served in executive roles for societies goveming their specific disciplines. These men were not simply cranks, enthusiasts, or "comupted" scientists. They represent a fair sampling of mainstream scientific opinion. Their thinking reflected the most current notions of eugenics, the relation of science to social policy, and social prejudice extant in the 1920s.

Teasing out the singular strands of scientific commitment, the desire for social control, and the influence of social prejudice from the university eugenicists' beliefs presents a formidable, and very possibly futile, task. Whatever the individual strength of each of these three factors, eugenics provided the ideological loom that wove them together into a strong ideology that bound these men to the eugenics movement's vision of a hierarchical society. These men all converted to the "gospel of social evolution" as constructed by

216Diane B. Paul, "Eugenics and the Left," in Diane B. Paul, ed., The Politics of Heredity: Essays on Eugenics, Biomedicine, and the Nature-Nurture Debate (Albany, NY: SUNY Press, 1998), 17. 
hereditarian biology. They then went forth to proselytize as many students, professional, and lay people as they could. That these men were educators only aided their efforts.

Education remained crucial to the popularization of eugenic ideals. All the eugenicists at the University of Virginia believed this; as a result they all sought to inculcate eugenics and the eugenic creed through their courses. The efforts of these educators eased the reconciliation of eugenical ideals with more traditional southern social mores, creating a new model for social policy. Education socialized Virginia elites to believe in the power of heredity over environment, while cementing their faith in the notion that the social order reflected the iron laws of nature. Even as the second wave eugenicists solidified their position at the University of Virginia, like-minded men began to occupy positions at other institutions. Educators continued to spread the word about hereditary inequality and the menace of the feeble-minded and the genetically unfit.

The surge in eugenics popularity, both nationwide and within the University of Virginia would be mirrored at other institutions. As the next chapter will show, biologists at Virginia's "lesser" institutions of higher education taught eugenics in much the same way as it was taught at Mr. Jefferson's university. Obviously, this widespread teaching of eugenics increased its currency among white Virginians. Among black Virginians, however, eugenics also found a receptive audience. Taught out of the Hampton Institute, the great historically black college that produced Booker T. Washington, and embraced by the followers of Marcus Garvey, eugenics took on a separatist tinge within the black community. The degree to which black adoption of eugenics represents an accommodationist capitulation to racist whites, an assimilationist attempt to "do science" just as whites did it, or a separatist revolt designed to coopt white eugenics and use its authority to subvert racial hierarchy will be considered in depth. 


\section{Chapter IV: Peopling Virginia}

Writing in Eugenics in 1930, Professor Rudolph M. Binder of New York University ruminated about "How to Interest College Students in Eugenics." After asserting that college students were interested mainly in joining "an exclusive fratemity or sorority," being able to "'get by' in examinations," and "have a handsome companion" at social occasions, Binder concluded that there seemed "little hope for eugenics there."

Reconsidering, however, Binder cited three factors that might open the door to eugenic instruction: students' believed that they were "omniscient," they desired to "order the world differently," and "being healthy animals, especially the boys, they are interested in sex and a family of their own." These conditions presented a "chance for eugenics" because, properly cast, eugenics could shake student faith in their supreme knowledge (by alerting them to the dysgenic threat), mobilize them to reform the world through eugenics, and excite them about having a "fit" family. Binder and others in the eugenics movement sought to exploit this opportunity. ${ }^{1}$ Eugenics leaders, from Galton forward, understood that eugenic education would be the only way for the movement to succeed-in perpetuating itself and seeing its aims enacted into public policy. By 1930 , most scientists were veering away from studying human heredity, toward other organisms that gave quicker results. Eugenic theory came under increasing attack from environmentalist academics. The old guard realized that they had to muster new recruits-if not to become eugenic scientists, then at least to become eugenic citizens. Eugenics, therefore, continued to be a "hot" topic in college classrooms across the country.

Historian of education Steven Selden has established the prevalence of eugenics in high school and college biology textbooks from the 1920s to the 1940s. His work also has revealed the role of eugenics in shaping the educational agenda of the National Education

\footnotetext{
${ }^{1}$ Rudolph M. Binder, "How to Interest College Students in Eugenics," Eugenics 3 (1930): 122-27, quotations 123.
} 
Association and other professional bodies dedicated to training the nation's teachers. ${ }^{2}$

More than a generation of teachers, it seems, learned eugenics as cutting edge science.

This should not surprise historians; every generation teaches those following them "cuttingedge," state-of-the-art science. Nevertheiess, the appearance of eugenics in texts does not guarantee that it was taught. Pressed for time, teachers often omit sections included in textbooks, to allow them to concentrate on other material. So, determining the impact eugenics had upon the high school and college curriculum requires more than just locating the various textbooks used to teach biology, and tracking what leading educators had to say about the relationship between eugenics and education. A more accurate appreciation of eugenics' permeation into higher education comes from polling teachers about what they actually taught.

The Eugenics Record Office's (ERO) Superintendent Harry Hamilton Laughlin surveyed America's colleges and universities on a number of occasions. ${ }^{3}$ As a true believer, the finding that eugenics instruction occurred on a less than universal basis appalled Laughlin. Yet, the frequency with which eugenics was taught, even as an incidental unit within a course dedicated to a larger topic, prompted Laughlin to comment in 1930, "Eugenics has become well established as the subject for college instruction and research." ${ }^{4}$ Laughlin's estimation represented more than wishful thinking. Hamilton Cravens noted that, "the number of colleges and universities offering courses in eugenics increased from 44 in 1914 to three hundred and seventy-six in 1928, when, according to

\footnotetext{
${ }^{2}$ Steven Selden, Inheriting Shame: The Story of Eugenics and Racism in America (New York: Teacher's College Press, 1999).

${ }^{3}$ The Charles B. Davenport Papers and the ERO Papers at the American Philosophical Society contain the replies to surveys conducted in 1912, 1916, and 1920. See "Eugenics and Genetics in the Colleges" folders, Charles Benedict Davenport Papers and "Eugenics Instruction Questionnaires," Box 1, Eugenics Record Office Collection, both held at the American Philosophical Society Library, Philadelphia. [Hereinafter respectively referred to as Davenport Papers and ERO Collection.] The Eugenical News published a list of colleges and universities offering eugenics in 1916. See "College Courses in Eugenics and Genetics," Eugenical News 1 (April 1916): 26-27.

4"Eugenics: The Word, The Content of the Science; and College Instruction in This Field," Eugenical News 15 (August 1930): 118.
} 
one estimate, some 20,000 students were enrolled in these courses." 5 While this

expansion represents impressive growth, these figures remain very rough estimates.

Errors in reporting made Laughlin's surveys_and estimates drawn from them-seriously underestimate the amount of eugenics instruction actually cccurring. ${ }^{6}$

To get a more accurate picture of eugenics education in action, one must examine course guides and high school curricula. The evidence from the University of Virginia confirms the teaching of eugenics there, through a number of disciplines over many years.

The question remains, however, whether the University of Virginia's experience was exceptional or typical. Just how widespread was the teaching of eugenics in Virginia's institutions of higher education? Surveying the course catalogs of many of Virginia's better-known colleges confirms Selden's suspicions, and actually exceeds the estimates made by Harry Hamilton Laughlin. The following series of institutional portraits reveals the near universality of eugenic teaching in Virginia's colleges and universities, white and black, for men and women. Without book lists, assignments, or lecture notes, for all of these courses, it is difficult to gauge the degree to which the instruction reflected mainline assumptions or more moderate positions. Context, timing, and the institutional background of the instructors allow for some inferences about the tenor of their teaching. In a few notable cases, especially that of Dr. Thomas Wyatt Turner of the Hampton

\footnotetext{
${ }^{5}$ Hamilton Cravens, The Triumph of Evolution: American Scientists and the Heredity-Environment Controversy, 1900-1941 (Philadelphia: University of Pennsylvania Press, 1978), 53. Cravens actually cites Garland Allen, "Genetics, Eugenics, and Class Struggle," Genetics 74 (1975): 33.

${ }^{6}$ During Laughlin's second survey, in late 1919 and early 1920, the University of Virginia's registrar, Anna Tuttle Heck responded that there was no course in eugenics. Ms. Heck had recently lost her husband who, until that time had taught eugenics; she was clearly unaware of Ivey Lewis's course. Moreover, although Ms. Heck reported that Harvey Jordan was probably the faculty member most interested in eugenics, she did not mention his teaching in the medical school. Jordan, however, also received Laughlin's questionnaire, and responded that he dealt with eugenics in his course on embryology. Beginning in 1907, he had devoted the last two weeks of the course to eugenics, giving "Lectures in heredity and eugenics with special emphasis on the importance of these subjects to medicine." Although he felt that, "Curriculum too crowded for further expansion in this direction," he believed that, "The students are intensely interested in this portion of the course in Human Embryology." University of Virginia and University of Virginia School of Medicine questionnaires in "Eugenics Instruction Questionnaires, Univ. of Mi-Y (1920)," folder, Box 1, ERO Collection.
} 
Institute, a great deal of information remains for analysis. In these cases, the contours of eugenical instruction, as experienced in the classroom, becomes readily apparent.

In the aggregate, the wide spread and durability of hereditarian thinking in Virginia colleges and university's is impressive. It is all the more daunting because, even at its best, this instruction consigned many individuals to the sub-human ranks of the "unfit" in the eyes of their contemporaries. As African-American eugenicist Thomas W. Tumer trenchantly observed, "Sound citizenship in a democracy depends in large measure upon the way in which information has become socialized, as it were, and utilized for the physical and spiritual development of the people." 7 All learned information bears the ideological impress of the teacher and the social context in which it is taught. The existence of ideological bias becomes problematic in a democracy if it enshrines social hierarchies in the minds of students as the fixed results of natural law.

\section{The College of William and Mary}

If the University of Virginia truly is, as Philip Alexander Bruce characterized it, the lengthened shadow of Thomas Jefferson, then the College of William and Mary remains the light source creating that shadow. Scholars at Jefferson's alma mater, to an extent that rivaled those at Jefferson's institution in Charlottesville, hewed to the tenets of mainline eugenics. Professor of Biology Donald W. Davis, like his good friends at the University of Virginia, worked to promote eugenics through his teaching and extracurricular activities. Davis, like the men at Virginia, believed in the efficacy of hereditarian science to diagnose society's ills and prescribe the specific remedy. ${ }^{8}$

\footnotetext{
${ }^{7}$ Thomas W. Tumer, "The Biological Laboratory and Human Welfare," Howard Univer sity Record (January 1924), 1, off-print in the Thomas W. Tumer Papers, Hampton University Archives, Huntington Memorial Museum, Hampton University, Hampton. [Hereinafter referred to as Turner Papers; all page references for this piece refer to the off-print.]

${ }^{8}$ These conclusions are taken from my study of the Donald Walton Davis Papers, Special Collections, Swem Memorial Library, College of William and Mary, Williamsburg. [Hereinafter referred to as Davis Papers.] Davis's interaction with the University of Virginia eugenicists is detailed in Chapter 6.
} 
Professor Davis responded to Harry Hamilton Laughlin's 1920 questionnaire regarding eugenics in the college curriculum. Davis commented that, beginning "about 1915," he had offered genetics to classes of approximately eleven students per year. ${ }^{9}$ "About two weeks of the term given to human heredity," Davis remarked, "these two weeks coming at the end of the course and based upon the earlier work." He also noted, however, that "A six weeks course in eugenics is announced for the summer session-meeting five hours per week."10 The course catalogs at William and Mary reinforce Davis's depiction of the curricular evolution. In the fall of 1912, Davis's predecessor, Dr. John Woodside Ritchie, began offering "Evolution and Heredity," a course described as "A series of lectures dealing with the broader aspects of biology and the social applications of biological problems."11 Ritchie left William and Mary in 1918, and his temporary replacement, Horace Edwin Hayden, instituted a more rigorously eugenic course. The course description became more overtly hereditarian, noting that the course considered "the philosophical side of biology and the fundamental laws of heredity as revealed by recent investigations."12 In 1920, Davis changed the course to "Genetics: The principles of variation and heredity in plants and animals, including man; and the practical application of these principles." The same year, Davis instituted a course on public health, "with a view to enabling prospective teachers, as well as citizens in their private capacity to co-operate intelligently with the health authorities in reducing the incidence of disease and in

\footnotetext{
${ }^{9}$ At that time, Davis was teaching in the biology department at Clark University.

${ }^{10}$ College of William and Mary questionnaire, "Eugenics Instruction Questionnaires, A-Ham (1920)," folder, ERO Collection.

${ }^{11}$ College of William and Mary, Catalog and Announcements, 1912-1913, p. 59, Special Coilections, Swem Memorial Library, College of William and Mary, Williamsburg. [Hereinafter referred to as Catalog, date.] Ritchie reported this course to Charles Davenport in 1915. See William and Mary Questionnaire in "Eugenics and Genetics in Colleges, \#1," Davenport Papers. Ritchie was an avid eugenicist. His 1941 high school biology text Biology in Human Affairs advocated biological determinism and eugenical marriage selection. See Steven Selden, Inheriting Shame: The Story of Eugenics and Racism in America (New York: Teacher's College Press, 1999), 76-78.

${ }^{12}$ Catalog, 1918-1919, 64.
} 
promoting the physical well being of the community." 13 From his first year, Davis linked eugenics and public health in the curriculum of his new department.

In the summer of 1921, the biology department offered "Genetics and Eugenics" to Virginia school teachers who came to William and Mary fo- the summer session. ${ }^{14}$ By 1923, Davis offered "Heredity" to regular students, promising "the principles of heredity, with special attention to the inheritance of human traits and the improvement of the inborn traits of the race." 15 While "Heredity" dropped from the curriculum in 1927, Davis added a course in advanced genetics. Finally, in 1934, the biology department began to offer "Biology and Human Affairs" to all students. "A broad cultural course, particularly intended for those not concentrating in Biology," the description began, "It deals with man's concepts of the universe, the origin of man; human races; the development of science and the scientific attitude; human population movements; man as a social animal; human heredity and capacities for training; eugenics." 16 This course remained in the curriculum until 1946, the year after the world learned of the Nazi eugenic atrocities. Professor Davis, still head of the biology department, approved the removal of eugenics from the course description.

For twenty-six years, Donald Davis taught or approved the teaching of eugenics at William and Mary. Davis's emphasis on eugenics stemmed directly from his own training. He attended Harvard for his undergraduate and graduate work. He took the A.B. degree in 1905 and the doctorate in 1913. In between, Davis worked under Samuel J. Holmes, one of America's pioneering eugenicists, as assistant in zoology at the University of California from 1905 to 1908. Upon returning to Harvard for graduate school in 1909, Davis worked under eugenicists William E. Castle and Edward M. East. Davis, like his classmate Orland

${ }^{13}$ Catalog, 1920-21, 106-107.

${ }^{14}$ Catalog, Announcement for the Summer Session, 1921, 25.

${ }^{15}$ Catalog, 1923-1924, 75.

${ }^{16}$ Catalog, 1934-35, 96. Dr. Raymond Leach Taylor (B.S., Cornell 1924; S.M., Harvard 1927; D.Sc. Harvard 1929) taught this course for the next decade. 
E. White, concentrated on botany under East. Holmes and East infused Davis with an enthusiasm for the eugenic uplift of humankind. Moreover, Davis studied genetics at Britain's John Innes Horticultural Institution in 1919, which brought him into close contact with the Mendelian eugenicists in England. Davis had also spent five summers at the Marine Biological Laboratory at Woods Hole, Massachusetts berween 1904 and 1909.17 Davis's training mirrored that which produced the University of Virginia eugenicists. These men, all socialized in eugenic ideology, came together in Virginia providing a scientific substrate for eugenic social policy.

Professor Davis immersed himself in Virginia's applied eugenics program immediately upon his appointment to William and Mary. In September of 1920, Governor Westmoreland Davis appointed Professor Davis to the "Governor's Advisory Board on Criminal Mental Hygiene" which performed a eugenic survey of the state's prison inmates. Davis served on this board with, among others, the Medical College of Virginia's Beverly R. Tucker and two of the state's pioneer's in eugenic sterilization, Dr. William Drewry and Dr. Joseph DeJarnette. In devising their method of examination and the form on which they would record their results, the committee followed Davis recommendation and used the ERO's "Individual Analysis Card" as a model. ${ }^{18}$ Two years later, Davis advocated a follow-up survey to Virginia's 1916 report Mental Defectives in Virginia. He applauded the state's efforts to gauge the incidence of "feeblemindedness" in the population. Davis also supported the law for the commitment of feebleminded individuals. He argued, however, that the state needed to enact a law banning marriage between the feebleminded. To enforce such a ban, he recommended circulating a "register" of names to all officials charged with issuing marriage licenses. They could then screen prospective applicants

\footnotetext{
${ }^{17}$ Davis's biographical information is published in the front of the Catalog, 1920-21, 9. He took the summer of 1906 to study at Columbia University.

18"War on Disease and ignorance in States's [sic] Prison," Richmond Times-Dispatch, September 8 , 1920,1 . See also the list of members and the draft forms (including a copy of the ERO form) in the "Criminal Mental Hygiene" folder, Box 2, Davis Papers.
} 
against this list, and deny the "unfit" the right to marry. Davis's attitude toward the feebleminded matched that of his friend and mentor on the subject, Henry Herbert Goddard. ${ }^{19}$

One.letter to Harry Laughlin and Lucien Howe, along with a single surviving paper, reveal the tenor of Davis's eugenic beliefs. Responding to a survey by Laughlin and Howe regarding the desirability of a law restricting the marriage of people deemed hereditarily blind, Davis expressed his eugenic beliefs. ${ }^{20}$ The law provided that people with hereditary blindness could not marry unless they posted a monetary bond against the possibility of procreating blind offspring. If this happened, the family forfeited the bond to the state, which would use it to help support the child once it reached maturity. Davis objected to the bond provision, because he was "fundamentally opposed to making the distinction between rich and poor which this would put in effect," and because the eugenic "disadvantage to the nation of...the blind strain among the rich is quite as dangerous as among the poor." Davis suggested "prohibition of the marriage of those having hereditary blindness" as a "more direct approach" to prevention. In this case, a bond levied against those who married in contravention of the law might, if geared to their class status, help to reduce hereditary blindness. Nevertheless, Davis said he "would not oppose such a law as [the one proposed] because of a possible educational value attached to it," despite his doubts about its efficacy. Such a law might help pave the way for eugenic intervention by educating people. "I believe that an awakening of the intelligent people of the community to the

\footnotetext{
${ }^{19}$ See Davis's manuscript "Mental Defectives in Virginia (n.d., but 1922 by internal references)," in "Mental Defectives in Virginia" folder, Box 4, Davis Papers. Davis was a close friend of Henry Herbert Goddard, the man who coined the term "moron" to describe the "highest grade" of feeblemindedness, those individuals who looked outwardly normal, but carried a severe mental defect thinly veiled. See Donald W. Davis to Henry Herbert Goddard, March 7, 1925 and Henry Herbert Goddard to Donald W. Davis, March 15, 1925, "Sex Education in College-American Eugenics Society" folder, Box 5, Davis Papers.

20 This survey and the law was sponsored by the Eugenics Committee of the United States, the precursor to the AES, and was drafted by Harry Laughlin and Dr. Lucien Howe. Howe gained fame for his pioneering use of silver nitrite eye-wash to prevent blindness in newborns (a similar treatment continues today). He was also an ardent eugenicist. See Barry Alan Mehler, "A History of the American Eugenics Society, 1921-1940," (Ph.D. diss., University of Illinois at Urbana-Champaign, 1988), 372.
} 
necessity for eugenic measures must come before," the passage of eugenic laws. Then, Davis argued, "when intelligent people know the facts I believe a more direct approach will be more effective." Absolute marriage restriction and sterilization offered more direct approaches that would have a significant eugenic effect, in Davis's view.

Davis's unlikely address, "Genetics and Orthodontia," is laden with the language of the eugenic metaphor. "We have only to notice the circumstances surrounding our herds of scrub cattle, our flocks of mongrel fowls, to realize how much is accomplished by even a little care in the selection of breeding individuals," Davis began, drawing the parallel between animal and human breeding. "Can anyone doubt what would be the effect of selecting for breeding purposes the weakest individuals, the most susceptible to disease, the most deformed, giving to them the great care necessary to keep them alive, the opportunity for mating and special care for their offspring? Can there be any doubt that the result would be strains of weak, disease susceptible, deformed incapables?"21 What human society needed, in Davis's view, was conscious direction of breeding-eugenics.

Shifting his emphasis explicitly to humankind, Davis acknowledged the phenomena "discovered" by Sir Francis Galton. "In any group of human beings, however homogeneous as to race," Davis asserted, "we find these characteristics 'running in families', i.e., having an hereditary basis." Davis then made the shift from a Galtonian, statistical notion of heredity to a Mendelian conception of particulate heredity govemed by clear rules. "In a few of these cases we know quite specifically the manner of inheritance of the trait in question, so that were we in the position of the animal or plant breeder, we could promptly eradicate the deficiency from the strain and develop a race with a certain special ability highly developed and, in general, establish a family that would more or less

${ }^{21}$ Donald W. Davis, "Genetics and Orthodontia," Dental Cosmos (September 1923), 3-4, "Papers by Davis" folder, Box 2, Davis Papers. 
constantly produce individuals bearing any known trait." 22 Eugenics made possible the permanent genetic improvement of humankind.

While Davis's view of the eugenic experiment embraced mainline notions of "fit" and "unfit" characteristics, and the ability to select the former and weed out the latter, he took a more moderate view regarding interracial crossing. "Not only do we find such variations as I have suggested in pure races," Davis remarked, "but in crosses between various human races we are finding new combinations, some of them desirable but the greater number from the social if not from the biological point of view highly undesirable." 23 Acknowledging the existence of "pure" races, a debatable contention that underpinned much of the mainline eugenic rationale, Davis admitted that racial crossing, per se, was not necessarily harmful. The social, not the biological, result of miscegenation was problematic. Nevertheless, he felt that the potential biological disharmonies warranted marriage and immigration restriction-particularly with regard to the feebleminded. Humanity, he felt, failed its responsibility to "excercis[e] intelligent selection." Invoking the language of the eugenic metaphor, Davis asserted that, "It has been shown by various studies, and is indicated by every-day experience that 'like tends to mate with like,' that the weak tend to mate with the weak and the strong with the strong." Thus the menace of the feebleminded was real and pressing, in Davis's opinion. America faced race suicide because, "there is much evidence that certain highly intelligent sections of our race show a far less tendency to mate than do the average or low. An even more important fact is that, in these highly intelligent groups, the number of offspring produced is smaller by far than among less intelligent groups....the lower grades, mentally as well as physically, are increasing at a greater rate than the higher." 24 The truths of biology and eugenics must be brought home to intelligent people.

\footnotetext{
22Ibid., 4.

${ }^{23}$ Ibid., 5.

${ }^{24}$ Ibid., 7.
} 
Davis believed dentists could assist physicians and sociai workers in spreading the gospel of eugenics. Dentists could spread "the knowledge of inheritance once clearly and definitely obtained" because the dentist "commonly deals with his patients when they are in more normal state of mind than does the physician who is usually called in during times of emotional strain and intellectual vacuity." 25 Whether or not Davis truly believed this contention, the significance of his effort to proselytize another group of health care professionals should not be neglected. Davis built on common assumptions-that dentists generally treated that segment of society intelligent and wealthy enough to care about dental hygiene, a crucial aspect in personal and social hygiene-in presenting his message to a group of influential professionals.

Davis remained active in Virginia eugenics throughout the 1920s. During the turmoil surrounding attempts to revise Virginia's eugenical Racial Integrity Act, a law that banned interracial marriage in Virginia. Davis sought to have the Virginia Academy of Science (VAS) present a symposium on eugenics. "The idea," Davis wrote George O. Ferguson of the University of Virginia, "is to have as many as possible of the science teachers from the high schools of the State present and to set forth the present status of genetics in its application to our racial problems in the state." 26 Davis wanted to get his version of the eugenics creed out to the teachers and high school students of Virginia. To that end, he answered the call to join the American Eugenics Society's "committee on education" for Virginia in 1927. "I shall be glad to serve as a member of the Virginia Eugenics

Committee," Davis wrote to AES President Roswell Johnson, "I am much interested in this work and shall be very glad to do all I can to forward it." 27 Both his involvement with the VAS and the AES brought Davis into close contact with the eugenicists at the University of

$25_{\text {Ibid., } 8 .}$

${ }^{26}$ Donald W. Davis to George O. Ferguson, March 6, 1925, "Sex Education in College-American Eugenics Society" folder, Box 5, Davis Papers. This incident is discussed in Chapter 6.

${ }^{27}$ Donald W. Davis to Rosewell H. Johnson, July 8, 1927, "Davis, Donald W." folder, American Eugenics Society Papers, American Philosophical Society Library, Philadelphia. 
Virginia. ${ }^{28}$ This web of association bonded together Virginia's academic eugenicists; it also, however, managed to squelch Davis's effort to introduce the public to more raciallymoderate, scientifically sophisticated eugenics.

Davis was not the only member of the William and Mary faculty teaching hereditarian ideas. George Oscar Ferguson had taught genetic psychology as early as 1907.29 Although sociology was not organized as its own department until 1931, Professor Daniel James Blocker clearly taught the courses pertaining to sociology from a hereditarian standpoint. Blocker had trained at the University of Chicago before Robert Park effected the shift toward environmentalism. ${ }^{30}$ Blocker's course "Social Problems" emphasized the "study of the biological, psychological, and sociological aspects of the population problem." Not only did the course exam Malthus's famous population theory, but, "Special emphasis will be given to race pride and prejudice, international population movements, inequality of wealth and knowledge, and the factors affecting social adjustments."31 Blocker's course on "Crime and Social Responsibility" gave "special emphasis" to "The hereditary, mental, economic, and social aspects of crime." His course on "Race Relations" focused on "theories of race origins, race differences and race distinctions." 32 Blocker did not begin to move away from the hereditarian standpoint until after 1936.

During the decade between 1936 and 1946, it seems likely that the tenor of the eugenical teaching at William and Mary shifted toward a more moderate strain. Eugenics remained in the course description for "Biology and Human Affairs," but it was only one topic among many addressed by the class. Surely the genetics course also touched

\footnotetext{
${ }^{28}$ Davis became very close to Ivey Foreman Lewis, the more so because he sat on the board of scientific directors for the University of Virginia's Mountain Lake Biological Station.

${ }^{29}$ Catalog, 1907-08, 23.

${ }^{30}$ Blocker took his bachelor's and mater's degrees from Chicago in 1909 and 1911, subsequently taking divinity degrees at Stetson University.

31 Catalog, 1929-30, 158.

${ }^{32}$ Catalog, 1931-32, 146-47.
} 
incidentally on eugenics, too. By 1946, when two of Orland Emile White's students joined the faculty, the mainline position —at least regarding race-probably underwent significant modifications. White's students represented the next generation of geneticists, educated after the most prominent geneticists began to distance themselves from the mainline camp. They were not likely to have espoused mainline racial doctrine, but they probably still supported the sterilization of mental and physical "defectives" whose maladies were known to be genetic. ${ }^{33}$ Similarly, Davis corresponded with the Human Betterment Foundation of California - a mainline eugenics organization headed by E. S. Gosney-as late as $1938 .{ }^{34}$ The eugenic ideal at William and Mary, as elsewhere, died a lingering death.

\section{The Medical College of Virginia}

The Medical College of Virginia (MCV), the state's "other" medical school, also taught eugenics, albeit much less aggressively than at the University of Virginia Medical School. Led by President William Thomas Sanger, the faculty at MCV tended toward a more environmentalist approach to medical education. While Sanger and others cultivated an active interest in eugenics, on the whole the teachings of the institution concentrated on nuts and bolts doctoring.

Responding to Laughlin's 1920 questionnaire, President Stuart McGuire noted, "This College gives no course in eugenics except incidentally in medicine and nervous and mental diseases and social service." At the time, MCV had "No definite plans" to provide instruction in eugenics in the future. President McGuire, son of the famed Dr. Hunter McGuire, suffered under a triple burden. He was chief of surgery and chief administrator for St. Luke's Hospital, the institution founded by his father. Simultaneously, he attempted to carry on a busy private surgical practice, and perform his duties as president of

\footnotetext{
${ }^{33}$ White's two students were James T. Baldwin and Bernice M. Speece.

${ }^{34}$ See E. S. Gosney to Donald W. Davis, November 9, 1938, "Sex Education in College-American Eugenics Society" folder, Box 5, Davis Papers.
} 
MCV. By 1920 he had been advocating the hiring of a full-time president for MCV. Five years later, McGuire achieved his wish. The Medical College of Virginia hired its first fulltime president, Dr. William Thomas Sanger. With Sanger's ascendance, MCV gained both a leader and another course - applied psychology — in which eugenics would be treated in a more than incidental fashion. ${ }^{35}$

Dr. Sanger spent a good deal of his life bouncing between his birthplace-Bridgewater, Virginia-and other towns. Somehow, his native state always called him home. Sanger's early education took place in Virginia; his family moved, and he took his high school diploma in South Bend, Indiana. Sanger returned to the Virginia Piedmont to attend Bridgewater College, where he eamed his bachelor's degree in 1906. He then moved to Indiana and took a master's degree in psychology from the University of Indiana in the spring of 1910. The following fall found Sanger back at Bridgewater College, where he taught a variety of subjects-English Writing, History, Philosophy, Greek Psychologyuntil 1920.

Sanger's quest for the doctor's degree brought him into contact with eugenical thinking. In the summer of 1911 he worked at Teachers College, Columbia University in psychology and physiology. At Columbia Sanger worked with Edward Lee Thorndike, like his contemporary William Henry Heck. Sanger did not stay with Thomdike, however. Instead he enrolled in Clark University, in 1912, to work under the equally eminent Dr. Granville Stanley Hall.36 Sanger decided to work on "senescence," what we would

\footnotetext{
${ }^{35}$ Sanger began offering "Applied Psychology" in 1926. Medical College of Virginia, Bulletin of the Medical College of Virginia 23 (1926), 38. All of the information that follows was taken from documents scattered throughout the William Thomas Sanger Papers at the Medical College of Virginia, Special Collections Archives, Tompkins-McCaw Library, Virginia Commonwealth University. [Hereinafter referred to as Sanger Papers]. For the relationship between Sanger and McGuire, see "Dr. William T. Sanger (obituary)," Richmond Times-Dispatch, April 22, 1975, Box 18; the MCV student newspaper, Skull and Bones, March 28, 1925, "Skull and Bones" folder, Box 19, Sanger Papers.

${ }^{36}$ Thomas Gossett remarks of Hall that, "Sterilization and segregation of the unfit were the only reform measures about which he could feel any degree of enthusiasm." Thomas Gossett, Race: The History of an Idea in America, 2d. ed., (New York and London: Oxford University Press, 1997), 169-170. For Hall's views on eugenics see, G. Stanley Hall, "Eugenics: Its Ideals and What It Is Going Tc Do," Religious Education 6 (June 1911): 152-9. One of the founders of psychology and sociology' in America,
} 
recognize today as the study of gerontology or growing old, with Hall. At the time, senescence captivated eugenicists like Hall, Alexander Graham Bell, and Vernon Kellogg, all of whom hoped to find in human heredity the secrets to eternal youth, or at least extended longevity. Sanger's choice of topic ingratiated him to Hall, and their correspondence reveals the deep warmth and friendship of their relationship. Sanger's work bears the imprint of Hall's hereditarian, racial, and eugenic beliefs.

Hereditarian ideas were not new to Sanger. Lecture notes and a term paper Sanger wrote in 1910 show that he was already well-aware of Mendelian heredity and eugenics by that time. ${ }^{37}$ In his notes, Sanger remarked on the power of heredity in families, invoking the eugenic metaphor. "Biologically considered, family traits are always repeated. The specific characteristics of different families are inherited and transmitted, the exact characteristics can not always be determined until late development." That same day, he noted the "law of biogenesis," the conventional wisdom that "An animal in development repeats the history of the race," also known by the axiom "Ontogeny recapitulates phylogeny," the dicta of recapitulation in evolution. A decade after Paul Barringer had advocated Ernst Haeckle's formulation, Sanger was memorizing this "short, crisp axiom" that Barringer and others used to prove the inferiority of blacks. ${ }^{38}$ Sanger also noted that, "Specific, general characteristics are always transmissible; racial characteristics are the same in man. Types, Teutonic, Italian, etc. are also transmissible. General tallness and shortness, ugliness and beauty may be transmissible." 39 Sanger clearly learned the hereditarian tendency to conflate nationality and race, genetics and culture. Sanger also leamed to associate complex phenomena with simple Mendelian relationships. "Application of Mendelian inheritance to man: Members marrying in which abnormal

Hall had passed the apex of his career but was still an enormous influential in the world of science. Hall drew his ideas about race, in part, from his study of Paul Barringer's writings. See Chapter 1 note 170. 37 "Heredity Notes," April 28, 1910, "Heredity" folder, Box 1, Sanger Papers.

${ }^{38}$ For a brief discussion of recapitulation
39 "Heredity Notes," May 10, 1910, Ibid. 
character is recessive, offspring $=1$ normal, 2 tainted, 1 abnormal; if characteristic is dominant all offspring are abnormal."40 A product of his time, Sanger carried these ideals into his dissertation and his educational life after Clark.

Financial necessity drove Sanger back to Virginia during the school sessions of 1913 and 1914, when he taught at Harrisonburg State Teachers College. Taking his doctorate in 1915, Sanger returned to Harrisonburg, ascending to the chairmanship of the department in 1917. During this time, Sanger undoubtedly met William Henry Heck; between 1917 and 1919 Sanger assisted in the Heck-inspired and directed inspection of Virginia High Schools. ${ }^{41}$ In the summers after Heck's death, Sanger taught at the University of Virginia with Heck's successor, the eugenically-minded psychometrician George Oscar Ferguson. Sanger relocated to Richmond in time for Virginia's peak eugenics lobbying effort. He served as the first full-time executive secretary of the Virginia State Teachers' Association, between 1921 and 1925, editing the Virginia Journal of Education and publishing articles on Ivey Lewis's eugenical views and Walter Plecker's views regarding the Racial Integrity Act. 42

For all his apparent eugenic orthodoxy, however, a number of factors exist that imply a more moderate stance on Sanger's part. First, he himself suffered from terrible eyesight. While he may have wanted to improve the chances of others not having his difficulty, he clearly knew that such a "hereditary" condition did not necessarily prevent success in life.

40"Heredity Notes," May 31, 1910, Ibid. Like Charles Benedict Davenport, Sanger also noted that, "Certain transmissible characteristics tend to hang together - Red hair and violent temper and freckles; Boldness and defective teeth." See "Heredity Notes," May 17, 1910, Ibid. Sanger leamed to dismiss Galton's notion of "blended inheritance," too. See his notes for May 24, 1910, "Galton studied hounds, sweet peas etc., and decided that the of fspring resembles the parents and grandparent and so on back. For him each parent furmished $1 / 4$, each granparent $1 / 16$, and each great grand parent $1 / 64$, and so on back. Galton's law is applicable to blended inheritance. By selecting ancestry this law can be invalidated. Pearson has revised this law."

${ }^{41}$ See clipping from Virginia Journal of Education , June 14, 1921, in "Virginia Journal of Education" folder, Box 20, Sanger Papers.

42 "Environment Cannot Mold Something Out of Nothing, Says Biologist," Virginia Journal of Education 18 (1924), 163-64; and Walter E. Plecker, "Birth Registration and Racial Integrity Law," Virginia Journal of Education 18 (1924), 13. "Teacheres are invited to write us," Plecker enticed, "for literature on this subject, and for our 'New Family' series of booklcts for use in teaching food values and race improvement." 
In a related vein, Sanger became a prominent advocate for the rights of "crippled" children. Mainline eugenicists like Davenport felt that children with sever physical defects ought to be prevented from procreating, and treated with the minimum medical therapy. ${ }^{43}$

Similarly, Sanger presided over an institution that, while operating separate, segregated hospitals and educational facilities, still cared for blacks and trained African American nurses. Sanger appears not to have fully indulged in the racial extremism of his mentor G. Stanley Hall. 44

\section{Harrisonburg State Normal School}

Sanger taught eugenics to a rising generation of Virginia's teachers while he was at Harrisonburg State Teachers College. Harrisonburg—now known as James Madison University-continued to employ instructors who taught eugenics to other generations of Virginia teachers. Perhaps the best known of these was George W. Chappelear.

Chappelear taught genetics and eugenics to students at Harrisonburg-Madison for over a decade. During the summers of 1935 to 1939 he taught eugenics through the University of Virginia's summer school, largely to Virginia high school teachers. Chappelear found that problems in eugenics captivated his students. He became so interested in teaching the subject that in 1939 he wrote directly to the now-retired Charles Benedict Davenport. "Is there any text or material available that gives a summary of the inheritance of human traits?" Chappelear asked. He wanted a good text for undergraduates without "so much contradiction and too much emphasis on the abnormal characteristics." 45 Chappelear, for

\footnotetext{
${ }^{43} \mathrm{Dr}$. Harry Haiselden went so far as to euthanize children with severe, but in some cases correctable, birth defects. See Martin S. Pernick, The Black Stork: Eugenics and the Death of 'Defective' Babies in American Medicine and Motion Pictures Since 1915 (New York and Oxford: Oxford University Press, 1996).

${ }^{44}$ Sanger was so beloved that the MCV board of directors created the position of chancellor for him, so that he could remain active in affairs of the school until his death in 1975 at age 89.

${ }^{45}$ George W. Chappelear to Charles Benedict Davenport, July 10, 1939, "Miscellaneous Questions 1939" folder, Charles Benedict Davenport Papers, American Philosophical Society Library, Philadelphia.
} 
all his experience as a teacher of teachers, was not a trained scientist, and so he approached eugenics largely from the standpoint of an interested lay person.

Despite teaching eugenics, Chappalear maintained a fairly tenuous connection to the eugenics community. Apparently unaware of the general drift away from the study of human genetics in America during the thirties, Chappalear did not even know about Davenport's retirement. Nevertheless, he complained that, "After the years that have been spent in this field [human heredity], there ought to be something that at least approaches the definite" for use in a textbook. His need was pressing, and revealed much about the appeal of eugenics among Virginia college students. "We have hundreds of students each year that are interested primarily in human inheritance and Drosophila [the fruit fly, the preferred organism for genetic study in the 1930s], while a means to an end, leaves them cold."46 Davenport recommended one of the standard college textbooks on genetics, H. E. Walter's Genetics, but also pointed Chappelear toward Erwin Baur, Eugen Fischer, and Friz Lenz's Human Heredity. This second work, an intensive two-volume tome for specialists, is one of the classics of modern genetics. ${ }^{47}$ It covered everything from evolution to heredity to eugenics in great detail. It also became the handbook of the Nazi eugenics program. Whether or not Chappelear took Davenport's advice is unknown. But he, like men elsewhere in the state, continued to teach eugenics, notwithstanding an imperfect understanding of human heredity and the current debates wracking the field.

\section{Life After Lewis: Eugenics at Randolph Macon}

Ivey Foreman Lewis began his career, as discussed in the last chapter, at Randolph Macon College. While it is unclear whether or not he taught eugenics to students there, it is evident that eugenics found one of its most congenial homes at this small college about

\footnotetext{
${ }^{46}$ Ibid.

${ }^{47}$ Charles Benedict Davenport to George W. Chappehar [Davenport could not decipher Chappalear's signature], Ju!y 12, 1939, Ibid.
} 
fifteen miles North of Richmond. A system of small colleges and feeder schools, Randolph Macon ran two boys high schools in Front Royal and Bedford City, as well as a woman's college in Lynchburg and a female institute in Danville. With this wide spread, Randolph Macon actually commanded a good deal of prominence in Virginia. The college modemized its curriculum from the traditional classical program around the tum of the century. By 1904 Randolph Macon offered a fairly diversified biology program; in 1905 the standard text was Alfred Lord Wallace's classic Darwinism. Ivey Lewis joined the faculty in 1908, and he may have taught some eugenics through his course "Hygiene and Sanitation."48 In 1920, President Robert E. Blackwell reported to Harry Hamilton Laughlin that the college offered no courses in eugenics. ${ }^{49}$ This situation would change five years later, with the hiring of Dr. Walter Edward Bullington.

Charles Benedict Davenport recommended Bullington to President Blackwell in August of 1925, in an interchange that highlighted the effect of the Scopes controversy and the history of eugenics at Randolph Macon. Writing in the immediate aftermath of the Scopes controversy, Blackwell attempted to reassure Davenport that fundamentalism did not guide curricular policy, despite the college's Methodist affiliation. Blackwell stated that, "our biologists have had full liberty to teach what they wanted to teach."50 Davenport recalled his. "five or six years" association with Bullington and wrote that, "He is a persistent, industrious investigator" who had "published valuable findings" about protozoa. Invoking his Yankee condescension, Davenport noted that Bullington was a southemer from Tennessee who, "seemed a little crude when I first saw him, but has shown great improvement through the years." Since Bullington had broad training and interests, Davenport felt that he could "develop your Department of Biology in a well rounded

\footnotetext{
${ }^{48}$ For a discussion of this course, see Chapter 3.

${ }^{49}$ Randoph-Macon College questionnaire in "Eugenics Instruction Questionnaires, R-Univ. of Ma (1920)" folder, Box 1, ERO Papers.

${ }^{50}$ Robert E. Blackwell to Charles Benedict Davenport, August 25, 1925, "Bullington, W. E." folder, Davenport Papers.
} 
fashion." Davenport continued his condescension, expressing surprise at Blackwell's mention of academic freedom. "Naturally you would not select a professor of biology who wanted to teach anything but what he regarded as the truth." 51 Blackwell, whose personal investment in maintaining southern institutions had prompted him to recommend Ivey Lewis to President Alderman, replied heatedly to Davenport-revealing a bit more of Randolph Macon's eugenical past. "As to my phrase that you were struck by," Blackwell seethed, "I wanted you to know that if a Professor of Biology wants to have in his course, as [Bullington's predecessor] did, such a book as Newman's Evolution, Eugenics, and Genetics, he can do so. I imagine he could not have done so at the University of Tennessee; though even there, I suppose the professors teach only 'what they regard as the truth."'52 Eugenics, it would seem, had indeed appeared at Randolph Macon before Bullington's arrival.

Bullington's interest in eugenics began in graduate school and continued at Randolph Macon. Bullington began his graduate work at the University of Tennessee; his advisor was so impressed by Bullington's work that he brought the young man with him when he took a job at the University of Kansas. Subsequent to this move, the University of Kansas awarded Bullington his doctorate in 1925. For the four summers preceding his degree, Bullington worked at the Long Island Marine Biological Laboratory in Cold Spring Harbor, Long Island. Working under the supervision of the laboratory's director Charles Davenport, and partaking in the collegial atmosphere between the LIBL, ERO and SEE, Bullington no doubt received intensive introduction to Davenport and Harry Hamilton Laughlin's brand of mainline eugenics.

${ }^{51}$ Charles Benedict Davenport to Robert E. Blackwell, August 25, 1925, Ibid.

${ }^{52}$ Robert E. Blackwell to Charles Benedict Davenport, August 28, 1925, Ibid. A chastened Davenport replied to this letter with a note, "I might have stated in my letter to you that Mrs. Bullington is a very notable person and will be an addition to a small college community." Charles Benedict Davenport to Robert E. Blackwell, September 3, 1925, Ibid. 
Bullington probably offered eugenics at Randolph Macon in his first term at the college. That year, 1925-1926, Bullington taught "Biology III: Evolution and Genetics" to the undergraduates at Randolph Macon. This course covered the "laws governing origin, growth, and development of species."53 Three years later, the course description changed to, "Two Lectures and two hours laboratory a week. Evolution the first term and Eugenics the second and third terms," reflecting a major shift in emphasis toward eugenics. ${ }^{54}$ The next year again saw a change in the course title and description to, "Evolution, Genetics, and Eugenics: A study of the probable origin and evolution of plant and animal life, principles of plant and animal breeding, and the application of these principles to man." 55 The course would maintain this designation for the next decade.

In 1939, the same year George Chappalear complained to Davenport about his inability to arouse student interest in fruit fly heredity, Bullington changed the description of his course and added the study of Drosophila. "Biology 31 -Genetics" offered students "A general study of the laws of inheritance, of variation, of the principles of plant and animal breeding, and a study of the possibility of the application of these principles to man." Using Drosophila to acquaint students with Mendelian heredity, Bullington continued to teach about the eugenic improvement of human beings. The course retained this designation for the next thirty-one years, long after Bullington retired. In 1976 the course description finally added an explicit reference to "population genetics" the study of genetics in large groups of people, the so-called "New Eugenics" of the post-World War II era. ${ }^{56}$

While Bullington taught eugenics in Ashville, Randolph Macon Woman's College in Lynchburg also developed hereditarian courses. Given the interest among women in the

${ }^{53}$ Randolph Macon College, The Catalog of Randolph Macon College (Ashland, VA: 1925), 47, Special Collections, McGraw Library, Randolph Macon College, Ashland. [Hereinafter referred to as Randolph Macon Catalog, date.]

${ }^{54}$ Randolph Macon Catalog (1928), 53.

55 Randolph Macon Catalog (1929), 53.

${ }^{56}$ Daniel J. Kevles appropriately includes population genetics under his rubric "New Eugenics" in, Daniel J. Kevles, In the Name of Eugenics: Genetics and the Uses of Human Heredity (New York: Alfred A. Knopf, 1985), 251. 
emerging field of sociology, and sociology's early hereditarian leanings, eugenics first entered the women's curriculum through the sociology department. By 1905 students taking sociology were making field houses to study prisons, alms houses, and other charitable institutions first hand. After 1912, the nearby Lynchburg Colony for the Epileptic and Feebleminded, an epicenter of eugenical thought and activity, undoubtedly became a stop for these classes. ${ }^{57}$ The year before the Lynchburg Colony opened, women taking "General Biology" leamed about "development and differentiation, genetic relations and adaptations." 58 In 1920, the department also offered a course in "The History of Biology and the problems of today," that could not possibly have avoided discussions of eugenics. Beginning in 1930, women could take "Taxonomy and Genetics" which in 1934 became "Genetics" and covered "some of the most important biological problems, such as: Biogenesis, Evolution, Genetics and Eugenics." Four years later, the course changed to "Genetics and Eugenics" and discussed "the possible improvement of the human race."59 Taught by Lorus Jchnson Milne, who eamed his doctorate from Harvard in 1936, this final course seemed to acknowledge the limitations of eugenic theory. By 1944 the course dropped any reference to human heredity at all. 60

Students training to become teachers at Randolph Macon Woman's College also encountered hereditarian ideas, and very likely eugenics. In 1916, mental testing entered the education curriculum, using Edward L. Thorndike's Educational Psychology as the textbook. The course emphasized "the value of such tests in ordinary education, and the extent to which they may be safely employed by teachers will be matters for general discussion."61 The course in "Genetic Psychology," instituted in 1918, treated "the facts

${ }^{57}$ Lynchburg's prominent role as the founding institution for Virginia's eugenic sterilization law is discussed in detail in Chapter 5.

${ }^{58}$ Randolph Macon Calalog (1911), 65.

${ }^{59}$ Randolph Macon Catalog (1930), 64; Randolph Macon Catalog (1934), 50; and Randolph Macon Catalog (1938), 48.

60 Randolph Macon Catalog (1944), 49.

${ }^{61}$ Randolph Macon Calalog (1916), 71. 
of structure and behavior in the race and in the individual with special stress on the mental development of the child" by discussing "[t]he laws of heredity, the origin and development of instincts, the conditions governing habit formation, and kindred topics."62 These young women, schooled in the psychometric tradition of E. L. Thomdike, entered the Virginia public schools in time to begin diagnosing students as feebleminded and referring them for commitment and sterilization. Only the inability of the Lynchburg Colony to handle greater numbers of "feebleminded," and the necessary delays caused by following the statutory procedures for commitment and sterilization, prevented Virginia from sterilizing many more young people.

$$
* \quad * \quad * \quad *
$$

\section{The University of Richmond: Baptist Eugenics}

Approached by the American Eugenics Society in 1927, President F. W. Boatwright of the University of Richmond declined to join the society. President Boatwright, a scholar of French and German language and literature, may not have seen the relevance of the AES to his career or institution. While he did not subscribe membership in the organization, the members of his biology faculty would take up the creed and pursue it for just over forty years. ${ }^{63}$

The University of Richmond's Baptist affiliation delayed the advent of eugenics in its curriculum. The school, known as the College of Richmond, only began offering biology in 1904. The rise of religious fundamentalism, with its Baptist ties, combined with the institutions entrenched traditionalism to retard the development of the biology curriculum. Hereditarian ideas appear to have entered the curriculum through courses in sociology and education. ${ }^{64}$

62 Randolph Macon Catalog (1918), 76. This course, and its description, is listed in Charles Davenport's survey of "Eugenics and Genetics in the Colleges, \#5" folder, Davenport Papers.

${ }^{63}$ President F. W. Boatwright to Chairman, November 26, 1927, "1927 Membership Campaign" folder, American Eugenics Society Papers, American Philosophical Society Library, Philadelphia.

${ }^{64}$ The college grew out of the Virginia Baptist Seminary, founded in 1832. The institution became Richmond College in 1840. See "Historical Sketch" in College of Richmond, Richmond College 
Richmond's psychology and sociology departments followed the pattern established at most American universities: they developed out of the offerings in philosophy. Unlike larger institutions, however, at Richmond one man would be responsible for teaching in all three areas. Daniel Bunyan Bryan worked under Edward Lee Thorndike at Columbia, eaming a master's degree in 1914. The following year, New York University awarded Bryan his doctorate. Bryan's course in sociology at the University of Richmond entailed the study of the defective, delinquent, and dependent classes-what eugenicists called the "3 d's" by 1916.65 The course emphasized the "study of poverty, its causes and cure...the criminal, the defective, and dependent classes; causes and character of crime and the criminal."66 Beginning in 1917, Bryan also began offering a course in "Educational Psychology." Designed for prospective teachers, this course covered "a genetic study of the evolution of animal mind compared with the development of child intelligence psychology," as well as mental testing and the administration of tests "practically applied in school room observation. ${ }^{67}$ Given his own training and the state-of-the art in 1917 , Bryan's courses certainly emphasized the hereditarian notions of intelligence that swept the nation during the Progressive Era. No doubt Bryan knew the University of Virginia's educational authority, William Henry Heck. Each man buttressed his institution's "scientific" training of teachers by introducing the new technologies and theories about feeblemindedness and its consequences. When Bryan left Richmond in 1920, his place was taken by Robert Collins Astrop. The University of Virginia awarded Astrop his master's degree. Astrop then studied at Columbia under Thorndike. ${ }^{68}$ Astrop continued

Catalogue, (Richmonc': Whittet and Shepperson, Printers, 1916), 5-7, University Archives, Virginia Baptist Historical Society, Boatwright Memorial Library, University of Richinond, Richmond. [Hereinafter referred to as Bulletin (date), page number.]

65.Nancy L. Gailagher, Breeding Better Vermonters: The Vermont Eugenics Project, (Hanover, NH: University Press of New England, 1999), 37.

${ }^{66}$ Catalogue (1916), 56. Bryan would also teach philosophy at various umes in his career.

${ }^{67}$ Bulletin (1917), 57. 
Bryan's tradition at Richmond for the next 26 years, retiring in June 1946. The biologically-influenced notion of "genetic psychology" taught to students of education, psychology, and sociology would be joined by courses in the biology department that led directly to eugenics.

Maintaining the classical curriculum until the 1910s, Richmond's offerings in biology remained scant until the 1910s. The first general biology course entered the curriculum in 1904, under the direction of Dr. C. M. Baggarly, whose medical training fit him to teach introductory biology. 69 Baggarly taught the course alone until 1912, when James M. D. Olmstead, a graduate of Middlebury and Oxford, took over the department. Omstead offered specialized courses in zoology and botany. ${ }^{70}$ Course descriptions fail to mention heredity until 1920, when "General Biological Problems" first appeared as, "A lecture and conference course, dealing with the problems ard theories of ontogeny, phylogeny, heredity, etc."11 According to Laughlin's 1920 questionnaire, Westhampton CollegeRichmond's coordinate woman's institution-Dr. Margaret Kuyk covered eugenics briefly in her course on physiology and hygiene. ${ }^{72}$ The year after the fundamentalists published their Fundamentals, Virginia's Baptist college and its coordinate woman's school began to teach hereditarian biology.

Fundamentalism and the Scopes trial appeared to have little or no affect on Richmond's biology department. Throughout the 1920s, the department continued to offer General

\footnotetext{
${ }^{68}$ Tracking Astrop's entry at the front of the Catalogue indicates that he became a "perepetual graduate student" who never took the doctorate. He studied at Columbia for portions of 1914, 1915, and 1923, as well as all of the 1926-27 school year.

${ }^{69}$ Bulletin (1904), 53.

${ }^{70}$ Bulletin (1912), 53.

${ }^{71}$ Bulletin (1920), 35. The instructor, Horace Edwin Hayden, graduated from Princeton in 1905 and took a master's degree from the University of Virginia in 1907, and graduated in Biology in 1910 from Virginia. He had also been an Instructor at Texas A\&M, NYU, and William and Mary before coming to Richmond in 1919. (16) Hayden returned to the University of Virginia in 1929 to pursue a doctorate in Biology. While there, in 1930, Harvey Ernest Jordan nominated him for membership in the American Eugenics Society, indicating Hayden's interest in the subject. "1930 A-Z by State $\# 2$ " folder, AES Papers.

${ }^{72}$ Westhampton College questionnaire in "Eugenics Instruction Questionnaires Univ. of Mi-Y (1920)" folder, Box 1, ERO Collection.
} 
Biological Problems and its evolutionary ideas. The department expanded its hereditarian curriculum, beginning a dedicated genetics course in 1927-the year Justice Oliver Wendell Holmes declared Virginia's eugenic sterilization statute constitutional. Genetics covered "the study of heredity" and emphasized "the Mendelian Theory of inheritance."73 Two years later, genetics blossomed into "Genetics and Eugenics," which addressed, "The reproduction of animals and plants; the origin of new races; the influence of heredity and environment; applications to animal breeding and human society. "74

Taught by two Harvard-educated Mississippians, Professor John Wendell Bailey and Associate Professor Robert Forte Smart, the course most likely approached eugenics from a fairly mainline stance. Both Bailey and Smart completed their graduate training under Edward M. East and William E. Castle. ${ }^{75}$ East's eugenic and racial views no doubt comported well with these men's Mississippi background. Eugenics remained in Richmond's curriculum until 1970, when it was finally listed as, "Biology 314, Genetics and Eugenics: The fundamental laws of heredity as they apply to both plants and animals and to the betterment of human society." The following year the course guide had changed the listing to, "Biology 314, Genetics: The fundamental processes of biological continuity operating in cells organisms, and populations." 76 While nothing remains to indicate the tenor of this course, it would seem safe to assume, judging from the change in the course description, that the discussion of eugenics had shifted to population genetics. By 1970 the biology faculty had expanded, including many younger men who might well have questioned the racial precepts of mainline eugenics.

The teaching of eugenics at the University of Richmond underscores the science's status as a bona fide subject for study. The presence of eugenics in the University of

73 Bulletin (1927), 43.

${ }^{74}$ Bulletin (1930), 48.

75 Bulletin (1930), 8-9. Smart held a Harvard master's until 1935, when he completed a dissertation on slime mold under East. The faculty lists in the Catalogue indicate the Bailey and Smart received undergraduate degrees from the University of Mississippi.

${ }^{76}$ Catalogue (1971), 80. Smart was still teaching at the college and serving as its provost. 
Richmond's curriculum also reveals that the school maintained a strong sense of academic freedom. Biology professors could teach evolutionary and hereditarian topics without fear of fundamentalist reprisals. The ability of eugenics and evolution to be cast in "liberal theistic" terms, which harmonized with Protestant teaching, also aided its survival. Nevertheless, eugenics did not appear until 1929, late in the discipline's "natural history" as judged by Mark Haller and other historians. ${ }^{77}$ This late entry, a year before Haller and others begin to argue for the demise of eugenics and the rise of reform eugenics, underscores how powerful eugenics remained as a scientific concept. This is particularly true for men like Bailey and Smalls, who were in touch not only with their mentor at Harvard, but also Orland White and Ivey Lewis at the University of Virginia. ${ }^{78}$ The professional climate in Virginia encouraged the persistence of eugenics, especially for those scientists who learned it at top-flight institutions, but then went on to careers dominated by teaching rather than active research. The probable consonance between eugenics and the racial views of Professors Bailey and Smart, as well as their students at the University of Richmond, kept eugenics vital at the University of Richmond for 40 years.

\section{Washington and Lee University}

Professor William Dana Hoyt taught eugenics at Washington and Lee University from 1920 until he died in 1945. In response to the Laughlin survey, Professor Hoyt noted that he covered eugenics in his course, "Theories of Biology." Hoyt replied, "After consideration of heredity and evolution, with the factors and mechanism, its application to human welfare is studied as an integral part of the course."79 Hoyt sent Laughlin a copy of

\footnotetext{
${ }^{77}$ Mark Haller, Eugenics: Hereditarian Attitudes in American Thought (New Brunswick, NJ: Rutgers University Press, 1963). See my discussion of periodization in the Introduction.

${ }^{78}$ Documents in Smart's biographical folder at the University of Richmond indicate that he taught at the Mountain Lake Biological Station. He would have become very familiar with Ivey Lewis and his views during these summer sojourns.

${ }^{79}$ Washington and Lee University Questionnaire, March 28, 1920, in "Eugenics Instruction Questionnaires Univ. Mi-Y (1920)" folder, Box 1, ERO Collection.
} 
Washington and Lee's course description pamphlet, "Biology at Washington and Lee," which described the course as "an advanced general course, open to graduates as well as undergraduates, treating of variation, heredity, the mechanism of inheritance, eugenics (the principles of inheritance as applied to man), the relationships of different groups of animals and plants, the determination of sex, and related subjects." 80 Rather than laboratory work, students were expected to do copious amounts of related reading, much like Ivey Lewis's Biology $\mathrm{Cl}$ course.

The tenor of Professor Hoyt's course can be fairly surmised from his training and professional affiliations. The parallels between Hoyt and Ivey Lewis's careers are striking, and they go a long way toward substantiating the similarity of the men's viewpoints. Hoyt, like Ivey Lewis, took his doctorate at Johns Hopkins, graduating two years after Lewis, in 1910. Hoyt also studied in Europe; at the University of Heidelburg, and a subsequent research stint in Naples at the Stazione Zoologica. From 1912 to 1915, Hoyt worked as a Fellow at Johns Hopkins, before answering the call to. Washington and Lee in the fall of 1915-the same year Lewis returned to Virginia. Despite being a botanist who worked on algae Hoyt, like Lewis, maintained an avid interest in eugenics. His biographical entry in Who Was Who in America lists Hoyt as a member of all the same organizations as Ivey Lewis: he was an instructor in botany at Woods Hole, a Fellow of the American Association for the Advancement of Science, a member of the Botanical Society of America, the American Genetic Association, the American Eugenics Society, the American Society of Naturalists, and the Virginia Academy of Science. ${ }^{81}$ Unlike Lewis, Hoyt also carried membership in the Association for Research in Human Heredity. Nevertheless, Hoyt taught mainline eugenics that was congruent with what was being

80"Biology at Washington and Lee," in Ibid.

${ }^{81}$ See "Hoyt, William Dana," Who Was Who in America, 1943-1950, vol. 2, (Chicago: Marquis Who's Who, Inc., 1975), 267. Ironically, Hoyt lived at 5 Lewis Sureet in Lexington. 
taught at the University of Virginia and most of the state's other institutions of higher education.

Professor Hoyt maintained formal ties with the eugenics movement and the AES. In 1921, he answered Laughlin and Howe's survey regarding a eugenics law aimed at preventing the procreation of hereditarily blind children. Hoyt's response reveals much about his view of theoretical and practical eugenics. "While strongly endorsing the principle," of preventing hereditary blindness, Hoyt remained unsure "that the prevention of legal marriage is the proper means of accomplishing the desired end." From a moral standpoint, Hoyt feared "that measures of this kind would tend to increase illegitimate intercourse, especially among the feebly inhibited [feebleminded] whom we would most desire to reach." Instead of a marriage restriction law, Hoyt advocated obtaining the eugenic goal through education and birth control for those at risk. "It seems to me that the ends could be more surely gained by allowing marriage and by teaching the dangers to which the off-spring would be subject with methods for preventing off-spring." Hoyt, who referred to "the repeal of the present foolish law prohibiting the means of limiting offspring," clearly favored birth control as a potentially eugenic measure. Finally, using prohibition as an example, Hoyt argued that "private acts cannot be controlled by law," which was "especially true in cases involving sexual passion." Economic concerns underpinned all of Hoyt's eugenic concerns, as they did for many eugenicists. He concluded, "Many of the [hereditarily blind] men, if not allowed to marry, would certainly gratify their passion in illegal ways and would tend to leave off-spring more likely to become the charge of the State than those born in wedlock." 82 Eugenics, for Hoyt, needed to rely on moral inculcation before it could achieve its aims.

Hoyt joined the AES at least as early as 1925, and in 1927 Hoyt volunteered his services as a eugenics speaker and propagandist. Listed as one of three speakers for

${ }^{82}$ Dr. William D. Hoyt to Lucien Howe, January 25, 1921, "Hcreditary Blindness Law Questionairres A-H (1921)" folder, Box 3, ERO Papers. 
Virginia - the other two were Harvey Emest Jordan and the Hampton Institute's Thomas Wyatt Tumer-Hoyt offered three different speeches. Hoyt would speak on "Heredity and Environment: Nature or Nurture?" or "Is There Danger of Race Deterioration?" or "Eugenics: Some Present Conditions and Suggestions" for a ten dollar honorarium, plus expenses. ${ }^{83}$ Hoyt's racial attitudes, and the degree to which he adhered to mainline eugenics dogma (beyond his desire to limit the procreation of the feebieminded), remains unclear from surviving evidence.

\section{Eugenics at Virginia's Women's Colleges}

As the discussions of Randolph Macon and the University of Richmond revealed, coordinate female colleges often offered eugenics to their students. Virginia's two most prominent independent women's colleges, Hollins and Sweet Briar, also gave substantial courses in eugenics. Both schools sent their students to train at the ERO during the summers. More than merely "finishing schools," these women's colleges used eugenics as pre-professional training for women interested in careers in school teaching, social work, and science. More important, from the eugenicists' point of view, these schools socialized the most genetically "fit" women to accept their role as mothers of the future. As Steven Selden notes, the appropriate role for women in society presented a number of problems for many eugenicists. ${ }^{84}$ Women often became, in the eyes of many mainline eugenicists, little more than the gestational repository of a nation's future.

A new American rhetoric arose, recasting the traditional notions of "republican motherhood" along expiicitly eugenic lines. Since women contributed genes as well as wombs to the procreative equation, eugenicists argued that only the "best" women should procreate, and they should reproduce in large numbers. Unfortunately, intelligence and a

${ }^{83}$ See member list in "AES Membership Campaign, 1925" folder, AES Papers. See also American Eugenics Society, "A List of Eugenics Lecturers (1927)," in "AES Printing Orders, 1926-1942" folder, AES Papers.

${ }^{84}$ Selden, Inheriting Shame, 46. 
desire for higher education and activity outside the home also characterized the "most fit" women. Both of these goals would delay childbearing, limit the number of children born to fit women, and generally exacerbate the dysgenics of "race suicide"- the "worst stock's" ability to "outbreed" the "best stock."85 The dilemma for eugenicists, then, became how to reconcile the fit women to sacrifice other aspirations and accept their "destiny" and "responsibility" as mothers. As Norwegian mainline eugenicist Dr. Jon Alfred Mjoen opined in the pages of Eugenics and on the American lecture circuit, "Young women should learn that where families are limited to one or two children, the stock in question must inevitably become extinct." Rather than adopting the reactionary stance of demanding that women eschew all higher education, Mjoen argued, "Women should not have an inferior but another education," presumably one that emphasized their eugenic responsibility. Similarly, Mjoen argued that women should be allowed to work outside the home, but, "A wise government will in the future work to lead her paths in such directions, both for her sake and the welfare of the race and state that she will be more and more fit for her divine calling as the renewer, the nourisher and the protector of the race."86 Training and working as a eugenics "field worker," assigned to interview families and ferret out genealogical information useful for eugenic family studies, would impress upon women their eugenic responsibility. Entering the hovels of the unfit, eugenicists thought, would redouble elite women's sense of urgency about forestalling race suicide.

While eugenicists believed that these educated, elite women accepted this line of reasoning, the bulk of the historical evidence suggests that many women actually used eugenic rationales to advance their own agendas. A desire to enter the professional realms of science and social work, and an even more pressing demand for reproductive control, ranked foremost among these other concerns motivating women who responded to the

\footnotetext{
${ }^{85}$ Charles L. Vigue, "Eugenics and the Education of Women in the United States," Journal of Educational Administration and History 19 (1987), 51-55.

86Jon Alfred Mjoen, "The Masculine Education of Women and Its Dangers," Eugenics 3 (1930), 323. 326, quotations 326; also quoted in Sclden, Inheriting Shame, 48.
} 
eugenicists' call. 87 With few notable exceptions, women remained excluded from the highest professional ranks and rarely became scientific investigators in their own right. ${ }^{88}$ Trained as eugenic field workers, women advanced to "helping" positions; semiprofessional, ancillary places-like nurse, research assistant, and social worker-in the emerging gendered division of labor within science and reform bureaucracy. ${ }^{89}$ The eugenicists' focus on rational procreation presented an entering wedge to birth control advocates like Margaret Sanger. Birth Control, still a legally and socially taboo subject in America, gained a certain legitimacy when coupled with eugenics, a discourse recognized as vital by most male authorities. While hard-line eugenicists like Charles Davenport feared that birth control would only exacerbate "race suicide" as only intelligent people would use it, others like Leon F. Whitney and Sanger advocated the eugenic use of birth control. Spread among the "unfit," Whitney, Sanger, and others believed birth control an effective eugenic measure. ${ }^{90}$

Feminist eugenicists also manipulated the eugenics creed to serve the class interests that they, as elites whites women, shared with elite white men. Both professionalization and birth control ran counter to the ideals held by most mainline eugenicists, whose pro-natalist schemes tended to circumscribe women's role to childbearing and rearing. 91 Women eugenicists, however, understood clearly that the movement offered them not only control

\footnotetext{
${ }^{87}$ Margaret Sanger penned two evocative books that became manifestos for feminist eugenics. Margaret Sanger, Woman and the New Race (New York: Brentano's, Inc., 1920); and Sanger, The Pivot of Civilization (New York: Brentano's, Inc., 1922). Sanger dedicated Woman and the New Race to her lover, British eugenicist Havelock Ellis. The sixth edition of the book was brought out by the Eugenics Publishing Company of New York in 1923. For a brief discussion of Sanger's involvement with eugenics, see Donald K. Pickens, Eugenics and the Progressives (Nashville, TN: Vanderbilt University Press, 1968), 75-85. For more on women in the eugenics movement, see Marouf A. Hasian, The Rhetoric of Eugenics in Anglo-American Thought (Athens, GA and London: The University of Georgia Press, 1996), Chapter 4.

${ }^{88}$ Margaret Rossiter, "'Woman's Work' in Science, 1880-1910," Isis 71 (1980): 381-89.

${ }^{89}$ See Nicole Hahn Rafter, White Trash: The Eugenic Family Studies, 1877-1919 (Boston:

Northeastem University Press, 1988), 20-22. Rosaleen Love examizes eugenics as an entryway for women into British science in "'Alice in Eugenics Land': Feminism and Eugenics in the Scientific Careers of Alice Lee and Ethel Elderton," Annals of Science 36 (1979): 145-58.

90For a more detailed discussion of the dcbate between birth control and eugenics, see Chapter 5.

${ }^{91}$ Kevles, In the Name of Eugenics, 88-9.
} 
over their own employment and reproductive destinies, but also that of other women whom they deemed inferior. Personally empowering, eugenic ideology also carved out a niche that allowed elite women an opportunity to try to control the procreation of other women. As Margaret Sanger phrased it in 1919, "More children from the fit, less from the unfitthat is the chief issue of birth control." 92

Edward J. Larson documented the involvement of women in the deep southem eugenics movement. ${ }^{93}$ Operating from women's clubs and other associations involved in social reform, these women exerted a major force in shaping, implementing, and policing eugenical public policy. While many of these women first learned about eugenics through their involvement with these groups, many others learned eugenics as part of their education at elite women's schools, North and South. 94

Evidence from both Hollins College and Sweet Briar indicates that women from both schools trained as eugenics field workers at the ERO and took biology courses at Cold Spring Harbor under Davenport and Laughlin. Leola Elizabeth Fields wrote to Charles Benedict Davenport in April of 1927 about spending the summer at Cold Spring Harbor. Ms. Fields and three other students, accompanied by one of the assistants in the Hollins biology department, accepted positions tabulating anthropometric measurements for Davenport's eugenic studies. ${ }^{95}$ Sweet Briar's professor of sociology, Ivan E. McDougle, routinely sent his students to Cold Spring Harbor for training as eugenics field workers. He then used his students in his own investigations.

Professor McDougle answered Laughlin's eugenics questionnaire in 1920 and told him of the vital eugenics program at Sweet Briar. McDougle himself established the course

\footnotetext{
92 Sanger quoted in Ibid., 90.

${ }^{93}$ Edward J. Larson, Sex, Race, and Science: Eugenics in the Deep South (Baltimore and London: Johns Hopkins University Press, 1995), 72-79.

${ }^{94}$ Both Smith and Mount Holyoke Colleges in Massachusetts, two of the nation's leading women's colleges, employed eugenicists on their staffs, taught eugenics in their classes, and sent students to the ERO training schools.

95 Leola Elizabeth Fields to Charles Benedict Davenport, April 4, 1927 and May 11, 1927, "Department of Genetics Assistants 1927" folder, Davenport Papers.
} 
"Social Problems" the year before, and had 18 young women in the class. As texts, he used Popenoe and Johnson's Applied Eugenics and Davenport's Heredity in Relation to Eugenics, two emphatically mainline eugenical treatises. Regarding future plans for teaching eugenics, McDougle envisioned, "A more complete cooperation between the departments of Biology and Sociology because this course in 'Social Problems' has proved to be one of the most popular courses among the college."96 Laughlin found this comment so promising that he underlined it and drew it to Davenport's attention.

Three years later, when Charles Davenport dispatched ERO researcher Arthur H. Estabrook to Amherst County, Virginia to make a eugenical family study of the "lost tribe" of Virginia Native Americans, he remembered McDougle and his student's enthusiasm for eugenics. McDougle and his students would join in the study-McDougle eventually becoming co-author of the book that was produced. Mongrel Virginians: The WIN Tribe, as its name implies, is a study of the cacogenics of racial crossing. McDougle, Estabrook, and the Sweet Briar students studied the pedigrees of Native Americans in and around Amherst County, concluding that their "retarded" way of life-the poverty, alcoholism, and lack of intellectual attainment-resulted from dysgenic inbreeding. Furthermore, the study substantiated the notion that the Native Americans had indeed been "lost" through racial intermixture. The "WIN" tribe referred to in the title was really an acronym for the "tri-racial mixture" of whites, Indians, and Negroes. Virginia eugenicists used early results of this study, made possible by the teaching of Ivan McDougle and his students' eager participation, to support their lobbying efforts for the eugenically-justified antimiscegenation law passed in March 1924. Fronı then until 1967, no white would legally marry a non-white person in Virginia until 1967. The research enabled by Sweet

${ }^{96}$ Ivan E. McDougle in Sweet Briar College's Questionairre, "Eugenics Instruction Questionairres, RUniv. of Ma (1920)" folder, ERO Papers. 
Briar's eugenics courses unleashed a reign of eugenic terror that victimized Virginia's Native American and black populations for over forty years. 97

\section{Genetics or Eugenics?: Black Institutions Confront Segregation's Science}

Virginia's African-American students who desired higher education faced a difficult decision. Leave home and head North to face the subtle racism on northern "integrated" college campuses, or stay put and attend one of the black-only colleges in the segregated South. Black Virginians who stayed in the Old Dominion had four obvious choices: Howard University, Virginia Union University, the Hampton Institute, and Virginia State University. Hampton, the institutional forebear of the Tuskegee Institute, remained atop the pyramid of black education for much of the early twentieth century. Howard, in the District of Columbia, offered the best of "modern" liberal arts and science training to those who could afford its tuition. Virginia Union University, located in Richmond, offered three separate academic programs—collegiate, theological, and vocational—on its campus. By the 1920s, each of these schools sought to develop a curriculum commensurate with that offered at white colleges and universities. Thus, each of these historically black colleges faced tough decisions regarding the hereditarian doctrines emerging during the Progressive Era. Whether and how these ideas would be taught created a good deal of tension for each school; how each institution resolved these tensions reveals much about the nature of "uplift" and the construction of black identity during the first half of this century. ${ }^{98}$

${ }^{97}$ Arthur H. Estabrook and Ivan E. McDougle, Mongrel Virginians: The WIN Tribe (Baltimore: Williams \& Wilkins Company, 1926), . See the extended discussion of these events in Chapter 6.

98Pathbreaking work on the relation of eugenics and African Amcrican culture has been done by Hasian, Rhetoric of Eugenics, Chapter 3; Michele Mitchell, "Adjusting the Race: Gender, Sexuality, and the Question of African-American Destiny, 1877-1930," (Ph.D. diss., Northwestern University, 1998); and Daylanne Kathryn English, "Eugenics, Modernism and the Harlem Renaissance," (Ph.D. diss., University of Virginia, 1996). 
Howard University provided the institutional base for America's most famous AfricanAmerican biologist Dr. Ernest E. Just. Dr. Just took his undergraduate degree from Dartmouth before going on to graduate work at [?]. When Just joined the Howard faculty, he set about building a comprehensive biology course, complete with laboratory instruction. Beset by financial difficulties, however, Just's painstaking efforts took many years to bear results. Nevertheless, by 1912 , Howard of ficials were able to report that eugenics was offered in the "Sex Hygiene," "Biology and Education," and "Social Biology" courses. ${ }^{99}$ Charles Benedict Davenport that

Laughlin's 1920 questionnaire, however, indicates the continuing difficulties faced by Howard, as well as the faculty's appreciation of eugenics as a new, cutting edge technology. President J. Stanley Durkee wrote to Laughlin, "Permit me to say that because of the great limitations here and the struggle we are making to get the school on a foundation where it can really minister to the scientific development of the colored race, there has, as yet, been no department organized in Eugenics." Nevertheless, Durkee added hopefully, "One of our former students is specializing in that subject and I hope will return here in a couple of years prepared to put in a department of Eugenics." 100 Dean E. A. Balloch answered the questionnaire addressed to Howard's medical school. He noted that E. E. Just was the faculty member most interested in eugenics, but commented that the medical school had no plans for work in eugenics because, "Curriculum too crowded and funds to limited to allow us to consider extra courses."101 Despite these reports, however, eugenics had been being taught at Howard since at least 1914.

Thomas Wyatt Turner was born in 1877, the year Reconstruction ended. The son of former slaves who had turned to sharecropping, Turner's parents reared him as a Roman

\footnotetext{
${ }^{99}$ See the Howard University Questionnaire in "Eugenics and Genclics in Colleges, \#5" folder, Davenport Papers.

${ }^{100}$ Howard University Questionnairc in "Eugenics Instruction Questionnaires Har-P (1920)" folder, Box 1, ERO Collection.

${ }^{101}$ Howard University School of Medicine Questionnairc in Ibid.
} 
Catholic in Charles County, southern Maryland. Reflecting on his background, Turner

liked to say he "came out of the woods" to become a leading black biologist and educator. ${ }^{102}$ When one reviews Tumer's life and career, he seems, at first glance, an unlikely eugenicist. His Catholic faith put him at odds with the mainline positions regarding procreation and sterilization. His racial heritage would seem to eliminate him as a member of the eugenics movement. ${ }^{103}$ Nevertheless, Tumer developed a well-articulated eugenic sensibility that harmonized his race, religion, and reformist tendencies. He creating a scientific ideology for racial uplift.

Tumer's hard-scrabble life toughened him and prepared him for a life of fighting racial injustice with scientific knowledge. After being schooled in country school houses and for two years as a scholarship student at Charlotte Hall, and Episcopalian school in southem Maryland, the eighteen-year-old Turner walked the fifty miles to Washington, D.C. to attend Howard University Preparatory School. Turner graduated from Howard Prep in 1897, then took a bachelor's degree at Howard in 1901 . He began graduate studies at Catholic University in 1901, but left when Booker T. Washington called him to teach biology at the Tuskegee Institute. For a decade from 1902 to 1912, Tumer taught high school biology and sought to advance his own graduate training. It was during this period that Tumer first encountered eugenics.

Thomas W. Tumer met Charles Benedict Davenport and learned incipient genetics and eugenics from him at the Long Island Biological Laboratory (LIBL) in the summer of 1904. Earlier in 1904 Davenport had acquired the Carnegie Institution's support for his

${ }^{102}$ The biographical information in this and the following paragraphs comes from Turner's obituary "T.W. Tumer, 101, Dies; Rights Activist, Educator," Washinglon Post, April 23, 1978, B6; and "Biographical Sketch" both in the Turner Papers. The author acknowledges his gratitude to the Hampton University Archives and its staff for permitting access to the Turner Papers. This collection comprises seventeen unnumbered boxes that often bear the same designation. The material is largely unsorted and, therefore more specific location references in these notes is impossible.

${ }^{103}$ Marouf Hasian reveals the degree to which eugenics could comport with both an individuals Catholic and African-American identity in The Rhetoric of Eugenics in Anglo-American Thought, Chapters 3 and 5 . 
Station for Experimental Evolution (SEE), operated in conjunction with the LIBL. These two institutions, though nominally separate, in actually operated simultaneously and with tremendous overlap in personnel and instruction; six years later the ERO would be grafted onto the other two organizations, all under Davenport's purview.

A single photograph survives documenting Turner's summer in Cold Spring Harbor. That picture, together with correspondence about blacks between Charles Benedict Davenport and Harvey Ernest Jordan, portrays the likely quality of Turner's experience at the laboratory. In the photograph, the white male and female investigators are mixed together on the verandah of the laboratory's main building. This heterosocial crowd also includes some children, presumably those of some investigators; Davenport is photographed with his daughter on his lap. Tightly bunched together, this crowd shot reveals a great degree of personal familiarity and the warm intimacy of a family reunionexcept for one striking exception. Toward the right-rear of the photograph, a lone black man stares solemnly at the camera. Thomas Tumer is alone in a crowd. There is a space of slightly more than a body's width separating him from those in front and to the side of him. No white person stands to his rear. While all the other fifty-one faces seem comfortable and relaxed, Turner's face is taught and anxious.

On his one-hundredth birthday, seventy-three years after that photograph was taken, Thomas Turner remarked, "I was one of the first black people to do a lot of things, I didn't get up and start cussing people out. But I said things."104 One wonders what he might have said during the summer of 1904 that earned him the lasting displeasure of Charles Benedict Davenport. Nine years later, when Harvey Ernest Jordan suggested that Davenport admit a "mulatto to the course next summer," Davenport replied that the last "colored" man, "a professor from a colored college," had displayed "a scandalousìy erotic 
nature. The example he set for the young people here was frightful."105 Whatever Tumer did, Davenport did not like it. While it is likely that Tumer could have done nothing to avoid Davenport's racism, the fact that Turner was brilliant, outspoken, and a Catholic probably increased the likelihood that Davenport would dislike him intensely. ${ }^{106}$ Nevertheless, the work in genetics and eugenics captivated Turner, and he continued his dogged pursuit of an advanced degree by attending Johns Hopkins on evenings and weekends for the next two years.

Turner retumed to Howard in 1913, teaching applied biology and assuming the post as acting dean of the school of education in 1914. He remained at his alma mater for the next ten years. In the summers of 1915 through 1917, Turner attended Cornell University and finished the coursework for his doctorate. During a sabbatical year in 1920-1921, Tumer finally achieved his goal, taking his degree in botany. ${ }^{107}$

Tumer began teaching eugenics as soon as he arrived at Howard. Lecture notes and examinations from his courses on Sex Hygiene and Biology and Education reveal his belief in the power of Mendelian genetics and eugenics. Judging from his notes, the work of the British "sexologist" and eugenicist Havelock Ellis deeply impressed Tumer. He assigned articles by Ellis and drew information from Ellis's work for his lectures on heredity and eugenics. He also assigned Davenport's work, and Popenoe and Johnson's Applied Eugenics. ${ }^{108}$ In the second examination for his course in biology and education, Tumer asked his students to "Describe three types of feebleminded persons. Explain applications

${ }^{105}$ Harvey Emest Jordan to Charles Benedict Davenport, July 16, 1913; Charles Benedict Lavenport to Harvey Emest Jordan, August 7, 1913, "Jordan, H. E." folder, Charles Benedict Davenport Papers, American Philosophical Society Library, Philadelphia.

${ }^{106}$ I cannot be certain that Davenport was referring to Thomas Turner in his letter to Jordan, since he does not name Tumer explicitly. Yet, in all my study of Davenport's papers and the laboratories ai Cold Spring Harbor, I have never come across another instance of a black man attending any of the summer programs at the institution. The bulk of the circumstantial evidence points to Turner and the "professor from a colored college" being the same man.

107 "Biographical Sketch," Turner Papers.

${ }^{108}$ See Tumers "Lecture Notes," particularly for "Breeding," "Heredity," and "Eugenics," Tumer Papers. 
of Mendel's law to the problem of Feeblemindedness and its control," and "Explain the application of Mendelism to Eugenics." 109 Examining his Sex Hygiene students in 1915, Tumer asked, "Define Eugenics. Explain how society may be helped by applying eugenic laws." He also wanted to know "Who was Mendel? Describe his work briefly. Why has his work become of such great importance?" Very similar questions appeared on his Sex Hygiene final examination in 1920.110 Clearly, biology students at Howard University between 1914 and 1924 learned eugenics from Thomas W. Turner.

For his own part, Turner taught mainline beliefs regarding feeblemindedness in a way that undercut racist notions of "reversion to type" and "atavism" that purportedly afflicted African Americans. Tumer adopted the most up-to-date ideas about psychology and "feeblemindedness." The three types of feebleminded people he quizzed his students on were, of course, Goddard's hierarchy of idiots, imbeciles, and morons. Turner defined "defectiveness" in a lecture as characterized by the "persistent infantile condition in one or more [hereditary] characteristics." Invoking the then current notion of "recapitulation," Tumer cited Davenport and wrote, "Biologically—man's ancestors didn't go in their adult stage beyond the point where the infant man is now."111 Yet even if "ontogeny recapitulated phylogeny" as Ernst Haeckl, Paul Barringer, and most other prominent white biologists believed, Turner adhered to the newer, Mendelian model explaining mental defectiveness.

Feeblemindedness in the new genetic scheme represented anomalous heredity, not an atavistic "reversion" to an earlier type. "Defectiveness is not a reversion but direct inheritance," Turner wrote, continuing, "Defectiveness in regard to several characteristics

109"Biology and Education, Second Examination (ni.d.)," Turner Papers.

${ }^{110}$ Thomas W. Turner, "Sex Hygiene Examination (May 17, 1915)," and "Sex Hygiene Final (March 19, 1920)," Turner Papers. In 1920 Turner asked, "Explain the meaning of the term 'Eugenics'. Explain how society may be helped by applying the laws of Mendel."

${ }^{111}$ Thomas W. Turner, "Leclure X-Eugenics," Turner Papers. For a discussion of the history of recapitulation theory and its successor "ncoleny" in evolutionary biology, sec Stephen Jay Gould, The Mismeasure of Man, revised and expanded ed., (Ncw York and London: W. W. Norton and Company, 1996), 142-151. 
that are socially important constitutes feeblemindedness." 112 The feebleminded person, Tumer wrote, in consonance with the established wisdom, "is incapable of competing on equal terms with his normal fellows, etc."113 While many white eugenicists argued that this inability to compete characterized black/white relationships, implying that blacks were inherently feebleminded, Turner viewed the situation differently.

A number of Turner's essays exist that underscore his belief in the "gospel of social evolution" that characterized the ideas of "biological progressives" like Edwin Grant Conklin. ${ }^{114}$ In "The Biological Laboratory and Human Welfare," Turner outlined a role for biology that perfectly fit the Progressive Era ethos of scientific social reform. "The aim of the biologist," Turner began, "'is to be useful in real human life."' Only with the advent of Darwin and Mendel, Turner argued, did people begin to focus "upon man as a living organism, and upon the need of improving the races of plants and animals and thus make them serve more adequately the uses of man." Since, "Biological activities are foremost and fundamental at every stage of human activity," Turner believed that, "The interactions of the biologicai laboratory...should center around a few well-chosen ideals, and should emphasize materials and methods leading to these ideals in proportion to their immediateness to the problems of life and human welfare."115 Turner listed "Health and Physical Development" alongside "Social Betterment and Social Uplift" as being among the "well-chosen" ideals toward which biologists should aspire. Turner's choices revealed his political heritage and his alignment with the traditional social reforms associated with the

${ }^{112}$ Turner, "Lecture X-Eugenics," Turncr Papers.

${ }^{113}$ Tumer, "Feeblemindedness," Turner Papers.

${ }^{114}$ In addition to the two essays discussed below, the collection of Turner papers housed at Howard University's Moorlard-Spingarn Research Center contains his essay "Biology and Race Progress" and "Science and Human Brotherhood." Both of these works are almost certainly relevant to the discussion at hand; however, I have not been able to obtain copies of these pieces. I borrow the terms "gospel of social evolution" and "biological progressive" from Kathy Janc Cooke's excellent dissertation "A Gospcl of Social Evolution: Religion, Biology, and Education in the Thought of Edwin Grant Conklin," (Ph.D. diss., University of Chicago, 1994), 5. Conklin, himself a believer in cugenics but a true racial liberal who taught in black schools, never adhered to the racialist theorics of mainline cugenics.

${ }^{115}$ Tumer, "Biological Laboratory and Human Welfare," 1. 
middle-class African-American intelligentsia of the Progressive Era. Ultimately, for Tumer the test of the biologist's success came in answer to the query: "To what extent has he contributed to making men better, to giving greater respect for their fellows, to making them more useful in improving the condition of mankind?"116 Biology prevailed only in so far as it advanced all these vaguely environmentalist goals.

Yet Tumer's ideology remained rooted to a hereditarian conception of life, as opposed to the traditional environmental focus of earlier efforts at black "uplift." Tumer wrote that "the vigorous movements which we see on all sides for social betterment and social uplift" must "look to the improvement of the individual as well as to the improvement of the race. It must seek to make society better by working upon the individual units of society. It must aim not only at ameliorating the conditions of life but also at bettering life itself."117 Fixing the environment was not enough in Turner's eyes. Such an approach only alleviated symptoms without curing the root cause of social problems, the quality of the individuals who comprised society. Biologically-informed social policy, particularly eugenics, offered the best hope for lasting social reform.

Just as Ivey Foreman Lewis and other white-Virginian eugenicists distrusted sociology's environmental analysis, Turner believed that, "The sociologist, then, if he will make anything more than a superficial survey of this problem must be primarily a biologist." The accuracy of the sociologists' interpretations "as to the varied expressions of human conduct will be determined," Turner argued, "largely by his fundamental concepts as to the laws of life." Only a strong biological understanding of social interaction would bear real analytic fruit. Thankfully, Turner commented, "The point of view in social uplift has undergone a remarkable change in the last decade." Instead of "the hit or miss method of dealing with delinquents, criminals, and many other groups that are socially important or troublesome," Turner averred that, "we have come to know the exact ideal toward which

${ }^{116}$ Ibid., 8.

${ }^{117}$ Ibid., 4. 
we should work in curing many of the social ills and to apply more intelligently the formulae which will bring us to the same end." Social problems like "infant mortality, child labor, the woman question," were all being studied as "problems intimately associated with the life, strength and health of the race."118 This new, eugenically-informed understanding of social problems promised, in Turner's view, the most efficient course of action toward solving social tensions.

Tumer, like most mainline eugenicists, argued that all public policy must stem from a biological understanding of life. "The legislator who would make laws concerning [social problems] without a due appreciation of their biological significance, may do much that is worthless and even positively harmful," Turner wrote. He then favorably quoted British eugenicist Karl Pearson:

'The man who has accustomed himself to marshal facts to examine their complex mutual relationships...sequences which we term natural laws...such a man we may hope will carry his scientific method into the field of social problems. He will scarcely be content... with vague appeal to the imagination, to the emotions, to individual prejudices. He will demand a higher standard of reasoning....and his demand cannot fail to be beneficial to the community at large.'

Ultimately, Turner believed in "the value of the methods of science in fitting one for sound citizenship."119 Turner, like most progressive scientists, remained convinced that proper scientific training could fit individuals to approach social problems dispassionately and objectively, without being influenced by personal bias. Ethical behavior would emerge, in this view, from a proper exercise of scientific inquiry. The dangerous syllogism-science is objective, objective things are moral, therefore science is moral-remained as attractive to Turner, seeking to liberate people from oppression, as it did to his ideological opponents who invoked it to legitimate their work.

Tumer built on the Jeffersonian tradition of a universal "moral faculty" in describing how biology might create a more humane society. "The foundation of ethics and the 
springs of human conduct may be very much more extensively bound up with our bodily structure and functions than most of us ever pause to realize," Turner averred. Tumer used this strict hereditarian notion to argue for the power of environment-professional training-in creating more ethical individuals. Biological study of "lower" organisms "offers a splendid opportunity to impart ethical values in their social relations and thus to contribute to building of better individuals and better communities." 120 If, in examining a toad, the biology student realized that the animal manifested "the same type of vital functions as himself," then, Tuner believed, "It will sooner or later dawn upon him that it is an act of savagery, wantonly, to destroy toads, unless they are found to imperil human welfare. Genuine respect for the living among lower foms will go far in reinforcing one's respectful reverence of personality among men." Perhaps a thinly veiled plea for racial tolerance, Tumer's logic inverted the usual biological rationale for studying non-human life forms. Instead of them being "expendable" and inconsequential, they became objects of ethical and moral reflection for the student.

"Another way in which the biological laboratory makes for ethical culture," Tumer said, revealing the thrust of his article, "is the part which it has played and is playing, in trying to establish the true relationship of races and nations to each other." The preceding March Virginia legislators had passed the eugenically-justified Racial Integrity Act (RIA) which banned all marriages between whites and non-whites in Virginia. ${ }^{121}$ Turner clearly viewed his article as a reply to the overheated rhetoric of the RIA's supporters. "We know how persistently certain scientists only a few decades ago classified races as superior and inferior," Tumer admitted. Championing the ability of "objective" science to ferret out the truth, however, Turner asserted that

${ }^{120}$ Ibid., $\epsilon$.

${ }^{121}$ In September of 1924, the month Turner's article appeared in the Howard University Record, the first legal cha!lenge to the law resulted in the denial of marriage licenses to a white man and a "colored" woman. The Racial Integrity Act, and the case of James Connor and Dorothy Johns, referred to here, is discussed in Chapter 6, below. 
[T] he microscopists and naturalists working along other lines are fairly united at present that these terms have no meaning as applied to races and nations, and the additional fact that some of the so-called inferior peoples have forged ahead to the front ranks of civilized nations, while some so-called superior ones have become apparently decadent, has completely upset these older calculations. ${ }^{122}$

Although many scientists by 1924 indeed agreed with Tumer, the situation was not nearly as clear cut as he portrayed it. In his own desire to further the political and social goals of racial uplift, Tumer remained willing to press for rhetorical advantage at the cost of strict accuracy. He remained convinced that the positive march of science would conquer all error, social or scientific. "A universal ethical conduct which must be the same to all men will surely follow as the ignorance and superstition of former days shall be supplanted by the truths of the laboratory," he asserted, concluding, "We are nearer the goal of universal brctherhood, I feel, today than we were a century ago, largely, because the pursuit of science has developed a larger sympathy among men, by teaching them that they are truly of one flesh, with a common parentage." 123 While Turner's position eventually captured the mainstream position in scientific circles, it would be another twenty-six years before most biologists would agree to a universal statement affirming the fundamental similarity of all human beings. ${ }^{124}$

Three years later, Turner would find himself fighting the same battle against racial eugenics. In "The Curriculum and Aims in Biological Teaching," Turner took a more pessimistic stance. After twenty-five years teaching biology, Tumer confessed his "growing opinion that the schools are playing a rather backward role in preparing the youth

122Turner, "Biological Laboratory and Human W'elfare," 7.

123 Ibid., 7.

${ }^{124}$ The famous UNESCO "Statement on Race," finally broke the silence among many scientists and allowed them to take an overtly political stand. Reacting to the horrors of science run amok in the Nazi eugenics program and the advent of the atomic bomb, scientists found their social conscience. The UNESCO statement bonded the majority of reputable scientists in favor of the position that "race" is merely a social construction that aids catcgorization without expressing anything about the innate biological essence of individuals. Nevertheless, dissenters from this position remained then and continue their invidious distinctions today. See Elazar Barkan, The Retreat of Scientific Racism: Changing Concepts of Rae in Britain and the United States between the World Wars (Cambridge: Cambridge University Press, 1991), 341-343; Kevles, In the Name of Eugenics, 138. 
of the country to cope with the innumerable problems, mostly biological, with which they and the whole populace are brought into daily contact." 125 The crucial biological problem confronting society, in Tumer's view, pertained to race. Unlike the white eugenical propagandists, however, Tumer perceived the problem as being exacerbated by the propagation of "false biology" by improperly educated authors. "In the last few years," Tumer complained, "the reading public has been deluged with flaming titles and their no less inflammatory contents, such as 'Yellow Peril,' 'The Rising Tide of Color,' 'Mankind at the Crossroads,' 'White America,' and many others." Singling out the works of Madison Grant, Lothrop Stoddard, Edward M. East, and Virginia's own Eamest Sevier Cox, Tumer mounted a charge against the racist use of biology. Although forced to acknowledge East's eminence as a biologist, Tumer still lambasted the others as "writers who have not had even a smattering of biological training in any formal manner."126 Claiming ignorance as the root of all evil, Tumer sought to wrest control of the eugenical impulse from white racists and turn the effort to the advantage of all "fit" people, white and black.

Tumer's anti-racist stance did not diminish his biological and hereditary determinism. While he believed that "the growing spirit of narrow mindedness, racial hatreds, and socalled controversies between Science and Theology may be traced unerringly to a mistaken school program," Tumer remained convinced that biology could indeed help to explain human history, and chart a course for the future. In a tortuous passage, Tumer poured forth his philosophy:

History, as a subject of the curriculum far antedates Biology. This subject deals with the vital events of human life. The application of biological principles to man, though admitted for plants and lower animals, still gives a shock to many minds, yet a conception of History as a struggle for existence among human beings with its attending natural selection and survival of the fittest, giving due consideration to the

${ }^{125}$ Thomas W. Turner, "The Curriculum and Aims in Biological Tcaching," School Science and Mathematics 27 (October 1927), 681-90, quotation 681; also publishcd in Morehouse Journal of Science (January 1928), 10-17.

${ }^{126}$ Ibid., 681. 
part which intelligence has played, would remove this subject from an ancient classic setting-a setting which portrays man as having no correlation, nor biological counterparts with other organisms - and would place it upon a background which has both the pedagogic appeal and the dynamic force to serve as a permanent stimulus in the acquisition of information about the life history of the race as a whole, as well as that of the different branches of the human race. ${ }^{127}$

Biology could explain the origins and development of humankind; not with an eye toward justifying social hierarchies by classifying difference, but instead by explaining surface differences in terms of the underlying organic similarity of all human beings.

Turner took the racist biology pervading popular textbooks to task, in an effort to reclaim hereditarianism as a tool for African-American — and more broadly human-social uplift. ${ }^{128}$ His attempt to present an effective counter-narrative to segregation's science depended upon his success in coopting its underlying logic - that biology did, indeed, determine much about how the world organized itself. "The systematic and genetic relationship of plants is carefully studied and drilled into youth in the schools and colleges," Turner argued, beginning his brief for the importance of learning biology. "The same is true in a larger sense with animals, but when we come to man, the statements which we find often border on the ludicrous and fail completely to do justice to the intelligence of even a grammar school child when offered as biological information." As an example, Turner quoted the hierarchical racial taxonomy presented in the popular textbook, Essentials of Biology. Written by George William Hunter, the book hewed to the mainline racial beliefs of eugenicists and physical anthropologists in the 1910s. Presenting a fivetiered hierarchy that ran up the spectrum of complexion from black, brown, red, and yellow, Hunter concluded with "'and finally, the highest type of all, the Caucasians,

\footnotetext{
127 Ibid., 682.

${ }^{128}$ As Michele Mitchell noted, "with its basic tenet that sexual bchavior was a decisive factor in determining whether children were 'well-born," eugenic thought suggested individuals possessed the potential to improve their offspring through strategic mating.... Thus, whereas African Americans had to contend with a legion of theory which implied that all people of color came from degenerate stock, they could actually subvert racism within eugenic thought through the guise of uplift." Mitchell, "Adjusting the Race," 154.
} 
represented by the civilized white inhabitants of Europe and America."'129 An indignant Tumer commented, "This is a fair sample of the material to which our youth are exposed. One sees at a glance that while biologists in other fields are spending their lives in trying to find relationships and compatibilities among the various groups of living things, when he comes to deal with his own species he is content to emphasize and present to his youth only the differences, the incompatibilities, the contrasts."130 Turner identified the possible harm done to black students' self-esteem in encountering these racist dicta in their biology books. ${ }^{131}$ More significantly, however, Turner unveiled the ideological program and professional hypocrisy of biologists writing in support of segregation's science. By articulating a new, fully organic vision of biology, that sought out the continuities and harmonies in organic life, Turner posited a completely new model for understanding human social organization as a function of biology. Social difference, in this scheme, became an artifact largely of political and social prejudice, with only minimal connection to underlying biological antagonism.

Turner hoped to engender cultural and racial tolerance on a biological basis. The pluralism of human races paled in comparison to the diversity of organic life, but all the different life forms relied on each other for existence. Implicitly drawing on the old "great chain of being" theory, Turner amplified another side of the taxonomists job-to explain the relationship between different types, not merely describe their differences. "[T]he turmoil, the strife, the intolerance, and the bigotry which we see around us would indicate

${ }^{129}$ George William Hunter, Essentıals of Biology (1911) quoted in Ibid., 684. Hunter was himself an avid eugenicist and staunch biological detcrminist; his textbooks were best scllers. Stcven Selden analyses the eugenic content in Hunter's high-school and collcge biology tex!books in Inheriting Shame, 70-76.

${ }^{130}$ Tumer, 684-85.

131 I realize the very real danger of siigmatizing African Americans as passive viclims of racism by ascribing "Jamage" to the collective black psyche as a result of encountering racism in textbooks, literature, and material culturc. African Americans remained active agents working against racist stigmatization throughout their history. Nevertheless, Turner definitely implied that this type of psychological harm could come from constantly encountering false bio!ogy. For more on the problematic of the "damage thesis" see generally, Daryl Michael Scctı, Contempt and Pity: Social Policy and the Image of the Damaged Black Psyche, 1880-1896 (Chapel Hill, NC and London: University of North Carolina Press, 1997). 
that there are still troublesome obstructions to be removed before men will see each other in the proper light," Turner wrote, emphasizing the apparent human tendency toward oppositional rather than associative thinking. Yet hope remained because, "The laboratory can do much toward removing these obstructions," Turner asserted, "by presenting impartially the achievements of each group in so far as these achievements are recognized as biological factors; for every race which has survived and made progress undoubtedly possesses many characteristics worthy of note." 132 Biological diversity presented numerous ways of appreciating human achievement in Turner's world-view-provided one viewed the world as an organic system and not a strict hierarchy.

Recognizing that there were readily apparent differences between cultures, Turner sought to place difference into an associational rather than a segregationist framework. Rather than seeing difference as a legitimation for separation, he viewed distinction as a basis for ccncerted action. 133 "We must give credit further to the intellectual acumen of the distinct and separate racial groups which have contributed to this progress [of modern humanity]," Turner wrote. Yet, while he acknowledged that, "[t]his has been an age characterized primarily by the ascendancy of the paler peoples," he believed that, "each group has made its contributions in no small measure" and "it is inconceivable that any [group] should claim that its accomplishment was unrelated to that which has gone before." Biology taught him the interdependence of all life, not its separate and independent existence. As a result, appeals to racial superiority seemed distinctly anti-biological and

${ }^{132}$ Ibid., 689.

${ }^{133}$ Turner's theme harmonizes with the emergent doctrine of cultural pluralism advanced during this period by philosopher Horace Kallen. Kallen argued that society should be viewed as a symphony, with each difíerent racial and ethnic group contributing its part to the overall score. In conflict, the various groups created a disonant cacaphony; isolated they created singular wails. Together, the groups created a harmony that could only advance human endeavor. Unfortunately, Kallen himself referred mostly to the stresses between white and white ethnic Americans in the 1920s. For all his appcals to pluralism, he could never quite envisage a part for African Amcricans in his greater Amcrican symphony. For Kallen's use of the symphony metaphor, and his limited appreciation for black cultural contributions, see Horace Kallen, Culture and Democracy in the United Stales (Ncw York: Boni and Liveright, 1924; reprint, New Brunswick, NJ: Transaction Publishers, 1998), xvii-xviii, xliii, and 117-18. 
ahistorical, because "this one fact is true, that whatever this age or the dominant people of the present have accomplished rests surely and firmly on the foundation of all that has gone before." 134

Tuming the "race suicide" thesis on its head, Turner argued for the relative impermanence of "civilization" in the face of the greater durability of human life. "The dominance of man and races is short-lived," Turner began. He then moved on to a ringing denunciation of cultural superiority that surely would have alarmed white readers even as it gave African-American readers a basis for hope and optimism.

The proud, haughty, domineering people of today may be the cringing, begging, sycophantic paupers of tomorrow. Within the brief span of man's authentic history, we have record of the rise to power and the decadence of various human tribes-black, yellow, and white; we do not know and probably cannot know what characteristics or lines of conduct have the greatest survival value and are the most enduring, but it should be the chief aim of courses in Human Biology to seek out and stress every factor which makes for peaceful, harmonious, cooperation among races and among nations. ${ }^{135}$

Tumer effectively refocused the eugenic quest. Instead of attempting to ensure the permanent superiority of any one group or civilization, a quixotic venture dependent on guesswork about what made for "fit" society, Turner aimed at creating tolerance. This effort allowed him to escape the trap of biological superiority while insisting on the deterministic basis of life. Turner, who almost certainly was influenced by Edwin Grant Conklin's theorizing about the relationship between science and society, arrived at the Hampton Institute ready to destroy racial hierarchies by teaching the "gospel of social evolution"-black uplift, eugenic and euthenic, could allow African Americans to equal whites in every way.

Others had taught hereditarianism at Hampton before Turner. Nowhere in the Hampton catalog, however, can one find explicit use of the word eugenics. This stands in marked contrast to all the white institutions in Virginia. Nevertheless, hereditarian thinking

${ }^{134}$ Turner, "Curriculum and Aims in Biological Tcaching," 689.

135I Ibid., 689-90. 
permeated the school's curriculum and, as we have seen, Turner taught his own form of "accomodationist" eugenics. The Institute's vocational thrust-which lasted until the 1920 s-retarded the introduction of modern science teaching, except as it applied to farming and stockbreeding. This focus actually aided the introduction of hereditarian teaching. As early as 1903, the Institute offered a course in "Principles of Stockbreeding." 136 By 1904, the graduate department offered "Plant BreedingVariations-Causes and fixation. Crossing. Selection."137 The following year a graduate course in stockbreeding introduced "Heredity; correlation; in-and-in breeding [sic]; crossbreeding; selection; pedigree."138 This course taught all the elementary terms that would be used by later genetic and eugenic thinkers. It also established the foundation for the acceptance of the eugenic metaphor by instructing students in the controlled breeding of "lower" plants and animals. In 1912, the Institute offered a course covering "The Theory of Evolution-Illustrations will be taken from the animal world," and "Ethnologyprimitive man, his activities and environment; development thought agriculture."139 Neither of these classes was ever taught again. When Turner arrived in 1923, the Institute had been offering formal courses in botany and zoology on and off for over a decade.

Tumer introduced a well-developed modern biological curriculum. He offered ten courses covering the entire discipline, ranging from elementary botany and zoology to human physiology and vertebrate anatomy. It is unclear in which course he taught eugenics, but its continued presence in his lecture notes, and the fact that he volunteered for the AES's list of eugenics lecturers in 1927 , along with his contemporary essays strongly suggests that he still taught eugenics during this period. ${ }^{140}$ In 1929 Turner offered "The

136The Hampton Normal and Agricultural Institute, Hampton Institute Catalog, 1903-1904 (Hampton, VA: The Press of the Hampton Normal and Agricultural Institute, 1903), 47, Hamplon University Archives, Huntington Memorial Museum, Hampton. [Hercinafter referred to as Hamplon Calalog, date.]

${ }^{137}$ Hampton Catalog, 1904-1905, 48.

138 Hampton Catalog, 1905-1906, 65.

${ }^{139}$ Hampion Catalog, 1912-1913, 65.

${ }^{140}$ American Eugenics Society, "A List of Eugenics Lecturers," 14. 
History of Life," which he billed as, "A comprehensive course giving a brief outline of astronomy, geology, paleontology, zoology, and botany and the bearing which these sciences have on life. The course covers what is known in regard to the origin of the universe and the earth, and the origin and development of life (Organic Evolution)." $141 \mathrm{He}$ almost certainly taught eugenics in this course. In 1933 he began offering work in embryology, anther likely course for incidental instruction in eugenics. Finally, in 1942, Biology 106 began covering "heredity at work in man," the closest reference to genetics or eugenics before World War II. In 1945-1946, perhaps in response to the Holocaust, the course description dropped notice of human heredity. Turner retired the following year.

The Hamptor Institute's main in-state rival, Virginia Union University, experienced its own interaction with hereditarianism and eugenic theories. Despite the conservative, fundamentalist tinge apparent in the university's self-description as "a Christian School of Leaming, in which none but Christian teachers are employed," Virginia Union was able to modernize its "collegiate" curriculum long before Hampton. As a result of its progressive outlook and its metropolitan location, Virginia Union became an epicenter of black intellectual activity. Following the passage of Virginia's RIA in 1924, Virginia Union became a rallying point for black resistance to eugenic public policy.

Virginia Union's interaction with hereditarian and racialist thought differs materially from Hampton's experience. By 1905 Virginia Union already offered a course in Biology that used famed Darwinist Thomas Henry Huxley's textbook. ${ }^{142}$ Notwithstanding this early appearance of evolutionary teaching, the course catalog betrayed no further eugenic or hereditarian influence for another twenty-four years. Given its urban environment, Virginia Union did not introduce hereditarianism through vocational training geared toward agriculture. This does not mean that students at Virginia Union did not consider the race

${ }^{141}$ Hampton Catalog, 1929-1930, 70.

142 Virginia Union University, Annual Catalogue of Virginia Union University (Richmond, VA: Virginia Union University Electric Print, 1905-1906), 26. [Hereinafter rcferred to as Virginia Union Catalog, date.] 
problem; they did, but from an environmentalist, sociological standpoint. The courses offered in sociology made race and the study of race differences central themes. This became especially true as eugenic public policy began to command attention in Virginia.

The concentrated attention to the sociology of the "race problem" runs through all of Virginia Union's offerings in sociology. The catalog's tone of resistance, however, increases after 1924 in synchronicity with the rise of Virginia's vocal mainline eugenics lobbying. By 1928, after white Virginians successfully enacted the RIA and a eugenicallyjustified public assemblages law that mandated segregated seating, Virginia Union offered a course in "Race Relations." Described as "A brief course in the survey of the actual relations that exist among the races" the course made common cause with other oppressed groups by presenting the "race problem...in its larger implication as it affects Chinese, Japanese, Jews and Negroes." In a veiled attack Virginia eugenicist Eamest Sevier Cox, author of White America, the course placed "special emphasis on the current literature of the white South," and examined, "[t]he social effects of race mixture" and "all the agencies working for racial cooperation in the South." Race relations offered an explicit counternarrative to the dominant message about blacks being trumpeted through Virginia's white newspapers in the 1920s. ${ }^{143}$

Along with the course in race relations, the sociology department also offered anthropology. This course addressed the central issues dividing American physical and cultural anthropologists along the fault-line of the nature-nurture debate. Listed as "An introduction to the physical and cultural evolution of man," the course description noted that, "Theories of the origin, the distribution and differentiation of mankind into races are critically studied with particular emphasis of 'geological crises' and their effects on the evolution of man." After presenting a counter-narrative to the theories of racial contact and decay articulated by Madison Grant, the course set up students for an Afrocentric review of

${ }^{143}$ The charged racial atmosphere between 1924 and 1930, and the controversy surrounding the RIA will be covered, in detail, in Chapter 6. Quotations from Virginia Union Catalog, 1928-1929, 38. 
history. Exciting discoveries in Egypt during the 1920s rocked the scientific world.

African Americans made the most of these new developments to argue that, since African societies once set the standards of civilization, nothing but prejudice prevented modern blacks from similar attainments. So, anthropology at Virginia Union discussed, "The archaeological researches of the present," because "The main purpose of this course is to lay a substantial foundation for the study of African archaeology which alone can give the Negro student a scientific grasp on his racial history and development." 144 Fully aware that, for two decades, studies in the biological sciences had consistently portrayed African Americaris as a decadent race destined for extinction, the sociology department provided a totally different perspective that laid similar claims to the authority of science. ${ }^{145}$

Although the biology department offered a diverse series of courses, genetics does not appear until 1929. Not coincidentally, the course was taught by a young scholar who had graduated from Virginia Union just the year before, and would go on to complete his advanced degrees at the University of Michigan. Beginning in 1930, this course used the least racially biased text available-Herbert Spencer Jennings's The Biological Basis of Human Nature-to teach students about heredity on the cellular level. Jennings's book included a critical discussion of eugenics that adhered to the mainline stance regarding "defective" genes and feeblemindedness: "To stop the propagation of the feebleminded, by thoroughly effective measures [segregation, sterilization, and marriage restriction], is a procedure for the welfare of future generations that should be supported by all enlightened persons," Jennings wrote. A ware that the vast majority of defective genes resided in otherwise "normal" people, Jennings still advocated the sterilization or segregation of the obviously defective because, "Even though it may get rid of but a small proportion of

${ }^{144}$ Ibid., 38.

145 Similarly, the psychology department offered "Tests and Measurements in Education" from a critical standpoint. Students were expected to "make critical evaluation of tests, to prepare new-type examinations as well as to give and score tests," rather than simply accept the conventional wisdom of racist, professional psychometricians like Carl. C. Brigham. Ibid., 41-42. 
defective genes, every case saved is a gain, is worth while in itself [sic]."146 While the feebleminded represented and obviously genetically "inferior" group to Jennings, blacks occupied a much more ambiguous position in his taxonomy of genetic "fitness." This latitude allowed African-American scientists at Virginia Union to capture the theories of eugenics and deploy them in the name of racial uplift.

Jennings adopted an almost agnostic position on the issues of racial difference, racial superiority, and the consequences of race crossing. Jennings supported the conclusions of the eugenical psychometricians like Carl Brigham, and he quoted the work of Charles B. Davenport and Morris Steggerda on race crossing in Jamaica-all of which supported the belief in inherent racial differences in intelligence, and apparent white superiority. ${ }^{147}$ Yet, in considering racial superiority, Jennings's final conclusion provided black eugenicists with the language they needed to support eugenics. "Where one race is superior in certain respects, another in other respects, all depends upon the relative worth of the features in which one or the other race is superior."148 Black scientists could again point to the achievement of prominent black intellects as providing hope for the eugenical improvement of the black race, despite the contentions of mainline eugenicists.

Finally, with regard to race crossing - the greatest bogey in the eugenicists' nightmares-Jennings again adopted an ambivalent stance. "Where mixture occurs among races which, though different, do not show marked superiorities and inferiorities in important respects, and under circumstances in which the hybrids are not at a lasting social disadvantage" Jennings saw no obstacle to miscegenation. In fact, he concluded that the

\footnotetext{
${ }^{146}$ Herbert Spercer Jennings, The Biological Basis of Human Nalure (New York: W. W. Norton and Company, 1930), 238.

147 Ibid., 285-86.

148 Ibid., 287. Jennings agáin quoted Davenport, bclying his own racism in his attcmpt to support a moderate position. "The blacks studied [by Davenport] were superior in matters that affect musical ability; the whites in matters of judgment, of adjustment to conditions (286)." These stereotypical characterizations map precisely to the distinctions Jefferson made almost 150 ycars earlier. Yet, compared to the vituperative writings of most other geneticists and mainline cugenicists, Jennings scemed tolerant. Jennings act might also be construed as a misplaced act of filial piety: he had been a student of Davenport's at Harvard, and lived for a time as a boarder in his house.
} 
"situation exemplified by the mixing of European races in the United States" fulfilled these necessary conditions. Sensitive to the volatile nature of discussing black-white mixture, Jennings avoided the topic. His discussion implicitly asserted that, since blacks and whites seemed greatly different in intelligence and "hybrids" of black-white races remained socially ostracized, such intermixture should not occur. Nevertheless, Jennings ultimately concluded that "the race finally emerging" after a long period of race crossing "will be superior to any one of those entering into the combination." 149 Miscegenation, under the proper circumstances-the selection of mates with "superior" qualities—did not presage dysgenic cataclysm.

Jennings's position presented the most palatable approach to human genetics and eugenics then available to African-American biologists that originated within the elite genetics community. ${ }^{150}$ His contention that all races could be improved by careful mate selection left open the door to black eugenics by valorizing "inbreeding" within the black population. Moreover, Jennings assertion that the products of long periods of race crossing — a cipher for mulattos—were probably "superior" conformed to many prejudices within both the African American and white communities. Black biologists could now continue to deny white charges that all blacks sought to have sex with whites, and offer an altemative that undercut white logic. Within the eugenic scheme, the most "socially efficient" mate selection for black racial improvement remained within the black community, broadly defined. The need to pass-for-white would be eliminated once black eugenic improvement had succeeded in uplifting the race. While some social cache may remain, among certain segments of the black population, for marrying whites, black biologists could now utterly refute that the relatively rare instances of interracial marriage represented a biological imperative.

149 Ibid., 288.

150 The most palatable scientific vision even as late as 1930 was probably held by Franz Boas, but his theories remained cbjects of scorn among many mainline eugenicists. Those same mainliners remained open to the theories of Jennings, and this provided black biologists with an entering wedge. 
For some African Americans, the promise of racial uplift through black eugenics emerged from The Biological Basis of Human Nature. Rhetorically, Jennings's treatment of eugenics allowed the "talented tenth" of black America-a group in which Virginia Union students would presume membership-to make reproductive control and pro-natalist programs a centerpiece for racial uplift. The class focus of positive eugenics could easily be wielded by African Americans as a tool for their advancement. ${ }^{151}$ Similarly, eugenics also offered elite African Americans a way to segregate the "dead weight" of "the race"often depicted in familiar tems borrowed from racist whites as shiftless, slovenly, inebriate, diseased, and defective-from the deserving members of black America. Apparently more and more comfortable with eugenic ideals, in 1932 biologists at Virginia Union expanded their survey course in "Biological Sciences" to cover the "coming of man, embryology, and human inheritance." A clear space had been carved out for considering the claims of eugenics in relation to black racial progress.

\section{At the Movies: Eugenics in Virginia Cinema}

It would be inappropriate to close this chapter on the spread of eugenics throughout Virginia's higher educationa! structure without noting the state's experience with eugenic motion pictures. While today we think of the popular cinema primarily in terms of entertainment, at least until the 1940s many Americans viewed motion pictures as the next great educational advance. Many felt that, properly constructed, motion pictures could impart important knowledge and moral lessons-propaganda-to mass audiences. ${ }^{152}$ Pro-

\footnotetext{
${ }^{151}$ Michele Mitchell treats this notion extensively throughout her dissertation "Adjusting the Race." See especially Chapters 3 through 5.

${ }_{152}$ This was true at least through World War I, when psychologists John Broadus Watson and Karl Lashley evaluated the power of instructional films on venercal discase. Shown to soldiers in an effort to deter hazardous sexual activity and teach prophylaxis, Watson and Lashlcy found that the movies had little lasting effect on behavior. Despite these films' obvious goals, soldier-audicnces "sclectively absorbed and actively reinterpreted the inteded messages of early health films." Sec Martin S. Pernick's excellent analysis of eugenics and medical films in, The Black Stork, quotation 120. This section relies heavily on the interpretive framework constructed by Pernick.
} 
and anti-eugenic cinema reached its high point, in terms of the number of films produced, during the 1910s. ${ }^{153}$ As Martin Pernick has shown, the early acceptance of these films helped to spread eugenic ideas, but often with unintended consequences. Moreover, by the 1920s, as states began to create censorship boards to limit the public's exposure to prurient material presented in the guise of "educational films," a process of erasure began that partially purged eugenic consciousness from the public mind. ${ }^{154}$ A consequence of this erasure was, of course, both a reduction in general, non-elite support for eugenics, and a concomitant concentration of eugenic knowledge among certain elite groups.

The Black Stork, "the most explicit depiction of negative eugenics to reach the silent screen,"155 was a cinematic melodrama supporting eugenic euthanasia. Chicago-surgeon Harry Haiselden starred in the film, which drew its inspiration from Haiselden's welldocumented euthanasia practices. Haiselden refused to operate on at least six infants he deemed "defective," and allowed them to die. 156 Released in 1917 , the film contrasts the experiences of two couples-Claude and Anne, and Tom and Mirriam-mediated by the eugenic advice of Dr. Dickey, played by Haiselden. The audience learns that Claude is afflicted with an unnamed "hereditary" disease, passed down from his grandfather, who had an affair with a "vile filthy" slave woman. Against the doctor Dickey's advice, illustrated in the film with scenes of severely disabled and mentally retarded children, Claude and Anne marry and, predictably, give birth to a "defective ' child.

Dickey/Haiselden refuses to operate on the child with the comment, "There are times when saving a life is a greater crime than taking one." Anne initially questions the surgeon's decision. Then, when a vision from God reveals the horror of her child's fate-rejection, poverty, crime, defective children of his own, mental breakdown, and finally murảer-

${ }^{153}$ Ibid., Chapter 7, especially 130-132.

${ }^{154}$ Ibid., 162-63.

155 Ibid., 143.

${ }^{156}$ Ibid., 1-6. Haiselden claimed that he euthanized others; Pernick documented at least six. 
Anne acquiesces and complies in the euthanasia. The child's soul is shown leaping into the arms of Christ. Claude and Anne thus provide the film's eugenic warning.

The movie's eugenic promise is fulfilled in the narrative of Mirriam and Tom. Mirriam, believing herself liable to the defect of epilepsy, and understanding the eugenic implications of marriage, refuses to marry her sweetheart Tom. As the dire consequences of Claude and Anne's marriage play themselves out, Mirriam and Tom remain chaste, but wracked with sorrow. In the end, however, their selfless dedication to the eugenics creed is rewarded. A twist of fate reveals that the epileptic woman Mirriam believed to have been her mother was really her step-mother. Cleansed of her taint, Mirriam is free to marry Tom. The film ends with the birth of their eugenically-sound, healthy baby. ${ }^{157}$

It is unclear whether The Black Stork ever played in its original form in Virginia. The Virginia State Motion Pictures Censorship Board formed in 1922, and no mention of The Black Stork appears in its records. The film would probably have been objectionable in its original form, even without the censorship board, because of its depiction of the liaison between master and slave. ${ }^{158}$ Indeed, so many critics of the film objected to this miscegenation that it was replaced in a re-cut version produced in 1918. In the new release, re-titled Are You Fit to Marry?, Claude's defect originated with his grandfather's liaison with an "unclean" white servant. 159

${ }^{157}$ This synopsis is distilled from Pernick's. Ibid., 144.

${ }^{158}$ As John Douglas Smith documented, the board of censors condemned any film depicting "improper" interracial relations. John Douglas Smith, "Managing White Supremacy: Politics and Culture in Virginia, 1919-1939," (Ph.D. diss., University of Virginia, 1998), 118-40. Smith concentrates on the attempts of Virginia's racist and eugenicist White Anglo Saxon Clubs to suppress the films of black filmmaker Oscar Micheaux. My research in the censorship records shows that they applied the standards they established in censoring Micheaux's work to the films of white production companies. The board rejected the 1930 film While Cargo, which it described as a "sombre but well acted photoplay" set in "a rubber plantation in a desolate, miasmatic section of Africa, where white men suffer alike from ennui and 'sex starvation." In rejecting the film, the board commented, "Miscegenation, at best, is an unwholesome theme for motion pictures, and in a State like Virginia, where the intermarriage of blacks and whites constitutes a felony, such plot material, in our opinion, would excite a universal sense of revulsion." See documents in the "White Cargo" folder, "General Correspondence and Controversial Films File" Box 56, Motion Picture Censorship Board Records RG 53, Virginia State Archives Records Center, Richmond. [Hereinafter referred to as Censorship Records.]

${ }^{159}$ Ibid. 
Retaining the 1918 revision, and further edited for re-release in 1927, Are You Fit to

Marry? did pass the Virginia censors on September 25, 1927.160 The timing of this release is crucial. Less than one month later, on October 19, 1927, Virginia would perform the first constitutionally sanctioned eugenic sterilization in America. The United States Supreme Court had upheld eugenic sterilization in Buck v. Bell the preceding May, amidst a great deal of fanfare in Virginia. ${ }^{161}$ The censorship board often consulted with officials from the Virginia Department of Public Health about the suitability of films. ${ }^{162}$

Presumably, if they consulted authorities regarding The Black Stork in 1927, those officials would have sanctioned its showing to help raise support for eugenics.

Unfortunately, very little remains indicating the circumstances surrounding this release of Are You Fit to Marry? The records indicate that the censors ordered additional eliminations from the films, but what those eliminations were is not specified. All that is certain is that the film received approval and was cleared for exhibition in Virginia theaters.

By the 1930s, however, films dealing with explicitly eugenic themes met a hostile reception from the Virginia film censors. This hostility is surprising, given the consideration accorded Are You Fit to Marry? Surveying the censorship files, one gains the distinct impression that the board's membership remained incredibly constant, thus ossifying its social views about what was and was not appropriate subject matter in films. Miscegenation, nudity, and the depiction of sexual innuendo in virtually any form routinely raised the censors' ire. Most "health" films failed to gain approval because they dealt too

\footnotetext{
${ }^{160}$ See Application for License, Are You Fit to Marry? in "Listing of Titles, Seal Numbers, and Eliminations c. 1928" folder, Box 41, Censorship Records.

${ }^{161}$ The passage of the sterilization law is discussed, in detail, in Chapter 5.

162In March of 1928, Director of the Department of Public Health Ennion G. Williams, wrote to censor Evan R. Chesterman about the anti-venereal disease film Is Your Daughter Safe? "I would appreciate it very much if you would let me know whenever this picture is referred to you," Williams wrote, indicating that he would like to screen the films. "As you know," he continued, "many of these pictures pretend to be of educational value, but really are shrewd money making schemes, capitalizing on salaciousness." This film eventually passed Williams scrutiny, and was shown to separate, sex-segregated audiences. See Ennion G. Williams to Evan R. Chesterman, March 8, 1927, in "Is Your Daughter Safe?" folder, "General Correspondence and Controversial Films File" Box 53, Censorship Records.
} 
frankly with sexual matters and were seen as immoral and obscene. Having received the board's approval once, one wonders why eugenics became unsuitable later.

Ultimately, historical context and how the film depicted eugenics accounted for the censors' change in attitude toward eugenics. In 1927 the censors deemed it politically and socially expedient to exhibit the "most explicit depiction of negative eugenics," particularly because it favored eugenic intervention. In 1936, the board approved the Paramount musical College Holiday-starring screen legends Jack Benny, George Burns, and Gracie Allen-which "used eugenics as the pretext for screwball farce."163 The film depicted eugenics in a vaguely positive light; the censors ordered only one elimination. "Cut to short flash scene of man dancing with girl, where man is in his shirt tail [presumably without pants]," commanded the censors, who found the scene so objectionable that they almost cut it entirely but left a "flash" to preserve the film's continuity. In this case sexuality, not eugenics, prompted the censors' scissors.

The censors rejected en toto two eugenics films, one for and the other against eugenics, in the 1930s. Race Suicide: The Tragedy of the Unborn, a film advocating positive eugenics, failed to win approval in 1938. ${ }^{164}$ Three years earlier, the board also rejected Tomorrow's Children, which stole its title from the eugenicist Ellsworth Hıntington's book, three times-in February and June of 1935 and June of 1941. An anti-sterilization film, Tomorrow's Children recounted the tria!s of a young woman run-afoul of her local eugenics board. Sentenced to be sterilized because her father is a drunkard, her mother slovenly, and her siblings obviously physically and mentally defective, even the efforts of a sympathetic physician and priest cannot save the girl. The female eugenic social workers are portrayed as domineering, uncaring elites; even the girl's perfect behavior-she is the sole force caring for her cacogenic family_fails to absolve her in their eyes. Even the

${ }^{163}$ Pernick, Black Stork, 160.

${ }^{164}$ See "Race Suicide: The Tragedy of the Unborn" folder, "Gencral Correspondence and Controversial Films File" Box 53, Censorship Records. No reason was given by the censors for condemning the movie. 
Judge who rules on the case is implicated in political corruption. In the case of an

obviously lewd and criminal young man, who is the son of a powerful politician, the Judge rejects the order for sterilization. The heroine seems doomed to the surgeon's knife when, in the penultimate scene, the doctor uncovers evidence that the woman is only the foster child of the defectives-a coincidence parallel to that which anointed Mirriam in The Black Stork. ${ }^{165}$ The film's message, that humans are too fallible to administer sterilization laws, actually carried a pro-eugenic undertone-the politician's degenerate son should have been sterilized. Nevertheless, in 1935, three years after Virginia achieved the second highest cumulative number of sterilizations in the nation, a film questioning sterilization was intolerable. Since it would be shown to mass audiences, perhaps awakening outrage among the relatives of sterilized Virginians (or even the sterilized themselves), the censors rejected the film en toto. The rejection order stated that the film was "sterilization propaganda" and characterized it as "Inexpedient, rejected on doctor's orders." 166 Apparently, Virginia's public health officials would not allow anyone to question the propriety of sterilization. The film received another rejection en toto in 1941, although it was exhibited briefly without the state seal in Martinsville. The owner of the theater eamed himself a $\$ 150.00$ fine from the censors. 167

Virginia officials, by 1930, no longer sought to draw wide-spread public attention to the eugenics program in the state. As the next chapters will show, after surviving the tumultuous period following the passage of the state's eugenical laws, elite eugenicists preferred to operate behind the scenes rather than in the public eye. Changes in science and broader cultural attitudes toward eugenics blew across the American intellectual landscape. This shift caused eugenicists to reconsider their public posture, and retrench to a more

\footnotetext{
${ }^{165}$ Hollywood Film Exchange, Tomorrow's Children, produced and directed by Brian Foy and Crane Wilbur, Foy Productions, 1934, Videocassctte in author's possession. Pernick, Black Stork, 132-33.

166"Tomorrow's Children" Notice of Rejection, February 20, 1935, "Gencral Correspondence and Conroversial Films, Rejections Filc" Box 53, Censorship Records.

167"Tomorrow's Children" folder, "Rejections Filc" Box 54, Censorship Records.
} 
defensive position. Eugenic education would remain focused on elite high school and college students, not the masses of Virginia's citizenry.

Mainline eugenics remained in the curriculum of Virginia colleges for one long professional generation. As the cohort of professors who had learned it as cutting-edge science during the 1900s and 1910s retired, no new generation rose to take their place. Although many scientists continued to believe in the qualitative difference between human beings, fewer and fewer remained willing to champion these ideas in public. The leading edge of genetic inquiry had swung away from human genetics, seen as too complex and dependent on poor research material to yield exciting results in the near tem. Fruit flies and plant hybrids offered rapid rates of reproduction and readily interpretable results that fueled additional rounds of investigation. With the retirement of Charles Davenport in the mid-1930s and the closing of the ERO in 1940, organized mainline eugenics lacked a viable institutional base. Yet, even as the mainline vanguard passed from the scene, mainline eugenic ideology, operating through the hosts of non-specialists who learned eugenics as part of their collegiate training, continued to effect public policy and the lives of tens of thousands of Virginians.

The progressive zeitgeist and eugenical ideology harmonized between 1910 and 1940, reinforcing the rapid transmission of eugenical theory to concrete public policy. Ultimately, Virginia's college-educated population carried the eugenic message into the public sphere. There, they formulated public policies based on eugenical propaganda learned in school. Virginia lobbyists and legislators pushed for and attained a compulsory sterilization law and an antimiscegenation law on the state level in 1924, even as nationallevel eugenicists won the battle for restricted immigration. The next four chapters document the results of these laws. Physicians practiced eugenical sterilization in state hospitals and private practice. Their use of eugenic "treatment" often guided only by their 
own prejudice and caprice. Intoxicated by the heady mixture of personal racial prejudice and mainline eugenic theory, public health officials policed the boundaries of segregation with redoubled vigor. Convinced that racial interbreeding would result in the downfall of civilization, public health officials in Virginia enforced the state's antimiscegenation statute. Outside the Old Dominion, Virginia-educated public health officers instituted medical experiments designed to prove the existence of racial differences in disease susceptibility. Finally, Jews and political radicals found themselves at the center of eugenical persecution in Virginia and Nazi Germany. The legacy of all these public policies remains with Virginia today. 


\section{Chapter V: "Sterilize the Misfits Promptly": Virginia Controls the Feebleminded}

The "Roaring Twenties" brought changes that seemed, to many Americans, to shatter every facet of life. America's economy soared as industries transformed their wartime productive capacity to creating consumer goods for the masses. The era of mass production and mass consumption also engendered "mass amusements" that transfigured American culture, opening an era of cultural homogenization as people consumed identical fare. Charles Lindbergh's "Lone Eagle" trans-Atlantic flight created the first truly national celebrity, idolized as the epitome of American technical ingenuity and rugged individualism. Yet, despite all these signs of the triumph of Progressivism, social, political, and economic tensions strained beneath the "jazz-age" prosperity-even before the era ended with the devastating stock market crash on "Black Thursday" in October 1929.1

Women voting, changing social mores where upper-class youth participated in lowerclass entertainment while blue-collar workers "aped" their "betters, Socialism, Communism, and increased militancy among African Americans, all of these dynamics impressed white elites as sure symptoms of American declension. Europe, destroyed in the recent "Great War" represented the modern technology run amok, the bane instead of the savior of western civilization. Nativists and eugenicists had warned of the impending doom both before and during the war. ${ }^{2}$ Now, with the best of Europe's genetic

\footnotetext{
${ }^{1}$ An excellent treatment of the 1920 s is Lynn Dumenil, The Modern Temper: America in the 1920s (New York: Hill and Wang, 1995). On the development of mass amuscments, see David Nasaw, Going Out: The Rise and Fall of Public Amusements (New York: BasicBooks, 1993); Kathy Peiss Cheap Amusements: Working Women and Leisure in Turn-of-the-Century New York (Philadelphia: Temple University Press, 1986); Lewis A. Erenberg, Steppin Out: New York Nightlife and the Transformalion of American Culture, 1890-19.30 (Chicago: University oi Chicago Press, 1981). For Lindbergh's cultural salience, see Lewis A. A. Scott Berg, Lindbergh (New York: G. P. Putnam's Sons, 1998), chapter 7.

${ }^{2}$ Harvey Ernest Jordan co-authored War's Aftermath: A Preliminary Study of the Eugenics of War with David Starr Jordan, the chancellor of Stanford University who also happened to be a biologist and an avid leader of the eugenics movement. This book "proved" the dysgenic effect of warfare. In the introductory essay, written in 1914 just after the beginning of World War I, Jordan wrole, "The sons of those whom war could not use replace those who gave their lives for the country. When a man of distinction gives up his life for any cause he sacrifices more than himself. He closcs the door of the lorig future of those who might have been." David Starr Jordan and Harvey Ernest Jordan, War's Aftermath: A Preliminary Study of the
} 
endowment lying dead on the battlefields of France-thanks, many eugenicists claimed, to the fateful shot of a clearly unfit, deranged anarchist-healthy "Nordic" immigration would give way to hordes of degenerate "stock" fleeing the desolation. To eugenicists, foreign immigration would now be composed only of those deemed unfit to have fought (and perished) in the war. The rise of socialist and communist revolts-first in Russia, then in Germany and Hungary — made some fear that the United States was next, leading to the post-war Red Scare. Eugenicists used the Red Scare itself to prove that the very "type" of people who started the World War had emigrated to America. ${ }^{3}$ These immigrants' genetic proclivity toward anarchism and revolution threatened the republic directly; their genes harbored the seeds of future revolt, an indirect threat one or more generations removed. Eugenicists argued for strict immigration restriction and selective breeding among "Old Stock" Americans as the only bulwark against the various -isms that promised to destroy civilization.

Especially for many southerners, the 1920s struck one sustained, ominous social and political note. New South boosterism helped urbanize the South. Urbanization seemed to cause crime and was even blamed for higher rates of insanity and "feeblemindedness." 4

Eugenics of War (Boston and New York: Houghton Mifflin Company, 1914), xviii-xix. The Journai of Heredity, successor to the American Breeder's Magazine as American eugenicists' journal of record, ran numerous articles concerning the eugenic implications of the war and the wave of immigration that would "inevitably" follow. See, "War and Biology," The Journal of Heredity 6 (February 1915): 51-53; "War's Aftermath," (review of Jordan and Jordan's book) JOH 6 (September 1915): 404-07; "The Effect of War," (review of book by D. S. Jordan) JOH 7 (March 1916): 118; "War Hurts Scientific Breeding Abroad," JOH 7 (April 1916): 168; "War, Immigration, Eugenics," (report of the Committee on Immigration) JOH 7 (June 1916): 243-48; "Emigration After the War," JOH 7 (October 1916): 477; "Immigration after the War" JOH 8 (April 1917): 147; "Some Eugenic Aspects of Military Registration," JOH 8 (July 1917): 298; "Eugenics and Military Exemptions," JOH 8 (August 1917): 360; "America's Fighting Stocks," JOH 8 (October 1917): 435-41; "Kaiserism and Heredity," and "Effect of War on Crime, Marriage and Insanity," JOH 9 (December 1918): 348-54 and 365-67; "The Fighting Ability of Different Races," JOH 10 (January 1919): 29-32; "War and Genetic Values," JOH 10 (May 1919): 223-26.

${ }^{3}$ This line of thinking culminated in Lothrop Stoddard's book Revoli Against Civilization: The Menace of the Under-Man (New York: Charles Scribner's Sons), 1922. Debates over the biological viability of democracy - whether or not humans were genetically fit for democracy - began as soon as April 1919 in the Journal of Heredity. See Edwin G. Conklin, "Heredity and Democracy," and Madison Grant, "Discussion of Article on Heredity and Democracy," and Frederick Adams Woods, "The Racial Limitations of Bolshevism," Journal of Heredity 10 (April 1919): 161-66 and 188-91.

${ }^{4}$ As late as 1942 the Virginia State Planning Board noted the correlation between urbanization and feeblemindedness, writing, "This group [the feebleminded] will become more of a social problem as the 
The chaotic jumble of people on city streets, mixing men and women, whites, blacks, and other people of color, the wealthy and the poor created a disquieting portrait for elites who prided themselves on their ability to maintain an ordered and predictable lifestyle. This sense of disorder disturbed the placid faith that an agrarian region gave rise to the best type of American citizen, the yeoman farmer. When a stricken Woodrow Wilson left office in 1921, many southerners wondered if the region would ever mount the political heights again. The end of Wilson's administration seemed both a political setback and a blow against "progressive" social projects purportedly aiding southern uplift.

Whites also witnessed an alarming display of black agency and mobility unprecedented since Reconstruction. "The Great Migration," an exodus of rural southern blacks to urban areas and the North, began in 1915 and did not end for another twenty-five years, draining millions of black workers from the South. White elites decried the loss of labor, even as they feared waves of unfamiliar, "uncontrolled," itinerant blacks passing through their communities. $^{5}$ Moreover, prompted by Frederick L. Hoffman's study Race Traits and Tendencies of the American Negro and the writings of men like Paul Brandon Barringer, southerners increasingly viewed blacks as hereditary inferiors predisposed to ciminality, disease, and insanity. 6 Not only did black/white contact threaten the white gene pool through miscegenation, but blacks posed real dangers to white civilization through crime and disease.

proportion of population living in urban areas increases, due primarily to the fact that mentally defective persons cannot easily adjust themselves to complex environments." Quoted in, Steven Noll, Feeble-Minded in Our Midst: Institutions for the Mentally Retarded in the South, 1900-1940 (Chapel Hill, NC:

University of North Carolina Press, 1995), 122. Noll traces the southern institutional response to the "menace of the feebleminded."

5 Nicholas Lemann, The Promised Land: The Great Black Migration and How it Changed America (New York: Alfred A. Knopf, 1991); James R. Grossman, Land of Hope: Chicagu, Black Southerners, and the Great Migration (Chicago: University of Chicago Press, 1989); John Hope Franklin and Alfred A. Moss, Jr., cover Red Summer in, From Slavery to Freedom: A History of African Americans, 7th ed., (New Yoik: McGraw-Hill, Inc., 1994), 340-41, 349-54.

${ }^{6}$ Hoffman was an actuary for the Prudential Life Insurance Company. He predicled black extinction as a result of the apparent rise in anti-social tendencies and mortality from syphilis, tuberculosis, and insanity. See Thomas F. Gossett, Race: The History of an Idea in America (New York and Oxford: Oxford University Press, 1963, New Edition, 1997), 281-82. 
Racial tensions rose throughout the country, in lock-step with anti-radical hysteria. While the "Red Scare" of 1919 inflamed northem fear of political radicals, the racial bloodshed in that summer and fall's riots and lynchings prompted James Weldon Johnson to dub it "Red Summer." National in scope, the rioting exacerbated tensions in the South. The second Ku Klux Klan, re-founded on Stone Mountain, Georgia in 1915, rose to its greatest strength in the early 1920s. Although it, too, was national in membership and scope, its southem origins and racial intolerance branded it as an institution of "southem" reaction. It also reflected the widespread anxiety among native-born, Protestant whites that helped fuel the eugenics movement. The Klan united a broad spectrum of American traditionalists in its march against enemies ranging from blacks to Roman Catholics, immigrants to divorced women. ${ }^{7}$

Economically "backward," many southemers also felt the region labored under a false stigma of social retardation. 8 The withering screeds of Henry Louis Mencken, writing from Baltimore, the gateway to the South, rent the cultural and intellectual fabric of Southern society. The image of the "benighted South" took root in the popular imagination. ${ }^{9}$ The 1925 anti-evolution trial of John T. Scopes brought the image of antiintellectual, anti-modem southem fundamentalist religion to the forefront of America's consciousness. As the decade came to a close, twelve southemers known as the "Vanderbilt Agrarians" penned their famous manifesto, I'll Take My Stand, extolling the virtue of a mythic Jeffersonian Southland. ${ }^{10}$

\footnotetext{
${ }^{7}$ Scholars now see the second Klan in a more sophisticated light: while on one hand it was the creation of savvy marketing and a pyramid scheme. Nancy McLean provides an insightful analysis of the Klan in Behind the Mask of Chivalry: The Making of the Second Ku Klux Klan (New York and London: Oxford University Press, 1994).

${ }^{8}$ Dewey Grantham, The South in Modern America: A Region at Odds (New York: HarperPerennial, 1995), 92-93

${ }^{9}$ Tindall, The Emergence of the New South, 208-18.

10Grantham, South in Modern America, 97, 113-14; George Tindall, The Emergence of the New South 1913-1945 (Baton Rouge, LA: Louisiana State University Press, 1967), 576-82.
} 
Even as the Klan, the fundamentalists, and the Agrarians uttered one last gasp for the Old South on the Old South's terms, grabbing headlines and making waves, eugenical advocates articulated an effective counter-narrative. Seeking to steer a middle course between Agrarian traditionalism and Progressive modemism, eugenicists created a "neoOld South" ideal. The refined racism, classism, and sexism of eugenics provided a genteel substitute for A grarian patemalism, the Klan, and lynching. As southern progressivism underwent a transformation that left the "impulse for 'good government' and public services strong" while "the impulse for reform somehow turned into a drive for moral righteousness and conformity," Virginia progressives experienced their own metamorphosis. ${ }^{11}$ Instead of rising to the bait of the Klan, the hysteria of the fundamentalists, or the recalcitrance of the Agrarians, Virginia progressives articulated a rational, "dispassionate" program of social control that emphasized social "management," racial "adjustments," public health, and education as the quadrumvirate for social harmony. Economic liberalism and urbanization could be accomplished without the negative consequences of social blight, provided the state was populated with eugenically sound people who could maintain traditional social hierarchies within the changing environment.

Elite guidance was crucial to this new ideology that merged the racial culture of the past with the technology, wealth, and progressivism of the future. Individuals at the forefront of Virginia's eugerics movement needed to increase the visibility of this eugenic solution to the South's problems. As Dewey Grantham has written, "By the 1920s, the South had become the most nativist part of the country. Aliens were defined in vague terms to include immigrants, Catholics, Jews, Negroes, Communists, and Socialists." 12 Just as southem congressmen helped lead the way for immigration restriction, Southem educators equated immigration restriction, marriage restriction, sterilization, and segregation as eugenic solutions to social problems. This effort required tact, however, because eugenics could,

\footnotetext{
${ }^{11}$ Tindall, Emergence of the New South, 219.
}

${ }^{12}$ Grantham, South in Modern America, 104. 
even in Virginia, elicit attacks from traditionalist politicians and social reformers who remained skeptical of interventionist programs.

Progressive southerners, searching for the causes of the region's social and economic malaise, joined the ranks of national progressives in blaming various groups of "problem" people. The so-called "feebleminded," the criminal, and the "delinquent"—whether black or white-all came under attack. Often lumped together under the rubrics "defective" or "mental defective," individuals accused of being delinquent, criminal, or immoral were assumed to be "feebleminded." The feebleminded needed to be controlled because, in the words of the Virginia State Board of Charities and Corrections, mental defectives were "responsible in large degree for pauperism, crime, prostitution, and other evils which burden society." 13 By the 1920s, the fear of the "menace of the feebieminded" had reached its peak. Mental health specialists, criminologists, and sociologists all began to follow the lead of eugenicists, who claimed the only way to solve social probiems was to eliminate those individuals who caused them. While euthanasia remained beyond the pale, the notion that society could be improved by preventing the further procreation of these groups gained great currency.

Many eugenically-minded progressives understood the institutional segregation of problem individuals—in penitentiaries, reformatories, asylums, and "colonies" where inmates worked at trades to sustain themselves-as a method to prevent the further procreation of "born criminals" and "moral imbeciles." By the 1920s, the cost of institutionalizing the apparently increasing numbers of "defectives" seemed prohibitive. Beyond cost, some Virginians believed that institutional care was "accually encouraging the

\footnotetext{
13 James W. Trent, Jr. presents the mcst comprehensive account of the rise of feeblemindedness as a scientific and social category in Inventing the Feeble Mind: A History of Mental Retardation in ine United States (Berkeley and Los Angeles: University of California Press, 1994); the quotation from the Virginia Board of Charities and Corrections' 1915 repcrt, Mental Defectives in Virginia, appears in Steven Noll, Feeble-Minded in Our Midst, 13. Nicole Hahn Rafter illuminates the history of "born criminals" in Creating Born Criminals (Urbana and Chicago: University of Illinois Press, 1997).
} 
anti-social classes to continue in their anti-social habits."14 Progressive eugenicists solved this problem by advocating sterilization. Sexually sterilizing "defectives" allowed them to be "paroled" back into society without the threat of creating "more of their kind." The new class, "the feebleminded" became the target for reform.

The definition of the feebleminded shifted over the course of the early 20th century, but by the 1920s the concept of feeblemindedness exhibited consistent race, class, and gender biases. The results of the Army Alpha and Beta intelligence tests purported to reveal a "rising tide" of mental defect. The tests depicted African Americans-the favored southem labor pool, and a large segment of Virginia's population —as predominantly feebleminded. Carl Brigham attributed northem blacks' superior performance to "differential migration": the smartest blacks emigrated in search of better conditions. "Duller" African Americans remained in the South. The results, and Brigham's interpretations, compounded stereotypes about black hyper-sexuality, criminality, and disease, stigmatizing blacks—and especially black women—as the most dysgenic population in Virginia. ${ }^{15}$

Poor whites, and especially poor white women, labored under stereotypes similar to those applied to African Americans. According to the Army tests, Virginia led the southem

\footnotetext{
${ }^{14}$ Virginia State Board of Charities and Corrections, Mental Defectives in Virginia quoted in Noll, Feeble-Minded in Our Midst, 20.

${ }^{15}$ Steven Noll remarks that "The apocalyptic expressions of physicians and superintendents concerning the 'menace of the feebleminded' rarely, if ever mentioned race." He attributes this silence to the agreement between white stereotypes and the Army test results. "Black intellectual inferiority was a given to these individuals [southern whites] - the army tests only verified what they had known all along. With order securely enforced by the apparatus of legalized segregation, there appeared little need for separate institutions for the black feebleminded." While these sweeping statements contain a good deal of truth, they neglect two significant features of Virginia's treaument of blacks. First, Virginia operated a segregated facility for feebleminded Atrican Americans, the first of its kind in the South. (Central State Hospital housed feebleminded blacks beginning in the 1890s despite the protests of officials who claimed the hosnital was only for the insane and indigent. Physicians began sterilizing black inmates in 1929, only two years after the first legal white sterilizations.) Second, despite being chronically underfunded, Virginia mental health professionals expended money for the eugenical sterilization of black inmates. Virginia applied its eugenic program equally to blacks, sterilizing African Americans and whites in equal proportion to each group's total population. Nevertheless, this sterilization was inherently racist, as it was done not for the "good" of the black population, but for the "good" of the white population. See Erin Himstedt, "Not For Their Own Good: African American Mental Health and Eugenic Sterilization Programs in Virginia," (M.A. thesis, University of Virginia, 1994), 44. Himstedt notes that black women incurred a higher rate of sterilization than black men (41-42).
} 
states in intelligence; however, its conscripts only averaged in the "moron" range.

Although this disheartening result could be ascribed to the effect of lower-class "mountain whites," it still undercut the traditional Jeffersonian notion of yeomen farmers as the backbone of democracy. Women posed a particular threat. Dr. H. W. Dew of Lynchburg, Virginia asserted that, "feeble-minded women are notroriously immoral," often giving birth to "illegitimate" children, including one woman who "had two illegitimate children by her own father."16 Other experts agreed with this estimation of feebleminded women. "The feeble-minded girl is vastly more dangerous than the feeble-minded boy," averred Hastings Hart, the director of the Russell Sage Foundation's Child Helping Division. "This arises partly from the fact that the feeble-minded woman is unable to protect herself, and partly from the fact that she is not affected by the moral restraints or the regard for consequences which restrain normal women." Virginians found further support for this contention by examining the records of 120 Richmond prostitutes and finding 86 of them, almost 72 percent, to be feebleminded. The State Board of Charities and Corrections's report concluded, "Feeblemindedness is responsible in large degree for the waywardness of these women. They should not be punished for doing what their heredity made almost sure, but society should segregate them where they will be protected from licentious men and lewd, avaricious women."17 Given these "diagnoses" of various groups' social pathologies, Progressive Virginians mounted lobbying efforts to pass laws that would allow for the control of these individuals through segregation and sterilization.

The Virginia eugenics movement began to achieve its legislative ends between 1916 and 1930. Virginia's experience parallels, in microcosm, that of the nation generally, as eugenicists organized within professions and mobilized to attain their goals. Outside of the academy, Virginia witnessed the rise of a devoted group of eugenics enthusiasts. Building

\footnotetext{
${ }^{16} \mathrm{H}$. W. Dew, "Sterilization of the Feeble-Minded, Insane and Habitual Criminals," Virginia Medical Semi-Monthiy 17 (April 11, 1913), 5.

${ }^{17}$ Hart quoted in Noll, Ibid., 40, statistics on 41 , second quotation on 115 .
} 
on the hereditary doctrines propounded by nationally-recognized eugenicists and supported by state educators, Virgina's would-be social engineers identified the genes of various segments of the population as the source of problems ranging from pellagra, tuberculosis, and syphilis to poverty, miscegenation, and unwed motherhood. Properly mobilized, this group then effectively militated in concert, along several fronts simultaneously, for the passage of eugenic acts.

Virginia's native eugenics promoters strengthened their affiliation with important figures in the national movement, increasing Virginia's reputation as a hospitable environment for eugenicists. The collusion between legal, medical, and educational professionals in the passage of Virginia's sterilization act reveals the homology between Virginian and national responses to fears of a rising population of feeble-minded individuals. Virginia's medical and public health community popularized the "eugenic metaphor" for public health, seeking to prevent disease through reproductive control rather than therapeutic intervention. Eugenicists argued that preventing the birth of those hereditarily predisposed to disease and anti-social behavior would decrease the incidence of "sickness" requiring therapy. The standard public health interventions of quarantine, fumigation and eradication became rhetorically paired with the eugenic notions of segregation, sterilization, and euthanasia. The passage of Virginia's laws to segregate and sterilize the feebleminded-the subject of this and the next chapter-occurred concurrently with Virginia's adoption of the Racial Integrity Act, which outlawed miscegenation between whites and non-whites (although not between native whites and white ethnics). While both Virginia acts appear to have resulted from the lobbying efforts of distinct groups, close examination reveals linkages between the efforts. Fundamentally, the adoption and implementation of these laws placed Virginia in the forefront of progressive social engineering, making its efforts match, and in many cases exceed, that of the most progressive northern states. Thus, the sectional reproachment was sealed over the bodies 
of poor whites and disfranchised blacks. Ironically, as the next chapter will show, many Virginia blacks joined in the racial purity crusade, making strange bedfellows of Pan Africanists and white supremacists.

The following chapters will examine Virginia's eugenic legislation against the backdrop of national eugenics mobilization during the 1920s. Much has been written about the eugenics legislation passed by Virginia's General Assembly in the 1920s. Little of this scholarship has attempted to synthesize these individual efforts into a coherent whole. ${ }^{18}$ Treating each enactment as the separate result of independent lobbying efforts neglects the powerful influence their common cultural context exerted in shaping public opinion. The Virginia legislature did not act in a cultural and ideological vacuum when it passed these measures. Moreover, artificially divorcing these acts neglects their common intellectual underpinning. Those who lobbied for each act were well aware of, and directly and indirectly connected to, efforts to pass the other acts. While the two acts are separated here into discrete chapters for clarity, the links between each act's principal proponents and the larger eugenics community will be emphasized. Moreover, the connections between the two lobbying efforts for the acts will be clearly developed in the course of both chapters.

Rather than being tendentious, analyzing public legislation from the vantage of eugenic mobilization reveals the subtle interaction between eugenic principle and racist expediency

\footnotetext{
${ }^{18}$ The one notable exception to this statement is John Douglas Smith, "Managing White Supremacy: Politics and Culture in Virginia, 1919-1939," (Ph.D. diss., University of Virginia, 1998). Smith's able study, however, focuses only on the racist dimension of the eugenics movement, neglecting the intraracial class and gender tensions addressed by eugenics. Nevertheless, he provides a useful framework for understanding the legislative manifestation of Progressivism as an attempt to "manage" society in along the lines of scientific business principles derived from organizational synthesis. Lisa Lindquist Dorr alludes to the connections between the acts in, "Arm in Arm: Gender and the Racial Integrity Act of 1924," forthcoming in The Journal of Southern History (September 2000). The major studies that concentrate on each act distinctly include: J. David Smith, The Eugenic Assauit on America: Scenes in Red. White and Black (Fairfax, VA: George Mason University Press, 1993); Paul A. Lombardo, "Miscegenation, Eugenics, and Racism: Historical Footnotes to Loving v. Virginia," University of California Davis Law Review 21 (1988), 421-452; Lombardo, "Three Generations No Imbeciles: ; Lombardo, "Eugenic Steriiization in Virginia: Aubrey Strode and the Case of Buck v. Bell," Ph.D. diss., University of Virginia (1982); Richard B. Sherman, "'The Last Stand': The Fight for Racial Integrity in Virginia in the 1920s," The Journal of Southern History 54 (February, 1988), 69-92; and Sherman, "The Teachings at Hampton Institute: Social Equality, Racial Integrity, and the Virginia Public Assemblages Act of 1926," Virginia Magazine of History and Biography 95 (July 1987).
} 
in shaping Virginia's culture of segregation. Actions taken "in the name of eugenics" represented both "true belief" in eugenical precepts, and the expedient use of eugenics as a mask for otherwise unvarmished racial hatred. Furthermore, eugenics provided a rationale for other forms of segregation based on class and gender distinctions, and cultural judgments about respectability or morality.

Digging beneath the obvious explanation of "progressivism run amok", the following account uncovers how politically-mobilized Virginia Progressives used eugenics as the catalyst for a political reaction that, they hoped, would establish a model structure for social management that could be copied by all the other states. In the end, the example would help to convince numerous other state legislatures to follow Virginia's lead. Virginia also provided the example for other nations flirting with eugenic social engineering. Watched with interest by the Germans, Virginia and California's experiments became part of the initial matrix for the eugenic policy that eventually lead to the Holocaust.

\section{Doctors and Delinquents: Early Eugenics Beyond the Academy}

Virginia physicians encountered the earliest instances of open eugenics discussion outside the walls of the academy. The Virginia Medical Semi-Monthly, the professional joumal for Virginia doctors, published numerous articles regarding the potential benefits of eugenic interventions in marriage and procreation. Written by practicing physicians, each of these pieces highlighted the growing eugenic consciousness among Virginia's medical establishment. The "preventive" ethos of Virginia's physicians, who saw in "hygiene" the ultimate social panacea, influenced their therapeutic approach to individual patients and to groups like blacks, women, the "feeble-minded," and the insane. Two major issues first attracted the attention of physicians: restricting marriage to the physically fit, and the eugenic segregation and sterilization of the "defective." 
In February of 1905, Dr. A. Einer of Rural Retreat, Virginia, wrote about the "Medical Supervision of Matrimony" in the Virginia Medical Semi-Monthly. This article represents an early enunciation of eugenic goals. Einer argued that physicians should certify the health—physical and hereditary—of parties contracting marriage before the state would issue a marriage license. Stating that "Just five years ago, as far as can be determined, the subject was for the first time considered in a serious way," Dr. Einer noted that, "the storm of unfavorabie comment defeated the suggestion before it could be discussed and acted upon in an impartial way." Einer argued that "no decided effort has been made by which to control diseases and improve the race by controlling marriage," despite the fact that he knew "of no more important preventive measure" than marriage restriction. "Sentiment" in marriage decisions should, according to Einer, be replaced by "A commision composed of intelligent, conscientious, non-partisan physicians" who would "render the verdict" on whether a couple should marry. Only marriage restriction promised to "hold in check the procreation of diseased and degenerate progeny." The threat of "degeneration" was real, according to Einer, for "All that is necessary is to repress the procreation of the better and higher and to multiply the number of the lower and less fit for two or three generations to make national degeneration perceptible and terribly real." Collapsing "nation" and "race" into the same category, Einer concluded that only eugenic marriage restriction could protect America from "defective and pauper progeny" which would swamp America with "unfit" people. 19

Dr. G. Frank Lydston's 1909 musings on eugenics followed Einer's early work. Lydston was well-known to established Virginia physicians as a result of an open letter he published in the Semi-Monthly's precursor, the Virginia Medical Monthly in May, $1893 .{ }^{20}$ In this article, Lydston supported the theory of racial "atavism"- that freed African

\footnotetext{
${ }^{19}$ A. Einer, "Medical Supervision of Matrimony," Virginia Medical Semi-Monthly 9 (February 10, 1905): 489-92. Einer had read this paper before the Southwest Virginia Medical Society at Bristol, Virginia-Tennessee in January of 1904.

${ }^{20}$ This article is discussed in detail in chapter 6 , below.
} 
Americans would regress to a hereditarily-determined savage state-and advocated castration of alleged black rapists. Both Lydston's 1893 and 1909 papers represent two of the earliest expositions of eugenics placed before Virginia physicians, an influential cohort of Virginia elites.

Given Lydston's early ruminations on the hereditary nature of the "negro problem" and his belief that blacks could not be improved by breeding, one might expect him to support eugenics. His 1909 article, "Some of the Difficulties in the Application of Eugenics to the Human Race," emphasized the difficulty of controlling mate selection among humans.

Lydston also discussed the question of how to define "normal" standards of fitness, debating whether eugenics should seek the physical or intellectual ideal. ${ }^{21}$ Characterizing himself as manifesting "great conservatism" in the application of eugenics to society, Lydston set out to discuss eugenics from a utilitarian standpoint. Noting that geniuses could be physically weak, morally degenerate, and as much a cull as many criminals," Lydston asked if America should "put him out of the way or segregate him?" Since the laws of heredity remained unclear-intelligent people could give birth to "culls" or be defective in some respects themselves-Lydston limited eugenic marriage intervention to assuring that the engaged couple "be proved to be physically and morally fit," rather than inscituting intelligence testing to certify fitness. Using an economic rhetoric that Justice Oliver Wendell Holmes would echo in 1927, Lydston argued that "Society has the same right as an insurance company to protect itself against loss." The calculus of social loss factored the "expense of our hospitals, asylums for the insane, prisons, and workhouses

${ }^{21}$ G. Frank Lydston, "Some of the Difficulties in the Application of Eugenics to the Human Race," Virginia Medical Semi-Monthly 14 (April 9, 1909): 16. The appearance of this article was noted in the "Current Medical Literature" of the Journal of the American Medical Association 52 (1909): 1715. Lydston was writing in response to an article published by E. Davenport (no relation to Charles B. Davenport), in the Illinois Medical Journal, "Light Thrown on Eugenics by Experiences of Animal Breeding," that was abstracted in JAMA 52 (1909): 1622-1623. Lydston would weigh in on eugenics again in 1913. See G. Frank Lydston, "Is Sterilization Destined to be a Social Menace?" Illinois Medical Journal (Derember 1913), which was also printed in the nationally-circulated Medical Record (November 8 , 1913). 
and ponderous legal machinery," to reveal that "taxing normal decent people for the support of degenerates is not only morally wrong, but an economic farce."22 Lydston supported applying negative eugenic measures to the most "unfit" far more than he advocated positive eugenic intervention in marriage selection. He thought that negative eugenics could have immediate utilitarian results without confronting the difficulty of defining normality-the seriously defective were easily identified.

Virginia physicians who read the article learned that positive human eugenics would largely fail because the "psychology" of humans stood in the way of their being bred like animals. There existed, Lydston believed, at least one "'divine' right of socially fit human beings," and that was the right to choose a sexual partner for procreation. Therefore, "Legislation by direct and radical interference will be impossible so long as the human heart throb dominates the human brain cell." While educating the public in eugenic precepts would "dc something" to improve humanity's eugenic prospects, Lydston believed that "proper physical, mental and moral training, particularly of children," would do more. With proper conditioning, heart and head might collaborate in making eugenic marriage decisions. It seemed to Lydston that, "It will be time enough to talk of the arbitrary legal application of the more minute principles of eugenics when degenerates-criminal, epileptic, insane and drunken-are prevented from marrying, and all children are reared under the supervision of the State, made healthy, well nourished and clean, and given proper mental training." 23 Negative eugenic control of the unfit seemed to offer the most direct path to improvement for Lydston. It was, for him, the logical first step toward social betterment.

"Human beings," Lydston lamented, "do the best they can to protect and rear their culis. Incubators for unfit babies and medical and surgical treatment are often irrational enough from the standpoint of eugenics. The sentimental salvation of the unfit is

\footnotetext{
22Lydston, Ibid., 17-18.

${ }^{23}$ Lydston, Ibid., 16.
} 
disastrous to the race." Lydston's negative eugenic scheme included segregation, marriage restriction, sterilization, and the most "radical" of all eugenic interventions-euthanasia. For all his protestations about being "conservative," a mainline negative eugenics argument emerges from Lydston's article. Marriage restriction should apply to "consumptives, epileptics, insane, incurable inebriates, and criminals unless they consent to sterilization." Advocating "voluntary" (individual "consent") rather than "compulsory" (state mandated) sterilization in these cases, Lydston cast himself as conservative-he was not mandating sterilization for all "culls." 24 Nevertheless, he proceeded to develop an astringent program. He believed that "all criminals and insane, epileptics, diseased prostitutes and confirmed inebriates should be regarded as culls until they have established their right to be considered 'cured'" and eligible to procreate. Should physicians and courts deem these individuals "incurable," Lydston considered them "social excreta" that "should be placed beyond the possibility of contaminating the body social." 25 Lydston thus invoked the "eugenic metaphor" for society: likening the "unfit" to excrement, Lydston argued for their segregation to prevent social "contamination." His prescription drew on medical, public health, and eugenic rhetoric.

Lydston saved his most provocative eugenic recommendations for last. Noting that Davenport called for the "segregation" of "culls," Lydston remarked, "I will go further than most and state that in my opinion some culls should be even more radically dealt with." In contrast to his earlier denigration of capital punishment, Lydston now came out in favor of capital punishment, not as a penal measure, but as a eugenic measure. Criminals should be given "full opportunity...to re-establish [their] right to freedom and membership in society." However, the incorrigible criminal should, "in extreme cases, be removed by

${ }^{24}$ Lydston, like many eugenicists, also left open the "loophole" of extramarital sex. Without any way to regulate "fornication"- which was often illegal in many states, anyway - and the associated problem of "illegitimacy," eugenicists concentrated on marriage laws to ensure that only the fit could "legally" procreate.

${ }^{25}$ Lydston, Ibid., 17. 
killing him." The executioner, became what Lydston termed the "social surgeon" who removed the "social cancer...quietly, humanely, and unexpectedly." Lydston's preferred procedure for excising human social malignancy was "A hermetically sealed sleeping apartment with a secret pipe for the admission of deadly gas" so that "the 'removal"' might "come in the still watches of the night so that death may be but the continuance of sleep." 26 The scope of the "social surgery" should extend beyond the executioner's chamber, to the asylum and nursery.

Unfortunately, Lydston lamented, "The world is not yet ready for the radical treatment of helfless inebriety, insanity, epilepsy and imbecility by 'removal at the hands of the 'social surgeon,' but, all the same, the world is paying a high price for its maudlin sentiment." Altogether too emotional, humanitarian reformers ended up wasting precious resources on the most "defective" individuals, instead of humanely euthanizing the most defective and reallocating the resources to those more worthy of the aid. People approve the hanging of murderers, but "A driveling imbecile, too obtuse to attend to nature's calls, sits all day on a commode in a hospital ward, covered black with loathsome flies, which the poor creature is too sluggish to notice and too helpless to brush away, and the world holds up its hypocritical hands and snivels in maudlin horror at him who would fain pass the chloroform." Euthanizing the most severely disabled seemed to Lydston to be the greatest mercy, because "Not to be borm is by no means always a misfortune. Being born is sometimes a calamity." 27

Despite the apparent similarities between Lydston's support for negative eugenics and the programs advocated by mainliners, there existed an important distinction between the two groups. Lydston remained firmly wedded to a Lamarckian view of heredity. His faith in acquired characteristics led him to believe that most criminals and defectives might well be rehabilitated. His eugenic schemes would apply only to the small portion of

26 Lydston, Ibid., 18.

${ }^{27}$ Lydston, Ibid., 18, 19. 
incorrigibles. Furthermore, Lydston denied the calculus of heredity that emerged from the application of Mendelian genetics. Lydston singled out the following quotation for special censure: "Let Mr. Jones be taken into court and his ancestry record be investigated. If we find his parents were dominantly bad it means that he is fifty percent. bad. If his grandparents were also bad he is twenty-five percent. bad, and so on. When he gets to ninety percent. bad, it is certain he must be colonized." 28 Such a solution seemed entirely impractical to the Lydston, who still believed in the Lamarckian idea that some acquired characters might be passed on and felt that this type of Mendelian analysis condemned men who might not ever manifest the negative attributes of their heredity. "Must he [the hypothetical Mr. Jones] perforce be condemned by mathematics? Shall the man of evil heredity not be permitted to live it down? How do we know that he has inherited evil tendencies until he has made a record which proves it?" objected Lydston. This response separated Lydston from Davenport and the other eugenicists who, although they too often invoked a mild form of Lamarckianism, truly felt that an individual's genetics did, to a great degree, predestine his or her fate.

Thus, the year before Harvey Ernest Jordan vegan touring V'irginia and presenting Mendelian eugenics before groups of social reformers, Virginia physicians encountered Lydston's interpretation of eugenics. Taken together, Lydston's two articles are significant because they serve as bellwethers of eugenic thinking within the medical press of Virginia. Both pieces reveal the increasing awareness among physicians of the importance of heredity, however construed, in shaping society. The publication of "Some of the Difficulties in the Application of Eugenics to the Human Race," the first article to explicitly address eugenics, inäicates eugenics' currency and familiarity within medical circles. The editors assumed that their readers would know and understand the basic concepts behind

\footnotetext{
28Lydston, Ibid., 19. "Colonized" in this sense means segregated for life in an institutional "colony" where inmates labored to make the colony as self-sufficient as possible, to free society from the burden of their upkeep and the threat $c^{f}$ their genes.
} 
the term. Indeed, surveying the Journal of the American Medical Association (JAMA) for the years 1893 to 1909 reveals two trends: an increasing interest in the incidence and treatment of insanity and feeble-mindedness, and a concomitant interest in eugenics. Protoeugenic sterilization first appears in the JAMA in 1908, stemming from discussions about castrating male and female insane patients. Later that year, the editors of the JAMA explicitly endorsed eugenics. "This new practical science of eugenics, then," the editors remarked, "which in the last decade has begun to attract so much attention from sociologists and anthropologists, deserves to have the benefit of some of the best thinking and careful observation and collection of statistics on the part of the more intelligent members of the medical profession." 29 So, while novel, eugenics was hardly unheard of among America's physicians and educated elites. ${ }^{30}$ In 1908, the year before Lydston outlined applied eugenics and advocated euthanizing criminals and "defectives," the Virginia Medical Semi-Monthly carried the first reports of therapeutic, proto-eugenic sterilizations performed in Virginia. Amidst the Virginia meciical community's early eugenic musings, one man was willing to conduct practical experiments with the negative side of Francis Galton's science.

Historians credit Indiana's aptly-named Doctor Harry Sharp with performing America's first self-consciously eugenic sterilizations in 1899. Citing Francis Galton as an authority, Sharp began sterilizing young male inmates at the Indiana State Reformatory at Jeffersonville. Sharp pioneered the use of vasectomy, a new procedure seen as far more humane and eugenic than castration because it left sexual function intact while destroying the individual's procreative potential. Despite the fact that no law authorized him to

${ }^{29}$ See "Race Suicide for Social Parasites"; "Eugenics"; and "Vasotomy or Castration for Perverts and Defectives?" Journal of the American Medical Association 50 (1908): 55-56; 613 (quotation); and 785. [Hereinafter referred to as JAMA.] "Eugenics" reported Alexaider Graham Bcll's address to the American Breeder's Association, calling for statistical studies and pedigree anal ysis, piquing the interesi of the editors. The JAMA ran increasing numbers of eugenics and eugenics-related articles up through the 1930s.

${ }^{30} \mathrm{On}$ the popular spread of eugenics, see Kevles, In the Name of Eugenics, 57-63; and Higham, Strangers in the Land, 150-51. Higham notes that between 1910 and 1914, "general magazines carried more articles on eugenics than on the three questions of slums, tenements, and living standards combined." 
perform these procedures, Dr. Sharp argued that the "higher," natural laws of heredity demanded that the state stop "permitting idiots, imbeciles, and degenerate criminals to continue the pollution of the race simply because certain religionists teach that 'marriages are made in heaven' and that the 'function of procreation is jivine."' Sharp felt that such religious scruples actually represented "the most damnable heresies" rather than fealty to divine injunction. Sharp continued to sterilize his "patients" without benefit of law until 1907 when the Indiana legislature and governor, following the abortive attempts of Michigan (1897) and Pennsylvania (1905), successfully passed and approved "an act to prevent procreation of confirmed criminals, idiots, imbeciles and rapists" who physicians deemed to be incorrigible wards of the state. ${ }^{31}$

While Indiana had Dr. Harry Sharp, Virginia also had its extra-legal eugenic pioneer. As Paul A. Lombardo noted, "Although Charles Carrington received little of the national attention that attended...Harry Sharp or other pioneer advocates of sterilization, he was among the first to perform the procedure on an institutionalized pop!nlation."32 Surgeon for the Virginia Penitentiary in Richmond, Dr. Carrington announced the results of two sterilization operations at the 1908 meeting of the National Prison Association, in a speech that was reprinted in the Virginia Medical Semi-Monthiy and subsequently abstracted in the

${ }^{31}$ Allan Chase, The Legacy of Malthus: The Social Costs of the New Scientific Racism (New York: Alfred A. Knopf, 1977), 125.

${ }^{32}$ Lombardo, "Eugenic Sterilization in Virginia," 86 note 37, 104. Lombardo's pathbreaking work on eugenic sterilization in Virginia presents the most comprehensive and accurate treatment of the subject in a single state. Erin Himstedt covers the sterilization of Virginia's blacks in, "Not for Their Oun Good: " (M.A. thesis, University of Virginia, 1994). Other important treatments of eugenic sterilization in America include: Philip R. Reilly, The Surgical Solution: A Histcry oj Involuntary Sterilization in the United States (Baltimore and London: The Johns Hopkins Uni:crsity Press, 1991); Jonas Robitscher, Sterilization (Springfield, Ill.: Thomas, 1973); The single most comprehensive source on eugenic sterilization from 1924 to 1965 is Julius Paul's unpublished manuscript, "'...Three Generations of Imbeciles Are Enough...': State Eugenic Sterilization Laws in American Thought and Practice," TMs, photocopy in author's possession. The finest primary sources are probably Leon Whitney. The Case for Sterilization (New York: Frederick A. Stokes Company, 1934): E. S. Gosney and Paul Popenoe, Sterilization for Human Betterment: A Summary of Results of 6,000 Operations in California, 1909-1929 (New York: MacMillan Company, 1931); and Harry Hamilton Laughlin, Eugenical Sterilization in the United States: A Reporı of the Psycropathic Laboratory of the Municifal Court of Chicago (Chicago: Psychopathic Laboratory of the Municipal Court of Chicago, 1922). 
JAMA. ${ }^{33}$ Carrington, born in Greenwich, Virginia, graduated from the University of

Virginia Medical School in 1889, where he studied under James Lawrence Cabell and Paul Brandon Barringer. Undoubtedly, Carrington first learned about heredity and developed his hereditarian ideas regarding "fitness" and "delinquency" from these two men. ${ }^{34}$

Carrington eventually published three papers advocating the sterilization of criminals in the Virginia Medical Semi-Monthly. ${ }^{35}$ The first two papers, reported the results of two sterilization operations Carrington had performed upon inmates of the Virginia State Penitentiary. The first "patient" was a black man who, after being "sentenced to the penitentiary for an especially brutal murder," became "so violent and homicidal in his actions that he was adjudged insane, and sent to the Colored Insane Asylum, at Petersburg, Virginia." After being transferred to the Petersburg facility—Virginia prided itself on being so progressive that it operated segregated institutions for its black insane and feeble-minded populations-the prisoner killed another inmate and "nearly killed" an attendant.

Carrington considered the prisoner "the wildest, most violent, and the most homicidal devil I have ever dreamed of seeing." He further de-humanized the inmate, describing him in the classic terms of the sexually perverted, animalistic "black beast-rapist." Carrington wrote, "He was also the fiercest, most consistent masturbator I ever heard of; as strong as a bull, as cunning as a hyena, and more ferocious and quite as dangerous as a Bengal tiger."

${ }^{33}$ Charles A. Carrington, "STterilization of Habitual Criminals, With Report of Cases," Virginia Medical Semi-Monthly 13 (December 11, 1908): 389-390; and "Stcrilization of Criminals," JAMA 52 (1909): 73-74. Carrington was not the first Virginia physician to call for the sterilization of criminals. Doctor Jejse Ewell advocated castrating rapists in a paper read before the Medical Society' of Virginia, in Charlottesville, 1906. See Jejse Ewell, "A Plea for Castration to Prevent Criminal Assault," Virginia Medical Semi-Monthly 11 (January 11, 1907): 463-64.

${ }^{34}$ The University of Virginia Catalog for 1888 shows that Carrington attended Cabcll's courses and received a "diploma" in anatomy in 1888. The 1889 Catalog reveals that he took Barringer's courses and completed his medical degree in 1889. See also Lewis D. Crenshaw, ed., Directory of the Living Alumni of the University of Virginia (Richmond, VA: W. C. Hill Frinting Co., 1921).

${ }^{35}$ Charles Carrington, "Sterilization of Habitual Criminals with Report of Cases," 389-90; Carrington, "Sterilization of Habitual Criminals," Ibid., 14 (December 24, 1909): 421-22; and Carrington, "Hereditary Criminals-The One Jure Cure," ibid., 15 (April 8, 1910), 4-8. See also Kevles, In the Name of Eugenics, 108. Paul A. Lombardo discusses Carrington's career as a prelude to Virginia's successful effort to obtain a sterilization law; my analysis differs significantly in its concentration on teasing out the race, class, and gender implications of Carrington's effort. Lombardo, "Eugenical Sterilization in Virginia," $104-08$. 
Shouldering his professional burden, Carrington "determined to tame him," and-without benefit of legal warrant-performed a vasectomy on the man in 1902. Six years after the operation, Carrington reported, invoking bamyard imagery, that the man had become "'a slick, fat, docile prisoner, a trusty about the yard—cured by sterilization."'36

The second "subject" to come under Carrington's knife, was "a debased little negro," whom Carrington characterized as "a notoriously lusty, beastful Sodomist and masturbator." Sterilized in 1905, the man was "now a strapping, healthy-looking young buck...."37 Again, the description of the second man's blackness, alleged criminality and immorality rendered him as an "other"—an individual not entitled to the autonomy granted to "normal," white Virginians. Instead, in both cases, these men earned the "privilege" of being subjected to the paternal control of a physician who, not coincidentally (and despite his extralegal and therefore unethical operations), happened to be a member of elite white Virginia society.

That Carrington chose to experiment on imprisoned and institutionalized black men should come as no surprise. American physicians, particularly those in the South, routinely performed experimental procedures upon individuals living at the margins of society, because they presented the least formidable opposition. Poor, disfranchised, and uneducated, lower-class blacks, poor whites, and women could not mount effective defenses against powerful, self-righteous authorities who believed they operated objectively, morally, and in the public interest. Stigmatized as diseased threats to the moral and physical sanctity of upper-class white America, doctors viewed these individuals as fitting subjects for vivisection. ${ }^{38}$ Hiding behind the physician's authority and prerogative

\footnotetext{
${ }^{36}$ Carrington, "Sterilization of Habitual Criminals, With Report of Cases," 390.

${ }^{37}$ Carrington, Ibid., 390; and Carrington, "Sterilization of Habitual Criminals," 422.

${ }^{38}$ For discussions of the abuse of human experimentation, and the particular abuse of blacks, see Susan E. Lederer, Subjected to Science: Human Experimentation in America before the Second World War (Baltimore and London: Johns Hopkins University Press, 1995), 15, 76, 107, 115-16, especially 121-23; and Lawrence Hammar, "The Dark Side to Donovanosis: Color, Climate, Race and Racism in American South Venereology," Journal of Medical Humanities 18 (1997): $40-47$.
} 
to perform "therapeutic" interventions, Carrington mounted a personal crusade to "Stop the breed!" of criminals in Virginia. ${ }^{39}$

Carrington's depiction of the patients' "recoveries" underscores how such "therapeutic" sterilization actually conflated scientific, medical, penal, and moral objectives. Sterilization proposed to fix multiple ills and buttress the social and cultural status quo from a number of angles simultaneously. While Carrington's use of imprisoned black men of allegedly immoral tendencies minimized the chance of objection, the fact that the operation appeared to have had a salubrious effect nullified the possibility of protest. This dynamic would hold true even if Carrington moved on to sterilizing white criminals. ${ }^{40}$

Even as Carrington cast his experiments as penal reforms "in an age of reformation and advancement in our ideas and modes of treatment of criminals," he also implicitly understood them as eugenic. ${ }^{41}$ Steilization represented a eugenic measure because if it were "properly enforced with habitual criminals, we would have fewer criminals." Carrington linked criminality to heredity and, foreshadowing the logic of later judicial opinion, claimed that three generations of criminality established the genetic basis of crime because, "certain families, from father to son, to grandson, furnish recruits regulariy for our army of criminals." Certainly, he reasoned, "if the grandfather had only been sterilized, what a lot of crime and suffering would have been prevented." 42

Carrington's second paper, an address at the 1909 annual meeting of the Medical Society of Virginia, called on the assembled physicians to lobby for a sterilization statute as

\footnotetext{
${ }^{39}$ Carrington, "Sterilization of Habitual Criminals, With Report of Cáses," 389. Carrington averred that "in each case it [sterilization] was as proper a health measure as the removal of an appendix, or the cutting off of a palate could have been" (390).

${ }^{40}$ Carrington never reported sterilizing whites. His second paper mentions two more cases, who werc "insane, debilitated masturbators" of undisclosed race. Carrington, "Sterilization of Habitual Criminals," 422. In his third paper, Carrington claims to have sterilized twelve men, only two of whom were n.t "insane masturbators." Of those two, one was "an epileptic masturbator" of undisclosed race; the nther was a "habitual criminal" who "judging from his color, is the son of a negress by sorne degenerate white man" and may well have been the second case Carrington sterilized. Thus, it appears tnat he may have only operated on African Americans.

${ }^{41}$ Lombardo, "Eugenic Sterilization in Virginia," 107 note 15.

${ }^{42}$ Carrington, "Sterilization of Habitual Criminais, With Report of Cases," 389-90.
} 
a matter of preventive medicine. Likening sterilization to Jenner's smallpox vaccination-. again foreshadowing later judicial opinion-Carrington asserted that "The medical mind of this generation, as well as that of previous generations, is centered on the great basic proposition of prevention." Sterilizing criminals wculd, in "fifteen o- twenty years" result in an "immense" decrease in criminality by preventing the birth of criminais. ${ }^{43}$

Other physicians followed Carrington's lead and sterilized black men. Dr. Bernard Barrow of Barrow's Store, Virginia reported on his eugenic sterilization of five black men in June of 1910. Unlike Carrington, Barrow sbtained the "consent" of his patients. ${ }^{14}$ Like Carrington, Barrow made explicit links between his use of vasectomv and the ultimate solution of the South's "negro problem." Interested in safeguarding white society through the sterilization of black "defectives," Barrow reported his operations to curry the opinion of other white physicians. "As Southern gentlemen," Barrow began, invoking images of ante-bellum paternalism, "with the usual sympathy and kindly feeling for the weak in mind, if strong in body and vicious in his desires, it becomes you to be as tolerant, sympathetic and helpful to even the worse [sic] element of our negro polpulation as reason will alow you to be...." Blacks needed white paternal control, according to Earrow, because, "The negro, as a savage race, cannot solve his social and sanitary problems, and he should not be blamed for it; it is a responsibility which rests on the shoulders of the stronger race-the white man." Shouldering the "white man's burden," Virginia physiciars could help improve black breeding. Barrow relt that "defective" blacks "with innerited savage instincts, many tirnes with strong bodies but little inental and no more development, procreate much more rapidly than those that have taken on many of the qualities of civilization." Thus, "defecrives" were increasing, and 'the physician, as a scientific man and the guardian of the physical well-being of future generations should be a competent

\footnotetext{
${ }^{43}$ Carrington, "Sterilization of Habitual Criminals," 421.

44Judging from Barrow's report, however, the degree to which the men he sterilized understood the procedure remains questionable. His claim that vasectomy could be reversed by "a delicate operation" was a great overstatement that undoubtedly misled some of the men.
} 
judge as to those who should not be deprived of this function of procreation." Barrow then explained why blacks would willingly submit to sterilization. Since "the average defective negro, who naturally wishes to shirk every buden and responsibility, and especially that of providing for his offspring," sterilization wouid appeal to him "as a remedy which will allow the gratification of his excessive sexual appetite without the usual results to follow." Barrow then affirmed the positive benefits accruing from sterilization: "it usually improves the general health and the manly vigor of the individual" and it might be reversed "by a skillful operation". If physicians could increase the use of sterilization among "this defective class of negroes," Barrow asserted that "within a few generations its effect will be so far-reaching that it will go a long way towards solving the negro problem by eliminating the vicious, criminally inclined, disease bearing portion of the race." 45 Coverage of these early experiments transformed them from an abuse of individual liberty and the doctor/patient relationship, to a rational, objective intervention for the benefit of the patient and society. No progressive could ask for anything more.

Based upon the "positive" outcomes of his eugenical experiments, Carrington led Virginia's first crusade for sterilization legislation. In 1910, Carrington lobbied for the passage of his bill "to prevent procreation by' confirmed criminals, idiots, imbeciles, and rapists," and read the bill before the Tri-State Medical Association. ${ }^{46}$ Carrington used the bamyard analogy first invoked by Jefferson as the basis of his eugenics, arguing, "We may become a nation of good animals if we direct the same intelligence to the breeding of human beings that we do to the improvement of domestic animals." Dr. Carrington acknowledged that, "Not all crime is a direct result of heredity." Nevertheless, he echoed Barringer when he employed "'atavism' or the tendency of nature 'to return to type'" as "recognized generally by scientists as the most potent causal factor in crime" and open only to eugenic

\footnotetext{
45 Bemard Barrow, "Vasectomy for the Defective Negro with his Consent," Virginia Medical SemiMonthly 15 (August 10, 1910): 226-28.

${ }^{46}$ Carrington published the text of the bill in his third article, "Hereditary Criminals," 6. See also Virginia Bills, 1910. (Senate) No. 298.
} 
reform. Relying on an economic analysis of the increase in crime and its cost to

Virginians, and drawing an explicit parallel between Richard Dugdale's The Jukes-the urstudy of eugenics-and "families in Virginia who have been constantly represented on our penitentiary rolls from grandfather to son, and now grandson," Carrington built his case for a sterilization law.

Carrington modeled his bill on the 1907 Indiana sterilization statute, and lauded that bill's progenitor Dr. Harry Sharp—the pioneer of vasectomy in America who had by 1910 performed over 500 operations under the law-as one of the "leading criminologists and humanitarians of the century. "47 Every state institution must, under the provisions of Carrington's bill, make mental examinations of its inmates. If such an inquiry revealed that the inmate was an incorrigible "criminal, a rapist, an idiot or imbecile," then it would be lawful to "perform such operation for the prevention of procreation by said inmate as shall be decided safest and most effective." To prevent surgeons from building a cottage industry in sterilization, the statute provided that in no case could the consultation fee exceed five dollars.

The language of the draft sterilization bill appeared to target men. Criminals and rapists remained categories commonly thought of as almost exclusively male, although women could fall into the "idiot" and "imbecile" classes. Carrington himself seems only to have performed sterilizations on male piison inmates, probably because those were the "patients" he had access to in his capacity as surgeon for the Virginia penitentiary. In each of his three papers, moreover, Carrington helpfully described the procedure for vasectomy. Women, however, did not entirely escape his attention. Arguing that, "Generally speaking a feeble-minded man has to find a feeble-minded woman before he can procreate; a feebleminded woman has no such limitations," Carrington revealed his sexual double-standard. He assumed that "normal" women would never be duped into sexual congress with

\footnotetext{
${ }^{47}$ Carrinton, "Hereditary Criminals," 6.
} 
"feebleminded" men (although they might be raped by them, as Carrington and others often elided the distinction between inborn criminality and feeblemindedness), because of their innate sexual reserve. "Normal" men, however, could indeed engage in sexual congress with feebleminded women in one of two ways. Subject to the vicissitudes of the "sex impulse," otherwise "honorable" men might be seduced by morally loose, feebleminded women. Less "honorable," but still "normal," men might prey on the weakened moral sense of feebleminded women to gratify their "normal" sexual desires. Abnormal men, whether feebleminded or criminal, could also capitalize on the reduced moral capacity of feebleminded women, according to Carrington and other experts. So, Carrington believed that "women may be sterilized as well as men-the operation on them being almost as easily done, for it consists in ligating the fallopian tubes." 48 So, while Carrington himself practiced on men, largely because of their availability, he enunciated the rationale for sterilizing women that would, over the course of time, result in women being sterilized almost twice as frequently as men. Whether focusing on "born criminals" or the "feebleminded," men or women, sterilization already looked attractive to many legislators.

Despite endorsements from the Virginia Medical Society and the House Committee on Prisons and Asylums, as well as passage by the state Senate, the bill was killed by members of the Virginia house. The editor of the Virginia Medical Semi-Monthly opined,

it has evidently been hard for many to disassociate the idea that sterilization in the criminal was done for other purpose than that of punishment; consequently, with strong prejudices to overcome, such bill must await a better understanding of its true object, when, perforce, sentiment will give way to reason, and the prevention of procreation in selected cases will be demanded by law. 49

Although failing in 1910, this effort laid the initial legislative planks in Virginia's eugenical platform. ${ }^{50}$ Building on this floor, Virginia eugenicists would succeed, fourieen years

${ }^{48}$ Carrington, Ibid., 7.

49 "To Prevent Procreation by Confirmed Criminals, Idiots, Imbeciles and Rapists," Virginia Medical Semi-Monthly 15 (April 8, 1910): 23.

50Lombardo, "Eugenical Sterilization in Virginia," 107. By 1912, Dr. L. S. Foster championed eugenic sterilization before the annual mecting of the Virginia Medical Society. 
later, in passing the eugenic sterilization law that would lead to the landmark 1927 Supreme Court case Buck v. Bell. The precedent set in Buck established the constitutionality of eugenic sterilization in America; a precedent that still stands, today.

Placed into their national context, and against the background of eugenical mobilization at Virginia's flagship medical school, these Virginia physician's efforts to obtain a sterilization law so not seem particularly extreme. These men viewed themselves as the scions of science, the heralds of a progressive utopia. Eugenics was the preferred "specific" remedy for many social ills, but its real appeal lay in the preventive promise of "cutting off the supply of defective germ plasm." Physicians mobilizing for eugenic sterilization in the 1910s stood at the nexus of science and society, where cutting-edge technology slashed through encrusted cultural taboos. Sterilization remained, in the 1910s, a controversial solution that aroused "strong public sentiment" in Virginia. As such, proponents of eugenics tailored their arguments to reach other educated and "progressive" elites-policy makers, legislators, and public officials—rather than the general public. ${ }^{51}$ Supporters of eugenics believed that only the most "altruistic" individuals would willingly accept limitations on their personal freedoms "in the name of eugenics"; other foiks would actively, if ignorantly in the eugenicists' view, resist eugenic intervention-particularly sterilization. 52

Ultimately, as Edward J. Larson reminds historians, "Some time interval inevitably exists between the formation of new scientific theories and their integration into medical or

51 Ibid., 108, 109.

52 Most eugenicists argued that, properly educated, many of the "unfit" would choose not to procreate. Carrington made this contention explicitly, citing "The incontestable fact...that many of this class prefer not to procreate, and when they see the good effects of sterilization, voluntarily submit to being sterilized." Carrington, "Hereditary Criminals," 7. In 1934, Leon F. Whitney made the same argument, in more crass terms. "Give them [the "high-grade feebleminded"] the necessary information and instruction and let them decide for themselves.... Here is a nice shiny automobile; and hore is a baby.... Here is a television apparatus, the newest and best on the market. Will you choose that, Mr. Moron, or would you like another baty?"

Whitney, The Case for Sterilization, 275. 
mental health practices. 53 In Virginia, given the close affiliation of important academic medical men with the national eugenics movement, this time lapse remained quite brief on the professional level. Academic physicians trained practicing physicians through the medical school and interactions in medical societies, hastening the acceptance of eugenics. Virginia public health and custodial-care physicians perched near the apex of eugenic mobilization, rapidly responding to the call of the academics. Significant time lags, however, did exist between the first professional discussions of eugenic sterilization and the enactment of a public law authorizing the procedure. Once institutionalized through public policy, another time lag developed between sterilization and the advance of professional knowledge. Sterilization in Virginia persisted long after most mental and public health authorities abandoned it as inappropriate and ceased performing operations. Eugenic sterilization's "punctuated evolution," a kind of call and response between theory and practice, explains why it took a decade to achieve a sterilization law. ${ }^{54}$ These time lags also account for the subsequent durability of sterilization as a treatment in Virginia, throughout the twentieth century.

While sterilization represented one way to handle "defective delinquents," institutionalization presented another option. Virginia's attempts to provide institutional facilities for the segregation of the feebleminded combined with the early thrust for a eugenic sterilization law. Founded in 1908, the yearly reports of Virginia's State Board of Charities and Corrections (BCC) echoed national fears about the "menace of the feebleminded" and the need to control their procreation. 55 Moreover, corrections

\footnotetext{
${ }^{53}$ Edward J. Larson, Sex, Race, and Science: Eugenics in the Deep South (Batiimore and London: Johns Hopkins University Press, 1995), 120.

${ }^{54}$ The term "punctuated evolution" was inspired by the evolutionary notion of "punctuated equilibrium," wherein change occurs rapidly in short intervals separated by long periods of stasis. First propounded by Niles Eldredge and Stephan Jay Gould, this idea is discussed in their chapter, "Punctuated equilibria: An alternative to phyletic gradualism," in T. J. M. Schopf, ed., Models in Paleobiulogy (San Francisco: W. H. Freeman, 1972), 82-115.

55Lombardo, "Eugenic Sterilization," 88-95; Arthur W. James, Virginia's Social Awakening: The Contribution of Dr. Mastin and the Board of Charities and Corrections (Richmond, VA: Garrett and Massie, Incorporated, 1939), 170-71.
} 
authorities returned to fears of "born criminals," individuals hereditarily predisposed to crime. Relying on circular logic, penologists and criminologists believed that recidivism and habitual criminality indicated an inborn tendency; simultaneously, they believed that most criminals were feebleminded and therefore hereditarily tainted. So, "correctable" inmates became the exception, not the rule, a significant shift from late-ninereenth century notions of penology and penal reform. Under this new paradigm, society could only protect itself from "the criminal class" through incarceration-the segregation of "deviants" from the normal. Over time, sterilization came to be seen as a preventive measure that would reduce crime limiting the procreation of criminals. ${ }^{56}$

Not all criminals and delinquents, however, were men. The penal approach to women shows a clear connection between eugenics, class, and middle-class standards of morality. One arm of Virginia's movement for penal and social reform emphasized the creation of "homes" for "wayward" women. As the discussion of Lawrence Thomas Royster's career revealed, efforts to "save" Virginia's wayward women began as an extension of the settlement house initiatives of reformers like Jane Addams. ${ }^{57}$ The 1908 fundraising drive mounted by Royster and Richmond's reform elite resulted in the purchase of a farm. Two years later, the Virginia's first reformatory for girls opened, with a capacity of twenty-five. Located in Bon Air, Virginia and known alternately as "Bon Air," "Kilbourne Farm," and "The Reformatory," the school was essentially a work-house that segregated "vicious" women from society, and sought to "reform" them. For the next six years the institution's operations were based on strict Victorian notions of sexual propriety. 58

\footnotetext{
1997).

56 Nicole Hahn Rafter, Creating Born Criminals (Urbana and Chicago: University of Illinois Press,

${ }^{57}$ For the discussion of Royster, see chapter 3.

${ }^{58}$ Paul W. Keve, The History of Corrections in Virginia (Charlottesville, VA: University Press of Virginia, 1986), 167-170. Virginia also had one of the nation's first settlement houses for AfricanAmerican women. Founded by Janie Porter Barrelt in 1915, the state acquiesced in funding the Virginia Industrial School for Colored Girls in 1920. It probably maintained ties with the Central State Hospital and Petersburg Colony - which served feebleminded blacks - that paralleled those between Bon Air and white state hospitals. Odem, Delinquent Daughters, 119; Keve, Virginia Corrections, 174-79.
} 
As hereditarianism and the emphasis on economic efficiency overawed Victorian

moralism and "sentimentality," the attitude of Virginia's reform community changed. As noted above, the spectral "menace of the feebleminded" and a lurking fear about "delinquent" children, coupled with the sexual double standard that held women to a more rigid moral code, placed young women at a distinct disadvantage. Reproductive biology, because conception and gestation occur inside the fernale, marked women as ready targets for reform. Class based fears of "race suicide" caused by highly-fecund lower-class mothers "out breeding" upper-class women, sparked eugenic concern. The social stigma of "illegitimate" children, the product of "fornication" and sexual avarice, reinforced images of lower-class women as the source of the least fit children. Most eugenically-minded physicians and social workers operated on a simple syllogism that damned unwed mothers and their children to "feeblemindedness." These professionals viewed sexual promiscuity and unwed pregnancy as markers of feeblemindedness, feeblemindedness was hereditary, and since "like beget like" then "illegitimate" children must, de facto, be feebleminded or at least tainted. Many officials believed any young woman convicted of a crime or a moral violation (like prostitution) was likely hereditarily tainted and very possibly incorrigible. Such women must be segregated in institutions to protect society. They might be released only under one of three conditions: they reformed (unlikely), aged beyond child-bearing age, or underwent sterilization. Only such draconian measures as these could protect society. 59

The state took control of Bon Air in 1914, and almost immediately moved to replace the superintendent with a "professional" expert trained in the modern administration of a "progressive" reformatory. Virginia authorities turned to a woman trained by America's

${ }^{59}$ Mary E. Odem, Delinquent Daughters: Protecting and Policing Adolescent Female Sexuality in the United States, 1885-1920 (Chapel Hill, NC: University of North Carolina Press, 1995), chapter 4, especially 96-97; Ruth M. Alexander, The "Girl Problem": Female Sexual Delinquency in New York, 1900-1930 (Ithaca, NY and London: Cornell University Press, 1995), chapter 2; and Regina G. Kunzel, Fallen Women, Problem Girls: Unmarried Mothers and the Professionalization of Social Work, 18901945 (New Haven, CT and London: Yale University Press, chapter 2, especially 53-55. 
most prominent eugenicists, Ms. Anna Marie Peterson. Ms. Peterson held a bachelor's degree from Western Reserve, and she had attended the Eugenics Record Office's training class for eugenical field workers in the summer of 1914. At the ERO she had been instructed by Charles B. Davenport and Harry Hamilton Laughlin. From the ERO, Peterson landed a job as a research fellow at the famous Vineland Training School in New Jersey. There she worked directly under Henry Herbert Goddard, America's foremost authority on female mental defectives and their eugenic treatment. Following this apprenticeship, Ms. Peterson leaped at the chance to bring Bon Air into line with the modern eugenics movement's notion of penal reform. In effect, she Datrolled the line between "normal" society and "deviant" behavior. Acting as gatekeeper, she decided which inmates might be retrained and "paroled" back into society, which were "incorrigibles" who needed indefinite segregation, and which of her charges were so feebleminded that they needed to be transferred to another institution and sterilized. She had been trained for these tasks by the most modern agencies available.

Peterson's instructor in eugenics, Harry Hamilton Laughlin, kept close tabs on her post-graduate activities, reporting them proudly in the Eugenical News. After receiving Ms. Peterson's "First Annual Report," Laughlin announced that it "displays an intelligence, an enthusiasm, and a breadth of vision that promises well for her success." A month later, Laughlin excerpted an article from the Richmond News Leader that commended Peterson's efforts. A year later, Laughlin reported that although, "The institution, formerly known as Bon Air, attained in former times a very unsavory reputation," Peterson had "instituted discipline and modern reform". He went on to note that Ms. Peterson had the support of her board and, "although modern field studies in eugenics have not been initiated, she has organized a field parole service." 60 Peterson also invited volunteers from various professions to come teach and study at Bon Air. Notable among these efforts was

\footnotetext{
${ }^{60}$ Eugenical News 1 (May, 1916): 34; Eugenical News 1 (June, 1916): 42, Eugenical News 2 (June,
} 1917): 43. 
Peterson's drive to have a physician give lectures on sex hygiene, one of the imperatives for awakening a eugenic sensibility in these women. Sex hygiene would hopefully allow them to avoid venereal infection and pregnancy, both measures that would have a dedicedly eugenic effect. 61

Although Peterson only stayed five years, she trained her successor Margaret Bair. Ms. Bair remained another twenty-two years, well into the period of eugenic sterilization. As a result, the Bon Air facility funneled so-called "defective delinquents" - that is, "high grade moron" girls- to state hospitals first for eugenic segregation, later to receive sterilizations. ${ }^{62}$ Ms. Peterson ushered in an era of applied eugenics in Virginia's approach to female "delinquents" that outstripped her institution. By 1930, the social worker at the Norfolk "rescue" home claimed, "sterilization is a wonderful blessing for the feeble-minded girl who is bound to become a repeater." These homes, both state run and private eleemosynary institutions, began to funnel women to the eugenic surgeon's table. As the Norfolk social worker remarked happily, "just this week we are sending one of these unfortunates to the hospital for the operation." 63

With the effective segregation of the feebleminded and the institutionalization of criminals and "delinquent" children, Virginia had created a formidable "first-line" of defense against the "mongrelization" of the state's best "blood." Institutionalization, however, despite its efficacy in removing the unfit from pl.blic life and sharply limiting their procreation, failed the progressive era's litmus test for advisable social intervention on

${ }^{6}$ Keve, Virginia Corrections, 172.

62Jean Underwood Thomas, "Bon Air Learning Center: 1910-1970," (Ph.D. diss., Curry School of Education, University of Virginia, 1984), 107-09, 217-19.

${ }^{63}$ Superintendent's Report, Florence Crittenton Home, Norfolk, Virginia (1930), quoted in Kunzel, Fallen Women, Probiem Girls, 53. The National Florence Criuenton Mission, founded by pharmaceutical millionaire Charles Nelson Crittenton, founded a chain of "rescue" homes designed to reform "wayward" women. As Regina Kunzel notes, "some Crittenton and Salvation Army homes formed a quasi-official partnership with the court system by providing an alternative to jail or reform school." (15) It is clear that in Virginia's case, the Crittenton Home formed a "quasi-official" rclationship with Virginia's state hospitals, directing women there to be sterilized so that they could return to society' without risk of becoming "repeaters"—women who had multiple pregnancies out of wedlock. 
a number of grounds. First and foremost, institutionalization seemed economically

inefficient. Segregation saved society from the threat of tainted blood and crime, but it cost society directly and indirectly. Directly, it cost the state thousands of dollars per year to keep an inmate segregated from society. Indirectly, with inmates taken out of public life, and away from any chance to make their own living, it cost society factors of labor. These concems resonated strongly in the cash-poor and labor-dependent South. Thus, Southem progressives welcomed the notion of "colonial" institutions.

Under the "colony" system, managers expected inmates to work at menial jobs in farm and basic industry that would make the institution as nearly self-sufficient as possible. Inmates would spend their time not in treatment, for most were deemed incorrigible, but instead in productive activity ranging from subsistence farming to handicrafts and light industry. 64

"The shiftless, ignorant, and worthless class of anti-social whites of the South": Virginia's Campaign for Eugenic Sterilization

As Paul Lombardo noted, "Virginia had been a pioneer, historically, in the institutional care of the mentally ill."65 A century before James Lawrence Cabell founded the state's first public health board, colorial administrators sought to care for both the insane and the society in which they lived by establishing a public institution for their care. Opened in October of 1773, Virginia's "Publick Hospital for Persons of Insane and Disordered Mind"

\section{8.}

${ }^{64}$ For a useful summary of the genesis of the colony systcm, Noll, Feeble-Minded in Our Midst, 35-

${ }^{65}$ Lombardo, "Eugenical Sterilization," 69. The following discussion of Virginia's effort for eugenical sterilization draws heavily on Lombardo's work, especially his article, "Three Generations, No Imbeciles: New Light on Buck v. Bell," New York Law Review 60 (1985), 30-62. Nevertheless, my interpretations stem from my own reading of the primary documents. The differing scope of the studies-Lombardo narrowly focused on the sterilization act as antecedent to $B u c k$, and my wider view of the act as part of a more general impulse-differentiates the two and results in new interpretations and conclusions. J. David Smith and K. Ray Nelson's sensational The Sterilization of Carrie Buck presents a melodramatic narrative drawn from Lombardo's thesis and other familiar material. Of note, however, is the inclusion of several documents from Carrie Buck's confidential medical records, obtained as the result of a concerted lobbying campaign on the part of Smith and state Senator Elliot Schewel. 
remained the only state-sponsored institution of its type in America until 1824. In 1828 Virginia opened a second hospital for the insane in the Shenandoah Valley at Staunton, Virginia. Three years after the Civil War, in 1868, Virginia again led the South in establishing an institution specifically for the care of insane African Americans at Petersburg. Now, Virginians categorized segregation by race and gender, as well as sanity. Virginia completed its push for public institutions in 1887 , when the fourth and final mental hospital opened in the southwestem town of Marion. Virginia, however, was not finished adopting innovative approaches to the "care" of the mental patients. Almost exactly 154 years after the opening of Virginia's first public custodial hospital, Virginia would again pioneer a new intervention: the constitutionally-sanctioned eugenic sterilization of the "feebleminded." On October 19, 1927, Dr. John H. Bell performed a "salpingectomy" - tubal ligation-—on a 20-year-old female resident at the Lynchburg Colony for the Epileptic and Feebleminded. Carrie Buck, a native of Charlottesville, Virginia, would not realize she had been sterilized until years later. As she put it, "They just told me I had to have an operation." 66

Sterilization of the institutionalized "unfit," long the poster-child of practical eugenics, found a receptive audience among Virginia's progressive physicians and, ultimately, Virginia's progressive intelligentsia and legislators. Placed under the govemance of "laymen with important civic and political power," the Publick Hospital established administrative precedents that would be paralleled in all Virginia's other public institutions. Fast hardening into bureaucratic custom, these precedents would persist well into the twentieth century, and they would provide the conduit through which popularized notions of eugenics would influence patient treatment in Virginia institutions. Physicians trained in eugenic ideology, convinced that the feebleminded only produced feebleminded children, remained at the center of treatment protocols. Lay people, however, sat upon the hearing

66Lombardo, "Eugenical Sterilization," 233. 
boards that approved the orders for sterilization. Both groups, physicians and interested, eugenically-minded lay administrators, became essential cogs in Virginia's institutionalized sterilization machinery.

Virginia would pave the way for the constitutionally-ratified sterilization of America's public wards with the infamous 1927 Supreme Court case, Buck v. Bell. Yet, for all the notoriety attracted by Buck, it is apparent that Virginia's involvement with eugenic sterilization antedated that famous case. Moreover, the prologue to Buck involved more than the historical actors and local context that are usually discussed in the literature. Eugenic mobilization by academics, physicians, and concerned lay-people paved the way for the passage of Virginia's sterilization law, and the ultimate success of Buck. Understanding Virginia's movement for eugenic sterilization requires placing that welldocumented lobbying effort within the context of both the larger Virginia and national eugenics movements. The history of Carrie Buck's sterilization, then, becomes less the story of a tiny group of co-conspirators hell-bent on social control, and more the story of a broader cohort of Virginia progressives seeking to establish Virginia as a leader in scientific, social engineering.

Following Dr. Charles V. Carrington's attempts to achieve a sterilization law, Virginia's next major proponents of eugenical sterilization were the Reverend Joseph Mastin, Doctor William F. Drewry, Doctor Albert Priddy, and Doctor Joseph DeJarnette. Mastin, a member of the State Board of Charities and Corrections, and Drewry, Priddy, and DeJarnette, all superintendents of Virginia state hospitals, were all acquainted with Harvey Emest Jordan and eugenics through their overlapping activities with the SBCC and the Virginia Medical Society. Moreover, Drewry, DeJarnette, and Priddy knew Paul Brandon Barringer, who himself moved more and more toward a mainline eugenical stance, arriving there by the 1910 s. ${ }^{67}$ Thus, the synergy between academic eugenics and

${ }^{67}$ Barringer served as a consulting physician at the Hill Crest Sanitarium in Charlottesville throughout the 1900s and 1910s. Doctors William F. Drewry and Joseph DeJamelue served as references for Hill Crest 
institutionalized, public-policy eugenics saw its first results, in the form of convinced believers among influential public servants and policy makers, in the 1910s.

All of these men championed the mainline eugenic solutions: marriage restriction, segregation, and sterilization of the unfit. As Mastin campaigned for the segregation of the feebleminded in institutions, he also called for marriage restriction and the sterilization of feebleminded men. 68 Doctors Drewry, DeJarnette, and Priddy also swelled the eugenic chorus growing within the state public health network. Dr. Drewry, the superintendent of the Central State Hospital in Petersburg, a facility for insane and "feeble-minded" African Americans, began arguing publicly for eugenics as early as 1912. Citing an increase in feeble-mindedness, Drewry claimed that such individuals should be segregated because, "To the community the presence of such individuals is a perpetual menace, a constant source of trouble and danger. Indeed, this army of defectives or defective delinquents...constitutes a serious problem." 69 Given the hereditary nature of most "defectiveness," Drewry believed that only two solutions "might be pursued with reasonably good results in checking this most subtle form of race suicide; one is to prevent the production of more defectives and the other is to segregate and give custodial care to those already in existence." He argued for marriage prohibition-"certainly during the reproductive period, of the unfit, and as far as practicable to forbid their cohabitation"-and sterilization and segregation. ${ }^{70}$ "Unless restrained and protected the 'moral imbecile,' or the imbecile without moral ideas, is especially foredoomed to a life of vice and crime," Drewry wrote. "It is criminal negligence," he continued, "to allow such defectives to remain free in the community" where they could do untold harm. Thus, Drewry advocated

and funnelled private-pay patients to the sanitarium. See Virginia Medical Semi-Monthly 11 (1907): 13 for a representative advertisement for Hill Crest that lists these men.

68 Ibid., 107-108.

${ }^{69}$ William F. Drewry, "The Mental Defectives," Virginia Medical Semi-Monthly 16 (January 26, 1912): 500-08. He also read this address, in part, before the Southside Virginia Medical Association in December of 1911. In this piece, he cites the work of Henry H. Goddard and Charles B. Davenport, and shows a clear appreciation of and sympathy for mainline eugenics.

${ }^{70}$ Drewry, "The Mental Defective," 506-07. 
sterilization for "epileptics, habitual criminals, imbecilews, and persons suffering from recurrent or incurable types of insanity. Such persons are unfit to assume parenthood, hence the power of procreating their kind should be taken from them by the relentless hand of science, under sanction and authority of law." Aware that such solutions might seem radical, Doctor Drewry also championed "a department of eugenics and experimental psychology at the State University" to help rectify the "appalling ignorance and indifference" to the problem. ${ }^{71}$ The hiring of the "second wave" of eugenicists would help to create an informal "department of eugenics" at the University of Virginia. Drewry never wavered in his eugenics advocacy. In 1923, the year before he retired, Drewry argued that, "sterilization in many cases of the mentally afflicted should be legalized...for the purpose of checking propagation of such stock, thereby further adding to human misery." 72

Doctor DeJamette, the superintendent of Western State Hospital in Staunton, Virginia, located less than 40 miles from the University of Virginia Medical School, was quite familiar with Paul Brandon Barringer, Harvey Jordan, and the "second wave" of university eugenicists, too. Beginning in 1908, DeJamette's annual reports from the Western State Hospital read like veritable primers in eugenics. His staunch hereditarianism and support of eugenics characterized every report for the next thirty-eight years. More importantly, DeJamette and the University of Virginia Medical School worked out educational and clinical exchanges that brought medical studer.ts under the tutelage of DeJamette, bolstering their eugenic training.

DeJarnette's inaugural report from Western State Hospital underscored the connection between eugenics and public health as a form of preventive medicine. Under the heading "Prophylaxis" DeJamette outlined his ideological commitments in the care of the mentally

${ }^{71}$ Ibid., 507.

72William F. Drewry, "Central Siate Hospital Annual Report, 1923," 25, quoted in Himstedt, "Not For Their Own Good," 26. 
ill. "In the treatment of all diseases," he began, "it is an established fact that prevention is far better than cure. This is especially true in the treatment of the insane, as heredity has been variously estimated to be the cause of from thirty to fifty per cent. [of all affliction]" DeJamette used heredity to elide the distinction between disease-treatment and diseasecause. He thus set up an eugenic train of logic: prevention is better than therapy, heredity causes a large part of mental disease, therefore eugenic solutions, which are hereditary prophylactics, represent the preferred "treatment" for insanity and feeble-mindedness.

DeJarnette privileged marriage restriction and sterilization as the preferred eugenic "therapies." "I believe that the marriage relation between the unfit, such as those who have dipsomania [alcoholism], insanity, epilepsy, feeble-mindedness, syphilis, and tuberculosis, should be prohibited by law, except in cases where the woman is over 45 years of age." DeJamette's restriction, linked to the onset of menopause and the cessation of female fecundity, implicitly constructed both syphilis and tuberculosis as hereditary, not bacteriological, diseases. The spread of syphilis and tuberculosis between individuals of a single generation did not appear to trouble DeJarnette as much as the possibility of transgenerational infection. He made this contention explicit in his next statement, "In this way [marriage restriction], we would perpetuate the race from healthy stock, and eliminate the defectives and weaklings to a great extent." 73

DeJamette also advanced the cause of sterilization by recommending it to the governor in his report. Noting that "Some writers" advocated sterilizing the feebleminded, DeJamette commented, "This sounds extreme to the unthinking, and appears harsh, but in the course of time, probably many years, some plan of this nature will almost certainly be

${ }^{73}$ Joseph DeJarnette, Report of the Western State Hospital (Richmond: Superintendent of Public Printing, 1908), 10. [Hereinafter referred to as Report, WSH (year).] See also Lombardo, "Eugenic Sterilization," 110. Under the heading "Buildings for Consumptives," DeJarnette announced the completion of a building for "female consumptives" noting that "we will have these patients segregated in a few days." $\mathrm{He}$ felt that the ward "will not only be beneficial to the consumptives themselves, but will remove the source of infection from our other patients." DeJarnette adhered to the bacteriological and hereditary views of tuberculosis held by men like Charles B. Davenport and Harvey Emest Jordan. Heredity made one susceptible to the disease, and likcly to pass that susceptibility on to onc's children. 
resorted to." Likening sterilization to tuberculosis prevention DeJarnette equated eugenics and public health. "A few years ago the antispitting acts and laws for the prevention of tuberculosis were ridiculed," DeJarnette contended," while now even the most ignorant are beginning to recognize their importance and observe them." 74 His rhetoric made explicit the "eugenic metaphor" that held "defective germ-plasm" to be a social pathogen that "sickened" society in a manner paralleling bacterial infection of an individual. Following DeJamette's logic, procreation among the unfit spread "germinal contamination" among the future population just as spitting spread the tubercle baccillus among the present generation. Such pronouncements placed DeJarnette firmly within the public-health/preventive medicine camp of the eugenics movement at an early date.

DeJarnette's views about "racial poisons" and their eugenic solutions remained remarkably constant, and his rhetoric increased yearly in vehemence until Virginia adopted its sterilization law. In addition to marriage restriction and sterilization, in 1909 DeJarnette added "proper education of the laity on the subject of heredity," probably as a means to reduce resistance to sterilization. DeJamette always acknowledged that these eugenic methods "may seem harsh," but he-like most eugenicists-believed that education would convince the public of their efficacy and necessity. After all, "allowing these classes [the unfit] to reproduce it not only multiplies the class, but makes them perpetual. It is a crime against their offspring and a burden to their State for such to reproduce."75 By 1911 , DeJamette's belief in the power of heredity prompted him to assert that heredity caused "from thirty to eighty per cent of insanity," an increase of thirty percent on the high end. His view about remedies similarly hardened: "Sterilization of all weaklings should be legally required," because, "the good to humanity is so great that it would be unjust to their

\footnotetext{
${ }^{74}$ Ibid., 10.

${ }^{75}$ Report, WSH' (1909), 17.
} 
posterity [the unfit progeny of the unfit], and even to the unfit themselves, to allow them to reproduce." 76

DeJarnette completed the discursive shift from "prophylaxis" to eugenics in 1913 when this section of the report was retitled "Eugenics or Stirpiculture." Acknowledging that environment could drive someone insane, DeJamette explicitly applied Mendel's genetic laws to prove that "with incubators for weak babies and the control of many diseases of childhood, numbers of weaklings are matured and reproduce much to the injury of the race." The only solution remained sterilization and segregation, the application of a compensatory negative eugenics to offset the initial increase in unfitness. Additionally, America needed "proper control of liquor and habit-forming drugs," the "systematic examination and control of the usual source of communicating syphilis [i.e. prostitutes]," and "compulsory instruction in sex hygiene in all the high schools." Without such programs, "our people will become weaklings and dependents, and our race fall by the wayside." Although farmers used great care in breeding their stock, "when it comes to our own race any sort of seed seems good enough, and the rights of the syphilitic, epileptic, imbecile, drunkard and unfit generally to reproduce must be allowed, for otherwise," DeJarnette scoffed, "we are encroaching upon the so-called inalienable rights of man." Instead he felt that humans should "bend our greatest efforts toward perpetuating the best and highest type of man from the best," in spite of individual rights. These statements perfectly mimicked those made by Harvey Ernest Jordan and other mainline eugenicists. ${ }^{77}$

Economics, efficiency, and humanitarianism became the watchwords of DeJarnette's eugenic program. He continued to preach the triptych of education, segregation, and

$76_{\text {Report, WSH (1911), } 11 .}$

${ }^{77}$ Report, WSIt (1913), 10-12. The term "stirpiculture" dates at least to John Humphrey Noyes's utopian community at Oneida, New York. Noyes's is credited with the earliest attempts at eugenic breeding in America. He named his program "stirpiculture" after the cultivation of the "stirp," the Greek word for "seed" or "stock." See Mark Haller, Eugenics: Hereditarian Attitudes in American Thought (New Brunswick, NJ: Rutgers University Press, 1963), 37-38, 206; Kevles, In the Name of Eugenics, 306 note 6. 
sterilization "in their order of efficiency and practicability — the least efficient first," in each of his yearly reports. ${ }^{78}$ Education seemed inefficient because it left too much to chance by requiring good teachers, attentive and attendant students, and great repetition of effort.

"Segregation during the reproductive age is a very expensive method," DeJarnette admitted, "but it is an hundred-fold more economical than to allow the unfit to reproduce." As an example, DeJamette lamented the fact that he was recently compelled to discharge a feebleminded mother who had given birth because she was not insane. He invoked the eugenic family studies, predicting, "if a correct record were kept, we would, in all probability, find a long line of defectives and dependents issuing from her, similar to the well-known Kallikak family of New Jersey." Sterilization, however, was "cheap and effective," and also humane because it, "could be done in childhood, before sexual desire is developed, and in this way all psychical shock would be eliminated." 79 People sterilized as children, according to DeJarnette, would never know what they were missing. By 1923, DeJarnette was aware that, "Sterilization can be done also by X-ray, which does its work silently, painlessly and without scar," making it even more humane than vasectomy or salpingectomy. Moreover, sterilization was more humane than segregation because it, "would not interfere with the individual's liberty, sexual gratification or pursuit of happiness but only with his power of reproduction." Therefore, sterilized patients could be released back into society to lead "normal" lives without risk of procreation. "For a higher

\footnotetext{
${ }^{78}$ Report, WSH (1915), 9.

${ }^{79}$ Ibid., 10. DeJarnette's comments underscore a significant ambiguity in eugenic thinking. Sterilization definitely prevented the procreation of the unfit, but that alone did not make it an unalloyed good. Eugenicists of a more Victorian mindset-at times Charles Davenport was among this groupworried that sterilization would increase sexual immorality, because it removed the possibility of unwanted pregnancy. Some worried that this dynamic would also incrcase the spread of vencreal disease, because people would have more sex. Others minimized these potential negative consequences. In the short run there might be more "illicit" sex and venereal disease, bui in the long run both would disappear as a necessary result of the birth of eugenically sound people-presumed to be hercditarily moral and insusceptible to venereal infcctions.
} 
grade and more intelligent citizenship and from the standpoint of state economics,"

DeJamette urged passage of a sterilization law. ${ }^{80}$

To drive home his argument in favor of sterilization, Dejamette frequently published a poem, "Mendel's Law: A Plea for a Better Race oí Men," alongside his pleas for eugenic reform. The poem, penned by DeJamette and reproduced below, is a striking paean to eugenics.

Oh, why are you men so foolish - / You breeders who breed our men Let the fools, the weaklings and crazy / Keep breeding and breeding again? The criminal, deformed, and the misfit, / Dependent, diseased and the restAs we breed the human family / The worst is as good as the best.

Go to the house of some farmer, / Look through his barns and sheds, Look at his horses and cattle, / Even his hogs are thoroughbreds; Then look at his stamp on his children, / Lowbrowed with the monkey jaw, Ape handed, and silly, and foolish-/ Bred true to Mendel's law.

Go to some homes in the Village, / Look at the garden beds, The cabbage, the lettuce and turnips, / Even the beets are thoroughbreds; Then look at the many children, / With hands like the monkey's paw, Bowlegged, flatheaded, and foolish_- / Bred true to Mendel's law.

This is the law of Mendel, / And often he makes it plain,

Defectives will breed defectives / And the insane breed insane.

Oh, why do we allow these people / to breed back to the monkey's nest,

To increase our country's burdens / When we should breed from the good and the best.

Oh, you wise men take up the burden, / And make this your loudest creed, Sterilize the misfits promptly- / All not fit to breed.

Then our race will be strengthened and bettered, / And our men and our women be blest,

Not apish, repulsive and foolish, / For we should breed from the good and the best. ${ }^{81}$

Compare DeJarnette's poem, first published in 1920, with Paul Brandon Barringer's contemporaneous effort, "Germ or Sperm":

Old Mother Earth is sick, I wot, / The human race is spent

${ }^{80}$ Report, WSH (1922-1923), 11. DeJarnette makes this explicit in his 1923 report, when he quotes Dr. Albert Priddy, superintendent of the Virginia State Colony for Epileptics and Feeble-minder, as saying he had "100 feeble-minded, whom if they were sterilized could be out in the world doing directed work without danger to posterity." This would save the state $\$ 20,000$ per patient per year.

${ }^{81}$ Although published 21 years later, DeJarnette's effort clearly betrays the influence of Rudyard Kipling's "The White Man's Burden" McClure's Magazine 12 (Fcbruary 1899). DeJamelle first published the poem in the Annual Report of the Western State Hospital for 1921. He also published it three times in the Virginia Medica! Monthly during the 1920s and 1930s. 
When almost every child begot / Starts as an accident

Go read the records, writ in blood / Of lust unloosed and fools in stud

Imbeciles were bom

Where every stratum of the earth / Tells tale of useless birth

Of Species dead and gone.

Go read the record see the need / Of type with type and breed with breed

Of germ and sperm the best

How matings wise of brains and size / Gave strains that captured every prize

And then outlived the rest

Blind force thus once shaped the human form / As it still drives the sea, sand and worm But better days have come

Man read the scroll so early given / He who with peas fearless strove

A light to read the law was given.

The striking similarities and hereditarian conviction evinced by these poems reveals how the eugenic wave swept along Virginia's most prominent exponents of public health. 82

Just as Dr. DeJamette worked assiduously to earn his moniker "Sterilization

DeJarnette,"83 so too did Dr. Albert S. Priddy, superintendent of the Virginia Colony for the Epileptic and Feeble-minded, cooperate whole-heartedly in lobbying for a sterilization law. Priddy's eugenical sentiments were congruent with Drewry's, DeJamette's, and Barringer's. Priddy believed that, "of the known causes which contribute to the development of epilepsy, that of bad heredity is the most potent, and with unrestricted marriage and intermarriage of the insane, mentally defective and epileptic, its increase is but natural...." Of feeblemindedness, Priddy maintained, "This blight on mankind [the feebleminded] is increasing at a rapid rate...[and]...unless some radical measures are adopted to curb the influences which tend to promote its growth, it will be only a matter of

\footnotetext{
${ }^{82}$ Barringer's papers reveal that he was a close personal and professional associate of Virginia's leading public heaith and eugenics officials, including Dr. William H. Drewry (supcrintendent of Central State Hospital) and Joseph DeJarnetle. Sce "1906-1908 Gencral Correspondence and Related Papers," Box 2, Barringer Papers.

${ }^{83}$ DeJarnette was proud enough of this sobriquet to makc it part of his oration at a dinner in his honor. See the transcript of the proceedings, "Celebration of Dr. J. S. DeJamcuc's Fifticth Annivcrsary of Continuous Service at the Western State Hospital," July 21, 1939, 31, DeJarnette Papers, Western State Hospital, Staunton, Virginia. [Hereinafter referred to as "DeJarnctle Celcbration".]
} 
time before the resuling pauperism and criminality will be a burden too heavy...to bear." 84 One way to alleviate this burden, both for society and the defective individual, was through sterilization. Like Carrington before him, Priddy performed sterilizations in advance of any legal sanction.

Priddy's extra-legal eugenic sterilizations may well have occurred under the guise of therapeutic intervention. In the same 1915 report bemoaning the increase among the feebleminded, Priddy reported a "success story" about a former Colony inmate. "We secured a home for one young woman in a family which keeps careful watch over her," Priddy began, boasting, "and she has, for the past three months, been making good her wages and has behaved well in every way." Why had she behaved well? Priddy's next sentence implies at least a partial reason for her rehabilitation: "Before she left the institution a surgical operation was performed on her for relief of a chronic pelvic disorder, which sterilized her." 85 Priddy most likely performed a hysterectomy, then (and often still) the indicated treatment for severe chronic pelvic inflammatory disease. His association of the therapeutic treatment and its social outcome, however, leads one to believe that more than mere coincidence may be operating.

Other evidence suggests that the pattern of "therapeutic" sterilizations reported by Priddy, and first revealed by Paul A. Lombardo, may really have masked eugenic procedures. As Lombardo wrote, "Future Reports, however, showed an amazingly coincidental pattern of sterilization among women judged to be 'morons' who also had the ill fortune of suffering from 'pelvic diseases' of vague and unspecified etiology." 86 In

${ }^{84}$ Lombardo, "Eugenical Sterilization," 115-19. Quotations are from Priddy's yearly Report of the State Epileptic Colony for 1910 (p. 7) and 1915 (pp. 15-16), respectively. Hereinafter these reports will be referred to as Report, SEC.

${ }^{85}$ Priddy, Report, SEC (1915), 12; Lombardo, Ibid., 116.

${ }^{86}$ Lombardo, Ibid., 118 . There is a long history of gynecological surgery being used to "cure" various forms of "aberrant" behavior, from neurasthenia and hysteria to fecblemindedness. By the 1920s, "bad behavior" in women was often seen, at its root, as a form of "pclvic discase." Sec Thomas Lacquer, Making Sex: Body and Gender from the Greeks to Freud (Cambridgc, MA and London: Harvard University Press, 1990), 175-181; Barbara Ehrenreich and Deirdre English, For ller Own Good: 150 Years of the Experts' Advice to Women (Ncw York: Anchor Books/Doubleday, 1978), 120-131. 
1917 alone, Priddy sterilized thirty women for unspecified "pelvic diseases". He noted, "We have continued the policy of sterilizing young women and girls of the moron type....In nearly all cases sterilized, the pelvic disease was found in a greater or lesser degree, such as to make the removal of the tubes necessary for the relief of physical suffering. "87 The fact that Priddy targeted "young women and girls of the moron type" is suggestive. This mental category - the highest on the then-accepted clinical hierarchy of feeblemindedness that ranged from idiot to imbecile to moron-represented that segment of the feebleminded population most feared by eugenicists. So-called "high-grade morons" posed the greatest threat to the nation's gene pool because they looked outwardly nomal to casual observation. A slight impairment of intellect, which itself could only be discovered by an intelligence test, might be the only clue of taint. Expressed in their progeny, this defect might result in an individual of even lower grade. As the American Breeder's Association reported in 1914, "It is the moron or high-grade feeble-minded class of individuals that constitute the greatest cacogenic menace, for these individuals...are able to, and do reproduce their unworthy kind." 88 Eugenicists viewed female high-grade morons as an especial threat, because gender conventions of the day worked to shield them from exposure: high-grade moron men might be exposed by failure to perform in the workplace whereas women might not be "working" at all.

Priddy's qualification that pelvic disease was present "in a greater or lesser degree" also, as Paul Lombardo notes, suggests that he had ulterior motives for sterilizing these young women. Gender, not disease, was the crucial factor controlling Priddy's sterilization decisions. Convinced that feebleminded women were at best besotted prey for

87Priddy, Report, SEC (19i7), 13; Lombardo, Ibid., 119.

${ }^{88}$ Harry Hamilton Laughlin, American Breeder's Association Committee to Study and to Report on the Best Practical Means of Cutting Off the Defective Germ-Plasm in the American Population, vol. 1 The Scope of the Problem in Eugenics Record Office, Bulletin 10A (Cold Spring Harbor, NY: Eugenics Record Office, 1914), 19. Psychologist and eugenicist Henry Herbert Goddard devised the three-step classification for feeblemindedness in 1910. See Diane B. Paul, Controlling Human Heredity 1865 to the Present (Atlantic Highlands, NJ: Humanities Press, 1995), 59-65; Haller, Eugenics, 98, 104. 
over-sexed men or at worst hyper-sexual predators that lured naive men into sexual congress, eugenicists disproportionately targeted women for sterilization. As shown by Dr. DeJarnette's Reports, he concentrated on segregating women for the duration of their fertility, or sterilizing them. He never explicitly suggested the sterilization of feebleminded men, implicitly exempting men from the full rigor of eugenic sterilization. Although vasectomy represented a less invasive, and therefore a markedly safer, surgical procedure than salpingectomy, eugenicists still targeted women. The well-documented occurrence of pelvic inflammatory diseases, and the established standard of care which included sterilization, provided a convenient shield for physicians operating under eugenic rather than therapeutic motives. While the first paper in America describing vasectomy lauded its therapeutic effects for men, the lack of a male analog for pelvic disease and the paucity of evidence documenting the therapeutic benefits of vasectomy marked the procedure as primarily for sterilization rather than therapy. ${ }^{89}$ Gender conventions of the day worked to condition medical and eugenic choices. As mentioned above, Women's role in reproductive biology placed them in the eugenicists' cross-hairs, as the root source of defective babies. Thus, given the gendered nature of the times, it is not coincidental that the first person legally sterilized in Virginia was a young woman accused of being the midpoint in a lineage of defective women.

Before Carrie Buck could be legally sterilized, however, Dr. Priddy would face prosecution for his extra-legal sterilizations. The case of Mallory v. Priddy reveals, as Paul Lombardo points out, "the abuses which occurred under the cover of "reform" legislation. Willie Mallory, the wife of poor sawyer George Mallory, was arrested in September of 1916 and charged with keeping a brothel. The mother of twelve, Mrs. Mallory watched

\footnotetext{
${ }^{89}$ Nevertheless, some California physicians claimed a definite therapeutic benefit for men. For an interesting discussion of this issue, see Joel Braslow, Mental Ills and Bodily Cures: Psychiatric Treatment in the First Half of the Twentieth Century (Berkeley, CA and London, 1997),61-62. Famed Chicago surgeon A. J. Ochsner first reported vasectomy as a therapeutic procedure in an 1899 issue of the JAMA. Paul, Controlling Human Heredity, 81.
} 
helplessly as a juvenile court concluded that nine of her children were "exposed to vicious an immoral influences," and turned over to the Children's Home Society. Three weeks later, on October 14th, Mrs. Mallory and two of her older daughters submitted to mental examinations at the behest of a "Commission on Feeble-mindedness," the lay body empowered by Virginia law to commit people to institutions for the feebleminded. The commission judged the Mallory women feebleminded, and remanded them to the custody of the Virginia Colony for Epileptic and Feebleminded. ${ }^{90}$ Six months and an unsuccessful escape attempt after her commitment, Mrs. Mallory found herself being prepared for surgery. Under the guise of "medical necessity," Dr. Priddy sterilized Mrs. Mallory and then her daughter Jessie. Priddy then ordered the release of Mrs. Mallory, now "safe" to reenter society. Sixteen year-old Nannie Mallorie escaped sterilization but remained in the colony with her sister.

George and Willie Mallory worked diligently to free their daughters, struggling to gather the funds necessary to obtain legal counsel. In October of 1917, George Mallory sued Dr. Priddy, asking for $\$ 5,000$ damages, back wages, and just compensation for the "pain and suffering" caused Mrs. Priddy by her "imprisonment" and sterilization. Lawyers for Priddy and the state colony argued that the 1916 state law mandating the "Commission of Feeblemindedness" empowered Priddy to take the Mallory women into clistodial care. Regarding Mrs. Mallory's sterilization, Priddy mounted a tri-partite defense: that she requested the procedure, that it was medically necessary, and that without the operation Mrs. Mallory "would most probably have died."91

As the legal process ground inexorably forward, George Mallory wrote Dr. Priddy, seeking the release of Nannie. Mallory's broken grammar still conveys his sense of loss and outrage. Four times he had written to Priddy regarding his child, all without response.

\footnotetext{
34.

90The facts of the Mallory case are recounted, in detail, in Lombardo, "Eugenical Stcriiization," 122-

${ }^{91}$ Priddy, quoted in Lombardo, Ibid., 126.
} 
Frustrated, he demanded, "I want to know when can I get my child home again-My family have been braked up on false pertents...." Incredulous, Mallory asked,

Dr what busneiss did you have opreateding on my wife and daughter with out my consent....you ought to be shamed of your selft opreateding on her at that age [43] Just stop and think of how she have been treated-what cause did you have to opreate her-please let me no for there is no law for such treatment-I have foud that out-I am a poor man but was smart anuf to find that out...

More than merely intelligent enough to seek legal counsel and leam about his rights, Mr. Mallory knew that he was poor, but keenly felt his social responsibilities. "I earn $75 \$$ a month I dont want my child on the state-I did not put her on them." Mallory clearly understood the economic arguments used by eugenicists and social reformers, and sought to turn them to his advantage. In fact, it angered him that his daughter was "...over there working for the state for nothing now." His anger got the best of him, however, and he threatened Priddy: "If you dont let me have her bye easy terms I will get her by bad. She is not feeble minded...let me no at once I am a humanbeen as well as you are-I am tired of being treated this way for nothing...."92 George Mallory clearly maintained a well developed sense of responsibility, personal integrity, and a knowledge of his and his family's human rights.

Priddy construed Mallory's anger as impertinence, his assertions of equality as arrogance, and his quest to free his daughter as a threat to the state. Bristling with outrage himself, Priddy fired his own salvo at Mallory. As Paul Lombardo has noted, Priddy's bellicose response underscores the unrestrained vehemence with which he pursued his own agenda, as well as the articulated system he used to identify potential "patients" for the state colony. Characterizing Mallory's letter as "insulting and threatening in its tone," Priddy answered with a threat of his own, assuring Mallory, "if you dare to write me another such communication I will have you arrested and brought here too." To back up this threat of incarceration and sterilization, Priddy boasted that, "I have the full record of you and your

${ }^{92}$ The entire text of Mallory's letter is reproduced in Lombardo, Ibid., 127-28. 
family from the State Board of Charities and Correctionss and the Juvenile Court of Richmond," implying that those documents would warrant action against Mallory. "Your wife and Jessie were both operated on because they asked me to do so," Priddy retrenched, justifying his actions by implying that the Mallory women were venereally infected, "and it was done for diseases they had." His anger largely spent, Priddy still could not resist a parting shot, "Now, don't you dare write me another such letter or I will have you arrested in a few hours." 93

As outrageous as Priddy's actions and words seem today, they convinced a jury of his peers that he had acted within his professional authority and duty. In March of 1918, the jury pronounced Priddy not guilty. ${ }^{94}$ Respecting Priddy's medical expertise, resenting the impertinence of "poor white trash," and sharing the conviction that the Mallory's represented a threat to society, the respectable citizens of Richmond who sat on the jury shared many of the biases that prompted Priddy to act. The verdict validated Priddy's role as "social surgeon" and public health officer. It also gauged the social climate and indicated that Virginians might be ready for a sterilization law.

Mallory v. Priddy catalyzed the movement for a comprehensive eugenic sterilization law in Virginia. Years later, Aubrey Strode, the author of the 1916 commitment law and the bill that would eventually become Virginia's eugenic sterilization law, noted that, "[Priddy] could only successfully defend [himself] on the ground that the operation was indicated for therapeutic purposes, rather than eugenically." 95 Therefore, a palpable need existed for a sterilization statute. Priddy and DeJarnette, two practicing physicians who headed important state institutions, would instigate the drafting of the sterilization law and

${ }^{93}$ The entire text of Priddy's letter is reproduced in Lombardo, Ibid., 128-29.

${ }^{94}$ Mallory's counsel then refocused the case on appeal to the Virginia Supreme Court of Appeals, emphasizing that the Children's Home Society had illegally incarcerated the Mallorys. On June 13, 1918, the Supreme Court of Appeals clarified the 1916 law for convening "Commissions on Feeblemindedness," deciding that the law had been improperly applied. As a result, they granted Nannie Mallory's writ of habeus corpus and she was released. Lombardo, Ibid., 130 note 51.

${ }^{95}$ Strode quoted in Lombardo, Ibid., 131. 
orchestrate the lobbying and passage of the law. Aubrey Strode would write the law and, with the assistance of Priddy's successor John H. Bell and other colleagues friendly to the cause, conspire to create a "friendly" test case to establish the constitutionality of the law. While this cadre of men worked hard to achieve their eugenic ends, their success depended, in large measure, on the sympathetic support or nonintervention of their medical and legal colleagues throughout the state. Thanks to the popularizing work done by Harvey Ernest Jordan, the eugenicists at the University of Virginia and elsewhere, and changes in the national attitude as eugenics came into great public favor, Virginia would pass a sterilization law and see it upheld by the United States Supreme Court before the 10th anniversary of Mallory v. Priddy. A decade may seem a long time; it was, however, fairly rapid given the delicate nature of the lobbying necessary to pass such an invasive measure for social control, the slow workings of the legal system, and the redirection of media attention in an era dominated by three "trials of the century" and Charles Lindbergh's "lone eagle" flight. 96

Aubrey Ellis Strode, another University of Virginia alumnus, who also had ties to Paul Brandon Barringer, collaborated with Priddy and DeJarnette in the effort to obtain a sterilization statute. Strode's father had taught Paul Barringer and Strode at the Kenmore School, on the Strode-family plantation, over which he presided as headmaster. Much younger than Barringer, Strode would come to know him well during when he attended the university and afterward, when, as a neophyte Virginia assemblyman, Strode would cross swords with Barringer over the University budget. Following a peripatetic educational path that took him from the University of Mississippi to Clemson, to Washington and Lee College - with brief stints teaching high school punctuating his course-Strode finally attended the University of Virginia in 1894-1895, and its school of law in 1898. During

\footnotetext{
${ }^{96}$ The three major trials that captivated the public mind and allowcd Buck v. Bell to sail through the courts with relatively little fanfare were the Scopes anti-evolution trial (1925), the Sacco and Vanzetti antiradical capital case (1927), and the Leopold and Loeb thrill-killing capital case (1927).
} 
these years Strode honed his oratorical and rhetorical powers, skills that would serve him in good stead later, when he entered political life. Forced to leave school because of his parents' death, Strode passed the Virginia bar without benefit of a legal degree in 1899. Strode established offices in Amherst and Lynchburg Virginia, and practiced law quietly until 1903, when his role in the impeachment of a Virginia judge placed him in the public eye. In 1905, Strode ran for and won a seat in the Virginia Senate. The thirty-three yearold lawyer began the first of three terms in $1906 .{ }^{97}$

Strode's principle biographer wrote that his entire career-as educator, lawyer, legislator, and then judge-"can be characterized in [a] single word: reform."98 In an unsuccessful bid to become a delegate to Virginia's 1901 State Constitutional Convention, Strode created a reform platform of interrelated planks upon which he would stand for the remainder of his political career: public school improvement, tax reduction, and election reform. A staunch Democrat, Strode supported the distinctive electoral "reform" of the Progressive South, African-American disfranchisement. Strode's election card noted that, "He wants every WHITE man to say what Constitution Virginia shall live under," and guaranteed that he was the "safe" candidate, "If you want a Constitution made up by White People," and "If you want Ignorant Negroes Disenfranchised." 99 Reactionary as this stance appears to the modem eye, this position placed Strode squarely within the southem Progressive movement. Not merely posturing, Strcde's later legislative record reveals his Progressivism in action regarding race, gender, and the rights of institutionalized people and prisoners. That his "reforms" often ended in programs we now view as "reactionary" or "conservative" — such as ardent support of "separate but equal" and compulsory sterilization—underscores the "meliorist" rather than "radical" or "revolutionary" nature of

\footnotetext{
${ }^{97}$ Aubrey Strode's father Henry Aubrey Strode, a confederate veteran, had attended the University of Virginia, graduating in 1868. He went on to head Kenmore profess at the University of Mississippi, and serve as the first president of Clemson. Aubrey Strode's early life and career, as well as his father's, is detailed in Lombardo, "Eugenical Sterilization," 35-62.

98Lombardo, Ibid., 35.

${ }^{99}$ Strode 1901 campaign card, quoted in Lombardo, Ibid., 51.
} 
the Progressive Era's reform impulse. Strode believed in the same technocratic guidance of society that would achieve social harmony through finely-calibrated and "efficient adjustments" of institutions shaping daily life.

Strode played a pivotal role in reforming Virginia's mental health system. Long before he wrote the law that would empower "Commissions on Feeblemindedness" in 1916, Strode himself had personal experiences with Virginia's insane asylums. Both his parents died in Virginia state hospitals for the insane. Most likely responsible for committing his parents, Strode inevitably obtained a painful, first-hand education in the need for improved treatment of the mentally ill. Beyond becoming a mental-health reformer, Strode worked hard to cleanse his pedigree of hereditary taint, by obtaining information from his parents' physicians. These testimonials attributed Mr. Strode's insanity to an aneurysm and Mrs. Strode's insanity to a septic condition resulting from an undiagnosed pelvic abscess. ${ }^{100}$ Humane enough to want improved conditions for patients in mental hospitals, Strode remained human enough to adopt uncritically the mainline eugenic understandings about hereditary insanity and "feeblemindedness." Thus, his crusade for mental health reform mirrored his notion of electoral reform: segregation was a rational adjustment that would solve the "Negro Problem" and the "menace of the feebleminded," provided it created "humane" separate but equal conditions. ${ }^{101}$ Eugenics became, for Strode and many other Virginians, segregation's science.

As mentioned above, Virginia long had institutions that segregated the insane from the mentally well. Aubrey Strode pioneered the successful effort to segregate another class of

100 Lombardo, Ibid., 62-65.

${ }^{101}$ Just as many southerners remained willingly blind to the absurdity of claiming disfranchisement actually "protected" the democratic process and black access to it, so too Strode appears to have turned a blind eye to abuses within the mental health hospitals. Lombardo notes that Stode's papers preserve numerous letters complaining of abusive treaunent at the Lynchburg Colony. In answering these letters, Strode disingenuously denied association with the colony's administration. Lombardo, Ibid., 145. While he may have done so to avoid involvement with mental patients, this would scem to run counter to his principled attempts to improve their treatment. Clearly, Strode privileged the protection of society over the protection of individual rights. 
Virginians-the feebleminded-in their own facilities. Strode sponsored the bill that funded the State Colony for Epileptics at Lynchburg, the very institution Dr. Priddy would head, which passed in February 1906. The bill authorizing the establishment of the colony, introduced by Strode, passed in 1910. The Governor then appointed Priddy superintendent, and a Special Board of Directors that including another University of Virginia graduate, Irving P. Whitehead. Whitehead and Strode had been friends since their boyhood in Amherst County; both men practiced law out of Lynchburg. These three men would become the protagonists in Virginia's quest to achieve the first sterilization statute. 102

Before considering the passage of the sterilization law, one must understand the process that governed the identification and institutionalization of Virginia's feebleminded. Virginia lawmakers created the first Board of Charities and Corrections (BCC) in 1908. The legislature charged this board with inspecting state custodial institutions of "eleemosynary, charitable, correctional, or reformatory character, or which are for the care, custody or training of the defective, dependent, delinquent or criminal classes," and for surveying the population of Virginia to collect statistics about "dependent, defective and delinquent classes." 03 In short, without ever using the word eugenics, the legislature had created the first board charged with the oversight of those individuals targeted for eugenic reform. To discharge its mandate, the BCC cooperated with Virginia physicians and educators in an attempt to generate a survey of Virginia's population that could determine the nature and extent of the "dependent, defective and delinquent classes."

The BCC began operation three years after William Henry Heck accepted the chair of education at the University of Virginia. In many ways, the board managed to piggy-back its survey on top of the ongoing surveys made by Heck and the other eugenica!ly informed officials who sought to reform Virginia education. This is not at all surprising, given the

102 Lombardo, Ibid., $71,74-81$.

${ }^{103}$ Lombardo, Ibid., 87. 
fact that eugenicists like Harvey Emest Jordan, William Harry Heck, and Lawrence

Thomas Royster regularly stressed the importance of eugenic interventions in their addresses to the BCC during this period. The BCC sent a questionnaire to 400 physicians and another, through the office of the Superintendent of Public Instruction, to public school teachers. Physicians were asked to "report the number of 'epileptics, idiots, feebleminded, and cripple children in their care,"' while teachers were asked to identify children who were "'unfit for education in the public schools,"' by reason of mental deficiency. The BCC sent teachers a checklist that enumerated the eleven "symptoms" displayed by "backward," which is worth reproducing in its entirety:

1. Blinking, twitching of the mouth, squinting, nervous movements of the hands and feet.

2. Inco-ordination, especially irregularities of gait.

3. Spasms, fits, hysterical crying and laughing.

4. Cold and clammy hands and excessive pallor or blushing.

5. Slight malformation of cranium, eyes, ears, teeth, palate and limbs.

6. Drooling, especially if accompanied by sore mouth, ears and eyes.

7. Carelessness, indolence, inattention, unreliable memory, obstinacy and either passion or stolidness.

8. Incapacity for simple acts (e.g.) to tie knots, button clothes, go up and down stairs properly, catch ball, etc.

9. Imperfections of speech, sight, hearing, etc.

10. Excessive exaggerations, falsehood, pilfering, and poor moral sense.

11. Inability to keep up in studies, as shown by persistent excess of the child's age over the average of his class.

Most of these "traits" relied on the subjective judgments of teachers, and remained open to bias and false correlations between physical condition and mental potential. Nevertheless, they reveal the overlapping relationship between physiognomy and psychology: various stigmata, both physical and behavioral, were thought to indicate the presence of hereditary taint and feeblemindedness.

Efforts by BCC officials and Dr. William Drewry succeeded in obtaining and enabling act and appropriation for the establishment of the Virginia Colony for the Feeble-Minded in 1912. This facility was located on the property of the epileptic colony, which would come 
to be known as the Virginia Colony for the Epileptic and Feebleminded. ${ }^{104}$ By 1913, concern aoout the menace of the feebleminded, so ably spread in Virginia by the University and medical eugenicists, reached new heights. The BCC's 1913 report emphasized the hereditary nature and eugenic threat of the feebleminded. A six-point list of "important facts conceming mental defectives highlighted the links made between heredity, immorality, and feeblemindedness. The list asserted first that "Feeble-mindedness is incurable"; second, that "The feeble-minded reproduce about twice as rapidly as normal stock"; third, "Feeble-mindedness is hereditary"; fourth, that "From twenty-five to fifty percent of our lawbreakers are feeble-minded...dominated by an inherited tendency to crime"; fifth, "From feeble-mindedness springs, by inheritance, insanity, epilepsy and all forms of neurotic degeneracy"; and finally, "A very large percentage of prostitutes are feebleminded."105 Thus, feeblemindedness explained a constellation of social ills—from the immorality of prostitution and criminality to epilepsy and mental disease-and located their etiology in heredity.

The only acceptable conclusion to be drawn in 1913, the very year Harvey Jordan wrote advocating compulsory sterilization in Clinical Medicine, was eugenic intervention. Dr. L. S. Foster, writing in the Virginia Medical Semi-Monthly, argued for segregation, marriage restriction, and sterilization of the feebleminded. "This is a day of prevention," Foster wrote, "and in order to stay this increasing amy of defectives, which are a great care and burden upon the country, requires the active co-operation of each of us; and to cope successfully with this menace w'e must lay aside sentiment and deal with the problem in a practical manner."106 Life segregation or sterilization would prevent the "defective" progeny of the "feeble-minded" from swamping the fit population of Virginia. Echoing

${ }^{104}$ Lombardo, Ibid., 90-91.

105 Report of the State Board of Charities and Corrections (1913), 11, quotcd in Lombardo, Ibid., 93.

106L. S. Foster, "Feeble-Minded Children," Virginia Medical Semi-Monihly 17 (January 10, 1913): 472. Foster had originally given this address before the Medical Socicty of Virginia in October, 1912. Foster cites Charles Davenport's Heredity in Relation to Eugenics and generally hews to a mainline position. 
Foster, Dr. H. W. Dew of Lynchburg, Virginia wrote that "only two remedies" existed that could deal with the increasing number of feeble-minded, "the regulation of marriage, and the sterilization of the confirmed criminal and the mentally defective."107 Public healthphysician C. P. Wertenbaker asked the rhetorical question, "Should Virginia Have a Marriage Law Based on Eugenics?" Answering affirmatively, Wertenbaker contended that, "It is unnecessary in this State and before this audience, to dwell upon the value of 'good blood' in man or in animals. Probably nowhere is the truth of the maxim 'blood will tell' more firmly believed than in Virginia." Virginia needed a law mandating pre-marital examinations conducted by "a division or bureau, similar to the bureau of vital statistics, that might be calied the 'marriage division,' 'eugenics bureau' or something of the kind." 108 Even Dr. Charles V. Carrington would weigh in on the side of eugenics with his piece, "Keep the Race Pure," an address delivered before the St. Paul's Club of Petersburg, Virginia. ${ }^{109}$ Not surprisingly, given the eugenic crescendo in the state's medical community, the BCC's annual report announced that, "the most pressing social need of our time is the segregation of the Feebleminded."110 Accepting the genetic and eugenic commonplace that feebleminded beget only feebleminded, the report also demanded that the legislature pass laws to restrict marriage among the feeble-minded and sterilization laws "for the prevention of the procreation of the feebleminded."111

In the coming years, Aubrey Strode would work in the legislature to increase the power of the BCC, Dr. Priddy, and all the other physicians advocating eugenics. Virginia physicians made concerted efforts to educate each other about eugenics and to establish a

${ }^{107} \mathrm{H}$. W. Dew, "Sterilization of the Feeble-Minded, Insane and Habitual Criminals," Virginia Medical Semi-Monthly 17 (April 11, 1913): S. Dew apparently held strident mainline eugenics views.

${ }^{108}$ C. B. Wertenbaker, "Should Virginia Have a Marriage Law Based on Eugenics?" Virginia Medica! Semi-Monthly 17 (December 12, 1913): 420-23.

${ }^{109}$ Charles V. Carrington, "Keep the Race Pure," Virginia Medical Semi-Monihly 17 (December 12, 1913): 434-38.

${ }^{110}$ Report of the State Board of Charities and Corrections (1913), 11, quoted in Lombardo, Ibid., 93. Emphasis in the original.

111 Ibid., 94. 
lobbying effort for eugenic laws. Each eugenics article published in the Virginia Medical Semi-Monthiy between 1910 and 1924 emphasized the need to educate legislators regarding eugenic imperatives. As Doctor H. W. Dew put the issue in 1913, "it is largely, in my opinion, a question of educating the people, and through the people the legislature, and I believe it is our duty as physicians to take upon ourselves this work of education....Is it an iridescent dream to believe that the next generation will see a healthier, happier, and saner race?"112 Doctor J. W. Williams, writing later in 1913, averred that "The father is the trustee of the germ cell, and the healthy germ cell is more imp[ortant to his child than 'high society' culture and refinement. Every young man should have this fact taught him at home and in school, and it should be the first article of his social creed."113 Children raised with the eugenics creed would demand eugenic laws from the government.

By 1916, the liberal sowing of eugenics ideology began to bear legislative fruit. Strode managed to pass three important bills. One allowed the BCC to track all people identified as feebleminded and institute commitment proceedings on behalf of the state. It also granted the BCC the power to deport non-resident feeble-minded and gave the board control over "all cases where feebleminded children were removed from their natural homes by court order." As Paul Lombardc noted, this law transformed the BCC "from an advisory agency to an agency with executive ano administrative prerogatives that could clearly affect the lives of those designated as feebleminded."114 In perfectly Progressive fashion, these laws substituted the judgment of impaneled experts for individual families in determining the disposition of the state's "feebleminded" population. Now this group had both surveillance and enforcement powers.

${ }^{112}$ Dew, "Sterilization of the Fecble-Minded, Insane and Habitual Criminals," 8. See also, Wertenbaker, "Should Virginia Have a Marriage Law Based on Eugenics?" 420-23; and Carrington, "Keep the Race Pure," 434-38. 460.

113 J. W. Williams, "Heredity-Eugenics," Virginic Medical Semi-Monthly 17 (December 26, 1913):

${ }^{114}$ Ibid., 98. 
Stode was also the architect of the bills that Priddy used to justify his extra-legal sterilizations and that legally defined feeblemindedness. These bills created the procedures "to register, examine and commit the feebleminded to institutions where they would be segregated from 'normal' citizens." Moreover, these last two bills introduced language that provided Priddy and others a shield for their early sterilizations. Superintendents were empowered to "see that such moral, medical and surgical treatment as they may deem proper shall be given such patients." 115 Although Strode was absent, serving in the Judge Advocate General's corps during World War I, the Virginia General Assembly passed laws refining the administration of mental health in the Commonwealth. These laws included additional appropriations, authorization of the use of the Binet-Simon mental examination by Commissions on Feeblemindedness, and a marriage restriction statute that prohibited "habitual criminal, idiot, imbecile...[and] epileptic" Virginians from marrying. ${ }^{116}$

Finally, in 1920 Strode answered Priddy's request for two more bills. One amended the Virginia law which allowed state mental patients to challenge the legality of their commitment. The second bill amounted to an ex post facto law that declared all current and future inmates of state institutions "lawfully committed patients" if they had been committed by court order or "Commissions of Feeblemindedness." In effect, this law immunized the courts and the Commissions of Feeblemindedness from legal challenge and prosecution for unlawful imprisonment. Patients committed by these agencies effectively lost their right to appeal. These enactments shielded superintendents from suits like Mallory v. Priddy, placing them almost beyond the reach of the law.

Finally, in 1921, Priddy approached Strode about sponsoring a sterilization law. Preliminary research that discovered the nature and legal weaknesses of other extant sterilization statutes, as well as the failed attempt by Dr. Carrington to obtain an enabling act in 1910, persuaded both men that the time was not ripe. Two years later, however, the

115 Ibid., 100; Virginia Acts of Assembly, 1916, Chapter 106, quotsd in Ibid., 100.

116 Ibid., 142. 
State Hospital Board, prompted by Priddy, approached Strode to draft a sterilization law.

After "curing such defects as [Strode] could in the form of the Acts declared invalid by the courts," the hospital board hoped that, "the growth of knowledge of the laws of heredity and eugenics and changing public sentiment might bring a more favorable attitude from the legislature and the courts." 117 Clearly, eugenic thinking had, by 1923, thoroughly permeated the bureaucratic structure of Virginia's state health community. Thus, late in what historian Mark Haller termed the eugenics' "period of greatest influence" in America, Virginia stood poised to make history, leading the way toward eugenic utopia through the enactment of a constitutionally sound sterilization law. ${ }^{118}$

Virginia eugenicists would raily behind the efforts of Strode, Priddy, and later John $\mathrm{H}$. Bell and Irving Whitehead, to produce an ironclad sterilization law. Cribbing liberally from the "Model Eugenical Sterilization Law" written by ERO-superintendent Harry Hamilton Laughlin, Strode drafted a bill that he felt would withstand constitutionai challenge. ${ }^{119}$

${ }^{117}$ Lombardo, Ibid., 156.

${ }^{118}$ Haller, Eugenics, 6. As discussed in the Introduction, above, the timing of Virginia's enactment and the rising popularity of eugenics among public health and private physicians during this period begs a reevaluation of Haller's periodization. Although some scientists at the forefront of genetics began to move away from eugenics by 1930, the vast mass of scientists remaincd eugenically minded. Moreover, the lag between theory and practice assured that from 1915 to the 1950s eugenics remained a viable basis for public health activities.

${ }^{119} \mathrm{~A}$ consensus slowly emerged in favor of eugenic sterilization, at least in the case of clear hereditary defect, among eugenicists, geneticists, and public policy officials. Harry Laughlin's work provided the framework that translated this theoretical assent into practical application. Laughlin's model law, first presented in the American Breeder's Association's 1914 "Report of the Committee to Study and Report on the Best Practical Means of Cutting Off the Defective Germ-Plasm in the American Pcpulaticn" and released as Eugenics Record Office Bulletin 10A and 10B, aroused a firestorm of protest. Laughlin updated the model law, and presented a complete history of eugenical sterilization in America in his book Eugenical Sterilization in America. This work provided the basis for all "successful" eugenic sterilization laws in America and elsewhere. In 1936, on the 550th anniversary, the Heidelberg University awarded Laughlin an honorary doctorate for his contributions to "the science of racial hygiene." Adolf Hitler signed the degree. For the debates among national-level cugeiticists regardıng sterilization, sce Diane B. Paul and Hamish G. Spencer, "Did Eugenics Rest on an Elementary Mistakc?" in Diane B. Paul, The Politics of ileredity. Essays on Eugenics Biomedicine, and ihe Nalure-Nurture Debale (Albany, NY: Stute University of New York Press, 1998), 117-132. On Laughlin and stcrilization, sce Frances Janct Hassencahl, "Harry H. Laughlin, 'Expert Eugenics Agent for the House Committee on Immigration and Naturalization, 19211931,"' Ph.D. diss., Case Western Reserve University, 1970), 150-54; Chase, Legacy of Malıhus, 133-35. On Laughlin and the Nazis see, Paul A. Lombardo, "The Pioneer Fund: Missing Link in the American Eugenics Movement," TMs, in author's possession; and Chase, Legacy of Malihus, 349-50. For a close textual analysis of the similarities between Laughlin's model and the Virginia law, see Paul A. Lombardo, "Eugenical Sterilization," 154-76. 
Using cool, rational rhetoric, and mindful of the weaknesses that had doomed earlier laws, Strode's work became itself a model outline for the eugenic metaphor. Through the skillful application of science to society, afflicted individuals, contemporary society, and future civilization could be safeguarded from the menace of defective protoplasm. Avoiding the use of buzzwords like eugenics, and relying on earlier precedents that established expert authority in physicians, the statute enabled the sterilization of institutionalized individuals, while leaving open the "backdoor to eugenics," the sterilization of others for "therapeutic" reasons. Strode expended the bulk of his energies emphasizing the procedural aspects of the law, rather than its social effect. In so doing, the law garbed a still "radical" social intervention in the robes of individual liberty protected by the armor of due process and equal protection. Thus sterilization became rational and conservative rather than alarmist and radical.

The first four clauses of the law outlined the scope of the law and the eugenic metaphor, contending that "both the health of the individual patient and the welfare of society may be promoted in certain cases by the sterilization of mental defectives under careful safeguard and by competent and conscientious authority." Reiying on the "three C's" of careful, competent, and conscientious authority, the bill appealed to the paternalist ethos common to both the Progressive Era and southern mores to assuage concern over the "radical" intervention of sterilization. Asserting the conventional eugenic wisdom that vasectomy and salpingectomy "may be performed without serious pain or substantial danger to the life of the patient," the second clause reminded legislators that this intervention passed beneath the Eighth Amendment's ban on "cruel and unusual punishment" because sterilization was both humane and therapeutic, not penal.

After identifying the essentially "humane" and "humanitarian" nature of sterilization, the third clause identified its potential benefits to individuals and society. Strode invoked the menace of the feebleminded and the economic burden they posed. Rhetorically, this move 
emphasized the pathological nature of a feebleminded cohort within the populace. Since Virginia had

in custodial care and is supporting in various State institutions many defective persons who if now discharged or paroled would likely become by the propagation of their kind a menace to society but who if incapable of procreating might properly and safely be discharged or paroled and become self-supporting with benefit both to themselves and to society

the legislature should pass a sterilization law to eliminate the threat of contagion and the expense of supporting defectives. Strode emphasized the necessity of this action by asserting the incurable, non-bacteriological, nature of feeblemindedness in the fourth clause. "Whereas human experience has demonstrated that heredity plays an important part in the transmission of insanity, idiocy, imbecility, epilepsy and crime" sterilization, the only way to affect heredity by cutting of the source of defective germ plasm, becaine the only "cure" for society. This clause placed feeblemindedness beyond the biomedical scope of public health and called for a new form of "therapy." Doctors could heal sick people by killing germs, sick germ-plasm could only be "cured" by preventing its transmission: either through segregation, sterilization, or euthanasia. Since segregation was too costly, and euthanasia was considered inhumane and immoral in a Christian society, sterilization remained the only option.

Strode's shrewd use of "human experience" brought to legislators' minds their own personal understandings of heredity and notions of "gooa" and "bad" blood among their communities. This rhetorical shift allowed law-makers to act on both the common-sense wisdom of the stockyard as well as the esoteric laws of the genetics laboratory. ${ }^{120}$ Thus, when the law later asserted that sterilization was indicated for individuals "afflicted with nereditary forms of insanity that are recurrent, idiocy, imberiiity, feeble-mindedness or epilepsy," lawmakers could refer to their own knowledge of families wherein these

120 Lombardo, too, notes the power of this "homely" construction. Lombardo, Ibid., 169. 
"afflictions" occurred with apparently greater frequency, and attribute the incidence of these maladies to heredity.

With the necessity of eugenic sterilization thus established, Strode merely had to reassure politicians that essential protections existed to insure the civil rights of the afflicted. In some ways, this exercise assuaged their own fears that the eugenicists might be out to "get" them or their families. While few lawmakers identified with the institutionalized feebleminded, most of ten poor and of ill-repute, they might well have been alarmed by the possibility of state investigation of their own hereditary background. As Joseph DeJarnette later remembered, some resistance cropped up from "law-makers who suggested they might fall victim to their own legislation."121 Proper procedural safeguard would ensure that those with access to lawyers-i.e. those who could pay their fees and whose family had an interest in preventing sterilization-could effectively challenge a sterilization hearing. Those without these resources had to rely upon state-appointed legal guardians, who received their fee whether or not they prevented the sterilization. ${ }^{122}$

Even as Strode established procedural protections designed to insure the integrity of sterilization hearings and the protection of patients, he broke new ground that recast the section in an active eugenic mode. In outlining the selection of inmates to be sterilized, the

${ }^{121}$ Lombardo, Ibid., 132. DeJamette joked that, when some legislators voted against the statute, "I really felt they ought to have been sterilized as unfit." See "DeJarneue Celcbration," 30. Whether or not Virginia legislators definitely felt this way is unclear. Lombardo notes that the elderly DeJarnette confused some events. I believe he may well have conllated resistance to the Racial Integrity Act, discussed below, with resistance to the sterilization act, as both were debated simultaneously. Alternatively, he may have merged the famous quotations of Pennsylvania's Governor Pennypacker with his memory of Virginia's situation. Pennypacker vetoed a 1905 stcrilization bill as cruel and unusual punishment. He later quieted hecklers at a political rally by quipping, "Gentiemen, gentlemen! You forget you owe me a vote of thanks. Didn't I veto the bill for the cas!ration of idiots?" Kevles, In the Name of Eugenics, 109; Chase, Legacy of Malihus, 125.

${ }^{122} \mathrm{My}$ research indicates that precisely this dynamic occurred alter the passage of the act. No inmate who challenged a sterilization order with the aid of a privately-retained atlomcy was ever sterilized. Conversely, records at the Williamsburg Circuit Court, which had jurisdiction over the Eastern State Hospital, revealed that a small number of lawyers made a collige industry of representing patients at the asylum and collecting the $\$ 15$ fee from the state while providing only the pretext of legal representation. Transcripts from many of these hearings, made public during the 1980 casc Poe v. Lynchburg (discussed in Chapter 8) revealed that these men did little or nothing other than facilitate a "rubber stamp" process that sped inmates to the operating tables. 
law left the initial decision solely to the superintendent of the institution, backed by its board of directors. This placed discretionary power in the hands of purportedly dispassionate and objective professionals. Priddy and DeJamette's earlier writings, however, completely destroy the notion that they would approach sterilization on a case-bycase basis. For them, the efficacy of the "treatment" and the need for its application had been established beyond doubt; all that was necessary was an efficient machinery for rotating the feeble-minded through the operating room. Moreover, as Paul Lombardo notes, Strode's use of the classification "the probable potential parent of socially inadequate offspring likewise afflicted" came directly from Harry H. Laughlin and the eugenics movement. Combining the menace of the feeble-minded with the new diagnostic category of "social inadequacy" widened the scope of the laws application. ${ }^{123}$ "Social inadequacy," unlike feeble-mindedness, required no special training to identify. Misfits, ne'er-do-wells, transients, criminals, prostitutes, the indolent and poor all could be shoe-homed into this ostensibly "objective" category. Coupled to the laws concluding sections, these assertions stealthily brought all Virginians under the shadow of eugenic sterilization. ${ }^{124}$

The law's coda, in two brief sections, immunized board members who ordered and physicians who performed sterilizations under the law. These two sections reveal the lasting impact of Priddy's legal entanglement on the thinking of Virginia eugenicists. The first section explicitly exempted "superintendents" and "any other person legally participating in [sterilization]" from civil or criminal prosecution. The final section left open the therapeutic "back door" to eugenic sterilization, the very egress Priddy had used to escape liability in 1916. "Nothing in this act shall be construed so as to prevent the medical or surgical treatment for sound therapeutic reasons of any person in this State, by a physician or surgeon licensed by this State, which treatment may incidentally involve the

\footnotetext{
123Lombardo, "Eugenical Stcrilization," 174.

${ }^{124}$ This is true in theory if not in practice. As stated, it remained difficult to stcrilize individuals of the "upper" class, because of thcir access to adcquate legal representation.
} 
nullification or destruction of the reproductive function."125 Ostensibly included to protect physicians from frivolous suits by people sterilized as a consequence of treatment for another disease, this clause left sterilization open to the discretion of the individual physician, and brought into his purview all Virginians, not merely those in institutions. Indeed, even during the first trial testing this law, Priddy-still smarting under the lash of his previous trial-would maintain that his role as physician justified his actions, sterilization law or no, because, "I have a right to do whatever is best for the physical and mental advantages of the patient." 126 Priddy, like most medical and lay-people of the time, viewed treatment decisions as the prerogative and sole province of the doctor; patient consent and wishes had little or nothing to do with the matter. The abuse of physician's prerogatives, and the coercive sterilization of non-institutionalized individuals for eugenic and proto-eugenic reasons, remained medicine's best-kept secret until 1973.127

The law received an enthusiastic reception by the Virginia General Assembly. An able and calculating politician, Strode marshaled his forces, including Governor E. Lee Trinkle and the powerfui Senator Marshall Booker of Halifax County. Booker, chairman of the Committee on the Courts of Justice, to which the bill was first referred, also became its legislative sponsor. The Richmond News-Leader briefly reported the Senate committee hearing, noting that the committee considered the bill for two hours, hearing testimony from "Superintendents of the state hospitals" (most likely DeJarnette and Priddy," and amended the bill "so as to provide that consent of the patient's guardian or parent must be given." Strode's effort to avoid inflammatory rhetoric paid dividends, as the News-Leader

\footnotetext{
125 Virginia Acts of Assembly, 1924, "An Act Providing for the Sterilization of Certain Inmates," section 6 .

126Lombardo, "Eugenical Sterilization," 200.

${ }^{127}$ Medicine for most of the twentiech century manifested a directive, not an advisorial relationship between doctor and patient. Doctors "dispensed" medicine and therapeutic instructions, patients wcre expected to be co-operative (or as doctors tellingly phrased it then, and today, "compliant") in acquiescing to the treatment protocol. See Lilian R. Furst, Between Doctors and Patients: The Changing Balance of Power (Charlottesville, VA: University Press of Virginia, 1998), 1-18. The coercive sterilization, particularly of poor and minority women, came to light in 1973 during Relf $v$. Weinberger.
} 
remarked that the measure "was not as drastic as senators at first thought." 128 In rapid succession, the bill was reported from committee, read before the Senate, and passed unanimously by a vote of 30-0. Virginia's lower house worked expeditiously as well, again hearing testimony in committee from DeJamette and Priddy, and passing the bill with scant opposition by a vote of 75-2. Governor Trinkle signed the bill into law on March 15, 1924. Strode's careful draftsmanship and astute parliamentary calculations virtually ensured this result. 129

Strode himself later ascribed the bill's success to public support, "so great had been the change of public sentiment on the subject" since Carrington's attempt in 1910. ${ }^{130}$ Public support per se, however, was not crucial. Undoubtedly, the efforts of Virginia's eugenical propagandists - from the physicians at the state's two medical schools, to the undergraduate teachers of eugenics, to the high school teachers taught to think and instruct eugenically-aided in securing passage of the bill. The increased attention paid to eugenics, curried by Harvey Jordan's early propagandizing, bolstered by the increasing number of eugenically trained physicians, and reinforced by national attitudes regarding the treatment of the reeble-minded and eugenics generally, all served to prepare Virginia's goveming and professional elites for the adoption of eugenic measures.

Grass-roots support remained far less crucial than the appropriate education of those elites charged with lobbying for and passing the bill. Judging by the newspaper reporting of the bill, public opinion had changed enough so that the bill hardly merited coverage and

128"Committce Favors Stcrilization Bill," Richmond News-Leader, Fcbruary 13, $1924,1$.

${ }^{129}$ Lombardo, "Eugenical Stcrilization, 164-67. This expeditious passage reflects both general agreement with the law and, more palpably, the intense pressure on the legislature at the end of the 1924 term. As a result of contentious wrangling over the state budget, legislators neared adjournment with a full docket of subsidiary bills. The front page of both the Richmond Times-Dispatch and the Richmond NewsLeader kept a running tally of the number of bills passed each day in March of 1924, often commenting on the great haste made by the legislature. Ironically, the legislature had "thrilled" to an address by one of America's most famous "defectives," Helen Keller, just one week after the introduction of the bill. Despite front-page news coverage of the Assembly's "awed" reception of "one of the great miracles of all time," legislators felt no compunction toward consigning all others so "afflicted" to summary sterilization. See articles on Keller's visit and speech, Richmond Times-Dispalch, Fcbruary 15, 1924, 1, 10.

${ }^{130}$ Strode quated in Ibid., 164-65. 
elicited no editorial protest. The News-Leader and theTimes-Dispatch alternated coverage, and gave scant space or attention to the bills. ${ }^{131}$ This lack of interest is indeed a fair barometer of changed social mores regarding the eugenic sterilization of the "unfit." While no direct "index of eugenical popularity" can be deduced from this, subsequent coverage of the law's test case before the Supreme Court indicates staunch support of the law among Virginians. This support, again, may be extrapolated to indicate solid support of eugenics. Linked to the popularity of the eugenic antimiscegenation statute, the Racial Integrity Act, passed by the same legislature, the support of the sterilization bill seems to indicate a more general agreement with eugenics.

Virginians' support for eugenics would be reflected in the press three years later, as the United States Supreme Court considered the constitutionality of eugenic sterilization in Buck v. Bell. This case, self-consciously designed to test the law and result in its affirmation, looms large in the annals of American medical jurisprudence. With the stunning epigram "Three generations of imbeciles are enough," America's great libertarian jurist, Oliver Wendell Holmes, Jr., consigned generations of American's to compulsory sterilization. An examination of the case reveals illegal collusion, medical obfuscation, and hereditary determinism run amok. This signal triumph for the American and Virginian eugenics movements represented less the self-evident truths revealed by eugenics, and more the ruthless determination of eugenicists.

Almost as soon as the legislature passed the law, doctors Priddy and DeJarnette set about trying to test $i t$ in the courts. Court affirmation of the law would galvanize the state's right to "adjust" the quality of its population. Such an outcome would empower physicians like Priddy and DeJamette with unprecedented control over the lives of their patients. To ensure that just this eventıaiity would transpire, Priddy worked hard, with Aubrey Strode

131 "Sterilization Bill Reported in House," Richmond Times-Dispalch, February 28, 1924, p. 14. The note indicated that both Joseph DeJarnetle and Albcrt Priddy testified beforc the Housc in support of the bill. 
and former-member of the Colony's board Irving Whitehead, to construct a "friendly" case that would technically challenge the law. ${ }^{132}$ The first step toward this outcome was the selection of a viable candidate for sterilization. Priddy chose 18 year-old Carrie Buck, "a highly proper case for the benefit of the sterilization act," he would later testify. 133

Ironically, Carrie Buck hailed from Charlottesville, seat of eugenics in Virginia. ${ }^{134} \mathrm{~A}$ poor young woman bom to a poverty-stricken, unwed mother, Emma Buck, in 1902, Carrie would live a life of destitution and frequent abuse until her death in 1983. At age three or four, Carrie became the foster-daughter Mr. and Mrs. J. F. Dobbs, who would care for her until they had her committed, at age 18, to the Virginia Colony for the Epileptic and Feebleminded. The Dobbses sought Carries commitment because they alleged "it was impossible for them to care for her or control her any longer...." It is clear now that the real reason the Dobbs family tumed Carrie out was to hide their shame. Carrie had been raped and impregnated by the Dobbses' nephew shortly before the Dobbses sought her commitment. During hearings on Carrie's commitment, the Dobbses noted that Carrie's mother Emma had been committed to the Colony, that Carrie was epileptic, subject to "some hallucinations and some outbreaks of temper," dishonesty, and "moral delinquency." On the basis of the Dobbses' testimony and that of two physicians, who testified that Carrie was "feebleminded within the meaning of the law," the Juvenile Court of Charlottesville ordered Carrie's commitment. ${ }^{135}$

132"Friendly" cases can amount to a legal shell game: they undercut the usual adversarial nature of a law suit through the collusion of counsei for the plaintiffs and defense. In some cases this collusion does not breach ethical bnendaries; both sides merely stipulate certain facts to be decided. In Carrie Buck's case, however, the lawyers' collusion aimed at an agreed upon outcome while maintaining the charade of adversarial compecition. The result was a miscarriage of justice, as one side of the case received inadequate representation and the court was actively mislead. Paul A. Lombardo first uncovered this legal malfeasance in his dissertation. His article, "Three Generations, No Imbecilcs: New Light on Buck v. Bell, presents this case in its starkest terms.

133Priddy quoted in Lombardo, "Eugenical Sterilization," 199.

${ }^{134}$ Carrie's sto:y is related in Lombardo, "Eugenical Sterilization," 177-90; Lombardo, "Three Generations," 49-55; Stephen J. Gould, The Mismeasure of Man, 65-66; and Gould, "Carrie Buck's Daughter," Constitutional Commentary 2 (1985), 331-39; and with considerable dramatic license in Smith and Nelson, The Sterilization of Carrie Buck, 1-52.

${ }^{135}$ Quotations from Lombardo, "Eugenical Sterilization," 178-79. 
Admitted on January 23, 1924, Carrie went before the Colony's Special Board of

Directors the following September, barely one month after the sterilization law went into effect. Represented by a guardian ad litem, with her own defense compromised by those who knew her best-her foster family, Carrie faced sterilization with only the most perfunctory protection. Strode acted as the Colony's lawyer, and walked Priddy through a presentation of Carrie's case. Priddy asserted that Carrie's Binet-Simon mental test results revealed that she had a mental age of nine, making her "feebleminded of the lowest grade Moron class." 136 Under cross examination, Priddy testified to the safety of salpingectomy, stating further that the operation was the only way to restore Carrie to society because, "in her mental defectives, self-control and normal conception are organically lacking and cannot be supplied by teaching or training, she being congenitally and incurably defective." Strode then asked Carrie one question, "Do you care to say anything about having this operation performed on you?" Innocently trusting her foster parents and those in authority, Carrie responded, "No sir, I have not, it is up to my people." With her mother already an inmate of the Colony and her foster parents trying to obliterate evidence of their nephew's assault, Carrie stood at the board's mercy. The board concluded that Carrie was indeed feebleminded and "by the laws of heredity the probable potential parent of socially inadequate offspring, likewise afflicted," therefore, "she may be sexually sterilized without detriment to her health, and that the welfare of the said Carrie Buck and of society will be promoted by such sterilization." 137

Appealed to the Circuit Court of Amherst County, old friends Aubrey Strode and Irving Whitehead contested the case of Buck v. Priddy before their mutual friend Judge Bennet Gordon. At this point, Strode entered detailed testimony from local witnesses and nationally-prominent eugenicists to build a solid foundation from which to defend the law.

\footnotetext{
${ }^{136}$ As Lombardo notes, a mental age of nine would have placed Carrie in the middle of the "moron" category, her mothcr's mental age of 8 placed her in the low ange. Priddy would correct this statement for trial. Lombardo, "Three Generations, No Imbeciles," 32 note 10, 49.

${ }^{137}$ Quotations from Lombardo, "Eugenical Sterilization," 181-82.
} 
Testimony from Charlottesville neighbors established that Carrie came from a "defective" family of loose morals. Nurses from Charlottesville, some possibly trained by the eugenicists at the University of Virginia, testified that Carrie's mother Emma Buck was "absolutely irresponsible" and constantly seeking charitable relief. Carrie's sister Doris was portrayed as a "very stormy individual...incorrigible." Of Carrie's passing notes to boys in grammar school, a nurse testified that "if a girl of sixteen had written that kind of note" she would be sent to a reformatory for "wayward" women-prostitutes. This appeared to establish Carrie's "moral delinquency," for even as a school girl she allegedly displayed a precocious sexual appetite.

Mary Duke and Caroline Wilhelm, social workers for the Red Cross, supplied supplemental testimony that decreased Carrie's prospects. Mary Duke had handled Carrie's case and knew both mother and daughter. She testified that Emma Buck was "of bad character" and her daughter Carrie "simply didn't seem to be a bright girl." Ms. Wilhelm, who replaced Ms. Duke on Carrie's case, declared Carrie and those like her "more or less at the mercy of other people [because of their feeblemindedness]...very likely to have illegitimate children." In her professional opinion, Carrie represented a "distinct liability to society." Ms. Wilhelm had examined Carrie's infant child, born out of wedlock and not quite eight years old, and labeled it as being "not quite a normal baby" because it had "a look about it that is not quite normal" although "just what it is [causing the appearance of abnormality] I can't tell."138 With this expert testimony, Strode felt he had established a pattern of hereditary degeneracy.

Paul Lombardo characterized Irving Whitehead's appearance as "purely a formality." 139 Whitehead conducted anemic cross examinations and raised perfunctory, but indecisive objections against hearsayy evidence. This is not surprising, given the fact

${ }^{138}$ Quotations from Lombardo, Ibid., 188-89.

${ }^{139}$ Lombardo, a lawyer himsclf, adheres to this conclusion which scems amply borne out by the trial transcripts. Lombardo, "Eugenical Sterilization," 192. 
that just seven years earlier, as Director of the Colony Board, Whitehead himself had moved the board to authorize Priddy's early sterilizations. Indeed, records show Whitehead himself to have adhered to precisely the same views as Priddy regarding the sterilization of the feeble-minded. Rather than being an advocate for his client's constitutional rights, Whitehead sympathized and conspired with her adversaries. ${ }^{140}$

The two eugenical experts who testified in the case, Harry Hamilton Laughlin and Arthur E. Estabrook, met a similarly light treatment from Irving Whitehead. Laughlin sent in a deposition from New York. From that remove, the superintendent of the ERO came to the conclusion that the Buck's "belong to the shiftless, ignorant, and worthless class of anti-social whites of the South". Basing his "scientific" opinion on second-hand evidence provided by Priddy, Laughlin presented a brief in favor of sterilization. Carrie, as a member of the South's eugenically unfit class, represented the perfect candidate for eugenic reform. Estabrook, a sociologist cum eugenicist who conducted field studies for the ERO had been trained by Charles Davenport and Laughlin. Estabrook actually went to Amherst County to appear at trial. Strode met Estabrook through his wife Louisa, who was herself a firm disciple of eugenics. ${ }^{141}$ Estabrook, who had updated Richard Dugdale's early family study The Jukes and published his own The Jukes in 1915, was a nationallyrespected authority on eugenical family studies and hereditary defectiveness. ${ }^{142}$ Carrie Buck, according to Estabrook, was both "feebleminded" and "socially inadequate" in the eyes of science and the law.

140 Lombardo, "Three Generations, No Imbeciles." 38-39; "Eugenical Sterilization," 192-93.

${ }^{141}$ On the Strode-Estabrook connection, see Lombardo, "Eugenical Sterilization," 196-97, especially 197 note 47. Estabrook would figure prominently in the successful elfort to pass Virginia's eugenic antimiscegenation statute, as will be discussed, below.

${ }^{142}$ Dugdale's book is the ur-study that set the pattern for all subsequent eugenical pedigree studies. Estabrook's 1915 volume was a crucial contribution to the literature sounding the tocsin over the "menace" of the feebleminded. See Nicole Hahn Rafter, White Trash: The Eugenic F amily Studies, 1877-1919 (Boston: Northeastern University Press, 1988); Arthur E. Estabrook, The Jukes in 1915 (Washington, DC: Carnegie Institution of Washington, 1916). 
The testimony of Laughlin and Estabrook bolstered that of Virginia's home-grown eugenics experts, Joseph DeJarnette and Albert Priddy. DeJamette established the dispositive relationship between heredity and feeblemindedness for the record. DeJamette discoursed on the relationship of venereal disease to defect and the economic benefits accruing to society from eugenic sterilization. In a particularly tortuous portion of his testimony, in answer to Irving Whitehead's questioning how sterilization benefited society, DeJamette answered, "It benefits society by not taking care [maintaining] of them [the feebleminded], and by the work they do [in the Colony]. They are the hewers of wood and the drawers of water, and there is not very much more likelihood that they would spread venereal disease if sterilized than if they were not."143 DeJarnette clearly wished society to expend only the bare minimum to maintain his charges. He viewed them as a social and economic underclass fit only for the manual labor that the "fit" found distasteful. Moreover, while they were a threat to pass on venereal disease, his testimony implied that sterilization would not make them any more licentious and likely to spread the disease than they already were; iilstead it would prevent the procreation of similar "moral imbeciles" who would bolster the ranks of the infected. Sterilization thus, for DeJarnette, offered a generations-long panacea for venereal infection. Once again, venereal disease, heredity, and eugenics all converged in the iteration of Virginia's eugenic creed.

Albert Priddy was the last man to testify in Carrie Buck's first trial. Priddy corrected his earlier estimate, upgrading Carrie from "the lowest grade moron" to "middle grade" and then testified to the economic benefits offered by sterilization. Priddy asserted that the high demand for household domestics was "so great that probably we could get rid of half of our young women of average [moronic] intelligence but I have had to abolish it [paroling inmates as domestics]." Priddy ceased paroling "middle" and "high grade morons" because, according to him, they invariably became pregnant. Rather than considering that

\footnotetext{
${ }^{143}$ DeJamette, quoted in Lombardo, "Eugenical Sterilization," 195.
} 
these women may have been coerced into sex and impregnated by male employers, Priddy blamed the women for their condition. He asserted that "People don't care to take them when there is the constant chance of them becoming mothers," as if it was always the women's fault that they became pregnant. Priddy implied that people felt inconvenienced, and appropriately so in his eyes, by the eventual loss of their help post-partum. His statement betrays no sense that "respectable" people were embarrassed, as Carrie Buck's foster parents were, by pregnancy's mute testimony to sexual abuse and marital infidelity. Or, if they were, Priddy again thought it was the woman's fault-her pregnancy disgraced the family for bringing the illicit behavior to light, the behavior that caused the pregnancy was not of itself disgraceful. Priddy, like his good friend DeJarnette, viewed his charges as a pool of labor. He asserted that while some eight to ten thousand Virginians might be eligible for colonization, "some of those people wouldn't come within the Virginia definition for sterilization." Priddy viewed this as "fortunate," else the state "wouldn't have any hewers of wood or drawers of water." In other words, those occupying the bottom rungs of Virginia's intellectual and economic ladders represented the optimal manual labor pool. What was needed to increase social stability was a little biologically informed social engineering, finely calibrated to adjust the mental capacity of this lowest group. The state wanted those who would be content to hew and draw responsibly, without crime, disease, and lasciviousness. Priddy and his colleagues envisioned a eugenically "pure" underclass, where "like breeds with like," thereby buttressing the extant class hierarchies and providing a tractable labor pool without social "cost."

The testimony presented in Amherst County, and the skillful collusion between Strode and Whitehead, created an ironclad case against the Buck clan. Although Priddy died before the case went to the Virginia Supreme Court of Appeals, its outcome was virtually assured. Strode was confident enough that he spent the interim writing "Sterilization of Defectives" for the Virginia Law Review, an article that provided a eugenic primer for 
Virginia's legal community. Strode answered the rhetorical question, "What are the limits of the police power of an American state over the liberty of persons within its jurisdiction to reproduce their kind?" by defending sterilization as "advanced eugenical science" and "enlightened medical practice."144 Priddy's place on the docket was taken by his successor at the Colony, Dr. John H. Bell. Bell, like Priddy and DeJarnette, was an ardent eugenics enthusiast.

The history of Buck v. Bell once it reached the appellate level is well known and amply detailed in other works. ${ }^{145}$ What remains significant is the degree to which Aubrey Strode and ultimately Supreme Court Justice Oliver Wendell Holmes, Jr., relied upon the "eugenic metaphor" in constructing their ruling. As a result, these men effectively understood the right to procreate as the potential to affect the public health and, as such, subject to the control of the state's police power. As Strode argued in "Sterilization of Defectives," eugenic statutes must also promote the welfare of the individual "inmate." While physicians largely agreed that vasectomy and salpingectomy offered no "therapeutic" benefits to patients, Strode argued that they provided what we might call "quality of life" benefits by freeing individuals otherwise destined for lifetime segregation in state homes. Strode invoked this "benefit" explicitly as a thin mask for his real concerns, the economic burden of the feebleminded, when he asked rhetorically,

Must such persons [hereditary defectives] languish for life in custody and must the government bear the perpetual burden of thus maintaining them...must this be so even when through a simple surgical operation not appreciably dangerous and involving the removal of no sound organs from the body such persons might be discharged from custody and become self supporting to the great advantage of themselves and society? May one liberiy be thus restored through the deprivation of another liberty? ${ }^{146}$

\footnotetext{
${ }^{144}$ Aubrey E. Strode, "Sterilization of Defectives," 11 Virginia Law Review (1925), $296-01$.

${ }^{145}$ Lombardo, "Eugenical Sterilization," 210-33;

${ }^{146}$ Strcde, "Sterilization of Defectives," 296.
} 
Strode felt the answer was "Yes." In November, the Virginia Supreme Court of Appeals concurred with Strode, clearing the way for an appeal to the United States Supreme Court. ${ }^{147}$

It would be more than a year before the Supreme Court finally heard Buck and welded together the police power and public health through eugenics. In April of 1927 the Court heard arguments from Strode and Whitehead. Clearly sounding editorial support for the law, the Richmond Times-Dispatch announced the case, under the headline "Assails Virginia Law / U. S. Supreme Court Hears Progressive Act Scored." Only a tiny note, the Times-Dispatch sketched the outlines of the case and remarked that the law was "defended by the State as medically progressive."148 Strode relied on one of the most "progressive" technologies in medicine and public health to cinch his argument for eugenical sterilization. He introduced the precedent set by the U. S. Supreme Court in the 1904 inoculation case, Jacobson v. Massachusetts. ${ }^{149}$ Jacobson affirmed the right of a state to punish individuals who refused a mandatory smallpox inoculation for public school pupils. The high court thus reinforced the state's right to enforce measures aimed at safeguarding the public health and safety. Strode picked a particularly significant precedent. His use of Jacobson cast eugenics in its most favorable light-not as an experimental science but as a calculated measure to preserve the health of the state's populace. Relying on Jacobson also appealed to Mr. Justice Holmes, who had sat on the court that decided Jacobson. Intentionally or not, Strode tapped the established eugenical beiiefs of the Court's most senior member.

Justice Holmes is rightly remembered as being an advocate of "judicial restraint," believing that legislatures, not the courts, should enact the will of the people. The Supreme Court, when reviewing legislation, should rule on the narrowest grounds possible, Holmes believed, thereby leaving the field open for legislation to further amend, clarify, and

\footnotetext{
${ }^{147}$ The opinion of the Supreme Court of Appeals appears in 143 Virginia Reports 310 (1925).

148 "Assails Virginia Law," Richmond Times-Dispatch April 22, 1927, 1.

${ }^{149}$ Lombardo, "Eugenical Sterilization," 218.
} 
articulate the law. Most important, for Holmes, was the ability of the judge to rule in a dispassionate, detached manner. It is clear that in Buck, Holmes's own sympathy with eugenics harmonized with the objectives embodied in the Virginia law. This resonance allowed him to write an opinion ringing with eugenic overtones. Coming from the Court's ancient Nestor, the ruling had both symbolic and material importance for Virginians. If Holmes upheld the law, certainly Virginia was on the most progressive track toward utopia.

Holmes expressed his eugenical views, which captivated his imagination enough to cloud his jurisprudence, in public writings and private correspondence. Always a libertarian, and skeptical of political "-isms," Holmes explicitly privileged biological over political interventions. As early as 1915 , lashing out against socialist utopianism, "I believe that the wholesale social regeneration which so many now seem to expect, if it can be helped by conscious, co-ordinated human effort, cannot be affected appreciably by tinkering with the institution of property but only by taking in hand life and trying to build a race." 150 Holmes's correspondence with the British intellectual Harold Laski revealed both his belief in the bio-social doctrines of Thomas Malthus and his tacit acceptance of eugenics. In phrasing that surely would have pleased Charles B. Davenport, Holmes wrote Laski, "As I have said, no doubt, often, it seems to me that all society rests on the death of men. If you don't kill 'em one way you kill 'em another-or prevent their being bom." Rather than supporting the "reform" work of "social meliorists" like Jane Addams, Holmes felt that "while propagation is free and we do ali we can to keep the products, however bad, alive, I listen with some skepticism to plans for fundamental amelioration. I should expect more from systematic prevention of the survival of the unfit." Given these views, Holmes's ringing endorsement of Virginia's eugenical sterilization statute seems

\footnotetext{
150Oliver Wendell Holmes, Jr., "Ideals and Doubts," Illinois Law Review 10 (1915), quoted in Lombardo, "Eugenical Sterilization," 221.
} 
foreordained, especially given Holmes's contemporary remark that, "sooner or later one gets a chance to say what one thinks." 151

As a Civil War veteran who carried shards of shrapnel in his body, Holmes believed he knew something about inhumane social interventions; compared to war, the sterilization statute hardly registered as anything but humane. He brought all his convictions to bear in the blast he issued as the Court's opinion. "We have seen more than once," the old soldier wrote, "that the public welfare may call upon the best citizens for their lives." By contrast, "It would be strange if it [the public welfare] could not call upon those who already sap the strength of the State for these lesser sacrifices, often not felt to be such by those concerned, in order to preveni our being swamped with incompetence." Indeed, the benefits that accrued to those sterilized surpassed being asked only to make "lesser sacrifices," for as Holmes reasoned, "It is better for all the world, if instead of waiting to execute degenerate offspring for crime, or to let them starve for their imbecility, society can prevent those who are manifestly unfit from continuing their kind." Drawing specifically on Strode's logic, Holmes averred, "The principle that sustains compulsory vaccination is broad enough to cover cutting the Fallopian tubes. Three generations of imbeciles are enough."152 With his concise prose, Holmes consigned Carrie Buck, and all those society viewed as like her, to the surgeon's knife. Holmes wrote to Laski thai eugenic sterilization "ivas getting near the first principal of real reform." The decision, he wrote to Lewis Einstein "gave me pleasure"; to Felix Frankfurter, he wrote, "I think my cases this term have been of rather a high average of interest e.g., the Virginia Sterilizing Act."153

The public reaction in Carrie Buck's hometown can be gauged by an editorial in the Charlottesville Daily Progress. Itself a "progress" mouthpiece, the paper ran an editorial

${ }^{151}$ Holmes to Laski, quoted in Lombardo, Ibid., 222, 224-25.

152 Buck v. Bell 247 U.S. 207 (1927).

${ }^{153}$ Holmes to Laski and Einstein quoted in Lombardo, "Eugenical Stcrilization," 228. Holmes to Frankfurter quoted in Robert M. Menriel arid Christine L. Compston, ed., Holmes and Frankfurter: Their Correspondence, 1912-1934 (Hanover, NH: University Press of New England, 1996), 212-13. 
"Safely Through the Gamut," that described the Buck case. "Over the protests of many who held up their hands in holy horror at the thought of merely discussing such a thing publicly, much less actually practicing it with the sanction of the state," the editor began, Virginia's General Assembly had authorized "the sterilization of mentally defective persons under carefuliy specified conditions." This action "placed Virginia in the front rank of the states which are committed to a progressive program of welfare legislation." The editor lauded the "obvious wisdom of this highly beneficial law" and claimed that Carrie Buck was a fit "subject for this type of treatment." Taking a cue from Justice Holmes's epigram, the editor then inaccurately related Carrie Buck's background, claiming that she was the "imbecile daughter of parents who were themselves members of the feeble-minded colony, and herself the mother of an illegitimate, mentally defective child." The paper then heaped accolades on "that incomparable jurist who, despite his eighty-five years, unfailingly is found in sympathy with the most progressive tendencies in our social machine, Justice Cliver Wendell Holmes," who "delivered a concise, convincing opinion, which is a genuine classic." The editors liked Holmes's prose so well that they reprinted the decision's peroration, "which bristles with the wisdom that has been nurtured by a long judicial experience, and which in Mr. Holmes, is the companion trait of a profound social insight." Seldom before the Progressive Era did southem newspapers speak so glowingly of the opinions held by former officers of the Grand Amy of the Republic. The editor concluded, "Virginia is fortunate in having had this eminently sane and beneficial law, safely run the gamut of judicial review and permanently enrolled upon its statute books." 154 The foliowing October, after Whitehead filed a perfunctory request for a rehearing, which the Court denied, Dr. John H. Bell sterilized Carrie Buck, the first of some 8,000 Virginians to be "treared" vetween 1924 and 1972.155

154"Safely Through the Gamut," Daily Progress, May 4, 1927, 4.

${ }^{155}$ The number of Virginians sterilized in institutions varies between conservative estimates of 7,500 to 8,500. Lombardo cites 8,300 in "Eugenical Sterilization in Virginia," 252. Erin Himstedt notes that Virginia sterilized approximately 1,660 African Americans, 20 percent of the total. 


$$
* \quad * \quad * \quad *
$$

Doctor Bell sterilized Carrie Buck on October 19, 1927. Five days later, the Richmond News-Leader ran a front page article entitled, "Says Eugenists Do Cause Harm." The newspaper reported the criticisms of Dector Raymond Pearl, as published in the forthcoming issue of the American Mercury. "Superior people do not produce superior children," the article began, continuing to quote Pearl's opinion that, "'In preaching as they do that like produces like, and inferior people produce inferior children, the orthodox eugenists are going contrary to the best established facts of science, and are, in the long rin, doing their cause harm. "'156 Pearl's opinion carried great weight; he was, after all, professor of biology in the Johns Hopkins University. With this statement, Pearl undercut the logic of "three generations of imbeciles" that condemned Carry Buck to sterilization. ${ }^{157}$ Pearl's paper, however, came too late for Carry Buck, her sister, and thousands of other Virginians and Americans.

The convergence of Virginia's social climate, progressive reform, and eugenic theories paved the way for the enactment of a law that obviously violated the civil rights of some Virginians. The noblesse oblige of the fabled Virginia Cavaliers, the scions of the First Families of Virginia, now manifested itself in the eugenic reform of mental health care. Protests for the humane treatment of the institutionalized, and the conviction that sterilization was more humane than institutional segregation, resonated with Virginia's established pattems of political paternalism.

Simultaneously, however, the indelible image of the "feebleminded" as a "menace" to society dehumanized institutional patients. Indeed, the segregation of the mentally retarded

156"Says Eugenists Do Causc Harm," Richmond News Leader, Octobcr 24, 1927, 1 and 12. See also Raymond Pearl, "The Biology of Supcriority," The American Mercury 12 (November 1927), 257-66, quotation 266.

${ }^{157}$ It is crucial to note that Pearl did not reject eugenics, merely the logic of the mainline camp. Pearl demanded a much more stringent definition of "unfitness." For an insightful analysis of Pearl's eugenics, see Elazar Barkan, The Retreat of Scientific Racism: Changing Concepts of Race in Britain and the United States Beiween the World Wars (Cambridgc and New York: Cambridge University Press, 1992), 210-20. 
into the sub-human categories of imbecile, idiot, and mcron paralleled the developing image of the sub-human "black beast-rapist" who also menaced the commonwealth. For the good of the public weal, both groups needed to be controlled eugenically, and in short order. The convergence of these various social trends is born out by the fact that the same session of the Virginia legislature passed the Racial Iritegrity Act, Virginia's second law for the eugenical control of its population. That the United States Congress passed the eugenically motivated 1924 Immigration Restriction Act, after Virginia's bills had become law, reveals the consonance between reform thinking in Virginia and throughout the nation in 1924. The sterilization act formed one prong of Virginia's bid to lead the nation in Progressive social engineering, the Racial Integrity Act-propounded by men like Eamest Sevier Cox, John Powell, and public health department physician Walter Plecker-formed another. 


\section{Chapter VI: "Mongrel Virginians": Eugenicai Politics and Social Policy}

Real estate agent and self-styled ethnologist Eamest Sevier Cox vividly enunciated

Virginia's eugenic fears with regard to the "negro problem." Introducing his book White

America, Cox wrote that,

It may readily be seen that the Negro problem is a part of the greater problem of heredity. When eugenics seeks to eliminate the unfit and establish the fit it has for its purpose not the betterment of physical types merely, but the establishment of those types of greatest value to progressive civilization.

A race which has not shown creative genius may be assumed to be an unfit type so far as progress in civilization is concerned and is a matter of concern for the eugenist. Those who seek to maintain the white race in its purity within the UnitedStates are working in harmony with the ideals of eugenics. Asiatic exclusion anci Negro repatriation are expressions of the eugenic ideal. ${ }^{1}$

While eugenic sterilization promised a solution to the "menace" posed by Virginia's feebleminded, it did nothing to alleviate fears of "miscegenation," the mixing of different "racial" genes that haunted the minds of many white Virginians. Even as Virginia's eugenics supporters mobilized to pass tiie sterilization law in 1924, an ailied group promoted a law to defend "racial integrity" by banning interracial marriage. Led by Cox, the famous pianist John Leslie Powell, and Virginia's registrar of vital statistics Dr. Walter Ashby Plecker, these lobbyists organized the Anglo-Saxon Clubs of America (ASCOA) and achieved the passage of the Racial Integrity Act of 1924 (RIA). Melding eugenic arguments with traditional negrophobia, the RIA represents the capstone of Virginia's eugenic public policy.

Virginia's adoption of the RIA paralleled the federal Johnson Immigration Restriction Act of 1924, representing the local analog to the national legislation. The ASCOA resembled the Immigration Restriction League in both composition and ideology. ${ }^{2}$ Both

\footnotetext{
${ }^{1}$ Eamest Sevier Cox, Wizite America (Richmond, VA: The White America Society, 1923; Special Revised Edition, 1937), 26-27. Cox's self-published book went through four editions, two of which carried revisions. He worked for the Laburnum Realty Company in Richmond.

2For a description of the ASCOA, see Lisa Lindquist Dorr, "Arm in Arm: Gender, Eugenics, and Virginia's Racial Integrity Acts of the 1920s," Journal of Women's History 11 (Spring 1999): 151-52; Paul A. Lombardo, "Miscegenation, Eugenics, and Racism: Historical Footnotes to Loving v. Virginia" University of California-Davis Law Review 21 (1988): 428-431; and Richard Sherman, "'The Last Stand': The Fight for Racial Integrity in Virginia in the 1920s," Journal of Southern H'istory 54 (1988): 69-92.
} 
groups championed racial "purity" and the definition and defense of a new "American race" that was the genetic descendant of the best Anglo-Saxon and Teutonic stocks from the Old World. Thus, Boston Brahmins tracing their ancestry to New Englarid's colonial generation understood the Virginia Cavaliers, the descendants of the so-called First Families of Virginia - whose social primacy depended on their ancestry. As Mark Haller put it, "eugenics and racism united in a scientific doctrine of an elite about to be swamped by the incompetence of those whose inheritance placed them among the enemies of civilization."3 North and South reunited in eugenics, seeking the exclusion of "inferior" whites from southeastern Europe and blacks, as well as the eugenic treatment of the "feebleminded" and poor of whatever race.

For all their overt nativism and xenophobia, however, both groups built on a supposedly scientific foundation. Beginning with the hereditary doctrines propounded by nationally-recognized eugenicists and supported by state educators, Virginia's would-be social engineers identified in African-American genes the source of tuberculosis, syphilis, insanity, and the pervasive racial tension that strained Virginia society. The Virginia eugenicists feared black/white amalgamation to the same degree that their northem counterparts feared the intermarriage of immigrants from Southeastern Europe and Jews with "Old Stock" Americans. As Thomas Gossett wrote, "There were, of course, men with different views in both the South and the North. But what is noticeable is that American thought of the period 1880-1920 generally lacks any perception of the Negro as a human being with potentialities for improvement." 4 The eugenic orthodoxy among social

Barbara Miller Solomon presents the best single-volume discussion of the Immigration Restriction I.eague in, Ancestors and Immigrants: A Changing New England Tradition (Cambridge: Harvard University Press, 1956). John Higham notes the eugenic connections between anti-European nativism and anti-black negrophobia in, Strangers in the Land: Patterns of American Nativism, 1860-1925 (New Brunswick, NJ: Rutgers University Press, 1955), 149-57, 173.

${ }^{3}$ Mark Haller, Eugenics: Hereditarian Attitudes in American Thought (New Brunswick, NJ: Rutgers University Press, 1963), 150.

${ }^{4}$ Thomas S. Gossett, Race: The History of an Idea in America (New York and Oxford: Oxford University Press, 1997), 286. 
theorists, doctors, scientists, and lay pundits in Virginia was every bit as strong as it was elsewhere.

This chapter will explore Virginia's racial integrity movement as part of the same, widespread eugenics impulse sweeping the nation and Virginia during the 1920s. Virginia's RIA can best be understood as the end product in a long trend of hereditarian thinking. Beginning during the 1890s, scientifically justified racism bombarded Virginia's physicians, educators, and legislators. The first effect of this rhetoric was the dehumanization of blacks in the eyes of white Virginians. Eugenicists reduced heredity to bamyard metaphor. Described in animalistic imagery black genes became subhuman genes in the minds of many Virginians. Destined to revert to savagery and fall prey to disease, blacks became a race destined, in the words of Paul Brandon Barringer, to "sacrifice." Physicians treating blacks ascribed to various theories of "racial medicine" taught by the faculty at Virginia's medical schools. This led to the stigmatization of blacks as repositories of disease and decay, a bacteriological threat to whites in whose communities and homes they worked. In spite of this purportedly endemic disease, blacks failed to "die off" rapidly and solve the "Negro problem" through extinction. By the 1910s and 1920s, Dr. Barringer's forecast was in need of serious revision. Whites used eugenics to hem in black aspirations by recasting the "prognosis" from a terminal condition for blacks to a terminal threat to whites.

During the 1910s and 1920s white Virginians used eugenics as a justification for limiting black political, social, and economic agency. First disfranchising blacks, then circumscribing black liberty with segregation ordinances, Virginia's attempt to "adjust" the "race problem" took its most drastic turn in 1924, with passage of the RIA. Forbidding interracial marriage, the RIA sought to maintain white racial purity. Alarmed at the possibility of light-skinned "pass-for-white" blacks marrying white men and women, and procreating "black" children that "looked" white, supporters of the RIA mobilized eugenic 
theory to fortify their social proscriptions. The connections between the RIA and the broader Virginia eugenics community fortified the relentless attempt to inculcate an entire generation of Virginians in segregation's science. Links between Powell, Cox, Plecker and national-level eugenicists highlights these Virginians' desire to cast their state as the model for "progressive race management."

Perhaps the most significant aspect of this study comes from analyzing the struggle over eugenics among Virginia's African-American community. While blacks at the Hampton Institute leamed eugenics from Professor Tumer, Virginia's broader AfricanAmerican community leamed about the science from the black press, the National Association for the Advancement of Colored People (NAACP) and the agents of Marcus Garvey's Universal Negro Improvement Association (UNIA). Blacks, as gauged by coverage in the African-American press, apparently paid little attention to the eugenic sterilization bill. Debate over the Racial Integrity Act, however, inspired both black support and protest, reactions reflected in Virginia's black and white newspapers.

Although many blacks resisted Virginia's eugenic legislation, cthers worked to advance it - in the name of securing black racial purity against whites depredations. Some black intellectuals articulated their own version of "reform eugenics" that accepted the principal of human improvement while denying the existence of a racial hierarchy within humanity. As Marouf A. Hasian reminded historians, "Much like other groups who opposed hereditarian eugenics, intellectual blacks did not abandon all interpretations of eugenics but rather attempted to create a 'reform' perspective that took into account the effects of environment and culture in the progress of the races." 5 Manipulated by black intellectuals, eugenics became another tool for black uplift. African Americans thus co-opted the science of eugenics, creating a narrative of liberation in direct opposition to white eugenicists' efforts to constrain black agency. Ironically, by the 1920s blacks advanced notions of eugenic

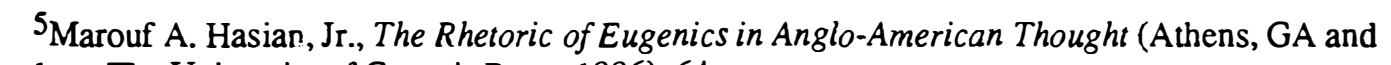
London: The University of Georgia Press, 1996), 64. 
salvation that harmonized with ideas of racist white Virginians like Harvey Ernest Jordan, Ivey Foreman Lewis, and the other supporters of the RIA. The rising popularity of Garvey's UNIA among black Virginians provided the basis for the political mobilization of black "separatist" eugenics.

\section{Sex, Crime, and Disease: Diagnosing Virginia's African Americans}

In the decades surrounding the turn of the twentieth century, racial tensions terrified white Americans. Rising rates of extra-legal violence against blacks, in the form of spectacular lynchings and race riots, sparked intense debate over the cause of racial friction. Southern whites, many old enough to remember the antebellum era, constructed a myth of black racial declension. Arguing that blacks prospered under the benign conditions of slavery, southerners, led by physicians scientists, and historians asserted that the black race was destined to become extinct because of its hereditary inability to compete with superior whites. ${ }^{6}$

Notwithstanding the general belief in the innate inferiority of all blacks, white Virginians believed that their black population represented the best the race had to offer. In 1917, Julian Street argued in Collier's Magazine that "only the bad ones [slaves] were 'sold South.'...Naturally, then, the Virginia negro of to-day, being descended from 'selected stock' - as slave dealers' advertisements used to put it—may be expected to average somewhat higher in the human virtues than the offspring of slaves of the black belt."7 Yet long before Street's assertion, Virginia physicians deployed ideas about racial atavism to explain the race problem in the Old Dominion. Despite this tradition of extolling "Virginia darkies" as the best bred and mannered slaves and servants, Virginians frequently

\footnotetext{
${ }^{6}$ Historians, led by Johns Hopkins University's William A. Dunning and Dunning's student Ulrich B. Phillips, began to characterized slavery as a basically benign institution around the turn of the century.

${ }^{7}$ Street's remarks quoted in "Selection of Negroes," The Eugenical News 2 (April, 1917), 24. White Virginians' nostalgia for the ante-bellum was reflected in the state song, "Carry Me Back to Old Virgirny," a paean to "loyal darkies" who loved their masters.
} 
argued that the "new" generation of blacks, born since Reconstruction, was destined for increased crime, sexual perversion, and disease. While things were not as bad as they might be elsewhere, it seemed only a matter of time before even Virginia's blacks reverted to their savage basis. Blacks would become a health hazard for whites, Virginia physicians argued, whether as the locus of infectious disease or hereditary criminality.

The Virginia Medical Semi-Monthly filled its pages with considerations of the "negro problem." In the spring of 1893, Richmond physician Dr. Hunter McGuire, then-president of the American Medical Association, invited Dr. G. Frank Lydston to address the topic of "Sexual Crimes Among the Southern Negroes-Scientificaliy Considered" through the pages of the Semi-Monthly. McGuire asked Lydston, who was then professor of genitourinary surgery and syphilology at the Chicago College of Physicians and Surgeons, to provide "some scientific explanation of the sexual perversion in the negro of the present day." Dr. McGuire, like his colleague Pauı Barringer and many other Southerners, believed that "Before the late War between the States, a rape by a negro of a white woman was almost unknown; now the newspapers tell us how common it is." The apparently increasing instances of racial violence, particularly lynchings, evinced the reversion of blacks to a savage state. McGuire asserted that "In the South, the negro is deteriorating morally and physically; and, as the American Indian, the native Australian, the native Sandwich Islander, and other inferior races, disappear before the Calicasian, so the negro, in time, will disappear from this continent.." Invoking the standard Spencerian refrain, McGuire noted that "All history...shows that no inferior race, without amalgamation, can exist for very many years in contact with the dominant white man, it is the frightful 'survival of the fiitest."'8 Increases of insanity, malnutrition, scrofula, tukerculosis, and

\footnotetext{
${ }^{8}$ Hunter McGuire and G. Frank Lydston, "Sexual Crimes Among the Southem Negroes-Scientifically Considered-An Open Correspondence," Virginia Medical Monthly 20 (May 1893); 105-107. McGuire's invocation of "survival of the fittest" unquestionably favored whites. By 1900, when Barringer wrote, after seven years of increasing racial tension and violence, the result was not so certain. Although both men agreed that blacks faced extinction, especially at the hands of enraged whites if their "perversion" continued, Barringer saw blacks as a threat to white civilization. McGuire, however, worried only about individual
} 
syphilis all indicated to McGuire that African Americans were destined for extinction.

McGuire and Lydston's discussion of this issue limned the debate in familiar terms that set the groundwork for subsequent racial medicine and eugenics. Both men posed as desiring to forestall this fate, or at least allow it to happen "humanely" rather than through disease or race war. 9

Lydston, honored by this request from the president of the AMA, reaffirmed his desire to "take the bull by the homs" in answering the question, though he might offend some individuals. Lydston, a native Californian, established his right to speak on the "Southern Question" by asserting that "no Northern doctor has more [southern friends] than myself," and "any bias which may appear to be in favor of what has been termed the 'Southern method' [lynching] of dealing with the criminality of the negro, is by no means due to a desire to pat my Southem friends upon the back, but is based upon absolutely independent reflection," although he did admit to having seen the effectiveness of "Judge Lynch." 10 Lydston set himstlf up as an "objective" observer, neither condemning nor condoning southern extra-legal violence, neither an apologist for nor an aficionado of lynching.

Lydston believed that whites and blacks differed in degrees, not kinds, of "sexual perversion." Both races, he maintained, were likely to engage in aberrant sexual behavior. "Rape, however," Lydston distinguished, "under the stimulus of this abnormal passion, is not so liable to be perpetrated by the white man for the reason that certain inhibitory influences, such as pride, fear of punishment and ordinary self-control, are more effective

instances of white women being "ruined" by blacks. A subtle ideological shift had occurred beiween McGuire and Barringer's writing. This shift reflects, dimly, the growing incidence of black resistance to white oppression. Blacks who defended themselves aga'nst lynch and riot mobs shook Barringer's faith in white power. He cast the options for racial peace as either white imposed segregation, disfranchisement, and manual education or genocide after race war. McGuire, writing before racial violence peaked, offered a palliative discussion of the question that he hoped would be of "some benefit to the negro race" in easing it into oblivion.

${ }^{9}$ Lydston felt that "there might be much of benefit to ourselves in retarding the march of the inevitable as long as we can by improving the physical condition and intellectual status of the negro race." Such intervention would help maintain a steady and docile labor force until the extinction of the black race. McGuire and Lydston, Ibid., 123.

${ }^{10} \mathrm{McGuire}$ and Lydston, "Sex Crimes," 108, 121. 
in the white than in the black race." 11 According to Lydston, African-American atavism stemmed from "Hereditary influences descending from the uncivilized ancestors of our negroes." Lydston mounted a Lamarckian argument, claiming that although "sexual crimes on the part of white men are due to a similar atavistic manifestation of savagery," whites were inherently more civilized because of their "inherent as well as acquired capacity of appreciation of those social obligations which constitute the greatest good to the greatest number". Since "the evolution of the negro can be only said to have fairly begun with his liberation," blacks had not had the time to evolve as far as whites.

Lydston identified seven factors contributing to black degeneration, four of which were hereditary, including "a distinct tendency to reversion to type." Put another way, purported black savagery was a racial characteristic that resulted from the fact that blacks had not evolved far from their animal ancestors which, by implication, were apes. Lydston argued that "cross breeding [with whites] will never eliminate" black atavism because, "The result is a degenerate type which very frequently has all the evil propensities of the negro plus those of the white man, associated with a physique of a much more degenerate type than either of the ancestors." The rare instances of "mulattoes" exhibiting higher traits resulted from "more intimate association with the white race as well as from white heredity" - white controlled environment could allow white genes to express themselves in otherwise atavistic blacks. White genes would be swamped by reversion under any other environment. Moreover, blacks lacked psychological inhibition because their heredity doomed them to "a relatively low grade of intellectual development." Finally, whatever civilized traits blacks had acquired would be the first stripped away, because they were the last acquired. Lydston, like Barringer and others, believed that "slavery merely bottled up the primitive instincts of the negro race; it did not destroy them." Any "thrift and decency" in blacks resulted from the coercive force of slavery. Ultimately, Lydston concluded, the

\footnotetext{
${ }^{11}$ McGuire and Lydston, Ibid., 109.
} 
"negro question" would "be settled by the physical degeneracy and death of the negro race" and nothing could stop it. ${ }^{12}$

Lydston had ideas for controlling blacks until their extinction. "I am not going to discuss this question [of control] from the standpoint of political buncombe, maudlin sentimentality, and intentional bias of certain blatherskite newspapers in the North," Lydston proclaimed. He approached it as a scientist, facing facts squarely. He opposed capital punishment, legal or extralegal, because he felt that the increase in crime revealed the failure of both lynching and execution to deter criminals. Moreover, "No matter how scientifically and legally an execution may be done, it is still a sacrifice of a human life, and as such has a demoralizing effect upon the community." Instead of state sanctioned killing, "To my mind," Lydston continued, "there is only one logical method of dealing with capital crimes and criminals as a habitual class-namely, castration." Lydston preferred castration to killing because, on a eugenic note, "It prevents the criminal from perpetuating his kind." Lydston viewed this as a particularly good solution for the southern "problem." Sex crimes might be reduced by "A few emasculated negroes scattered around through the thickly-settled negro communities of the South," because, "Executed, they would be forgotten; castrated and free, they would be a constant warning and ever-present admonition to others of their race." 13 Lydston's solution wed the ritualized violence of spectacle lynchings, which often featured the emasculation of the victim, to the modem, antiseptic rationalism of the surgical theater. The result would be a constant deterrent and the eugenic prevention of the procreation of the "criminal" class of blacks.

Other articles from the Virginia Medical Semi-Monthly reveal Virginia physicians' agreement with Lydston and Barringer's views. Speaking before the Tri-State Medical Association of the Carolinas and Virginia, Dr. John Herbert Claiborne, a former president of the Medical society of Virginia argued that, "The worst character of the negro was

${ }^{12}$ McGuire and Lydston, Ibid., 110-15.

${ }^{13}$ McGuire and Lydston, Ibid., 122-23. 
elevated by the environs of slavery." As a result, "The peculiar and nameless crime [the rape of white women] which is now so often attributed to him, and which is visited with so terrible a retribution, he seems never to have dreamed of." Claiborne believed that, "the negro had developed before his emancipation into fine specimens of manhood." Since emancipation, however, blacks had suffered grievous injury to their genetic makeup.

Like many other physicians and breeders of the time, Claiborne adhered to the notion of "disharmonious crossing." Mating between widely divergent forms would result in weakened offspring. Claiborne asserted that "pure" blacks "had no heredity of disease," and were racially immune to many afflictions. Conveniently neglecting the South's "dirty secret" of sex between slaves and slave owners, Claiborne argued that blacks were responsible for their own degradation through interracial breeding, which brought on "consumption, scrofula, cancer, syphilis." Blacks, according to Claiborne, "paid the usual penalty of inoculation of a superior on an infericr race; his heredity to disease was increased and his resistance to disease decreased." Moreover, Claiborne attributed the apparent increase in black insanity - from 70 insane blacks in 1869 to 1,026 in 1900-to this same hereditary degenzration. ${ }^{14}$ A month later, James Addison Hodges, Professor of Nervous and Mental Diseases in Richmond's University College of Medicine, came to conclusions that echoed Claiborne's.

Educated at the University of Virginia under James Lawrence Cabell, Hodges's paper revealed the imprint of his mentor's teaching. Like Cabell (and Jefferson before him) Hodges asserted that "Science has demonstrated that he [the Negro] is a moral being," but he held that blacks were inferior because they were "without the high moral character or broad brain abilities of the white man, it being an anatomical fact" that black and white

\footnotetext{
${ }^{14}$ John Herbert Claiborne, "The Negro," Virginia Medical Semi-Monthly 5 (April 13, 1900): 3-6, quotations 5. Virginia opened its first insane asylum for blacks in December of 1869 . The possibility that slaveowners would keep insane slaves penned up on the farm doing whatever work they might, simply because they still represented a valuable piece of propirty, never occurred to any of these writers. slave owners were unlikely to forfeit property, even insane property.
} 
brains differed. Hodges made an apology for slavery that w'as nearly identical to

Claiborne. Hodges asserted that African Americans' "worst character was uplifted and elevated [under slavery], but under the present conditions of life, and under their own leaders, I do not hesitate to say that the race is degenerating and fast reverting to their original types of savagery." The solution for Hodges, the same solution advocated by Paul Barringer, was to keep blacks firmly under white control—disfranchised politically and socially, and manually educated. Hodges likened uncontrolled blacks to infection: "The negro is in the South to remain...he will remain, however, as a parasite upon the body politic, and unless led [by whites] with consummate skill through the dangers that confront him he will become a standing menace to the welfare of the South." 15

Hodges argued that miscegenation or racial amalgamation could not be brooked as a method of uplift because, "Southem civilization stands aghast at such a thought. If such should ever occur, it wili be the first time in the history of man that a Teutonic Stock has so fallen." Invoking the reverence for "Nordic" blood that was sweeping America, Hodges claimed, "The Latin races naturally mingle their blood with any race they touch, but the Teutonic roots never....The Anglo-Saxon blood has never yet gone down before any race and never will." Unlike Barringer, Hodges did not foresee a racial holocaust because, "I am no pessimist, and I have too much faith in human kind not to believe that white supremacy will make itself felt before that day to the everlasting good of the negro race."16 While it would take another 24 years for that white supremacy to achieve its ultimate end in the Racial Integrity Act, doctors would continue to agree with Hodges and develop his argument along specifically eugenic lines.

In 1903, the Virginia Medical Semi-Monthly printed an article by a Texas physician that joined eugenics, preventive medicine, and the race problem. Doctor James Orr's paper,

\footnotetext{
15James Allison Hodges, "The Effect of Freedom Upon the Physical and Psychological Development of the Negro," Virginia Medical Semi-Monthly 5 (May 25, 1900): 109.

${ }^{16}$ Hodges, Ibid., 110.
} 
"Some Suggestions of Interest to Physicians on the Scientific Aspect of the Race

Question," trotted out all the usual arguments about black atavism, slavery's patemalism, and the threat facing the South through amalgamation. First, however, Orr resolved the nagging issue of blacks who displayed exceptional intellectual gifts, a problem that had bothered racial thinkers since Jefferson's time. Orr believed these exceptional individuals proved the rule of general black inferiority. He wrote, "I desire to be understood as dealing with classes or races [groups], not individuals, for isolated exceptions prove or disprove nothing." Orr then listed black cultural and intellectual inferiority, the supposed increase in insanity and disease susceptibility, and cocaine abuse as evidence of black hereditary inferiority. Unlike its predecessors, however, this paper invoked eugenic notions of racial improvement as the solution to the "Negro Problem." Disfranchisement and segregation alone were not enough for Orr. Recentiy, he argued, "labors have been extended along broader and more scientific lines in the direction of attainment of bodily perfection and the prevention or control of disease" that promised a revolution in social relations. Asserting that whites and blacks represented the two extremes of human evolution brought into contact, Orr contended that, "As physicians, it is our duty to study the physiologicai and psychological effect of this association and possible admixture of such widely dissimilar beings, their influence on the mental, moral or physical development of each otner, and, consequently, on the State and nation."17 The question of racial mixture thus became a question of public health.

Although by 1903 most southern states had disfranchised almost all blacks, Orr articulated the lingering fears of black social equality. "Political equality, official place and power must inevitably bring social equality to some extent or in some form from which miscegenation will soon follow, and this is a serious race problem in the South," Orr

${ }^{17}$ James Orr, "Some Suggestions of Interest to Physicians on the Scientific Aspect of the Race Question, with Particular Reference to the White and Negro Paces," Virginia Medical Semi-Monthly 8 (Niay 22, 1903): 90-95, quotations 90. 
argued, ignoring disfranchisement. Dr. Orr identified lower-class whites and immigrants as responsible for miscegenation, wondering "Will racial pride predominate and the white blood be kept pure, except among a certain poor and foreign element?" Thus, the very people alarming northern white eugenicists posed a threat to the South, too. Despite his belief that, "Every instinct of racial pride, every feeling of race superiority, every teaching from animal life is against amalgamation," Orr still felt that, "the immediate and remote results following miscegenation and the breeding of a hybrid race are important themes for scientific investigation." 18

Doctor Orr, like many earlier investigators writing on race, couched his prejudices as an appeal for further study. His disquisition on "mulattoes" revealed his real fear; that genetically inferior "pass-for-white" blacks were disrupting the southern social system. "We of the South know that mulattoes almost invariably inherit the vices or infirmities of both parents; hence it is commonly remarked that they constitute the most objectionable element in our negro population," Orr asserted, stating a sentiment widely shared among whites North and South. What Orr wanted was scientific proof of the inequality of the races so that "the human race" would not have to "seek information necessary for national unity and prosperity and ethnical advancement from ignorant and unthinking demagogues, laboring under the guise of philanthropy." who counseled racial equality from sentiment not science. Protesting that, "I have sought to free myself from partisanship or bias" Orr felt that he had presented evidence that "unquestionably establishes the white as the superior race," proving "that this superiority grows out of scientific differences which no statutory enactment can ever change or the bombastic dictum of egotistic officialism nullify." 19 What began as an attempt to pose the question of racial difference became an exercise in establishing a new ideological status quo. Revamping old racism on the basis of the

\footnotetext{
${ }^{18}$ Or, Ibid., 95.

${ }^{19}$ Orr, Ibid., 95.
} 
assertion of scientific objectivity and empirical proof would come to characterize much of the eugenic project in Virginia.

That the Virginia Medical Semi-Monthly printed Orr's paper is an indication that the editors believed the piece well within the bounds of science, if not an outright editorial endorsement of the author's thesis. By December 1903 the journal also published the findings of Dr. William F. Drewry regarding the "Increase of Insanity in the Negro, and Causes." Drawn from Drewry's annual report as Superintendent of Central State Hospital, the editors endorsed his finding that apparent increases in insanity and tuberculosis were "a result as well as an indication of race degeneration" among Virginia's blacks. Drewry endorsed the narrative of degeneration described by the earlier contributors. He concluded that "Depraved and immoral habits have brought about more widespread venereal diseases" among blacks which would themselves become dysgenic taints "transmitted to the third or fourth generation." Drewry, who became one of the leading eugerics advocates in the state, contended that "Formerly heredity was not a factor in the causation of insanity in the race, but now that predisposing cause has become one of considerable consequence." 20 The hereditarian stigma damning blacks to inferiority and extinction seemed justified by these "scientific" investigations.

The passage of time would disprove the early predictions of African-American extinction. They did not, however, prompt a re-evaluation of the belief that blacks were hereditarily inferior to whites, or that blacks suffered disease as a result of their differing heredity. Nor did the survival of blacks reduce white fears of "passing" and the possibility of black/white miscegenation tearing the social fabric of southem civilization. Instead, what accurred would be subtle shifts in the hereditarian ideology underpinning the drive for new statutory restriction of blacks. Eugenics would come to justify the efforts for both the Racial Integrity Act, and the Public Assemblages Act of 1926 that mandated segregated

\footnotetext{
${ }^{20}$ Drewry quoted in "Increase of Insanity in the Negro, and Causes," Virginia Medical Semi-Monthly (December 25, 1903): 450-51.
} 
seating at public events. The fact that most physicians and public health officials embraced the hereditary concepts underpinning these segregationist efforts provided lobbyists with powerful allies when they approached the legislature. Re-evaluating the crusade for racial integrity against this backdrop reveals the significant influence exerted by eugenic ideology in the construction of Virginia's public policy.

\section{Virginia as the Foundation for a White America}

If one endeavored to rank Virginia white supremacists in order of their dedication to the cause, surely the aptly-named Eamest Sevier Cox would find a place near the top of this dubious list. Part academic, part propagandist, and part moral zealot, Cox became a tireless, life-long crusader for the "progressive" reform of race relations in Virginia. A real estate agent by trade, a self-proclaimed ethnologist by training and avocation, Cox provided the scientific ideology undergirding Virginia's eugenic Racial Integrity Act (RIA) of 1924. His efforts on behalf of eugenics and the RIA actually represented subsets of his overarching concem, the repatriation of all African Americans to colonies outside the United States. He leagued with such reactionary southern politicians as Mississippi's Senators Theodore Bilbo and James K. Vardaman, and Wyoming's Langer to promote colonization bills sporadically introduced to Congress between the 1910s and 1960s. His efforts brought him into contact with numerous eugenicists and race supremacists. He also became a "friend" and advocate of Marcus Garvey, Amy Jacques Garvey, and the Universal Negro Improvement Association (UNIA), Garvey's Fan-Africanist organization that, at least rhetorically, advocated the repatriation of blacks to an African homeland, and a form of separatist eugenics. ${ }^{2 i}$

${ }^{21}$ Cox's principal biographer is Ethel Hedlin, "Eamest Cox and Colonization: A White Racist's Response to Black Repatriation, 1923-1966" (Ph.D. diss., Duke University, 1974). The links between Cox, Powell, Plecker and Garvey are discussed in William Edwards, "Racial Purity in Black and White: The Case of Marcus Garvey and Eamest Cox;" Journal of Ethnic Studies 15 (1987): 117-42; and Barbara Bair, "Remapping the Black/White Body: Sexuality, Nationalism, and Biraciai Antimiscegenation Activism in 1920s Virginia," in Martha Hodes, ed., Sex, Love, Race: Crossing Boundaries in North 
Eamest though he was in pursuit of repatriation, Cox generally acted "in the name of eugenics." Although he was in sympathy with the eugenics movement's main goals and tenets, he ultimately viewed them as supports for his own insistence on African-American removal. Cox agreed with eugenicists that "mongrelizing" white Americans through racial intermixture would lead to the fall of American civilization, as well as the destruction of the limited civilization attained by Diaspora blacks. Therefore the Racial Integrity Act, prohibiting intermarriage between whites and non-whites, seemed to Cox like an expedient stop-gap, preventing declension until repatriation might be achieved. Cox's interactions with national-level and Virginia eugenicists reveals the resonance between both colonization and eugenics, underscoring how each served to amplify the other, resulting in loud cries for permanently segregating the races. Using eugenics and genetics as a foundation, Cox erected an ideological edifice that lasted over 50 years and coordinated the efforts of white supremacists from the 1910 s to the 1970 s.

Cox's 1963 autobiography, Black Belt Around the World, wove together the themes guiding Cox's life. First, a paean to his sister Emma, the bonk represents the last product of a man who spent his life in the "chivalrous" defense of southern white women, whom he considered jeopardized by the foolhardy proximity of the white and black races.

Second, the book essayed Cox's personal genealogy, often explicitly comparing his hereditary worth against the unfitness of da-ker peoples. Throughout his life Cox remained intensely proud of his heritage, claiming relation to the First Families of Virginia and the Tennessee "volunteers," in both places the "pioneers" who "showed aptitude and leadership in beating back marauding Indians." Finally, the book presented a travel log, documenting Cox's trip around the world from 1910 to 1915, during which he made "a 
study of the white race in colonial contact with solored races." 22 Combining observations from the 1960s with his reminiscences, Cox's book highlights his hereditarian understanding of ethnology, and his conviction that races could not live in contact and remain civilized. Cox's belief in eugenics and racial improvement derived from his personal background and provided a quasi-scientific justification for deep-seated racial animosities.

Cox attributed all the achievements of his life to good heredity. Confessing that "male members of my kin were given to marrying Yankees," but allowing that, "these Northern women were of a good hereditary strain which shows in their descent," Cox cited "an emotional trend toward the ministry" that he "may have inherited" from his father and grandfather. ${ }^{23}$ At the age of 17, Cox "experienced a remarkable burst of energy," that "issued from some hereditary factor" that allowed him to work on only five hours of sleep nightly. Educated on a farm in rural Tennessee, where he was "put through religious rites seven times each day," Cox eamed a bachelor of science degree from the unaccredited Roane College and taught school. Cox later spent time at the Moody Bible Institute and Vanderbilt University studying theology. After Vanderbilt he went to the University of Chicago, which admitted him for the Summer of $1906 .^{24}$

American History (New York and London: New York University Press, 1999), 399_419. My discussion here builds on my reading of the Earnest Sevier Cox Papers, William R. Perkins Library, Duke University, Durham [hereinafter referred to as ESC Papers].

${ }^{22}$ Cox, Black Belt Around the World at the High-Noon of Colonialism, (Richmond, VA: Earnest Sevier Cox, 1963), 9.

${ }^{23}$ Cox, Black Belt, 9-32. In a letter to his mother, Cox wrote that he studied law from three to six a.m. each moming, and added the revealing comment that "Buonoparte often had only 3 hours of sleep yet the whole continent of Europe trembled to its very foundation at a word from this man who spent less than one fourth of his time in sleep." Comparing himself to Napoleon, Cox never lacked in self-confidence or persistence. Earnest Sevier Cox to Mrs. A. M. Cox, November 14, 1900, Box 1, ESC Papers.

${ }^{24}$ Vanderbilt would not recognize Cox's work at Roane College, yet admitted him as a "special student" for three years. The Examiner for Colleges at the University of Chicago notified Cox that the work he had done at Roane and Vanderbilt would be accepted as the equivalent of a bachelor's degree. His two years of work at Chicago could then count toward his master's degree. Examiner to Earnest Sevier Cox, May 8, 1908, Box 1, ESC Papers. 
Cox studied sociology at Chicago under Reverend Charles R. Henderson, Dr. W. I.

Thomas, and Albion Small, "But the book that gripped me powerfully was Social Control

by Dr. E. A. Ross." Cox would carry Ross's book around the world; he adopted Ross's

racial views, which extolled the "Aryan type of man particularly the Celto-German

stock." 25 Although he never mentions it in his autobiography, the event that transformed

Cox's life was not arriving at the University of Chicago. Instead, it was the Atlanta race

riot that erupted that September. In a heated letter to his sister Emma, who lived in Atlanta,

Cox revealed the burning passion that would fuel his lifelong career as a racial separatist.

"On last Sunday moming I passed a news stand and saw the headlines telling of the race

riot in Atlanta," Cox wrote, "and since then I have read every word coming from the

South." Wishing he had been able to join the fight, Cox continued, "No warfare ever

waged was more righteous than this defense of home, family, and posterity." Cox released

a torrential diatribe that mixed chivalry, Christianity, and the contemporary wisdom that the

riot resulted from black men raping white women:

There is nothing half so important to my people [white southermers] as the disposal of the Negro, no not even the principle of representative govemment for which the Revolution was fought or the principle of centrilization [sic] of govermment which produced the fiercest conflict of all history-the Civil War.... The negroes killed in Atlanta was the result of an effort to protect those whom God has ordained that we must protect, an effort that cannot be legally justified but has its good and justification in a law that is higher than laws made by men.

The white man of the South has bome with negro outrages upon white womanhood longer than any man whom god has created would have bome; and the wonder of future generations will be, not that forty brutes have been sacrificed but that the whole brute race has not in red stains been blotted from our fair civilization. The conditions are intolerable and there is but one way of escape. Vengeance must have her fullest satiation until our white brethren the world over will aid us in deporting the black savage again to his native jungle.

\footnotetext{
${ }^{25}$ E. A. Ross quoted in Dorothy Ross, The Origins of American Social Science (Cambridge and New York: Cambridge University Press, 1991), 233; Gossett, Race, 168-72. Ross coined the phrase "race suicide" in his 1901 essay "The Causes of Race Superiority." He latcr adopted eugenics as a method to improve society. Ross worried that America's "energy and character" was "lowered by the presence in the South of several millions of an inferior race." (Ross, "The Causes of Race Superiority," quoted in Gossett, 169.) Although by the 1920 s Ross would reject the racial essantialism of his earlier work, Cox never matched his idol's retrenchment.
} 
Cox felt that the South was "over a volcano that shall soon burst forth with the penned up fury of a half century's delayed retribution." Cox welcomed the bloodshed and justified it on the grounds of the "noble blood of chivalry and courage and honor" that would "demand the blood of a thousand black fiends for every outraged daughter of the South". Cox felt that, "The rational thing to do is to recognize the inevitable, vix. [sic] wholesale butchery must come and its coming will awaken the nation to the fact that the negro must be moved. He must be taken back to the jungle, the glare of which is still in his eye." 26 Cox then determined to direct his life's work, beginning with his graduate study, to the resolution of the "Negro problem" through repatriation.

Cox believed that he could study the "race problem" objectively by examining how other white countries controlled their black colonies. Justifying his choice of dissertation topics, he made the revealing comment, "I am a southemer by birth and sincerely desire to contribute what I can to a general enlightenment on our race problem."27 Notwithstanding his sincerity, Earnest Cox never transcended his own cultural biases, ingrained during his southem childhood. He wrote to Henderson from South Africa that, "I left America interested in the political status of the Negro under other governments, but soon realized that a mixture of blood is the real danger outside of America, the German possessions excepted." Fixated on "the prevalency of rape by Natives upon European women," Cox was even more alarmed by consensual sexual congress that resulted in children light enough to pass. "Again the mix-blooded, if passed [sic] of property, may gain entrance to white society. The white race is in process of hybridization," Cox groaned, noting, "the newly arrived European is not capable of drawing the colour line in matrimony." As a

\footnotetext{
${ }^{26}$ Eamest Sevier Cox to Emma Cox, September 26, 1906, Box 1, ESC Papers. This account of the riot is wildly inaccurate. See

${ }^{27}$ Draft letter, 1907, Box 1 ESC Papers. Cox's advisor, Charles Richmond Henderson wrote a letter of recommendation that reveals the tenor of his racial views. Affirming that Cox had worked with him "in subjects relating to the lower races of man, and has shown a particular interest in the negro" Henderson certified Cox as being "well-trained, has good ability, and is determined to work out some aspects of the negro question exhaustively and scientifically." Letter of Recommendation from Charles Richmond Henderson, Box 1, ESC Papers.
} 
result, "Where inter-marriage is legal the half cast, both legitimate and illegitimate, finds entrance into the white race." This hybridization, so repugnant to Cox's southem sensibilities, seemed to him an admirable explanation for the decline of Egyptian civilization. Thus, at precisely the time Madison Grant was writing The Passing of the Great Race, Cox independently struck upon the same thesis: civilizations fall as the result of racial miscegenation.

Cox became the South's analog to Madison Grant and Lothrop Stoddard. Indeed, the three men would become close acquaintances and share each other's views regarding America's race problem: Cox's first book, White America, resulted from his five-year trek around the world. White America developed the thesis that white races, in contact with races of color, inevitably decayed as a result of hereditary degeneration brought about by interbreeding. America represented, for Cox, the only civilization that had managed to subsist in contact with another race. Admitting that blacks were not dying out in America, Cox then came to the real point of his argument.

The most sanguine temperament cannot look upon the results of Caucasian contact with colored races in the past and feel secure as to America's future. Civilization has never survived intimate and prolonged contact with the colored races, and, though the United States will outrank all other civilizations in the successful preservation of the physical type from which civilization proceeds, there are present in America implications as to the eventual disintegration of this cultural stock. ${ }^{28}$

The "implications" Cox identified were, of course, the presence of "mulattoes" or "mixedbreed" blacks in America. These individuals represented physical proof of the begirning of degeneration, "the slow and ill-appreciated disintegration, or replacement, of the physical type which has made America great."

Beyond merely documenting the phenomenon of decay, however, Cox offered a specific remedy drawn as much from his southem heritage as from his "scientific" outlook. Cox, invoking the ideal of a secular creed similar to Galton's hopes for eugenics, believed

${ }^{28}$ Eamest Sevier Cox, White America (Richmond, VA: The White America Society, 1923), 237. 
that America needed "Those who believe in and will spread the cult of Caucasianism." In order to achieve this end, America needed to "sink sectionalism in national patriotism" and "forget past differences between North and South in a common purpose to preserve a common civilization." Cox's appeal to a common patriotism, founded on a white racial identity, harked all the way back to the writings of Thomas Jefferson. Cox, who quoted Jefferson and Lincoln in defense of repatriation, chose this rhetoric self-consciously. ${ }^{29}$

White Americans had two major "assets" that had delayed decay, but they were failing according to Cox. "The chief Caucasian asset in the struggle for permanency of civilization," Cox wrote, "is race. There has been less miscegenation in the United States than elsewhere in the world." Cox believed, like the eugenicists, that America represented a bastion of relative "Nordic" purity. The second American strength was "the still prevailing color line."30 All hope for civilization was not lost. Americans must strengthen the color line in the short term, according to Cox. This could be done by rigid enforcement of segregation, adoption of strict antimiscegenation laws, and the limitation of immigrants from southeastern Europe-methods that would purify, concentrate, and increase the proportion of "Nordic blood" in America. ${ }^{31}$ In the long term, America must repatriate all blacks to Africa if a "White America" would survive. Cox's last six chapters formed a sustained plea for intersectional cooperation to solve the "negro problem" in favor of a "White America." He rapidly located a hospitable environment for his theories.

Virginia provided fertile ideological soil for Cox's ideas. Upon returning to America, he wrote his sister from Knoxville, Tennessee, "I hope to leave for Richmond,

\footnotetext{
${ }^{29}$ Cox, Ibid., 238, 321-328. The original dust-jacket for the book, reproduced at the back of the 1937 edition, bore quotations from Lincoln, Jefferson, DeTocqueville, and Madison Grant.

${ }^{30}$ Cox evenhandedly acknowledged that "There were some whites in the North who advocated miscegenation, as there were some whites in the South who practiced it." The saving grace, however, was that "But few of the present number of mixbreeds are the product of a first crossing with the white race of the South. The mulatto, the quadroon, the octoroon, and the still lighter colored, have injected into the negro race an overwhelming proportion of the Caucasian blood which this race manifests." Cox, Ibid., 241.

${ }^{31}$ Cox, Ibid., Chapter 15. Southeastern Europeans were also viewed, by Cox and those like him, as already having engaged in miscegenation, making them hereditarily and culturally inferior to Nordics.
} 
Va....Much interest has been shown in me in Richmond and I am anxious to meet a few people with whom I can correspond and upon whom I can depend to further my publications when they are out." 32 In an undated letter to Henry L. West, president of the American Colonization Society, Cox wrote that he chose Richmond because, "I have made the acquaintance of a number of men and women, some of local prominence, who have warmly assured me of their sympathy with the colonization idea." 33 Already, the year before Madison Grant's book appeared, Cox had found a receptive audience in the Old Dominion for his ideas about racial decay through interracial contact.

Unlike Grant, whose book was published promptly, Cox experienced difficulties finding a publisher. Similar to Grant's book but without Grant's prose style, and lacking the authority conferred by university degrees certifying the author's expertise, Cox's manuscript "Decay of Culture" was rejected by G. P. Putnam's Sons in 1917. America's entry into World War I, and Cox's service delayed further publication attempts. Putnam's again rejected a revised edition of the manuscript in the aftermath of the race riots of "Red Summer," although Cox felt that, "The recent violent symptoms of race discord between the blacks and whites should do much in preparing the national mind for such a solution of the negro problem [repatriation] as is here proposed, for it is evident that race friction will grow more intense with the increase of the races." Repatriation seemed, to most blacks, whites, and experts on race, a quixotic scheme by 1919. The dissonance between Cox's

\footnotetext{
${ }^{32}$ Earnest Sevier Cox to Sister [Emma], November 29, 1915, Box 1, ESC Papers. Cox had already encountered resistance to his ideas. After reading a New York Times article that quoted Cox, the Urban League's associate director, Eugene Kinkle Jones, wrote Cox, "The infusion of the white blood in the Negro people is not more real than the infusion of the Negro blood in the white people and no one but a fool would make the statement that any other than the white people are responsible for this infusion." He wamed Cox against "further utterances of this kind" or else, "you will commit intellectual suicide as soon as these statements appear in print." Nevertheless, Cox found an all too ready audience in Virginia and elsewhere. Eugene Kinkle Jones to Earnest Sevier Cox, December 21, 1915, Box 1, ESC Papers.

${ }^{33}$ Earnest Sevier Cox to Henry L. West, n.d. [filed in 1918-1920], Box 1, ESC Papers.
} 
solution and the contemporary wisdom, and the slow initial sales of Grant's book, may well have stymied Cox's efforts. ${ }^{34}$

His frustration mounting, Cox contacted Grant directly in 1920. He confessed that he had learned of Grant's book with great surprise, only after he returned to America and was writing up his own work. Seeking to ingratiate himself to the powerful Grant, Cox wrote, "At once I realized that here was an authority who would appreciate the issues involved in the presence of the negro in the U.S. Especially was I convinced when reading your statement which definitely asserts that if the purity of the two races is to be preserved they cannot continue to dwell together." Cox's gambit paid off, and he began an association with Grant that would last until Grant's death in 1933.

Grant read Cox's manuscript and replied positively saying, "I am heartily in sympathy with the purpose of your writings." Grant offered "frank criticisms" that disputed Cox's citation of outdated anthropological work, and the work of "liberal" arthropologists who did not hew to Grant's views on race. So, he also told Cox to "Beware of quotations from Boas in the Immigration Reports as he is now discredited." Far from being "discredited," Franz Boas's famous work disproving the anthropometric work of eugenicists and physical anthropologists like Grant and Charles B. Davenpoitt was merely dismissed out of hand as the work of a Jew. Grant also wamed Cox to use care in discussing the relative readiness of northem and southern whites to "mix with the negro" because, "Mutual recrimination on this point is useless and interferes with the spread of correct knowledge." Instead of provoking sectional discord abcut miscegenation, Grant suggested that Cox elaborate on his notion that Native Americans in Virginia had so thoroughly interbred with blacks as to have become blacks. This contention matched Grant's refutation of "blending" inheritance. As Grant wrote, "I think one race or one type or one strain replaces another and in the mixture the lower types prevail. In other words, I regard the mulatto as a negro and not as

\footnotetext{
${ }^{34}$ G. P. Putnam's Sons to Eamest Sevier Cox, May 1, 1917; Cox to G. P. Putnam's Sons, Novernber 20, 1910, Box 1, ESC Papers.
} 
an intermediate type." 35 This interchange would have tremendous ramifications for

Virginia's racial minorities in the coming years.

With Grant's help, Cox continued to revise his manuscript and make the acquaintance of like-minded eugenicists and physical anthropologists. While Grant could not secure publication for Cox's book from a major house, the men helped each other in other ways. $^{36}$ Of particular interest was the revival of the Ku Klux Klan. Cox noted "much opposition among conservative Southerners to the attempt to revive the Ku Klux Klan," including his own distaste to "any secret organization of this nature". Still, he believed that "it will force the negro problem to the immediate attention of many people in the South" which might help his own cause for repatriation. Grant responded enthusiastically, "I am interested in seeing the revival of the Ku Klux Klan all over the country. I think they should be approached with a view to spreading the proper kind of information on the relations of the races throughout the country." He asked if Cox knew, "how they could be reached for this purpose?"37

As fate would have it, Cox did have a number of established connections to the Klan. From 1915 to 1916, Cox had worked on Capitol Hill as an assistant to Mississippi Senator

\footnotetext{
35Madison Grant to Eamest Sevier Cox, December 14, 1920, [and appended "Notes"]; Madison Grant to Earnest Sevier Coג, January 3, 1921, Box 1, ESC Papers.

${ }^{36}$ Lnthrop Stoddard's The Risiıg Tide of Color Against White World-Supremacy was released by Scribner's in 1920, making Cox's book even less original. Most of Cex's rejection letters remain in his files. Grant interceded with Scribner's on Cox's behalf, yet nis guarded report to Cox reveals an attempt to soften the blow. "I had a talk with Mr. Scribner this morning...They said the book was a little out of their line and suggested some other publishers. I have very little doubt of the success of the book when you once get it published." Grant's assertion that the book was "out of their line" rings hollow because Scribner's not only brought out his books, but also all of Lothrop Stoddard's works. Compared to Grant and Stodjard, who both held Ivy League undergraduate and graduate degrees, Cox probably looked underqualified. Their stab!e well-filled, Scribner's dropped Cox. Other publishers clearly recognized Cox's attack on blacks at home as toc explosive. Horace B. Livright saw right through Cox's "scientific" posture, writing, "I must admit, if it's decidedly anti-negro, I hardly think that I will care to publish it. I hate the idea of doing anything that would stir up race prejudice. You will very likely tell me, however, that your book will help to solv'e the problem that the sentimentalists are doing nothing to solve." Horace B. Livright to Earnest Sevicr Cox, December 28, 1922, Box 2, ESC Papers. Sce also George H. Doran Company to Earnest Sevier Cox, June 9, 19?.0, Box 1 ESC Papers; and Scribnər's to Eamest Sevier Cox, May 10, 1921; Madison Grant to Eamest Sevier Cox, December 7, 1921; Maitin and Hoyt to Earnest Sevier Cox, January 30, 1923; and Bobbs-Merrill to Cox, July 13, 1923, Box 2, ESC Papers.

${ }^{37}$ Eamest Sevier Cox to MaGison Grant, December 6, 1920; Madison Grant to Eamest Sevier Cox, January 12, 1921, Box 2, ESC Papers.
} 
James K. Vardaman. One of the most outspoken racists ever to hold high office in

America, Vardaman had won election to the Senate in 1911 by advocating the repeal of the Fourteenth and Fifteenth Amendments to the Constitution. Cox explained his work to the Senator in 1916 and won an appointment to his staff. Cox would become the authority for many of Vardaman's subsequent statements about American race relations. Vardaman maintained close ties to the Klan throughout his long career, and would put Cox in touch with many Klan sympathizers. ${ }^{38}$

Cox had also made the acquaintance of noted Virginia pianist, John Leslie Powell. Exactly when Cox and Powell met is uncertain. It is, however, certain that Powell was one of the individuals of "local import" that Cox met shortly after his move to Richmond. ${ }^{39}$ In 1922, Powell and Cox founded the Anglo-Saxon Clubs of America (ASCOA) as an alternative to the Ku Klux Klan. Powell and Cox's organization blossomed to over 400 members by June of 1923 . Among those early members, the chairman, president, and secretary of the Richmond Post ASCOA all had been active Klansmen. ${ }^{40}$ Cox's ties to the Klan, which he always held in reserve, would serve him throughout his career as life-lines to committed support for white supremacy. Nevertheless, in the near term, Cox redirected Grant's interest away from the Klan and toward the ASCOA.

The stated program of the ASCOA was consonant with Grant's interests and predispositions. Organized in contradistinction to the Klan, offering a genteel approach to white supremacy and eschewing extra-legal violence and the over-heated rhetoric of the Klan, the ASCOA fit Grant's personality. The ASCOA announced that it sought "the

\footnotetext{
${ }^{38}$ Edward L. Ayers, Promise of the New South, 412; C. Vann Woodward, Origins of the New South 1877-1913 (Baton Rouge: L.ouisiana State University Press, 1951), 480; Earnest Sevier Cox to James K. Vardaman, September 19, 1916, Box 1, ESC Papers.

${ }^{39}$ In his booklet Lincoln's Negro Policy, Cox related that he had met Powell as a result of showing his manuscript to Mr. Archer Jones, founder of Duplex Envelope Company and prominent Richmond businessman. Earnest Sevier Cox, Lincoln's Negro Policy (Richmond, VA: Earnest Scvier Cox, 1972), $16-17$.

${ }^{40}$ John Douglas Smith uncovered the long-suspected ties between the Klan and the ASCOA. He discusses these connections in, "Managing White Supremacy: Politics and Culture in Virginia, 19191939" (Ph.D. diss., University of Virginia, 1998), 87.
} 
preservation and maintenance of Anglo-Saxon ideals and civilization in America" through three programs. The ASCOA desired "the strengthening of Anglo-Saxon instincts, traditions and principles among representatives of our original American stock," next the group wanted "intelligent selection and exclusion of immigrants," and finally the ASCOA hoped to achieve, "the fundamental and final solutions of our racial problems in general, most especially of the Negro problem."41 Signaling its political intentions the ASCOA constitution limited membership to "all native bom, white, male American Citizens, over the age of 18 years...who are qualified voters or who will pledge themselves to qualify at the earliest opportunity." 42 The ASCOA position regarding immigration corroborated Cox's statement that he had been loaning his copy of Grant's book "to certain individuals who are interested in restricting immigration" in Richmond.

The ASCOA had direct ties to Virginia's university eugenicists as well as the national eugenics propagandists Grant and Stoddard. By June 1923, the society's informational pamphlets listed twelve Virginia posts, including chapters at the University of Virginia, University of Richmond, William and Mary College, Virginia Polytechnic Institute, and Hampden-Sydney College. As mentioned in Chapter Two, Dr. Harvey Earnest Jordan was a member of the University of Virginia chapter. Circumstantial evidence suggests that both biology Professor Ivey Foreman Lewis and Paul Brandon Barringer were also members of the University of Virginia chapter. ${ }^{43}$ Of the student members of the Virginia

\footnotetext{
41 "Post No. 1, Anglo-Saxon Clubs, Has 400 Members," Richmond News-Leader, 5 June 1923, 18.

42 "Constitution of the Anglo-Saxon Clubs of America," in "Racial Integrity Material," Box 56, John Powell Collection, Special Collections, Alderman Library, University of Virginia,

${ }^{43}$ Jordan acknowledged his membership in a letter to the American Eugenics Society. "I am a member of the Anglo-Saxon Clubs of America of which Dr. Plecker is one of the leaders, Jordan wrote. Harvey Emest Jordan to Leon Whitney, Executive Secretary, American Eugenics Society, December 13, 1927, American Eugenics Society Papers, American Philosophical Society Library, Philadelphia. Ivey Lewis presented his 1924 lecture, "What Biology Says to the Man of Today," under ASCOA auspices at the University's YMCA. In 1915, Barringer anticipated Cox and the ASCOA. During America's military intervention in Haiti. Barringer wrote to President Woodrow Wilson asked if Haiti might not be "a place where our American negroes would be free to emigrate in numbers and be properly safeguarded till they got a footing?" He saw in Haiti another Liberia, and a solution to the "Negro Problem." Paul Brandon Rarninger to Woodrow Wilson, August 28, 1915, "1915-1925 Correspondence" folder, Box 2, Barringer Papers. The Barringer Papers also contain various ASCOA literature, including a copy of the 1923 informational pamphlet. See "Anglo-Saxon Clubs of America," "1896-1925 folder," box 10, 2588, Paul
} 
chapter, the president John Powell Williams became a physician, and vice-president $\mathrm{O}$. Arthur Kirkman and secretary Curtis Simpson became a lawyers. Thus, the ASCOA tapped the loyalties of men destined to enter the South's professional elite. ${ }^{44}$

The university ties ran on a deeper, personal level as well. By the 1920s John Powell may well have been Richmond's most famous resident. Known as one of America's greatest concert pianists and composers, Powell was the brightest star in Richmond's social elite. From this lofty position, Powell circulated among the most influential Virginians wielded a great deal of influence. ${ }^{45}$ Powell graduated from the University of Virginia in 1901, and thus knew Paul Brandon Barringer when he was chairman of the faculty and at the height of his influence regarding racial matters. Powell's program bears the imprint of Barringer's thought, as well as the ideas of Madison Grant, Lothrop Stoddard, and most importantly Earnest Sevier Cox. Correspondence between Powell, Cox, and Plecker reveals that Powell maintained close personal friendships with Ivey Foreman Lewis. Letters in the University of Virginia President's Papers also indicates that Powell was a close personal friend of John Lloyd Newcomb, successor to Edwin Anderson Alderman as Virginia's president. As John Douglas Smith has shown, the ASCOA drew on the deepest

Brandon Barringer Papers, Special Collections, Alderman Library, Charlottesville. [Hereinafter referred to as Barringer Papers.] Barringer also saved the innaugural issue of The Saxon: A Magazine Devoted to the Purity and Perpetuity of the Great Race. The first article, "Why 'The Saxon'" begins, "To the student of that branch of Anthropology conımonly called Biology or Eugenics, it will be quite unnecessary to give a reason for the appearance of a publication bearing this title." The article goes on to outline the mainline eugenic arguments. The issue contains Plecker's article "Race Suicide," Madison Grant's "The Racial Transformation of America. and Cox's "Let My People Go." See The Saxon, Barringer Papers, Ibid.

${ }^{44}$ Virginius Dabney identified Barringer as president of the University of Virginia chapter, although this is contradicted by the evidence. Vi-ginius Dabney, Mr. Jefferson's University: A History (Charlottesville, VA: University of Virginia Press, 1981), 66. The president of the Farmville post, Dr. J. L. Jarman was a student at Virginia under Barringer. For these men's connections to the University of Virginia and their professions see McLanc Tilton, ed., Directory of the Living Alumni of the University of Virginia 1931 (Charlottesvilie, VA: The Michie Company, 1931), 139, 167. Williams could have been taught by Heck as an undergraduate; he was certainly taught by Robert Bennett Bean, Harvey Eamest jordan, and Lawrence Thomas Royster as a medical student. He joined the ASCOA in his last year of medical school. Kirkman and Simpson could have taken Ivey Lewis's biology course and Heck's education course, as well as George Oscar Ferguson's courses in psychology.

${ }^{45}$ Sherman, "The Last Stanci," 73; Bair, "Remapping the Black/White Body," 
pockets in Richmond. ${ }^{46}$ Clearly the society also tapped some of the state's pre-eminent and influential minds.

The confluence of these men, eugenic theory, and the national surge in nativism and hereditarianism led directly to the passage of Virginia's Racial Integrity Act. Beginning in June 1923, with the provocatively entitled newspaper article "Is White America to Become a Negroid Nation?", John Powell began to mount a media blitz designed to rally support to the ASCOA cause. Mixing negrophobia and Cox's ethnology with a liberal amount of eugenic theory, Poweli and Cox bombarded Virginians with dire predictions regarding the fate of white civilization in the South.

Cox and Powell's argument echoed that of the Virginia physicians writing at the turn of the century. Just as men like Barringer, Claiborne, Hodges, and later Jordan worried about "racial degeneration" through amalgamation, so too did Cox and Powell. The time lag signifies both the slow dispersal of ideas from the leading edge of science to the trailing edge of lay society, and the ossification of Cox's and other's scientific beliefs. Powell came to these theories late. As a well-educated socialite, he arrived at the "science" behind his beliefs as a follower, not as an investigator. In the same way F. Scott Fitzgerald portrayed the socialite-boor Tom Buchanan fretting over the fate of the white race, so too did John Powell adopt the avant-garde fears aroused by Grani, Stoddard, and Cox. ${ }^{47}$ Merged with his southem upbringing, Powell's negrophobia became a holy crusade that appealed to many other southemers. Cox, trammeled by his hereditarian beliefs that insulated him from advancing currents in cultural anthropology, merged outdated science with his native prejudices, blinding himself to the power of his own biases. A similar

\footnotetext{
${ }^{46}$ Smith, "Managing White Supremacy," 85.

${ }^{47}$ F. Scott Fitzgerald, The Great Gatsby, New Edition, (New York: Simon and Schuster, 1995), 1718. For an extended analysis of eugenics in "Jazz Age" American literature, see Betsy Lee Nies, "Eugenic Fantasies: Racial Ideology in the Literature and Popular Culture of the 1920s" (Ph.D. diss., University of Florida, 1998), 168-213 (Fitzgerald).
} 
dynamic occurred among the university professors who continued to advocate eugenics long after its theories had been disproved or fundamentally altered by advances in genetics.

The publication of Cox's book White America provided the catalyst for much of this ideological ossification. A testament to his commitment to white supremacy, Cox himself bore the expense of publishing the first edition of White America. Circulating it among various scholars for their opinions, Cox gathered numerous accolades that he would later use in promoting the book. Predictably, Madison Grant and Lothrop Stoddard lavished praise on the book. Cox also published blurbs from other famous eugenicists. Reviewing it for the Eugenical News, the Eugenics Record Office's Harry Laughlin proclaimed, "It is a stirring volume....America is still worth saving for the white race, and it can be done." Harvard's William McDougall agreed entirely with Cox's separatist thesis. R. W. Shufeldt, one of America's premier naturalists from the Smithsonian Institution called it "the ablest book on the negro problem." Cox's personal hero, Edward A. Ross, whose own views on race had changed somewhat since he wrote Social Control, delivered a backhanded compliment, "Your book White America is a staggering one and it will probably take years for me to know' where I stand regarding it." Ross continued on a brighter note, "Your description of the results in different parts of the world of the mixing of whites with colored races is new and profoundly impressive."48 The Secretary of the Southern Cooperative League for Education and Social Service, J. E. McCulloch, wrote that White America "points the way of salvation for both races. For either race to ignore the argument of White America would be a crime against all the future." As a result of these reviews, White America became a textbook for university professors and the handbook for white supremacists throughout the South.

\footnotetext{
${ }^{48} \mathrm{Cox}$ published all the testimonials at the back of all subsequent editions of the book-two of which appeared in 1925, one in 1937. Ross continued to consider Cox's plan of repatriation, although he believed it would have to be compulsory and that any "African territory to which American negroes might be deported should be governed not by the inhabitants but from this country." E. A. Ross to Eamest Sevier Cox, January 27, 1925, Box 2, ESC Papers.
} 
University of Virginia eugenicist Ivey Foreman Lewis wrote Cox at length. Lewis "read with great interest and approval" and agreed that "The drag of the negro on our civilization is blinked by the large class of the falsely sentimental and is consciously ignored by many who see in him one who by his cheap and willing service helps to relieve the daily burden of living." Lewis believed that efforts to stop "the greatest danger, probable amalgamation" were hindered by "a conspiracy of silence." Many people confronted with miscegenation "simply say, That is too horrible to consider,"' Lewis felt, and ignored the threat. "Of course the solvent here," Lewis concluded, "is more light. Such a book as yours should help powerfully in bringing the facts before our people," he applauded. Expressing his "hearty sympathy" with Cox's position, Lewis encouraged Cox to "continue your efforts in bringing home the truth to the minds of the white people. It is a tremendous job, but by no means a hopeless one." For his part, Lewis promised to bring the book to the attention of his students. He followed through on this by buying two additional copies of the book for the school of biology, assigning it regularly as a text in his eugenics course, and inviting Cox to speak before his class. ${ }^{49}$

Cox thus established himself as the ideological authority behind the Racial Integrity Act. The press repeatedly referred to him as an "expert ethnologist," as much because of his own billing and the plaudits of his supporters as because of any certified expertise. As a scathing review of White America in the Journal of Social Forces commented, "Now there is no doubt that Cox is a student, for he has coilected a great amount of historical material and has studied the race problem on every continent. But there is plenty of doubt as to his being a scientific student. His logic...is faulty at every step." 50 Despite being

\footnotetext{
${ }^{49}$ Ivey Foreman Lewis to Eamest Sevier Cox, Februar y 26, 1924, Box 2, ESC Papers; a carbon of this letter resides in the "1924 Letters" folder, Box 1, Ivey Foreman Lewis Collection 5119a, Special Collections, Alderman Library, Charlottesville. Ivey Foreman Lewis to Earnest Sevier Cox, April 25, 1924, Box 2; and Ivey Foreman Lewis to Eamest Sevier Cox, June 4, 1936, Box 4, ESC Papers.

${ }^{50}$ Anthropologist Melville Herskovits, a student of Franz Boas, wrote the review, "Extremes and Means in Racial Interpretation," Journal of Social Forces 2 (May 1924): 550-551. Ironically, the review was printed under the heading "Inter-Racial Cooperation." In sending the review to Cox, the editor of Social Forces, famed University of North Caroiina Sociologist Howard Odum, called it "a little severe" but
} 
roundly criticized in the scientific press outside of the eugenics movement, Cox considered himself — and convinced others to agree—as a "renowned" ethnologist.

Fingers in the Dike: John Powell, Walter Plecker, and the Racial Integrity Act

Alongside Cox then, Powell and state registrar of Vital Statistics became the two other members of a triumvirate that linked science, spectacular performance, and government enforcement. Cox provided the ideology, Powell's public speaking brought the issue before the public backed by his fame and influence, and Plecker-as state Registrar of Vital Statistics and a public health official-provided an institutional mechanism for policing and enforcing racial integrity. John Powell stood as the sultural figurehead for the ASCOA movement; as Richard Sherman noted, Cox, Plecker, and the titular President of Richmond's Post No. 1, Dr. Lawrence T. Price tended to much of the organization's dayto-day business. Beginning in June 1923, with the formal incorporation of the ASCOA, Powell stepped up the pressure for a law guarding racial integrity. 51

Powell also relied on the women's auxiliary, the forty-member Women's Racial Integrity Club of Richmond, headed by his wife Louise Burleigh Powell.52 In December, 1923, Earnest Cox sent thirty prominent Richmond women, including Powell's then-fiance Louise Burleigh and the famous southern author Ellen Glasgow, complimentary copies of

commented that, "What we want is to get the thing discussed." Howard Odum to Eamest Sevier Cox, May 30, 1924, Box 2, ESC Papers. John Powell wrote an indignant rebuttal, "The Search After Values," Journal of Social Forces 3 (Noyember 1924): 3; and the editors replied dismissively with "The Nordic Alarm Again," Journal of Social Forces 3 (January 1925): 317-19.

51 By this time, Poweil's racism had spilled over into his professional activity. A striking irony is that Powell's major musical composition Rhapsodie Negre drew its inspiration from African-American musical forms. Yet Powell derided black music, claiming most of it was inspired by European music because, "When the negro music is analyzed, we see at once that that part of it which is purely negro is aimost as meager and monotonous as the Indian music." The famous so-called "Negro spirituals," Powell claimed, "show clearly in their melodic and harmonic structure their Caucasian origin" when analyzed. Powell quoted in J. David Smith, Eugenic Assault on America, 17. For Powell's significance as a musician, see Sherman, "The Last Stand," 74, note 11.

52 Bair, "Remapping the Black/White Body," 402; Smith, "Managing White Supremacy," 94. Burleigh took her undergraduate degree from Radclif?e in 1912 and undoubtedly was exposed to both eugenic and nativist thinking while in Cambridge. 
White America. "History and biology teach that when two races dwell in the same land the one will drive the other out or the races will amaigamate. Thomas Jefferson had these altermatives in mind when he stated that amalgamation or separation was the only solution of the negro problem," Cox averred in his cover letter..$^{53}$ Richmond's elite women thus gained an introduction to the racial imperatives of eugenics as played out in America, and the South, through the threat of miscegenation.

Many women accepted the eugenical creed whole cloth. In fact, as Lisa Lindquist Dorr and Barbara Bair demonstrate, the very structure of the ASCOA and its women's auxiliary embodied the larger masculinist ideals of eugenics. Debarred from membership, ensconced on the pedestal of southem white female purity and republican motherhood, female supporters of the ASCOA conducted much of the grass-roots lobbying as a pass-time. Such subservience comported well with the gender hierarchy eugenics sought to maintain. ${ }^{54}$ Women, in the eyes of mainline eugenicists like Davenport, and sympathizers like Powell and Cox, should engage primarily in the bearing and rearing of children, and secondarily in ensuring the health of ail mothers and children, through limited social reform involvement. Even the ERO's training program emphasized gender hierarchies and gender essentialism. Davenport and Laughlin trained single women as "field workers." These women were expected to collect data through observation, and were instructed to avoid making interpretive conclusions, which should be left to the male eugenicist/scientist. ${ }^{55}$

${ }^{53}$ Eamest Sevier Cox to Mrs. J. K. Bowman, et. al., December 20, 1923, Box 2, ESC Papers.

${ }^{54}$ Sherman, "The Last Stand," 76; Lindquist Dorr, "Arm in Arm," 152; Bair, "Remapping the Black/White Body," 404.

55 In the first part of the century, women rarely became scientists in charge of independent investigations. Trained as laboratory assistants, women became the help-meets for male scientists, who viewed women as constitutionally fragile and unfit for the rigors of bench research arid abstract thinking. Davenport's own wife conformed to this model. An early collaborator in investigations with ner husband, as scon as she began to bear children she retired from active investigation and instead became the administrative director of the ERO's facilitics and her family. She so thoroughly integrated her homemaking and administrative capacity that the ERO became an extension of her household. For women in science and eugenics, see, Margaret Rossiter, "'woman's Work' in Science, 1880-1910," Isis 71 (1980): 381-89; Nicole Hahn Rafter, White Trash: The Eugenic Family Studies, 1877-1919 (Boston: Northeastern University Press, 1988), 20-22. Rosaleen Love examınes eugenics as an entryway for women into British science in "'Alice in Eugenics Land': Feminism and Eugenıcs in the Scientific Careers of Alice Lee and Ethel Elderton," Annals of Science 36 (1979): 145-58. 
Given the support of these loyal female lieutenants, Powell found himself freed to concentrate on publicizing the mission of the ASCOA.

Powell and Cox orchestrated a media blitz that introduced the reading public to the eugenics of racial purity. 56 Virginia's two leading newspapers, the Richmond TimesDispatch and the Richmond News-Leader, published dozens of articles between June 1923 and March 1924 that simultaneously promoted the ASCOA as the genteel option to Virginia's discredited Klan, and provided mouthpieces amplifying racial purity rhetoric. Both men wove the language of the eugenic metaphor throughout their writing. While Powell often directly invoked eugenics and Mendelian heredity, both men used the language of "blood" to cxpress heredity, "mongrelization" to express miscegenation, and "breeding" to underscore the necessity of preserving racial "purity."

Cox and Powell's first effort, the inflammatory "Is White America to Become a Negroid Nation?" outlined their commitment to eugenic principles. Calling Powell "America's premier pianist and composer" and Cox a "world-noted ethnologist and explorer," the editor of the Times-Dispatch underscored Powell and Cox's cultural and scientific authority. The editor then paraphrased Fowell and Cox's assertion, drawn directly from Madison Grant's 1920 letter to Cox, that when two races mixed, "the blood of the negro is prepotent... [and] negro race traits and predispositions revert in mixbreeds far-removed." For his part, Powell explicitly invoked eugenics as a rationale for preventing the "absorption of Negro blood into our white population." Powell claimed that his call to amend Virginia's existing antimiscegenation law arose from "the more general knowledge of Mendel's discoveries and the development of eugenical science," which proved that, "in crossing two varieties [races], the more primitive, the less highly specialized always dominates" both physically and psychologically. Moreover, hewing to the anti-immigration sentiment enunciated by northem eugenicists, Powell noted that the

\footnotetext{
${ }^{56}$ Richard Sherman's article "The Last Stand" provides the hest narrative tracing the lobbying effort for the RIA and analyzing the role of newspaper coverage. See Sherman, Ibid.
} 
danger of black/white mixing was increased by "accretions to our white population of foreign whites more deficient in the pride of racial integrity than our native stock." 57 Apparently, foreign whites posed a double threat to native white Americans: they risked diluting the native gene pool directly through marriage and indirectly by procreating with blacks and creating more pass-for-white mulattoes. Agreeing with Dr. James Orr's 1903 thesis that disfranchisement alone was not enough to quell the threat, Powell claimed that Antimiscegenation law offered "a final solution" to the Negro problem. ${ }^{58}$

Cox echoed all of Powell's claims, invoking the language of eugenic racism while declaring his fear of passing. ${ }^{59}$ "Near whites" alarmed Cox because they could deceive even the well-trained southern eye, since they "may be of lighter complexion than the Mediterranean Caucasian and possess eyes as blue as the Nordic." Cox also called for national unity in adopting eugenic racial segregation. "If after three centuries of race contact Virginia perfects rather than abandons the color line such act cannot have other than a beneficial effect upon those States which are without a legal color line," Cox wrote. He explicitly held up Virginia as the model for Progressive race relations based on the teachings of eugerics. Raising the specter of American civilization declining through amalgamation, Powell and Cox called for a law banning intermarriage. The TimesDispatch's editor approved the program of the ASCOA in an editorial that ran the same day. 60

Powell found six Senate and eighteen House sponsors for an antimiscegenation bill. The bill had three salient provisions. First, it enlarged the scope of Virginia's 1912 Vital

57John Powell and Earnest Sevier Cox, "Is White Ameica to Become a Negroid Nation?" Richmond Times-Dispatch, July 22, 1923. The notion that "lower" race traits dominated "higher" traits on intermixture came to be known as the doctrine of "Grantism." This idea, however, predated Grant, as the articles in the Virginia Medical Semi-Monthly prove. See Hodge, "The Effect of Freedom Upon the...Negro," 110. For Grant's letter outlining "Grantism," see note 35, above.

58 Orr, "Some Suggestions of Interest to Physicians," 94-95.

${ }^{59}$ That fear of passing was behind these laws is self evident. It is discussed explicitly in Lindquist Dorr, "Arm in Arm," 154; and Joseph R. Washington, Jr., Marriage in Black and White (Boston: Beacon Press, 1970), 106-13.

${ }^{60}$ Ibid. 
Statistics Law by requiring that every Virginian file a certificate recording the individual's racial composition. If a person was of "mixed" race, the bill provided that "the racial composition of the parents and other ancestors, in so far as ascertainable, so as to show what generation such mixture occurred," might be certified. Willfully misrepresenting race would be a felony punishable by a year in jail. The bill's second major provision stated that, "No marriage license shall be granted until the clerls or deputy clerk has reasonable assurance that the statements as to color of both man and woman are correct." So, ail people applying for a marriage license had to present their racial certificates to local clerks because, "It shall hereafter be unlawful for any white person in this State to marry any save a white person." Finally, the bill provided clerks and the Bureau of Vital Statistics with a definition of whiteness: "For the purpose of this act, the term 'white person' shall apply only to a person who has no trace whatsoever of any blood other than Caucasian; but persons who have less than one sixty-fourth of the blood of an American Indian and have no other non-Caucasic blood shall be deemed to be white persons." The final clause, often referred to as "The Pocahontas Exception" immunized descendants of Pocahontas and John Rolfe-many of Viriginia's most prominent citizens—against being considered racially "tainted."61 This law greatly increased Dr. Walter Plecker's power, by making him the gatekeeper to whiteness, not just birth and death, in Virginia. Virginia had laws banning interracial marriage that dated back to 1691; this iaw, however, put the old prejudices on the firm foundation of eugenical science. 62

Powell's steady stream of alarmist articles and addresses garnered support among elites and either convinced or cowed legislators into accepting the ASCOA program. As Richard Sherman noted, Powell's tactics aimed at intimidation because, "white politicians were not likely to risk the consequences of being portrayed as supporters of 'social equality' or

${ }^{61}$ Sherman, "The Last Stand," 77.

62Peter Wallenstein, "Race, Marriage, and the Law of Freedom: Alabama and Virginia, 1860s-1960s," Chicago-Kent Law Review 70 (1994): 371-437, especially 389. The earliest antimiscegenation law in America appears to have been passed oy Maryland in 1663. Washington, Marriage in Black and White, 45. 
opponents of white political and cultural dominance."63 In testifying before the General Assembly on February 12, Powell posed as a dispassionate, scientific observer of the race problem who sought the RIA not to punish diviant people but to insure the integrity of every race. Citing African American's "great loyalty and devotion during the trying days of the War Between the States," Powell remarked, "We [white Virginians] owe him [the black man] a debt which can never be repaid. But accepting racial amalgamation is no way of showing our gratitude." Relying on the argument of Grant, Stoddard, and Cox, Powell averred that, "6,000 years of history does not fumish one instance where races living together have not amalgamated, and not one instance-where the white race has absorbed the negro which did not result in the complete disintegration of its civilization."64

Powell provided "evidence" for the necessity of the bill in the form of anecdotes about "cases" of racial amalgamation from around the state. He particularly focused on the mountain counties of Rockbridge and Amherst—not coincidentally the same counties Harvey Ernest Jordan had identified in 1911 as prime locations for eugenic studies of miscegenation. 65 Powell also read into the record testimonials from Madison Grant, Lothrop Stoddard, and the noted eugenicist Franklin H. Giddings. The Richmond TimesDispatch ran a front-page article the next day that reproduced this testimony. Calling them "[l]etters from the greatest authorities on ethnology and sociology," the reporter quoted Madison Grant's assertion that "it would be living up to Virginia's great traditions if she took the lead in legislation of this character and set, once for all, the stamp of her approval upon the importance of maintaining race purity." Stoddard, whom the reporter dubbed "perhaps the best known ethnologist in this country," affirmed his staunch support of the proposed law and opined "White race purity is the corner-stone of our civilization. Its mongrelization with nonwhite blood, particularly with negro blood, would spell the

\footnotetext{
${ }^{63}$ Sherman, Ibid.

64"Powell Asks Law Guarding Racial Purity," Richmond Times-Dispatch, February 13, 1924, 1.

${ }^{65}$ See Harvey Ernest Jordan to Charles B. Davenport, ; See also Chapter 2, page 154, above.
} 
downfall of our civilization." Emphasizing the national significance of Virginia's local action, Stoddard concluded, "This is a matter of both national and racial life and death."66 After Powell finished, the reporter gauged his success by noting that, "several leading members of the House, in congratulating him and promising to support the bill, spoke of similar cases [of miscegenation] in their own communities." 67 The Richmond New'sLeader reported that, "He painted the 'spectre of miscegenation' so clearly that he shocked and startled his hearers."68 Powell clearly touched a nerve with his address, playing on a widespread apprehension about passing and its consequences.

Despite the surge of support from most Assemblymen, the RIA did not pass into law unchanged. Supporters had to make a number of concessions to get the bill ratified. Legislators, concemed about the cost of registration and the indeterminacy of old records, made voluntary the retroactive registration of individuals bom before 1912, the year mandatory birth registration began. Furthermore, legislators raised the Pocahontas exception to "one-sixteenth" which, in the calculus of racial purity, equated to having one great-great-grandparent of "pure" Native American derivation. ${ }^{69}$ To mollify the ASCOA, legislators placed the burden of proof for racial heritage on the individual by amending the act to read, "If there is reasonable cause to disbelieve that applicants [for marriage] are of pure white race, when that fact is stated, the clerk or deputy clerk shall withhold the granting of the license until satisfactory proof is produced that both appiicants are 'white persons' as provided for in this act." To emphasize the fact that the law ostensibly protected both races, this clause concluded, "The clerk or deputy clerk shall use the same

\footnotetext{
${ }^{66} \mathrm{All}$ of these letters, and the documents providing the anecdotal evidence of racial mixing, reside in the Powell Papers.

67"Powell Asks Law Guarding Racial Purity," Richmond Times-Dispalch. February 13, 1924, 1.

68"John Powell Discusses Racial Amalgamation in Virginia Before Solons," Rlchmond News-Leader, February 13, 1924, 2.

${ }^{69}$ Paul Lombardo provides an excellent narrative of the passage of the RIA and its subsequent history. The following draws heavily on his work, although my interpretation differs in focus. See Lombardo, "Miscegenation, Eugenics, and Racism," 432-437; see also Smith, "Managing White Supremacy," 98.
} 
care to assure himself that both applicants are colored when that fact is claimed."70

Nevertheless, the act did not explicitly prohibit intermarriage among any of the other enumerated races - Negro, Mongolian, American Indian, Asiatic Indian, Maylay, or mixture thereof"- - only between whites and any other race. After all, the Richmond TimesDispatch argued, nothing in the bill should "give offense to the right-thinking colored man. $\mathrm{He}$, as well as his white friend, is anxious to preserve his racial integrity." Powell's protestations that he acted in the interest of all races had a decidedly hollow tone. ${ }^{71}$

The amendment of the bill allowed it to pass the Senate by a vote of 23 to 4 on February 27 . This success did not satisfy all interested parties. The revised measure placated members of the First Families of Virginia whose whiteness was jeopardized by the law. The Richmond Times-Dispatch, however, expressed its displeasure in telling language. Under the title "Emasculating a Good Bill," the editor mixed metaphors and claimed that "The Senate deliberately cut the heart out of a good bill." By removing compulsory registration, the new law failed to "determine once and for all who is a Caucasian and who is not, in order that further intermingling of the races might be prevented." Attempting to save the measure from ruin, the editor noted that while the House felt that the "emasculated" bill was now "utterly unnecessary in the scheme of things," men who "have given the matter serious thought" felt that "this country is headed straight toward mongrelization." Given the danger, "Only heroic measures, taken immediately" would "save the United States to the white man pure and undefiled." Hoping to restore the bill's potency, the editor expressed his hope that the House would "amend the

\footnotetext{
70" An Act to Preserve Racial Integrity," Virginia Acts of rissembly (1924), 534-35.

${ }^{71}$ Richmond Times-Dispatch, February 28, 1924 quoted in Sherman, "The Last Stand," 79. Powell used this rhetoric of "fair play" from the beginning. See Powell and Cox, "Is White America to Become a Negroid Nation." Paul Lombardo points out that the Senate amended the bill's title from "A Bill to Preserve the Integrity of the White Race" to "An Act to Preserve Racial Integrity," masking its real intent. Plecker revealed his real purpose when he wrote that a proposed antimiscegenation bill for the District of Columbia bill revolved around "the integrity of the white race," which was "preferable, as it is the protection of the white race that is aimed at, and not the others." Plecker quoted in Lombardo, "Miscegenation, Eugenics, and Racism," 435-36 note 68.
} 
Senate measure so as to cure it of its deadiy defect."72 Powell, on tour performing

"canceled several engagements in order to return to Richmond...to appear before the committee with Dr. W. A. Plecker," reported the Times-Dispatch. ${ }^{73}$ Powell and Plecker did not insist on compulsory registration, and the amended bill sailed through the House by a vote of 72 to 9 on March $8 .^{74}$ Govemor Elbert Lee Trinkle signed the bill into law on March 20, 1924. A firm supporter of the bill, Trinkle earned the congratulations of the ASCOA by promptly registering himself and his family. Trinkle also helped Walter Plecker orchestrate an effort to convince other states to pass similar bills. ${ }^{75}$

Among those voting in favor of the RIA was a young member of the House from Charlottesville. Assemblyman Lemuel Smith graduated from the University of Virginia in 1916 and remained in Charlottesville. Undoubtedly he had been introduced to eugenics as a student at the university. Not only did he vote in favor of the RIA, but he also voted for the eugenic sterilization statute. His vote is important because, thirty-one years later, Assemblyman Smith would be Justice Lemuel Smith of the Virginia Supreme Court of Appeals. He would sit on the bench and hear the case Naim v. Naim, and uphold the annulment of a marriage between a white woman and a Chinese man. The first direct challenge of the law's constitutionality, the United States Supreme Court would avoid deciding Naim and the RIA would stand until 1967.76 Before then, however, the act

72"Emasculating a Good Bill," Richmond Times-Dispatch, February 29, 1924, 8.

73"Amended Racial Bill Wins Favor in the House," Richmond Times.Dispatch, March 4, 1924.

${ }^{74}$ Lombardo, "Miscegenation, Eugcnics, and Racism," 435. John Douglas Smith astutely notes that abstentions may have indicated tha: "a number of state senators and delegates feared opposing the bill openly" and "reasoned that it would have litule practical effect" and so decided to abstain rather than vote. Thirteen of forty senators and ninetcen of one hunured delegates abstained. Smith, "Managing White Supremacy," 102 note 35.

75 Plecker's correspondence, preserved in the Cox Papers, illuminates the wide geographic scope of his effort. See also Smith, "Managing White Supremacy," 100; Sherman, "The Last Stand," 79. Ultimately this work met with limited success. Georgia surengthened her law in 1926, but Mark Haller notes that little change occurred "in most states where sentiment demanded such laws...and in other states the National Association for the Advancement of Colored Peopie led the fignt against their passage." Haller, Eugenics, 159,236 note 44

${ }^{76}$ For a detailed account of Naim, see Gregory Michael Dorr, "Principled Expediency: Eugenics, Naim v. Naim, and the Supreme Court," American Journal of Legai 'Iistory 42 (1998): 119-159; and see Chapter 8 , below. 
would face other challenges. These confrontations revealed the varied power eugenical ideology held in conditioning white responses to inteıracial sexuality.

In the immediate afterglow of passage, Dr. Walter A. Plecker began a heated campaign of "eugenical education."77 Dr. Plecker's devotion to racial integrity approached the monomaniacal. The day before Governor Trinkle signed the bill into law, Plecker managed to run an article appealing to Virginians to register their race. ${ }^{78}$ "The bill aims at correcting a condition which only the more thoughtful people of Virginia know the existence of," Plecker said, appealing to people's self-image as intelligent, Progressive, and white. Any Virginian wishing to be thoughtful would, by implication, register under the law. Raising the specter of passing, Plecker noted that between 10,000 and 20,000 "near-white people" lived in Virginia. "In the past it has been possible for these people to declare tiiemselves white or even to have the court so declare them. Then they have demanded admittance of their children to white schools and in not a few cases they have intermarried with white people." Thus, thirty years before Brown v. Board of Education, Plecker made the connection between the schoolroom and the bedroom. Plecker finished by noting that the Bureau of Vital Statistics had "kept a watchful eye on the situation, and has guarded the welfare of the State as far as possible with inadequate law and power." Ncw the time had come for "radical measures" to prevent the decline of civilization through miscegenation. ${ }^{79}$

Plecker stepped to the fore as the law's greatest champion. popularizer, and enforcer. To an even greater degree than Cox and Powell, Plecker became the clearinghouse for information about the RIA. ${ }^{80}$ Plecker, himself a physician and a member of the state

\footnotetext{
77Lombardo, "Miscegenation, Eugenics, and Racism," 438-40; Smith, "Managing White Supremacy." 100-01.

78"To Further Aims of Racial Law," Richmond Tirnes-Dispatch, March 19, 1924, 2. A similar article ran in the News Leader the day Governor Trirkle signed the Law. "Asks Virginians to Register As to Color Under 'Integrity' Law," Richmond News Leuder, March 20, 1924, 13.

${ }^{79}$ Plecker quoted in "To Further Aims of Racial Law,".

80 All earlier scholars have focused on the papers of John Powell ior their information concerning Walter Plecker. Powell's papers contain a large sampling of Plecker's work. While representative, they do not reflect the incredible scope of his efforts to proselytize racial integrity. A virtually complete, and heretofore unnoticed, record of Plecker's activities is preset ved in the Eamest Sevier Cox Papers. Plecker's
} 
department of public health, turned first to educating physicians, midwives, and the local registrars of vital statistics. He attempted to league all professionals involved with childbirth and delivery with the Bureau of Vital Statistics to ensure the prompt and accurate recording of race.

Immediately upon passage of the law, Plecker set about instructing local registrars in the taxonomy of racial classification. His pamphlet, "Instructions to Local Registrars and Other Agents in Administration of Law," circulated among public health officials, physicians, and local registrars. This booklet detailed the calculus of racial purity through the traditional nomenclature-"mulatto," "quadroon," and "octoroon"—representing onehalf, one-quarter, and one-eighth black "blood." The pamphlet instructed that, "mixtures of either of these crossings with true negroes ["pure" blacks] should be designated as Black, Negro, Colored." Evidently, black-white mixture could dilute the blood fractionally. Matings of mixed blood, however, immediately reconstituted pure blood-but only of the inferior black, not the white. Plecker also defined the terms "mixed" and "issue," to classify individuals in whom white "blood" predominated over black. "That is the class that should be reported with the greatest care, as many of these are on the borderline, and constitute the real danger of race intermixture," he cautioned. ${ }^{81}$

The first line of racial defense, then, came through government bureaucrats and the physicians and midwives most intimately associated with births and the background of

letters are filed throughout Cox's papers, beginning about 1923 and ending with his retirement in 1947. They document his efforts linking the Virginia movement to other white supremacist and segregationist organizations throughout the country. As Plecker once wrote the ERO's Harry Hamilton Laughlin, "One of our chief desires is to influence legislation in other states. Virginia can do but little to protect herself when she is the only State attempting it." Walter A. Piecker to Harry Hamilton Laughlin, March 11, 1925, Harry Hamilton Laughlin Papers, Pickler Memorial Library, Truman University, Kirksville, Missouri. [Hereinafter referred to as Laughlin Papers. Copies in author's possession.]

${ }^{81}$ The pamphlet also indicated that the term "Indian" could only be used to classify those of "pure" Native American ancestry. Crosses between whites and Asians were to be hyphenated with the "inferior" (and hence genetically dominant by "Grantism") race coming first, i.e. Japanese-white. Black/Asian crosses "should be designated as black or negro, but it may be viritten negro-Japariese." Walter A.

Plecker/Department of Health, "Instructions to Local Registrars and Other Agents in Administration of Law," Virginia Health Bulletin 16 (March 1924), 2. A copy of this pamphlet resides in Box 56 of the Powell Papers. Smith, "Managing White Supremacy," 101, especially note $3 \hat{3}$. 
parents. Plecker's dragnet was quite finely woven. "I have the supervision of 6,000 midwives; 2500 physicians; 1300 local registrars and about 2500 undertakers who report deaths, beside the Clerks who report marriages and divorces," he reported to the American Medical Association. 82 "We thus have one or more representatives in every local community within two to five miles of every person." Doctor Plecker truly believed that these vigilant informants would allow the Bureau of Vital Statistics to ensure that no blacks "passed" as whites in Virginia. ${ }^{83}$

Viewing racial integrity as a matter of public health and national survival, Plecker targeted large audiences of physicians in an attempt to crystallize professional support for the law. In October of 1924, Plecker read his address, "Virginia's Attempt to Adjust the Color Problem," before "one hundred and fifty or two hundred members of the American Public Health Association." He noted that it was "very favorably received and was discussed by three leading members, all of whom agreed with the views expressed." 84 In his address, Dr. Plecker emphasized the major strands of the eugenic metaphor-the value of pure racial stocks, the threat posed by miscegenation, the need for eugenic segregation to maintain racial purity. Invoking the image of "Cavaliers" and "Puritans" who were "the best that the world could then offer" racially, Plecker played on the notion of a distinctly "American race" that represented the epitome of Nordic civilization. For authority he alluded to Cox, Grant, and Stoddard ("Recently published ethnological studies of history") and the Army psychology tests from World War I (Carl Brigham's epochal A Study of American Intelligence had appeared in 1923).

\footnotetext{
${ }^{82}$ Between 1914 and 1933, Plecker published five papers on "the midwife problem" and his attempts io control midwives to lessen infant mortality and increase surveillance of racial integrity. Gertrude Fraser notes the burden the role as "gatekeeper" to whiteness placed on African-Amcrican midwives. Gertrude Jacinta Fraser, African American Midwifery in the South: Dialogues of Birth, Race, and Memory (Cambridge, MA and London: Harvard University Press, 1998), Chapter 3 (especially 74-5); and 278. ${ }^{83}$ Walter A. Plecker to American Medical Association, September 19, 1924, Box 2, ESC Papers.

${ }^{84}$ Walter A. Plecker to Earnest Sevier Cox, October 24, 1924, Box 2, ESC Papers.
} 
Plecker argued that America must defend itself from the genetic threat of miscegenation. To highlight the genetic danger that "in the hybrid rnixture the traits of the more primitive will dominate those of the more specialized or civilized race," Plecker noted that "these culturally destructive characters are heredicary, carried in the germ plasm" and beyond environmental correction. ${ }^{85}$ Plecker applauded the Immigration Restriction Act, but argued that it did not address the great dysgenic threat posed by southern blacks. Birth control, too, offered no answer. According to Plecker, who followed Charles Davenport's lead, birth control acted dysgenically because it reached "our native born intelligent American stock" but failed "to reach the uneducated, the feeble-minded, the morons, the negroes, criminals and undesirables". 86 While Plecker agieed that "Laws are needed to prevent the increase of feeble-minded, morons and criminals by segregation or steriiization," he felt too little had been done to stop the great threat of interracial mating.

Quoting Cox, Plecker claimed that Virginia's RIA offered the answer because it was, "the most perfect expression of the white ideal, and the most irnportant eugenical effort that has been made in 4000 years. "87 Claiming that studies of Virginia's "mixed breeds" revealed that "the mongrel races are liable to perpetuate the undesirable qualities of their constituent stocks," Plecker announced that the RIA offered "an adjustment of the larger number of racial differences" by controlling mating. The RIA could "hold the situation

85 Walter A. Plecker, "Virginia's Attempt to Adjust the Color Problem," in Walter A. Plecker, Eugenics in Relation to the New Family and the Law on Racial Integrity (Richmond, VA: Davis Bottom, Superintendent of Public Printing, 1924), 14-15. As proof, Plecker cited the work of Arthur H. Estabrook, fieldworker for the Eugenics Record Of iice and the Carnegie institution, whose book Mongrel Virginians will be discussed later.

${ }^{86}$ Plecker, Ibid., 23. Plecker's categorization reveais his low estimation of blacks, despite his claims about safeguarding both races. Plecker wrote to Madison $\mathrm{G}_{1}$ ant as early as 1923 oullining his hostility toward birth control. "As a public health worker, and as an American," Plecker wrote, "I am interested in maintaining a satisfactory birth-raie, with reduced infant-death rate, amongst our native white stock." Plecker tried to "counteract the harmful tcaching of the 'Birth Con!rol' people, who are reaching only the intellectual and well-to-do native bom, and are not touching the Roman Catholic foreign population of Alpine and Mediterranean stocks, nor the ncgro of the South and the mongolian races of the Pacific Coast." Plecker enclosed a copy of his 1920 "New Family" pamphlet that touchcd upon this subject. Grant sent this information on to Harry Hamilton Laughiin of the ERO. See Walter A. Plecker to Madison Grant, March 8, 1923; and copy of Walter A. Plecker to Ms. Annie G. Porritt (Birth Control Review), March 5, 1923, both in the Laughlin Papers. [Copıes in author's possession.]

${ }^{87}$ Plecker, Ibid., 24. 
[miscegenation] in check until Lincoln's real remedy [repatriation of blacks] can be adopted."88 Throughout, Plecker adhered closely to Cox's thesis. His address was published in the American Journal of Public Health and excerpted, under the title "Shall We All Be Mulattoes," in the popular Literary Digest. Thus, Plecker managed to have his views broadcast before a wide professional and educated-lay audience. ${ }^{89}$

After addressing the American Public Health Association, Plecker traveled to the annual meeting of the Southem Medical Association to trumpet the new law in his address, "Shall America Remain White?" Remarking that over 2,000 physicians attended the conference, the Richmond News Leader reported that the RIA "is creating a great deal of inierest in the North as well as the South, and Dr. Plecker's discussion will be widely attended. The success of any such movement is said largely to depend upon the physicians, since they are in a position best to know of racial coniact and its effects." The News Leader commented that racial integrity depended upon the "conscientious preparation of birth certificates," a position wholly endorsed by Plecker..$^{90}$ Consonant with his previous address, Plecker outlined the threat posed by unchecked miscegenation, and averred that America would remain white "today, but if delayed for several generations it may be forever to late." The discussion following the address centered on a basic agreement among the physicians that Plecker had touched on a vital and real problem and presented an excellent overview of possible solutions. ${ }^{91}$

Plecker did not sacrifice local attention for regional or national appeal. Plecker engaged Cox to join him in spreading the word about racial integrity in the schools. ${ }^{92}$ If the altar

\footnotetext{
88Plecker, Ibid., 27.

${ }^{89}$ Walter A. Plecker, "Shall We All Be Mulattoes?" Literary Digest 23 (March 7, 1925): 23.

90"State's Racial Integrity Law Will Be Discussed at Medical Menı's Meet," Richmond News Leader, November 20, 1924, 4.

${ }^{91}$ In his address, Plecker called for physicians and public health workers "to include eugenics as a whole or a part of regular and legitimate public health work." Plecker, "Shall America Remain White," reprinted in, The New Family and Racial Improvement, 14, 23-29 (quotation in note, 22).

92 By 1925 Plecker was speaking to the summer "Normal Schools" where high schoci teachers iouk additional training. In a letter to the ERO's Charles Davenport he wrote, "I am endeavoring to reach the higher schools and colleges of the state on the question of Race Improvement. I am handling the subject
} 
presented the front line of segregationists' battle for racial purity, then the schoolroom became the second most contested terrain. Plecker sought to use school officials as a network of informants who could reveal instances of passing that might escape registrars. He tapped Professor Ivey Lewis for assistance in patrolling Albemarle County. Lewis congratulated Plecker on seeing "the situation as it is" and trying "so effectively to do what can be done." He assured Plecker that he would "try to find out more about the cases mentioned" and inform him of any results. ${ }^{93}$ Cox began to address biology classes throughout the state, especially in the colleges. Ivey Lewis arranged two engagements for Cox, one before his biology class and another with a larger audience, hoping to "make the occasion widely public throughout the student body." 94 Emphasizing his ultimate preference for repatriation, Cox sought to convince the students that eugenics, embodied in the RIA, provided the necessary first step toward the "final solution" of the "Negro Problem." 95

Meanwhile, Doctor Plecker started enforcing the new law with a rigor that surprised even its supporters. By any standard, Plecker's actions in enforcing the law exceeded the statutory warrant provided his office. 96 Plecker resorted to bullying, threats, and outright lies in enforcing his conception of the spirit of the law. Plecker targeted mothers, particularly white mothers, for his intimidation. Perhaps most outraged by their

from the standpoint of the prevention of racial intermixture and for the prevention of the rapid increase of the feeble-minded and other undesirables, and I am appealing also to these intelligent young people from the point of patriotism and duty..." Plecker to Davenport, August 17, 1925, Davenpor: Papers.

93 Walter A. Plecker to Ivey Foreman Lewis, October 29, 1926; and Ivey Foreman Lewis to Walte: A. Plecker, November 9, 1926, both in the ivey Forman Lewis Collection 5119a, "1926 Letters" folder, Box 1, Special Collections, Alderman Library, Charlottesville. Plecker was worried about a number of families that descended from eight mixed children of a white man and a black woman. These families had been "intermarrying into white families and are endeavoring to force their children into the white schools."

${ }^{94}$ See Ivey Foreman Lewis to Eamest Sevier Cox, April 25, 1924; and Ivey Foreman Lewis to Eamest Sevier Cox, May 5, 1924, Box 2, ESC Fapers.

95"Major Ernest G. [sic] Cox Addresses Students," Richmond Times-Dispalch, November 21, 1924, 18. This article reports Cox's address before the "students and citizens" in Lexington, Virginia. Cox spoke at the Virginia Military Institute on "The Color Line in History," and before the Anglo-Saxon Club at Washington and Lee University.

96Lombardo, "Miscegenation, Eugenics, and Racism," 44i-50. 
transgression of the color line and defilement of the southem iconography of "pure white womanhood," Plecker lashed out furiously. In "a specimen of our daily troubles and how we are handling them," which Plecker sent to Cox and Powell, he informed a new white mother that her child's father was "negro," not white. He continued,

This is to give you waming that this is a mulatto child and you cannot pass it off as white. A new law passed by the last legislature says that if a child has one drop of negro blood in it, it cannot be counted as white. You will have to do something about this matter and see that the child is not allowed to mix with white children, it cannot go to white schools and can never marry a white person in Virginia.

It is an awful thing. 97

Plecker minced no words in dealing with anyone he thought to be in breach of the law. He threatened the midwife in the same case. "This is to notify you that it is a penitentiary offense to willfully state that a child is white when it is colored," he began. "You have made yourself liable to very serious trouble by doing this thing. What have you got to say about it?"98 This early case, just over a month after the law passed, set the tone for Plecker's administration. Predictably, he aroused fear and indignation among those he confronted. Some had the temerity to take Plecker and his law to court.

Much to the chagrin of Virginia's eugenicists, the RIA split its first two legal decisions. Ironically, the same Judge, Henry W. Holt, ruled in both cases. Both incidents involved the attempted marriage of white men to colored women, traditionally the least stigmatized form of interracial sexuality. ${ }^{99}$ Both cases came out of Rockbridge County, one of the areas where miscegenation reputedly ran rampant. At issue in both instances was the race of individuals who claimed Native American descent. The first case, involving James Connor and Dorothy Johns, came before the court in September

${ }^{97}$ Walter A. Plecker to Mrs. Robert Cheatham, April 30, 1924, Box 56, Powell Papers; quoted in entirety in Lindquist Dorr, "Arm in Arm," 153; and Lombardo, "Miscegenation, Eugenics, and Racism," 448 note 126.

98Walter A. Plecker to Mrs. Mary Gildon, April 30, 1924, Box 56, John Powell Papers. Quoted in Lombardo, Ibid.

${ }^{99}$ Lombardo, "Miscegenation, Eugenics, and Racism," 440-43. J. David Smith also details these cases in Eugeric Assault on America, 71-82. My interpretation extends Lombardo's and differs substantially from that offered by Smith. 
1924. Judge Holt accepted Plecker's testimony and that of a corroborating witness that

Dorothy Johns was not white but instead was a "triple mixture" of Native American, black, and white "blood." In the second case, however, Holt ruled in favor of Atha Sorrells, declaring that her heritage betrayed no evidence of racial mixture. In his decision, Holt excoriated the weaknesses in the racial definitions embodied in the RIA.

In dismissing the Sorrells case, Judge Holt pronounced himself "in cordial sympathy with the general purpose of the statute." He noted that, whether "based upon pride, prejudice, or instinct" whites "look upon ourselves as a sceptered race and stand for its preservation in all its integrity." Nevertheless, as a Judge charged with the impartial administration of the law, Holt felt that the statute, "goes far beyond anything that has heretofore been enacted." The RIA, Holt held, did not explicitly traduce due process considerations, because plaintiffs could appeal to the courts. However, since the burden of proof remained upon the applicant and not the state. Holt felt that "the relief granted [by appeal to the courts] is no relief at all," because no one could prove their absolute racial purity. Using himself as an example, Holt noted, "In twenty five generations one has thirty-two millions of grandfathers, not to speak of grandmothers....Certainly in some instances there was an alien strain. Beyond peradventure I cannot prove that there was not, and so the relief granted by appeal is no relief at all". Holt also noted, as Madison Grant had indicated to Cox, that the category "Caucasian" entirely lacked scientific precision and rigor, thereby undercuiting the terms of the RIA. ${ }^{100}$

Holt fell back on the traditional southem method of determining the racial character of an individual's "blood," the entirely unscientific method of "appearance." Holt was inclined to "discard the letter of the law" and apply "the 'rule of reason' which is that there

100Ironically, this builds on the same logic Powell admitted in "Is America to Become a Negroid Nation" when he admitted that "there never was an Anglo-Saxon race" because it derived from the mixing of many ethnic, what Powell called racial, "stocks." The majority of Holt's decision, including the quotation above, appears in Smith, Eugenic Assault on America, 72; see also "Woman, Listed Negrcid, Wins Right to Be Called 'White'," Richmond Times Dispatch November 18, $1924,1$. 
must be an appreciable amount of foreign [non-white] blood". Since he could not "see" the non-white blood, either in Atha Sorrells' face, physiognomy, or pedigree, Holt ruled that "no strain is present in the applicant of any blood other than the white, except the Indian, and there is not enough of that to come within the statute."101 Holt had, in the eugenicists' eyes, fallen victim to the very danger posed by miscegenation: that racial intermixture-the "taint" of inferior blood-could not be detected with the naked eye. On this level, the eugenic effort against miscegenation was precisely identical to the eugenic effort for sterilization; both sought to uncover "hidden taints" and "defectiveness" and prohibit their propagation.

Holt's decision so horrified Powell, Cox, Plecker and the Virginia eugenicists that they immediately mounted a two-pronged effort to ensure that it never happened again. First, they sought to mount a direct challenge to Judge Holt's decision. Second, they organized a lobbying effort to close loopholes in the statute and achieve an "iron clad" lilly-white RIA. Both of these efforts would prompt outrage among segments of the Virginia elite otherwise sympathetic to the causes of eugenics and racial integrity.

Holt's decision in the Sorrells case gained immediate notoriety. The Richmond NewsLeader ran a lengthy front-page article reporting the decision and Plecker's resistance. The editor of the Richmond Times-Dispatch openly questioned the propriety of Judge Holt's substituting "the rule of reason" and an "appreciable amount" of black blood in favor of the "letter of the law."102 Doctor Plecker, embarrassed by the defeat, also challenged Judge Holt publicly. He flew in the face of Judge Holt's decision by stating, for the record, that the Judge's ruling "would have no affect on the position taken by the bureau," and, "'The persons recorded as colored will remain colored, so far as we are concerned"'. 103

101 Smith, Ibid., 73.

102"Woman, Listed Negroid, Wins Right to Be Cálled 'White'," Richmond News Leader, November 18, 1924, 1; "Testing the Racial Integrity Law," Richmona Times-Dispatch, November 20, 1924.

103"Inter-racial Law Ruling is Rapped," Richmond Times-Dispalch, November 19, 1924, 1. A day later he stated to the Richmond News Leader that he believed "the opinion of Judge Holt in the case assails the structure" of the RIA. Plecker paraphrased in "Woman, Listed Negroid," 1. 
Plecker's rash words would have a lasting effect on Virginia's eugenics movement. The battle over Holt's decision raged in the newspapers for the remainder of November, with Dr. Plecker making increasingly bellicose statements to the press. ${ }^{104}$

Behind the scenes, Plecker and Powell began considering a legal appeal. ${ }^{105}$ Supporters of the law within the government rallied to the ASCOA's standard. Assistant Attorney General Leon M. Bazile notified Powell that the Attomey General's office would pursue an appeal if Plecker and Powell thought it advisable. Judge Holt backed up his assertion of being in sympathy with the law. He informed Commonwealth's Attorney A. Willis Robertson that he would amend his ruling to declare the law unconstitutional, if an appeal was forthcoming. Such a ruling would make appeal easier. He later wrote similarly to Powell, stating, "I have no pride of opinion and have done what I could to make an appeal in that case easy."106 By December, Powell felt confident enough to announce, through the Richmond Times-Dispatch, that the ASCOA was considering making an appeal of the Sorrell's decision. The ASCOA released Powell's pamphlet A Breach in the Dike: An Analysis of the Sorrels Case Showing the Danger to Racial Integrity from Intermarriage of Whites with So-Called Indians to alert Virginians to the implications of the Judge Holt's decision.

A Breach in the Dike displayed the Janus-faced reasoning so typical of Powell and those who hoped to act "in the name of eugenics." Reminiscent of the rhetoric of Progressives like Alderman, Powell remarked that the Sorrells case threatened "to overflow the bounds of the scientific and the judicial, and invade the political field," a prospect that "would be a tragic misfortune." Echoing Alderman, Powell made the disingenuous claim

\footnotetext{
${ }^{104}$ See "Trinkle Given Facts On Racial Law Ruling," Richmond Times-Dispatch, November 22, 1924; "Controversy Rages Further in Racial Integrity Law Case," Richmond Times-Dispatch, November 24, 1924; and "Racial Integrity Case Fought Over," Richmond News Leader, November 24, 1924.

105 "May Test Law on Racial Integrity," Richmond News-Leader, November 19, 1924, 1; "State May Appeal From Decision of Judge Henry Holt," Richmond News-Leader, November 20, 1924, 2.

${ }^{106}$ Lombardo, "Miscegenation, Eugenics, and Racism," 442 note 100; and Smith, "Managing White Supremacy," 106-107; Henry W. Holt to John Powell, April 9, 1925, Powell Papers.
} 
that, "the political cockpit is not the proper arena for this debate" which should be handled with "stemest self-control and the coolest judgment," even as he distributed a pamphlet setting out to inflame the passions of the electorate. Claiming he was not blaming the older generation, Powell went on to detail their "ostrich-like antics" in believing that

disfranchisement, segregation ordinances, and the spurious declining black birth rate would solve the "Negro Problem." He valorized the younger generation, whose opinions had been "formed under the influence of modem biology, by the new ethnology, by the new philosophy of cultural history, by the knowledge that institutions and civilizations are the effect and not the cause of racial psychology."107

Breach in the Dike presented the Cox/Grant/Stoddard interpretation of interracial contact: it always led to the loss of civilization. Powell used "Grantism" as authority for asserting that "'one drop of negro blood makes the negro' is no longer a theory based on race pride or color prejudice, but a logically induced, scientific fact."108 Using the medicalized language of the eugenic metaphor, Powell claimed that "The need of the time is not for opiates, but for surgery." Drastic action needed to be taken to save white civilization.

Judge Holt, Powell intimated, was "imperfectly acquainted, perhaps, with the catastrophic biologic and social results of the infusion of even an infinitesimal strain of African blood" into the white body. Powell patronizingly conceded that the judge, in his ignorance, could have been "swayed by an impulse essentially generous." Powell then came back with a remark calculated to insult, "On the other hand, it is to be feared that many individuals who, for personal reasons of intimate and delicate nature, would desire to oppose the law...." Without saying so directly, Powell impugned the racial background of racial liberals, and by implication Judge Holt's own racial background. Relying on the

107John Powell, A Breach in the Dike: An Analysis of the Sorrels Case Showing the Danger to Racial Integrity from Intermarriage of Whites with So-Called Indians (Richmond, VA: The Liberty Printing Press, n.d.), 2. A copy of the pamphlet resides in the John Powell Papers.

108Powell, Ibid., 3. 
studies of the ERO's Arthur H. Estabrook, Powell argued that all Virginia "Indians" presented "proof of mongrelization." Moreover, he wamed, "even if our present law did not inhibit their intermarriage with whites, the commonsense of eugenics would dictate the advisability of special legislation preventing the dissemination of their blood with its hereditary traits in the general population."109 Given this "scientific background," Powell then presented a blow-by-blow analysis of the testimony in the Sorrells case to prove the Judge's error. Hoping to strong-arm Judge Holt and other prominent Virginians with the threat of his club's action, Powell overplayed his hand. ${ }^{110}$

Plecker and Powell's actions crossed the fine behavioral line that separated "Virginia gentlemen" from arrivistes. Counterclaims emerged almost immediately from the powerful supporters of Judge Holt, many of whom lived in Richmond. Both the News Leader and the Times-Dispatch ran articles in which those supporting Judge Holt affirmed the rectitude of his ruling. Certifying Holt's own ancestry, one supporter remarked, "Judge Holt is a native of Surry County and comes of a prominent Old Virginia family... his judicial record has received commendation from the highest legal sources." Having linked Holt's status and claim to gentility to the soundness of his judgment, the unnamed source continued, "He is particularly desirous of perpetuating the spirit of the recent law to preserve racial purity." Holt's decision reflected his legal convictions, not his personal fealty to white supremacy. ${ }^{111}$

Ultimately, as Paul Lombardo notes, Powell and Plecker decided an appeal risked too much. ${ }^{112}$ Fearful that the law would be declared unconstitutional, Powell and Plecker followed the second prong of their effort to nullify the precedent set by Judge Hoit. First, Plecker continued his efforts to "educate" local officials in the law's necessity and

${ }^{109}$ Powell, Ibid., 6-7.

${ }^{110}$ At least fifty members of the ASCOA's powerful Richmond post met to debate an appeal. "AngloSaxon Club May Take Appeal In Sorre!ls Case," Richmond Times-Dispatch, December 10, 1924, 1-2.

111 "Action of Judge Holt Defended by Friends," Kichmond Times-Dispatch, November 21, 1924, 2. See also "State May Lose in Racial Cases," Richmond News Leader, November 21, 1924, 27.

${ }_{112}$ Lombardo, "Miscegenatiun, Eugenics, and Racism," 442. 
administration, effectively ignoring the implications of Holt's decision. Plecker relied on the professional deference and personal prejudice to ensure that local officials overcame any scruples raised by Holt's ruling. Simultaneously, Powell, Plecker, and Cox organized a campaign to cinch the law's loophole by promoting an iron-clad, lilly-white revision of the law's racial classification.

The importance of eugenics as a rationale for the RIA increased during this period of mobilization. Plecker embarked on a writing campaign that sought to rally all Virginians, and especially Virginia's physicians, behind the RIA as a eugenic measure. His 1924 pamphlet, Eugenics in Relation to the New Family and the Law on Racial Integrity sounded the eugenic tocsin. Stating that the Bureau of Vital Statistics sought "to make a genetic and racial study of the population," Plecker remarked that the "chief hope is that the public may speedily become aroused to the danger [of racial degeneration] and be led to unite in an effort to remove it." Plecker confessed that his program aimed at present and future elites, not the entire public. He hoped the pamphlet would be "read by the young people of our schools and colleges, and by others who are, or will be our leaders in thought." Again, Plecker recognized in the school system a ready audience; and, judging from his acquaintance with eugenic-minded professors, he knew teachers would respond favorably. The pamphlet went through two editions by March 1925, totaling over 65,000 copies distributej statewide. ${ }^{113}$

The first nine pages of Plecker's pamphlet contained a detailed discussion of mainline eugenics. He railed against intermarriage of the "feebleminded," insane, and those with physical malformations like clubfoot and hairlip. The first sentence invoked the eugenic metaphor, defining eugenics as "the science of improving stock whether human or animal." Plecker then embarked on a discussion of eugenics in relation to marriage. "Eugenics may

${ }^{113}$ Plecker, Eugenics in Relation to the New Family, 1. Plecker wrote, "Virginia teachers are specially requested to as.s for the ir quota for older pupils." He also noted that many northern teachers of biology and sociology had requested the pamphlet. 
be wisely applied by the young man or woman when considering marriage," Plecker began. He immediately shifted his emphasis from individual empowerment to a patemalist, authoritarian tone, because "those who have the preservation and improvement of the most valuable race stocks as their chief purpose should guide the thoughts and actions of the young into proper channels." 114

Plecker then retumed to the barnyard imagery of the eugenic metaphor. His examples, like those used at "Fitter Families" exhibitions by the American Eugenics Society, emphasized heredity and race. Saying that eugenics was "based upon the principle that like begets like," Plecker then used white hens mated to a black rooster as a model for racial mixing. ${ }^{115}$ Likening humans to hens, Plecker stated that when hlimans mated, "The black may appear to be bred out of the family, but according to the rule of reversion a black child will appear though both parents seem white and neither be conscious of any black blood on either side." Charles Davenport had already indicated the near impossibility of "reversion to type" in skin color; Plecker completely disregarded Davenport's findings in this exaggeration. ${ }^{116}$ Plecker, therefore, was capitalizing on the common southern mythology of reversion to scare whites into supporting the RIA.

Plecker merged the menace of the feebleminded with the menace of passing and then explained the result in homely imagery. First Plecker asserted that "there is nothing that may be more certainly foreseen than the disastrous results of feeble-minded individuals

\footnotetext{
114 Plecker, Ibid., 4.

115 Plecker, Ibid., 4. The fact that Plecker used a white female and a black male merely underscores his intention to talk about the "worst case sccnario"—at least for southern white males—of interracial marriage among humans, white female/black male.

116Plecker, Ibid., 5. Sec Charles B. Davenport, The Heredity of Skin Co'or in Negro-White Crosses (Washington, D.C.: The Camcgie Institution, 1913), 28-31. Paul Lombardo claims that Powell and Plecker had been wamed about this problem by Franklin Giddings and Edward Grant Conklin. Actually, Giddings and Conklin objected to Cox's belief that in black/u hite "crosses" the "lower" characteristics dominate and cause the progeny to "revert" to the lower type-the doctrine of "Grantism." This is slightly different from a discussion of reversion in skin color between "near whites." Davenport wculd embrace "Grantism" in his 1928 study Race Crossing in Jamaica. By that time, however, most other geneticists no longer adhered to the idca publicly; many criticized Davenport's work as flawed. In any case, Plecker was guilty of both misconstructions. See Franklin Giddings to John Powell, January 3, 1924, Box 56, John Powell Papers; and Lombardo, "Miscegenation, Eugenics, and Racism," 439.
} 
being permitted to marry and bear children," because, "their children are almost sure to be of the same or worse kind." Plecker implied that the feebleminded composed Virginia's so-called mixed-breeds and poor white trash, then blamed these individuals for miscegenation. Citing one county with two or three racially-intermixed families, Plecker said, "These furnish nearly all of the criminals, moonshiners and women of low morals for the county. As other families do not intermarry with them, the only foreign strains introduced are out of wedlock [a symptom of dysgenic taint], and this is all to frequent." Thus, the mixed-race population was, by definition, feebleminded and likely to stay that way. From this analysis, Plecker concluded, "The worst forms of undesirables born amongst us are those when parents are of different races." He then used a final bamyard image to drive the point home. "Stockbreeders have learned that the offspring of greatly different breeds are inferior to either parent, and that it is not wise to perpetuate such strains. This is likewise true with man."117 Borrowing on familiar imagery and example, the eugenic metaphor surely swayed many with its appeal to conventional wisdom.

Plecker concluded this section of the pamphlet with a discussion of how Virginians could prevent "race deterioration" at home, thereby rising in national power. First he championed scrupulous mate selection. "See by careful investigation," Plecker counseled, "that you are not marrying into a family containing members who are hereditarily defective physically, mentally, or morally." If young Virginians did this, Plecker argued, "we may expect in the next generation to have in our State a large body of Virginians strong in body, mind and character, capable of overcoming difficulties at home, and of influencing the Nation to push to a successful finish the reforms necessary to fit us to fill the place as leader of the nations of the world." Virginia would then lead the way to the eugenic utopia. Before Virginia could experience this apotheosis, Virginians had to "suppress the shameful intermixture of the races". Plecker, who in enforcing the RIA targeted women, focused

${ }^{117}$ Plecker, Ibid., 6. It is clear from the crid of the pamphlet that the county to which he refers is either Rockbridge or, more likcly, Amherst, because he decries "negro-Indian-white" intermixture. 
here on men. "Let the young men who read this realize that the future purity of our race is in their keeping, and that the joining of themselves to females of a lower race and fathering children who shall be a curse and a menace to our State and civilization is a crime against society," he preached, calling for a single sexual standard among white Virginians. He presented similar arguments to Virginia's physicians through the pages of the Virginia Medical Semi-Monthly. At least one Virginia physician, Paul Brandon Barringer, felt that Plecker's appeals were not only well advised, but "gentle and persuasive" in their tone. ${ }^{118}$

Plecker presented "Eugenics or Race Deterioration-Which?" before the Augusta County Medical Association in May of 1925.119 The lengthy address congratulated the "leading position" taken by the medical society in holding a symposium on eugenics, then presented mainline eugenic arguments. For eugenics to "secure good results for families, and, through these the State and Nation," Plecker felt that "it is necessary, by education and by law, to prevent the marriage, or illegitimate mating, of feeble-minded, epileptic, and hereditarily insane and criminal individuals and those with serious transmissible diseases and defects or members of the white race with those of any other race." Dr. Plecker cited

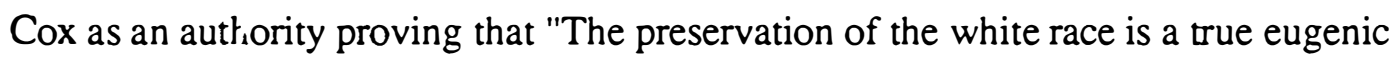
measure...." Like eugenicists everywhere, Plecker emphasized that "Education of the young, in particular, and for this end, of their parents and teachers also, is necessary to secure the best and most positive eugenic results of correct selection in marriage." 120 Quoting from eugenics-popularizer Alfred E. Wiggam, Plecker went on to show how eugenics could lower divorce rates by insuring virtue, lower the incidence of contagious disease by producing people resistant to disease, lower illegitimacy by cultivating race

118 Walter A. Plecker to Dr. Paul Brandon Barringer, April 22, 1925, Box 2, "1915-1925 Correspondence" folder, Barringer Papers. Plecker quiotes Barringer's words back to him. Barringer had sent Plecker a copy of "The American Negro: His Past and Future," which Plecker liked so well that he tried to convince Barringer to have it reprinted. Plecker also mentions in this letter that he is to spcak before Dr. [Donald] Davis's class. Davis taught eugenics at the College of William and Mary.

${ }^{119}$ Walter A. Plecker, "Eugenics or Race Deterioration-Which?" Virginia Medical Semi-Monthly 52 (August 1925): 282-88.

120Plecker, Ibid., 283. 
pride, and preserve racial purity through antimiscegenation law. All this depended upon "a system of propaganda and intensive education, especially in the schools, so to raise the ideals of the general public that it would desire the better things and would apply to our Bureau for facts and advice before entering upon matrimony, and assuming the greatest of all responsibilities, that of raising new citizens."121

Plecker again attacked "mixed-breeds," whom he called the "unfortunate third race created by the sins of the more responsible white, as well as the too-willing blacks," who were "now in the position of being rejected by the whites, while they reject the blacks." He warned that many were seeking to pass over the color line, especially those who claimed Native American lineage. Asserting that, "there are probably no native born Virginia Indians free from negro intermixture," Plecker highlighted the implications for whites. "The saddest feature of this situation is the fact that a considerable number of degenerate white women are giving birth to mulatto children." With a pang of Victorianism, Plecker sputtered, "The facts in the office of the Bureau of Vital Statistics are really too sickening to discuss." Faced with this "sickening" situation, Plecker cried, "This is a time when the practice of ordinary eugenic measures is too slow and too weak." Without adverting to the Sorrelis case, Plecker insisted that "The State must strengthen its present law and enact another to prevent if possible some of the illegitimate intermixture, by making the father responsible" for child support payments. ${ }^{122}$

The significance of Dr. Flecker's eugenic appeal is heightened by the fact that it was made, and then printed alongside, pro-eugenic articles by a Presbyterian minister and none other than Dr. Joseph S. DeJarnette. The Reverend W. E. Davis, of Staunton, Virginia, a town about 35 miles West of Charlottesville, spoke on "The Divine Plan of Racial Integrity." Davis's address resurrected nineteenth-centı!ry arguments derived from Scripture to prove that "Divine revelation accounts for the threefold racial grouping that we 
generally recognize today and specifically testifies to the latest teachings of science that in blood they are one." Despite this unity of "blood," the facts of geographic distribution, the resistance of the "Hebrew nation" to intermarriage, and Christ's incarnation "in a personality, with a genealogy proving racial purity for generations and centuries," proved "a Divine plan for racial purity." 123

DeJamette, picking up on the theme of antimiscegenation, developed the connection between feeblemindedness and "race mixing." DeJamette also used the homely language of the eugenic metaphor. Beginning with the "law of the j..ngle" and "survival of the fittest," DeJamette noted that the "importance of good seed and well bred animals" was obvious to most thinking people. "Alas," he moaned, "it is only in human breeding that the laws of heredity are almost entirely ignored and dysgenics run riot." Dr. DeJamette pointed to the usual suspects-the "insane, epileptics, alcoholics, syphilitics and feebleminded"-in assigning blame for the declining quality of Virginia's citizenry. After a brief lesson in Mendelian genetics that highlighted the "menace of the feebleminded," DeJamette asserted, "I believe we should have an eugenic society in every county and city in the State with a secretary devoting his entire time to securing data as to the dysgenic situations in his territory, keeping records, examining school children as to mentality, and lecturing on eugenics before the students of the high schools." He called for courses in eugenics in all the colleges, to awaken students and teachers to their procreative responsibility. Echoing eugenicists nationwide, DeJamette argued that these most eugenically "desirable classes" were "practically sterilized, especially when compared with the feebleminded and colored races." 124 The situation needed to be rectified if the white race was to survive the flood of color and incompetence.

${ }^{123}$ Reverend W. E. Davis, "The Divine Plan of Racial Integrity," Virginia Medical Semi-Monthly 52 (August 1925), 289-90.

${ }^{124}$ Joseph S. DeJamette, "Eugenics in Relation to the Insane, The Epileptic, the Feeble-Minded and Race Blending," Virginia Medical Semi-Monthly 52 (August 1925): 290-92, quotations 291. 
DeJarnette concluded with a number of suggested solutions to Virginia's eugenic problem. His correctives ranged from the familiar to the fantastic. Segregation occupied a central position. Working directly from Cox's book (upon which he heaped praise), DeJarnette averred that, "Segregation of the races is the only way to keep each race pure." To that end, he also supported "more stringent" immigration laws "admitting only the most desirable of our predominant [Nordic] race" and barring the rest. Parenthood should be "encouraged among those with the best hereditary traits, and discouraged among defectives by segregation and sterilization." His more original and ambitious programs included regulating wages "according to the number of children and the mental quality of parents," establishing the eugenic "Registration of family pedigrees, traits, etc.," and competition among children in crop growing and breeding which "would tend to make them more careful in selecting their own mates in later years." Also, he argued, Mendel's laws should be exhibited at county and state fairs as a constant reminder to all Virginians. Finally, disagreeing with Plecker, DeJarnette stated that "Birth selection and control is the ideal for eugenics." Noting that Virginia's sterilization law was being tested in the courts, he predicted that when affirmed "it will sever the black thread of inheritance, give many segregated people their liberty and save untold suffering, crime and expense in the years to come."125 To convince his auditors, DeJarnette then reprised his poem "Mendel's Law."

Plecker, however, was not finished admonishing the Virginia's physicians. In October he delivered "Racial Improvement," before the annual meeting of the Medical Society of Virginia, and the Virginia Medical Semi-Monthly published the speech in November. Plecker began by appealing to physicians' common sense and professional wisdom. Racial improvement should interest the physician, Plecker argued, "because he has intimate knowledge of the truths brought out, and can discuss intelligently the problem and its remedy." He then launched into a Nordic paean. "This great country would have remained

125DeJarnette, Ibid., 291-92. 
forever dormant had not settlers of a different type come to its shores, representing the best that northern Europe could offer," Plecker said. "America was claimed by the great Nordic race as its final and chiefest possession," and as such was destined for greatness, if racial purity might be maintained.

Plecker identified three threats to racial purity and improvement: blacks, the legacy of the Civil War, and race suicide. The introduction of blacks to America, however, represented "a danger a hundred times greater than the savage Indians with tomahawk and scalping knife," according to Dr. Plecker. Again citing Cox's work, Plecker called for vigilance in guarding racial integrity. Plecker asserted that Virginia, like elsewhere, contained no "pure" Native Americans. To prove this contention, Plecker paraphrased a letter from Charles B. Davenport, in which Davenport asserted that in the only "'Indian' colony I am acquainted with (the so called Shinnecock Indians of Long Island) the amount of negro blood is far greater than that of Indian and white combined. There has probably been in the reservation no pure blooded Indian for thirty years." ${ }^{26}$ After praising the RIA, pleading for strengthening it, and arguing for "raising the standard of either race—white or black—within itself," Plecker documented the dysgenic effects of the Civil War.

Perhaps building on the work of David Starr Jordan and Harvey Earnest Jordan, Plecker noted that during "the war between the states," Virginia and North Carolina lost "40 per cent of their choicest young men, while the other Southern States were not far behind." While the war exerted this dysgenic effect, "the lower fourth, who now produce half of the increase by births, naturally untrustworthy and unfit for duty at the front" worked in safety at the rear and "returned home to breed their kind." Merging cultural and scientific definitions in a manner common among eugenicists, Plecker claimed that as a

126Davenport to Plecker, August 13, 1925, Davenport Papers; Davenport to Plecker, September 26, 1925, Ibid. Plecker wanted to invoke the authority of the Eugenics Record Office and the Carnegie institution in support of his work. Davenport, however, al ways wary of how the Carnegie Institution would react to bad publicity, and warned him away from citing the ERO by name. Davenport to Plecker, October 5, 1925, Ibid. Nevertheless, Davenport and the ERO would remain in contact with Plecker until Davenport's retirement in 1936. 
result of the war, "our noblest young women lived and died without husbands, or wed their social inferiors." In relating this dysgenic dynamic, Plecker revealed his class bias: "social inferiors" were equivalent to genetic inferiors, because social inadequacy was considered a marker and effect of hereditary taint.

Combining "race suicide" - the differential birth rate between the fit and unfit across the nation-to this already bleak picture, Plecker again argued for the usual eugenic interventions. Racial integrity cculd only be insured by repatriation. Race suicide could be prevented by positive and negative eugenics. Plecker argued that "our middle and upper classes must be impressed with a sense of their individual responsibility to set aside their own selfish and indolent desires, and to realize that it is their religious and patriotic duty to do their part in saving their race and country." He advocated four children as the minimum for such families. Negative eugenics should be pursued by the state in the form of "restraint or operative measures"—segregation or sterilization. ${ }^{127}$ Plecker's eugenic stance remained consistent over time. He viewed racial integrity as just one aspect of the eugenically-minded physician's duty.

Believing that they had aroused public opinion to the dysgenic threat of intermarriage, Powell and Plecker began their end game for a revised Racial Integrity Act. Explicit eugenics, in the form of a "family study" of Virginia's "mixed breeds" partially supplanted Cox's book in this final gambit. At the same time, the ASCOA would be distracted by an effort to achieve the South's most stringent segregation law. Despite Powell's repeated assertions that segregation ordinances alone were not enough to protect white civilization, the ASCOA's actions to achieve the so-called Massenburg Public Assemblages Act, would belie his words. So, while eugenics would not disappear, by the 1930s the ASCOA had become a moribund assembly.

\footnotetext{
127Plecker, "Eugenics or Race Deterioration," 490. Plecker argucu for mandatory life imprisonment for criminals "who escape the electric chair" as "an eugenic measure of high value". Life imprisoninent would segregate criminals and keep them from passing on their "taint" to their children.
} 


\section{"The Last Stand" Against Mongrel Virginians}

Plecker and Powell never abandoned Cox's book as their ideological guide, but by 1926 they supplemented Cox's work with a book by sociologist Ivan E. McDougle and the Eugenics Record Office's Arthur H. Estabrook. Mongrel Virginians, as Estabrook and McDougle titled their work, was a study of the "tri-racial" mixed breeds of Virginia's Amherst County. Referred to in the book's subtitle as the "Win Tribe," the pseudonym was really an acronym comprised of the first letters of the three races being mixed, White, Indian, and Negro. Although Powell and Plecker relied on the study's preliminary and final results in their lobbying efforts, Mongrel Virginians represents more than a timely piece of eugenic scholarship that assisted in the passage of the RIA and the battle for its amendment. Viewed against the backdrop of Virginia's more diffuse eugenic mobilization, Mongrel Virginians was the culmination of over 15 years of eugenic theorizing. The book itself came about as a result of the cooperation of local eugenicists with the national eugenicists at the Eugenics Record Office. In a roundabout way, Virginia eugenicists enlisted the aid of the American eugenics movement's most powerful organization in support of the RIA.

Serendipity brought Arthur H. Estabrook to Virginia in time to become the linch-pin linking the national eugenics movement to the RIA and the sterilization act. Estabrook, the ERO's chief field investigator, stumbled upon Amherst County while working on "the Southem Appalachian population problem."128 As a result of contacts with "several men in Virginia," Estabrook became privy to the efforts for both eugenic sterilization and racial integrity. Although he cited "men" in his year-end report, it is almost certain that Ms. Louisa Hubbard, a Virginia-native working as a nurse and social worker in Greensboro, North Carolina, put Estabrook in touch with Virginia eugenicists through her fiance Aubrey

${ }^{128}$ Arthur H. Estabrook to Charles B. Davenport, August 4, 1923, Davenport Papers. This letter is Estabrook's year-end report. 
Strode and his friend Albert Priddy. ${ }^{129}$ Arriving in Virginia in January 1923, Estabrook would become a central player, most often behind the scenes, in Virginia's eugenic mobilization. Not only did he study the results of miscegenation in Virginia, but he also did his share to aid in the passage of the state's eugenic sterilization law.

Estabrook breathed new life into an old idea in the winter of 1923. "I have found quite a bit of data," Estabrook wrote Charles B. Davenport, "about a very interesting group of people near Amherst, Virginia, an inter-mixture of Indian, negro, and white, who have lived in a segregated region for many generations...." Members of the group were known locally as "Ishes," short for "issue" because they lived in a liminal area neither black nor white and "there was discussion as to how they should be registered, black or white." Noting that "Dr. Pretty [sic, he meant Priddy] of the Virginia School for the Feeble Minded knows them," Estabrook reported the presence of "feeblemindedness" in the population. Knowing Davenport's interest in issues of racial inbreeding and outbreeding, Estabrook wrote, "I think this Virginia work would interest you as there is the segregation and the intermarriage and the mental defectiveness." 130

This was not the first time Davenport had heard of the "Ishes." His friend Dr. Harvey Emest Jordan, first suggested performing a eugenic family study based on the inhabitants of Rockbridge and Amherst Counties in 1911. Davenport advised Jordan to attempt a study. Jordan never undertook this work in earnest, however, because he was too overburdened and underfunded in his university position. Davenport, however, never forgot Jordan's 1911 suggestion that someone study the "lost tribe of Indians" that had

${ }^{129}$ Exactly when and why Estabrook came to Virginia remains shrouded in mystery. Paul Lombardo first made this connection. See "Miscegenation, Eugenics, and Racism," 446 note 119; Lombardo, "Three Generations, No Imbeciles: New Light on Buck v. Bell," New York University Law Review 60 (1985): 59. Lombardo details Louisa Hubbard's eugenic sensibilities and her connection to Estabrook in Paul Lombardo, "Eugenic Sterilization in Virginia: Aubrey Strode and the Case of Buck v. Bell (Ph.D. diss., University of Virginia, 1982), 151-52; 195-99.

${ }^{130}$ Arthur H. Estabrook to Charles B. Davenport, January 28, 1923, "Estabrook, Arthur H." folder, Charles Benedict Davenport Papers, American Philosophical Society Library, Philadelphia. [Hereinafter referred to as Davenport Papers.] 
"disappeared" through racial interbreeding. ${ }^{131}$ When Estabrook wrote and noted the high incidence of "feeblemindedness" in an inbred population, a population also characterized by race crossing, he presented Davenport with the perfect eugenic experiment. Davenport might now determine the correlation between feeble-mindedness and race crossing. The presence or absence of such a correlation might answer the question of whether race crossing led to degeneration. Estabrook invited Davenport down for February 5th or 6th, and approached Dr. Ivan McDougle of Sweet Briar College about assistance.

Davenport, always efficient, combined three tasks in the trip to Virginia. He scouted out the "Ishes," he spoke before a sociology class at Sweet Briar College, and he stayed with Professor and Mrs. Ivan E. McDougle. ${ }^{132}$ The visit assured him of the suitability of the "material" for study, and provided him with a chance to develop a base of operations at Sweet Briar College. The choice of the women's college, over that of the University of Virginia, was dictated by geography and gender. Sweet Briar was closer to the study site than the university, an important consideration in an era before the widespread paving of roads. Moreover, since Sweet Briar was a women's college, its students offered a pool of potential field workers that Virginia's male population lacked. ${ }^{133}$ Finally, it offered Davenport the opportunity of turning the minds of sociology students away from environment and toward heredity as the causal factor in social malaise. Either way, it offered him the chance to recruit for the ERO's summer classes.

Davenport was so favorably impressed by what he saw on his visit that he wrote McDougle, "The Eugenics Record Office will be glad to cooperate with you as far as in its power in the proposed study of the Ishes [sic]." Davenport offered the services of Estabrook, the ERO's chief field worker. Given that McDougle was a sociologist, this

${ }^{131}$ See Chapter 2, p. 154, above. The following narrative is reconstructed from correspondence between Davenport and McDougle, Davenport and Estabrook, and Davenport and Plccker that resides in the Davenport Papers.

${ }^{132}$ Charles B. Davenport to Ivan E. McDuugle, February 6, 1923; and McDougle to Davenport, March 3, 1923; Davenport to McDougle, March 5, 1923, "McDougle, Ivan" folder, Davenport Papers.

${ }^{133}$ See note 55 , above. 
offer may seem out of character. Davenport, however, had formed a decided opinion of McDougle. As he wrote later, "I felt that he took a very progressive attitude (may I say for a sociologist!); especially did he entertain the hypothesis that in this mountain segregate there were hereditary factors, as well as environmental, that were responsible for the end result." 134 This ideological consonance convinced Davenport that the study could proceed. It also reveals the bias inherent in his work; always touchy about criticism, Davenport tended to surround himself with sympathizers. ${ }^{135}$

For his part, McDougle worked hard to inculcate mainline eugenic viewpoints in his classes and fieldworkers. In preparing his students to collect data on the "Ishes," McDougle used Davenport's The Hill Folk and Nam Family studies. ${ }^{136}$ The result revealed the consonance between Davenport and McDougle's hereditarianism. McDougle accepted Davenport's offer of Estabrook's services, remarking, "With my twenty college majors trained for the field work we ought to complete the census of the Isshy group in three or four weeks."

Estabrook had already continued working with the "Ishes,". administering intelligence tests. Perhaps not surprisingly given eugenicists' valorization of the "pioneer spirit," he found that "the better ones of these people have gone up into the top of the Blue Ridge Mountains."137 He noted that McDougle had made plans for further field work, and accepted Davenport's charge to return in May to "work up" the data collected. By August, Estabrook could report that "Approximately five hundred members of this Amherst group have been located, traced to a common head, and studied," preliminary findings showed

${ }^{134}$ Charles B. Davenport to Professor F. Stuart Chapin, January 25, 1926, "McDougle, Ivan" folder, Davenport Papers. Davenport was writing in support of McDougle's application for a Social Science Research Council Fellowship.

135Oscar Riddle, "Charles Benedict Davenport 1866-1944," in Biographical Memoirs 25 (Washington, D.C.: National Academy of Sciences, 1948), 87-89.

${ }^{136}$ McDougle to Davenport, September 6, 1923, Ibid. Davenport sent McDougle copies of these studies "with the compliments of the Eugenics Record Office, in view of your cooperation and with a desire to help along your work." Davenport to McDougle, September 12, 1923, Ibid.

${ }^{137}$ Arthur H. Estabrook to Davenport, February 10, 1923, Davenport Papers. 
"much illegitimacy and feeble-mindedness have been found and a low social status present in practically all the huts and log cabins where these folk live."138 Estabrook held fast to these early conclusions, which characterize Mongrel Virginians. He would work on the "Win tribe" sporadically for the next three years.

Estabrook's 1924 annual report presented firmer conclusions. The "social segregation" of the "Isshies" was "caused by the 'dark skin' of the crosses," and their geographic isolation which "caused much interbreeding." He determined that, "The intellectual level of the group is below the average for the whites and apparently about the same as the negro." This poor performance on the Binet-Simon tests was "no doubt due to the preponderance of Indian and negro blood." His final estimation of this group of 550 Virginians was that, "Only a few can be said to be socially adequate; the great majority are a social and biological problem not only because of their low mental level but because of the presence of the negro blood in a mixed Indian-white race which claims for itself all the rights and privileges of the Indian." Estabrook, too, in the summer after the passage of the RIA, worried about the "passing" of "Isshies" as white. He concluded that, "These groups represent a definite problem to society" because of mental defect and miscegenation. He advocated further study of race mixing so that "data may be available upon which to build proper marriage laws for matings between races."139 Unlike Plecker, Estabrook did not seem to adhere to the "one drop" rule of racial "pollution."

Following the Sorrells debacle, Plecker began to pester Davenport and Estabrook for the final report on the "Isshies." Writing to the Carnegie Institution in December, he noted, "I am very anxious to secure a copy [of Estabrook's report] as soon as it is out." Fishing for more data to buttress the attempt to revise the law, he asked, "Is there any likelihood also of having a survey made of other colonies in Virginia claiming to be of Indian

\footnotetext{
${ }^{138}$ Arthur H. Estabrook to Davenport, August 4, 1923, Ibid.; Ivan E. McDougle to Davenport, September 6, 1923, Ibid.

${ }^{139}$ Estabrook to Davenport, July 10, 1924, Ibid.
} 
descent?"140 Davenport, always looking to subsidize ERO activities, told Plecker the report could not be issued until respondents' names were changed; he then inquired if the State of Virginia would underwrite publication. Plecker, equally strapped for cash, responded evasively, "As there are not many persons who are deeply interested in the publication of the report, perhaps ten or twelve typewritten carbon copies on thin white paper might be made and be sufficient." He also came to his larger concern, "The report would not be of much value to us unless the names were included," because without names the report could not be used to enforce the RIA.

Uncertain about Plecker's motives, Davenport sought Estabrook's advice. Estabrook replied in no uncertain terms. Plecker wanted the data, Estabrook knew, "to use in the various cases now appearing in the Virginia courts". Providing the data to Plecker "would involve us in a great deal of trouble and I fear publicity that would come back to hurt us." A better judge of Virginia's political winds than Plecker, Powell, and Cox, Estabrook noted that, "The White America book and the new society started in Richmond 'for the purity of the white race' is egging Dr. Plecker on, and while he says this is only 'Virginia's attempt to settle the race problem,' many people in Virginia feel that he is not attacking the problem correctly." 141 Davenport, always wary of drawing bad publicity to the ERO for fear that Carnegie would cut its funding, hid behind the spurious excuse that Estabrook obtained the information in confidence. "Of course," Davenport regretfully wrote, "we desire to be of use in the advancement of society [through enforcement of racial integrity law] but if the impression gets around that our promise of confidence is not to be relied upon that would be an end to our power to collect data". 142 Davenport's genteel tone did

${ }^{140}$ Walter A. Plecker to Carnegie Institution, December 18, 1924, Ibid.

${ }^{141}$ Estabrook to Davenport, January 17, 1925, Ibid. Davenport, as was his habit, drew a line next to the portion of Estabrook's letter regarding bad publicity, indicating his alarm. He had no problem with the RIA or the White America society. This is apparent from his letter about the Shinnecock Indians quoted above. Estabrook, too, felt that "The matter of the data being confidential would not enter into this so much if Dr. Plecker did not wish to use this data in court...." He also had no problem with the RIA, just Plecker's methods.

${ }^{142}$ Davenport to Plecker, January 19, 1925, Ibid. 
not penetrate the thick armor of Plecker's determination. Instead, Plecker continued to hound Davenport for information and advice. ${ }^{143}$

Davenport, for his part, attempted to shield his professional position, yet aid Plecker in an endeavor that comported with Davenport's eugenic world-view. ${ }^{144}$ One of Davenport's letters, sent after a series of Plecker's letters bemoaning Native American resistance to the RIA , captures Davenport's ambivalence. "I am in some doubt whether the Carnegie Instittition of Washington ought to be drawn into the matter of the administration of the law in the State of Virginia," Davenport began. "As a student of eugenics I am immensely interested in the racial integrity law of Virginia but must not participate in the carrying out of that law." Nevertheless in the very next sentence Davenport added advice about how to calculate racial intermixture, and his next paragraph suggested changing Virginia's inheritance law to deny the child of a "man with colored blood" and a white woman from claiming land. Regular Plecker-Davenport correspondence would continue in this vein through $1928 .{ }^{145}$

\footnotetext{
${ }^{143}$ Plecker fired off such a rapid volley of letters, Davenport did not have time to respond to one before the next arrived. See Plecker to Davenport, August 17, August 19, and September 21, 1925, Daveriport Papers.

${ }^{144}$ The voluminous Plecker-Davenport correspondence is replete with examples of this "cat and mouse" parley. Individual letters are too numerous to list and the reader is referred to the "Plecker, W. A." folder in the Davenport Papers.

${ }^{145}$ Davenport had an abiding intercst in antimiscegenation legislation as it pertained to eugenics. In 1912 he published "State Laws Limiting Marriage Selection: Examined in the Light of Eugenics," Eugenics Record Office Bulletin 9 (Cold Spring Harbor, NY: Eugenics Record Office, 1913). This survey presented the eugenic need for laws banning consanguineous, miscegenetic, and discased marriages. Despite his support for Plecker's cause he repeatedly warned Plecker not to make statements that would involve the ERO, and through it the Camegie Irstitution. See Daverport to Plecker, October 5, 1925; and Davenport to Plecker December 23, 1925 ("It is not appiupriate for a Deparunent of the Carnegie Institution of Washington to take part in a matter which has become one of politics and probably one in which there is a difference of opinion in any state. Personally, I am very much interested in your attempts to keep pure the white population of Virginia."); and Davenport to Piecker, November 22, 1928 ("I regret that in my position as an investigator I am stopped from entering into such eugcnical movements or undertakings.") Davenport Papers. Davenport raised similar objections throughout his career and 'with other people; they do not represent merely an attempt to discourage Plecker. Davenport was afraid that, should the ERO be invoked in a political dispute, politicians might threaten revocation of the Carnegie Institution's federal charter in reprisal.
} 
Estabrook and McDougle's Mongrel Virginians finally appeared in 1926. The book is a classic example of an extended eugenic family study. ${ }^{146}$ Just over 200 pages long, the book concluded,

Unquestionably the people covered by this study represent an ever increasing social problem in the South. Social consciousness has only begun to be awakened. Amidst the furor of newspaper and pamphlet publicity on miscegenation which has appeared since the passage of the Virginia Racial Integrity Law of 1924 this study is presented not as theory or as representing a prejudiced point of view but as a careful summary of the facts of history. ${ }^{147}$

Estabrook and McDougle tried to reclaim their position as dispassionate and scientific observers of the "race problem" from Powell, Plecker, Cox, and their ilk. Despite Estabrook's distaste for Plecker's methods, his diagnosis of the problem remained identical to the ASCOA's. Moreover, he and McDougle backed the goal of racial integrity enough to print the text of the RIA as an appendix. Estabrook and Davenport's actions speak to the heterogeneity of the eugenics movement. Ideologically, eugenics remained flexible enough to gather true believers, parvenus, and opportunists around the same table, fighting for the same goals, albeit for different reasons.

The ASCOA's tactics jeopardized the solidarity of Virginia's eugenics movement as well. Beginning in March of 1925, the ASCOA began militating for the enactment of a stringent segregation law that would require the races to be separated in public assemblies. ${ }^{148}$ Grace Copeland, the wife of Newport News newspaper editor Walter Scott Copeland was the spark that ignited the tinder of racial animosity. After his wife objected to sitting near blacks while attending a production at the Hampton Institute's auditorium, Walter Scott Copeland charged that the famed black institution taught and practiced "socia]

\footnotetext{
${ }^{146}$ For other examples, as well as an insightful essay analyzing the function these studies played within the eugenics movement and popular culture, see Nicole Fiann Rafter, White Trash. The Eugenic Family Studies, 1877-1919 (Boston: Northeastern I Iniversity Press, 1988).

${ }^{147}$ Arthur H. Estabrook and Ivan E. McDougle, Mongrel Virginians: The WIN Tribe (Baltimore: Williams \& Wilkins Company, 1926).

${ }^{148}$ The history of the so-called Massenburg Act is treated exhaustively in Smith, "Managing White Supremacy," Chapter Three; Sherman, "The Last Stand," 82--85; Sherman, "The Teachings at Hampton Institute: Social Equality, Racial Integrity, and the Virginia Public Assemblage Act of 1926," Virginia Magazine of History and Biography 95 (July i987): 281.
} 
equality" between the races. The issue erupted into a firestorm of protest from both sides of the racial divide. Powell and the ASCOA rapidly joined forces with Copeland who, ironically, was an erstwhile friend and supporter of black education and the Hampton Institute. ${ }^{149}$ Noting that Copeland had been "regarded by colored citizens as a friend of the race," the black press puzzled over the source of his actions. His wife made clear the origins of her protest in a private letter written to Governor E. Lee Trinkle. Grace Copeland, childhood friend of John Powell, told Trinkle that she had been oblivious to the danger of racial mixing until Powell taught her a true appreciation for "the seriousness of the negro problem in America." 150

Powell and Cox again relied upon eugenical arguments against interracial contact as they lobbied for the bill. This time, however, the ASCOA's campaign elicited a mixed response. Many whites and blacks felt that this measure was unnecessary; after the recent passage of the RIA, they perceived the new bill as overkill. People on both sides of the color line-from local black newspapers like the Norfolk Journal and Guide to the NAACP's national magazine The Crisis, from the Richmond Times-Dispatch to Governor E. Lee Trinkle's office-decried the ASCOA for inciting racial animosity. A large group of white Virginians, meeting in Richmond's St. Paul's Episcopal Church, led by the prominent Reverend Beverly D. Tucker, passed resolutions opposing the bill. This group concluded that while they were "desirous of preserving white racial purity and white social supremacy," they did not "wish to hurt or humiliate the negro by unnecessarily harsh legislation".151 Governor Trinkle, no enemy of eugenics or segregation, warned, "we are getting along splendidly with the colored people in Virginia and we want to meet this situation in a way that will tend to solve the problem with as little enmity between the races as possible." The white Norfolk Virginian-Pilot argued for the easiest solution; rather than

${ }^{149}$ Smith, "Managing White Supremacy," 144.

${ }^{150}$ Smith, "Managing White Supremacy," 147

151"Resolutions Oppose Pending Racial Bills," Richmond Times-Dispatch, February 17, 1926, 13; "The Leading White Citizens Make Protest," Richmond Planet, February 20, 1926, 1. 
a bill barring mixed seating, "why do not these white people who object to mixed seating stay away?" 152 Eleven days later, on November 27, 1925, three hundred members of the Hampton ASCOA called on their delegate, Alvin Massenburg, to sponsor a bill banning interracial mixing at public assemblages. Massenburg, a first-term delegate, acquiesced and introduced the "Massenburg Bill." Thanks to its eugenic underpinnings, the bill would, in the words of one historian, "define segregation in Virginia for four decades to come." 153

In February of 1926, John Powell poured oil on the smoldering fire by releasing his thirteen-part series "The Last Stand" through the Richmond Times-Dispatch. ${ }^{154}$ Calculated to draw attention, the articles sought to pressure legislators, who were considering amendments to the RIA alongside the Massenburg Bill. Cox, Plecker, and Powell had created a revision to the RIA that attempted, through a sleight of hand, to cinch the loophole created by the Pocahontas clause. ${ }^{155}$ Citing Cox, Estabrook and McDougle, Powell's articles relied on unsubstantiated "case studies" that purported to demonstrate the deleterious effects of miscegenation brought about by interracial contact. Powell's alarmist tone, coupled with his insistence on the necessity of the Massenburg Act, alienated many Virginians. In a lengthy screed, I. F. Love stated that the bills, "unnecessarily insult, and irritate the best negroes among us, put all non-white nations in the same category, and, chief of all, advertise on their faces both the ill-manners and the shame of Virginia

152See Smith, Ibid., particularly 148-149 (The Crisis), 155 (Norfolk Journal and Guide), and 157 (Trinkle quotation), 158 (Norfolk Virginian-Pilot quotation); and 160.

${ }^{153}$ Smith, Ibid., 159.

${ }^{154}$ The articles ran between February 16 and March 2, 1926.

${ }^{155}$ See "Says Integrity Bill Is Not Harsh," Richmond Times-Dispatch, February 21, 1926, 18. The amendment proposed to increase the allowable amount of "Indian" blood to one-eighth, but restricted the definition of white to those who descended from Native American/white marriages prior to 1620, i.e. to the lineal descendants of John Rolfe and Pocahontas. The law took away with one hand what it gave with the other. It also ignored two other important Native American/white marriages that occurred in 1644 and 1684. No one was fooled. The Richmond News-Leader ran two articles that reflect the popular outrage. "Integrity Act Affects 20,000 Whites, Claim," February 8, 1926; and "Bill Brands '63 First Families' of VA. 'Colored'," February 9, 1926. See Smith, "Managing White Supremacy," 164. 
whites."156 State senators, one of whom took umbrage at Powell's characterization of Virginia as "a state fast becoming mongrelized," tabled the revised racial integrity act by a vote of twenty to nine. The Massenburg Bill, however, passed the House of Delegat€s and became law without the signature of newly elected Governor Harry Flood Byrd. ${ }^{157}$

Powell, Plecker, and Cox managed to polarize opinion among white Virginians. Their overheated rhetoric and hyper-thyroid commitment to their version of racial eugenics drove away many erstwhile supporters. The net result was to shatter the potential for a unified "mass" eugenics movement comprised of all elite Virginians. Virginians would not shy away from eugenics, or continuing the enforcement of the sterilization and racial integrity laws. Instead, they would opt for more diffuse forms of organization, and less public modes of enforcement. Winning the battle for the Massenburg Act ensured that Plecker, Powell, and Cox could not assume leadership of a unified eugenics movement based on white supremacy. Instead, the eugenics movement in Virginia fractured into various smaller cells arrayed along a spectrum from mainline racial eugenics to the non- or a-racial form of eugenics that would come to be known, after 1930, as reform eugenics.

\section{Unable to Operate Harmoniously: Faction in the Ranks}

Correspondence between eugenicist-members of the Virginia Academy of Sciences and between Dr. Harvey Ernest Jordan and Leon Whitney, executive secretary of the American Eugenics Society (AES), reveals the extent to which Plecker, Powell, and Cox managed to marginalize themselves. Although the scientific community failed to mount any damning condemnation of the ASCOA triumvirate, the men lost their claim to scientific authority

156I. F. Love, "'The Last Stand'," Richmond Times-Dispatch, February 21, 1926, 7. Sherman, "The Last Stand," 87. Many other editorials essentially supported the bills, but said they did not go far enough and added suggestions for laws punishing illicit interracial sex and fathers of "illegitimate" interracial birth. See Mary Mabane, "An American Problem" and R. Cary Montague, "A Reäl Remedy," Richmond TimesDispatch, February 24, 1926, 6; and W. G. Richardson, "Evading the Issue," Richmond Times-Dispatch, February 28, 1926, 7; Mrs. R. J. Owen, "From a 'Grandma'," Richmond Times-Dispatch, March 1, 1926, 6.

${ }^{157}$ Sherman, "The Last Stand," 84, 87; Smith, "Managing White Supremacy," 164-65, 171. 
within Virginia's scientific community. Nevertheless, the inability of the VAS to articulate its objections underscores the power of University of Virginia eugenicists in shaping Virginia's culture of segregation. Ivey Lewis and Harvey Jordan effectively colluded to keep the VAS from addressing eugenics in public, which would have undermined the salience of the RIA's racial justification in the eyes of lay people. Instead, Lewis and Jordan squelched this effort, leaving the silence to imply to the general population that all Virginia's prominent white scientists condoned the actions of the ASCOA.

As alluded to in Chapter 4, William and Mary eugenicist Donald Davis collaborated with faculty members from the Medical College of Virginia (MCV) in leading the charge against the scientifically specious claims made by Powell, Plecker, and Cox. In January 1925, Dr. E. C. L. Miller, Dr. J. Shelton Horsley, and another Dr. Ryland of MCV formed a committee to "attend the meeting of the committee on race relations" that was convening in Richmond. The scientists hoped to defuse the tensions engendered by Plecker and Powell's actions in the wake of Judge Holt's ruling in the Sorrels case. Miller told Davis that, "we listen to both sides and at the end calmly and dispassionately suggest that rather than act hurredly [sic] and perhaps make matters worse instead of better that the [committee on racial relations] recommend to the governor the appointment of a fair minded and judicial committee...to study the whole problem and bring in a report for the next legislature." The obvious aim of this committee of academic physicians and scientists was to wrest the debate from the crucible of public opinion, and quench the inflammatory activities of Dr. Plecker, John Powell, and Earnest Cox by undermining their claims to scientific authority. None of these scientists disagreed with the RIA; they objected to the tactics of the ASCOA. Miller wrote, "Dr. Horsley [wants] to say something about the desirability of a scientific attitude in the matter, you something about the biology, and then I think [Dr. Ryland] wants to suggest the commission plan." By establishing their credentials and acting as calm, deliberate scientists, these men hoped to capture attention, 
quell anger among the state's people of color, and quietly let the matter die. Miller averred that "at present the com[mittee on race relacions] is in a quandary and would be glad of so easy a way of escape."158 Angered by the imbroglio incited in the name of eugenics, Miller and his associates hoped to reclaim the field for science.

In the following months, Davis attempted to take this effort to an even broader scientific audience, the Virginia Academy of Science. Davis had been instrumental in the founding of the Academy just two years earlier; Ivey Lewis had been its first president in 1923. Beginning in March, Davis began attempting to organize a symposium on eugenics to be held at the Academy's annual meeting. "I have been directed, rather informally," he told the University of Virginia's George Ferguson, "to arrange to have a symposium at the May meeting of the Academy of Science on the subject of human genetics with special reference to Virginia problems." Davis's conscious avoidance of the word eugenics underscored his diplomatic tact. "The idea is to have as many as possible of the science teachers from the high schools of the State present and to set forth the present status of genetics in its application to our racial problems in the State." Davis did not deny that genetics could explain the race problem, he merely implied that, as invoked by the ASCOA, more heat than light was being shed on the problem." Davis asked Ferguson for "a comparison of the negro and white races (Indians also if information is available) as to the mental traits and capabilities." Knowing Ferguson's scholarship, he would only have affirmed the position that differences between the races existed, and that whites were superior to the other groups. Ferguson's status as a "dispassionate" scholar, however, had not been compromised in the flap over the Sorrels case. Davis closed by asking if Robert Bean "could give us anything on the physical comparison of the races? I am thinking of these comparisons as a reasonable basis for differential treatment of the races in the State. We

${ }^{158}$ E. C. L. Miller to Donald Davis, January 28, (1925?), "Sex Education in College-American Eugenics Society" folder, Box 5, Davis Papers, Special Collections, Swem Mcmorial Library, College of William and Mary, Williamsburg. [Hereinafter referred to as Davis Papers.] 
should have a proper foundation, I think, and a general understanding of the problem, especially in view of the movement of the Anglo-Saxon League."159 Clearly the effort was not to undercut the RIA, merely to usurp the scientific authority from the ASCOA and place it on a more "reasonable" and scientific basis.

Ferguson agreed to give a talk on racial differences in intelligence and concurred that Bean should present on physical differences between the races. "In view of your mention of the Anglo Saxon League," Ferguson added, "I hope you will arrange a paper on the Nordics from a scientific rather than the present enthusiastic point of view."160 In contemplating Davis's proposal Robert Bean mused, "A symposium on Eugenics sounds interesting, but who would sympose? A demonstration that the Nordic is a myth, more or less, might be worth while, or something about the Negro." Bean continued, "I would be glad to contribute something on either subject or on both if desired, although I would not like to monopolize the time. Whatever we do we should avoid any Madison Grant or Stoddard stuff. Make it truly scientific, and yet of interest to the public, and it may be worth while." 161 Bean offered to present a paper on the anatomical differences between the races' intemal organs. As will be recalled from Chapter 3, Bean's conclusions buttressed white supremacy and remained racist to the core. His demurrer about Nordics split a rather fine hair: while he agreed with his mentor Ales Hrdlicka that no "pure" Nordic race existed, he would, in his book The Races of Man, written seven years after this exchange, recreate a racial taxonomy that placed Nordics atop the white race, which surmounted all others. ${ }^{162}$ Never doubting white supremacy, Ferguson, Bean, and the others again objected to what they perceived as the abuse of anthropological, psychological, and biological science by the ASCOA. Eugenics promoted by active

${ }^{159}$ Donald W. Davis to George O. Ferguson, March 6, 1925, Ibid.

${ }^{160}$ George O. Ferguson to Donald W. Davis, March 10, 1925, Ibid.

${ }^{161}$ Robert Benett Bean to Donald W. Davis, March 30, 1925, Ibid.

162Robert Bennett Bean, The Races of Man: Differentiation and Dispersal of Man (New York: The University Society, Inc., 1932), 86. 
scientists was fine; propounded by dilettantes it was propaganda. What emerges from this correspondence is a turf war, not a dispute over the scientific rectitude of white supremacy or the RIA.

Davis also sought to enlist the aid of nationally prominent eugenicists. He approached the ERO's Arthur H. Estabrook-whose data he felt the ASCOA abused-and Henry Herbert Goddard, father of eugenic psychometrics and the "menace of the feebleminded." On March 6, Davis wrote to Estabrook to enlist his support against the ASCOA triumvirate. "My idea is that we shall have one paper to present the elementary facts of heredity, something in the manner of the first chapter in Davenport's Heredity in Relation to Eugenics," Davis began, "followed by a paper perhaps on the characteristics of the negro and the Indian contrasted with those of the white race; a paper dealing with inheritance of feeble and anti-social traits, etc." 163 Davis did not object to the RIA or its eugenic underpinnings. What angered him and others were the "unscientific" claims made by the ASCOA. Estabrook offered to "read a paper on the biological and sociological problems in connection with the negro-indian-white crosses in the state," but cautioned that, "Outside of that, little specific field work in eugenics has been done in the state." On a more hopeful note, Estabrook suggested, "The recent sterilization law and its test case might be of interest to the group," and he suggested that, "Professor Wilson H. Gee of the University at Charlottesville...might be able to add a good bit and has an eugenic viewpoint in his thinking." 164

In approaching Goddard, Davis again made clear that scientists objected to the ASCOA, not eugenics. Recounting his desire to arrange a symposium before the VAS and many high school teachers, Davis noted, "through [the teachers] we hope to spread throughout the State quite widely information bearing on these problems which are now being agitated under the leadership of the Anglo Saxon League." Davis and the others wanted the 
students to defend white supremacy from a thoroughly scientific standpoint, not one tinged with the "emotion" evinced by the ASCOA. Goddard, Davis averred, "could contribute very largely to this symposium dealing with the description and inheritance of feeblemindedness and other traits. Of course, application to the treatment of these classes in the schools and in other institutions will be valuable." Goddard, unfortunately, could not attend because of the press of work. ${ }^{165}$

Notwithstanding all these careful preparations, this symposium would never occur. ${ }^{166}$ Davis found himself unable to get it slated on the schedule for the VAS meeting. Unbeknownst to Davis, Harvey Jordan and Ivey Lewis worked together to block its adoption. More thoroughly in league with the ASCOA than the others, these men let their politics and prejudice dictate their science even more than usual. Two years later, as racial tensions began to rise again and just following the Supreme Court's ruling in Buck, Davis attempted to have the newly appointed American Eugenics Society's Committee on Education for Virginia - on which he sat with Lewis and Horsley under Jordan's chairmanship_address the VAS. Jordan replied, "After conference with Dr. Lewis, I have decided that the time is not yet quite opportune for allocation of any considerable part of the program of the annual meeting of the VAS to the subject of eugenics....However, since all members of the State Committee will probably be at the meeting at William and Mary in May, I may want to call a meeting at that time for a brief consideration of future policy."167 Lewis and Jordan had not lost their enthusiasm for eugenics, racial purity, or the ASCOA. They merely understood the political climate and sought simultaneously to shield both their scientific reputations and their political agenda from censure.

165Donald W. Davis to Henry Herbert Goddard, March 7, 1925; and Henry Herbert Goddard to Donald W. Davis, March 15, 1925, Ibid. This correspondence reveals that the men were longstanding friends.

${ }^{166}$ See Donald W. Davis to Gcorge O. Ferguson, March 25, 1925, Ibid.

${ }^{167}$ Harvey Emest Jordan to Donald W. Davis, February 15, 1928; and Donald W. Davis to Harvey Emest Jordan, July 19, 1927 and Fcbruary 11, 1928 
As Jordan attempted to organize the AES committee, he encountered the backlash created by the ASCOA triumvirate. The AES asked Jordan to nominate three men to join him on the committee. Jordan suggested Ivey Foreman Lewis and two notable Richmonders: Reverend Beverly D. Tucker and surgeon J. Shelton Horsley. Lewis accepted immediately. Tucker and Horsley declined, but Horsley later reconsidered. Understanding Powell, Plecker, and Cox's role in the RIA debacle illuminates the reasons these men resisted joining the organization, and why Davis became Jordan's second choice.

Reverend Tucker, the minister of the powerful St. Paul's Episcopal Church, who organized a petition against the Massenburg Act and the revised RIA, politely declined the offer to join the committee. He stated, "I am already a member of so many committees and find that my membership is of necessity merely nominal, and, therefore, I do not think that at this time I ought to extend the number, inasmuch as I can not render helpful service thereby." Tucker's labored prose quite likely veiled deeper grounds for objection. During the furor between the Sorrells decision and the Massenburg Bill, Tucker came to oppose the ASCOA. He even testified against the Massenburg Bill before the state Senate. ${ }^{168}$ [need to get Tucker's speech and see what he said] Tucker, who was a close associate of University of Virginia eugenicist Ivey Foreman Lewis, felt no qualms about eugenics. Jordan's nomination reinforces this conclusion. Tucker objected to the character of the program put forward by the ASCOA, not its eugenic underpinnings. So, his rather strained excuse for declining membership on the AES committee, while certainly based in fact, also represented his scorn for Powell, Cox, and Plecker.

That concern about association with the ASCOA swayed these men becomes even more apparent when one considers the actions of Dr. J. Shelton Horsley. At the time, Dr. Horsley was chief of staff at St. Elizabeth's Hospital, perhaps the most prominent hospital

${ }^{168}$ Sherman, "The Last Stand," 84. 
South of Washington, D.C. ${ }^{169}$ Doctor Horsley, who had been trained by Paul Brandon

Barringer at the University of Virginia and Dr. Hunter McGuire at St. Elizabeth's, held strong hereditarian and eugenic convictions. ${ }^{170} \mathrm{He}$, too, however, objected to the brand of eugenics pedaled by the ASCOA. So, when first approached by the AES, he declined to serve on the education committee. Alerted to the fact that his nomination came from Dr. Jordan, Horsley reconsidered and wrote, "I did not understand that my friend, Dr. H. E. Jordan of the University of Virginia, was chairman of the Virginia Section of the American Eugenics Society." This realization changed things for Horsley. Unlike Powell, Plecker, and Cox, whose status as scientists and racial theorists Horsley questioned, Jordan was an eminent scientist, who had managed to stay above the RIA fray. Horsley wrote, "I feel that if he is much interested in this [the AES] it must be a good cause, and I will be glad to accept the appointment as indicated on the Virginia Committee." Doctor Jordan's reputation rehabilitated active participation in eugenical organization for Horsley. ${ }^{171}$

Jordan's views, however, remained nearly identical to those of Plecker, Powell, and Cox. The crucial difference, and this was a distinction shared by most of the academic eugenicists in Virginia, was that Jordan possessed a finely calibrated political sense. He understood that eugenics could achieve more through quiet education of those destined for powerful positions, than by Powell's muckraking. Correspondence between Executive

${ }^{169}$ The facility had been founded and operated by Dr. Hunter McGuire, discussed at the opening of this chapter. John Powcll had run afoul of McGuire's son, Dr. Stuart McGuire, in 1924. Powell accused a professor at the Medical College of Virginia (MCV), of making untoward statements about interracial marriage. McGuire, who was president of MCV, denied the allegations when confronted by Powell. Despite the resignation of the professor in question, Powell continucd to badger McGuire, earning his enmity. John Powell to Dr. Stuart McGuire, January 1, 1925; McGuire to Powell, January 9, 1925, John Powell Papers.

170 In 1925 he joined the AES at the sustaining membership level, contributing the large sum of $\$ 10.00$. See list in "American Eugenics Society Membership Campaign, 1925" folder, American Eugenics Society Papers, American Philosophical Society Library, Philadelphia. [Hereinafter referred to as AES Papers.]

${ }^{171}$ During the ill-fated 1930 membership effort, Horsley nominated four prominent Richmonders, including President W. G. Sanger of the Medical College of Virginia, for membership in the organization. "1930 S-Z by State" folder, AES Papers. The other three men nominated were John M. Miller of First Merchant's National Bank, and Dr. Douglas S. Freeman and Mr. John Stewart Bryan of the Richmond News Leader. 
Secretary Leon Whitney of the AES and Jordan in late 1927 reveals just this political savvy. Whitney suggested putting Dr. Plecker on the education committee because, "Dr. Plecker seems to be publishing a good many useful eugenics booklets from time to time and he might be a very valuable man for you." Realizing that, "Perhaps there is some reason that you have for not having included him before," Whitney emphasized that, "I am merely suggesting his name."172

Doctor Jordan's response enumerated his various concerns about Plecker. Noting that he intended to add two more members to the four-man panel, one of whom would be a woman, Jordan then spelled out why Plecker should not be included on the committee. "In conversation with Dr. Horsley last summer I suggested that we add Dr. Plecker. I have followed Dr. Plecker's work and am in entire sympathy with it." Moreover, Jordan stated, "I am a member of the Anglo-Saxon Club of America of which Dr. Plecker is one of the leaders." Notwithstanding his personal convictions, however, Jordan clearly understood the hazards posed by a loose cannon like Dr. Plecker. "In some of his work," Jordan continued, "Dr. Plecker has run afoul of Dr. Horsley's brother-in-law, a Judge in one of the Southem Districts of Virginia." The judge to whom Jordan alluded was none other than Judge Henry W. Holt, the jurist with whom Plecker had battled so publicly over the Atha Sorrells case. Mincing no words. Jordan remarked, "I fear that we would not be able to operate harmoniously with Dr. Plecker and Dr. Horsley on the same Committee, and of the two I much prefer Dr. Horsley." Horsley was a man of prominence, sage judgment, and science-he published regularly in Virginia's medical journal and was a recognized surgical authority throughout the South. ${ }^{173}$

Jordan's objections to open association with Plecker ran deeper, however. He believed that "Dr. Plecker's membership on this Committee would affiliate us rather more ciosely than I think desirable at present, with the race purity problem of the Anglo-Saxon clubs."

${ }^{172}$ Leon F. Whitney to Harvey Ernest Jordan, December 7, 1927, "Jordan, H. E." folder, AES Papers.

${ }^{173}$ Harvey Ernest Jordan to Leon F. Whitney, December 13, 1927, AES Papers. 
Jordan remarked that he was "fully aware" that "that race purity is a eugenics problem," but he believed that "at this time we would only hurt our best interests by having anything directly to do with racial problems as they concern negro-white relationships." Keenly aware of the animosity stirred up by Plecker and Powell, Jordan felt it best to insulate the AES effort from any charges of collusion with the ASCOA. As Jordan put it, "My only motive is to serve the cause of eugenics, but for the present I am of the opinion that this can best be done in Virginia by steering clear of racial questions." 174 Whitney deferred to Jordan's judgment, acknowledging that in the choice of leaders, "we also have to take everything into consideration." Plecker's enthusiasm for eugenics was not enough. Whitney closed by indicating that, "In regard to race mixture perhaps you will notice when you receive the legislative program from the Board of Directors [of the AES] that this has been entirely omitted. I know you will approve." 175 By 1927, the AES was beginning a subtle ideological shift that would, after 1932, result in what Mark Haller and Daniel J. Kevles have termed "reform" cugenics_eugenics that eschewed the overtly racist dimension of the earlier movement, but still backed all the same policies with regard to "fit" and "unfit" genes. 176

Tucker and Horsley held a prominence beyond that of Powell, and far above Plecker and Cox. They also believed that they, unlike the ASCOA's leaders, were men of "liberal" racial views and "objective" science. This does not mean they objected to eugenics. On the contrary, they supported eugenical science and eugenical objectives-provided they could be implemented, like the sterilization act and the first RIA, without exacerbating social

${ }^{174}$ Jordan to Whitney, Ibid.

175 Whitney to Jordan, December 16, 1927, AES Papers.

${ }^{176}$ On so-called "reform" eugenics, Kevles, In the Name of Eugenics, 173-76; and Kennelh Ludmerer, Genetics and American Sosiety: A Historical Appraisal (Baltimore and London: The Johns Hopkins University Press, 174-182. See also Haller, Eugenics, 182. This reform, as many historians, including myself, have argued, was one of degree and not kind. Discarding the obviously racial and class thetoric of the 1920s did not mean the movement entirely rejected race and class biases. See generally Diane B. Paul, The Politics of Heredity: Essays on Eugenics, Biomedicire, and the Nature-Nurture Debate (Albany, NY: State University of New York Press, 1998). 
tensions within the Old Dominion. Even before it became clear that the racist doctrines of Powell, Plecker, and Cox lacked the necessary scientific basis for action, politically shrewd eugenicists understood that harping on these issues would tend to awaken more resistance than support. Nowhere is this more apparent than when one examines the reaction among Virginia's African Americans when confronted with eugenic social policy.

\section{Intellectual Miscegenation: Black Responses to Eugenics Legislation}

Studying the rhetoric of the eugenics movement, particularly as embodied in Virginia's RIA, one might assume that "American blacks would have been univocally opposed to any form of racism or biologically deterministic arguments". 177 Recent work by historians has begun to explode this view, uncovering a variety of black responses to the eugenics movement. Nationally-prominent black intellectuals like W. E. B. DuBois could, just like their white counterparts, denigrate racist eugenics without denying the salience and potential of the eugenic improvement of humankind. Other African-American leaders, like Marcus Garvey, actively embraced notions of racial purity, joining common cause with John Powell and his followers. Virginia's African-American population manifested a similarly diverse response to eugenical public policy. The timing and character of this reaction shows how black Virginians sought to coopt the movement and make it serve their own ends. Just as the rhetoric of the eugenic metaphor drew upon powerful and familiar images for white Americans, it also evoked familiar concepts for African Americans. Once again, because of the flexibility imparted to eugenic ideology by the rhetoric of the eugenic metaphor, the movement could appeal to blacks and be adopted, turned, and used against whites seeking to control black destiny.

${ }^{177}$ Hasian, Rhetoric of Eugenics, 51. The work of Hasian, and especially Michelle Mitchell, shaped my understanding of African-American eugenics. See Michelle Mitchell, "Adjusting the Race: Gender, Sexuality, and the Question of African-American Destiny," (Ph.D. diss., Northwestem Univ ersity, 1998). 
Given the history of slavery, a system that dehumanized blacks and attempted, though not always successfully, to "breed" better slaves, blacks maintained visceral memories of a proto-eugenic program. Experience seared this knowledge in the minds of Virginia's black population, people who lived in a state that prided itself on being a "slave producer." When eugenic ideology began to become commonplace, African Americans also found familiar the attempt to stigmatize their race as inferior. Eugenics used new methods and data-in the form of Mendelian genetics, ethnology, and family studies— to remake old claims about blacks. In coming to terms with eugenics, African Americans first resisted racial biology. They then tumed the arguments of racial biology back on themselves to create a new ideology to assist black attempts at uplift. Indeed, it is instructive to note the strong parallels between eugenic "racial improvement" and African American efforts for "racial uplift." The rough homology between the two, despite the black emphasis on environmental interventions, helped to pave the way for the infiltration of eugenic ideas into "uplift" rhetoric.

Tracing the trajectory of African-Americans' response to eugenics from a national perspective, Hasian noted two major trends. First, African Americans "tried to deconstruct the arguments of the hard-line eugenicists by pointing out contradictions in the racist literature." African Americans' primary resistance stemmed from merely continuing their lives and raising families. This natural activity undercut early hereditarian and eugenic claims that blacks and "mulattoes" were less fertile than whites and destined for extinction. Others, notably black intellectuals like W. E. B. DuBois, continued the battle against racial essentialism begun by Benjamin Banneker. Equipped with education and keen intellects, these individuals inverted many of the most offensive eugenical arguments.

Mainline eugenicists claimed that "Nordics" represented the apex in the development of human civilization. Arguing against these supremacists, Howard Long, writing in the Urban League's joumal Outlook, noted "If mental heredity is fixed, specific, and 
unchanged by environment, why was it that the Caucasians in Western Europe awoke from their mental slumbers only recently?" Marcus Garvey explicitly inverted the racial hierarchy, claiming that ancient Egypt had been a "black" nation that fell from greatness because of intermixture with whites. Later he would propound the necessity for both races to protect their racial purity. ${ }^{178}$ Others, like W. E. B. DuBois, argued that black achievement disproved white superiority. Whites eugenicists, predictably, countered that Booker T. Washington, DuBois, and other talented blacks succeeded because they were "mulattoes," white "blood" had improved their chances of success. ${ }^{179}$ African Americans' cited the work of liberal race-thinkers like Franz Boas, who disproved the contentions of the racial supremacists by unveiling their faulty reasoning. Mainline eugenicists smugly replied that Boas proved nothing. They argued that since Boas was a Jew, his work was biased in the same way as that of African Americans-both engaged in a spurious attempt to disprove harsh, but unfortunately "true" conclusions found by objective eugenicists, who just happened to be members of the favored group. In the eyes of mainline eugenicists, Boas and his black champions were merely deluded sentimentalists unable and unwilling to admit the truth.

Those in DuBois's "talented tenth" of black achievers occupied a liminal position in the struggle with eugenical essentialism. At first they destroyed notions of innate inferiority by proving that they could achieve as much or more than their white colleagues. Faced with the adaptability of white eugenic argumentation in accounting for achievement without destroying racial hierarchy, these individuals sought ways to adapt and adopt the logic of

${ }^{178}$ Garvey wrote, "When the great white race of today had no civilization of its own, when white men lived in caves and were counted as savages, this race of ours boasted a wonderful civilization on the Banks of the Nile." Marcus Garvey, Philnsophy and Opinions of Marcus Garvey, ed. Amy Jacques Garvey, vol. 1 (1923), in 2d ed. (Totuwa, N.J.: Frank Cass and Company, Ltd., 1967), 17. For more on purity of race, see Ibid., 29-30; and most of volume two.

${ }^{179}$ This retort was as old as Jefferson's Notes on the State of Virginia where he wondered if black achievement was due to white intcrmixture. See Chapter 1, above. Virginia's Harvey Emest Jordan made the same contention in "The Biological Worth and Sosial Value of the Mulatto," The Popular Science Monthly 82 (June 1913): 573-82. 
eugenics themselves. The "talented tenth" extolled themselves as the model for all blacks. They began their own eugenic program—which sought to replicate "fit" blacks, with "fitness" defined by conformity to the intellectual, social, and economic norm of the "talented tenth" - which was "a male, often mulatto, intellectual, middle class, Northem urbanite." 180 Reproduction of this type of black would be done both by education and wise mating. This did not necessarily include racial intermarriage-instead it implied a class-based eugenics not unlike that found in Britain. The black bourgeoisie, generally coextensive with the talented tenth, should procreate more and more. "Respectable" blacks of the lower class - the upright and God-fearing, too-should obey the divine injunction to "be fruitful and multiply." African Americans to whom the talented tenth could apply the eugenic litmus test of the " $3 \mathrm{~d}$ 's"- defective, delinquent, dependent—should not propagate.

Fighting white eugenicists, DuBois and his followers tried, in the words of Daylanne English, "to negotiate an uneasy balance between collectivity (race-wide solidarity) and selection (intra-racial/class identity)."181 In articulating his notion of the "talented tenth," DuBois assumed an inborn superiority that could be uncovered through merit and training. As early as 1912, one sees the impact of ambient hereditarian and eugenic ideology on DuBois's thinking. In the October issue of The Crisis, DuBois argued that the "duty" of "honest colored men and women" was to breed selectively "to bring not aimless rafts of children into the world, but as many as, with reasonable sacrifice, we can train to largest manhood...." Much like Jefferson's attempt to "rake scholars from the rubbish," DuBois hoped "to find that Talented Tenth and encourage it by the best and most exhaustive training in order to supply the Negrc race and the world with leaders, thinkers and

180Daylanne Kaihry'n English, "Eugenics, Modernism and the Harlem Renaissance," (Ph.D. iiss., University of Virginia, 1996), 28. English persuasively argues that, "Both acsthetic modernist and "New Negro" projects reflect eugenic thinking." The whole notion underlying the "New Negro" movement of the Harlem Renaissance was redolent with eugenic imagery and connotations.

${ }^{181}$ English, Ibid., 31. 
artists." 182 Blacks should not merely procreate to insure survival by quantity, but they should procreate rationally and promote the creation of quality individuals.

In 1922 DuBois highlighted the eugenic implications of birth control and the effect of the differential birth rate within the black population. He lamented in August that African Americans failed to "breed for brains, for efficiency, for beauty," precisely the diagnosis white eugenicists applied to white society. The October "Children's Issue" of The Crisis contained his eugenic ruminations on birth control that highlighted the threat of differential fertility between the classes, a long staple of white eugenic concern. DuBois wrote, "Birth control is science and sense applied to the bringing of children into the world, and of all who need it we Negroes are the first. We in America are becoming sharply divided into the mass who have endless children and the class who through long postponement of marriage have few or none."183 Albert Sidney Beckham argued in The Crisis that, "Eugenics will improve the Negro of the future," a conclusion shared by DuBois. ${ }^{184}$ In covering his daughter Yolande's 1928 wedding to the poet Countée Cullen (surely a eugenic mating of two "fit" members of the Talented Tenth), DuBois wondered, "should we black folk breed children or commit biological suicide?" The reaction of guests leaving the wedding, crying out that it created "a new race," answered DuBois's question and provided a prescription to cure his fears. ${ }^{185}$

${ }^{182}$ DuBois in a 1915 issue of The Crisis quoted in English, "Eugenics, Modemism and the Harlem Renaissance," 30.

${ }^{183}$ DuBois in the August and October, 1922 issues of The Crisis quoted in English, Ibid., 93, 202203. In 1926, DuBois again articulated the class bias of white eugenicists and applied it to blacks, writing, "There are to be sure not enough children in the [Negro] families of the better class," and this would slow, cr even stall, "racial uplift."

${ }^{184}$ Albert Sidney Beckham, "Appiicd Eugenics," riee Crisis (1924), 177.

${ }^{185}$ DuBois in October, 1922 and October, 1926 issues of The Crisis quoted in English, Ibid., 9, 93 201-02. As late as 1932, DuBois would contribute to the "Negro Number" of Margaret Sanger's Birth Control Review. DuBois wrote, "the mass of ignorant Negroes still breed carclessly and disastrously, so that the increase among Negrocs, even more than the increase among whitcs, is from that part of the population least intelligent and fit, and least abıc to rear their children properly." W. E. B. DuBois, "Black Folk and Birth Control," Birth Control Review 16 (June 1932), 166-67. Note the environmentalist implication: the poor and unintelligent were the least able to rear their chiluren (presumably because of environment, but possibly because of heredity), not necessarily doomed to bear unfit children. Similar arguments were made by Sutton Peters, a black man who addressed the 1935 meeting of the Eugenics Research Association in New York. Sec Sutton Peters, "The Negro and Race Integrity," Eugenical News 
Despite these eugenic undertones, DuBois openly reviled the racial eugenicists of the Davenport/Cox/Grant/Stoddard school. Stoddard he called a "fool." DuBois savaged the RIA and Massenburg Bills in The Crisis. DuBois wrote that, "In the future, miscegenation is going to be widely practiced in the world and that despite the likes and dislikes of present living beings." Yet he argued for a "eugenic" race mixing not unlike that promoted by later white reform eugenicists. "We today can at least determine whether such race mixture shall be between intelligent, self-respecting and self-determining people, or between masters and slaves."186 To Copeland, Plecker, and Cox's charge that the Hampton Institute taught social equality, he threw the countercharge that whites, not blacks had been responsible for most miscegenation. "The results of the social equality practiced at Hampton have been fine friendships, real knowledge of human souls, high living and high thinking," DuBois argued, continuing, "we know of no single racial inter-marriage or mulatto child as a result; while, on the other hand, the result of racial segregation in the state of Virginia was officially reported at 164,171 mulattos in 1920."187 Many black Virginians were exposed to similar views in national black newspapers, particularly the Pittsburgh Courier, and Virginia's black press.

Judging from the African-American press, eugenic sterilization alarmed few or no African Americans, certainly not enough to warrant coverage or mention. While the white press at least followed the passage of the sterilization law, and the course of the legal challenge, the black press took no notice whatsoever. Progressive African American newspapers, hoping for equal institutional treatment of the black "feebleminded," probably had no problem with the sterilization of institutionalized blacks. African Americans, seeking access to all "Progressive" methods for social uplift likely embraced sterilization.

19 (May-June 1935), 29. ERA President Clarence G. Campbell described Peters as an "Antiguan colored man (1/4 Carib, 1/4 Negro, and 1/2 white)." Clarence G. Campbell to Earnest Sevier Cox, June 11, 1938, Box 5, Cox Papers.

${ }^{186}$ DuBois, quoted in Hasian, Rhetoric of Eugenics, 67.

187W. E. B. DuBois, "Social Equality at Hampton," The Crisis 30 (Junc 1925): 59-60. 
After all, these individuals reasoned, if whites were willing to perform these operations on their own race for its progress, could it not help African Americans? Given the fact that the official in charge of the state hospital for blacks, Dr. Walter F. Drewry, was one of the principle exponents of sterilization and considered "a friend of the race," the procedure probably seemed less threatening in these early years.

As news of "Mississippi appendectomies"-the coercive steriiization of noninstitutionalized African-American women-spread, however, resistance began to emerge. In 1935, eleven years after Virginia enacted its sterilization law, the Richmond Planet ran a front-page story about Alabama's eugenic sterilization bill. In "Sees scientific Race Elimination In Alabama's Sterilization Bill," the Planet commented that, "Many, knowing the past record of the state of Alabama in dealing with its Negro citizens, fear that this new instrument would be used viciously against them by a public opinion that 'stomachs' lynchings_-inside as well as outside the courtroom."188 Alabama's sterilization law, unlike Virginia's, provided for the sterilization of habitual criminals. Since Alabama's supreme court had recently upheld the obviously corrupt convictions and death sentences of nine black men accused of raping two white women, the paper worried that the court would likely use the sterilization statute against all blacks. The Planet warned, "With a majority of the white population already thinking every Negro 'an habitual criminal' one imagines he can see the end of the race in Alabama when the hundreds of thousands of strong Negro men and women will walk the streets and highways of that State bereft of the God-given right to propagate their kind." Despite this concern over Alabama, Virginia blacks did not voice similar fears abcut their own position. This may have stemmed from the belief that, given the infrequent incidence of lynchings in Virginia, Virginia blacks received better

${ }^{188}$ Richmond Planet, February 2, 1935, 1. The reference to lynchings inside the courtroom stemmed from the notorious Scottsboro case which occurred three years earlier and was still making headlines during appeals. In that case, nine black men were sentenced to death even after their accusers retracted their testimony. It would take more than twentv years and numerous appeals to overturn their convictions. See, Dan T. Carter, Scottsboro: A Tragedy of the American South, (Baton Rouge, LA and London: Louisiana State University Press, 1969; revised edition, 1979). 
treatment from Virginia whites than blacks could expect elsewhere in the South. The RIA called this into question, however, and black newspapers pounced on the issue.

The first sign of displeasure with the RIA came in the Richmond Planet. The Planet's editor decried the Richmond Times-Dispatch's editorial favoring Powell and Cox's "Is America to Become a Negroid Nation?" John Mitchell, Jr. feared that some whites would "use this discussion in stirring up race hatred against the colored people of the southland." Believing that the laws already on the books rendered further legislation unnecessary, Mitchell pointedly blamed whites for miscegenation. "All has been done [to protect racial integrity] that can be done. The lynchers endeavor to do more, but their efforts are futile," the editor proclaimed, because "they lynch colored men who are criminally intimate with white women but they do not exercise their fury upon white men who are criminally intimate with colored women". The editor then asserted, tongue firmly in cheek, "Certainly colored folks are in favor of maintaining racial integrity. They are handicapped and embarrassed...on account of this abominable white face that certain white men have given to them." Acknowledging that the only real solution was repatriation, Mitchell commented that "Hon. Marcus Garvey now in the Tombs Prison, New York advocates [repatriation]. His present location shows just how favorable his plan was considered." The editorial concluded dismissively, "Let the disturbers be sent to ine rear and for Gcd's sake let us have peace." 189 Peace would not come, however, and the Planet and Richmond's black community adjusted their approach accordingly.

"Race Amalgamation Bill Being Passed in Va. Legislature," trumpeted the Planet's March 1, 1924 banner headline. Even the w/Grding indicates African-American resistance,

180" Racial Integaity," Richmond Planel, July 28, 1923, 4. In the same issue, the paper reported two different scientific findings that used biolcgy against white supremacists. Lifting items foom the Pittsburgh Courier, the Planet reported the findings of a Chicago optometrist that "the bionde with the baby blue eyes is doomed to extinction," because their eyes were not protected by sufficient pigment to allow them to survive at the American latitude. The paper also reported Ales Hrdlicka's initial findings on "Old Americans" that "two-thirds of the men and three fourths of the women...are found to have skin of intermediate ccloring. Brownish but not dark enough to be termed dusky." These itcms represent an attempt to use "science" to present counterclaims against the eugenicists' conclusions. 
as Mitchell recast the bill's purpose from antimiscegenation to amalgamation. Richmond's black intelligentsia began debating the ramifications of the bill immediately at a meeting of "La Critique," a chautauqua-like discussion group composed of black economic elites and faculty from Richmond's black Virginia Union University. "The general trend of the discussion," the Planet reported, "was against the assumption of blood preeminence of the white race and a denial that the progeny of two races is inferior to both." Thus, the members of La Critique attacked the heart of the racial integrity bill, the eugenic doctrine of "Grantism." The group maintained these opinions even though "There were several white persons present," among them Eamest Sevier Cox, the "noted biologist and traveler" who was allowed to present his theories. Clearly Richmond's black elite did not cave in the face of oppression. ${ }^{190}$ Indeed, Virginia Union University's Kappa Gama [sic] Chi Literary Society invited Cox to speak before them not because they "subscribe to your theory of the inherent inferiority of the colored races," but "merely because [they] would like to hear mcre of your side of the question," presumably the better to attack it in a fair-minded fashion. ${ }^{191}$

From March of 1924 forward, the Planet assiduously publicized all scientific findings adverse to the RIA's eugenical underpinnings. In May, the Planet reported the meeting of America's most august learned society, the American Philosophical Society. At this convention, which focused on race issues in science, Charles Davenport and many mainline eugenicists received a serious blow from Franz Boas and others. "Nordics

${ }^{190}$ Richmond Planet, March 1, 1924, 1. The Planet also ran an article from "Skull and Bones," the newspaper of the Medical College of Virginia. This article criticized the RIA as anti-Christian, clearly a discussion that would appeal to the Planei's highly-churched African-American readership, and might shame any God-fearing white who happened to read the piece. The authors claimed that, "The sane and educated Negro does noi want social equality....They do not want intermarriage....They have race pride as well as we. They want racial purity a's much as we." Editor Mitchell heartily agreed with this view.

${ }^{191}$ See the correspoiddence between Mrs. I. Dabney [wife of Virginia Union University President T. L. Dabney] and Eamest Sevier Cox, March 23, 27, and 29, 1924, Box 2, ESC Papers. In 1947, on the back of the second letter, Cox noted that "This meeting opposed by certain negrocs." He also commented, "Dabney became a Communist I think and went to Russia. He is a mulatto." Cox clearly still adhered to the theories of Lothrop Stoddard in Revolt Against Civilization that mulattocs were inherently prone to trouble-making and becoming Communist insurgents. 
Knocked Out At Great Science Meet," cheered the Planet's headline, "The 'Superior Race Itch' Is Carried Out on Stretchers." Applauding the efforts of Boas and Dr. Alexander Goldenqeiser, the paper reported that, "The theory that the so-called Nordics have a superiority among the white races was dismissed lightly," but acknowledged that the question of "whether any inherent superiority of the white races over the black" remained open to debate. ${ }^{192}$ The victory was at best partial, yet the Planet made the most of it, bolstering blacks' self-image by presenting a counter-narrative to the rhetoric of eugenics, the ASCOA, and the RIA. Whites, of course, readily dismissed the results of the meeting as wishful thinking - the predictable response of biased members from an inferior racial group. Even the Planet's statement that "There might be less racial prejudice in Europe and in America if the truth were more widely recognized that even the 'purest' races are a product of endless mixtures of stocks throughout the ages," could not shake white supremacists. John Powell and the ASCOA openly conceded the larger premise of this point, that no pure Anglo-Saxon race ever existed, but they countered that the mixture that resulted in the "Caucasian race" was of nearly related racial types, and not widely divergent racial forms like whites and blacks. This opinion would be held by Charles Davenport and major geneticists like Edward M. East throughout their careers. ${ }^{193}$ Black newspapers would work consistently to present alternative visions.

192"Nordics Knocked Out Al Greal Science Meet," Richmond Planet, May 24, 1924, 5. The Planet, like so many other libcrals, oversimplified Boas's conclusions. Boas never maintained that there were no inherent inequalities between the races. Rather, he argued-and the Planet quotes him on this point-that "no scientific method had bcen found of measuring the fundamental capacity of different races, as distinct from the mental and moral development due to custom, history, economic and social environment." Boas did not deny that such differences might exist, he simply denied that they had been proven. His scientific rigor governed his own racial views. See Gosselt, Race, xiv-xv. For a succinct statement of Boas's position, see Franz Boas, "The Question of Racial Purity," American Mercury 3 (1924), 163-169. For another Planet report of anti-eugenic findings, see "Bye, Bye, 'Highbrows'," Richmond Planet, December 6, 1924, 4. This orief piece repnrts Ales Hrdlicka's critique of craniometry and the notions of brachycephaly (round headedness) and dolichocephaly (long headedness) that figured so largcly in the works of men like Gobineau, Grant, Stoddard, Cox, and Chamberlain.

193"Is There Any Pure Race?" Richmond Planet, October 4, 1924, 3. The editorial acknowledges the contenticus nature of ethnological and anthropological study at the time, then states, "Clear as it is that there are numerous snarply distinguishable racial types among the white peoples of the world-as among the red, yellow, and black-it is also clear that there is a common confusion between race and nationality, 
The Richmond Planet increasingly scored the RIA at every opportunity, often using sarcasm and carefully chosen diction that hammered at the act. During the Sorrells controversy, John Mitchell, Jr. editorialized that while the RIA "seems to be worrying some of the white folks" it had "but little interest for the colored ones." Mitchell, showing how little blacks cared about the act, again refused to refer to the RIA by its "proper" name. In commenting that black Virginians "welcome" Judge Holt's decision in the Sorrells matter, he noted that she had "only a slight strain of Negro blood in her veins and this is traced back 136 years." This, of course, was not quite the Judge's finding. Mitchell cast his sentence subtly to vindicate all blacks, while simultaneously ridiculing the calculus of blood relied upon by whites like Walter Plecker. The remainder of the editorial parodied this racial algebra and white fear. "The colored folks have enough white Negroes on their side of the line already," Mitchell opined, "and...they have no desire to multiply the number." Arguing that African Americans were "desirous of curbing or stopping this intermingling of the races," Mitchell denied that the RIA would "accomplish the purpose." "We are already so mixed up over here," Mitchell chided, "that we have a difficult time telling 'which from tother' and it is our desire that if any Negro white folks are over the other side of the line, let them remain there and not confuse us with any more white Negroes with which we are now embarrassed."194 In a later article, Mitchell used the RIA to enlarge the sphere of black agency. If a black man "wants a brown woman, his race, thanks to the white folks legal definition, he can secure her." Noting that black and yellow women were available if they consented, he then stated, "If he [the black man] wants a white woman, he has only to launch his courtship. Thanks to the mongrel, cohabiting labors of the white folks and he can go ahead with his suit with confidence." He again decried the effort of whites to place "Negro white folks" on the colored side of the color 
line." This ridicule, a powerful subversive tool for creating intraracial solidarity, may also have been cast in a way that whites would misinterpret it as support for the law. Mitchell used humor to veil his attack, encoding it so only familiar black or careful white readers might decipher all of it. ${ }^{195}$

In a less sarcastic vein, P. B. Young, editor of the black Norfolk Journal and Guide wrote Cox, "The question of 'keeping the white race white and the black race black' is one upon which I fear you and your associates in the White America Society entertain a wide range of misapprehension." To Young's knowledge, no "Negroes occupying any position of leadership or influence" opposed Cox's "ideals of racial integrity." Instead, Young averred, "Negroes are just as much opposed to the intermingling of the races in improper ways as white people are." What blacks and some whites objected to, Young claimed, were Cox's methods not his goal. Young viewed Cox and his associates as kindling racial friction, risking a firestorm of violence. Young rued this possibility because, "I do not think it is necessary to bring on a race war in America in order to establish racial integrity."196 A proper regard for everyone's feelings would do more than inflammatory laws.

The black press came out in eamest, however, in response to another of Walter Plecker's overzealous miscalculations. Plecker disseminated 65,000 copies of his pamphlet, Eugenics in Relation to the New Family, using the franking privilege he obtained as a special agent for the United States Departrnent of Labor. This pamphlet, containing a brief description of eugenics and the programs for racial improvement, also contained his address before the American Public Health Association, "Virginia's Attempt to Adjust the

${ }^{195}$ Other black editors lambasted Cox directly. E. Washington Rhodes, in a personal letter to Cox, wrote, "Has it ever occurred to you and other white men witi the superiority complex that the inere fact that you are scared stiff on account of the strength and rapid progress of the race that you brand inferior, kills the argument that the Negro cannot compete effectively with the white race? I am not af raid of white men surpassing me. Surely you, a member of a great strong race, should have no fcar of a poor struggling race." E. Washington Rhodes to Earnest Sevier Cox, April 8, 1925, Box 2, ESC Papers.

${ }^{196}$ P. B. Young to Earnest Scvicr Coy., July 23, 1925, Box 2, ESC Papers. 
Color Problem." Enraged by the pamphlet's assertion of innate black inferiority, the

Richmond Planet and Norfolk Journal and Guide led the charge against Plecker. The editor of the Journal and Guide wrote, "With the sanction and seal of the great State of Virginia upon his utterances, Dr. Plecker, as a Virginia health officer, paid by the taxpayers of the State, Negroes included, is industriously engaged in sowing the seeds of bitterest racial discord, from one end of the country to another." 197 The newspaper called for Plecker's resignation and, while they did not achieve that result, the Labor Department, under pressure from the NAACP. terminated his position.

The white press defended Plecker, arguing that the Labor Department's action amounted to "federal political censorship."198 Plecker himself claimed the pamphlets were "designed to be helpful to the negro," and expressed surprise that certain "supersensitive" blacks objected. 199 Only a temporary setback, Plecker answered this rebuke with 70,000 copies of The New Family and Racial Improvement in 1928. This pamphlet sounded the tocsin of white "race suicide" due to the differential birth rates between the upper and lower classes. It also alerted people to the danger of "the ultimate complete intermixture of the white and colored races if they continue to live together."200 Despite the negative publicity, Plecker continued to promote his views. Black protest simply lacked a local power base that could effectively challenge Plecker who, for all his extremism, still expressed the conventional wisdom among most white Virginians. ${ }^{201}$

${ }^{197}$ Plecker's federal position was nominal; his only recompense was $\$ 1$ per year and franking privileges. See "Asks Removal of Dr. Plecker," Richmond Planet, April 4, 1925, 1 and 8. Norfolk Journal ard Guide quoted in Smith, "Managing White Suprer.acy," 118.

198 Richmond News Leader quoted in Ibid.

${ }_{199}$ Plecker quoted in the Richmond Times-Dispatch, March 30, 1925; also quoted in "Dr. Plecker Aroused," Richmond Planet, April 4, 1925, 8.

200 Walter A. Plecker, The New Family and Racial Improvement (Richmond, VA: Bureau of Vital Statistics, 1928). Relcased in time for the second effort to amend the RIA, the pamphlet reprinted Plecker's addresses "Shall America Head for Race Suicide or Race Improvement" and "Shall America Remain White."

${ }^{201}$ Nevertheless, blacks rallied again in 1926 and 1928, objecting to the ASCOA's attempts to amend the RIA. See "The Leading White Citizens Make Protest"; "Price Racial Integrity Bill Defeated," February 18, 1928, 1; and "Hon. W. A. Plecker Writcs His Approval," February 25, 1928, 1. 
The third time Virginia considered racial integrity in its legislature, in 1928's Price Bill, black Virginians adopted a new protest strategy. The Price Bill attempted to resolve an internal contradiction in Virginia law. The RIA defined a white person as anyone with no trace of "non-caucasic blood" other than one-sixteenth the blood of the Native American. It did not define a colored person, other than by implication. A preexisting 1910 law defined anyone with more than one-sixteenth Negro blood as colored. Thus, by the laws' terms, anyone with less than one-sixteenth black blood was neither colored nor white. ${ }^{202}$ Still harping on the doom facing civilization, Plecker, Cox, and Powell rehashed the usual arguments for tightening racial classification. The Price Bill "sought to define as colored any person having any ascertainable amount of negro blood without regard to time or generation removed," and an "Indian" would be "every person not a colored person, but having one-fourth or more Indian blood."203 Now, leaders of Native American tribes entered the fray and uncovered deep divisions between blacks and the Native American minority. Wah-hun-sun-a-cook of the Pamunkeys testified before the Senate that, "I will tie a stone around my neck and jump in the James River rather than be classed as a Negro."204 After four years of persecution by Plecker, the Native American groups, with the assistance of sympathetic whites, began to fight back. 205

Wah-hun-sun-a-cook's statement, however, stuck a raw nerve and elicited condemnation from the Richmond Planet. In responding to the Native American Leader, however, John Mitchell, Jr. adopted the "race purity" rhetoric of the whites to highlight its absurdity. What was wrong with the bill, in his opinion, was that it failed to define "a pure unmixed Anglo-Saxon as white and pure and a pure unmixed Negro as a Negro." As he reminded Wah-hun-sun-a-cook, "Certain it is that Negroes join with him in his effort to

202Sherman, "The Last Stand," 88-89.

${ }^{203}$ Richmond Times-Dispatch quoted in Richmond Planet, February 18, 1923, 4.

${ }^{204}$ Sherman, "The Last Stand," 88.

205Plecker's correspondence with Davenpor: is replete with his concem about Native Americans acting as the conduit for the passage of "Negro germ-plasm" into the white "bloodstream." Davenport Papers. 
maintain the racial integrity of his tribe and they do not want any of its mongrel members thrown over on their side of the contention." Wah-hun-sun-a-cook's proclamation so deeply offended Mitchell that three times he asked the Native American to name the time and place of his drowning so that "all of the manufacturers and employers of Negroes will be asked to give a holiday in order that they may enjoy one day of complete and Prayerful satisfaction," in witnessing the event. Finally, Mitchell asked to clarify the racial matter because,

the pure, unadulterated Negroes here are loaded down and held responsible for all kinds and sorts of people masquerading as Negroes when they are not Negroes. We have Chinese Negroes, Japanese Negroes, Mexican Negroes, Indian Negroes, German Negroes, French Negroes, English Negroes, Italian Negroes, Jew Negroes, Irish Negroes and last but not least, either as to quality or quantity, we have white Negroes.

Dropping his relentless sarcasm, Mitchell asked "to change, nullify, modify or prove to be false the following declaration of the Scriptures: 'And hath made of one blood all nations of men for to dwell on all the face of the earth."' Alongside this affirmation of essential racial similarity, and plea for racial integrity, Mitchell ironically ran an add for Dr. Fred Palmer's Skin Whitener, a product developed to aid passing. 206 Plecker, of course, entirely missed Mitcheli's point and wrote the editor, "I am glad to know that the true negroes are becoming interested in preserving the purity of their race....I hope the true negroes will be wise enough to know what to do with mixed breeds who are not white and whom the negroes do not consider black. They are the probletr. The true negro is no problem from the racial standpoint, so long as he remains pure." Apparently "what to do with mixed breeds' w'as report them to Plecker for monitoring, and shun them in marriage. 207

Other black Virginians shared whites' views regarding the need for racial purity. Led by Marcus Garvey and his organization, the UNIA, many black Virginians supported the

\footnotetext{
${ }^{206}$ All quotations from the serics of editorials reprinted in the Richmond Planet, Fcbruary 18, 1928, 1, 4-5.

${ }^{207}$ Walter A. Plecker to Editor, Fcbruary 18, 1928 in Richmond Planet, Fcbruary 28, 1928, 1.
} 
eugenic theory undergirding the RIA. This endorsement expressed their own deeper convictions about the rectitude of Garvey's political economy of race. Racial purity for them, as for Garvey, became the foundation of personal identity. From a belief in black "racial integrity," a corporate sense of solidarity emerged that, when combined with a capitalist economic perspective, constituted Garvey's notion of Pan-African black nationalism. By 1921, Garvey's rhetoric of Pan-Africanism and racial purity became so thoroughly homogenized that, in the minds of sympathetic whites and critical blacks, he represented simply a "back to Africa" movement bent on repatriating all Diaspora blacks. 208 It was on the basis of this oversimplification that Garvey built his alliance with the Ku Klux Klan and, later, the ASCOA and its leaders.

Much has been written about the cooperation between Garvey himself and the leadership of the ASCOA. ${ }^{209}$ Garvey's belief that the integrationist mission of the NAACP and other bi-racial groups represented a "dangerous race destroying doctrine" led him to proclaim, "The Universal Negro Improvement Association on the other hand believes in and teaches the pride and purity of race. We believe that the white race should uphold its zacial pride and perpetuate itself, and that the black race should do likewise." 210 Garvey's notion that nations embodied the best of a people's aspirations and were the products of racial determinism, placed him squarely within the camp of Madison Grant, Lothrop Stoddard, and Earnest Sevier Cox. Garvey differed in believing that a pure black race

${ }^{208}$ Amy Jacques Garvey, Garvey's vife and chief lieutenant, deniud this vehemently. She wrote, "the, term, back-to-Africa, was used and promoted by the newspapers, Negro newspapers mostly, to ridicule Garvey. There was no back-to-Africa movemer.t except in a spiritual sense." For similar expressions, see Amy Jacques Garvey, Garvey and Garveyism (Kingston, Jamaica: Privateiy Published, 1963), 127, 252, and Chapter 25.

${ }^{209}$ Excellent pieces are Barbara Bair's insightful gender analysis of this affiliation, "Remapping the Black/White Body" and William A. Edwards's "Racial purity in Black and White" which traces the ideological affinities between the movements in more traditional political terms. See note 21, above.

${ }^{210}$ Garvey quoted in Edwards, "Racial Purity in Black and White," quotation 121. 
could equal or exceed the achievements of the white race in civilization. ${ }^{211}$ It is clear that the movements converged partly based on an apparent ideological congruence.

Investigating this similarity, however, reveals the instrumental reasons for the alliance. Social movements like the UNIA and the ASCOA ultimately "seek the enhancement of their self-interests," and they often rely on establishing common cause in ends, if not in means. In the case of Garvey's black nationalism and the ASCOA's white supremacy (basically a cipher for white nationalism), ends and means appeared to be perfect matches. While Garvey had his own reasons for allying with white supremacists, what is more significant is the effect his adoption of racial purity had upon his followers. 212

Although Powell again became the figurehead in the relationship between the ASCOA and the UNIA - because his fame made him familiar to both blacks and whites-his effect in spreading Garvey's doctrine was limited. Powell made the big, publicized speeches at New York's Liberty Hall, but it was his associates who built national support for Garvey among white supremacists. Eamest Cox became "the most important White man in this country in the dissemination of Garveyism among those who believed in the purity of the White race." 213 As Cox wrote to an imprisoned Garvey, "I would endeavor to show white men that you were fighting the white man's battle without the white man's aid. It is my

${ }^{211}$ Garvey encouraged his followers to read the works of Cox, Grant, and Stoddard; not to convince them of black inferiority, but to instill a like-minded respect for racial pride and a hatred of miscegenation. Garvey developed an Afro-centric rhetoric that extolled the achievements of Ancient Egypt, a nation of darkskinned blacks that, in Garvey's ethnology, that fell as a result of intermixture with whites. Significantly, the only portions of ancient black culturc Garvcy valorizcd were those that contributed to westcm scientific advance like mathematics, architecture, and astronomy.

${ }^{212}$ Garvey was nothing if not politically shrewd. He well knew that by coopting the hostility of the most virulently anti-black organizations, he would buy himsclf timc and room to outflank his opponentsboth black and white. Nevertheless, Garvey's alliance with the KKK and ASCOA was noi merely Machiavellian. He believed quite strongly in racial purity, if not in repatriation of all blacks, so he was joining common cause on that level. Some explain this 1921 shift to racial purity as a product of Garvey's desire tc differentiate himself from other black "uplift" organizations, or as the resolution of racial anxiety that plagued Garvey since his Jamaican childhood. Ed'wards, Ibid., 125-27.

${ }^{213}$ Edwards, "Racial Purity in Black and White," 117. Cox himself once wrote that "the essential elements of the Garvey movement, if properly presented to the white people of America, will be supported by a tremendous number of whites. I am not sure I will be the one best qualified to do it." Eamest S. Cox to Mr. John Ditto, n.d. circa March 1925, Box 2, ESC Papcrs. 
purpose to do all that I can for you and your cause."214 Garvey complimented Cox's work, writing, "It strikes at the root of the evil-the mulatto-who is the principal cause of nearly all the troubles of the poor Negro in America, as well as elsewhere." It was clear to Garvey who stood behind the "Negro Problem" in America. "The race enemy organization the National Association for the Advancement of Colored People, is destructive to both races. They are seeking to build up a mongrel America, and those who are associated with them are either crazy or positively immoral, at least they are misguided."215 Garvey's race purity crusade revealed the operation of racialist thinking in his approach to uplift.

Cox, in working to advance the Garveyite movement, corresponded with numerous members of the UNIA in Virginia and across the country. ${ }^{216}$ The letters between Cox and these men open a window on the meeting of these two organizations. John J. Fenner, president of the Richmond Division of the UNIA, worked to place Cox's tracts "in the hands of members of my race intelligent enough to understand." He worked with Cox to secure him black audiences throughout Virginia. ${ }^{217}$ During the firestorm surrounding the Massenburg bill, he wrote to Cox, "I am under fire by the would be local leaders of the race. Yet I am unafraid. I have been interviewed by several local race newspapermen but no news from me." Instead of informing on Cox to the black press, Fenner informed Cox of the "true" black public opinion. "In my contact with the public, I find an increased

${ }^{214}$ Earnest Sevier Cox to Marcus Garvey, May 26, 1925, Box 2, ESC Papers. Garvey was serving a sentence in the Atlanta Federal Penitentiary as the result of a conviction for mail fraud.

${ }^{215}$ Garvey to Cox, June 10, 1925, Box 2, ESC Papers. Garvey claimed that the entire purpose of the NAACP was miscegenation. "I know that some of the white supporters only desire easy contact with colored women and that the principal aim of the DuBois. Johnson, [illegible, possibly Black] Pickens and Bagnall group is to meet and associate with white women."

216 This correspondence is so massive, and scattered throughout Cox's papers, as to make comprehensive citation impossible. For representative examples se2, J. J. Pcters to Cox, August 17, 1925 (New Orleans); Mrs. W. C. Corbin to Cox, October 15, 1925 (New York); A. S. Connclly to Cox, November 5, 1925 (Washington, D.C.), Box 2, ESC Papers; J. W. McHurst to Cox, April 10, 1926 (Chicago); S. M. Phillips to Cox, November 24, 1926 (Independence, Kansas); William Ware to Cox, May 8, 1929 (Cincinnati), Box 3, ESC Papers.

${ }^{217}$ Correspondence between John J. Fenner and Earnest Sevier Cox, Box 2, ESC Papers. Quotation is taken from Fenner to Cox, June 17, 1925, Box 2, ESC Papers. 
sentiment agreeing that the INTEGRITY OF THE RACES IS A FINE IDEA AND THE APPROVAL OF SAME IS GROWING."218

Cox received praise from black Virginians outside of Richmond, too. From Norfolk, home of the anti-Cox Journal and Guide, a black minister wrote that he was "so well pleased" with Cox's repatriationist pamphlet "Let My People Go" that he had to write. "No truer word never was spoken," Reverend A. A. Boyd affirmed, "Than when you said, the only way to have pure stock, is to separate them [races] by sending the Negroes to Africa, where they can work out their own destiny, they have the knowledge to do so." $\mathrm{He}$ implored Cox to convince black ministers who preached against Garvey to reconsider. "Just one word from you white People will work wonderously [sic], toward tearing down this so called high Negro," Boyd affirmed.

One of the most striking letters came from Professor Amold H. Maloney, who taught in the Department of Philosophy and Psychology at Wilberforce University in Ohio. Ironically, the mulatto children of southern planters comprised the majority of the initial student body of Wilberforce. ${ }^{219}$ Nevertheless, by 1925 Professor Maloney was able to say to Cox, "Your views as a white man are quite analogous to my views as a colored man. I am for the governmental independence and racial integrity of my race as you are for yours. Hence, it seems to me that some rapprochement can be arrived at between us. That would expedite the solution of the dogged and inveterate race problem."220

Despite Richard Sherman's characterization of RIA lobbyists as a "dedicated coterie of extremists," and notwithstanding his assertion that "few really prominent Virginians [were] among the [ASCOA's] active members," it becomes apparent that many Virginia elites

${ }^{218}$ Fenner to Cox, September 28, 1925, Ibid.

219John Hope Franklin and Alfred A. Moss, Jr., From Slavery to Freedom: A History of African Americans, 7th ed., (New York: McGaw Hill, Inc., 1994), 162.

${ }^{220}$ Amold H. Maloney to Earnest Sevier Cox, July 24, 1925, Box 2, ESC Papers. 
embraced eugenics, particularly as it supported traditional racial hierarchies. ${ }^{221}$ Eugenics generally, and in Virginia specifically, never became a mass movement because it was always meant to be an impulse directed by expert authorities. Scientific and medical experts hoped to educate the populace enough to ensure compliance, but not enough to engender resistance. Thus, the involvement of physicians in the Anglo-Saxon movement, whether as leaders like Dr. Lawrence Price and Dr. Paul Barringer, was not the result of coincidence. Physicians, perhaps better than many other supporters, believed they understood the science underpinning the ASCOA. Harvey Ernesi Jordan, Robert Bennett Bean, Lawrence Royster, and Ivey Foreman Lewis, all powerful members of both Virginia's scientific and medical community, actively supported the ASCOA program. These Virginians convinced nationally prominent eugenicists to testify in favor of the RIA. This interaction between local and national leaders created coalitions with overlapping memberships. Arthur Estabrook testified in support of both Virginia's eugeric sterilization and eugenic marriage laws. Doctor Albert Priddy, and many other Virginians, supported both laws as well.

Evaluating the "popularity" of eugenics in Virginia, as evinced by the passage of the Racial Integrity Act and the sterilization law, presents a number of problems. Considering each measure individually because of their apparently discrete lobbying groups artificially isolates the efforts, wrenching them out of their larger context. Sherman and other commentators are undoubtedly correct in observing that the Racial Integrity Act was not "the product of a great popular groundswell," if by popular groundswell he means some kind of mass, democratic, Populist revolt. "It is not obvious," Sherman argues, "that large numbers of Virginians believed that their state was on the verge of a cataclysm."222

${ }^{221}$ Sherman, "The I ast Stand," 69 and 76. Sherman s statements, of course, depend on his definitions of "influential" and "active." Most influential Virginians agrecd with the basic premise of the ASCOA's program; they differed over execulion. Many supported the organization with time, money, and "backstage" action; relatively few made public speeches or published cditorials. This does not necessarily make them passive. They organized like minded people and exerted subule, but no less effective, political pressure.

222 Sherman, "The Last Stand," 87. 
Certainly thousands of letters did not appear in the newspapers supporting the eugenic bills; yet by far the greater number of those that did appear viewed the acts favorably. That the editors of the papers supported almost all of the acts also speaks to the popularity of eugenics. Editors would not risk the circulation of their papers on a whim. They knew their audience and played to their beliefs, whether racist, eugenic, or both. Thus, the conclusion that legislators and the Governor "appeared to have been guided more by perceptions of public opinion than by personal conviction" also misses the point. Of course legislators generally act in ways least likely to raise the ire of their constituents; those actions may or may not have anything to do with their beliefs about eugenics. ${ }^{223}$ To deny the popularity of eugenics-and its near-universal appeal among significant segments of elite Virginia society—simply tecause no readily-apparent "mass" membership organization arose, is surely misleading on two levels.

First; as has been repeatedly shown, many if not most well-educated and professional Virginians adhered to the major tenets of eugenics. They differed only in the degree of rigor with which they would apply eugenics as a practical social policy. By 1924, virtually no-one protested the eugenic sterilization law's enactment. Virginia's physicians and mental health professionals all rallied behind it as efficacious preventive medicine. Virginia's legislators and social workers backed it as an economically efficient measure for social reform. The eugenic stigmatization of poor whites fueled simmering class tensions, yet it simultaneously provided relief through the institutionalization and sterilization of

${ }^{223}$ Smith, "Managing White Supremacy," 114. Governor Trinkle's regret that press coverage "makes it look as if we are probably working on them pretty hard and continually exposing their misfortune of having colored blood," was politically expedient-he did not want to inllame racial tensions and call his leadership into question. His statement that "I know this [revclation of "colored blood"] is humiliating if it is true and I was in hopes that this cuuld be handled in a quiet way so as not to emphasize and embarrass them any more than possible," reveals his gentility, patemalism, policical savvy, and support for eugenics. He did not compel Plecker to stop his investigations, he mercly hoped he would use greater tact in enforcing the RIA.. A sensitive approach might forestall bitierness and bad publicity while still getting the job done. Smith contradicts his own assertion later, noting that "Trinkle had consistently supported Plecker's positions and methods in correspondence 'with both private citizens and public officials." (116) If Trinkle did not believe in the RIA, one would suspect that somewhere in his voluminous correspondence his "true" feelings would out; the fact is they did-he was in favor of the RIA and the ideas bchind it. After all, he signed both it, and the eugenical sterilization bill, into law. 
"poor white trash." Faced with incarceration and surgery, poor whites leamed to keep their peace.

Similarly, very few white Virginians contested the eugenic underpinnings of the Racial Integrity Act. Eugenical race-theory comported well with long-standing cultural notions of black inferiority. Intelligence testing and racial-purity rhetoric added the weight of science to the demonization of blacks as diseased, lazy, and lascivious. Policing procreation through the RIA allowed elite Virginians to reinforce segregation by creating a mechanism for racial registry and surveillance. The terror of blacks "passing" abated as Plecker mobilized the coercive force of the state, through the Bureau of Vital Statistics and the Public Health Department.

Protest only arose from whites and blacks when the ASCOA outstripped its social mandate. As long as the group merely re-cast traditional racism in the terms and policies of "Progressive" science, it remained in favor. When the ASCOA moved from controlling blacks to threatening the position of prominent whites, however, resistance formed rapidly. The "Pocahontas clause" quieted initial protests against the ASCOA agenda. Anger at the mobilization after the Sorrells case, and during the debates over public assemblage, however, ultimately derived from the ire of prominent whites being "controlled" by other prominent whites. Classifying mountain whites and "Indians" as black was acceptable. Repeatedly jeopardizing the descendants of Pocahontas-or questioning their authority by disputing Judge Holt-was unacceptable. Denying blacks and whites the right to marryindividuals whose mere desire to marry marked them as aberrant and "low class"-was acceptable. Telling well-heeled whites that they could not attend "high" cultural attractions because their proximity to black attendees increased the possibility of miscegenation, was unacceptable. In their rush to achieve a "one drop" rule, extremists impugned the morals of an important group of eugenics sympathizers. Thus, John Powell's actions alienated men and women who, like J. Shelton Horsley, were sympathetic to eugenics and sensitive to its 
racial aspect, but unwilling to engage in any ultra activity that unnecessarily exacerbated racial tensior.

On a second level, demanding a highly-visible, centrally-administered organization to "prove" the popular appeal of eugenics neglects the intemal logic of the eugenics movement and its relationship to traditional southem patemalism. The eugenic metaphor relied on the existing mindset, common to all people, to engender support without the need for overt organizing and institution building. This preserved the elitist character of the movement, and helped it mesh with extant Virginia political culture. As stated above, eugenicists selfconsciously tried to keep the movement elitist-eugenical experts leading the masses.

Eugenicists viewed themselves as an enlightened elite, charged with educating members of the "best stock" to "right thinking" positions. Since the "best stock" correlated precisely with the white upper class, eugenical education became an exercise in self-congratulation for these folks. Eugenical education of the "masses" was rarely contemplated, as such. Such inculcation was always linked to the public schools, particularly the high schools, which presupposed teaching the "fit." High school students were, by and large, members of the fit by definition, provided that the earlier schools performed their selective function by tracking students into educational programs based on intelligence.

No eugenicist ever seriously advocated teaching the "unfit" that they represented human dross. Again, by definition, the unfit were incapable of understanding these concepts, and even if they could understand them, unfit individuals lacked the self-control and "altruism" necessary to limit voluntarily their own procreation. So, those eugenicists who advocated teaching birth controi to white-ethnic immigrants, the poor, and racial minorities emphasized appealing to self-interesi-the perceived desire of "selfish, indolent, and lascivious" people be free of the "burden" of children. The unfit lacked a eugenic "conscience," and therefore could not be appealed to by arguing for individual sacrifice in the name of social improvement. This approach, coopting those likely to enter positions of 
power and hoodwinking or ignoring the rest, made perfect sense to eugenicists who realized that their programs could elicit strong emotional (and sentimental) responses. After all, as Antonio Gramsci pointed out, the best forms of social control are often those that are the least overtly visible and most reliant on cultural socialization.

Other Virginians, including black Virginians, also tumed to eugenics as a potential meliorative for deep-seated social problems. Those blacks who directly contested the eugenicists' rhetoric, pointing out the internal contradictions in the language and logic of racial supremacy, sought to use eugenics as its own foil. Others tried to coopt the discipline, to argue for the eugenic improvement of the black race, or to promote notions of black racial superiority that could be cultivated. These individuals, like Professor Tumer at the Hampton Institute, understood the eugenics metaphor and deployed it for their own uplift. Whichever way an African American argued, in Virginia that individual could be certain that the people in power understood the terms of the debate.

That powerful elites understood this language has far-reaching ramifications for the Virginia polity. Philosopher Charles Mills argues that all westem social contract theory is grounded upon an implicit, unacknowledged "racial contract" that "is not a contract between everybody ('we the people'), but between just the people who count, the people who really are people ('we the white people')."224 Contracts imply consent of all the parties. The implici: racial contract is "an agreement or set of agreements" between whites, who view themselves as "full persons," to "categorize the remaining subset of humans as 'nonwhite' and of an inferior moral status, subpersons, so that they have a subordinate

${ }^{224}$ Charles W. Mills, The Racial Contract (Ithaca, NY and Lendon: Cornell University Press, 1997), 3. Mills extends Carole Patentan's work in The Sexual Contract to show that western contract theory is not only inherently gendered but also inherently raced. Mills presents tiree conceptual claims about white supremacy: it "exists and has cxisted for many ycars," it "should be thought of as itsc! a political system," and that, "as a political system, white supremacy can illuminatingly be theorized as based on a 'contract' between whites." (7) Thus racism is a normal and central concepl constitutive of America's social polity, not a deviation from an inclusive ideal. Only by acknowledging the normal function of racism can we hope to shift the terms of the racial contract and destroy the stranglehold of white supremacy on American social and political thought. 
civil standing in the white or white-ruled polities." Although, "All whites are beneficiaries of the Contract," Mills states that, "some whites are not signatories to it" since they do not behave in ways that imply agreement. 225 Mills also states that this contract evolves "not merely by altering the relations between whites and nonwhites but by shifting the criteria for who counts as white and nonwhite [emphasis in original]."226 The power of the racial contract, then, lies in its mutability and whites' generally tacit acceptance of its terms. Seldom do whites self-consciously expose the terms of the contract and revise them publicly. To do so opens the contract, and its power for normalizing white supremacy, to attack from non-white and rebellious white (those who do not wish to be part of the racial contract) populations.

In America generally, and Virginia specifically, during the 1920s whites exposed the racial contract and attempted to use the "science" of eugenics and genetics to justify the categoric exclusions demanded by white supremacy. The entire eugenics movement, both nationally and in Virginia, can be seen as an effort to rationalize and articulate in detail the provisions of the racial contract in biological terms. ${ }^{227}$ White Virginia elites created a eugenic hierarchy that parsed humanity into increasingly fine gradations since "Phyenotypical whiteness and European origin were not always sufficient for full Whiteness" and "acceptance into the inner sanctum of the racial club".228 This allowed white elites to "write out" blacks, poor whites, Jews, Europeans of southeastern descent, other racial minority populations, and the "feeble-minded." Elite whites used science to deny these other groups access to the racial contract and the privileges it conferred. So, even though eugenicists invoked the Constitution and the Fourth, Tenth, and Fourteenth amendments in advocating interventions like sterilization, immigration restriction, and

225 Ibid., 11

${ }^{226}$ Ibid.

${ }^{227}$ Ibid., 78.

228 Mills, Ibid., 80. 
marriage restriction, they were really only using the terms of the national compact to justify and rationalize their adjustment of the underlying terms of the binding racial contract.

Given its well-developed eugenic program, and its oft-articulated progressive ethos, Virginia thus appeared more "modern" and "progressive" than many other states, North or South. Ultimately, however, the "effectiveness" of Virginia's eugenic programs cannot be measured in the economic and medical terms proponents argued. Changing definitions of mental disease and "defect," coupled with changing forms of social intervention, make it nearly impossible to try to calculate "savings" or "defectiveness prevented" as a result of the sterilization law, provided it could ever achieve its goal. This task is absolutely confounded in any attempt to arrive at a quantitative estimate of the impact of the Racial Integrity Act. ${ }^{229}$ The sterilization rate provides one index of the eugenic programs' "success," particularly when one notes the persistence of sterilization as a remedy, and the timing of its activity. An assessment of the social and cultural legacy of these 1924 laws is best arrived at by tracing the continuing evolution of eugenic ideology within the state during the ensuing generations. Far from disappearing after 1932 and the Third International Congress of Eugenics, eugenics in Virginia remained in action for another twenty-five years, only slowly falling into disfavor later.

\footnotetext{
${ }^{229}$ John Douglas Smith observed, "Those who emphasize that the Anglo-Saxon movement was essentially the work of a small group of racial zealots often overlook the impact that the law wrought on the lives of hundreds of Virginians." Smith might safely have increased his estimate to thousands. The legacy of suspicion and hostility toward government and public health officials among Virginia's Native American and poor population traces its roots to the actions of Dr. Plecker. J. David Smith and other scholars have noted that Plecker is still remembered by the older members of these communities, invoked as a bogey to remind people of a terrible time. The pain, suffering, and deprivation that resultcd from these communities' reluctance to partake in subsequent public health initiatives is incalculable, yet directly attributatle to the eugenic ideology and its adherents.
} 